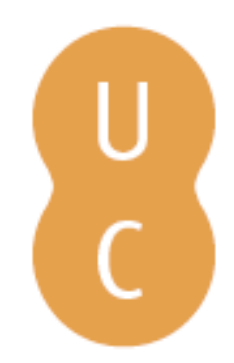

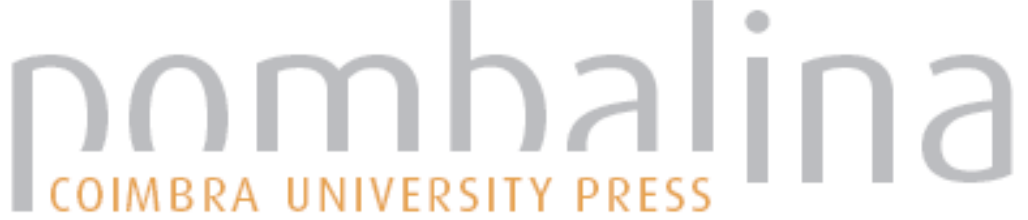

\section{Humanismo e Ciência: Antiguidade e Renascimento}
Autor(es): $\quad$ Andrade, António Manuel Lopes; Miguel Mora, Carlos de; Torrão, João Manuel Nunes

Publicado por: UA Editora - Universidade de Aveiro; Imprensa da Universidade de
Coimbra; Annablume
URL persistente:
URI:http://hdl.handle.net/10316.2/35685
DOI:
DOI:http://dx.doi.org/10.14195/978-989-26-0941-6

Accessed : $\quad$ 6-Feb-2018 08:27:12

A navegação consulta e descarregamento dos títulos inseridos nas Bibliotecas Digitais UC Digitalis, UC Pombalina e UC Impactum, pressupõem a aceitação plena e sem reservas dos Termos e Condições de Uso destas Bibliotecas Digitais, disponíveis em https://digitalis.uc.pt/pt-pt/termos.

Conforme exposto nos referidos Termos e Condições de Uso, o descarregamento de títulos de acesso restrito requer uma licença válida de autorização devendo o utilizador aceder ao(s) documento(s) a partir de um endereço de IP da instituição detentora da supramencionada licença.

Ao utilizador é apenas permitido o descarregamento para uso pessoal, pelo que o emprego do(s) título(s) descarregado(s) para outro fim, designadamente comercial, carece de autorização do respetivo autor ou editor da obra.

Na medida em que todas as obras da UC Digitalis se encontram protegidas pelo Código do Direito de Autor e Direitos Conexos e demais legislação aplicável, toda a cópia, parcial ou total, deste documento, nos casos em que é legalmente admitida, deverá conter ou fazer-se acompanhar por este aviso.

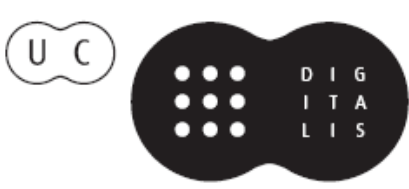




\section{HUMANISMO E CIÊNCIA Antiguidade e Renascimento}

António Manuel Lopes Andrade

Carlos de Miguel Mora

João Manuel Nunes Torrão
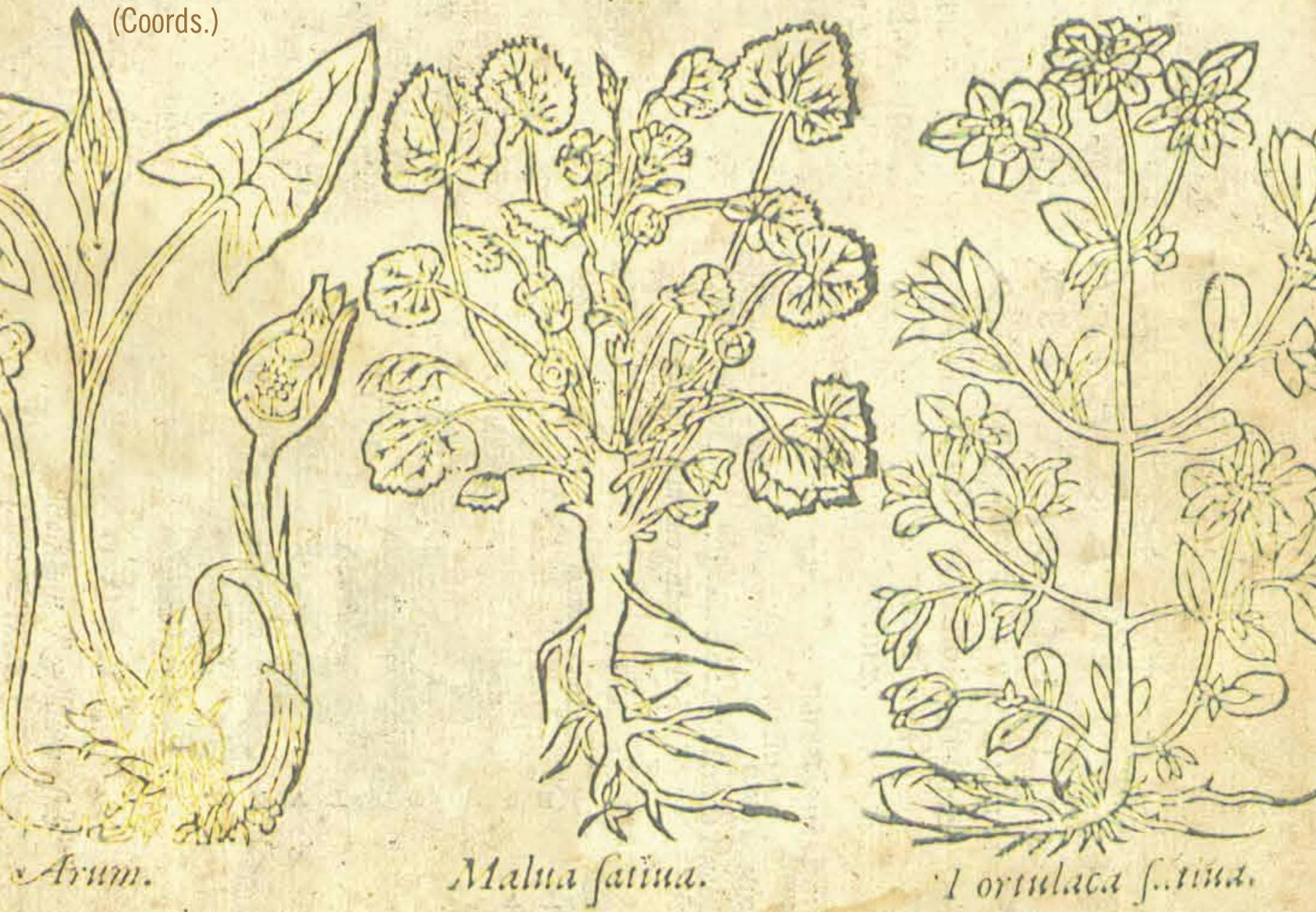

Aveiro I Coimbra I São Paulo 2015

UA Editora - Universidade de Aveiro I Imprensa da Universidade de Coimbra I Annablume 
Este volume resulta de várias iniciativas desenvolvidas no âmbito do projecto de I\&D "Dioscórides e o Humanismo Português: os Comentários de Amato Lusitano" (http://amatolusitano.web.ua.pt), recoIhendo contribuições de mais de duas dezenas de colaboradores, tanto de membros da equipa como de outros investigadores nacionais e estrangeiros. Entre os eventos que estiveram na origem deste livro destacam-se as três edições do Ciclo de Conferências promovido pelo projecto, realizadas entre 2010 e 2013, e sobretudo o Colóquio Internacional "Dioscórides e o Humanismo Português: os Comentários de Amato Lusitano", que decorreu no Departamento de Línguas e Culturas da Universidade de Aveiro, nos dias 21 e 22 de Novembro de 2013.

0 objectivo principal do projecto é a edição e tradução para português dos dois livros que Amato Lusitano dedicou ao comentário do tratado grego De materia medica de Dioscórides, ou seja, o Index Dioscoridis (Antuérpia, 1536) e as In Dioscoridlis Anazarbei de medica materia libros quinque... enarrationes (Veneza, 1553), estando contemplada, também, a tradução de mais duas obras directamente correlacionadas com os livros do médico português: a montante, a do próprio tratado grego de Dioscórides; a jusante, a do livro intitulado Apologia adversus Amathum Lusitanum (Veneza, 1558) de Pietro Andrea Mattioli.

OBRA PUBLICADA COM A COORDENAÇÃO

CIENTÍFICA DE:

Centro de Línguas, Literaturas e Culturas da Universidade de Aveiro

Centro de Estudos Clássicos e Humanísticos da Universidade de Coimbra

Cátedra de Estudos Sefarditas "Alberto

Benveniste" da Faculdade de Letras da Universidade de Lisboa 


\section{HUMANISMO E CIÊNCIA}

\section{Antiguidade e Renascimento}

ANTÓNIO MANUEL LOPES ANDRADE

CARLOS DE MIGUEL MORA

JOÃO MANUEL NUNES TORRÃO

(COORDS.)

AVEIRO • COIMBRA • SÃO PAULO

2015

UA EDITORA • UNIVERSIDADE DE AVEIRO

IMPRENSA DA UNIVERSIDADE DE COIMBRA

ANNABLUME 


\section{HUMANISMO E CIÊNCIA: Antiguidade e Renascimento}

\author{
EDIÇÃO

UA EDITORA • UNIVERSIDADE DE AVEIRO
IMPRENSA DA UNIVERSIDADE DE COIMBRA
ANNABLUME

ORGANIZAÇÃO E COORDENAÇÃO EDITORIAL ANTÓNIO MANUEL LOPES ANDRADE

CARLOS DE MIGUEL MORA

JOÃO MANUEL NUNES TORRÃO

\author{
DESIGN DA CAPA \\ MEIOKILO DESIGN STUDIO
}

DESIGN

CARLOS COSTA

IMPRESSÃO E ACABAMENTO

SERSILITO • MAIA

ISBN

UA • 978-972-789-434-5

IUC • 978-989-26-0940-9

\section{ISBN DIGITAL}

UA • 978-972-789-435-2

IUC • 978-989-26-0941-6

DOI

http://dx.doi.org/10.14195/ 978-989-26-0941-6

DEPÓSITO LEGAL 368241/13

TIRAGEM 500 Exemplares

(C) 2015

UA EDITORA • UNIVERSIDADE DE AVEIRO IMPRENSA DA UNIVERSIDADE DE COIMBRA

ANNABLUME

\section{COMISSÃO CIENTÍFICA}

António Manuel Lopes Andrade

Carlos de Miguel Mora

Delfim Ferreira Leão

Henrique Leitão

João Manuel Nunes Torrão

Maria de Fátima Reis

Maria do Céu Zambujo Fialho

Miguel Ángel González Manjarrés

\section{TEXTOS}

Adelino Cardoso

Ana Leonor Pereira

Ana Margarida Borges

António Guimarães Pinto

António Maria Martins Melo

Bernardo Mota

Carlos A. Martins de Jesus

Carlos de Miguel Mora

Cristina Santos Pinheiro

Donald Beecher

Emília Oliveira

Isabel Malaquias

James W. Nelson Novoa

Joana Mestre Costa

João Manuel Nunes Torrão

João Rui Pita

Jorge Paiva

José Sílvio Moreira Fernandes

Maria de Fátima Silva

Miguel Ángel González Manjarrés

Rui Manuel Loureiro

Telmo Corujo dos Reis

Teresa Nobre de Carvalho

Vinicije B. Lupis

Virgínia Soares Pereira 


\section{HUMANISMO E CIÊNCIA}

\section{Antiguidade e Renascimento}

ANTÓNIO MANUEL LOPES ANDRADE

CARLOS DE MIGUEL MORA

JOÃO MANUEL NUNES TORRÃO

(COORDS.)

AVEIRO • COIMBRA • SÃO PAULO

2015

UA EDITORA • UNIVERSIDADE DE AVEIRO

IMPRENSA DA UNIVERSIDADE DE COIMBRA

ANNABLUME 
OBRA PUBLICADA

COM A COORDENAÇÃO

CIENTÍFICA DE:

CENTRO DE LÍNGUAS,

LITERATURAS E CULTURAS DA

UNIVERSIDADE DE AVEIRO

CENTRO DE ESTUDOS

CLÁSSICOS E HUMANÍSTICOS DA

UNIVERSIDADE DE COIMBRA

CÁTEDRA DE ESTUDOS SEFARDITAS

"ALBERTO BENVENISTE"

DA FACULDADE DE LETRAS DA

UNIVERSIDADE DE LISBOA 


\section{SUMÁRIO}

PREFÁCIO

1.1 "Teofrasto, Tratado das plantas. No alvor de uma nova ciência" 13

Maria de Fátima Silva

1.2 "Francisco de Melo e os fragmentos de teoria óptica de Pierre Brissot" 21 Bernardo Mota

1.3 "Algumas reflexões sobre as pedras preciosas nos Colóquios dos simples de Garcia de Orta" 37 Rui Manuel Loureiro

1.4 "Estratégias, patronos e favores em Colóquios dos Simples de Garcia de Orta" 63 Teresa Nobre de Carvalho

1.5 "As plantas na obra poética de Camões (épica e lírica)" 95 Jorge Paiva

1.6 "Nicolás Monardes, John Frampton and the Medical Wonders of the New World" .141 Donald Beecher

1.7 "Literatura e Medicina: alguns textos de Justo Lípsio e de dois doutores Luís Nunes" 161 António Guimarães Pinto

1.8 "Ontologias e idiossincrasias dos Amantes, à luz da Archipathologia de Filipe Montalto" ...... 211 Joana Mestre Costa \& Adelino Cardoso

1.9 "Gabriel da Fonseca. A New Christian doctor in Bernini's Rome". .227 James W. Nelson Novoa 


\section{2) DIOSCÓRIDES E O HUMANISMO PORTUGUÊS: OS COMENTÁRIOS DE AMATO LUSITANO}

2.1 "Léxico científico português nos Comentários de Amato: antecedentes e receção"

Ana Margarida Borges

2.2 "Usos medicinais das plantas, em Amato Lusitano: o bálsamo"

António Maria Martins Melo

2.3 "Amato Lusitano e a importância da ilustração botânica no século xVI.

Em torno das edições lionesas das Enarrationes (1558)"

Carlos A. Martins de Jesus

2.4 "Sobre la identificación entre ébano y guayaco en una entrada

del Index Dioscoridis de Amato Lusitano".

Carlos de Miguel Mora

2.5 "Os partos distócicos em Amato Lusitano e em Rodrigo de Castro:

fontes, doutrinas e terapias greco-romanas"

\section{Cristina Santos Pinheiro}

2.6 "Do carvalho ao castanheiro: usos e propriedades medicinais

de fagáceas nas Enarrationes de Amato Lusitano".

Emília Oliveira

2.7 "O mundo mineral nos Comentários a Dioscórides de Amato Lusitano".

Isabel Malaquias \& Virgínia Soares Pereira

2.8 "Alguns comentários de Amato: entre a estranheza e a realidade"

João Manuel Nunes Torrão

2.9 "Caracterização e usos terapêuticos de produtos de origem marinha

nos Comentários de Amato Lusitano a Dioscórides"

José Sílvio Moreira Fernandes

2.10 "La mandrágora de Amato Lusitano: edición, traducción y anotación"

Miguel Ángel González Manjarrés

2.11 "O vinho e os vinhos - usos e virtudes de um dom dos deuses

nas Enarrationes de Amato Lusitano"

Telmo Corujo dos Reis

2.12 "Amatus Lusitanus e Didaco Pirro: due ebrei portoghesi

e cerchia umanistica di Dubrovnik" 481

Vinicije B. Lupis

2.13 "Estudos contemporâneos sobre Amato Lusitano". 513

João Rui Pita \& Ana Leonor Pereira 


\section{Prefácio}

Este volume resulta de várias iniciativas desenvolvidas no âmbito do projecto de I\&D "Dioscórides e o Humanismo Português: os Comentários de Amato Lusitano", financiado pela Fundação para a Ciência e a Tecnologia (http://amatolusitano.web.ua.pt), recolhendo contribuiçóes de mais de duas dezenas de colaboradores, tanto de membros da equipa do projecto como de outros investigadores nacionais e estrangeiros. Entre os eventos que estiveram na origem deste livro destacam-se as três ediçóes do Ciclo de Conferências promovido pelo projecto, realizadas entre 2010 e 2013, e sobretudo o Colóquio Internacional "Dioscórides e o Humanismo Português: os Comentários de Amato Lusitano”, que decorreu no Departamento de Línguas e Culturas da Universidade de Aveiro, nos dias 21 e 22 de Novembro de 2013.

O objectivo principal do projecto é a edição e tradução para português dos dois livros que Amato Lusitano dedicou ao comentário do tratado grego De materia medica de Dioscórides, ou seja, o Index Dioscoridis (Antuérpia, 1536) e as In Dioscoridis Anazarbei de medica materia libros quinque...enarrationes (Veneza, 1553), estando contemplada, também, a tradução de mais duas obras directamente correlacionadas com os livros do médico português: a montante, a do próprio tratado grego de Dioscórides; a jusante, a do livro intitulado Apologia adversus Amathum Lusitanum (Veneza, 1558) do humanista Pietro Andrea Mattioli.

Os trabalhos em curso constituíram-se como o ponto de partida de uma reflexão alargada sobre as relaçóes entre Humanismo e Ciência, percepcionadas a partir do diálogo fecundo entre dois tempos tão próximos quão afastados: Antiguidade e Renascimento. Naturalmente, a própria matéria médica representa o eixo central em torno do qual gravita a maioria dos estudos deste volume, cujas ramificaçôes se estendem a múltiplos saberes no domínio da Botânica, Farmácia, Geologia, História, Lexicografia, Literatura, Medicina ou Zoologia.

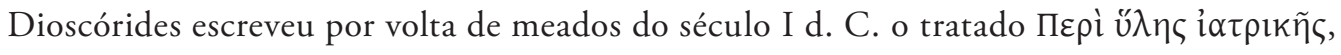
conhecido comummente pela sua designação latina De materia medica, uma obra matricial no âmbito da Medicina e da Farmácia desde a Antiguidade Clássica até ao Renascimento, porquanto os cinco livros em que se divide constituem um verdadeiro catálogo das substâncias com propriedades medicinais de origem animal, mineral e sobretudo vegetal. Esta obra conheceu 
ao longo dos séculos uma tradição manuscrita riquíssima e uma difusão a todos os títulos extraordinária (latina e árabe) em razão da enorme utilidade que sempre lhe foi reconhecida.

O interesse pela obra de Dioscórides viria a recrudescer no final do século xv, após a publicação da primeira edição em língua grega do De materia medica, saída dos prelos venezianos de Aldo Manúcio, em 1499. Esta edição singular constituiu um autêntico marco de viragem no estudo e na divulgação do tratado grego, já que colocou a obra de Dioscórides no centro do interesse e da atenção dos mais reputados humanistas e homens do saber. Ao longo do século XVI, sucedem-se por toda a Europa as edições, traduçôes e comentários do tratado a um ritmo verdadeiramente impressionante, favorecidos pela ampla generalização da imprensa e pela rápida evolução das técnicas e métodos utilizados no processo editorial. Surgem em múltiplos formatos novas edições do texto grego, inúmeras traduções tanto em latim como em vernáculo, acompanhadas com frequência de profusos comentários, por vezes publicados de forma independente.

Os diversos humanistas que desde os finais do século Xv editaram, comentaram e traduziram o tratado matricial de Dioscórides estão na origem de um processo acelerado de (re)conhecimento do mundo natural, ancorado no método filológico de estudo dos textos greco-latinos, propugnado por Nicolò Leoniceno, e nos resultados cada vez mais desafiantes carreados pela observação e pela experimentação de uma realidade tantas vezes nova e completamente desconhecida. Quase em simultâneo, os descobrimentos portugueses e espanhóis desempenharam um papel crucial no avanço do conhecimento do mundo natural, contribuindo para a ultrapassagem definitiva dos limites que condicionaram as grandes referências da Antiguidade (Hipócrates, Teofrasto, Dioscórides, Plínio, Galeno). E, neste movimento de largo espectro, tomaram parte alguns dos autores em destaque neste volume, seja através do estudo da própria matéria médica e/ou da medicina (Amato Lusitano, Filipe Montalto, Gabriel da Fonseca, Garcia de Orta, John Frampton, Luís Nunes de Santarém, Nicolás Monardes, Rodrigo de Castro), seja através do culto da poesia (Camóes, Diogo Pires, Luís Nunes), seja através da matemática (Pierre Brissot, Francisco de Melo).

A partir dos alvores do século XVI, a matéria médica torna-se indiscutivelmente um tema de primeira grandeza entre os membros da República das Letras, objecto de estudo e de acesa controvérsia entre os mais notáveis humanistas europeus, em particular entre aqueles que se dedicavam ao exercício da arte de Galeno. Entre os autores em destaque neste volume encontram-se, à cabeça, os nomes de Amato Lusitano, Garcia de Orta e Nicolás Monardes, famosos pelos contributos que deram para o conhecimento do mundo natural. Os restantes médicos em evidência nos estudos apresentados neste livro possuíam igualmente um interesse particular pela matéria médica, tanto mais que o exercício da sua actividade dependia directamente desse conhecimento. Bastará recordar, por exemplo, que Pierre Brissot, doutor em Medicina pela Universidade de Paris, viajou para Portugal, em 1518, com o fito de investigar as novíssimas matérias que eram trazidas dos territórios ultramarinos e que estavam a chegar 
aos mercados europeus através do eixo Lisboa-Antuérpia; ou que Luís Nunes de Santarém, colega de Amato no Estudo de Salamanca, depois de chegar a Antuérpia em 1544, após ter honrado a Universidade de Coimbra com o seu magistério, decidiu permanecer bastante mais tempo do que previa no empório do Escalda, segundo relata em carta dirigida a Diogo de Murça, porquanto aí foi encontrar, em larga abundância, duas coisas do seu maior interesse: livros e matéria médica.

Não se estranha que entre os autores estudados neste livro figurem vários médicos cristãosnovos em diáspora (Amato Lusitano, Filipe Montalto, Gabriel da Fonseca, Garcia de Orta, Luís Nunes, Luís Nunes de Santarém, Rodrigo de Castro), confirmando a antiga predilecção hebraica pelo exercício da arte de Galeno e evidenciando a profunda chaga aberta na sociedade portuguesa pela questão judaica. É assim possível acompanhar neste livro o percurso e a actividade de muitos destes médicos notáveis, que se destacaram por toda a Europa no exercício, estudo e ensino da Medicina.

$\mathrm{O}$ volume encontra-se dividido em duas partes distintas: a primeira, subordinada ao título "Humanismo e Ciência", alberga os estudos que versam sobre todos os autores supramencionados, à excepção de Amato Lusitano; a segunda está reservada a um conjunto de trabalhos dedicados exclusivamente ao médico albicastrense, cuja autoria se fica a dever, em grande medida, aos membros da equipa do projecto de investigação, tomando, por isso, o seu próprio título - "Dioscórides e o Humanismo Português: os Comentários de Amato Lusitano". No fundo, nesta segunda parte, oferece-se, desde já, aos leitores deste livro uma amostra significativa do trabalho que tem vindo a ser desenvolvido no âmbito do projecto e que culminará, assim o esperamos, na edição e tradução integral para língua portuguesa das quatro obras previstas de Dioscórides, Amato Lusitano e Pietro Andrea Mattioli.

$\mathrm{Na}$ verdade, os comentários de Amato Lusitano a Dioscórides constituíram-se como o coração deste projecto ambicioso, que envolve um conjunto alargado de investigadores, tanto de tradutores do grego e do latim como das áreas científicas mais directamente ligadas à matéria médica. Os comentários de Amato Lusitano a Dioscórides inserem-se no movimento humanista de regresso à pureza das obras matriciais da Antiguidade Clássica, de que o tratado grego é um exemplo paradigmático. São textos de carácter muito diversificado que não se cingem apenas ao âmbito estritamente filológico, porquanto constituem, no seu todo, uma manifestação significativa da contribuição decisiva dada pelo Humanismo português para a revolução cultural e científica que, nos séculos XV e XVI, abalou as estruturas da sociedade europeia e rasgou as fronteiras do mundo conhecido, abrindo as portas à modernidade.

A publicação deste livro muito deve à parceria estabelecida entre o Centro de Línguas, Literaturas e Culturas da Universidade de Aveiro, no âmbito do projecto de I\&D "Dioscórides e o Humanismo Português: os Comentários de Amato Lusitano”, o Centro de Estudos 
Clássicos e Humanísticos da Universidade de Coimbra e a Cátedra de Estudos Sefarditas "Alberto Benveniste" da Faculdade de Letras da Universidade de Lisboa, que uniram esforços com o objectivo de proporcionar uma reflexáo alargada sobre o tema que deu o mote a este volume - Humanismo e Ciência —, no qual se entrecruzam saberes, espaços e tempos diversos.

Tem sido para nós um grato privilégio levar por diante a coordenação deste projecto de investigaçáo, cuja consecuçáo se deve, em primeiro lugar, ao empenho e à dedicaçáo dos membros da equipa e dos consultores científicos, bem patente na forma maciça como deram a sua colaboração para este volume. Cumpre-nos manifestar aqui os nossos penhorados agradecimentos a todos quantos contribuíram para que este livro fosse publicado, muito particularmente aos autores dos estudos, que gentilmente aceitaram o nosso desafio, aos membros da Comissão Científica e às instituições editoras e financiadoras.

\author{
António Manuel Lopes Andrade \\ Centro de Línguas, Literaturas e Culturas \\ Universidade de Aveiro \\ aandrade@ua.pt
}

NOTA: neste volume respeitou-se a opção de cada autor quanto à adopção do novo Acordo Ortográfico (1990). 
(Página deixada prepositadamente em branco.) 


\section{Teofrasto, Tratado das plantas. No alvor de uma nova ciência}

MARIA DE FÁTIMA SILVA ${ }^{1}$

\section{RESUMO:}

Ao propor-se a abordagem de uma nova ciência - a Botânica — Teofrasto pondera também a metodologia a seguir e a definição de uma terminologia técnica adequada. Para responder a estas questões, serve-se da experiência colhida já numa ciência paralela - a Biologia - , com a qual convivia dentro da escola de Aristóteles. Apesar de encontrar nessa aproximação sugestões úteis, Teofrasto nunca deixa de afirmar as diferenças que distinguem os dois objectos de estudo, animais e plantas.

\section{PALAVRAS-CHAVE:}

metodologia; terminologia; partes; peripatéticos.

\section{ABSTRACT:}

On approaching a new science - Botanic - Theophrastus reflects on methodology and a specific terminology to be used. The experience of a parallel science - Biology - , quite well known in the Lyceum, is clearly useful. Although being conscious about similarities between the two sciences, Theophrastus also recognizes differences between the object of each of them, animals and plants.

KEYWORDS:

methodology; terminology; parts; peripatetic school.

1 Centro de Estudos Clássicos e Humanísticos da Universidade de Coimbra: fanp@fl.uc.pt. 
Porque se trata do arranque para uma ciência inovadora ${ }^{2}$, o Tratado das plantas abre com uma reflexão sobre o que parece a Teofrasto essencial nos objectivos a atingir e na metodologia a praticar ${ }^{3}$. Ora justamente as questóes metodológicas, conformes com as praticadas entre os peripatéticos e que estão na base das colocadas pela ciência através do tempo ${ }^{4}$, constituem um dos aspectos mais atractivos no estudo dos tratados científicos legados pela Antiguidade, apesar de todas as dúvidas ou limitaçóes que a definição de uma metodologia deixa de pé. No Tratado das plantas esta é matéria que ocupa o Livro I e os primeiros capítulos do II (1-4).

O Liceu e o seu mestre fundador, Aristóteles, proporcionaram a Teofrasto um modelo natural: o estudo de um outro grupo de seres vivos, os animais, a que haviam sido já dedicados tratados abrangentes, A História dos animais - que enumera e descreve os animais e tenta uma classificação através do estabelecimento de semelhanças e diferenças entre os diversos grupos - e As Partes dos animais - que avança para um estudo mais específico, procurando identificar as partes e a sua utilidade para a vida de cada espécie 5 . Nessa investigação, levada a cabo por Aristóteles, o próprio Teofrasto terá tido uma intervenção directa. Não há dúvida de que as remissóes para esses dois tratados aristotélicos são numerosas no Tratado das plantas, do mesmo modo que é constante a preocupação de estabelecer contrastes entre o raciocínio que funciona no estudo dos animais, mas não no das espécies vegetais (1.3): 'Não se deve estabelecer uma correspondência total com os animais, nem no que se refere à reprodução, nem sob outro qualquer ponto de vista'.

Teofrasto acentua e especifica, entre animais e plantas, as divergências sob perspectivas encaradas em paralelo - ou seja, a partir de ciência feita, procede por sucessivas comparaçóes: se, por exemplo, os frutos de uma planta podem ser considerados 'partes', as crias dos animais

2 Apesar de já ter havido, em época anterior, algumas abordagens das questões suscitadas pelas plantas - nos tratados hipocráticos, ou por nomes avulso de interessados pelo poder curativo das plantas, como Díocles de Caristo, por exemplo - tem sido reconhecido a Teofrasto o mérito de ter dado os primeiros passos no sentido de fazer do estudo das plantas uma verdadeira ciência e, nessa medida, ser o verdadeiro criador da Botânica.

3 Diógenes LAÉRCIO 5. 42-50 atribui a Teofrasto dois tratados dedicados às plantas; além daquele em que se centra este estudo (em 9 livros), também o intitulado Causas das plantas (em 6 livros), voltado para questões de morfologia e fisiologia. Aristóteles teria já avançado com algumas considerações elementares nesta matéria; por um lado, são frequentes as observações comparativas entre animais e plantas nos estudos que o Estagirita dedicou à biologia; vide Costas A. Thanos, "Aristotle and Theophrastus on plant-animal interactions", in Margarita ARIANOUTSOU and Richard H. GROVES, Plant-Animal Interactions in Mediterranean-Type Ecosystems. Dordrecht/Boston/London, Kluwer Academic Publishers, 1994, pp. 3-11; e num estudo em dois livros Sobre as plantas, de autoria controversa, que seria uma tentativa de classificação das espécies. Teofrasto teria levado esta abordagem bastante mais longe.

4 O mérito que Wolfgang KullmanN, "Aristotle as a natural scientist", Acta Classica 34 (1991), p. 137. atribui a Aristóteles - 'o de ter validado, com suporte teórico, a fundação das ciências' — seria oportuno também para Teofrasto, na perspectiva das plantas em particular, dada a estreita colaboração que ambos partilharam.

5 O próprio TeOfRASto foi autor de um tratado de biologia, Sobre os animais, em sete livros, referido também por Diógenes LAÉRCIO 5.44. 
não; uns e outros têm partes caducas (no animal, cornos, penas e pêlos, HA 600a 15-16); mas, sob o ponto de vista da reprodução, o fruto desvincula-se por completo da planta, enquanto, nos animais, há produtos que prevalecem para além da gestação (o leite, a placenta, por exemplo); a reprodução animal tende à propagação da espécie, enquanto a planta se desenvolve toda ela ao longo da sua existência ${ }^{6}$; logo as flores, folhas e frutos poderiam ser partes, as crias não' (1.3).

Ponderadas estas diversas razóes, pode Teofrasto concluir pelas limitações deste método comparativo entendido sistematicamente, quando estão em causa seres tão diferentes (1.4): 'É pura perda de tempo empenharmo-nos em estabelecer comparações impossíveis, acabando por nos desviarmos do nosso objecto de estudo'. Mesmo assim, embora forçado a encontrar para a Botânica uma índole científica própria, face às características do seu objecto de estudo, a comparação nunca é posta de lado pelas comodidades que oferece apesar de todas as suas limitaçôes. Como nota Jacques Desautels ${ }^{7}$, 'o propósito de Teofrasto assenta numa investigação em que não só as conclusões mas também a própria metodologia estão em progresso'.

Parece inevitável considerar a observação como a primeira técnica a pôr em prática; um tratado científico credível tem de assentar na recolha de dados, sua comparação e análise. Antes de satisfeitas as regras da historia, ou seja, a recolha de testemunhos directos e a sua avaliação, não há condições para definir e tratar qualquer objecto de estudo. A seguir, a classificação é, para o Tratado das plantas, a questão de fundo: o que distingue uma planta de outra, ou seja, a possibilidade de estabelecer uma classificação por critérios de semelhança ou diferença entre elas e o que constitui a natureza própria de cada uma perante as demais; logo, a comparação entre os diversos seres que constituem um mesmo género e o confronto com géneros equivalentes está no cerne da proposta. A relação entre 'o mais e o menos' é usada como um critério decisivo no estabelecimento de semelhanças ou diferenças morfológicas. A História dos animais é, para este propósito, o modelo directo.

Embora reconhecendo as dificuldades que a classificação coloca, por divergência de critérios ou por ineficácia ou incompletude de alguns deles, mesmo assim Teofrasto defende esta metodologia como a mais correcta (1.3.1); o resultado que almeja, após a observação das plantas e suas partes, é poder compará-las e, a partir daí, estabelecer grupos. Desautels ${ }^{8}$ sublinha a importância e frequência com que Teofrasto usa a expressão 'considerar em termos gerais', talvez desde logo uma salvaguarda para rentabilizar princípios e critérios, torneando a sua falibilidade no particular. O resultado produzido é, em concomitância, uma visão de conjunto das plantas, acrescida de noçôes de base sobre os problemas gerais que estes seres implicam.

6 Suzanne Amigues, Théophaste. Recherches sur les plantes. Paris, Les Belles Lettres, 2010, p. 4.

7 Jacques Desautels, "La classification des végétaux dans la Recherche des plantes de Théophraste d'Erésos", Phoenix 42.3 (1988), pp. 231-232.

8 Jacques Desautels, "La classification ...", op. cit., p. 224 n. 16. 
A metodologia comparativa exige o estabelecimento de critérios de distinção; à semelhança dos estabelecidos por Aristóteles em $H A$ 487a 11-12 - 'As diferenças entre os animais dizem respeito ao seu modo de vida, actividade, carácter e partes que os constituem' - também Teofrasto (1.1) enumera, como factores a considerar neste caso, 'as partes, as qualidades, a reprodução e as fases da vida'; e tem o cuidado de excluir 'o carácter e as actividades' e de justificar essa opção com as diferenças que distinguem plantas e animais; embora sendo todos seres vivos, os factores de distinção impóem à partida diferenças radicais.

Além do critério de semelhança e diferença, Teofrasto recupera, da ciência feita para os animais, o de analogia. Lembremos a definição, acrescida de exemplos, que dele dá Aristóteles (HA 645b 6-8): 'Por analogia entendo que, por exemplo, uns tantos animais tenham pulmão e outros não; mas que estes últimos, em contrapartida, tenham um outro órgão correspondente; ou ainda: uns têm sangue e outros um líquido análogo, com a mesma função que aquele desempenha nos sanguíneos' (cf. HA 486b 17 sqq., PA 644a 18). Claramente a analogia pode dar também um contributo útil para o propósito de fundo em Teofrasto, o da classificação das plantas.

Estabelecidos os factores relevantes para a caracterização das plantas, há que hierarquizá-los, do ponto de vista pragmático, fazendo avultar aqueles que se podem abordar por simples observação e que portanto surgem, ao estudioso, como mais imediatos e menos complexos. Esta verificação coloca as 'partes', referidas em primeiro lugar, como um elemento a merecer, pela sua complexidade, um tratamento longo e destacado. Naturalmente o tratado aristotélico das Partes dos animais tem, com esta preocupação, um diálogo próximo.

A objectividade que se exige dos factores utilizados na determinação de semelhanças, diferenças e analogias cria, no que diz respeito às partes das plantas, um problema metodológico de base; a questấo resulta, por um lado, da variedade que lhes é própria, criando, do ponto de vista metodológico, alguma instabilidade; mas dada a importância que têm na caracterização das plantas, impóem-se como um factor prioritário e tornam outros aspectos — as qualidades, a reprodução e o modo de vida —, porque mais visíveis ou mais simples, secundários. Assim, antes de se partir para a classificação segura das plantas, há que clarificar o que se pode ou não considerar 'partes' e estabelecer uma nomenclatura técnica correspondente.

É interessante apreciar as dificuldades colocadas pela definição de uma nomenclatura técnica e as soluções usadas para a construção de um vocabulário científico. Desautels ${ }^{9}$ não hesita em considerar a insegurança terminológica 'como uma das maiores lacunas de Teofrasto', 'que o impediu de atingir um certo nível de ciência ou, pelo menos, de estabelecer entre os seres distinçôes válidas na perspectiva moderna'; talvez haja nesta reprovação do estudioso francês

9 Jacques Desautels, "La classification ...", op. cit., p. 238. 
algum exagero, ou desconhecimento do percurso moroso que a análise científica trilha em diálogo com a língua que lhe dá expressão.

O chamado 'senso comum' foi para Teofrasto, como antes para Aristóteles, uma fonte importante de informações e de soluçôes terminológicas; a consulta de agentes comuns — jardineiros e médicos, por exemplo, uns e outros, por motivos diferentes, bons conhecedores das plantas - forneceu-lhe uma visão concreta e uma designação, buscada na linguagem quotidiana, para as plantas, sua estrutura e grupos em que se dividem. Também aqui o confronto com as soluçóes encontradas pela biologia pôde servir de modelo e, de uma forma que se poderá dizer 'analógica', fornecer respostas. É o caso das 'fibras' e 'veias' nas plantas, que não chegam a ter uma designação específica, mas 'por semelhança, recebem as das partes correspondentes nos animais' (1.2.3, cf. 1.2.5). Igual estratégia é usada por outros fisiólogos que se viram a braços com o mesmo problema (1.2.6): 'A medula é o miolo da madeira e vem em terceiro lugar a contar da casca, como nos ossos a medula. Há quem lhe chame 'coração', outros 'coração da madeira'. É curioso registar o recurso a uma nomenclatura bem assente para situaçôes equivalentes nos animais, com o acrescento de uma precisão que assinale a semelhança e a novidade de aplicação ('coração da madeira', por exemplo). Teofrasto parece não hesitar, também nesta perspectiva, em recuperar uma nomenclatura que se tinha tornado corrente entre outros autores dedicados a especulaçóes semelhantes.

A abordagem das partes das plantas reparte-se em várias perspectivas: além da definição do que seja 'parte' e do estabelecimento de uma nomenclatura adequada, impóe-se fazer a caraterização de cada uma dessas partes e da sua finalidade. A definição de 'parte' cita-se como uma primeira exigência (1.2): 'É algo inerente à natureza específica de qualquer planta e parece estar sempre presente, quer em termos absolutos, quer quando aparece (à semelhança do que, nos animais, se desenvolve mais tarde)'. Por 'estar sempre presente' deve entender-se como permanente em todas as plantas do mesmo grupo. Não estamos muito longe do que Aristóteles entende por partes, referindo-se aos animais; a 'partes' é por ele dado um sentido abrangente, que inclui tecidos, órgãos, membros e, de um modo geral, os elementos constitutivos de todos os grupos de animais.

Este aspecto fulcral da 'permanência' que, nos animais, era adequado, coloca, no caso das plantas, dificuldades manifestas. É que há elementos na planta (flor, folha, fruto) que são de uma relevância incontestável, e no entanto têm uma duração limitada a um ano e sempre renovável. Variação e caducidade tornam a definição de 'parte' metodologicamente difícil e em conflito com a que, se aplicada aos animais, funciona. Uma tentação poderia ser a de excluir estes elementos como 'partes', pelos seus aspectos de incompatibilidade com questôes de base nessa definição; e, no entanto, a importância dos elementos referidos, 'que constituem a plenitude e a fisionomia das plantas', não pode ser eliminada sem grave prejuízo para o propósito científico em causa. De resto a finalidade - que é um critério essencial na definição de 'parte' 
- implica a sua inclusão: 'Porque qualquer planta se torna bela e parece atingir, ou melhor, atinge de facto, a sua plenitude quando rebenta, floresce ou frutifica'.

Verificada a inconveniência de ir pela exclusão deste factor, Teofrasto integra-o na sua abordagem e passa então a procurar uma esquematização geral da própria parte; nesse sentido, diferentes critérios podem ser adoptados. Dividi-las em internas e externas estabelece uma dicotomia de base, a que se anexa uma estratégia de estudo conforme com as exigências que tal divisão acarreta: para o conhecimento das partes exteriores basta a simples observação; para o das internas existe, como para os animais, a dissecção (cf. HA 503b 23-25, 531b - 532a). Junta-se-lhe uma segunda perspectiva, a da abrangência que uma parte pode ter dentro do universo das plantas: se é comum a todas, se particular a um determinado grupo apenas; e, num ou noutro caso, se apresenta semelhanças ou diferenças — de acordo com um critério de excesso ou defeito (cf. HA 486b) — e se existe na mesma posição ou noutra (1.6-7) — problema que se coloca em relação aos frutos, folhas e rebentos.

Só depois de estabelecidos estes critérios gerais de identificação e de comparação, se pode especificar cada uma das partes e passar à sua caracterização. Ao leitor atento do tratado não passarão despercebidas algumas incongruências ou imperfeições metodológicas; além da complexidade sempre assinalada do objecto de estudo, a natureza do tratado, como repositório de um conhecimento a divulgar oralmente em espaço de aula, implica um registo mais ou menos condicionado e uma actualização progressiva, responsável por muitos desajustes.

As partes que, certamente de acordo com a sua função, se podem considerar mais importantes, como também comuns a um maior número de plantas e tendencialmente perenes, são então referidas: raiz, caule, ramo e rebento; a que se acrescentam as que se renovam cada ano e contribuem para a sua reprodução: folhas, flores e fruto. A raiz pode desempenhar, no conjunto, um papel destacado; do mesmo modo que Aristóteles define a boca como o órgão mais relevante do ser vivo, que lhe permite alimentar-se e nutrir-se, Teofrasto faz da raiz, nas plantas, o seu equivalente (1.1.9), dentro do conceito aristotélico (cf. PA 650a) de que 'a terra é o estômago dos animais'.

As árvores, sendo as espécies a que estes elementos essencialmente correspondem, podem considerar-se paradigmáticas na classificação que se pretende esboçar (1.1.11). Tomadas como modelo, é a partir delas que, demarcando diferenças (abundância ou carência, densidade ou rarefacção, por exemplo), se pode caracterizar melhor as restantes plantas; no reino vegetal, parece caber às árvores o papel que, entre os animais, cabe ao Homem, como o mais bem conhecido e mais perfeito de todos os seres dessa espécie ${ }^{10}$. Esta é uma metodologia que obedece

10 Também ARISTóteles coloca no centro do seu projecto um primeiro caso individual, e esse é o ser humano, sobre o qual um melhor conhecimento está garantido pela própria familiaridade que dele aproxima o cientista (491a 23). E se preferimos o animal que melhor conhecemos, dele se exploram também, em primeiro lugar, 'as partes mais importantes, que compõem o corpo na sua totalidade' (491a 27-28). 
a um enunciado prático (1.2.3): 'Como se deve avançar do que é conhecido para chegar ao desconhecido e mais conhecido é o que é maior ou mais patente aos nossos sentidos, é óbvio que se deve tratar desses assuntos segundo essa metodologia'11. Uma lógica de paralelismo permitirá, a partir do que é conhecido e perceptível, especular sobre o desconhecido e menos acessível ${ }^{12}$.

Identificadas as várias partes, o estudo das plantas pode então processar-se tendo em consideração dois aspectos: o estabelecimento de diferenças gerais entre as plantas no que se refere às partes essenciais; e a consideração das potencialidades e razão da existência ou finalidade de cada uma dessas partes. A partir das árvores, não só se pode estabelecer diferenças em relação a cada planta, como demarcar conjuntos de plantas; ou seja, de uma abordagem analítica encara-se a necessidade de promover sínteses, de modo a criar grupos. Estamos realmente a caminho de uma classificação.

Tidas as árvores como paradigma, devido às partes que nelas são claramente visíveis, Teofrasto ensaia uma primeira classificação de plantas em quatro grandes grupos: 'árvores, arbustos, subarbustos e ervas' (1.3.1). A execução prática desta primeira grande classificação — que assenta apenas em aspectos exteriores, como o tamanho e a ausência ou presença de certas partes — irá denunciar debilidades, que recusam ou contestam a virtude dos critérios dicotómicos estritos (1.3.2): 'Em certos casos pode parecer que a nossa classificação sofre alteraçóes; e, em contrapartida, há plantas que, em cultivo, se tornam diferentes e parecem mudar de natureza'. A complexidade vai-se tornando patente, pela intromissão de vários factores no rigor básico das diferenças entre grupos. Factores exteriores às próprias plantas condicionam-nas e podem criar alteraçôes profundas nas suas características. É o caso das condições de manutenção, que distinguem de modo profundo plantas de cultivo e as suas correspondentes em estado selvagem; ou naturalmente o habitat (por exemplo a distinção entre plantas terrestres e aquáticas) e as condiçôes geográficas ou climatéricas ${ }^{13}$. Apesar dos imprevistos que estes outros factores acarretam, há que tê-los em consideração na sua 'permanência', na medida em que a vida de nenhuma planta lhes é alheia.

11 Cf. HA 495b 14-16, 506a 7-8, 513a 33-36, 515a 19-23.

12 Como fontes para a sua investigação, Teofrasto terá privilegiado a observação directa, processada em deslocações ou estadias mais ou menos prolongadas por várias regiões (a ilha de Lesbos, a Tróade, a Macedónia e a Ática, Arcádia e Egipto), como também a leitura de informações produzidas por outros autores que, por diversas razões, se interessaram por questões relacionadas com vegetais, desde logo os historiadores e geógrafos, relatores de paisagens estranhas ou desconhecidas; já antes deles Homero e as artes plásticas foram responsáveis pela menção de um número elevado de espécies vegetais; vide Arthur Stanley PEASE, "A sketch of the development of ancient botany", Phoenix 6.2 (1952), pp. 44-51. A partir de todos estes elementos, o fisiólogo elabora uma reflexão, depurando os usos tradicionais e estabelecendo uma verdadeira problemática.

13 S. Amigues, Théophraste. Recherches ... , op. cit., p. xv, não hesita em afirmar que a transplantação de espécies selvagens para jardins ou o cultivo de plantas exóticas, provindas de outros habitats, constituía um tipo de experiência corrente. 
Assim, a observação das plantas, tal como a dos animais, permite ao naturalista reconhecer, no concreto, as consequências dos grandes princípios que regem a actuação da natureza, no que é a constituiçáo dos seres com vista a uma funcionalidade harmoniosa, na relação interna entre as partes que os constituem e, pontualmente, no convívio entre espécies ou de cada uma com o habitat que a cerca. Há que estabelecer critérios que permitam a transição de um conhecimento geral ou indeterminado para outro, circunscrito e específico às situaçóes concretas.

E é talvez esta a exigência que trava, de certa forma, o alcance do tratado de Teofrasto dedicado à Botânica. O grau de sistematização conseguido é modesto, o efeito final aproxima-se mais de um relato de diferentes espécies do que de uma classificação, o desrespeito pela própria proposta metodológica é patente em certos momentos, a hierarquização das plantas carece de rigor. Mesmo assim, Teofrasto abre caminhos, no estabelecimento de parentescos entre as espécies, de grandes divisões e agrupamentos, que se tornam remissão necessária para os grandes passos dados pela Botânica no futuro.

\section{BIBLIOGRAFIA}

Amigues, Suzanne, Théophraste. Recherches sur les plantes. Paris, Les Belles Lettres, 2010.

Desautels, Jacques, "La classification des végétaux dans la Recherche des plantes de Théophraste d' Erésos", Phoenix 42.3 (1988), pp. 231-232.

Kullmann, Wolfgang, “Aristotle as a natural scientist”, Acta Classica 34 (1991), pp. 137-150.

Pease, Arthur Stanley, "A sketch of the development of ancient botany", Phoenix 6.2 (1952), pp. 44-51.

Thanos, Costas A., "Aristotle and Theophrastus on plant-animal interactions", in Margarita Arianoutsou, and Richard H. Groves, Plant-Animal Interactions in Mediterranean-Type Ecosystems. Dordrecht/Boston/ London, Kluwer Academic Publishers, 1994, pp. 3-11. 


\section{Francisco de Melo e os fragmentos de teoria óptica de Pierre Brissot ${ }^{1}$}

BERNARDO MOTA ${ }^{2}$

\section{RESUMO:}

Nos comentários a obras de Euclides e de (pseudo-)Arquimedes escritos por Francisco de Melo (1490-1536) enquanto esteve ligado à Universidade de Paris, apresentam-se dois argumentos de natureza óptica que são atribuídos a Pierre Brissot. Neste artigo, explicaremos o significado e o contexto destes argumentos, para mostrar o que eles nos dizem dos comentários do próprio Melo.

\section{PALAVRAS-CHAVE:}

Francisco de Melo; Pierre Brissot; Euclides; Óptica.

\section{ABSTRACT:}

In the commentaries on works of Euclid and (pseudo-)Archimedes written by Francisco de Melo (1490-1536) while he was affiliated with the University of Paris, one can read two arguments about optical matters which are attributed to Pierre Brissot. In this article, I explain the meaning and context of these arguments, in order to unveil what they tell us about the nature of Melo's commentaries.

KEYWORDS:

Francisco de Melo; Pierre Brissot; Euclid; Optics.

1 A investigação que deu origem a este artigo foi realizada no âmbito do Projecto Melo, financiado pela Fundação para a Ciência e Tecnologia (EXPL/IVC-HFC/1290/2012). Gostaria de deixar expresso o meu agradecimento aos organizadores do Colóquio Dioscórides e o Humanismo Português: os comentários de Amato Lusitano (Departamento de Línguas e Culturas da Universidade de Aveiro, 21-22 de Novembro de 2013), onde apresentei o conteúdo deste artigo, em especial a António Andrade. Agradeço também a Henrique Leitão, pelo apoio inestimável e pela leitura do artigo.

2 Centro de Estudos Clássicos — Faculdade de Letras da Universidade de Lisboa: bernardomota@ campus.ul.pt. 


\section{CONTEXTUALIZAÇÃO}

Francisco de Melo foi um importante matemático português que viveu entre 1490 e 1536. Estudou e leccionou na Universidade de Paris, onde redigiu, em latim, um conjunto de comentários a obras de Euclides (Óptica, Catóptrica) e de pseudo-Arquimedes (Sobre objectos incidentes em líquidos). Durante muito tempo, conhecia-se apenas uma única cópia destes comentários, que pertencia às colecçóes da Biblioteca Nacional de Portugal. Em 2011 descobriu-se, numa biblioteca alemã (Arquivo Municipal de Stralsund), o manuscrito original que Melo mandou executar, a partir do seu autógrafo (que não possuímos), e ofereceu ao Rei D. Manuel I, como forma de agradecimento pelo apoio dado pelo monarca à sua estadia em Paris. ${ }^{3}$

O texto de Francisco de Melo é amplamente conhecido entre especialistas, desde que António Ribeiro dos Santos o referiu, em 1806. ${ }^{4}$ Desde então, a necessidade de o estudar numa perspectiva portuguesa e europeia tem sido realçada por muitos estudiosos nacionais e estrangeiros. ${ }^{5}$ As razóes apontadas são muito fortes: trata-se da única obra de matemática sobrevivente de Francisco de Melo, é a única do género escrita por um matemático português de renome internacional e constitui uma das primeiras tentativas de interpretação de textos ligados a Euclides e Arquimedes do Renascimento europeu.

Apesar disso, o conteúdo do manuscrito permanece, na sua maior parte, inédito. Dois motivos fundamentais o justificam: a transcrição e a leitura do texto era especialmente difícil de fazer devido à caligrafia e ao mau estado do códice BNP 2262 (hoje, com a descoberta do

3 O COD BNP 2262 começa com um pequeno tratado sobre a estrutura do olho e teoria geral da visão que ocupa 20 folhas e possui cerca de 20 proposições e 18 figuras ("Francisci de Mello de uidendi ratione atque oculorum forma in Euclidis perspectiuam corollarium"; ou: "Corolário de Francisco de Melo à Óptica de Euclides sobre a teoria da visão e a estrutura dos olhos"); seguem-se os comentários à Óptica de Euclides, que ocupam cerca de 35 folhas e têm 56 proposições e 101 figuras ("Perspectiua Euclidis Cum Francisci de Mello commentariis"; ou: "Óptica de Euclides, com os comentários de Francisco de Melo"), os comentários à Catóptrica do mesmo Euclides, que ocupam cerca de 40 folhas e apresentam 31 proposições e 89 figuras ("Francisci de Mello in Euclidis Megarensis speculariam Commentaria"; "Comentários de Francisco de Melo à Catóptrica de Euclides de Mégara") e, um pequeno estudo de estática durante muito tempo atribuído a Arquimedes, com apenas 8 folhas e 19 figuras ("Liber Archimedis de ponderibus siue de incidentibus in humidis"; ou: "Livro de Arquimedes Sobre os Pesos, ou Sobre os Objectos que Caem em Líquidos"). No final, existe ainda um comentário dedicado a uma obra do astrónomo árabe conhecido pelo nome latino de Gebre, deixado em estado muito incompleto. O manuscrito de Stralsund (Stadtarchiv Stralsund, ms. HS 0767) possui um texto idêntico, a que foi acrescentado um prólogo inicial e no qual falta o tratado final dedicado a Gebre.

4 António Ribeiro dos Santos, "Memória da Vida e Escritos de D. Francisco de Mello", in Memórias de Literatura Portuguesa publicadas pela Academia Real das Ciências de Lisboa, tomo VII. Lisboa, Academia das Ciências de Lisboa, 1806, pp. 237-249.

5 Assim o faz, por exemplo, uma autoridade como Luís de Albuoueroue ("Pedro Nunes e Diogo de Sá", Memórias da Academia de Ciências - Classe de Ciências-, tomo xxı, 1976-1977, pp. 339-357). O estudo mais recente sobre Francisco de Melo (com bibliografia actualizada até à data) é a tese de Mestrado de Luís Miguel Ferreira SANTOS (D. Francisco de Melo. Biografia e escritos. Universidade de Coimbra, 2007). 
manuscrito de Stralsund, a tarefa ficou muito facilitada); a tradução e estudo complementares são tarefas complexas porque o texto está redigido num latim muito técnico e a interpretação do conteúdo requer competências muito específicas nos domínios da matemática, filologia, estudos clássicos e história da ciência. O estado da arte e o programa de actividades a prosseguir em relação a este códice mantêm-se, por isso, inalterados desde há 120 anos, quando Teófilo Braga os sintetizou da seguinte forma: "é pena que estes trabalhos permaneçam inéditos; publicados com um estudo crítico-histórico, relacionariam Portugal de um modo digno com o movimento intelectual da Renascença” ${ }^{6} \mathrm{Na}$ verdade, os estudos produzidos até hoje não se debruçaram senão sobre os títulos de cada capítulo e sobre partes do prefácio; o conteúdo científico propriamente dito permanece por avaliar, excepçáo feita à parte do manuscrito relacionada com Arquimedes, que foi editada por Marshall Clagett em obra premiada internacionalmente.

Neste artigo pretendemos tão-somente divulgar um pouco do conteúdo matemático desta obra de Francisco de Melo e apontar algumas das suas características fundamentais. Para tal, decidimos concentrar a nossa análise nos passos em que se apresentam argumentos de um dos professores da Universidade de Paris, Pierre Brissot. ${ }^{8} \mathrm{~A}$ informação de que Francisco de Melo estudou matemática com Pierre Brissot é habitualmente referida entre especialistas. O documento que atesta esta afiliação é o próprio prefácio escrito por Melo no início dos seus comentários a Euclides. ${ }^{9}$ Além deste passo, Melo refere o nome do seu professor mais duas vezes: no comentário à Óptica, atribui-lhe uma proposição inteira, que cita textualmente (trata-se da proposição vigésima sétima: "Se a distância entre os olhos for menor do que o diâmetro da esfera, a parte da esfera que se observa ver-se-á menor do que um hemisfério"); no comentário à Catóptrica, antes das proposiçóes, descreve uma experiência conduzida por ele a fim de estabelecer um princípio de óptica fundamental ("Em espelhos, uma coisa vê-se com visão nítida e distinta quando os raios visuais de cada olho, prolongados a direito, são concorrentes"). ${ }^{10}$

6 Teófilo Braga, História da Universidade de Coimbra nas suas relações com a Instrução Pública Portuguesa, vol. 1 (1289 a 1555). Lisboa, Tipografia da Academia Real das Ciências, 1892, p. 324.

7 Marshall Clagett, Archimedes in the Middle Ages: The Fate of the Medieval Archimedes. Philadelphia, American Philosophical Soc., 1978, vol. 3, pp. 146 ss.

8 A principal fonte para o estudo biográfico de Brissot é a Vita Petri Brissoti de René Moreau (veja-se De missione sanguinis in pleuritide [...] auctore Renato Moreau. Parisiis, Apud Abrahamum Pacard, MDCXXII, pp. 85 e ss.). Sobre ele, veja-se ainda: Michel Reulos, "Brissot, Pierre", in P. G. Bietenholz, Thomas B. DEUTSCHER (eds.), Contemporaries of Erasmus: A Biographical Register of the Renaissance and Reformation, Vol. 1. Toronto, University of Toronto Press, 1985, p. 203; António M. L. ANDRADE, "O confronto entre Pierre Brissot e Dionísio: o epicentro da polémica da sangria", in Luana GIURGEVICH, Teresa Nobre de Carvalho, Henrique Leitão (eds.), O Livro Científico lido de perto (séc. XV-xVIII) / The Scientific Book closely read (15th-18th cent.). Lisboa, Biblioteca Nacional de Portugal, 2015 (no prelo).

9 O trecho encontra-se em BNP COD 2262, f. 5v e Stadtarchiv Stralsund, ms. HS 0767, f. 6v (traduzido, mais abaixo, neste artigo).

10 As referências encontram-se, respectivamente, em BNP COD 2262, f. 43r e f. 66r; Stadtarchiv Stralsund, ms. HS 0767, f. $44 \mathrm{v}$ e f. $70 \mathrm{v}$ (os passos encontram-se traduzidos mais abaixo, neste artigo). 
Estas referências a Brissot constituem tudo o que resta do pensamento óptico deste autor. Só por isso, mereceriam análise. No entanto, o que justifica a nossa atenção é o facto de que uma apresentação do conteúdo destes argumentos e um esclarecimento das suas principais características acaba por realçar, por contraste, algumas marcas dos comentários do próprio Melo. Pretendo mostrar que Melo prossegue um programa que lhe foi, sem dúvida, sugerido pelo espírito do tempo e apontado por Brissot, mas que acabou por se afastar da perspectiva do seu mestre e mostrar virtuosismo e originalidade matemática.

\section{FRAGMENTOS DE BRISSOT SOBRE A ÓPTICA EUCLIDIANA}

A primeira referência a Brissot, que ocorre logo no início dos comentários, no prólogo, aparece traduzida em baixo com contexto um pouco ampliado.

Perspectiua Mathematices pars haud contemnenda magno cum fenore pertractanda suscepit. In qua multi apud Grecos, Pauci apud Latinos excelluerunt. Nam preter vnum Vitellionem sinuosa prolixitate fastidiosum, qui decem libris omnem videndi rationem complexus est. Nihil apud Latinos lectione dignum reperi. Dudum tamen inter absolutissima Euclidis Mathematicorum Principis opera Eiusdem specularia et Perspectiua mira breuitate summoque ordine conscripta leguntur a Bartholomeo Zamberto Veneto Latinitate donata cum Theonis Mathematici Excellentissimi demonstrationibus. Sed tam confusis atque mutilis vel librariorum negligentia, aut Greci codicis deprauatione, vt illas putem Theonem ipsum si superuiueret, non recogniturum. Nihil deinde ad Mathematicorum theorematum cognitionem illustrandam conducunt, quin potius omnem prorsus eorum intelligentiam si his innitaris, subuertunt adeo prestat nouas omnino excogitare, quam misere in malifidis traditionibus ingenium diu torquere. Quapropter postquam sub eruditissimo Philosopho atque Mathematico Petro Brisoo Artium, et medicinae professore puriores literas [sic] atque Mathematices rudimenta subodoratus sum, nihil antiquius habui, quam huic desertae ab omnibus Euclidem profitentibus parti sucurrere. Nec tamen ignoro haec elegantissime nostrum Brisoum excoluisse, sed eius Commentaria nescio quo consilio ita ab his, quibus elaborata sunt supprimuntur, vt pauca tantum fragmenta confusa admodum ad nos peruenerint, a quibus cum saepe adiutus sum, tum saepius consulto discessi. ${ }^{11}$

11 BNP COD 2262, ff. 5r-5v; Stadtarchiv Stralsund, ms. HS 0767, ff. 6r-6v. 
A Perspectiva [=Óptica] é uma parte não desprezável da matemática que [Euclides] decidiu tratar com grande sucesso. Nela sobressaíram muitos entre os Gregos, mas poucos entre os Latinos. A verdade é que tirando um apenas, Vitelo, fatigante pela sinuosa prolixidade, e que abarcou toda a doutrina da visão em dez livros, nada encontrei digno de leitura em autores latinos. No entanto, desde há já algum tempo, entre as obras completas de Euclides, Príncipe dos Matemáticos, lêem-se, traduzidas em latim, a sua Especulária e Perspectiva, escritas com admirável concisão e magnífica disposiçáo por Bartolomeo Zamberto, Veneziano, em conjunto com as demonstraçóes do extraordinário matemático Teão, mas a tal ponto confusas e truncadas, seja por descuido dos copistas, seja por corrupção do códice grego, que penso que o próprio Teão, se fosse vivo, as não reconheceria. Além disso, em nada contribuem para clarificar a explicação dos teoremas matemáticos. Pelo contrário, dificultam mesmo a sua compreensão, se nelas te apoiares, a ponto de ser preferível excogitar provas completamente novas, a cansar o engenho durante muito tempo em tradiçôes tão pouco merecedoras de confiança. Por isso, depois de ter explorado sob orientação do eruditíssimo filósofo e matemático Pierre Brissot, professor de Artes e Medicina, as humanidades superiores e os rudimentos de matemática, considerei que nada era mais importante do que socorrer a esta parte negligenciada por todos os que ensinam Euclides. Não desconheço o facto de que o nosso Brissot trabalhou cuidadosamente estes assuntos, mas os seus comentários, não sei por que razão, a tal ponto foram negligenciados por aqueles que os elaboraram, que apenas uns escassos fragmentos confusos chegaram até nós, de que me socorri amiúde, mas dos quais me afastei deliberadamente muito mais vezes. ${ }^{12}$

O texto é interessante por muitas razôes. Nele podemos ler a descrição de todo um contexto medieval e renascentista da história da óptica apresentada de forma sintética, mas muito completa. O ponto mais importante é a referência a dois dos principais momentos da reapreciação da óptica antiga, personificados em Vitelo, autor da obra latina de referência neste domínio científico (escrita por volta de 1270), e Bartolomeo Zamberti, autor da primeira tradução impressa feita a partir do grego (a primeira edição data de 1505). Também interessante é ainda a menção de duas características atribuídas à edição zambertiana: por um lado, as dificuldades envolvidas, quer na sua concepção, quer na sua interpretação; por outro lado, o facto de se considerar, na época, que apenas o texto das enunciaçôes remontavam a Euclides, e que o texto

12 As traduções dos comentários de Melo apresentadas ao longo do artigo foram feitas conjuntamente por mim e Henrique Leitão. 
das demonstraçóes pertenceria antes a um comentador de Euclides, Teão de Alexandria (séc. IV d. C.). Fica claramente patente o programa matemático renascentista, firmemente enraizado na reapreciação da tradição textual e fortemente empenhado em reinterpretar os aspectos matemáticos dessa tradição. Esta é a primeira marca distintiva dos comentários de Melo. ${ }^{13}$

Só depois desta contextualização, aparece o apontamento à filiação com Brissot, interessante também a diversos níveis. Em primeiro lugar, porque, na referência ao mestre, sobressai não só o propósito de esclarecer uma afiliação intelectual (o que permite atribuir mérito e reputação científica a Brissot), mas também o de realçar o papel deste no estabelecimento de uma agenda científica entre discípulos, muito concordante com a época que se vivia; afinal de contas, é afirmado que a óptica é um domínio não totalmente explorado da matemática, mas que Brissot a estudou e ensinou. Em segundo lugar, por indicar subtilmente que Melo estudou matemática com Brissot, mas não óptica, dado que são enunciadas de forma clara, apesar de superficial, as matérias que estudou com o mestre e nelas estão referidas as letras e a matemática elementar, mas não se encontra expressamente referida a óptica, o que faria sentido no contexto; além do mais alude-se a uma busca dos escritos do professor francês relacionados com este domínio da matemática que não faria sentido se Melo tivesse assistido a aulas sobre o tema e registado o seu conteúdo. O breve apontamento de Melo permite inferir, aliás, que o próprio Brissot não cuidara de guardar (ou emprestar) uma cópia pessoal dos apontamentos das suas aulas sobre óptica. Seja como for, Melo dá a entender que, apesar de o grosso da teoria óptica de Brissot se ter perdido, ele deve ter tomado conhecimento de tudo quanto restara. Finalmente, as suas palavras indicam o uso que deu aos escritos de Brissot: elas atestam que os seus argumentos se afastam frequentemente dos do mestre e que pretende apresentar uma perspectiva original e um programa autónomo. Como corolário, inferimos que os argumentos atribuídos a Brissot ao longo dos comentários de Melo à óptica euclidiana servem de referencial para determinar o que é original no pensamento de Melo. Tem valor, portanto, proceder a uma breve análise dos restantes dois passos em que Melo cita Brissot. Com efeito, apesar de, ao longo dos comentários, Melo apenas incorporar dois contributos explícitos de Brissot, eles são fundamentais para avaliar as características dos argumentos matemáticos construídos por ambos.

Uma diferença fundamental é que Brissot recorre a experimenta como fundamento demonstrativo, ao passo que Melo prefere realçar que prossegue um programa de fundo teórico que, sem eliminar o apelo à experiência, prefere fortalecer o encadeado demonstrativo. Isto é o que mostra a citação de Brissot incluída no comentário à Catóptrica de Euclides, como mostrarei.

13 Estas marcas de época encontram-se bem descritas no conhecido estudo de Paul L. RosE, The Italian Renaissance of Mathematics. Studies on Humanists and Mathematicians from Petrarch to Galileo. Genève, Droz, 1975. 
A Catóptrica de Euclides começa com uma sequência de seis postulados. Destes, Melo elimina os últimos três, por desnecessários para a parte proposicional do tratado que se segue. No entanto, após a explicação dos três primeiros (que definem e caracterizam o raio visual, e fundamentam a lei da reflexão), acrescenta dois "corrogados" que não se encontram no texto euclidiano. O primeiro torna assente que "qualquer objecto vê-se por meio do raio mais curto que se estende do olho até ele", o que Melo faz derivar de proposiçôes anteriormente demonstradas por si mesmo. O "segundo corrogado" apresenta a seguinte formulação: "Em espelhos, uma coisa vê-se com visão nítida e distinta quando os raios visuais de cada olho, prolongados a direito, são concorrentes". O argumento que serve para provar o facto enunciado começa por citar o contributo de Brissot: "Isto foi demonstrado sem margem para dúvidas pelo meu doutíssimo professor Pierre Brissot por meio de inúmeras experiências, perante uma plateia cheia de muitos dos nossos amigos." Das "experiências” levadas a cabo por Brissot, que não são marca de originalidade mas continuam uma prática comum enraizada entre estudiosos medievais de óptica, nada mais se diz, porque o passo está construído, não tanto de forma a clarificar o contributo de Brissot, mas de forma a realçar o do próprio Melo. ${ }^{14}$ No seguimento, sob pretexto de ter um problema de visão num dos olhos que o impedia de observar os efeitos da experiência, Melo apresenta uma demonstração desenvolvida por si próprio e que transforma o argumento experimental do mestre num argumento intelectual e puramente teórico. No seu argumento, constata-se, em primeiro lugar, que "os objectos aparecem em espelhos para lá do espelho, no sítio onde encontra o raio visual prolongado a direito" ("Constat tamen quamcunque rem ex speculis post speculum apparere, vbi visus, ni ex speculi densitudine flecteretur, in directum productus occurreret"), em segundo lugar, que "dois raios visuais são emitidos da pupila de cada olho para o mesmo ponto" ("At ex vtriusque oculi pupilla in idem signum duo visus emittuntur"), o que permite concluir que,

Si ergo res apparet in recto visu post speculum producto si non in vtriusque occursu appareret, aut illi nusquam post signum reflexionis occurreret res vna in pluribus locis sita videretur ab vnius quidem oculi visu dextra, ab altero vero leua. Atque ex speculo quidem integro non nisi vnicum rei visilis conspectum ${ }^{15}$

14 Sobre as "experiências" empreendidas por ópticos medievais, veja-se Elahe KHEIRANDISH, "The Footprints of 'Experiment' in Early Arabic Optics", in Edith Dudley SyLLA, William R. Newman (eds.), Evidence and Interpretation in Studies on Early Science and Medicine. Leiden, Brill, 2009, pp. 79-104 (com bibliografia actualizada).

15 Os manuscritos apresentam a lição impossível "conspectrum". O termo "conspectus" serviria, mas, sendo masculino, impediria a forma dos adjectivos "unicum" e "situm". A errada escolha lexical deve ser da responsabilidade de Melo, e o copista deve ter tentado salvar a situação como pôde. 
apparet, atque in vnico loco situm. Res igitur quelibet ex speculis visa ibi cernitur vbi ex vtroque oculo producti visus iunguntur. ${ }^{16}$

Portanto, dado que o objecto aparece no raio visual directo prolongado para lá do espelho, se não aparecesse no ponto de encontro de cada um [dos dois raios visuais], ou eles náo se encontrassem para lá do ponto de reflexão, um objecto ver-se-ia situado em muitos lugares; à direita, pelo raio visual de um olho, à esquerda pelo outro. Mas num espelho inteiro não aparece senão uma única visão do objecto visível, e situada num único lugar. Portanto, qualquer objecto visto em espelhos vê-se onde os raios visuais de cada olho, prolongados, se encontram.

Desta forma, Melo remete para outras proposiçóes anteriores dos seus comentários e torna o encadeado demonstrativo irrepreensível. ${ }^{17}$ A nota de Melo chama a atenção para esta característica dos seus comentários que é a de procurar um maior rigor no discurso demonstrativo e tentar fortalecer de um ponto de vista teórico a herança antiga, medieval e a do seu próprio professor.

Uma outra diferença que queremos destacar está relacionada com as estratégias divergentes em relação à escolha dos argumentos matemáticos utilizados para sustentar as proposiçóes euclidianas.

Esta divergência fica patente por meio da leitura de um passo mais técnico dos comentários de Melo à Óptica, em que o português atribui a Brissot uma proposição inteira, que cita textualmente (trata-se, como já afirmámos, da proposição vigésima sétima: "Se a distância entre os olhos for menor do que o diâmetro da esfera, a parte da esfera que se observa ver-se-á menor do que um hemisfério"). O texto é o seguinte (ver figura 1):

Demonstratio brissoti. A duobus oculis .ab. spectetur sphaera .cde. cuius centrum .f. sitque ipsius .ab. dimidium .ag. eritque minus quam .ef. semidiameter postquam tota .ab. minor est diametro. Dico spherae visam partem minorem hemispherio. Sit enim vt prius .gf. perpendicularis super .ab. connectanturque af. Igitur plani .afg. cum sphera .f. sectio erit, circulus vt .cdem. In eo itaque plano sphaeram contingentes sunt radii .ae. .bc. connexisque .ef. .fc. ducatur .fh. parallela ipsi .ea. a signo .f. per 31.am primi elementorum secans .ab in signo .h. continget eam productam aliquando postquam ipsam .ea. .ab. linea contingit et sunt in eodem plano. Item ducatur .ak. parallela ipsi .ef. secans .fh. in signo .k. parallelogra-

16 BNP COD 2262, f. 66v; Stadtarchiv Stralsund, ms. HS 0767, ff. 70v-71r.

17 Apesar de discutível, de um ponto de vista moderno. 
mum enim est .efka. per trigintesimam quartam ergo primi elementorum .efk. .eak. anguli aequales sunt, et cum .aef. rectus sit per decimam ${ }^{18}$ octauam tertii et per vigesimam nonam primi .efk. rectus erit et per consequens etiam .eak. rectus, .kfa. igitur et .fak. duobus rectis minores sunt (sunt enim partes ipsorum) quare per quintum postulatum .fh. ${ }^{19}$.ak. [concurrunt in .k. ${ }^{20}$ Quoniam igitur .aef. rectus est erit per trigintesimam quartam primi etiam .akf. rectus et per vigesimam nonam eiusdem .efk. rectus, eruntque per eandem .ef. .ak. aequales. At ex hypotesi maior est .ef. quam .ag. maior igitur est .ak. quam .ag. Si igitur .ak. sit eadem ipsi .ah. maior erit .ah. quam .ag. Sin minus quoniam rectus est .akf. angulus maior angulo .ahk. per decimam sextam primi et aequalis ipsi .akh. per decimam definitionem eiusdem, maior igitur est angulus .akh. angulo .ahk. quare latus .ah. maius est latere .ak. per decimam nonam, multo igitur maior est .ah. quam .ag. quare per nonam communem sententiam angulus .afh. maior est angulo .afg. Addito igitur communi .afe. maior erit angulus rectus .efh. angulo .efg. igitur per trigintesimam tertiam, sexti circunferentia .de. minor est .ep. quarta circuli. Similiter de circunferentia .dc. fiet demonstratio. Minor igitur est .cde. semicirculo et proinde minus hemispherio videtur igitur etc. ${ }^{21}$

\section{DEMONSTRAÇÃO DE BRISSOT}

A partir dos dois olhos A e B, observe-se a esfera CDE, com centro F. Seja AG metade de $A B$; $[A G]$ será menor do que o semidiâmetro $E F$, visto que toda $A B$ é menor do que o diâmetro. Afirmo que a parte vista da esfera é menor do que um hemisfério. Como antes, seja GF perpendicular a $\mathrm{AB}$ e ligue-se A a F. Então, a intersecção do plano AFG com a esfera será um círculo, seja CDEM. Assim [sendo], nesse plano estão os raios tangentes à esfera $\mathrm{AE}$ e $\mathrm{BC}$. Ligue-se $\mathrm{E}$ a F e F a C; trace-se FH, a partir do ponto F, paralela a EA, pela trigésima primeira [proposição] do primeiro [livro] dos Elementos, [e] secante a $\mathrm{AB}$ no ponto $\mathrm{H}$ (com efeito, $\mathrm{AB}$ será contingente à que foi traçada [ou seja, $\mathrm{FH}$,] em algum momento, visto que a linha $\mathrm{AB}$ é contingente à linha EA e estão no mesmo plano). Do mesmo modo, trace-se AK, paralela a EF, secante a FH no ponto K. Com efeito, EFKA é um paralelogramo. Então, pela trigésima

18 Os manuscritos apresentam a lição: "vigesimam". Aparentemente, uma abreviatura "18am" foi mal entendida.

19 Ambos os manuscritos apresentam a lição errada ".fk.".

20 Os parêntesis rectos incluem uma expressão que está em falta nos manuscritos mas que é necessário subentender para conferir significado ao passo.

21 BNP COD 2262, ff. 43r-43v; Stadtarchiv Stralsund, ms. HS 0767, ff. 44v-45r. 
quarta do primeiro dos Elementos, os ângulos EFK e EAK são iguais. Visto que AEF é recto, pela décima oitava do terceiro, [então] EFK também será recto, pela vigésima nona do primeiro. Em consequência, EAK também é recto. Então, KFA e FAK [somados] são menores do que dois rectos (pois são partes daqueles). Por esta razão, pelo quinto postulado, [as rectas] FH e AK concorrem em K. Então, visto que AEF é recto, AKF também é recto, pela trigésima quarta do primeiro. Pela vigésima nona do mesmo, EFK também é recto e, pela mesma [trigésima quarta do primeiro], EF e AK serão iguais. Mas EF é maior do que AG, por hipótese, Então, AK é maior do que AG. Portanto, se AK é igual a AH; [então,] AH será maior do que AG. Se não, visto que o ângulo $\mathrm{AKF}$, recto, é maior do que o ângulo $\mathrm{AHK}$, pela décima sexta do primeiro, e é igual a $\mathrm{AKH}$, pela décima definição do mesmo; então, o ângulo $\mathrm{AKH}$ é maior do que o ângulo AHK. Por esta razão, o lado AH é maior do que o lado AK, pela décima nona; logo, $\mathrm{AH}$ é muito maior do que AG. Por esta razão, pela nona noção comum o ângulo AFH é maior do que o ângulo AFG. Somado o ângulo comum AFE, o ângulo recto EFH será maior do que o ângulo EFG. Então, pela trigésima terceira do sexto, a circunferência DE é menor do que o quadrante de círculo EP. Da mesma forma, far-se-á a demonstração sobre a circunferência DC. Logo, CDE é menor do que um semicírculo e, em consequência, vê-se menor do que um hemisfério. Portanto, etc.

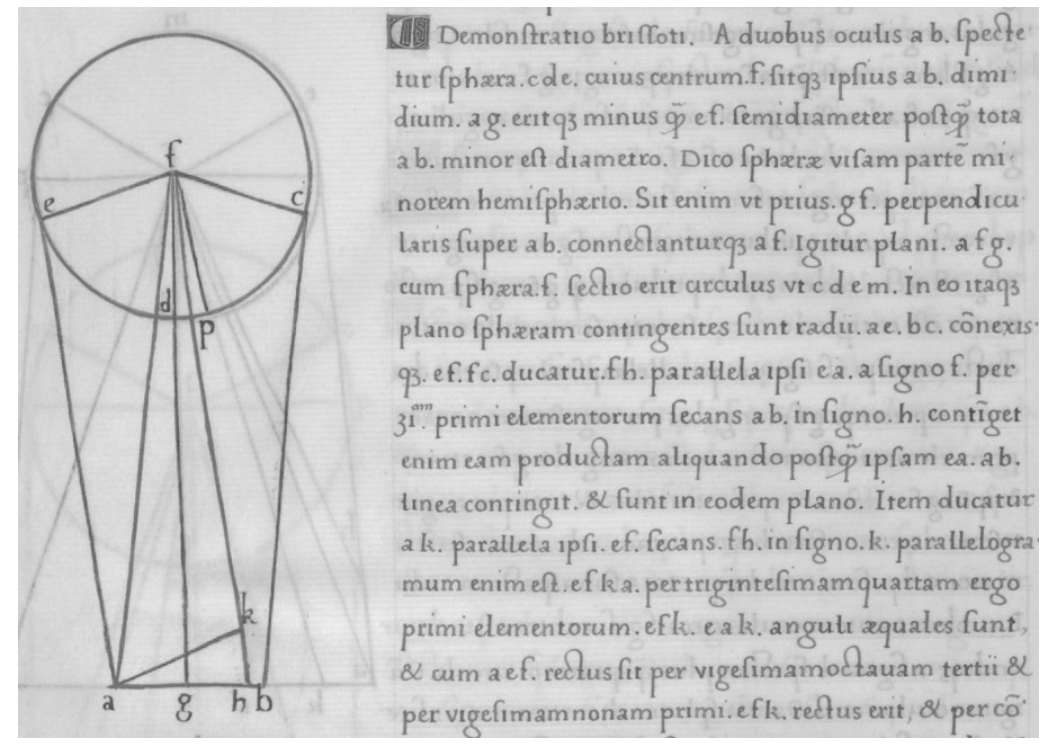

Imagem 1 Comentário de Melo à primeira prova da proposição vigésima sétima da Óptica de Euclides, atribuída a Pierre Brissot (Stadtarchiv Stralsund, ms. HS 0767, f. 44v). 
O texto ganha importância porque Melo apresenta imediatamente a seguir uma prova alternativa que não encontra correspondência na tradição óptica anterior e que lhe deve ser atribuída, portanto, a ele. Apresentamo-la em tradução em baixo (ver fig. 2).

\section{ALITER IDEM DEMONSTRARE.}

Sit sphaera cuius centrum .c. sitque eius diameter interuallo inter duo oculos .ab. a quibus videtur ipsa sphaera maior. Dico quod minus spectatur hemisphaerio diuisa .ab. bifariam per 10.am primi, excitetur a .g. ${ }^{22}$ signo dimidiae sectionis perpendicularis .gc. per vndecimam eiusdem, sic quod contingat centrum sphaerae visae connectantur .ac. .cb. planum igitur .acb. secans sphaeram circulus est ad quem cadant radii visuales .ae. .bd. connexisque .ec. .cd. per 20.am tertii elementorum erunt .cea. .cdb. anguli recti. Cum igitur .cea. angulus rectus sit erit per 47.am primi $\square^{23}$ ipsius .ca. aequum duobus $\square$. .ec. .ea. Quoniam etiam .cga. angulus rectus sit ex definitione perpendicularis erit per eandem $\square$.ca. aequalem $\square \square$.ag. .gc. Sunt igitur per primam communem sententiam .ec. .ea. $\square \square$ aequa quadratis .cg. .ga. Cum autem .ec. maior sit .ag. erit eius $\square$ maius $\square$.ag. illis ergo demptis, ab aequalibus remanebit $\square . c g$. maius $\square$.ea. quare .cg. ${ }^{24}$ linea maior est quam sit .ea. linea. At per tertiam primi elementorum ab ipsa .cg. abscindatur aequalis ipsi .ea. quae sit .hg. ponatur etiam per eandem .ek. ipsi .ag. aequalis connectanturque .ak. .ha. et quoniam .ek. .ag. aequales sunt, et .gh. ipsi .ea. et .kea. angulus angulo .agh. ${ }^{25}$ (vterque enim rectus) ergo per quartam primi elementorum .ahg. angulus aequus est angulo .kae. et angulus .eka. angulo .gah. At per trigintesimam secundam primi .eka. .eak. anguli recto aequales sunt. erunt etiam .eka. .ahg. vni recto aequales. Sed .eka. angulus exterior est trianguli .akc. ergo per Decimam sextam primi interiore et sibi opposito .kca. maior est et per eandem .gha. ipso .gca. maior est. Totus igitur .ecg. recto minor est. Similiter probabitur .dch. recto minor quare vt probatum est in vigesima tertia huius, erit .ed. semicirculo minor. voluendo igitur .ab. oculos manente .gc. continuo minus semicirculo spectabitur quare et minus hemisphaerio. Quod erat probandum. ${ }^{26}$

22 Ambos os manuscritos apresentam a lição errada ".ag.".

23 O manuscrito do Arquivo Municipal de Stralsund utiliza sempre um símbolo próprio para o termo "quadrado", ao passo que o manuscrito da BNP opta sempre por escrever o termo por extenso.

24 Ambos os manuscritos apresentam a lição errada ".eg.".

25 Ambos os manuscritos apresentam a lição errada ".agb.".

26 BNP COD 2262, ff. 43v-44r; Stadtarchiv Stralsund, ms. HS 0767, ff. 45r-45v. 


\section{DEMONSTRAR O MESMO DE MANEIRA DIFERENTE}

Seja uma esfera com centro C e seja o seu diâmetro maior do que a distância entre os dois olhos A e B, a partir dos quais se vê a dita esfera. Afirmo que se vê menos do que um hemisfério. Bissectada $\mathrm{AB}$, pela décima [proposição] do primeiro [livro dos Elementos], levante-se, a partir do ponto $\mathrm{G}$ da bissecção, a perpendicular GC, pela undécima do mesmo, de tal forma que seja contingente ao centro da esfera vista. Ligue-se A a C e C a B. Então, o plano ACB secante à esfera é um círculo. Nele caiam os raios visuais $\mathrm{AE} e$ BD. Ligados $\mathrm{E}$ a C e C a D, pela vigésima do terceiro dos Elementos, ${ }^{27}$ os ângulos CEA e $\mathrm{CDB}$ serão rectos. Visto que o ângulo CEA é recto; então, o quadrado de CA será igual aos dois quadrados de EC e EA [somados], pela quadragésima sétima do primeiro. Visto que o ângulo CGA é recto, pela definição de perpendicular, o quadrado de CA será igual aos quadrados de AG e GC [somados], pela mesma. Então, pela primeira noção comum, os quadrados de EC e EA [somados] são iguais aos quadrados de CG e GA [somados]. Mas, visto que EC é maior do que AG, o quadrado dessa será maior do que o quadrado de AG. Subtraídos aqueles de iguais, restará o quadrado de CG maior do que o quadrado de EA. Por esta razão, a linha CG é maior do que a linha EA. Ora, pela terceira do primeiro dos Elementos, corte-se, de CG, uma [recta] igual a EA, seja HG. Pela mesma, ponha-se EK igual a AG. Ligue-se A a K e H a A. Visto que EK e AG são iguais, e GH é igual EA, e o ângulo KEA [é igual] ao ângulo AGH (pois ambos são rectos); então, pela quarta do primeiro dos Elementos, o ângulo AHG é igual ao ângulo KAE e o ângulo EKA [é igual] ao ângulo GAH. Mas, pela trigésima segunda do primeiro, os ângulos EKA e EAK [somados] são iguais a um recto. Os ângulos EKA e AHG [somados] também serão iguais a um recto. Mas o ângulo EKA é externo do triângulo AKC; logo, pela décima sexta do primeiro, é maior do que o interior e oposto KCA. Pela mesma, GHA é maior do que GCA. Entáo, o ângulo todo ECG é menor do que um recto. Da mesma forma se provará que $\mathrm{DCH}$ é menor do que um recto. Por esta razão, como se provou na vigésima terceira deste, $\mathrm{ED}$ será menor do que um semicírculo. Então, rodando os olhos $\mathrm{A}$ e $\mathrm{B}$, e permanecendo GC imóvel, observar-se-á continuamente menos do que um semicírculo. Por esta razão, também [se verá] menos do que um hemisfério. O que se queria provar.

27 Trata-se da proposição décima oitava do terceiro [livro] dos Elementos na conhecida edição de ]. L. Heiberg (HeiberG, J. L.; StAmatis, E.S., Euclidis Elementa, vol. 1. Lipsiae, Teubner, 1969). 


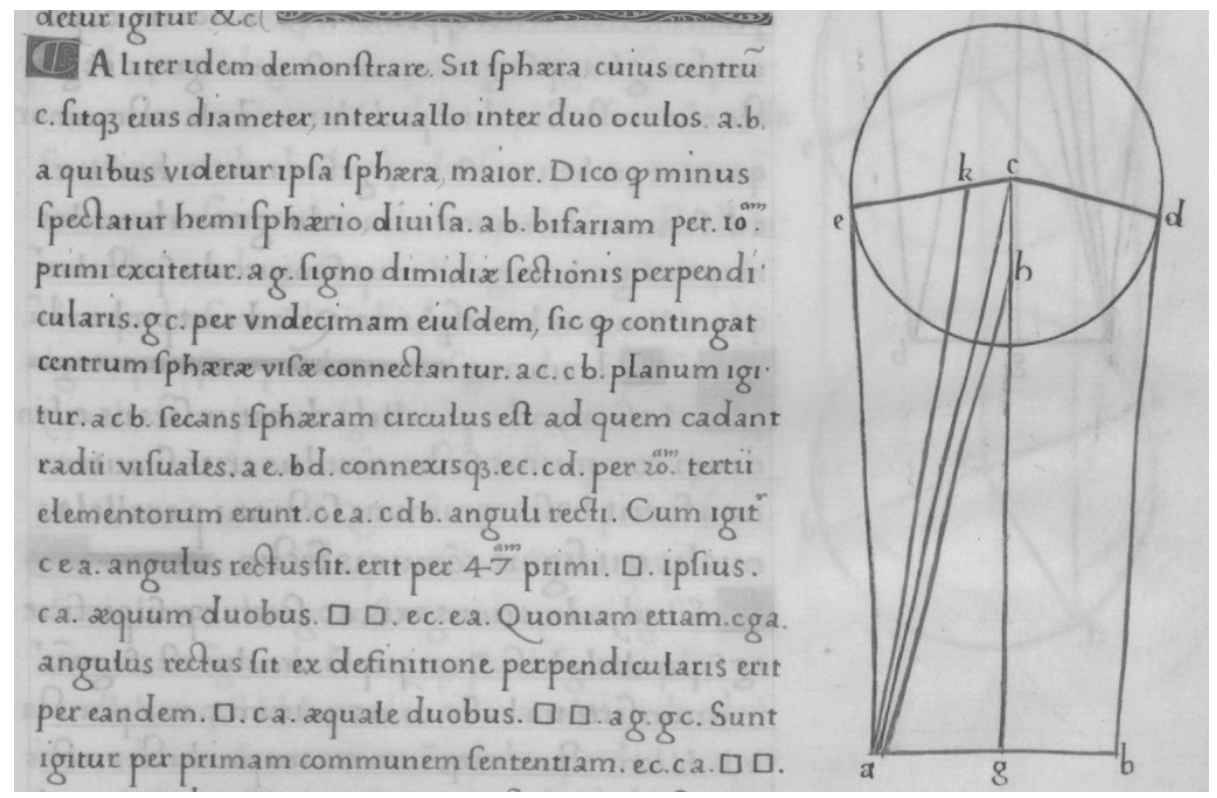

Imagem 2 Comentário de Melo à primeira prova da proposição vigésima sétima da Óptica de Euclides, atribuída a Pierre Brissot (Stadtarchiv Stralsund, ms. HS 0767, f. 45r).

Comparando as duas, percebemos o que aproxima e distancia um e outro autor. Por exemplo, há um esforço considerável da parte de Brissot em justificar que determinados dois ângulos somados são inferiores a dois rectos (o que faz com que duas linhas sejam concorrentes, por aplicação do famoso postulado quinto dos Elementos). Ora, este argumento, que amplia de forma exaustiva e até cansativa o original euclidiano, ocupa espaço considerável em diversas provas dos comentários de Melo. No entanto, podemos afirmar, pelo trecho citado em cima, que esta minuciosidade em particular não constitui uma inovação sua, uma vez que ela já se encontra na prática ensinada por Brissot, dado que surge num passo que lhe é atribuído.

Mais interessante é o facto de podermos conhecer as proposiçôes dos Elementos em que cada autor prefere basear a sua demonstração. Ambos aplicam diversas proposiçóes do livro primeiro e a última do sexto. No entanto, Brissot apela a proposiçóes do livro primeiro que não incluem o teorema de Pitágoras (antes incluem teoria das perpendiculares e paralelas e dos paralelogramos), ou seja, utiliza proposiçóes anteriores à quadragésima sétima. Melo, pelo contrário, baseia o seu argumento fundamental na aplicação deste teorema, o que aproxima a sua prova da álgebra geométrica do livro segundo dos Elementos. Por outras palavras, Melo é mais algébrico do que Brissot. A algebrização é observável, aliás, na própria notação e simbolismo, que nesta prova aparece alterada: a palavra "quadrado" é constantemente substituída 
pelo símbolo do quadrado. O facto é assinalável por outra razão. Esta proposição faz parte de um conjunto de proposiçóes que analisam propriedades da visão de esferas, cones e cilindros. Sucede que em várias delas (por exemplo nas vigésima quinta e sexta) o argumento se assemelha ao da parte da prova da proposição vigésima sétima que atribuímos tentativamente a Melo e não ao da parte que é atribuída a Brissot. Assim, pode assumir-se que a forma de justificação dessas proposições é também da autoria de Francisco de Melo.

\section{CONCLUSÃO}

A análise dos passos em que se apontam contributos de Brissot permitem, portanto, clarificar o que é que pode constituir uma originalidade introduzida pelo próprio Melo.

De resto, Francisco de Melo é muito parco em identificar contributos próprios. No entanto, fá-lo expressamente logo no início do trabalho, como se vê no trecho traduzido em baixo.

itaque post elementorum Euclidis interpretationem, qua frequenti ac publico auditorio functus sum hos duos Euclidis libros interpretandos nouisque demonstrationibus augendos suscepi. quod vtrum prestiterim eruditorum lectorum iudicio relinquo. Ego certe hoc ambitu laboraui vt nihil in his libris esset, quod ad Euclidem intelligendum desideraretur. Nec enim per hunc late campum euagari collibuit, Multa tamen adieci sequentibus admodum necessaria ne quid esset quod legentem in ipso operis cursu moraretur, que a principio exponere atque ab aliis seiungere placuit, ne diuina Euclidis scripta nostris additionibus contaminarentur. Addidi etiam nostrum interpretis in demonstrationibus Nomen. vt facilius nostra ab alienis interstingantur, nostrumque in literariam Rem publicam studium agnoscatur. ${ }^{28}$

Portanto, depois da explicação dos Elementos de Euclides, que realizei perante um vasto auditório público, decidi traduzir estes dois livros de Euclides e ampliá-los com novas demonstraçôes. Se me distingui em qualquer destas tarefas, deixo-o ao juízo dos leitores instruídos. Quanto a mim, trabalhei pelo menos com este propósito: o de que nada faltasse nestes livros, de que se sentisse falta para a compreensão de Euclides. Tão pouco me agradou espraiar-me neste campo excessivamente; contudo, acrescentei muitas coisas necessárias, sem margem para dúvidas, para o que vinha a seguir, para que não houvesse motivo para o leitor se demorar no decurso da própria obra, coisas que decidi expor ao

28 BNP COD 2262, ff. 5v-6r; Stadtarchiv Stralsund, ms. HS 0767, ff. 6v-7r. 
início e separá-las das demais, para que os divinos escritos de Euclides não fossem contaminados pelos nossos aditamentos. Também acrescentei o nosso nome de interpres às demonstraçôes, para que mais facilmente se distinga o nosso contributo do de terceiros e o nosso zelo seja reconhecido na República das Letras.

Melo refere que fez ampliaçóes e acrescentos indispensáveis, referindo-se em especial ao corolário que precede o comentário ao texto da Óptica e Catóptrica, e onde acrescentou o seu nome. No entanto, no texto restante nunca refere o que é que lhe deve ser atribuído expressamente. O contraste com Brissot constitui um primeiro passo na tarefa de identificar o que pertence, de facto, a Melo, nos seus comentários a Euclides.

De entre as características do seu pensamento, podemos, por isso, apontar estas sem receio de falhar: inclusão no espírito do Renascimento matemático do século xvi (reavaliação textual e fortalecimento argumentativo, reelaboração matemática, revalorização de áreas científicas onde houve desinvestimento), contraste com um programa anterior, estabelecido pelo seu professor em Paris, que pretende prosseguir mas de forma alterada, tentativa de melhoramento da qualidade matemática dos tratados dos autores antigos divulgados na sua época.

\section{BIBLIOGRAFIA}

\section{Fontes manuscritas}

Biblioteca Nacional de Portugal COD 2262 (Francisco de Melo: In Euclidem)

Stadtarchiv Stralsund, MS. HS 0767 (Francisco de Melo: In Euclidem)

\section{Impressos}

René Moreau, De missione sanguinis in pleuritide [...] auctore Renato Moreau. Parisiis, Apud Abrahamum Pacard, MDCXXII.

\section{Estudos}

Albuquerque, Luís, "Pedro Nunes e Diogo de Sá", Memórias da Academia de Ciências - Classe de Ciências, tomo xxi, (1976-1977), pp. 339-357. 
Andrade, António M. L., "O confronto entre Pierre Brissot e Dionísio: o epicentro da polémica da sangria", in Luana Giurgevich, Teresa Nobre de Carvalho, Henrique Leitão (eds.), O Livro Científico lido de perto (séc. XV-XVIII) / The Scientific Book closely read (15th-18th cent.). Lisboa, Biblioteca Nacional de Portugal, 2015 (no prelo).

BRaga, Teófilo, História da Universidade de Coimbra nas suas relações com a Instrução Pública Portuguesa, vol. I (1289 a 1555). Lisboa, Tipografia da Academia Real das Ciências, 1892.

Clagett, Marshall, Archimedes in the Middle Ages: The Fate of the Medieval Archimedes, vol. 3. Philadelphia, American Philosophical Society, 1978.

Heiberg, J. L.; Stamatis, E.S., Euclidis Elementa, vol. 1. Lipsiae, Teubner, 1969.

Kheirandish, Elahe, “The Footprints of 'Experiment' in Early Arabic Optics”, in Edith Dudley Sylla, William R. Newman, Evidence and Interpretation in Studies on Early Science and Medicine. Leiden, Brill, 2009, pp. 79-104.

Reulos, Michel, "Brissot, Pierre”, in P. G. Bietenholz, Thomas B. Deutscher (eds.), Contemporaries of Erasmus: A Biographical Register of the Renaissance and Reformation, Vol. 1. Toronto, University of Toronto Press, 1985.

Ribeiro dos Santos, António, "Memória da Vida e Escritos de D. Francisco de Mello", in Memórias de Literatura Portuguesa publicadas pela Academia Real das Ciências de Lisboa, tomo VII. Lisboa, Academia das Ciências de Lisboa, 1806.

Rose, Paul Lawrence, The Italian Renaissance of Mathematics. Studies on Humanists and Mathematicians from Petrarch to Galileo. Genève, Droz, 1975.

SAntos, Luís Miguel Ferreira, D. Francisco de Melo. Biografia e escritos, Tese de Mestrado. Universidade de Coimbra, 2007. 


\title{
Algumas reflexões sobre as pedras preciosas nos Colóquios dos simples de Garcia de Orta ${ }^{1}$
}

RUI MANUEL LOUREIRO²

\begin{abstract}
RESUMO:
Algures na cidade de Goa, na costa ocidental da Índia, num dia não especificado de meados do século XVI, dois europeus estão envolvidos em animada conversação a respeito de marfim e elefantes. Um deles é Garcia de Orta, o outro é Ruano, ambos médicos formados nas mesmas universidades espanholas. 0 animado debate é interrompido pela chegada de um lapidário milanês, 0 qual deseja falar com Orta, em relação à venda de algumas esmeraldas. Este curioso episódio, um dos muitos que se podem encontrar nas páginas dos Colóquios dos simples e drogas medicinais da Índia, publicados em Goa em 1563, levanta questões interessantes, que serão abordadas no presente texto, e nomeadamente: a larga rede de correspondentes e informadores que Orta convoca para participarem nos seus eruditos colóquios; a metodologia que utiliza para construir uma verdadeira enciclopédia sobre história natural asiática; o discreto mas persistente envolvimento do naturalista português em assuntos mercantis; e também a sua atitude em relação às pedras preciosas e à chamada medicina lapidária.
\end{abstract}

PALAVRAS-CHAVE:

Garcia de Orta; Colóquios dos Simples; História Natural; Pedras Preciosas; Ásia; Século xvı.

1 O presente texto retoma um anterior escrito, em inglês, que preparei para HOST - Journal of History of Science and Technology (no prelo), pois considera-se oportuna a respectiva divulgação em língua e contexto distintos. Entretanto, aqui ficam os meus sinceros agradecimentos aos editores do presente volume, pelas pertinentes sugestões e pelas valiosas pistas bibliográficas.

2 Instituto Superior Manuel Teixeira Gomes \& Centro de História de Aquém e Além-Mar, FCSH - Universidade Nova de Lisboa / Universidade dos Açores: descobrimentos@gmail.com. 


\section{ABSTRACT:}

Somewhere in the city of Goa, on the west coast of India, on an unspecified day in the middle of the sixteenth century, two Europeans are involved in a learned conversation about elephants and ivory. One of them is Garcia de Orta, the other is Ruano, both are physicians trained at the same Spanish universities. The lively discussion is interrupted by the arrival of a Milanese lapidary, who wishes to speak to Orta, concerning the sale of some precious stones. This curious episode, one of the many that can be found in the pages of the Colóquios dos simples e drogas medicinais da Índia, published in Goa in 1563, raises several interesting questions, which will be dealt with in the present text, and namely: the large network of informers that Orta brings into play throughout his learned colloquies; the methodology he uses to build a veritable encyclopedia of Asian natural history; the discreet but persistent involvement of the Portuguese naturalist in matters of merchandise; and also his attitude towards precious stones and the so-called lapidary medicine.

\section{KEYWORDS:}

Garcia de Orta; Colóquios dos Simples; Natural History; Precious Stones; Asia; Sixteenth Century. 
Algures na cidade de Goa, na costa ocidental da Índia, num dia não especificado de meados do século XVI, dois europeus estão envolvidos em animada conversação a respeito de marfim e elefantes. Um deles é Garcia de Orta, famoso médico português treinado em Salamanca e Alcalá de Henares, e um residente de há muito na capital do Estado da Índia, onde praticou medicina durante muitos anos; o outro é Ruano, também graduado pelas mesmas universidades espanholas, e acabado de chegar à Índia com propósitos mercantis, a bordo da frota anual oriunda de Lisboa. O animado debate decorre na residência goesa de Orta, pouco antes do jantar, quando os dois médicos e conhecidos de longa data são interrompidos por uma serva, que entra para anunciar a chegada de um visitante bem-conhecido do dono da casa — "Está ahi micer André Milanés, o lapidairo" —, o qual deseja falar com Orta, em relação à venda de algumas pedras preciosas. Aparentemente, o médico lusitano estaria na posse de duas esmeraldas, uma grande, outra menor mas mais clara, e o mercador italiano teria encontrado um possível comprador para ambas as gemas. Garcia de Orta saúda o visitante, declara que está disposto a vender ambas as esmeraldas — "Tudo venderei, e volas darei ambas" — e imediatamente tira proveito da presença de Andrea para orientar a conversa novamente para o tema dos elefantes, pois sabe que o lapidário milanês possui informações relevantes sobre este tema, já que anteriormente visitara o Pegu (na actual Birmânia), onde teria testemunhado práticas de captura e domesticação destes paquidermes. ${ }^{3}$

Embora provavelmente baseada em eventos reais, a cena é totalmente fictícia, sendo descrita no capítulo ou colóquio 21 do celebrado tratado Coloquios dos simples, e drogas he cousas mediçinais da India, escrito por Garcia de Orta e publicado pela primeira vez em Goa em 1563, por um impressor identificado na portada como "Ioannes de Endem", nome que certamente corresponde a Johannes von Emden. ${ }^{4} \mathrm{O}$ livro em questão é bem conhecido dos especialistas, como o primeiro compêndio europeu moderno sobre história natural e matéria médica oriental a merecer as honras da tipografia. Depois de quase três décadas de vida e experiência indiana, o médico português decidira escrever e publicar um trabalho sobre, nas palavras do respectivo título, os "simples e drogas e cousas mediçinais da India, e assi dalgumas frutas achadas nella, onde se tratam algumas cousas tocantes a medicina pratica, e outras cousas boas pera saber". Principalmente por razões de ordem pedagógica, Orta escolhera um formato de diálogo para

3 Garcia de Orta, Colóquios dos simples e drogas da Índia, ed. Conde de Ficalho, 2 vols.. Lisboa, Imprensa Nacional - Casa da Moeda, 1987, vol. 1, p. 311. Sobre o tema dos elefantes asiáticos existem numerosos estudos; ver Donald F. LACH, Asia in the Making of Europe - Volume II: A Century of Wonder, 3 tms.. Chicago, The University of Chicago Press, 1970-1977, tm. 1, pp. 124-158, e Gérard BusouET; Jean-Marie JaVron, Tombeau de l'éléphant d'Asie. Paris, Chandeigne, 2002.

4 Nada de especial se consegue apurar sobre o impressor dos Colóquios, que se manteve activo em Goa entre 1561 e 1573, e que provavelmente era originário de Emden. Sobre esta cidade alemã, famosa pelas suas tipografias e por ser um refúgio de protestantes, ver Andrew PETTEGREe, Emden and the Dutch Revolt: Exile and the Development of Reformed Protestantism. Oxford, Oxford University Press, 1992. 
o seu tratado, dividindo-o em conversas sucessivas entre dois personagens principais, ORTA e RUANO, dois colegas da profissão médica que haviam estudado juntos em Espanha, mas não se encontravam desde há longos anos: Orta assume o papel do expatriado veterano, possuidor de uma grande experiência prática da Ásia, complementada com um conhecimento teórico profundo das suas áreas de especialização, a história natural e a medicina; Ruano, por outro lado, é o conceituado académico, portador de uma sólida formação universitária europeia, muito bem informado em termos de erudição ocidental, mas totalmente inexperiente em assuntos orientais. Talvez Ruano possa ser visto como uma espécie de heterónimo de Garcia de Orta, criado para expressar alguns dos pontos de vista e perplexidades do autor numa fase mais jovem da sua vida, quando chegara pela primeira vez à Índia na década de 1530. Paralelamente a estes dois protagonistas, também um significativo grupo de várias dezenas de personagens menores toma parte nos eruditos colóquios goeses - a parte visível do universo social do autor da obra. ${ }^{5}$ Mas os Colóquios dos simples, na realidade, e como bem é sabido, abrangem muito mais assuntos do que aqueles que o respectivo título anuncia, pois além de lidarem com plantas, drogas e práticas médicas, abordam de forma amiúde prolixa muitos outros temas relacionados com a vida quotidiana nas Índias, tais como práticas mercantis e rotas marítimas, costumes sociais e crenças religiosas, eventos políticos e sucessos diplomáticos, entre muitos e muitos outros. ${ }^{6}$

O episódio envolvendo o lapidário milanês, o primeiro, mas certamente não o único, nos Colóquios dos simples onde as pedras preciosas são mencionadas, imediatamente levanta várias questôes relevantes. ${ }^{7}$ Em primeiro lugar, trata-se de um exemplo paradigmático da metodologia utilizada por Garcia de Orta no seu vasto empreendimento literário e científico, já que ele recorre de forma sistemática a uma vasta rede de informadores muito competentes sempre que o assunto a ser discutido extravasa os seus conhecimentos e/ou as suas experiências concretas. ${ }^{8}$ Andrea é apenas mais um informador, entre tantos outros, que possuía um saber especializado

5 Sobre o diálogo como um recurso literário típico da época, ver Consolación BARANDA LeTURIO, "Formas del discurso científico en el Renacimiento: tratados y diálogos", Sudia Aurea 5 (2001), pp. 1-21.

6 Para recentes e estimulantes estudos sobre Orta e a sua obra, ver: Teresa Nobre de CARVALHO, "Colóquios dos Simples de Garcia de Orta: Conversas no interior da Índia", in Gabriela FraGoso; Anabela MENDES (orgs.), Garcia de Orta e Alexander von Humboldt: Errâncias, Investigações e Diálogo entre Culturas. Lisboa, Universidade Católica Editora, 2008, pp. 165-174; Palmira Fontes da CostA, "Geographical expansion and the reconfiguration of medical authority: Garcia de Orta's Colloquies on the Simples and Drugs of India (1563)", Studies in History and Philosophy of Science 43 (2012), pp. 74-81; e Palmira Fontes da Costa; Teresa Nobre de Carvalho, "Between East and West: Garcia de Orta's Colloquies and the Circulation of Medical Knowledge in the Sixteenth Century", Asclepio - Revista de Historia de Medicina y de la Ciencia 65.1 (2013), pp. 1-13.

7 As referências a pedras preciosas na obra de Orta são sistematizadas em Carlos Fernando Torre de AssunçÃo, "A Mineralogia nos Colóquios", Garcia de Orta 11.4 (1963), pp. 715-721.

8 Sobre a rede de informadores de Orta, ver Rui Manuel LourEIRO, "Garcia de Orta e os Colóquios dos simples: Observações de um viajante sedentário", in Gabriela FraGoso; Anabela MEndEs (orgs.), Garcia de Orta e Alexander von Humboldt, op. cit., pp. 135-145. 
sobre alguma regiáo oriental, ou sobre algum produto natural, ou sobre algum bem raro ou valioso, ou sobre algum costume exótico. No caso em apreço, o lapidário italiano era relevante para os propósitos de Orta pela sua familiaridade com Pegu, região asiática que visitara mais do que uma vez, com o objectivo de ali adquirir pedras preciosas. O reino do Pegu era famoso pelos seus rubis, que são mencionados já nos primeiros relatórios portugueses sobre a Ásia de inícios do século Xvi, como os de Tomé Pires e de Duarte Barbosa. O primeiro escrevia em carta de 1516, dirigida e el-Rei Dom Manuel de Portugal, que os rubis mais apreciados vinham de uma mina situada em "Capeláguã", localizada algures nos reinos de Arracão e de Pegu, enquanto o segundo preparara no mesmo ano um relatório sobre as pedras preciosas orientais, confirmando que os melhores e mais valiosos "robis" eram oriundos de um reino chamado Pegu. ${ }^{10}$ Ao longo da primeira metade do século XVI, muitos portugueses, bem como outros europeus que lhes estavam associados, e nomeadamente italianos, visitaram regularmente as cidades portuárias de Baçaim, Dagon e Martabão no Pegu, em busca destas mercadorias de luxo, que encontravam compradores interessados tanto na Índia como na Europa. ${ }^{11}$

Em segundo lugar, a referência ao lapidário Andrea é significativa porque, de repente, o leitor dos Colóquios dos simples toma consciência de que Garcia de Orta, além de ser um médico reputado e um notável botânico, era também um mercador, uma vez que traficava em pedras preciosas. As secções anteriores do seu tratado não tinham ainda revelado este facto, pois o naturalista português afirmara ser um apenas um 'filósofo', interessado principalmente em 'assuntos sérios', e de forma alguma um comerciante, preocupado com mercancia e mercadorias. Na verdade, no colóquio sobre o índigo, Orta afirmara explicitamente que "Anil nam he simple medicinal, senam mercadoria, e per isso nam ha que fallar nella”, ou seja, não haveria necessidade de abordar este produto no âmbito das suas eruditas conversas com Ruano. ${ }^{12}$ Contudo, passagens incluídas em diversos diálogos subsequentes mostram claramente as intensas relaçóes que Orta mantinha com o mundo mercantil asiático. $\mathrm{Na}$ discussão sobre o cardamomo, por exemplo, o médico português menciona "hum meu navio", que havia sido enviado ao Ceilão, seguramente num empreendimento comercial, o que significa que Garcia de Orta possuía pelo menos uma embarcação mercante que navegava regularmente através dos mares asiáticos. ${ }^{13}$ Noutra ocasião, o autor dos Colóquios dos simples alude novamente a "hum

9 Armando Cortesão, A Suma Oriental de Tomé Pires e o Livro de Francisco Rodrigues. Coimbra, Acta Universitatis Conimbrigensis, 1978, p. 456.

10 Duarte BARbosa, O Livro de Duarte Barbosa, ed. Maria Augusta da Veiga e Sousa, 2 vols.. Lisboa, Instituto de Investigação Científica Tropical, 1996-2000, vol. 2, p. 476.

11 Sobre os primeiros contactos europeus com o Pegu, ver Donald F. LACH, Asia in the Making of Europe - Volume I: The Century of Discovery, 2 tms. Chicago \& Londres, The University of Chicago Press, 1965, tm. 2, pp. 539-560.

12 Garcia de ORTA, Colóquios dos simples, op. cit., vol. 1, pp. 86-87.

13 Garcia de ORTA, Colóquios dos simples, op. cit., vol. 1, p. 181. 
navio meu", que desta feita tinha sido despachado para Bengala em viagem de negócios. ${ }^{14}$ Os seus interesses comerciais eram certamente muito mais vastos, em termos de produtos, áreas geográficas e rotas mercantis, e parece evidente que Garcia de Orta fez uso de tais expediçóes comerciais para adquirir fornecimentos de produtos médicos que utilizava regularmente na sua prática clínica diária, bem como de amostras de produtos naturais raros ou incomuns, de que tinha ouvido falar e/ou que lhe despertavam a curiosidade. Contudo, as pedras preciosas eram certamente uma das mercadorias que mais lhe interessavam, não obstante a sua alegação, em outro diálogo, de que não estaria muito bem informado sobre os seus preços correntes. ${ }^{15}$ No colóquio dedicado à "raiz da China”, Orta refere um episódio em que um dos seus pacientes lhe paga os serviços médicos com "hum anel com hum diamam", que ele mais tarde veio a vender por "50 crusados", outra prova de que era um homem de muitos ofícios. ${ }^{16}$

Nos alvores da era moderna, as pedras preciosas encontravam-se no rol dos produtos mais cobiçados no âmbito de negócios intercontinentais, já que para além de serem extremamente valiosas eram muito fáceis de transportar e/ou camuflar. As gemas eram artigos especialmente convenientes para empreendimentos comerciais de longa distância e os portugueses tinham estado muito atentos a esta mercadoria altamente valorizada desde os seus primeiros contactos com a Índia. O degredado que Vasco da Gama desembarcou à sua chegada ao porto indiano de Calecute anunciou que os portugueses vinham em busca de "cristãos e especiaria", ${ }^{17}$ mas bem poderia ter acrescentado 'e pedras preciosas'. Na verdade, o conhecido relato da viagem de Vasco da Gama preparado por Álvaro Velho inclui um apêndice descrevendo "as coisas que em cada reino há e como valem", onde as pedras preciosas são mencionadas, e nomeadamente os rubis, as espinelas e as safiras. ${ }^{18}$ Nos anos seguintes, à medida que o chamado Estado da Índia começou a tomar forma, com o estabelecimento por toda a Ásia marítima de uma ampla rede de fortalezas e feitorias instaladas em lugares estratégicos, os observadores portugueses mostraram-se especialmente atentos a quaisquer mercadorias disponíveis que pudessem ser movimentadas com algum tipo de proveito. Estas incluíam, obviamente, uma grande variedade de pedras preciosas. Por volta de 1516, Duarte Barbosa, desde há muito residente na cidade de Cananor, no litoral ocidental da Índia, incluía na sua extensa relação geográfica da Ásia marítima um longo apêndice dedicado exclusivamente às pedras preciosas. O Livro das cousas do Oriente descrevia os aspectos mais notáveis de muitas regióes orientais que estavam a ser

14 Garcia de ORTA, Colóquios dos simples, op. cit., vol. 2, p. 375.

15 Garcia de OrTA, Colóquios dos simples, op. cit., vol. 2, pp. 218-219: "E posto que há outras muytas especias destes rubins, delles vos nam quero falar, nem de seus preços, porque não sei isto muito bem sabido, scilicet, o dos preços".

16 Garcia de OrTA, Colóquios dos simples, op. cit., vol. 2, pp. 269-270.

17 José Manuel Garcia (ed.), Viagens dos Descobrimentos. Lisboa, Editorial Presença, 1983, p. 183.

18 José Manuel GARCIA (ed.), Viagens dos Descobrimentos, op. cit., pp. 217-219. 
contactadas pelos portugueses pela primeira vez, mas na pena do tratadista português as gemas recebiam um tratamento especial, devido à sua enorme relevância mercantil. ${ }^{19}$ Goa, epicentro do Estado da Índia, muito em breve veio a tornar-se num dos mais importantes entrepostos mundiais do comércio de pedras preciosas. ${ }^{20} \mathrm{E}$ as frotas anuais da carreira da Índia passaram a transportar regularmente para Lisboa enormes quantidades de gemas orientais, muitas das quais eram depois encaminhadas para outros destinos europeus. ${ }^{21}$

Regressando à citada passagem dos Colóquios dos simples, esta levanta um terceiro problema, que respeita à verdadeira natureza das pedras mencionadas por Garcia de Orta: estaria o naturalista português a referir-se efectivamente a esmeraldas ou tratar-se-ia antes de outro tipo de gemas verdes, como peridotos ou safiras? As referências a esmeraldas nos primeiros relatórios portugueses sobre a Ásia não abundam, e são um pouco confusas. Duarte Barbosa afirma que as verdadeiras esmeraldas eram originárias da "terra de Babilonia”, sem ser perfeitamente claro onde se situaria esta região, uma vez que este topónimo foi consistentemente usado pelos noticiaristas portugueses da época para identificar a zona de Bagdade, e nenhuma outra evidência aponta para a existência de minas de esmeraldas naquelas partes. Contudo, o já citado apêndice do Livro das cousas do Oriente explica que estas pedras eram "verdes e muito claras", "mui leves e moles", deixando uma marca da cor do cobre, e em Calecute custavam tão caro como os diamantes. ${ }^{22}$ A descrição de Barbosa não se encaixa perfeitamente, uma vez que as esmeraldas deixam "um traço claro ou esbranquiçado". ${ }^{23} \mathrm{Na}$ verdade, as esmeraldas eram bastante raras na Ásia no século xvi, pois não havia minas conhecidas, sendo apenas algumas gemas ocasionalmente encontradas em áreas dos actuais Afeganistão e Paquistão. Garcia de Orta, aliás, expressou-se de forma clara sobre este assunto, já que num dos seus colóquios refere que "esmeraldas há muito poucas, e de muito grande preço; e não se sabe a própria roca dellas". ${ }^{24}$ Ruano responde-lhe, lembrando um episódio - que aliás confirma o envolvimento de Orta no comércio de pedras preciosas - em que o médico português tinha sido desafiado

19 Duarte BARBosa, O Livro de Duarte Barbosa, op. cit., vol. 2, pp. 473-503.

20 Para uma abordagem genérica, ver João Teles e CUNHA, "Hunting Riches: Goa's Gem Trade in the Early Modern Age", in Pius MalekandathiL; T. Jamal Mohammed (orgs.), The Portuguese, Indian Ocean and European Bridgeheads: Festschrift in Honour of Prof. K.S. Mathew. Kannur, Institute for Research in Social Sciences and Humanities \& Fundação Oriente, 2001, pp. 269-304.

21 Ver Donald F. LACH, Asia in the Making of Europe - Volume II, op. cit., tm. 1, pp. 113-122; e Nuno Vassallo e SILVA, Subsídios para o estudo do comércio das pedras preciosas em Lisboa, no século xvı. Lisboa, Assembleia Distrital de Lisboa, 1989.

22 Duarte BARBosa, O Livro de Duarte Barbosa, op. cit., vol. 2, p. 493.

23 Kris LANE, Colour of Paradise: The Emerald in the Age of Gunpowder Empires. New Haven \& Londres, Yale University Press, 2010, p. 28.

24 Garcia de OrTA, Colóquios dos simples, op. cit., vol. 2, p. 219. 
a comprar "huma joia, com muitas esmeraldas meudas", mas recusara-se a fazê-lo, alegando que pensava estar diante de pedras falsificadas, feitas de vidro. ${ }^{25}$

A maioria das verdadeiras esmeraldas em circulação no século xvi era originária de Nueva Granada, nome atribuído pelos conquistadores espanhóis à actual Colômbia. Os exploradores espanhóis haviam encontrado as mais variadas pedras preciosas nas partes setentrionais da América do Sul, nas primeiras décadas do século xvi. Contudo, as minas de esmeraldas só foram identificadas por observadores europeus nas terras altas do leste da Colômbia no final da década de 1530. Logo de seguida, quantidades significativas destas pedras começaram a ser exportadas para a Europa, nomeadamente para Sevilha e Lisboa, e a partir dessas cidades ibéricas para os estabelecimentos portugueses na Ásia. ${ }^{26}$ Gonzalo Fernández de Oviedo foi um dos primeiros a prestar informações sobre as esmeraldas colombianas, na sua Historia General y Natural de las Indias, partes da qual foram primeiro publicadas em Sevilha em 1535 e em Salamanca em 1547. ${ }^{27}$ Durante a sua residência em Hispaniola, o cronista espanhol tinha-se cruzado com dois compatriotas veteranos que haviam estado em Nueva Granada, os quais, para além de lhe descreverem as minas, tinham-lhe mostrado um punhado de esmeraldas. O seu comentário é esclarecedor: "hasta nuestro tiempo nunca se supo haberse hallado tales piedras de nascimiento, por cristianos”, o que significa que González de Oviedo tinha noção de que os europeus estavam a confrontar-se com uma pedra preciosa até então desconhecida, ou muito pouco conhecida. ${ }^{28}$ Daí a escassez de informaçóes consignadas nos Colóquios dos simples sobre as esmeraldas; mas Garcia de Orta, sempre interessado em mostrar a sua consumada erudição, aproveitou a oportunidade para revelar amplas leituras sobre o assunto, citando uma série de autoridades. Esta, claro, era outra faceta relevante do seu método de trabalho, a interacção permanente que manteve com a bibliografia especializada do seu tempo sobre os assuntos ou temas que estavam a ser discutidos nos diferentes colóquios. Através dos Colóquios dos simples, uma rica rede intertextual foi sendo criada, incluindo dezenas e dezenas de obras impressas, na sua maioria relativas ao campo da história natural, mas também pertencendo a muitas outras áreas disciplinares. ${ }^{29}$

25 Garcia de OrTA, Colóquios dos simples, op. cit., vol. 2, p. 220.

26 Kris LANE, Colour of Paradise, op. cit., pp. 44-56.

27 A versão integral da crónica de Fernández de Oviedo só foi publicada no século xIx. Ver Francisco Esteve BARBA, Historiografia Indiana. Madrid, Gredos, 1992, pp. 72-81.

28 Gonzalo Fernández de Oviedo, Historia General y Natural de las Indias, ed. Juan Pérez de Tudela Bueso, 5 vols.. Madrid, Biblioteca de Autores Españoles, 1992, vol. 3, p. 94.

29 Sobre a biblioteca de Orta, ver Conde de Ficalmo, Garcia de Orta e o seu tempo, ed. Nuno de Sampayo. Lisboa, Imprensa Nacional - Casa da Moeda, 1983, pp. 281-305; e também Rui Manuel Loureiro, "European books and libraries in sixteenth century Portuguese India", RC — Review of Culture 31 (1997), pp. 17-30. 
Os nomes pelos quais as esmeraldas eram conhecidas foram o pretexto para Garcia de Orta citar nada menos que quatro autores: "Mesue" e o seu comentador "Cristoforo de Honestis", "Serapio" e "Matheus Silvaticus". ${ }^{30}$ Nesta ocasião, o naturalista português estava a referir-se a autoridades médicas bem conhecidas dos seus contemporâneos. Cristoforo degli Onesti foi um médico italiano do século XIV, autor de um tratado sobre venenos que conheceu ampla circulação, ${ }^{31}$ e que talvez Orta conhecesse; mas o autor dos Colóquios dos simples estava aqui a referir-se à Expositio super Antidotario Mesue, primeiro impressa em Bolonha em 1488, com muitas reimpressōes posteriores, e nomeadamente nas edições das obras de Mesué Júnior tais como Mesue cum expositione Mondini super canones universales ac etiam cum expositione Christophori de Honestis in antidotarium eiusdem (Veneza, 1502). O Pseudo-Mesué, como também era conhecido, era um misterioso autor dos séculos viII-IX, cujo verdadeiro nome, de acordo com o célebre Leão Africano, era Yuhanna ibn Masawayh. ${ }^{32}$ Apesar de as suas obras terem sido amplamente lidas no século XVI, não se sabe muito sobre ele. "Serapio", no presente contexto, parece referir-se ao Pseudo-Serapião, um autor árabe anónimo do século XıII, sobre o qual também pouco se conhece, e que escreveu De simplicibus opus medicinalis, tratado que foi repetidamente publicado no século Xvi. ${ }^{33}$ Quanto a Matteo Silvatico, foi um médico e botânico medieval, activo em Salerno, autor de uma famosa farmacopeia enciclopédia, o Liber pandectarum medicinae, também publicado amiúde ao longo do século Xvi, e que Orta cita numerosas vezes nos seus Colóquios dos simples. Curiosamente, Silvatico refere-se em múltiplas ocasiōes ao Pseudo-Serapião, mas é muito provável que o físico português conhecesse os autores e obras que cita. ${ }^{34}$ De resto, todas as quatro autoridades referidas incluíam informaçóes nos seus escritos sobre as propriedades curativas das pedras preciosas, incluindo as esmeraldas.

Este facto, assim, introduz a pergunta final sugerida pela passagem inicialmente citada dos Colóquios dos simples, a respeito da presença de referências a pedras preciosas num livro sobre matéria médica; mas talvez estejamos apenas perante uma questão de perspectiva histórica.

30 Garcia de ORTA, Colóquios dos simples, op. cit., vol. 2, p. 220.

31 Sobre este curioso livro, De venenis, ver Joël CHANDELIER, "Théorie et définition des poisons à la fin du Moyen Âge", Cahiers de recherches médiévales 17 (2009), pp. 23-38.

32 A respeito da referência de Leão Africano a Mesué Júnior, ver Cyril ELGOoD, A Medical History of Persia and the Eastern Caliphate. Cambridge, Cambridge University Press, 2010, pp. 93-95; sobre o autor granadino, ver Natalie Zemon DAvis, Trickster Travels: A Sixteenth Century Muslim Between Worlds. Nova Iorque, Hill and Wang, 2006, pp. 183-184. Para uma edição recente da geografia de Leão Africano, ver Giovanni Battista Ramusıo, Navigazioni e Viaggi, ed. Marica MILANESI, 6 vols.. Turim, Einaudi, 19781988, vol. 1, pp. 9-469.

33 Não deve ser confundido com o Serapião mais antigo, Yuhanna Ibn Sarabiyun, um quase contemporâneo de Mesué Júnior, sobre o qual se pode consultar P. E. PormanN, "Yuhanna Ibn Sarabiyun: further studies into the transmission of his works", Arabic Science and Philosophy 14.2 (2004), pp. 233-262; sobre Mesué, ver Raymond LE Coz, Les médecins nestoriens au Moyen Âge: les maîtres des Arabes. Paris, Éditions L'Harmattan, 2004, pp. 127-147.

34 Ver Conde de Ficalmo, Garcia de Orta, op. cit., pp. 289-290. 
As gemas, claro, são um produto da natureza e o respectivo estudo estava integrado de direito na história natural. Além disso, de um ponto de vista quinhentista, muitas pedras preciosas eram tradicionalmente investidas com uma variedade de propriedades medicinais - curativas, protectivas ou profilácticas —, sendo, portanto, assunto de legítimo interesse para qualquer praticante de medicina minimamente sério. ${ }^{35}$ Os eruditos europeus do século Xvi estavam decerto cientes da longa tradição de estudos mineralógicos, que remontava ao autor grego Teofrasto, supostamente o primeiro ocidental a tentar reunir e organizar informaçóes sobre as propriedades das pedras preciosas, entre os séculos iv e III AEC. ${ }^{36}$ Às esmeraldas, por exemplo, atribuía Teofrasto a propriedade de melhorarem a visão daqueles que as usavam como adorno. ${ }^{37}$ Uma tradução latina da sua obra — De lapidibus — foi publicada pela primeira vez em Veneza nos últimos anos do século xv, com várias reedições posteriores. Apesar de Garcia de Orta provavelmente conhecer a traduçáo latina do tratado de Teofrasto De historia et causis plantarum, preparada no século xv pelo estudioso grego Teodoro Gaza e impressa pela primeira vez em $1476,{ }^{38}$ é duvidoso que conhecesse o tratado sobre pedras preciosas do mesmo autor. ${ }^{39}$ Mas grande parte dos dados recolhidos por Teofrasto sobre pedras preciosas tinham sido compilados por Plínio-o-Velho, no século I, na sua Naturalis Historia, um trabalho enciclopédico que foi repetidamente impresso na Europa nos séculos XV e XVI, e foi amplamente lido pelos naturalistas quinhentistas. Garcia de Orta possuía pelo menos uma edição desta obra na sua biblioteca particular, a qual cita nos seus Colóquios dos simples página sim, página não, muitas

35 Ver Lynn Thorndike, A History of Magic and Experimental Science, 8 vols.. Nova Iorque, Columbia University Press, 1923-1958, vol. 6, pp. 298-324.

36 Para uma história genérica das pedras preciosas e das crenças a elas associadas, ver as obras clássicas de George F. Kunz, The Curious Lore of Precious Stones. Nova Iorque, Halcyon House, 1938, e Joan Evans, Magical Jewels of the Middle Ages and the Renaissance, particularly in England. Oxford, Clarendon Press, 1922. Para abordagens mais recentes, ver: Nichola E. HARRIS, The Idea of Lapidary Medicine: Its Circulation and Practical Applications in Medieval and Early Modern England, 1000-1750, dissertação de doutoramento inédita. New Brunswick, New Jersey, The State University of New Jersey, 2009; Claude LeCouteux, Dictionnaire des pierres magiques et médicinales. Paris, Éditions Imago, 2011; e também J. C. Duffin; R. T. J. Moody; C. Gardnaer-Thorpe (orgs.), A History of Geology and Medicine. Londres, The Geological Society of London, 2013, passim.

37 Teofrasto [Teophrastus], On Stones, ed. Earle R. Caley; John F. C. Richards. Columbus, Ohio, The Ohio State University, 1956, pp. 99-100.

38 Ver Garcia de ORTA, Colóquios dos simples, op. cit., vol. 2, p. 327, onde "Teodoro Guaza" é mencionado. Para uma opinião contrária, ver Conde de FICALHo, Garcia de Orta, op. cit., p. 285 ("é mesmo duvidoso que o tivesse (ido"). Sobre Gaza, ver Deno John Geanakoplos, Constantinople and the West: Essays on the Late Byzantine (Palaeologan) and Italian Renaissances and the Byzantine and Roman Churches. Madison, The University of Wisconsin Press, 1989, pp. 68-90.

39 Sobre Teofrasto, ver Charles B. Schmitt, "Theophrastus", in Paul O. KRISTELLer; F. Edward CRAnZ (orgs.), Catalogus translationum et commentariorum: Mediaeval and Renaissance Latin translations and commentaries - Volume II. Washington D.C., The Catholic University of America Press, 1971, pp. 239-322; ver também Annibale MOTTANA, "Il pensiero di Teofrasto sui metalli secondo i frammenti delle sue opere e le testimonianze greche, latine, siriache ed arabe", Rendiconti Lincei - Scienze Fisiche e Naturali 9.12 (2001), pp. 133-241. 
vezes com referências explícitas a determinados livros e capítulos. O material sobre pedras preciosas estava concentrado no livro 37 da enciclopédia de Plínio. Entretanto, o médico português, que frequentemente expressava a sua discordância em relaçáo a Plínio a respeito de informações e/ou hipóteses relativas a assuntos asiáticos, também possuía as Castigationes Plinianae publicadas por Ermolao Barbaro, com nada menos que cinco mil correcçóes, bem como uma edição da Naturalis Historia anotada por este erudito veneziano do século xv. ${ }^{40}$

No colóquio "da pedra diamáo”, em que Orta e Ruano discutiam diamantes, este último questionou o médico português, alegando que esta pedra preciosa "tem eminencia sobre todas, e loguo as perolas, e loguo as esmeraldas, e loguo os robins, se cremos a Plinio". ${ }^{41}$ A resposta de Orta foi um pouco enigmática, pois declarou que, embora as gemas mencionadas fossem certamente valiosas por serem raras e muito apreciadas como ornamentos, de um ponto de vista médico eram inúteis, ao contrário da "pedra de cevar, e a que estanca o sangue", ambas portadoras de muito mais virtudes, amplamente experimentadas. ${ }^{42}$ Tal significa que ele alimentava sérias reservas relativamente às supostas propriedades de algumas pedras preciosas: "quanto he á fisica, nam se costuma usar destes diamães", por outras palavras, os diamantes não possuíam qualquer utilidade em termos médicos. Apesar desta posição, o físico português estava bem ciente de que alguns dos seus colegas indianos utilizavam amiúde injecçóes de diamantes moídos com o propósito de quebrar cálculos da vesícula. ${ }^{43}$ Neste mesmo colóquio sobre os diamantes, entretanto, Garcia de Orta exibia mais uma vez a sua erudição, trazendo para o debate diversas autoridades espanholas, a respeito dos nomes e das supostas propriedades desta pedra preciosa. Algumas dessas referências merecem menção especial.

Uma dessas autoridades era Andrés Laguna, um médico e filólogo que preparara uma tradução anotada espanhola do antigo tratado grego De materia medica de Pedânio Dioscórides, que foi publicada em Antuérpia em 1555, com muitas ediçóes posteriores. Orta possuía uma edição da tradução de Laguna, que menciona repetidamente ao longo dos Colóquios dos simples. ${ }^{44}$

40 Garcia de ORTA, Colóquios dos simples, op. cit., vol. 2, p. 295: "nas Anotações de Plinio, diz Hermolao Barbaro". Sobre Plínio, ver Trevor MURPHY, Pliny the Elder's Natural History: The Empire in the Encyclopedia. Oxford, Oxford University Press, 2004; e sobre os comentários de Ermolao, ver Brian W. OGILVIE, The Science of Describing: Natural History in Renaissance Europe. Chicago \& Londres, The University of Chicago Press, 2006, pp. 122-126.

41 Garcia de ORTA, Colóquios dos simples, op. cit., vol. 2, p. 195.

42 Garcia de OrTA, Colóquios dos simples, op. cit., vol. 2, p. 195.

43 Garcia de ORTA, Colóquios dos simples, op. cit., vol. 2, p. 196. O procedimento não parece ser muito consistente com os sistemas médicos indianos tradicionais, e nomeadamente com o Ayurveda. Ver Robert SigalÉA, La médecine traditionnelle de l'Inde. Geneva, Olizane, 1995. Sobre a relação de Orta com o Ayurveda, ver Michael N. PEARSON, "Portuguese and Indian Medical Systems: Commonality and Superiority in the Early Modern Period", RC - Revista de Cultura / Review of Culture 20 (2006), pp. 116-141.

44 Conde de Ficalmo, Garcia da Orta, op. cit., p. 293. Sobre Laguna, ver Miguel Ángel González Manjarrés, Andrés Laguna y el Humanismo Médico. Salamanca, Junta de Castilla y León, 2000. 
Mas tinha uma relação complicada com o seu colega espanhol. Por um lado, como anota Ruano num dos últimos colóquios, chama-lhe de forma consistente "Tordelaguna chamandose elle Andreas de Laguna”. A justificação do médico português foi bastante frouxa, pois limitou-se a alegar que em Alcalá de Henares conhecera boticário "que se chamava Tordelaguna", o qual "sabia algun pouquo de arabio, e era grande ervolario", e tinha-o confundido com o Andrés Laguna tradutor do Dioscórides. Ironicamente, Orta acrescentava que, tendo em conta os muitos erros encontrados na edição de Dioscórides preparada por Laguna, estava feliz por não se tratar da mesma pessoa, pois "Tordelaguna" tinha sido seu amigo na universidade e tinha-o em elevada conta. ${ }^{45}$

Andrés Laguna era mais novo que Garcia de Orta, mas poderiam ter-se cruzado durante os respectivos períodos de estudo. ${ }^{46}$ Contudo, o português defende que nunca se haviam cruzado, nem em Salamanca, nem em qualquer outro lugar. Outra das referências de Ruano a Laguna, no colóquio sobre a pimenta, esclarece um pouco toda esta questão, pois regista-se a informação de que o tradutor e comentador espanhol de Dioscórides teria declarado nos seus escritos que os portugueses não estavam interessados em escrever sobre as Índias, pois "não tem mais cuidado que de robar e esfolar os Indios”. ${ }^{47}$ Esta observação, seriamente crítica, e que de facto se encontra na primeira edição da obra de Laguna, onde ele critica duramente os portugueses pela sua falta de interesse em assuntos de história natural, seria suficiente para explicar a animosidade de Orta em relação a ele, e até mesmo, talvez, para justificar a própria existência dos Colóquios dos simples como uma patriótica resposta do naturalista português. ${ }^{48}$ Dioscórides tinha escrito sobre as pedras preciosas e as suas virtudes, claro, e Laguna traduzira o texto original, acrescentando inúmeras anotaçôes. ${ }^{49}$ Mas, escusado será dizer, as observaçôes de Andrés Laguna acerca dos diamantes foram totalmente descartadas pelo médico português, com base na sua experiência indiana: "Asi que dizem que os diamães sam venenosos he abusam, e cousa não scita per doutores autenticos". ${ }^{50}$

45 Garcia de ORTA, Colóquios dos simples, op. cit., vol. 2, pp. 378-379.

46 Ver Miguel Ángel González Manjarrés, Andrés Laguna, op. cit, p. 40.

47 Garcia de OrTA, Colóquios dos simples, op. cit., vol. 2, p. 248.

48 A anotação de Laguna relativa aos portugueses que regressavam da Índia, inserida no capítulo sobre a pimenta, era na verdade muito crítica: "como no sean nada curiosos de lo que conviene al bien publico, ni à la cõmun disciplina, sino solamente de acumular dinero, y dessollar los Indios desuenturados, no se curan mucho de contemplar aquellas diuinas plantas, para darnos acà entera relation dellas" (Andrés LAGUNA, Pedacio Dioscorides Anazarbeo, acerca de la matéria medicinal, y de los venenos mortíferos. Antuérpia, Juan Latio, 1555, p. 237).

49 Andrés Laguna, Pedacio Dioscorides Anazarbeo, op. cit., liv. V, passim.

50 Garcia de ORTA, Colóquios dos simples, op. cit., vol. 2, pp. 196-197. Mas Orta, nesta instância, parece ter treslido o texto de Laguna, pois a tradução espanhola de Dioscórides afirmava que os diamantes eram úteis contra os venenos; o tradutor espanhol declarava ainda ter tido conhecimento desta propriedade por intermédio de "Maestre Juan Portugues, medico excellentissimo", que vivia em Roma (Andrés LAGUnA, Pedacio Dioscorides Anazarbeo, op. cit., p. 577). Não consegui identificar este físico português. Tratar-se-ia de João Rodrigues de Castelo Branco, mais conhecido como Amato Lusitano, 
Por outro lado, as reservas de Orta relativamente a Laguna poderiam indiciar uma estratégia de afastamento premeditado em relação a um autor que era conhecido como cristão-novo, numa tentativa de evitar que sobre si próprio se desenvolvessem quaisquer suspeitas de ligaçóes ao judaísmo. O físico português, é bem sabido, era ele próprio originário de uma família de conversos, pois os seus antepassados judeus tinham-se convertido ao cristianismo. ${ }^{51}$ No período em que os Colóquios dos simples eram concluídos, em inícios da década de 1560, a Inquisição portuguesa acabava de instalar uma delegação em Goa, sobretudo com o propósito de reforçar a vigilância e a perseguição em relação à larga comunidade de cristão-novos que se havia estabelecido em diversos territórios dependentes do Estado da Índia. ${ }^{52}$ Uma figura pública como Garcia de Orta, assim, deveria nos seus escritos destinados à impressão reforçar as suas precauçôes, nomeadamente em termos de declaradas simpatias para com outros colegas de ofício e de escrita que fossem ou pudessem ser suspeitos de ligações à religiáo judaica. De resto, esta lógica explicaria a quase total ausência de referências a Amato Lusitano, o físico cristão-novo que abandonara definitivamente Portugal em 1534 - precisamente o ano da partida de Orta para a Índia - e que publicara um alargado conjunto de obras de medicina em diferentes prelos europeus, cuja referência seria perfeitamente legítima numa obra como os Colóquios dos simples. ${ }^{53}$

Para além de Andrés Laguna, outro autor espanhol é citado nos Colóquios dos simples na discussão sobre os diamantes, quando Ruano menciona "hum coronista, chamado Francisco de Tamara”, que havia escrito que se encontravam diamantes no Peru. ${ }^{54}$ Num colóquio anterior, este estudioso já havia sido mencionado, como "Francisquo de Tamara, no livro que fez

com quem Laguna se cruzou em Roma? Sobre este encontro, ver Miguel Ángel GonzÁLEz MANJARRÉS; María Jesús PÉRez IbáÑEz, "Andrés Laguna y Amato Lusitano, el desencuentro de dos humanistas médicos", in Ferran Grau Codina et alii (eds.), La Universitat de València i l'Humanisme: Studia Humanitatis i renovació cultural a Europa i al Nou Món. Valência, Universitat de València, 2003, pp. 689-711. A respeito de Amato Lusitano, existe uma bibliografia imensa, que poderá ser consultada através da página electrónica do projecto de investigação "Dioscórides e o Humanismo Português: Os Comentários de Amato Lusitano", em http:// amatolusitano.web.ua.pt/ [consultado em 26-02-2014].

51 Sobre as origens judaicas de Garcia de Orta, ver Augusto da Silva CaRvalho, Garcia d'Orta. Coimbra, Imprensa da Universidade, 1934; e I. S. RÉVAH, "La Famille de Garcia de Orta", Revista da Universidade de Coimbra 19 (1960), pp. 407-420.

52 Sobre a Inquisição goesa, ver Ana Cannas da CunHA, A Inquisição no Estado da Índia: Origens (15391560). Lisboa, Arquivos Nacionais / Torre do Tombo, 1995; e também Ines G. Županov, "'The Wheel of Torments': mobility and redemption in Portuguese colonial India", in Stephen GREENBLATT et alii (orgs.), Cultural Mobility: A Manifesto. Cambridge, Cambridge University Press, 2009, pp. 24-74. Sobre a problemática dos cristãos-novos no Estado da Índia, ver sobretudo José Alberto Rodrigues da Silva TAVIM, Judeus e Cristãos-Novos de Cochim: História e Memória (1500-1662). Braga, Edições APPACDM, 2004.

53 Amato Lusitano é referido uma única vez na obra de Garcia de ORTA, Colóquios dos simples, op. cit., vol. 1, p. 210. Sobre as obras de Amato, ver João José Alves DiAs, Amato Lusitano e a sua obra - Séculos XVI exVII. Lisboa, Biblioteca Nacional de Portugal, 2011.

54 Garcia de ORTA, Colóquios dos simples, op. cit., vol. 2, p. 201: "que ha diamães no Peru". 
dos Custumes". ${ }^{55} \mathrm{Na}$ verdade, Orta estava a referir-se em ambos os casos ao tratado Omnium gentium mores, leges et ritus, de Johann Boemus, publicado em Augsburgo em 1520, e que depois fora traduzido em várias línguas europeias. ${ }^{56} \mathrm{O}$ médico português conhecia bem a obra célebre, que tinha lido na tradução espanhola preparada por Francisco de Támara e publicada em Antuérpia em 1556, com o título de El Libro de las Costumbres de todas las Gentes del Mundo. O tradutor espanhol tinha incluído novos materiais na sua versão do livro de Boemus, descrevendo "todas las Indias y tierras nueuamente descubiertas por gente de España" ${ }^{57}$ Orta mostrou-se extremamente crítico em relação à versão de Támara, e o trabalho é sempre citado nos Colóquios dos simples em tom discordante. No presente caso, a sua resposta a Ruano foi directa, contradizendo sumariamente as histórias sobre minas de diamantes que eram vigiadas por cobras venenosas: "eu vi nesse autor que alegaes, muitas fabulas". 58

Um terceiro autor mencionado na discussão sobre diamantes é "hum frade dominico, chamado frei Domingos de Baltanas", que tinha escrito que havia minas dessas pedras preciosas em Espanha. ${ }^{59}$ Garcia de Orta referia-se a Domingo de Baltanás e ao seu Compendio de algunas cosas notables de España, publicado em Sevilha em $1558 .{ }^{60}$ As suas dúvidas sobre as alegações do frade espanhol são expressas, mais uma vez, através de um procedimento metodológico regularmente utilizado ao longo dos Colóquios dos simples: a opiniāo ou informação de um determinado autor era registada, apenas para ser de imediato contestada. A referência a Baltanás (ou Valtanás, como também é conhecido) é bastante curiosa, já que o dominicano espanhol tinha sido recentemente aprisionado pela Inquisição em Sevilha, e fora a julgamento entre 1561 e 1563, sob várias acusações, nomeadamente de conduta imprópria em relação à sua

55 Garcia de ORTA, Colóquios dos simples, op. cit., vol. 1, p. 213.

56 Sobre Boemus, ver a análise clássica de Margaret T. HodGEN, Early Anthropology in the Sixteenth and Seventeenth Centuries. Filadélfia, University of Pennsylvania Press, 1971, pp. 111-161; e também Klaus A. Vogel, "Cultural Variety in a Renaissance Perspective: Johannes Boemus and 'The Manners, Laws and Customs of all People' (1520)", in Henriette BuGGE; Joan Pau RuBıÉs (orgs.), Shifting Cultures: Interaction and Discourse in the Expansion of Europe. Münster, LIT Verlag, 1995, pp. 17-34.

57 Francisco de TÁmARA, El Libro de las Costumbres de todas las Gentes del Mundo. Antuérpia, Martin Nucio, 1556, fl. 249. Sobre o tradutor espanhol, ver Victoria PINEDA, "El arte de traducir en el Renacimiento (La obra de Francisco de Támara)", Criticón 73 (1998), pp. 23-35; e Hélène RABAEY, "Francisco de Támara: algunos aportes biográficos", Calamus Renascens 3 (2002), pp. 249-254.

58 Garcia de ORTA, Colóquios dos simples, op. cit., vol. 2, p. 201. De facto, Támara não era o único responsável pela lenda acerca das serpentes que guardavam minas de diamantes, pois a história havia sido repetida por muitos autores antigos e medievais. Ver Berthold LAUFER, The Diamond: A Study in Chinese and Hellenistic Folk-lore. Chicago, Field Museum of Natural History, 1915.

59 Garcia de ORTA, Colóquios dos simples, op. cit., vol. 2, p. 201: "que ha roca de diamães em Espanha".

60 Garcia de OrTa, Colóquios dos simples, op. cit., vol. 2, p. 201. Ver Domingo de Baltanás, Compendio de algunas cosas notables de España y de la conquista y toma del reyno de Granada. Sevilha, Martín de Montesdoca, 1558, fl. vii. Sobre Baltanás, ver Gianclaudio Civale, "Domingo de Baltanás, monje solicitante en la encrucijada religiosa andaluza: Confesión, Inquisición y Compañía de Jesús en la Sevilla del Siglo de Oro", Hispania Sacra 59.119 (2007), pp. 197-241. 
congregação feminina. Orta afirmava que havia conhecido Domingo de Baltanás em Espanha: "Eu conheci ese frade em Salamanca, segundo me parece, e tenhoo por bom religioso" ${ }^{61}$ Será que o médico português desconhecia os recentes problemas de Baltanás com o Santo Ofício? Talvez estivesse a tomar uma posição pública em favor do seu velho colega universitário, que, por sinal, era bem conhecido pelas suas posições de apoio aos conversos espanhóis.

Resumindo, o colóquio sobre a "pedra diamão", de um ponto de vista estritamente informativo, é bastante inovador, uma vez que Garcia de Orta critica severamente uma série de noções errôneas que eram correntes na sua época, sobre a localização de minas de diamantes, a extracção dessas pedras preciosas, e as supostas propriedades da gema. ${ }^{62}$ Mas no início deste mesmo colóquio, Orta tinha mencionado as virtudes da "pedra de cevar", à qual regressa nas páginas finais. Mais uma vez refuta uma das alegaçôes de Laguna, aquela sobre a natureza venenosa da magnetite. O médico português explica que, muito contrariamente a esta opinião, os físicos indianos alegavam que a pedra de cevar, "comida em pouca cantidade os faz não emvelhecer", e lembra a história do soberano cingalês que fazia cozinhar as suas refeiçóes em panelas feitas deste material. A observação de Orta sobre esta alegada virtude da magnetite errava a pontaria, claro, mas mais uma vez ele era suficientemente cuidadoso para, como em outros casos duvidosos, invocar a opiniáo de terceiros. Neste caso, a sua fonte era um informador local, "Isac do Cairo", o bem conhecido colaborador judeu das autoridades portuguesas do Estado da Índia, que havia sido encarregado de fornecer as referidas panelas, talvez ao rei Bhuvaneka Bâhu, que governou no reino de Kotte entre 1521 e $1551 .{ }^{63}$ Ainda em relação à magnetite, os Colóquios dos simples mencionavam os escritos de um "filosofo pariense", que não é identificado. ${ }^{64}$ Talvez se tratasse de uma referência críptica ao médico francês Jean de la Ruelle, que é mencionado em outro lugar, no colóquio sobre o "Altiht". ${ }^{65}$ Johannes Ruellius, como também era conhecido, foi autor de várias obras de referência nos campos da medicina e da história natural, e designadamente De medicinali materia, uma tradução latina de Dioscórides publicada em Paris em 1516, com sucessivas reediçôes. Garcia de Orta possuía uma destas, bem como um exemplar de um outro dos tratados de Ruellius, De natura stirpium libri tres, publicado em 1536, também em Paris. ${ }^{66}$ Em ambas as obras, contudo, as passagens relevantes sobre a pedra de cevar não concordam

61 Garcia de ORTA, Colóquios dos simples, op. cit., vol. 2, p. 201.

62 Ver a nota do Conde de Ficalho: Garcia de ORTA, Colóquios dos simples, op. cit., vol. 2, pp. 206-212.

63 Garcia de ORTA, Colóquios dos simples, op. cit., vol. 2, p. 204. Sobre esta interessante figura, ver José Alberto Rodrigues da Silva TAVIM, "Os Judeus e a Expansão Portuguesa na Índia no Século xvI. O Exemplo de Isaac do Cairo: Espião, 'Língua' e 'Judeu de Cochim de Cima'", Arquivos do Centro Cultural Calouste Gulbenkian 33 (1994), pp. 137-261.

64 Garcia de ORTA, Colóquios dos simples, op. cit., vol. 2, p. 205.

65 Garcia de ORTA, Colóquios dos simples, op. cit., vol. 1, p. 85.

66 Sobre Jean de la Ruelle e as suas obras, ver Edward Lee GREEN, Landmarks of Botanical History, ed. Frank N. Egerton. Stanford, California, Stanford University Press, 1983, pp. 598-657. 
totalmente com a referência de Orta. ${ }^{67}$ Assim, talvez ele se estivesse a referir a François de la Rue, também conhecido como Franciscus Rueus, que publicou o tratado De gemmis em Paris em 1547 , o qual incluía um capítulo sobre a magnetite. ${ }^{68}$

As informaçóes sobre as pedras preciosas, excluindo os diamantes, estão concentradas no colóquio que ostenta precisamente no seu título essa referência a "pedras preciosas". ${ }^{69}$ Neste lugar, com efeito, Orta discute os dados relevantes sobre as gemas valiosas às quais a erudição clássica e medieval tinha atribuído propriedades medicinais, nas palavras de Ruano, "pedras preciosas que emtram nas composiçôes e letuairos cordiaes" ${ }^{70} \mathrm{Nas}$ linhas de abertura do colóquio, o médico português definiu os limites da temática a tratar, alegando que iria debruçar-se apenas sobre "pedras medicinaes e das que ha na India", pois caso contrário a sua narrativa não teria fim..$^{71}$ Em primeiro lugar, tratou das safiras, descrevendo a pedra e identificando os seus locais de origem, sendo as de Ceiláo e de Pegu consideradas mais valiosas; as safiras, na opinião do médico português, configuravam uma excelente mercadoria para levar de volta para a Europa, pois habitualmente atingiam preços elevados. De seguida, referem-se os jacintos e granadas, que abundavam na Índia, especialmente em Cambaia, e não eram gemas tão valiosas. Em terceiro lugar, surgem os rubis, explicando Orta que existiam "muitas especias", uma das quais era o "carbunculus". Respondendo a uma questão directa de Ruano, o naturalista de imediato descartou a ideia de que carbúnculos emitiriam luz durante a noite, classificando essas histórias como "ditos de velhas". ${ }^{72}$ Os rubis, de acordo com os Colóquios dos simples, apresentavam-se em diversas cores e outras tantas variedades, a maioria deles estando acessíveis a preços razoáveis nos portos indianos. Até ao momento, assim, os comentários de Orta parecem identificar-se com os de um qualquer mercador de gemas, e não com os de um médico interessado nas virtudes curativas das pedras preciosas.

67 Tendo presente a frase de Garcia de Orta, "Hum filosofo pariense [sic] diz, que a pedra de cevar move o ferro pera si, mediante a vertude que nelle emprimio, pera que se mova a ella" (Colóquios dos simples, op. cit., vol. 2, p. 205), outra hipótese mais rebuscada seria identificar este filósofo com Cristoforo da Recanati, alquimista italiano do século xv, também conhecido como Christophorus Parisiensis; mas as suas obras apenas terão circulado sob forma manuscrita. Sobre Recanati, ver Lynn THORNDIKE, A History of Magic and Experimental Science, op. cit., vol. 4, pp. 348-351.

68 Sobre Rueus, ver Lynn THORNDIKE, A History of Magic and Experimental Science, op. cit., vol. 6, pp. 303-306.

69 Garcia de OrTA, Colóquios dos simples, op. cit., vol. 2, pp. 215-222 (ver notas de Ficalho, pp. 223-230).

70 Garcia de OrTA, Colóquios dos simples, op. cit., vol. 2, p. 215.

71 Garcia de OrTA, Colóquios dos simples, op. cit., vol. 2, p. 215. Para a localização de pedras preciosas na Índia, ver Arun Kumar BIsWAS, "Gem-Minerals in Pre-Modern India", Indian Journal of History of Science 29.3 (1994), pp. 389-420.

72 Garcia de OrTA, Colóquios dos simples, op. cit., vol. 2, p. 217. 
A esmeralda é outra pedra preciosa presente neste colóquio, sendo, de acordo com a opiniáo de Ruano, classificada como a "milhor pedra e a mais nesseçaria", ${ }^{73}$ como foi anteriormente referido. Contudo, valerá a pena acrescentar aqui que o interlocutor de Garcia de Orta alegava que "as nossas esmeraldas do Perú, diz hum doutor moderno, que sam muyto más pera o uso da medecina". ${ }^{74}$ Estava a referir-se, possivelmente, a Andrés Laguna, que produziu um tal comentário a respeito das esmeraldas, nas suas anotaçóes à matéria referente a safiras na tradução de Dioscórides. ${ }^{75}$ Como de costume, a atitude de Orta para com a opinião de Laguna foi totalmente negativa. De imediato informou o seu colega Ruano que muitas dessas esmeraldas do Peru tinham chegado à Índia, sendo inicialmente consideradas muito valiosas; contudo, a opiniáo comum logo se havia alterado, e em breve as esmeraldas americanas seriam totalmente desvalorizadas e consideradas de inferior qualidade. Tendo em consideraçáo que as esmeraldas do Novo Mundo eram na realidade excelentes, tanto em água como em cor, a opiniáo de Garcia de Orta é um pouco desconcertante. Todavia, a mesma informaçáo aparece numa "Memoria das drogas e pedras preciosas", manuscrito datado da década de 1560, e possivelmente escrito em Lisboa por um lapidário português. ${ }^{76}$ De facto, o anónimo autor confirmava que muitas pessoas tinham adquirido essas esmeraldas que eram conhecidas como "do peru" e as tinham levado para a Índia como produto comercial, mas tinham-nas trazido de volta a Portugal como se fossem gemas orientais, para tentarem aumentar o seu valor, lucrando com a noçáo subjectiva, mas amplamente difundida, de que todas as pedras preciosas provenientes das Índias Orientais eram mais valiosas. ${ }^{77}$

O colóquio sobre "pedras preciosas" avança depois para as turquesas, com Ruano a questionar se esta pedra era usada em física. No que toca à medicina lapidária em geral, a resposta de Orta tornara-se já proverbial: "Alguns me dixeram que si, e outros que não". ${ }^{78} \mathrm{Ou}$ seja, sempre que a conversa girava em torno de pedras preciosas e suas supostas virtudes na prática da medicina, o físico português, por via de regra, recusava-se a tomar uma posiçáo clara, em alguns casos remetendo para os seus informadores, em outros ignorando abertamente o problema. O leitor atento dos Colóquios dos simples sentir-se-ia algo perdido quando tentasse descobrir a posição

73 Garcia de ORTA, Colóquios dos simples, op. cit., vol. 2, p. 219.

74 Garcia de ORTA, Colóquios dos simples, op. cit., vol. 2, p. 221.

75 Andrés Laguna, Pedacio Dioscorides Anazarbeo, op. cit., p. 563. Ver José Luis Fresouet Febrer, "El uso de produtos del reino mineral en la terapêutica del siglo xvı. El libro de los Medicamentos simples de Juan Fragoso (1581) y el Antidotario de Juan Calvo (1580)", Asclepio - Revista de Historia de Medicina y de la Ciencia 51.1 (1999), pp. 55-92.

76 A "Memoria" conserva-se na Biblioteca Nacional de Portugal; foi publicada por Nuno Vassallo e SiLva, Subsídios para o estudo do comércio das pedras preciosas, op. cit., pp. 21-37.

77 Nuno Vassallo e SILva, Subsídios para o estudo do comércio das pedras preciosas, op. cit., p. 32. Ver Kris LANE, The Colour of Paradise, op. cit., pp. 100-102.

78 Garcia de ORTA, Colóquios dos simples, op. cit., vol. 2, p. 221. 
do respectivo autor sobre as reais virtudes das pedras preciosas. Nada era afirmado em termos concretos sobre as propriedades medicinais de safiras, jacintos, granadas, rubis, esmeraldas ou turquesas. E também nada era referido sobre as virtudes da "crisolita e da amatista, e do birilo [...] e da alaqueca, e do jaspe", ${ }^{79}$ apenas algumas noçôes eram avançadas sobre as origens das várias gemas, por vezes com referências às suas designaçóes em diferentes idiomas. Valerá a pena mencionar uma curiosa nota sobre o jaspe, pois Garcia de Orta alegava que "pode ser que a pedra que está em Genoa, que dizem ser de esmeralda, seja desta pedra" ${ }^{80} \mathrm{O}$ médico português estava a referir-se ao famoso sacro catino, que se conservava na catedral de San Lorenzo, em Génova, deduzindo correctamente que não era feito de esmeralda. Não é fácil descobrir como ouviu Orta falar do lendário cálice, que alguns afirmavam não ser outro senão o Santo Graal, ${ }^{81}$ mas poderia ter lido alguma referência numa colecção de vidas de santos como o Flos Sanctorum, que foi traduzido para português e impresso em Lisboa em $1513 .{ }^{82}$

De resto, apenas duas excepçóes relativas às virtudes das pedras preciosas se encontram neste colóquio. Por um lado, os "olhos de gato" (crisoberilo), que de acordo com Orta os indianos afirmavam ter a "a propriedade de conservar ao homem nas riquezas que tem". ${ }^{83}$ Mais uma vez o médico português citava opiniôes de terceiros, recusando-se a revelar a sua posição sobre o assunto. Por outro lado, a "alaqueca" ou cornalina, uma pedra que "tem a vertude mais crara que todallas outras, porque estanca o sangue mui de supito", e que tinha sido previamente citada por Garcia de Orta na sua discussão sobre os diamantes. ${ }^{84}$ Aparentemente, esta parece ser a única concessão directa do autor dos Colóquios dos simples relativamente à medicina lapidária: ele acreditava e testemunhava, com base na sua própria experiência, que as cornalinas eram eficientes para estancar o sangue. Todas as outras pedras preciosas, tanto quanto o naturalista português entendia, não tinham qualquer valor medicinal.

A recusa de Garcia de Orta em aceitar abertamente a atribuição de virtudes mágicas — por oposição a propriedades verificadas experimentalmente — às pedras preciosas poderia ser uma estratégia bem planeada para ultrapassar o olhar atento da Inquisição portuguesa, que, como referido, acabara de se estabelecer em Goa. Garcia de Orta tinha, afinal, raízes judaicas, o que o transformava em suspeito aos olhos do Santo Ofício. E antes da publicação, os Colóquios dos simples tinham de superar uma série de medidas legais, que incluíam a obtenção de uma

79 Garcia de ORTA, Coloquios dos simples, op. cit., vol. 2, p. 221.

80 Garcia de OrTA, Coloquios dos simples, op. cit., vol. 2, p. 221.

81 Sobre o sacro catino, ver Richard W. BARBER, The Holy Grail: Imagination and Belief. Londres, Penguin, 2004, pp. 168-169.

82 Ver Maria Clara de Almeida LuCAS (ed.), Ho Flos Sanctorum en Lingoage: os Santos Extravagantes. Lisboa, Instituto Nacional de Investigação Científica, 1988.

83 Garcia de OrTA, Coloquios dos simples, op. cit., vol. 2, p. 222.

84 Garcia de OrTA, Coloquios dos simples, op. cit., vol. 2, p. 222 
autorização de Aleixo Dias Falcão, "inquisidor nestas partes” da Índia, como o frontispício da edição goesa testemunha. ${ }^{85} \mathrm{Tal}$ motivo parece suficiente para justificar a cautela de Orta em relação às crenças sobre pedras preciosas e para explicar por que motivo os Colóquios dos simples evitam a todo o custo a temática da medicina lapidária. Esta estratégia de evitar temas sensíveis, de resto, explicaria a ausência de mençóes explícitas a um certo número de referências livrescas, num trabalho que, por outro lado, aproveitou todas as oportunidades para demonstrar que o seu autor possuía um profundo conhecimento da literatura médica do seu tempo. Garcia de Orta, curiosamente, não cita ou menciona qualquer um dos lapidários que corriam no seu tempo, um conjunto de obras que compilavam os conhecimentos disponíveis sobre pedras preciosas, juntamente com conselhos detalhados sobre a forma de as utilizar como meios de protecção ou curativos. Este rol de obras incluía, entre muitas outras: o Speculum lapidum do físico italiano Camillo Lunardi, publicado em Veneza em 1502; o Libellus de lapidibus preciosis, escrito no século xi por Marbode, bispo de Rennes, mas publicado pela primeira vez em Viena em 1511; o tratado De natura fossilium, do erudito alemão do século xvi Georg Bauer, também conhecido como Georgius Agricola, publicado em Basileia em 1546; ou o já citado De gemmis de François de la Rue. ${ }^{86}$

Os Colóquios dos simples incluem muitas outras referências a produtos naturais classificados por Garcia de Orta como 'pedras', e nomeadamente pedras-arménias, pedras-bezoar, pedras de coral, pedras de porco-espinho e pérolas. ${ }^{87} \mathrm{~A}$ todas estas atribui o físico português virtudes

85 Garcia de ORTA, Colóquios dos simples, op. cit., vol. 1, p. 1.

86 Sobre estes lapidários, ver, respectivamente: Carla DE BELLIS, "Astri, gemme e arti medico-magiche nello 'Speculum lapidum' di Camillo Leonardi", in G. FormiCHETTI (org.), Il mago, il cosmo, il teatro degli astir: Saggi sulla letteratura esoterica del Rinascimento. Roma, Bulzoni, 1985, pp. 67-114; MARBODE DE Rennes, Marbode of Rennes' (1035-1123) De lapidibus, ed. John M. RIDDle; trad. C. W. KING. WIESBADEN, Steiner Verlag, 1977; Georgius AGRICOLA, De natura fossilium (Textbook of Mineralogy), ed. Mark C. BANDY; Jean A. BANDY. Nova Iorque, The Geological Society of America, 1955; e Lynn THORNDIKE, A History of Magic and Experimental Science, op. cit., vol. 6, pp. 298-306. Outra ausência interessante nos Colóquios dos simples são as obras de António Luís, um médico baseado em Lisboa, onde publicou em 1540 o tratado De occultis proprietatibus, tratando de plantas, animais e minerais. Sobre este cristão-novo muito pouco estudado, que poderia ter coincidido brevemente com Orta em Salamanca, ver Lynn THORNDIKE, A History of Magic and Experimental Science, op. cit., vol. 5, pp. 550-552; e também Américo da Costa Ramalho, "António Luís, corrector de Erasmo", Humanitas 45 (1993), pp. 243-254. Ver ainda a recente tradução de uma das suas obras: António Luís, Cinco Livros de Problemas, ed. António Guimarães PINTo. Lisboa, Centro de Filosofia da Universidade de Lisboa, 2010.

87 A utilização por Orta de vários tipos de 'pedras' merecerá decerto uma investigação mais aprofundada. Alguns destes produtos foram já objecto de investigação. Ver Jorge Manuel dos Santos ALves, "A pedra-bezoar — realidade e mito em torno de um antídoto (séculos XVI e XVII)", in Jorge Manuel dos Santos Alves; Claude GuILlot; Roderich PTAK (orgs.), Mirabilia Asiatica: Produtos raros no comércio marítimo / Produits rares dans le commerce maritime / Seltene Waren im Seehandel. Wiesbaden, Harrassowitz Verlag \& Fundação Oriente, 2003, pp. 121-134; Francesca TRIVELLATO, "From Livorno to Goa and Back: Merchant Networks and the Coral-Diamond Trade in the Early-Eighteenth Century", Portuguese Studies 16 (2000), pp. 193-217; R. A. DonkIN, Beyond Price - Pearls and Pearl-Fishing: Origins to the Age of Discoveries. Filadélfia, American Philosophical Society, 1998; Peter BorsChberG, "O comércio, 
medicinais, declarando tê-las usado regularmente na sua prática diária. Mas esta posição está em nítido contraste com o seu silêncio ou ambiguidade relativamente às verdadeiras gemas. Aparentemente, Orta não terá sido um grande apologista da utilização de pedras preciosas em curas médicas. O seu cepticismo é suficientemente interessante, e tem sido amiúde caracterizado como um sinal da sua 'modernidade' científica. ${ }^{88}$ Talvez aqui o naturalista português estivesse a seguir o conselho de um de seus autores favoritos, Antonio Musa Brasavola, que tinha apresentado sérias reservas em relação aos poderes atribuídos às pedras preciosas e à respectiva utilização na farmacopeia. ${ }^{89}$ Entre outras obras, o médico italiano publicou um Examen omnium simplicium medicamentorum, em Roma em 1536, no qual criticava abertamente os naturalistas antigos e medievais, alegando que o seu conhecimento das plantas e das substâncias naturais havia sido muito limitado. ${ }^{90} \mathrm{O}$ tratado de Brasavola fora escrito em forma de diálogo, e decerto que serviu de modelo a Garcia de Orta para os seus próprios Colóquios dos simples, nos quais cita repetidamente o autor italiano, que apresenta como homem "curioso e bem entendido". ${ }^{1}$

A posição de Garcia de Orta sobre o uso de pedras preciosas em medicina parece ecoar a de Brasavola, pois enquanto aceita de modo implícito a sua inclusão na farmacopeia do médico praticante, descarta completamente todas as propriedades ocultas que por tradição lhes eram atribuídas. ${ }^{92}$ Teria esta posição origem numa firme convicção, baseada em anos de aprendizagem e experiência como médico em Portugal e na Índia? Afinal, é dele a famosa tirada que refere que "se sabe mais em hum dia agora pellos Portuguezes, do que se sabia em 100 annos pellos Romanos". ${ }^{93}$ Mas talvez Garcia de Orta estivesse apenas a ser cauteloso, num contexto em que a Inquisição portuguesa e a sua delegação goesa monitorizavam de perto os cristãos-novos, ao mesmo tempo que, na esteira da Contra-Reforma, impunham severas limitaçóes aos livros que indivíduos particulares podiam possuir e/ou ler. ${ }^{94} \mathrm{O}$ estudo metódico do mundo natural

uso e falsificação dos bezoares de porco-espinho na Época Moderna (c.1500-1750) / The Trade, Use and Forgery of Porcupine Bezoares in the early Modern Period (c.1500-1750)", Oriente 14 (2006), pp. 60-78.

88 Ver, por exemplo, A. J. Andrade de GouvelA, Garcia d'Orta e Amato Lusitano na ciência do seu tempo. Lisboa, Instituto de Cultura e Língua Portuguesa, 1985, pp. 23-54.

89 Lynn Thorndike, A History of Magic and Experimental Science, op. cit., vol. 6, p. 303.

90 Sobre Antonio Brasavola, ver Lynn Thorndike, A History of Magic and Experimental Science, op. cit., vol. 5, pp. 445-471; e Edward Lee GREEN, Landmarks of Botanical History, op. cit., pp. 658-701.

91 Garcia de ORTA, Colóquios dos simples, op. cit., vol. 1, p. 355. Ver Conde de Ficalho, Garcia da Orta, op. cit., p. 293: "Entre todos os auctores modernos, Antonio Musa era o seu predilecto". Ver também Lynn ThORNDIKE, A History of Magic and Experimental Science, op. cit., vol. 5, pp. 467-468.

92 Lynn ThorNdike, A History of Magic and Experimental Science, op. cit., vol. 5, p. 455.

93 Garcia de ORTA, Colóquios dos simples, op. cit., vol. 1, p. 210.

94 Sobre as actividades censórias da Inquisição no que respeita a livros, ver Henrique LeITÃo (org.), O Livro Científico dos Séculos xv e xvı: Ciências Físico-Matemáticas na Biblioteca Nacional. Lisboa, Biblioteca Nacional, 2004, pp. 45-51. 
e do uso dos produtos da natureza na promoção do bem-estar humano eram áreas de actividade muito sensíveis, que poderiam cair sob o olhar atento de uma instituição cujo principal objectivo era garantir a salvaguarda da ortodoxia católica. Seja como for, parece perfeitamente claro que os Colóquios dos simples continuam a merecer novas investigaçóes: a extensa rede intelectual que dá forma ao livro de Orta, composta por um enorme conjunto de escritores e suas obras, ainda necessita de estudos adicionais; os complexos métodos de trabalho do médico português ainda são insuficientemente conhecidos; e sua visão do mundo natural e de todos os seus produtos e seres aguarda esclarecimentos mais aprofundados. ${ }^{95} \mathrm{O}$ célebre Garcia de Orta, passados 450 anos sobre a publicação dos Colóquios dos simples, não revelou ainda todos os seus segredos, e nomeadamente os meandros de sua "identidade dividida" de cristão-novo, ${ }^{96}$ que parece ter sido metodologicamente relevante no processo de produção de conhecimento científico do médico português.

\section{BIBLIOGRAFIA:}

Agricola, Georgius, De natura fossilium (Textbook of Mineralogy), ed. Mark C. BAndy; Jean A. BAndy. Nova Iorque, The Geological Society of America, 1955.

Alves, Jorge Manuel dos Santos, "A pedra-bezoar — realidade e mito em torno de um antídoto (séculos Xvi e Xvir)", in Jorge Manuel dos Santos Alves; Claude Guillot; Roderich Ptak (orgs.), Mirabilia Asiatica: Produtos raros no comércio maritimo / Produits rares dans le commerce maritime / Seltene Waren im Seehandel. Wiesbaden, Harrassowitz Verlag \& Fundação Oriente, 2003, pp. 121-134.

Assunção, Carlos Fernando Torre de, “A Mineralogia nos Colóquios”, Garcia de Orta 11.4 (1963), pp. $715-721$. Baltanás, Domingo de, Compendio de algunas cosas notables de España y de la conquista y toma del reyno de Granada. Sevilha, Martín de Montesdoca, 1558.

Baranda Leturio, Consolación, "Formas del discurso científico en el Renacimiento: tratados y diálogos”, Sudia Aurea 5 (2001), pp. 1-21.

Barber, Richard W., The Holy Grail: Imagination and Belief. Londres, Penguin, 2004.

95 Algumas destas questões foram abordadas de forma inovadora no recente trabalho de Teresa Nobre de Carvalho, O mundo natural asiático aos olhos do Ocidente. Contribuição dos textos ibéricos quinhentistas para a construção de uma nova consciência europeia sobre a Ásia, dissertação de doutoramento inédita. Lisboa, Universidade de Lisboa, 2013.

96 Sobre este tópico extremamente relevante, ver Yirmiyahu Yovel, The Other Within: The Marranos, Split Identity and Emerging Modernity. Princeton, New Jersey, Princeton University Press, 2009. Ver também Walter J. FISCHEL, "Garcia de Orta - A Militant Marrano in Portuguese India in the 16th Century", in Saul LiBERMAN et alii (org.), Salo Wittmayer Baron Jubilee Volume on the Occasion of His Eightieth Birthday, 3 vols.. Jerusalem, American Academy for Jewish Research, 1974, vol. 1, pp. 407-432 (que não tive ocasião de consultar). 
Barbosa, Duarte, O Livro de Duarte Barbosa, ed. Maria Augusta da Veiga e Sousa, 2 vols.. Lisboa, Instituto de Investigação Científica Tropical, 1996-2000.

Biswas, Arun Kumar, "Gem-Minerals in Pre-Modern India”, Indian Journal of History of Science 29.3 (1994), pp. 389-420.

Borschberg, Peter, "O comércio, uso e falsificação dos bezoares de porco-espinho na Época Moderna (c.15001750) / The Trade, Use and Forgery of Porcupine Bezoares in the early Modern Period (c.1500-1750)", Oriente 14 (2006), pp. 60-78.

Busquet, Gérard; Javron, Jean-Marie, Tombeau de l'éléphant d'Asie. Paris, Chandeigne, 2002.

Carvalho, Augusto da Silva, Garcia d'Orta. Coimbra, Imprensa da Universidade, 1934.

Carvalho, Teresa Nobre de, “Colóquios dos Simples de Garcia de Orta: Conversas no interior da Índia”, in Gabriela Fragoso; Anabela Mendes (orgs.), Garcia de Orta e Alexander von Humboldt: Errancias, Investigaçôes e Diálogo entre Culturas. Lisboa, Universidade Católica Editora, 2008, pp. 165-174.

Carvalho, Teresa Nobre de, O mundo natural asiático aos olhos do Ocidente. Contribuição dos textos ibéricos quinhentistas para a construção de uma nova consciência europeia sobre a Ásia, dissertação de doutoramento inédita. Lisboa, Universidade de Lisboa, 2013.

Chandelier, Joël, “Théorie et définition des poisons à la fin du Moyen Âge”, Cahiers de recherches médiévales 17 (2009), pp. 23-38.

Civale, Gianclaudio, "Domingo de Baltanás, monje solicitante en la encrucijada religiosa andaluza: Confesión, Inquisición y Compañía de Jesús en la Sevilla del Siglo de Oro”, Hispania Sacra 59.119 (2007), pp. 197-241.

Cortesão, Armando, A Suma Oriental de Tomé Pires e o Livro de Francisco Rodrigues. Coimbra, Acta Universitatis Conimbrigensis, 1978.

Costa, Palmira Fontes da, "Geographical expansion and the reconfiguration of medical authority: Garcia de Orta's Colloquies on the Simples and Drugs of India (1563)", Studies in History and Philosophy of Science 43 (2012), pp. 74-81.

Costa, Palmira Fontes da; Carvalho, Teresa Nobre de, "Between East and West: Garcia de Orta’s Colloquies and the Circulation of Medical Knowledge in the Sixteenth Century", Asclepio - Revista de Historia de Medicina y de la Ciencia 65.1 (2013), pp. 1-13.

Cunha, Ana Cannas da, A Inquisição no Estado da Índia: Origens (1539-1560). Lisboa, Arquivos Nacionais I Torre do Tombo, 1995.

Cunha, João Teles e, "Hunting Riches: Goa’s Gem Trade in the Early Modern Age”, in Pius Malekandathil; T. Jamal Монаммеd (orgs.), The Portuguese, Indian Ocean and European Bridgeheads: Festschrift in Honour of Prof. K.S. Mathew. Kannur, Institute for Research in Social Sciences and Humanities \& Fundação Oriente, 2001, pp. 269-304.

Davis, Natalie Zemon, Trickster Travels: A Sixteenth Century Muslim Between Worlds. Nova Iorque, Hill and Wang, 2006. 
De Bellis, Carla, “Astri, gemme e arti medico-magiche nello 'Speculum lapidum' di Camillo Leonardi”, in G. Formichetti (org.), Il mago, il cosmo, il teatro degli astir: Saggi sulla letteratura esoterica del Rinascimento. Roma, Bulzoni, 1985, pp. 67-114.

Dias, João José Alves, Amato Lusitano e a sua obra - Séculos XVI e XVII. Lisboa, Biblioteca Nacional de Portugal, 2011.

Donkin, R. A., Beyond Price - Pearls and Pearl-Fishing: Origins to the Age of Discoveries. Filadélfia, American Philosophical Society, 1998.

Duffin, J. C.; Moody, R. T. J.; Gardner-Thorpe, C. (orgs.), A History of Geology and Medicine. Londres, The Geological Society of London, 2013.

Elgood, Cyril, A Medical History of Persia and the Eastern Caliphate. Cambridge, Cambridge University Press, 2010.

Esteve Barba, Francisco, Historiografía Indiana. Madrid, Gredos, 1992.

Evans, Joan, Magical Jewels of the Middle Ages and the Renaissance, particularly in England. Oxford, Clarendon Press, 1922.

Fernández de Oviedo, Gonzalo, Historia General y Natural de las Indias, ed. Juan Pérez de Tudela Bueso, 5 vols.. Madrid, Biblioteca de Autores Españoles, 1992.

Ficalho, Conde de, Garcia de Orta e o seu tempo, ed. Nuno de Sampayo. Lisboa, Imprensa Nacional — Casa da Moeda, 1983.

Fischel, Walter J., "Garcia de Orta - A Militant Marrano in Portuguese India in the 16th Century", in Saul Liberman et alii (org.), Salo Wittmayer Baron Jubilee Volume on the Occasion of His Eightieth Birthday, 3 vols.. Jerusalem, American Academy for Jewish Research, 1974, vol. 1, pp. 407-432.

Fresquet Febrer, José Luis, "El uso de productos del reino mineral en la terapéutica del siglo Xvi. El libro de los Medicamentos simples de Juan Fragoso (1581) y el Antidotario de Juan Calvo (1580)", Asclepio Revista de Historia de Medicina y de la Ciencia 51.1 (1999), pp. 55-92.

Garcia, José Manuel (ed.), Viagens dos Descobrimentos. Lisboa, Editorial Presença, 1983.

Geanakoplos, Deno John, Constantinople and the West: Essays on the Late Byzantine (Palaeologan) and Italian Renaissances and the Byzantine and Roman Churches. Madison, The University of Wisconsin Press, 1989.

González Manjarrés, Miguel Ángel, Andrés Laguna y el Humanismo Médico. Salamanca, Junta de Castilla y León, 2000.

González Manjarrés, Miguel Ángel; Pérez Ibáñez, María Jesús, “Andrés Laguna y Amato Lusitano, el desencuentro de dos humanistas médicos", in Ferran Grau Codina et alii (eds.), La Universitat de València i l'Humanisme: Studia Humanitatis i renovació cultural a Europa i al Nou Món. Valência, Universitat de València, 2003, pp. 689-711.

Gouveia, A. J. Andrade de, Garcia d'Orta e Amato Lusitano na ciência do seu tempo. Lisboa, Instituto de Cultura e Língua Portuguesa, 1985.

Green, Edward Lee, Landmarks of Botanical History, ed. Frank N. Egerton. Stanford, California, Stanford University Press, 1983. 
Harris, Nichola E., The Idea of Lapidary Medicine: Its Circulation and Practical Applications in Medieval and Early Modern England, 1000-1750, dissertação de doutoramento inédita. New Brunswick, New Jersey, The State University of New Jersey, 2009.

Hodgen, Margaret T., Early Anthropology in the Sixteenth and Seventeenth Centuries. Filadélfia, University of Pennsylvania Press, 1971.

Kunz, George F., The Curious Lore of Precious Stones. Nova Iorque, Halcyon House, 1938.

LACH, Donald F., Asia in the Making of Europe - Volume I: The Century of Discovery, 2 tms.. Chicago \& Londres, The University of Chicago Press, 1965.

Lach, Donald F., Asia in the Making of Europe - Volume II: A Century of Wonder, 3 tms.. Chicago, The University of Chicago Press, 1970-1977.

Laguna, Andrés, Pedacio Dioscorides Anazarbeo, acerca de la matéria medicinal, y de los venenos mortíferos. Antuérpia, Juan Latio, 1555.

Lane, Kris, Colour of Paradise: The Emerald in the Age of Gunpowder Empires. New Haven \& Londres, Yale University Press, 2010.

Laufer, Berthold, The Diamond: A Study in Chinese and Hellenistic Folk-lore. Chicago, Field Museum of Natural History, 1915.

Le Coz, Raymond, Les médecins nestoriens au Moyen Âge: les maîtres des Arabes. Paris, Éditions L'Harmattan, 2004 .

Lecouteux, Claude, Dictionnaire des pierres magiques et médicinales. Paris, Éditions Imago, 2011.

Leitão, Henrique (org.), O Livro Científico dos Séculos xv e xvi: Ciências Físico-Matemáticas na Biblioteca Nacional. Lisboa, Biblioteca Nacional, 2004.

Loureiro, Rui Manuel, "European books and libraries in sixteenth century Portuguese India”, $R C$ - Review of Culture 31 (1997), pp. 17-30.

Loureiro, Rui Manuel, "Garcia de Orta e os Colóquios dos simples: Observações de um viajante sedentário”, in Gabriela Fragoso; Anabela Mendes (orgs.), Garcia de Orta e Alexander von Humboldt: Errâncias, Investigaçōes e Diálogo entre Culturas. Lisboa, Universidade Católica Editora, 2008, pp. 135-145.

Lucas, Maria Clara de Almeida (ed.), Ho Flos Sanctorum en Lingoage: os Santos Extravagantes. Lisboa, Instituto Nacional de Investigação Científica, 1988.

Luís, António, Cinco Livros de Problemas, ed. António Guimarães Pinto. Lisboa, Centro de Filosofia da Universidade de Lisboa, 2010.

Marbode de Rennes, Marbode of Rennes'(1035-1123) Delapidibus, ed. John M. Riddle; trad. C. W. King. Wiesbaden, Steiner Verlag, 1977.

Motтana, Annibale, "Il pensiero di Teofrasto sui metalli secondo i frammenti delle sue opere e le testimonianze greche, latine, siriache ed arabe", Rendiconti Lincei - Scienze Fisiche e Naturali 9.12 (2001), pp. 133-241.

Murphy, Trevor, Pliny the Elder's Natural History: The Empire in the Encyclopedia. Oxford, Oxford University Press, 2004. 
Ogilvie, Brian W., The Science of Describing: Natural History in Renaissance Europe. Chicago \& Londres, The University of Chicago Press, 2006.

Orta, Garcia de, Colóquios dos simples e drogas da Índia, ed. Conde de Ficalho, 2 vols.. Lisboa, Imprensa Nacional — Casa da Moeda, 1987.

Pearson, Michael N., "Portuguese and Indian Medical Systems: Commonality and Superiority in the Early Modern Period", RC - Revista de Cultura / Review of Culture 20 (2006), pp. 116-141.

Pettegree, Andrew, Emden and the Dutch Revolt: Exile and the Development of Reformed Protestantism. Oxford, Oxford University Press, 1992.

Pineda, Victoria, "El arte de traducir en el Renacimiento (La obra de Francisco de Támara)", Criticón 73 (1998), pp. 23-35.

Pormann, P. E., "Yuhanna Ibn Sarabiyun: further studies into the transmission of his works", Arabic Science and Philosophy 14.2 (2004), pp. 233-262.

Rabaey, Hélène, "Francisco de Támara: algunos aportes biográficos", Calamus Renascens 3 (2002), pp. 249-254. Ramalho, Américo da Costa, "António Luís, corrector de Erasmo", Humanitas 45 (1993), pp. 243-254.

Ramusio, Giovanni Battista, Navigazioni e Viaggi, ed. Marica Milanesi, 6 vols.. Turim, Einaudi, 1978-1988. RÉvah, I. S., "La Famille de Garcia de Orta”, Revista da Universidade de Coimbra 19 (1960), pp. 407-420.

Schmitt, Charles B., "Theophrastus", in Paul O. Kristeller; F. Edward Cranz (orgs.), Catalogus translationum et commentariorum: Mediaeval and Renaissance Latin translations and commentaries - Volume II. Washington D.C., The Catholic University of America Press, 1971, pp. 239-322.

Sigaléa, Robert, La médecine traditionnelle de l'Inde. Genebra, Olizane, 1995.

Silva, Nuno Vassallo e, Subsidios para o estudo do comércio das pedras preciosas em Lisboa, no século xvi. Lisboa, Assembleia Distrital de Lisboa, 1989.

Támara, Francisco de, El Libro de las Costumbres de todas las Gentes del Mundo. Antuérpia, Martin Nucio, 1556. Tavim, José Alberto Rodrigues da Silva, "Os Judeus e a Expansão Portuguesa na Índia no Século xvi. O Exemplo de Isaac do Cairo: Espiáo, 'Língua' e 'Judeu de Cochim de Cima'”, Arquivos do Centro Cultural Calouste Gulbenkian 33 (1994), pp. 137-261.

Tavim, José Alberto Rodrigues da Silva, Judeus e Cristãos-Novos de Cochim: História e Memória (1500-1662). Braga, Ediçôes APPACDM, 2004.

Teofrasto [Teophrastus], On Stones, ed. Earle R. Caley; John F. C. Richards. Columbus, Ohio, The Ohio State University, 1956.

Thorndike, Lynn, A History of Magic and Experimental Science, 8 vols.. Nova Iorque, Columbia University Press, 1923-1958.

Trivellato, Francesca, "From Livorno to Goa and Back: Merchant Networks and the Coral-Diamond Trade in the Early-Eighteenth Century”, Portuguese Studies 16 (2000), pp. 193-217.

Vogel, Klaus A., "Cultural Variety in a Renaissance Perspective: Johannes Boemus and 'The Manners, Laws and Customs of all People' (1520)”, in Henriette Bugge; Joan Pau Rubiés (orgs.), Shifting Cultures: Interaction and Discourse in the Expansion of Europe. Münster, LIT Verlag, 1995, pp. 17-34. 
Yovel, Yirmiyahu, The Other Within: The Marranos, Split Identity and Emerging Modernity. Princeton, New Jersey, Princeton University Press, 2009.

Županov, Ines G., “'The Wheel of Torments': mobility and redemption in Portuguese colonial India”, in Stephen Greenblatt et alii (orgs.), Cultural Mobility: A Manifesto. Cambridge, Cambridge University Press, 2009, pp. 24-74. 


\title{
Estratégias, patronos e favores em Colóquios dos Simples de Garcia de Orta
}

\author{
TERESA NOBRE DE CARVALHO ${ }^{1}$
}

\section{RESUMO:}

Em 1563, foi publicada em Goa, uma obra notável. Editada na tipografia de Endem, Colóquios dos Simples e Drogas e Coisas Medicinais da Índia, da autoria do médico português Garcia de Orta (c.1500-1568), divulgou no Ocidente um saber renovado sobre os recursos naturais da Ásia.

Numa altura em que os sábios europeus ainda hesitavam em pôr em causa os conteúdos científicos transmitidos pelos tratados médico-botânicos herdados da Antiguidade, Orta aventurouse a enfrentar a tradição. Socorrendo-se da sua erudição e apoiando-se na autoridade que the conferia a sua ampla experiência clínica no Oriente, o médico ousou corrigir, actualizar e rever o saber sobre a matéria médica asiática então em circulação. Para garantir o crédito e aplauso da comunidade erudita, o seu arrojado plano aconselhava um suporte institucional sólido.

Ao longo deste ensaio percorremos os bastidores de Colóquios dos Simples em busca dos seus patronos. Propusemo-nos explorar os contextos em que o tratado surgiu, reconhecer as principais personagens implicadas na sua construção e esclarecer as motivações do médico na sua publicação.

\section{PALAVRAS CHAVE:}

Garcia de Orta; Colóquios dos Simples; Martim Afonso de Sousa; Patronos.

\section{ABSTRACT:}

In 1563, a remarkable work was published at the Endem's print-shop, in Goa: Colóquios dos Simples e Drogas e Coisas Medicinais da Índia. Written by the Portuguese physician Garcia de Orta (c. 15001568), this volume revealed a renewed knowledge about the Asian natural resources.

At a time when the European scholars still hesitate to question the scientific content of the Ancient treatises, Orta dared to question tradition. Relying on the authority that his extensive clinical experience in the Orient gave him, Orta took the risk to correct, update and revise the knowledge about the Asian resources in circulation. But to ensure the credit and applause of the erudite community to his work he needed institutional support.

Throughout this article we discover the Colloquies backstage searching for Orta's patrons. We explore the contexts in which the book emerged, recognizing the main characters involved in its construction.

\section{KEYWORDS:}

Garcia de Orta; Colóquios dos Simples [Colloquies on the Simples]; Martim Afonso de Sousa; Patrons.

1 Doutorada em História e Filosofia das Ciências pela Universidade de Lisboa-CIUHCT - Faculdade de Ciências da Universidade de Lisboa: tercarvalho@gmail.com. 
Quando buscamos em Colóquios dos Simples e Drogas e Coisas Medicinais da Índia (Goa, 1563) o nome do seu patrocinador, somos confrontados com um aparente silêncio. $\mathrm{O}$ autor, Garcia de Orta (c. 1500-1568), apesar de no seu tratado nos ter lançado algumas pistas, deixou-nos várias dúvidas sobre este ponto.

Nesta obra, escrita em diálogo, o saber sobre os recursos naturais asiáticos foi integralmente revisto, actualizado e, sempre que necessário, corrigido. ${ }^{2}$ Ao longo do seu compêndio, Garcia de Orta revelou aos seus leitores a sua inquestionável competência técnica, alicerçada numa escrupulosa formação científica adquirida, na década de 1520, nas universidades de Salamanca e Alcalá de Henares. Mas o saber de Orta não se limitava aos conhecimentos angariados durante os seus estudos médicos. Apesar da sua prolongada permanência no Oriente (1534-1568), o físico, referindo numerosas obras médicas entretanto editadas na Europa, atestou uma cuidada e permanente actualização científica. ${ }^{3}$ Alardeando uma vasta experiência clínica adquirida nos hospitais do Oriente e um profundo conhecimento das drogas e especiarias asiáticas, não se coibiu de manifestar a sua autoridade relativamente a estes valiosos recursos.

Se é inquestionável a relevância dos novos saberes que o médico adquirira ao longo da sua vivência asiática, continuam por esclarecer numerosos aspectos relativos ao patrocínio desta obra.

Ao longo deste ensaio percorremos os bastidores de Colóquios dos Simples. Propusemo-nos explorar os contextos em que o tratado surgiu, reconhecer as principais personagens implicadas na sua construção e esclarecer as motivações do médico na sua publicação. O que este artigo propóe é uma aproximação às origens deste tratado.

2 Ao longo de 59 capítulos, o autor descreveu as conversas entre dois médicos ibéricos - Orta e Ruano - que esgrimiram argumentos textuais e testemunharam experiências sobre os recursos naturais asiáticos. Em relação a cada produto, Garcia de Orta apresentou aos seus leitores uma renovada e autorizada descrição.

3 Sobre a biblioteca de Orta ver: Conde de Ficalho, Garcia de Orta e o seu tempo. Lisboa, Imprensa Nacional, 1886, pp. 280-298; Rui Manuel Loureiro, "Garcia de Orta e os Colóquios dos Simples: Observações de um viajante sedentário", in Anabela Mendes e Gabriela Fracoso (org.), Garcia de Horta e Alexandre von Humboldt. Errâncias, Investigações e Diálogos entre Culturas. Lisboa, Universidade Católica Editora, 2008, pp. 135-145; Teresa Nobre de CARVALHo, O mundo natural asiático aos olhos do Ocidente. Contribuição dos textos ibéricos quinhentistas para a construção de uma nova consciência europeia sobre a Ásia. Lisboa, UL, 2012, pp. 225-313 (dissertação de doutoramento - texto policopiado). 


\section{CONTEXTO DA OBRA}

"O poder não é uma coisa mas sim um processo e o mecenas é alguém que pode fazer coisas pelo seu cliente. Um mecenas tem poder, na medida em que o pode fazer circular e ser produtivo. Por consequência, um mecenas moderno dos primeiros tempos era frequentemente um agente, um trait d'union entre o cliente e uma fonte de mais poder [...]."4

Buscando em Colóquios dos Simples as forças que sustentaram a edição, tentámos reconstituir os contextos em que o médico se movia. Procurámos, por isso, o círculo de influentes que cruzava. Apesar de, ao longo do texto, Orta descrever variadas situações que têm como protagonistas governantes e prelados destacados no Oriente, parece-nos que as circunstâncias próximas da data da edição são as mais esclarecedoras sobre a oportunidade da publicação. ${ }^{5}$

Vale a pena abrir aqui um parêntesis para salientar que a revelação, a uma escala global, de novidades desta importância estava destinada aos "grandes" do Reino. Pietro Andrea Mattioli (1501-1577), um dos mais destacados comentadores de Dioscórides, na sua edição de 1544, havia exortado o rei de Portugal, D. João III, o Piedoso, (r.1521-1557) a chamar a si esta responsabilidade. O médico prometia "imortalidade" ao nome do soberano, caso este tomasse a seu cargo o patrocínio desta tarefa que traria tão grande bem a toda a humanidade. ${ }^{6}$

Até ao momento não conseguimos reunir elementos que nos permitam comprovar o empenhamento do soberano na edição desta obra. No entanto, e porque nos parece plausível a implicação de D. João III e dos homens da sua confiança na génese de um trabalho desta natureza, acalentamos a esperança de vir a conseguir reunir os dados que demonstrem a aspiração do rei em publicar um tratado científico sobre esta temática, com impacto à escala do império e do mundo. ${ }^{7}$

4 Mario BiAGıOLI, Galileo cortesão. Lisboa, Porto Editora, 2003, p. 22.

5 Ao longo da obra, Orta narrou episódios que tinham como protagonistas, entre outros, Nuno da Cunha (g.1529-1538), Martim Afonso de Sousa (g.1542-1545), D. João de Castro (g.1545-1548), D. Pedro de Mascarenhas (g.1554-1555), D. Constantino de Bragança (g.1558-1561), para além de religiosos, missionários e alguns fidalgos que nomeou mas que não identificou.

6 Sobre esta afirmação de MATTIOLI ver, por exemplo, a versão francesa de Commentaires à Dioscoride. Lião, Rouille, 1572, Cap. 12, p. 40: "Et vous Messieurs les Médecins du Portugal, si la Médecine vous est en recommandation, si voulez enrichir votre profession, exalter $\&$ faire grand votre nom, si charité a lieu en votre endroit, si vous avez ce naturel instinct $\&$ désir d'aider le genre humain, prenez cette charge: car si le Prince est par vous averti que ce lui sera un grand moyen d'immortaliser son nom, \& qu'il sera cause d'un grandissime bien à tout le monde...".

7 Sobre o desenvolvimento das ciências e técnicas em Portugal na primeira metade de Quinhentos, há uma vasta bibliografia. Nas mais diversas áreas científicas surgiram portugueses que se destacaram pela profundidade dos seus estudos ou pela inovação dos seus trabalhos. Numa lista que permanecerá sempre incompleta destacam-se todos quantos desempenharam funções em torno do monarca e das instituições de saber dele dependentes. Aos tratados dos físicos, matemáticos, astrónomos, cosmógrafos e cartógrafos teremos que aliar os relatos e saberes de boticários, cirurgiões, jardineiros, artesãos e outros técnicos que, com a sua experiência, resolveram questões pragmáticas relativas à medicina, à agricultura, 
Não devemos, assim, desligar a edição desta obra de um contexto mais alargado no qual se assistiu, à produção e circulação de numerosa informação manuscrita e impressa, de carácter científico e técnico, compulsada e redigida por portugueses ao longo do século XVI. ${ }^{8}$

O empenho dos monarcas ibéricos no desenvolvimento das ciências foi, aliás, amplamente comprovado por investigaçóes do século passado. Pesquisas recentes despertaram um interesse crescente sobre este assunto e têm trazido a lume novas evidências. ${ }^{9}$ Como foi demonstrado, o encontro com novos territórios e realidades diversas obrigou sábios, funcionários régios e artesãos a repensar muitos dos métodos e técnicas tradicionais. Para lidar com a novidade, os governantes

à náutica, à construção naval, à arquitectura militar ou à balística. Sobre a inovação técnico-científica ocorrida em Portugal na primeira metade de Quinhentos, vide, entre outros: Reijer HooYKAAS, "Science in manueline style. The historical context of D. João de Castro's Works", in Armando CoRTESÃo and Luís de Albuqueroue, Obras Completas de D. João de Castro. Coimbra, Academia Internacional da Cultura Portuguesa, 1981, vol. IV, pp. 231-426; Luis de AlbuQueroue, Introdução à história dos descobrimentos. Coimbra, Atlântida, 1962; Francisco Contente Domingues, Os navios do mar oceano. Teoria e empiria na arquitectura naval portuguesa dos séculos XVI exVII. Lisboa, CHUL, 2004; José Mendes FERRÃo, A aventura das plantas e os descobrimentos. Lisboa, Chaves Ferreira, 2005; Henrique LEITÃo, "Um mundo novo e uma nova ciência", in Henrique LEITÃo (ed.), $360^{\circ}$ Ciência Descoberta. Lisboa, Fundação Calouste Gulbenkian, 2013, pp. 15-40. Sobre a importante reforma na universidade portuguesa verificada neste período vide José S. Silva DIAS, A política cultural da época de D. João III. Coimbra, Universidade de Coimbra, 1969, 2 vols.

8 A abundância de tratados, regimentos e descrições de territórios publicada ou colocada em circulação neste período impede-nos, no âmbito deste estudo, de apresentar uma lista exaustiva. Limitamonos, por isso, a título de exemplo, a registar alguns dos textos de autores portugueses editados nas oficinas gráficas de Portugal e do resto da Europa: Gaspar Nicolas, Tratado da Pratica d'Arismetica (Lisboa, 1519); Amato Lusitano, Index Dioscoridis (Antuérpia, 1536); Pedro Nunes, Tratado da Sphera (Lisboa, 1537); António Luís, De re medica opera quae hic sequuntur (Lisboa, 1540); Pedro NunES, De crepusculis liber unus (Lisboa, 1542); Pedro NunEs, De arte atque ratione navigandi, (Coimbra, 1546); AmATo LusitANo, Curationum medicinalium (Florença, 1551); AmATo LusITANo, Enarrationes eruditissimae (Veneza, 1553); António Galvão, Tratado dos descobrimentos (Lisboa, 1563); Garcia Lopes, Comentarii de varia rei medica lectione (Antuérpia, 1564); Pedro Nunes, Petri Nonii Salaciensis Opera, (Basileia, 1566), Pêro Magalhães GÂNDAVo, História da Província de Santa Cruz (Lisboa, 1576); Francisco SANCHES, Quod nihil scitur (Londres, 1581); Gabriel Soares de SouSA, Tratado descritivo do Brasil (Lisboa, 1587) ou João Baptista Lavanha, Regimento Nautico de loão Baptista Lauanha, Cosmographo môr de El Rey Nosso Senhor (Lisboa, 1595).

9 Para além das obras de Luís de PINA, "As ciências na história do Império colonial português (séculos XV-XIX)", Extracto dos tomos dos anos 1937 a 1945 nos Anais da Faculdade de Ciências do Porto. Porto, Imprensa Portuguesa, 1945 e José-Maria LóPEz-PIÑ̃ero (dir.), Historia de la ciência y de la técnica en la corona de Castilla, Vol. III. Siglos xv y XVII. Salamanca, Junta de Castilla y Léon, Consejeria de Educación y Cultura, 2002, vide também as de David Goodman, Power and Penury: Government, technology and science in Philip II's Spain. Cambridge, Cambridge University Press, 1988; Jorge CAÑIZAREs-EsGuerRA, "Iberian Science in Renaissance: ignored how much longer?", Perspectives on Science 12, n. ${ }^{\circ} 1$ (2004), pp. 86-124; Antonio BARRERA, Experiencing nature. The Spanish American Empire and the Early Scientific Revolution. Austin, University of Texas Press, 2006; Londa SCHIEBINGER and Claudia SWAN, Colonial Botany. Science, Commerce and Politics in Early Modern Europe. Philadelphia, University of Pennsylvania Press, 2007; Daniela BLEICHMAR, Science in the Spanish and Portuguese Empires, 1500-1800. Standford, Standford University Press, 2009; Antonio SÁnChez-MARTínez, "Ciencia ibérica y el mundo Atlántico", Dynamis 31 (2011), pp. 245-269 ou Antonio Sánchez-MARTínez, "La voz de los artesanos en el Renacimiento científico: cosmógrafos y cartógrafos en el preludio de la "nueva filosofía natural", Arbor, CLXXXVI, 743 (Maio-Junho 2010), pp. 449-460. 
portugueses e espanhóis viram-se a braços com dificuldades muito concretas. Para além da necessidade de uma mais correcta localização e demarcação dos limites dos lugares alcançados, da busca de rigor no registo das informaçóes cartográficas, da concepção de instrumentos mais precisos, da criação de métodos mais fidedignos de ajuda à navegação ou da construção de naves cada vez mais adequadas às grandes travessias oceânicas, foi fundamental estabelecer aprofundados recenseamentos dos recursos naturais e pesquisar soluçôes terapêuticas para novos e velhos males. Estes foram alguns dos desafios a que os funcionários régios tiveram que responder e para os quais contaram com o apoio dos monarcas e o assentimento das suas cortes. A recolha de notícias e informaçóes relativas a tão amplos territórios levou à criação, em Lisboa e Sevilha, de instituiçôes de acumulação e gestão de novos saberes assim como à fundação de instituições dedicadas ao ensino das bases científicas e técnicas consideradas fundamentais para possibilitar o domínio de mares e leitura dos céus por parte de pilotos e demais tripulação. ${ }^{10}$

Não nos restam hoje quaisquer dúvidas que apesar de, desde a chegada dos portugueses à Índia, se ter verificado um acentuado interesse na recolha de notícias sobre os recursos naturais asiáticos, como o atestam os relatórios circunstanciados de Duarte Barbosa ou Tomé Pires e como o revela o corpus epistolar enviado do Oriente a D. Manuel I (r.1498-1591), esta prospecção só tomou um cariz mais sistemático durante o reinado de D. João III. ${ }^{11}$ Datam deste período numerosos relatos de funcionários destacados no Oriente que, pela relevância estratégica dos seus conteúdos foram resguardados do olhar púbico. Parece-nos por isso plausível que o soberano estivesse interessado na edição de um tratado que divulgasse informação credível sobre a matéria médica asiática. ${ }^{12}$

10 Sobre estes novos desafios e instituições vide: Barbara MUNDY, The mapping of New Spain: indigenous cartography and the maps of the Relaciones Geograficas. Chicago, Chicago University of Chicago Press, 2000; Maria PorTuONDo, Secret Science. Spanish cosmography and the New World. Chicago, The University of Chicago Press, 2009; Daniela BLeICHMAR, Science in the Spanish and Portuguese empires, 1500-1800, op. cit., pp. 35-56 e 219-232; Henrique LeITÃo (ed.), $360^{\circ}$ Ciência Descoberta, op. cit., pp. 15-40.

11 Banha de Andrade, Novos mundos do Mundo. Panorama da difusão, pela Europa, de notícias dos Descobrimentos geográficos Portugueses. Lisboa, Junta de Investigações do Ultramar, 1972, 2 vols.

12 Sobre esta diversidade de relatórios, cartas e listas redigidos pelos funcionários régios, vide: Adelino Almeida CALADo (ed.), "Livro que trata das cousas da Índia e do Japão", Boletim da Biblioteca da Universidade de Coimbra, Vol. XXIV, pp. 1-138. Sobre o acesso de Orta a esta documentação classificada vide: Rui Manuel LoureIRo, Animais Orientais: Fauna exótica dos descobrimentos. Lagos, Câmara Municipal de Lagos, 2008; IDEM, "Information networks in the Estado da India, a case study: was Garcia de Orta the organizer of the Codex Casanatense 1889?", Anais de História de Além-Mar XIII (2012), pp. 41-72. Teresa Nobre de CARVALHo, "Invisible travelers and virtual tracks: knowledge construction in Colóquios dos Simples e Drogas da India of Garcia de Orta (Goa, 1563)", in Antoni RocA-Rosell (ed.), Proceedings of the 4th ESHS Conference, Barcelona, 2010, pp. 288-293; Teresa Nobre de CARVALHO, O mundo natural asiático aos olhos do Ocidente, op. cit., pp. 271-313. 
O desaparecimento do monarca em 1557, a ausência, no Oriente, de oficinas tipográficas capazes de levar a cabo tão difícil empreitada ${ }^{13}$ e a constante actualização e validaçáo de informes que uma obra desta natureza implicava afiguram-se-nos ser alguns dos factores que estorvaram a publicação de tal obra durante a vigência do reinado do Piedoso. A edição do tratado viu-se assim adiada para um momento mais oportuno, tendo surgido apenas em 1563, em Goa, na capital do Estado da Índia, com o selo institucional do recém-chegado Vice-Rei, D. Francisco Coutinho (g. 1561-1564).

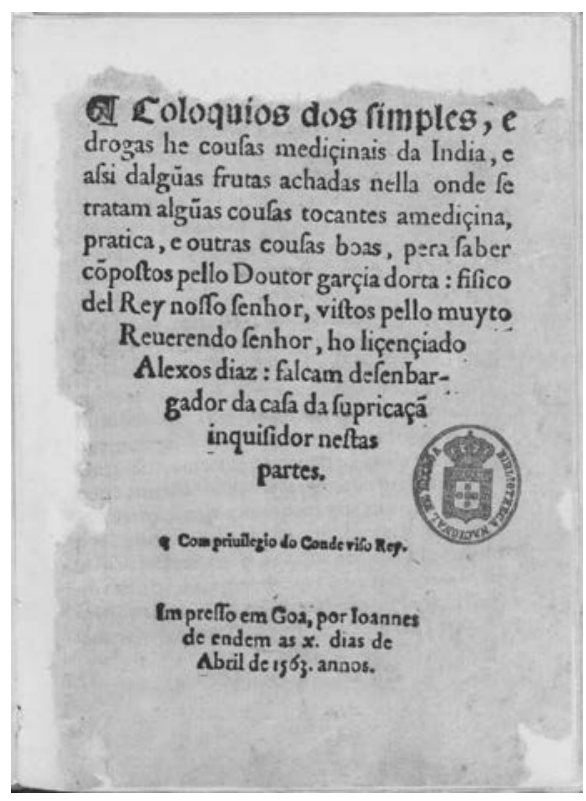

Figura 1 - Na portada de Colóquios dos Simples é bem evidente o apoio institucional que os poderes, político e religioso, deram à obra. Para além do assentimento manifestado pelo licenciado Aleixo Dias Falcão, "inquisidor nestas partes", o Vice-Rei da Índia, o Conde de Redondo assegurou protecção à obra. (Cortesia da Biblioteca Nacional de Portugal)

13 Sobre a instalação das oficinas tipográficas em Goa vide: António ANSELMo, Bibliografia das obras impressas em Portugal no século xVI. Lisboa, Biblioteca Nacional, 1977, [1926], p. 151; Charles R. Boxer, A tentative check-list of Indo-Portuguese imprints. Paris, Centro Cultural Português, 1975, pp. 567-599; H. SCholdberG, Bibliography of Goa and the Portuguese India. New Delhi, 1982, pp. 210-211; Manuel Cadafaz de Matos, "Humanismo e evangelização no Oriente no século xvI", Revista ICALP, n. ${ }^{\circ}$ 7-8, 1987. pp. 41-72; Teresa Nobre de CARVAlHo, O mundo natural da Ásia aos olhos do Ocidente, op. cit., pp. 99-155; Teresa Nobre de CARvalho, "Os enigmas de uma edição goesa: Colóquios dos Simples de Garcia de Orta", in H. Leitão; L. GiURGevitch; T. N. de Carvalho (eds.), O livro científico lido de perto. Lisboa, BNP, 2015 (aceite para publicação). 


\section{UMA OBRA OPORTUNA}

Perante a falta de dados inequívocos sobre o autor da encomenda de Colóquios dos Simples, voltámo-nos assim para a análise dos textos preliminares do tratado. Procurando captar a atenção e a benevolência dos leitores, este conjunto de textos assentou levar ao conhecimento público um saber classificado, até então mantido no âmbito privado. ${ }^{14}$ Integrando o conhecimento relativo aos recursos naturais asiáticos no discurso político da Goa quinhentista, este conjunto de cartas, odes e sonetos, destacou a importância do novo saber veiculado por Orta. ${ }^{15}$

Neste caderno, para além da página de título, onde destacamos a autorização do licenciado Aleixo Dias Falcão, “desenbargador da Casa da Supricaçam, Inquisidor nestas partes”, o volume de Garcia de Orta apresenta: o privilégio do "Conde Viso Rey”, a dedicatória de Garcia de Orta "ao muy ilustre Senhor Martim Afonso de Sousa", um poema "do autor falando co ho seu libro", uma ode de Camóes ao Conde do Redondo e uma carta dirigida pelo "liçenciado Dimas Bosque ao leitor". ${ }^{16}$ Parece-nos interessante realçar desde já que, neste conjunto de escritos, apenas os destinados a Martim Afonso de Sousa (1500-1570) foram da autoria de Orta. Pela relevância que reconhecemos a este facto, detalharemos este aspecto mais à frente.

Sendo D. Francisco Coutinho, 3. ${ }^{\circ}$ Conde de Redondo, o Vice-Rei da Índia em exercício à data da publicação do tratado, não nos surpreende o destaque que este político alcançou nos paratextos. ${ }^{17}$ Se a sua posição central na cena política do Estado da Índia tornava desejável o seu apoio à edição, a relevância estratégica do tema em apreço tornou imprescindível a sua protecção ao autor e aos conteúdos.

Cedendo informações novas sobre as regiōes de origem, as rotas de distribuição, os mercados, a utilidade terapêutica e o valor comercial dos principais recursos naturais do Oriente, Colóquios

14 Sobre o controlo da informação no âmbito imperial há uma ampla bibliografia: Peter BURKE, A social history of knowledge. From Gutemberg to Diderot. Cambridge, Polity Press, 2008, pp. 116-148; David Goodman, Power and Penury..., op. cit., pp. 50-87.

15 Sobre os paratextos de Colóquios dos Simples vide: Rogério Manuel PuGA, "Os elementos paratextuais dos Colóquios de Garcia de Orta", in Anabela Mendes e Gabriela Fragoso (org.), Garcia de Horta e Alexandre von Humboldt. op. cit. pp. 119-134 e Teresa Nobre de CARVALHO, O mundo natural asiático aos olhos do Ocidente, op. cit., pp. 122-138.

16 Garcia de ORTA, Colóquios dos Simples e Drogas da Índia, Edição fac-similada da dirigida e anotada pelo Conde de Ficalmo. Lisboa, Imprensa Nacional, 1987 [1891], vol. 1, pp. 3-11. No âmbito deste ensaio recorremos a esta edição que passamos a referir de forma abreviada.

17 Referimo-nos à Ode que Luís de Camões dirigiu ao Vice-Rei. Reveladora de uma proximidade entre o poeta e o médico, esta foi a primeira poesia impressa de Camões. Para o poeta, os grandes feitos bélicos eram tão valiosos como o apoio ao avanço do conhecimento. O mesmo empenho de Camões relativamente à divulgação de saberes sobre novos espaços sob domínio português verificou-se na obra de Pêro Magalhães GÂNDAvo, História da Província de Santa Cruz. Lisboa, 1576, na qual também dedicou um poema a um ilustre fidalgo. Vide: Teófilo BRAGA, A primeira poesia impressa de Luis de Camões. Lisboa, Adolfo Modesto, 1867 e Teresa Nobre de CARVALHO, O mundo natural asiático aos olhos do Ocidente, op. cit., pp. 122-138. 
dos Simples destacou-se no panorama científico de Quinhentos. ${ }^{18} \mathrm{O}$ nome daquele que conferiu protecção jurídica a obra tão inovadora ficou-lhe ligado de forma indelével. Independentemente da relevância política dos feitos que D. Francisco Coutinho realizou ao longo da sua governaçáo, o seu nome seria para sempre lembrado pelo patrocínio que cedeu a este volume. Apoiar, de forma activa, um tratado científico desta natureza inscreveu D. Francisco Coutinho naquele grupo de homens de corte capazes de grandes feitos, na guerra como nas letras. O nome de Orta, por seu turno, ao ser identificado com o do médico do Vice-Rei, tornou-se, de imediato, numa referência credível para os leitores da sua obra.

Convém salientar que quando o Conde de Redondo entrou em funçóes, a obra de Orta já estava adiantada uma vez que a assinatura do Privilégio data de 5 de Novembro de 1562. Do seu texto salientamos o parágrafo inicial:

O Conde Viso-Rey da India, etc., faço saber a quantos este meu alvará virem, que o doutor Garcia d'Orta me inviou dizer que elle tinha feito hum livro pera enpremir das mézinhas e fruitas da India, que era muyto proveitoso, pedindome que ouvesse por bem e mandasse que, por tempo de tres annos, nenhuma pessoa o podesse enpremir sem liçença delle doutor, por quanto era em seu prejuizo, e visto por mim seu pedir e avendo respeito ao que diz: ei por bem e por este mando que pello dito tempo de tres annos, que se começaráo da noteficaçam deste em diante, nenhuma pessoa, de qualquer calidade e condiçam que seja, possa enpremir nem mandar enpremir por nenhuma via o dito livro sem licença do dito doutor...19

Segundo assinalou o governante, a iniciativa da publicação da obra partiu de Garcia de Orta. Realçando a formação académica do médico, não se coibiu de aludir ao "Doutor" de forma respeitosa. Mais do que apenas a garantia da protecção dos direitos de autor relativos aos conteúdos, este Privilégio revelou, de forma inequívoca, a atitude cortês do poder político face ao trabalho do "físico d'El Rei".

Redigida pelo médico, a dedicatória, foi dirigida "Ao muyto illustre senhor Martim Afonso de Sousa do conselho Real senhor das villas de Alcuentre, e o Tagarro, seu criado o doutor Orta

18 Sobre o impacto que a obra de Garcia de Orta teve na Europa de então, nomeadamente através das versões latinas de CLusıus, Aromatum et simplicium (Antuérpia, 1567) assim como das suas traduções em italiano e francês e sobre as obras em castelhano elaboradas a partir da de Orta, como a de Juan FRAGOSO, Discurso de las cosas aromáticas (Madrid, 1572) e Cristóvão da CosTA, Tractado de las drogas (Burgos, 1578) há uma extensa bibliografia. Destacam-se os trabalhos: Teresa Nobre de CARvalHo, "A apropriação de Colóquios dos Simples por dois médicos ibéricos de Quinhentos", in Palmira Fontes da Costa e Adelino CARDoso (orgs.), Percursos na história do livro médico (1450-1800). Lisboa, Edições Colibri, 2011, pp. 59-72 e Florike EGMOND, The world of Carolus Clusius: Natural History in the making: 1550-1610. Londres, Pickering \& Chatto, 2010.

19 Garcia de OrTA, Colóquios dos Simples, op. cit., vol. 1, p. 3. 
lhe deseja perpetua felicidade com inmortal fama pera seus decendentes." ${ }^{20}$ Garcia de Orta intitulou-se "doutor" mas também "criado" do "ilustre" fidalgo que pertencia ao "Conselho Real". O recurso a uma linguagem clientelar, táo usual neste tipo de carta, onde imperava a cortesia e a deferência, mais do que afastar as duas personalidades, tornou-as solidárias. Este aparente cumprimento de um protocolo da expressão escrita parece revelador de um dos objectivos de Orta: reestabelecer a solidez da imagem do seu patrono e amigo. ${ }^{21}$ Orta serviu-se assim deste espaço para descrever, a todos quantos no Reino censuravam Martim Afonso de Sousa, quem este era aos olhos do público asiático. O herói que muitos recordavam, entre feitos grandiosos e decisóes controversas tinha, afinal, permitido que muito do saber reunido na obra viesse a lume. ${ }^{22}$

Com este gesto, Orta saldava uma dívida que ao zarpar de Lisboa, em 1534, contraíra com Martim Afonso de Sousa, o então Capitão-Mor da Armada. ${ }^{23}$

Ao longo da Carta, Garcia de Orta recorreu a numerosas referências clássicas, colocando Martim Afonso ao nível dos grandes heróis da Antiguidade. A familiaridade do fidalgo com os textos antigos foi realçada por Orta no Colóquio $2^{\circ}$, do aloés. Neste, Orta recordou a leitura da vida de S. Silvestre, narrada por Platina, que fizera em casa do seu amigo. ${ }^{24}$ A convivência entre os dois homens manifestava-se não apenas pelas relações de vassalagem que Orta insistiu em realçar, mas também pela partilha dos espaços, das leituras e dos saberes.

20 Garcia de ORTA, Colóquios dos Simples, op. cit., vol. 1, pp. 4-5. Martim Afonso de Sousa é uma figura fascinante da nossa História. Não pretendemos detalhar a sua biografia. Esta foi recentemente analisada por Alexandra Pelúcia, Martim Afonso de Sousa e a sua Linhagem: Trajectórias de uma elite no Império de D. João III e D. Sebastião. Lisboa, CHAM, 2009. No âmbito deste ensaio recorremos amiúde a esta pesquisa.

21 Ao longo desta carta, Garcia de Orta usou vários epítetos para apelidar Martim Afonso de Sousa: para além do referido "muito ilustre Senhor" socorreu-se de um "ilustríssimo Senhor" e da "vossa senhoria". Utilizando estas formulações, o médico subalternizou-se e enalteceu os feitos e valor daquele cuja "fortaleza é tão conhecida não tão somente por todas as três partes do mundo, mas pela outra quarta parte, que agora os cosmógrafos acrescentam". Garcia de ORTA, Colóquios dos Simples, op. cit., vol. I, p. 5 .

22 Sobre as polémicas em torno da governação de Martim Afonso de Sousa à frente do Estado da Índia voltaremos mais adiante.

23 Face à alegada ascendência judaica de Garcia de Orta e ao crescente clima de instabilidade que se vivia em Lisboa devido à iminente instauração do Tribunal da Inquisição em Portugal (1536), deixar a capital do Reino afigurava-se a melhor solução. Embarcado como médico pessoal do Capitão-Mor da Armada a 12 de Março de 1534, Garcia de Orta viu a sua vida amparada pelo, então, inviolável estatuto de Martim Afonso de Sousa. A este respeito vide: Augusto da Silva Carvalho, "Garcia d'Orta", Revista da Universidade de Coimbra 12 (1934), pp. 80-82.

24 Segundo Ficalho, Orta referia-se a Platianae de vitis pontificum historia. Garcia de OrTA, Colóquios dos Simples, op. cit., vol. 1, p. 40. 
Na sua dedicatória, Orta incluiu Martim Afonso de Sousa no seu projecto editorial reconhecendo-o como grande impulsionador daquele trabalho: "e porque o vosso conselho he mandado pera mi, determinei de fazer este breve tratado". 25

O médico acrescentou:

"mas temia o oçioso povo e mordaces linguoas, por onde o tratado tinha neçesidade de hir arrimado a quem o defendese dellas, assi como fazem os esprementados agricultores que, querendo plantar algumas dellicadas plantas as arrimam a alguns fortes arvores pera que as defendam dos tempestuosos ventos e fortes chuivas e asperas geadas, assi quis eu plantar esta fraca planta debaixo do emparo de vossa senhoria, com o qual será defendida de toda a mór parte do mundo..."26

Martim Afonso de Sousa surgiu assim como aquele que assegurava a protecção da obra das censuras dos leitores. Não deixa de ser interessante realçar que este representante do poder político, famoso no Oriente como no Ocidente, foi apresentado no trabalho de Orta como protagonista na busca de uma verdade científica. Convém aqui sublinhar que, apesar deste género de discurso laudatório ser usual nos textos preliminares das obras então publicadas, nem sempre era tão explícita a participação do protector no âmago do projecto científico. Um dos aspectos curiosos que ressalta da leitura deste tratado é o aparente envolvimento de Martim Afonso de Sousa na construção do saber contido nos Colóquios. Ao longo da obra, Orta detalhou múltiplos episódios que o fidalgo protagonizou e parecem atestar esta co-responsabilidade do nobre na reconfiguração do saber divulgado por Orta. ${ }^{27}$ Esta participação efectiva do aristocrata num projecto erudito contribuiu para descrever Martim Afonso de Sousa como um fidalgo que, para além dos feitos heróicos, se destacava pelo seu empenho na busca de novos saberes. Cabe ainda recordar que a curiosidade científica e as qualidades de observação de Martim Afonso tinhamno levado a apresentar a Pedro Nunes (1502-1578) pertinentes questôes ligadas à navegação. ${ }^{28}$

Ao longo da sua obra, Garcia de Orta realçou os nomes de outros governantes e religiosos que lhe trouxeram importantes esclarecimentos ou empolgantes questóes relativas ao mundo

25 Garcia de ORTA, Colóquios dos Simples, op. cit., vol. 1, p. 4.

26 Garcia de OrTA, Colóquios dos Simples, op. cit., vol. 1, pp. 4-5.

27 O conhecimento relativo aos recursos naturais revestia-se de enorme importância estratégica para o governo do Estado da Índia. Para além disso, Martim Afonso estava pessoalmente empenhado no comércio de alguns produtos orientais, como foi o caso das avultadas quantidades de anil, lacre e gengibre que pretendia transaccionar ou expedir para o Reino. Também a colocação de vedores de fazenda da sua inteira confiança em postos chave, atesta bem o valor que dava ao comércio destes recursos analisados por Orta. Alexandra PelúciA, Martim Afonso de Sousa e a sua Linhagem, op. cit., pp. 221-229.

28 Luís de Albuoueroue, Martim Afonso de Sousa. Mem Martins, ALFA, 1989, pp. 76-77 e Alexandra PelúciA, Martim Afonso de Sousa e a sua Linhagem, op. cit., p. 140. 
natural da Ásia. Uma nova elite esclarecida deixava um contributo indelével para esta inovadora descrição dos recursos naturais do Oriente.

Orta terminou a epístola, justificando a opção da redacção em português:

Bem pudera eu compor este tratado em latim, como o tinha muytos annos antes composto, e fora a vossa senhoria mais aprasível; pois o entendeis milhor que a materna linguoa, mas traladeo em portugues por ser mais geral, e porque sei que todos os que nestas indianas regiōes habitam, sabendo a quem vai entitulado, folgaram de o leer. ${ }^{29}$

Nesta alusão à familiaridade de Martim Afonso com o Latim, o médico parece querer recordar o nobre berço e a brilhante formação que o fidalgo gozou na corte do príncipe D. João. Com notável habilidade, Garcia de Orta justificou a sua decisão. Mais do que enaltecer as suas virtudes de académico, o médico pretendia que as gentes "que nestas indianas regióes habitam" recordassem, através da sua obra, os feitos e a memória de Martim Afonso de Sousa. Nesta Carta, cheia de subtilezas, para além de enaltecer as múltiplas qualidades de Martim Afonso de Sousa, o médico identificou uma parcela importante do público a quem a obra se destinava: os seus leitores residentes na Ásia.

\section{MARTIM AFONSO DE SOUSA: PROTECTOR OU PROTEGIDO?}

Martim Afonso de Sousa desempenhou funçôes militares e governativas no Oriente em dois períodos distintos: Capitão-Mor da Armada (1534-1538) e Governador (1542-1545). ${ }^{30}$ Como acima referimos, Garcia de Orta partiu para a Índia em 1534, a bordo da nau Rainha capitaneada por este fidalgo. Como as suas funçóes de médico pessoal do capitão obrigavam, acompanhou-o em todas as campanhas militares.

Alguns biógrafos de Garcia de Orta admitem que a relação entre os dois homens já vinha dos tempos de Lisboa. ${ }^{31}$ Apesar de não termos, até ao momento, reunido evidências seguras sobre este relacionamento, o certo é que, imediatamente após terminar os estudos médicos nas universidades castelhanas, Orta se instalou em Castelo de Vide. Só após um período

29 Garcia de OrTA, Colóquios dos Simples, op. cit., vol. 1, p. 5.

30 Sobre a actividade de Martim Afonso de Sousa no Brasil e no Oriente, vide: Alexandra PeLúCiA, Martim Afonso de Sousa e a sua Linhagem, op. cit., pp. 127-255.

31 O Conde de Ficalho, suportando-se nos escritos de Barbosa MACHADO, faz recuar a amizade destes dois personagens aos tempos da mocidade. $O$ estudioso admite mesmo ter sido Lopo de Sousa, pai de Martim Afonso de Sousa, a custear os estudos médicos de Orta. Conde de Ficalho, Garcia de Orta e o seu tempo, op. cit., pp. 65-84. 
experimental, em que desenvolveu actividade clínica sob a vigilância de um médico desta cidade, e a aprovação num exame realizado perante o Físico-Mor, é que Orta viajou até Lisboa. ${ }^{32}$ O médico aproximou-se então dos Estudos Gerais de Lisboa, procurando, desde finais da década de 1520, integrar o mundo académico da capital. ${ }^{33}$

Quanto ao fidalgo, deixando Lisboa logo a seguir à morte de D. Manuel I para acompanhar de regresso a Castela a Rainha viúva, D. Leonor, por lá casou com D. Ana Pimentel. ${ }^{34}$ A união das famílias Sousa e Pimentel já tinha tradição e Martim Afonso tirou partido da sua permanência no Reino vizinho para reestabelecer laços entre as linhagens. ${ }^{35}$

O fidalgo permaneceu alguns anos próximo da corte castelhana. Segundo relatou, nas contendas franco-castelhanas combateu ao lado das tropas imperiais, o que lhe valeu um louvor público por parte de Carlos V (g.1519-1556). ${ }^{36}$ Como escreveu, o monarca chegou mesmo a

32 Para os licenciados em medicina pelas universidades estrangeiras, o Regimento do Físico-Mor de 1521 exigia um período de estágio acompanhado ao qual se seguia um exame perante o Físico-Mor do reino. Sobre este Regimento vide: Tello da FonseCA, História da farmácia Portuguesa através da Legislação. Porto, Empresa Industrial Gráfica do Porto, 1935, vol. 1, pp. 27-34. Após a conclusão dos estudos académicos, a residência de Orta em Castelo de Vide está atestada por dois documentos datados de Abril de 1526, presentes na Chancelaria de D. João III (Livros 12, fl. 43 v e 36, fl. 97). Nestes, o FísicoMor Diogo Lopes, após o exame ao candidato, considerou o licenciado Garcia de Orta, "morador em Castelo de Vide", "autossuficiente e idóneo assim na teórica como na prática" e autorizou-o a "andar de mula". Publicadas em finais do século xıx no Archivo da Pharmacia da Índia Portugueza por Pedro José da SILVA e analisadas pelos principais biógrafos do médico foram recentemente retomadas por Teresa Nobre de CARVALho na sua dissertação de Doutoramento, O mundo natural asiático aos Olhos do Ocidente, op. cit., pp. 68-80.

33 Sobre a passagem de Orta pelos Estudos Gerais de Lisboa, vide: Joaquim Teixeira de CARVALHo, Homens de outros tempos. Coimbra, Imprensa da Universidade, 1924 e Luís de PINA, "Garcia de Orta e o Magistério Universitário de Filosofia Natural em Lisboa", O Médico, vol. 636 (1963), pp. 3-26.

34 "e fiquei servindo até que El-Rei D. Manuel faleceu e a rainha D. Leonor foi para Castela, e fui com ela e lá casei com minha mulher", Luís de Albuoueroue, Martim Afonso de Sousa, op. cit., p. 68. Este trecho encontra-se integrado na "Brevíssima e sumária relação que fez de sua vida e obras", datada de 1557 e atribuída a Martim Afonso de Sousa. A epístola é dirigida à "Sereníssima Senhora Rainha Dona Catarina, mulher de El-Rei D. João, o terceiro, estando ela na regência dos reinos. A qual relação se achou escrita de sua própria mão e letra muito tempo depois dele morto." Foi desta carta, publicada e comentada por Luís de Albuquerque, que retirámos elementos biográficos de Martim Afonso que nos permitiram ilustrar este ensaio. O rigor histórico de muitos dos episódios relatados faz com que esta "Brevíssima relação" seja tomada como uma autobiografia de Martim Afonso de Sousa. Tirando partido do então recente falecimento do Rei, o fidalgo não quis deixar de reivindicar perante a Regente as recompensas que este the prometera. Luís de Albuquerque não se coibiu de classificar esta atitude como "oportunismo que tomava o aspecto de pura chantagem". Luís de AlbuQueroue, Martim Afonso de Sousa, op. cit., pp. 67-84.

35 Sobre a promoção política e social de Martim Afonso através deste matrimónio e em relação à integração da família Pimentel entre os Grandes e Titulares de Espanha vide: Alexandra Pelúcia, Martim Afonso de Sousa e a sua Linhagem, op. cit., pp. 111-123.

36 "e assim de caminho nos fomos descer ao paço e beijar a mão do imperador [Carlos V]; e ele me disse palavras públicas muitas e de tantos gabos do que eu fizera, diante de toda a corte, de que eu podia ter muita vaidade...", Luís de Albuqueroue, Martim Afonso de Sousa, op. cit., pp. 68-69. Alexandra PeLÚciA, Martim Afonso de Sousa e a sua Linhagem, op. cit., p. 117. 
convidá-lo para entrar ao seu serviço. Apesar da generosidade da oferta, Martim Afonso sentiuse na obrigação de declinar. Deste modo, afirmou a sua rectidão de carácter em detrimento da ambição pessoal ou da sua projecção social.

A pedido de D. João III, regressou a Lisboa em 1525 acompanhando o séquito da prometida do rei, D. Catarina de Áustria. ${ }^{37}$ O nobre permaneceu na capital até 1529 , altura em que o monarca o enviou para o Brasil para proteger o território da ameaça dos avanços franceses. ${ }^{38}$ Para esta nomeação, além da confiança que o Rei nele depositava poderá ter contribuído a insistente

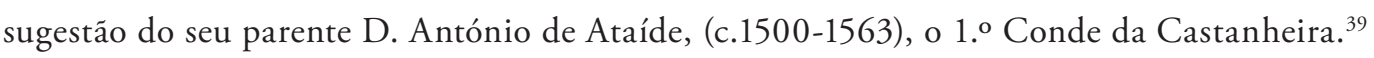

Martim Afonso de Sousa privou, desde muito cedo, com o príncipe D. João. Apesar de D. Manuel não o considerar uma companhia adequada para o infante, o gentil-homem, desde a juventude, frequentou o meio cortesão. Na referida "Brevíssima e sumária relação", que Martim Afonso dirigiu a D. Catarina, pode ler-se:

Neste tempo estavam alguma coisa diferentes El-Rei [D. Manuel I] e o príncipe [D. João], e, por parecer a El-Rei que eu o podia inclinar contra ele (o que nunca, Deus me perdoe, tal foi), me mandou dizer por D. Nuno Manuel e pelo Bispo do Funchal que me agradecia muito ir-me para casa de meu pai, e por lá estar um ano, e que ele me fazia toda a mercê que eu quisesse [...] e lhes respondi que eu vivia com o príncipe e era seu criado, e merecia dele muito mais honra e mercê da que eu merecia, e que não era homem para nenhum interesse me dobrar, para deixar de servir o senhor com quem vivia. ${ }^{40}$

Acompanhando de muito perto a educação do jovem herdeiro da Coroa, o fidalgo teve certamente uma instrução privilegiada. ${ }^{41}$ Uma formação humana integral e completa que, para além do ensino criterioso de disciplinas científicas e o treino intensivo da destreza física,

37 "E neste tempo se concertou o casamento de Vossa Alteza [D. Catarina] com El-Rei Nosso Senhor [D. João III], e ele me escreveu vir com Vossa Alteza e trazer minha mulher em sua companhia, o que fiz com muito gasto da minha fazenda e da alheia...", Luís de Albuqueroue, Martim Afonso de Sousa, op. cit., p. 69.

38 "e fiquei servindo assim na corte até à era de vinte e nove, que por El-Rei ter novas que no Brasil havia muitos franceses, me mandou lá em uma armada", Luís de Albuoueroue, Martim Afonso de Sousa, op. cit., p. 69.

39 Sobre a relevância da relação familiar entre D. António de Ataíde e Martim Afonso no seu percurso político e estratégico vide as cartas que este último lhe dirigiu a pedir intercessão junto do Rei em: Luís de Albuqueroue, Martim Afonso de Sousa, op. cit., pp. 12-20, 30-36 e 52-58, assim como Alexandra PelúCIA, Martim Afonso de Sousa e a sua Linhagem, op. cit., pp. 161-169. Recorde-se que D. António de Ataíde permaneceu na Corte até à morte de D. João III, em 1557.

40 Luis de Albuqueroue, Martim Afonso de Sousa, op. cit., p. 68.

41 Sobre a educação do príncipe D. João vide, entre outros: Ana Isabel BUESCU, D. João III, 1502-1557. Rio de Mouro, Temas e Debates, 2008, pp. 26-72. 
valorizava a doutrina cristã e o cultivo das virtudes. Com os mestres de D. João, Martim Afonso aprendeu a ser sábio e honrado. Com os exemplos de arrojados guerreiros, aspirou a deixar a sua marca na História. ${ }^{42}$ Não pretendemos aqui repetir caminhos trilhados por outros, mas apenas salientar a riqueza da bagagem científica, retórica, literária e o arrojo que revelou o Capitão-Mor da Armada de 1534.

Orta, por seu lado, nunca nos testemunhou a sua proximidade da corte de D. João. No entanto, o título de "Físico d'El Rey nosso senhor" que o frontispício do seu tratado proclama, atesta um reconhecimento, ao mais alto nível, do valor do seu trabalho. Em Colóquios dos Simples, Orta aludiu ainda à sua fazenda na ilha de Bombaim que lhe foi cedida pelo monarca, testemunhando a admiração e reconhecimento do soberano pelo seu trabalho. ${ }^{43}$

A leitura do tratado sugere-nos uma relação leal e cúmplice entre o fidalgo e o médico. Orta, que, referindo-se a Martim Afonso de Sousa, se intitulou "seu criado", afirmou ter escrito no tratado "cousas que me ensinastes, e outras, que eu aprendi na vossa escola militar e cortesãa." ${ }^{4}$

Esta escola "cortesã” referida por Orta, não parece limitar-se à passagem de Martim Afonso pelas cortes ibéricas. Para além da familiaridade com as cortes peninsulares o fidalgo dialogou com soberanos de outros meios cortesãos como Bahadur Shah, sultão indiano do Guzerate (1526-1537); Idalcão, sultão indiano de Bijapur (1535-1557); Bhuvaneka Bahu VII, rei cingalês de Kotte (1521-1551); Tabarija, o sultão de Ternate, (1532-1545); e o rajá de Cananor, Kolattiri (1527-1547). Orta não foi alheio aos contactos que o fidalgo estabeleceu com cada um destes governantes. Como veremos mais à frente, ao longo de Colóquios dos Simples, aludiu a encontros de Martim Afonso com algumas destas personalidades. ${ }^{45}$

42 Referimo-nos ao encontro, por volta de 1514, de Martim Afonso de Sousa com um dos seus heróis da arte da guerra: Gonzalo Fernández de Córdova, um valeroso guerreiro por quem o fidalgo nutria uma profunda admiração. Sobre o encontro deste combatente com o jovem, vide: Alexandra PelúciA, Martim Afonso de Sousa e a sua Linhagem, op. cit., pp. 87-89.

43 José Gerson da Cunha, The origins of Bombay. Bombay, Society's Library, Town Hall, 1900, pp. 95-107.

44 Garcia de ORTA, Colóquios dos Simples, op. cit., vol. I, p. 5. É curioso notar que os termos usados por Martim Afonso de Sousa na carta que enviou à Regente para descrever a sua relação com D. João III são os mesmos que Garcia de Orta usou para descrever a sua relação com Martim Afonso.

45 Veja-se, por exemplo, Garcia de OrTA, Colóquios dos Simples, op. cit., vol. I, p. 119 e vol. 2, p. 101. 


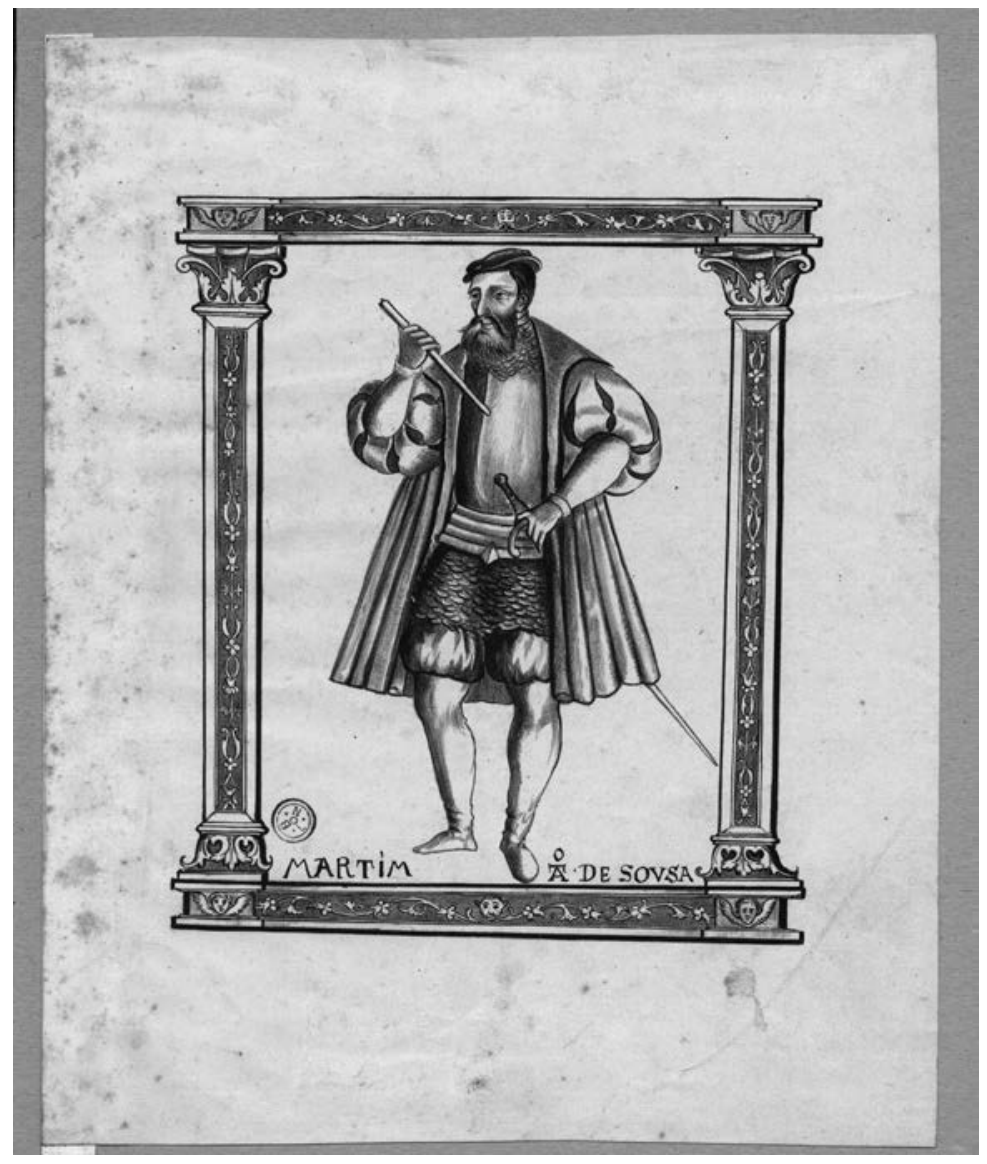

Figura 2 - Martim Afonso de Sousa exerceu funções militares e governativas na Índia em diferentes momentos: Capitão-Mor da Armada (1534-1538) e Governador (1542-1545). Foi com este fidalgo que Garcia de Orta partiu, em 1534, para Oriente e foi como seu médico privado que visitou as cortes de soberanos locais onde teve a oportunidade de confrontar o seu saber com o de outros práticos. (Cortesia da Biblioteca Nacional de Portugal)

Se a sugestáo de produzir a obra parece, como vimos, ter partido de Martim Afonso vale a pena esclarecer que papel desempenhou este fidalgo durante a sua governação no comércio de drogas e especiarias ou na melhoria da qualidade dos cuidados de saúde dos portugueses residentes em Goa.

Segundo o fidalgo narrou a D. Catarina, mal aportou em Goa, ao constatar a pobreza que grassava entre os portugueses, foi obrigado a tomar medidas drásticas para melhorar a qualidade de vida dos muitos soldados que deambulavam pelas ruas da cidade. Denunciando a 
inabilidade para governar dos seus antecessores, tomou a seu cargo todos quantos estes tinham votado ao abandono. ${ }^{46}$

Comparando a Índia que então encontrava com a que tinha conhecido anos antes, escreveu: “... achei a terra tão perdida que verdadeiramente não a conheci...”.

Segundo relatou, de imediato lançou máos à obra procurando repor a ordem pública e reorganizar as finanças reais. $\mathrm{Na}$ "Brevíssima e sumária relação...” escreveu:

Tudo isto foi logo remediado, porque para a necessidade dos soldados ordenei logo fidalgos que lhe dessem mesas, e comecei a entender na fazenda de Sua Alteza e [a] apertar com os feitores, de maneira que houve dinheiro, com que comecei a fazer pagamentos a esta gente pobre, e mandei lançar pregão que todo o homem que mais andasse pedindo esmola fosse açoutado publicamente. ${ }^{47}$

A entrega, em 1542, à Misericórdia da gestão do Hospital Real de Goa, delegando em homens da sua confiança o trabalho de organização, gestão, tratamento e administração de cuidados aos doentes e aos mais necessitados foi um enorme serviço prestado aos portugueses residentes na região. ${ }^{48}$

Como escreveu a D. Catarina:

Nos hospitais gastava El-Rei nosso Senhor muito dinheiro, de que os doentes haviam mui pequena parte e os seus oficiais quase toda; e para tirar este inconveniente, ajuntei-os com a Misericórdia, que foi um grande serviço de Nosso Senhor e de Sua Alteza, por quanto melhor curados foram os doentes daí por diante; e para que isto não arrefecesse ia todas as sextas-feiras ouvir missa ao hospital, onde estava e tomava larga informação de como a casa era servida. ${ }^{49}$

Ainda no decorrer deste mesmo ano, o Governador ordenou ao seu vedor de fazenda, Fernão Rodrigues de Castelo Branco, o estabelecimento de uma "Pauta de Mezinhas", onde o

46 Apesar de ser frequente a crítica do novo governante designado face ao trabalho desenvolvido pelos seus antecessores, Martim Afonso de Sousa, nas numerosas cartas que enviou ao Reino, nunca escondeu a especial antipatia que nutria por D. Nuno da Cunha (g.1529-1538). Luis de AlbuQueroue, Martim Afonso de Sousa, op. cit., pp. 9-58.

47 Luís de Albuqueroue, Martim Afonso de Sousa, op. cit., p. 76.

48 Estas decisões competiam aos Governadores e Vice-Reis. Anos antes, verificando o abandono a que eram votados muitos doentes e feridos, o Vice-Rei D. Francisco de Almeida (g.1505-1509) havia ordenado a construção do Hospital Real de Santa Cruz de Cochim para o qual destacou um físico, um cirurgião, enfermeiros e servidores. Catarina Madeira SANTOS, "Goa é a chave de toda a Índia". Perfil político da capital do Estado da Índia (1505-1570). Lisboa, CNCDP, 1999, pp. 153-197.

49 Luís de Albugueroue, Martim Afonso de Sousa, op. cit., p. 77. 
preço da generalidade das drogas, simples ou preparadas, fosse fixado e respeitado no Reino e na generalidade do Estado da Índia. Reformulando o velho "Regimento de Preços das drogas e mezinhas" de 1497, a "Pauta das Mezinhas" de 1542 permaneceu em vigor até $1573 .{ }^{50}$

Para além destas medidas de relevância social e estratégica, a gestão enérgica da terrível epidemia que assolou a cidade em 1543 deixou na memória de muitos sobreviventes a notável capacidade do fidalgo em enfrentar um dos males mais temíveis que grassava no Oriente: a cólera. ${ }^{51}$

Como descreveu Gaspar Correia, o flagelo dizimou, indiscriminadamente, crianças e velhos, homens e mulheres, ricos e pobres. Poucos dos afectados sobreviveram, e a cidade viveu momentos de angústia intensa. Para tentar serenar os ânimos, Martim Afonso proibiu os sinos das igrejas de tocar a dobrar e ordenou a autópsia a cadáveres. ${ }^{52}$

Esta investigação directa das causas da doença, recorrendo a uma prática tão invulgar na época, é reveladora do interesse do Governador em compreender, para melhor dominar, o temível inimigo que tinha por diante. ${ }^{53}$ Garcia de Orta participou certamente nestas investigaçôes. Em Colóquios dos Simples, o médico integrou no "Colóquio décimo sétimo, do Costo e da Colérica passio", a primeira descrição sobre a etiologia desta enfermidade que, uma vez contraída, matava em 24 horas. ${ }^{54}$ Revelando-se conhecedor dos sinais e sintomas e detentor dos segredos da cura, o médico demonstrou, com o seu tratado, o imprescindível valor da sua presença em Goa. Uma valia que revelou através dos interlocutores de posses que fez entrar em cena neste "Colóquio do costo". O pajem de um suposto "D. Jerónimo", que irrompeu noite dentro por entre a sossegada conversa de Ruano e Orta, atesta bem a gravidade desta doença, cujo tratamento "não padece tardança". A prontidão com que o médico visitou o doente, inquiriu as gentes da casa, estabeleceu o diagnóstico e preconizou o tratamento, assim como

50 Esta lista de especiarias, mezinhas e formulações terapêuticas e respectivos preços de aquisição e venda, vigorou em todos os hospitais e boticas do Oriente durante mais de 30 anos. Durante a governação de D. Constantino de Bragança (g.1558-1561), os preços de alguns simples foram revistos e actualizados pelo então físico-mor Dimas Bosque, permanecendo o resto da lista inalterada até 1573 altura em que Duarte Lopes assinou uma nova Pauta de Mezinhas que entrou em vigor de imediato. Tello da FonseCA, História da Farmácia portuguesa através da legislação, op. cit., vol. 3, pp. 5-21 e Teresa Nobre CARVALHO, O mundo natural asiático aos olhos do Ocidente, op. cit., pp. 221-224.

51 Sobre este episódio, vide: Ines Županov, "Drugs, health, bodies and souls in the Tropics. Medical Experiments in Sixteenth century Portuguese India", The Indian Economic and Social History Review 39, 1 (2002), pp. 1-43.

52 Gaspar Correia, Lendas da India, (Rodrigo de Lima Felner ed.). Lisboa, 1864, vol. 4, pp. 288-289. O trecho foi integralmente reproduzido pelo Conde de Ficalho nas notas ao Colóquio $17 .{ }^{\circ}$ em Colóquios dos Simples, op. cit., vol. I, pp. 273-274.

53 Nesse mesmo ano, verificou-se uma onda de contestação por toda a Europa causada pela publicação da obra de André Vesálıo, De humani corporis fabrica libri septem. Basileia, ex of. J. Oporini, 1543, na qual o corpo humano era investigado a partir do seu interior, com grande minúcia de detalhes. Alguns anos mais tarde, D. João III viria a ordenar a entrega de cadáveres à Universidade de Coimbra com o intuito de nesta serem aprofundados os estudos de Anatomia.

54 Garcia de ORTA, Colóquios dos Simples, op. cit., vol. I, pp. 255-267. 
o diálogo franco que estabeleceu com o boticário pessoal do fidalgo parece justificar o respeito das elites portuguesas por Orta e sublinhar a pertinência do seu saber. ${ }^{55}$

Mas se a atitude do governante perante a ameaça desta epidemia mereceu a admiração dos funcionários régios destacados no Oriente, nem todas as decisóes de Martim Afonso foram aceites pelas elites portuguesas. Algumas atitudes do governador provocaram acesa controvérsia em Lisboa. Não deixam, por isso, de nos soar algo desafiantes as palavras que Orta inscreveu na carta dedicatória: "porque sei que todos os que nestas indianas regiôes habitam, sabendo a quem vai entitulado, folgarão de o leer."

$\mathrm{Na}$ verdade, ao longo da sua governação, Martim Afonso de Sousa tomou atitudes extremamente polémicas, condenadas no Reino pela generalidade da elite política. Se a sua ousadia em mandar construir um navio para fins comerciais ou a sua implicação na compra de pedras preciosas, lhe valeram a crítica do Rei e de D. António de Ataíde, outras atitudes mais gravosas indignaram as elites dirigentes do Reino. ${ }^{56}$

Como escreveu Alexandra Pelúcia,

Resultaria longa e fastidiosa a pormenorização dos temas sujeitos a denúncia. Em termos gerais, retenham-se as liberdades comerciais distribuídas, as expediçóes organizadas pelo governador, os problemas de Meale e do tesouro de Asad Kahan, os distúrbios ocorridos em Cananor após o assassinato do Cádi local, o deficiente abastecimento dos armazéns, o estado deplorável a que chegara a armada [...] e o escândalo mais recente de cunhagem de moeda de circulação corrente em Goa, os bazarucos, com menor percentagem de cobre. ${ }^{57}$

Não pretendemos detalhar cada um destes assuntos. Parece-nos, no entanto, evidente que, no Reino, a imagem do fidalgo tinha sofrido uma importante deterioração durante a sua governação no Oriente. A chegada apartada do seu navio a Lisboa, deixando para trás as outras naus da armada, atesta bem o desconforto que envolvia o seu nome.

$\mathrm{Na}$ "Brevíssima e sumária relação", à qual temos vindo a fazer referência, Martim Afonso revelou uma enorme audácia. O discurso do fidalgo parece sugerir a desconsideração a que tinha sido votado por muitos cortesãos. Importunando a Rainha viúva com solicitaçóes e pedidos, o nobre procurou, da forma que lhe pareceu adequada, reestabelecer a sua posição e cabedais. ${ }^{58}$ Fazendo-se valer da sua família numerosa, do bom nome de sua mulher, do já

55 Como demonstraremos mais abaixo, também as elites locais consideravam valioso o saber de Orta.

56 Estas repreensões foram-lhe comunicadas em carta que D. António de Ataíde the enviou em 1544. Alexandra PelúciA, Martim Afonso de Sousa e a sua Linhagem, op. cit., pp. 226-228.

57 Alexandra Pelúcia, Martim Afonso de Sousa e a sua Linhagem, op. cit., p. 240.

58 Talvez valha a pena não esquecer que o seu parente, D. António de Ataíde, o sólido interlocutor que 
antigo conhecimento que tinha da governante, que remontava à viagem de Tordesilhas para Lisboa, e tirando partido da fragilidade que a morte de D. João III deixara em aberto, o fidalgo encontrou em D. Catarina o apoio e amparo de que necessitava.

$\mathrm{Na}$ realidade, durante a sua regência (g.1557-1562), a Rainha veio a solicitar ajuda de Martim Afonso de Sousa. Não parece, no entanto, que este seu apoio ao fidalgo reunisse consensos. Como se pode ler num episódio relatado nos Ditos portugueses dignos de memória, o fidalgo dirigiu, em nome da Regente, as reuniôes preparatórias que tiveram lugar em Lisboa, em 1562.59 No decorrer de uma dessas reunióes, ocorreu o episódio que o anónimo autor dos Ditos registou:

Sendo el-rei D. Sebastião de pouca idade e a Rainha D. Catarina, sua avó, que por ele governava, querendo largar o governo, mandou chamar as cortes; e, depois de chegados os procuradores de todos os povos do Reino, estando já juntos no lugar deputado para o auto, estando Martim Afonso de Sousa, que fora governador da Índia, sentado em uma cadeira para, em nome da rainha, lhes propor e praticar o para que foram chamados, por ela o ter escolhido para isso, começou a prática por estas palavras:

— Vós outros, Senhores, sois aqui vindos para Sua Alteza vos manifestar...

E, indo prosseguindo a sua prática, um Diogo Soares Homem, que era procurador de Lamego, sabendo que todos os procuradores que ali vinham eram cavaleiros muito honrados e os principais dos lugares que os elegeram, não lhe parecendo decentes as palavras do intróito com que Martim Afonso começara, atalhou-lhe passar avante com lhe dizer estas:

— Vós outros não estão aqui, nem Martim Afonso está na Índia. ${ }^{60}$

Martim Afonso tinha junto do Rei, abandonou a corte em 1557, pelo que o fidalgo já não podia contar com a sua intercessão.

59 Ditos portugueses dignos de memória é uma compilação de ditos, provérbios, anedotas, episódios e sentenças que circulavam no Reino, no século xVI. Permanecendo inéditos até ao século passado, conhecem-se diversas versões manuscritas, o que parece indicar a sua importante circulação. Reunidos por um autor anónimo, ilustram momentos do quotidiano português, ocorridos entre os reinados de Afonso V e D. Sebastião. Segundo José Hermano Saraiva, o compilador terminou a recolha perto de 1575. Elementos da nossa cultura oral, pela sua irreverência que não deixa ninguém de fora, estes ditos constituem preciosas achegas à narrativa historiográfica. Ditos portugueses dignos de memória. História íntima do século XVI anotada e comentada por José Hermano SaRAIVA. Póvoa do Varzim, Publicações Europa-América, pp. 5-10. Para uma análise mais detalhada sobre as diversas versões manuscritas desta obra quinhentista vide Mário Justino SILVA, O rei e os nobres: imagens do quotidiano nos ditos portugueses dignos de memória (século xVI). Cascais, Patrimonia, 2004.

Ditos Portugueses dignos de memória, op. cit., p. 422. 
Como recordou Mário Justino da Silva, em muitos episódios relatados nos Ditos, o descurar o uso de uma fórmula adequada de tratamento pronominal dava azo, a frequentes queixas, ofensas e conflitos. ${ }^{61}$ Este reparo que o procurador de Lamego dirigiu ao fidalgo faz adivinhar alguma advertência a Martim Afonso. Apesar de a situação ocorrer num contexto em que era clara a confiança que D. Catarina depositava no fidalgo, o representante parecia querer recordar ao nobre que este apoio da Regente se aproximava do fim, já que, em breve, as Cortes reuniriam assinalando o encerramento do período de Regência de D. Catarina e portanto, a transição do seu poder. Com o cessar do apoio da Regente, vozes como as de Garcia de Orta contribuíam para manter viva a memória da grandiosidade dos feitos de Martim Afonso. ${ }^{62}$

De facto, encontrando numerosos entraves no Reino, a restauração do nome do fidalgo parece ter sido lenta. Afigura-se-nos, como tal muito oportuno, o aparecimento, em 1563, de uma obra inteiramente dedicada aos recursos naturais da Ásia, na qual a dedicatória enalteceu os feitos, saberes, arrojo e distinção de um fidalgo que, no Oriente, era saudado pela sua alta estirpe. ${ }^{63}$

Com as suas breves palavras, Garcia de Orta parece ter querido recuperar a memória do nobre e salientar a admiração que os portugueses espalhados por toda a Ásia nutriam pela sua pessoa e pelo trabalho que, durante a sua permanência no Oriente, realizara.

Não deixa de ser curioso que, ao associar Colóquios dos Simples a Martim Afonso, Garcia de Orta comprovava muitos dos feitos grandiosos que o fidalgo descrevera na "Brevíssima e sumária relação...”, de 1557, para além de o implicar nos complicados processos de conquista de mercados de especiarias e aromas e de aquisição de saberes relativos às maravilhas do Oriente.

Mas talvez o problema fosse um pouco mais profundo do que aparenta. Com o fim da regência de D. Catarina e o avizinhar de tempos de indefinição de governo, é possível que o investimento régio em pesquisas como a que Garcia de Orta apresentava fosse questionado. Martim Afonso surgia assim como um dos derradeiros elos ainda visíveis de um projecto construído ao longo de várias décadas e que, agora, com o apartamento da Regente, ameaçava desvanecer-se.

Convém sublinhar que, desde a sua chegada a Portugal, D. Catarina tinha revelado um enorme gosto pelas maravilhas do Oriente. Para além dos animais exóticos que mantinha nos seus zoológicos privados, a Rainha coleccionava objectos raros, artigos de luxo e preciosidades asiáticas. ${ }^{64}$ Em Goa, Cochim e Malaca mantinha homens da sua confiança que encarregava

61 Mário Justino da SILVA, 0 rei e os nobres, op. cit., pp. 71-78.

62 Foi também no final de 1562 que Garcia de Orta terminou Colóquios dos Simples no qual redigiu a carta dedicatória a Martim Afonso de Sousa.

63 É com alguma ironia que verificamos que no momento em que a obra fica finalmente pronta, a Regente já tinha renunciado ao cargo, deixando no seu lugar o cardeal Infante D. Henrique (r.1562-1568), Inquisidor-Mor do Reino.

64 O fascínio de Catarina de Áustria pelas maravilhas e raridades tem sido alvo de aturado estudo por Annemarie Jordan. Para além de peças de grande requinte adquiridas pelos seus feitores europeus em Roma, Génova, Florença, Milão, Valência, Sevilha, Medina del Campo e Paris, esta investigadora, 
de adquirir pedras preciosas e raridades como cocos-das-Maldivas e bezoares, para além de porcelanas e outras maravilhas exóticas que guardava nos seus aposentos ou distribuía pelos seus familiares. ${ }^{65}$

\section{MARTIM AFONSO DE SOUSA E A NOVIDADE}

O respeito por Martim Afonso de Sousa era, aliás, compartilhado por alguns dos soberanos locais. Ao longo de Colóquios dos Simples, em diversas ocasiōes, Orta relatou a sua experiência enquanto médico pessoal do então Capitão-Mor da Armada, durante a sua passagem pelas cortes destes governantes. Nestes episódios, ocorridos entre 1534 e 1538, Garcia de Orta testemunhou a sua passagem pelas cortes de "Nizamoxa" ${ }^{66}$ e de Bahadur. ${ }^{67}$ Foi em algumas destas ocasióes que Orta fez valer o seu saber médico perante os dirigentes locais e os sábios que os rodeavam.

Foi enquanto físico do Capitão-Mor que Orta visitou a corte do rei do Balagate "cujo pay curey muitas vezes, e ao filho algumas" ${ }^{68}$, onde esclareceu a diferença entre folio e betre ${ }^{69}$ e provou as mangas mais saborosas. ${ }^{70}$

assinalou na colecção real artigos orientais provenientes de Goa, Ceilão Macau, Malaca, Japão, China e Ryukyu. Annemarie Jordan, A rainha colecionadora. Catarina de Áustria. Maia, Círculo de Leitores, 2012, p. 110. De entre os numerosos estudos que esta estudiosa tem publicado sobre o assunto, destacamos: Annemarie Jordan GsCHWEND, "Catarina de Áustria: Colecção e Kunstkammer de uma princesa renascentista", Oceanos 16 (1992), pp. 62-70; Annemarie Jordan GsCHWEnd, "Marvels of the East. Renaissance curiosity collections in Portugal» in Nuno Vassallo e SILvA (coord.), A herança de Rauluchantim. Lisboa, 1996, pp. 82-127 e Annemarie Jordan, A rainha colecionadora. Catarina de Áustria, op. cit., pp. 99-126.

65 De entre a vasta lista de funcionários encarregados de adquirir raridades para a rainha destacamse nomes como os do ourives da corte Diogo Vaz, do feitor Manuel Botelho ou do moço-de-câmara António Correa. Annemarie JoRdAn, A rainha colecionadora. Catarina de Áustria, op. cit., pp. 110-111.

66 "Nizamoxa" resulta de uma adaptação para português de "Nizam Shâh", termo que designava o Sultão de Ahmadnagar. No período em que Garcia de Orta permaneceu no Oriente reinaram Burhan Nizam Shâh (r.1503-1553) e Husain Nizam Shâh (r.1554-1565). Ao longo de Colóquios dos Simples, Garcia de Orta refere-se a estes governantes com admiração e apreço.

67 Bahadur Xá foi Sultão de Guzarate, (r.1526-1537). Perante a ameaça Mogol, o Xá viu-se obrigado a socorrer-se da ajuda dos portugueses para proteger as suas possessões. Segundo consta, Martim Afonso de Sousa conquistou a confiança do soberano e manteve relações frutuosas com este tendo firmado, em 1535, o Tratado de Baçaim, através do qual Damão, Diu, Bombaim e Baçaim passaram para a posse dos portugueses. O Sultão morreu em circunstâncias ainda não esclarecidas.

68 Garcia de ORTA, Colóquios dos Simples, op. cit., vol. 1, p. 119.

69 Garcia de OrTA, Colóquios dos Simples, op. cit., vol. 2, pp. 393-394.

70 Garcia de OrTA, Colóquios dos Simples, op. cit., vol. 2, p. 101. 
Foi ao serviço de Martim Afonso que o físico conheceu a corte do Sultão do Guzarate, “o maior rey que avia na Mourama." ${ }^{71}$ Nesta, Orta testemunhou o hábito de mastigar o bangue ${ }^{72}$ e pôde observar as práticas médicas de outros.

Ao longo da sua vivência asiática, Orta observou e ajuizou os costumes dos médicos locais. Presenciar como outros estabeleciam os diagnósticos, avaliar as práticas terapêuticas que preconizavam, levou-o a questionar a sua própria modalidade de curar. Em algumas circunstâncias, teve mesmo de admitir que as práticas clínicas de físicos árabes e hindus eram mais eficazes do que as europeias. Corrigindo algumas metodologias ocidentais, vulgarizando as práticas de outros nas equipas médicas hospitalares, permitindo o acesso quotidiano dos físicos gentios a sua casa, inquirindo os seus colegas sobre os seus conhecimentos, Orta edificou um saber híbrido onde convergiam as práticas de tradições médicas distintas e que se revelava, globalmente, mais eficaz no combate aos males que grassavam no Oriente. ${ }^{73}$

Foi durante as suas deslocaçóes às cortes de Cambaia ou do Balagate que Orta estabeleceu os principais contactos com hakims. ${ }^{74}$ Estes homens letrados poucas vezes se deslocaram a Goa, já que não ponderavam a possibilidade de ocupar lugares de subordinação nos hospitais lusitanos e, aparentemente, os portugueses não estavam dispostos a considerá-los como iguais. Foi assim, no âmbito de um meio político definido, que Orta confrontou o seu saber com o dos seus colegas árabes: homens com quem discutiu conteúdos de textos e debateu as práticas médicas usadas, mas também de quem aprendeu múltiplos saberes sobre a sinonímia e as propriedades terapêuticas das drogas locais.

Por terem um ensino médico baseado, em grande parte, nos mesmos textos, por praticarem nas cortes de soberanos locais e por estarem mais perto das drogas orientais do que os sábios europeus, Orta dedicou ao saber destes médicos particular atenção. Por vezes, salientava a proximidade das práticas dos médicos árabes e europeus, e o seu distanciamento face às terapêuticas dos físicos gentios. ${ }^{75}$ Mas Orta confiava no sistema médico em que se formara. Como salientou

71 Garcia de OrTA, Colóquios dos Simples, op. cit., vol. 2, p. 140.

72 Garcia de ORTA, Colóquios dos Simples, op. cit., vol. 1, p. 97.

73 Parece-nos oportuno realçar alguns estudos sobre esta temática, como os de Ricardo JorGe, La médecine et les médecins dans l'éxpansion mondiale des Portugais. Lisboa, Tip. Seara Nova, 1935; Harry FriedenWALD, "The medical pioneers in the East", op. cit., pp. 487-501 ou Luís de PinA, As ciências na história do Império Colonial Português (séculos xV a xIX), op. cit.; ver também Kapil RAJ, Relocating Modern Science. Circulation and the construction of knowledge in South Asia and Europe, 1650.1900. Nova lorque, Palgrave Macmillan, 2007, pp. 1-26; Teresa Nobre de CARVALHo, O mundo natural da Ásia aos olhos do Ocidente, op. cit., pp. 257-270.

74 Garcia de ORTA, Colóquios dos Simples, op. cit., vol. 2, p. 147; P. GaITONDE, Portuguese pioneers in India. Spotlight in medicine. Bombay, Popular Prakashan, 1983, p. 139.

75 Michael PeArSON, "Hindu medical practices in Sixteenth-Century Western India: Evidence from Portuguese sources", Portuguese Studies 17 (2001), pp. 100-113. 
a Ruano, "primeiro provo as mezinhas dos meus doutores, quando me não aproveitam, tomo as dos Brâmanes desta terra." ${ }^{\prime 6}$

A sua dependência face aos médicos gentios era de outra ordem. Estes homens guardavam um tesouro: o saber relativo às propriedades terapêuticas das plantas locais. Assim, a desqualificação destes detentores de um património insondável era apenas aparente. Na verdade, Orta estava ciente que o saber dos vaydias era um poderoso aliado que os portugueses no Oriente tinham que conquistar. ${ }^{77}$

Não nos restam hoje dúvidas de que, nos hospitais portugueses do Oriente, se aviavam receitas de mezinhas locais. As listas de botica que hoje conhecemos testemunham o uso vulgar de drogas indígenas. ${ }^{78}$

\section{D. CONSTANTINO DE BRAGANÇA E O SEU MÉDICO}

Atestando a sua adesão aos produtos usados na farmacopeia local, Dimas Bosque (s/d) contribuiu para consolidar as novidades apresentadas no tratado de Orta. O testemunho deste médico valenciano revelou-se imprescindível. A ele se deveram dois dos paratextos ${ }^{79} \mathrm{e}$ a descrição de novidades, no Colóquio 58. ${ }^{\circ}$, "Das cousas novas". ${ }^{80}$

Como relativamente a tantas outras personalidades do seu tempo, pouco se sabe sobre a vida de Dimas Bosque. Como escreveu Jaime Walter: "Dimas Bosque [...] formou-se em Medicina. Se completou o curso em Coimbra, não se pode afirmar, pois a única conclusão que podemos extrair das suas palavras é ter assistido às liçóes e ter contactado com o Professor da Universidade Dr. Tomás Rodrigues da Veiga." ${ }^{81}$

76 Garcia de ORTA, Colóquios dos Simples, op. cit., vol. 2, p. 138.

77 Sobre a importância das plantas asiáticas para os portugueses vide K. S. MATHEW, "The Portuguese and the study of medicinal plants in India in the sixteenth century", op. cit., pp. 369-376; Sobre a relevância dos saberes locais no contexto dos impérios ibéricos vide: Daniela BLEICHMAR, Science in the Spanish and Portuguese empires, 1500-1800, op. cit., pp. 219-232; Jorge CAÑIZARES-EsGUerRa, "Iberian Science in Renaissance: ignored how much longer?", op. cit., pp. 86-124; Londa SCHIEBINGER and Claudia SWAN, Colonial Botany, op. cit., pp. 83-99 e 119-133 e Palmira Fontes da CostA, Teresa Nobre de CARVALho, "Between East and West: Garcia de Orta's Colloquies and the circulation of medical knowledge in the sixteenth century", Asclepio, Revista de Historia de la Medicina y de la Ciencia 65, 1 (enero-junio 2013), pp.1-13.

78 Banha de AndRade, "Drogas do Oriente", Arquivo do Centro Cultural Português 3 (1971), pp. 112-188 e Jaime Walter, "Simão Álvares e o seu rol das drogas da Índia", Studia 10 (1962), pp. 117-149.

79 Referimo-nos a duas cartas: uma dirigida ao leitor e outra a Tomás Rodrigues da Veiga. Garcia de ORTA, Colóquios dos Simples, op. cit., vol. 1, pp. 10-13.

80 Garcia de OrTA, Colóquios dos Simples, op. cit., vol. 2, pp. 371-384.

81 Jaime Walter, "Dimas Bosque e as sereias", Studia 12 (1963), p. 262. 
Dimas Bosque chegou à Índia, em 1558, como físico-mor de D. Constantino de Bragança (g.1558-1561). Filho de D. Jaime de Bragança e de D. Leonor de Mendoza, D. Constantino era um homem de nobre linhagem e da inteira confiança de D. João III, como o atestam as importantes missóes diplomáticas que desenvolveu, em França, junto da corte de Henrique II. Durante o seu governo do Estado da India, D. Constantino revelou a integridade do seu carácter mas também uma rigorosa ortodoxia. Motivado pelo ideal da Contra-Reforma, a sua governação deu mostras de grande intolerância religiosa. ${ }^{82}$ Homem crente, de convicçôes fortes, a ele se deveram importantes campanhas militares. ${ }^{83}$

Como as suas funçóes o exigiam, o licenciado Bosque acompanhou o Vice-Rei nas expediçôes guerreiras. Conforme relatou, na campanha do Jafanapatão, face ao esgotamento das drogas de botica que trazia, viu-se forçado a buscar na região novas soluçóes terapêuticas. Ao inquirir as populaçóes locais, o médico deu-se conta da enorme diversidade de ervas e plantas com propriedades curativas que eram usadas na farmacopeia tradicional. Convencido, pela sua experiência, da eficácia destas novas mezinhas, Dimas Bosque alargou o leque de drogas à disposição dos médicos e boticários portugueses. Através de Colóquios dos Simples, Dimas trouxe ao conhecimento dos leitores novas drogas como os marmelos-de-Benguela ou a pedra-de-Malaca. ${ }^{84}$

Como atrás referimos, Dimas Bosque reviu e actualizou os preços da Pauta das Mezinhas que se usavam no Hospital Real de Goa. O médico desempenhou as funçóes de Físico-mor, provavelmente até ao regresso de D. Constantino ao Reino em 1561. A partir de então estabeleceu-se na Índia tendo arrematado a ilha de Santa Cruz, em Setembro do mesmo ano. ${ }^{85}$

Desconhecemos se D. Constantino esteve directamente implicado na publicação de Colóquios dos Simples. Regressado ao Reino numa altura em que a obra ainda permanecia manuscrita, manteve a sua presença no texto através do testemunho do seu físico pessoal.

Supóe-se que o licenciado Dimas Bosque animou a actividade científica do Colégio de São Paulo de Goa. Os eventos que organizou nesta instituição Jesuíta teriam a maior relevância para a afirmação de Goa como pólo cultural no Oriente. ${ }^{86}$ Também a carta que endereçou de Goa, em 1565, ao Reitor do Colégio de Córdova, o Padre João Baptista de Ribera SJ, descrevendo o

82 Em Oriente Conquistado encontra-se uma carta que o P. Luís Fróis dirigiu a um seu irmão do Colégio romano, na qual revelou as mudanças introduzidas por D. Constantino na Igreja, em Goa. Aquilino RIBEIRO, Constantino de Bragança VII Vizo-Rei da Índia. Venda Nova, Bertrand Editora, 1987, pp. 182-185.

83 Sobre este Vice-Rei, vide, entre outros, Aquilino RıBEIRo, Constantino de Bragança..., op. cit., ou Charles R. Boxer, O Império Colonial Português 1415-1825. Lisboa, Edições 70, 2001, pp. 77-93.

84 Garcia de ORTA, Colóquios dos Simples, op. cit., vol. 2, pp. 371-384.

85 Augusto da Silva Carvalho, "Garcia d'Orta", op. cit., p. 238.

86 Num destes momentos, ocorrido em 1559, no Colégio de São Paulo, Garcia de Orta pertenceu ao grupo de jurados que avaliou as provas de um jovem noviço. O episódio relatado pelo irmão Luís Fróis foi publicado na Documentação das Missões do Padroado Português do Oriente, vol. VII, pp. 297-236. 
"estupendo milagre da natureza" que examinara alguns anos antes na ilha do Manar, atesta a sua permanência no Oriente depois da saída do Governador. Para além da descrição daqueles peixes "obra admirável do Criador", a carta revelou-se da maior importância, já que comprova que Dimas Bosque manteve relações epistolares com os mais altos representantes dos Colégios da Companhia de Jesus estabelecidos na Península Ibérica e, muito provavelmente, exercia prática clínica no Colégio dos Jesuítas de Goa e no respectivo Hospital. ${ }^{87}$

Não é, por isso, surpreendente o respeito com que Orta se referiu a este médico. A admiração de Orta surgiu plasmada em algumas das suas alusôes ao físico de Valência: "hum físico letrado e homem que fala verdade em seus ditos" 88 ou "o licenciado Dimas Bosque, pessoa de muito boas letras, e homem de muyta verdade nas curas que faz [...] e ao menos seivos dizer que me avia de dizer verdade." ${ }^{89}$ A mútua afeição entre os médicos ficou claramente demonstrada no Colóquio 58. ${ }^{\circ}$, no qual Garcia de Orta convidou Dimas Bosque a emendar os erros que tivesse encontrado em Colóquios dos Simples. Ao sujeitar-se à correcção de um colega claramente menos conhecedor das práticas e saberes locais do que ele próprio, Orta submeteu-se ao que Dimas representava: uma harmoniosa convivência com o poder de um Bragança.

A epístola que Dimas Bosque dirigiu ao leitor, na qual traçou alguns passos da biografia de Orta, surgiu assim, neste grupo de textos preliminares como um fecho adequado.

Mas Garcia de Orta deu a este licenciado renovado destaque antes de encerrar o livro. Referimo-nos a uma epístola que o médico valenciano dirigiu ao seu antigo mestre de Coimbra: Tomás Rodrigues da Veiga (1513-1579). Natural de Évora, onde aprendeu as primeiras letras, fez os seus estudos médicos em Salamanca. O físico foi autor de comentários a Galeno e de outros textos eruditos. ${ }^{90}$ Homem da confiança de D. João III, a quem este se referia como "meu médico", foi transferido, em 1540, de Lisboa para a Universidade de Coimbra. Durante a sua permanência nesta Universidade, o seu salário foi sucessivas vezes aumentado por alvarás do Rei. Ordenado Cavaleiro da Ordem de Santiago em 1558, teve como testemunhas o então físico-mor do Reino, o Doutor Diogo Lopes (Cavaleiro da Ordem de Santiago) e o Doutor Diogo de Santiago (Cavaleiro da Ordem de Avis). ${ }^{91}$ Era, assim, um médico bem cotado na corte de

87 Jaime WALter, "Dimas Bosque e as sereias", op. cit., pp. 260-271.

88 Garcia de ORTA, Colóquios dos Simples, op. cit., vol. 2, p. 164.

89 Garcia de OrTA, Colóquios dos Simples, op. cit., vol. 2, p. 186.

90 Commentaria in Galenum, quibus complectitur interpretatio trium librorum Arti Medicae, (Antuérpia, 1564); Commentariorum in Claudii Galeni Opera, medicorum principis complectens interpretationem Artis Medicae, (Antuérpia, 1566) e Commentarij in libros Claud. Galeni duos De febrium differentiis (Coimbra, 1578).

91 Francis Dutra, "The practice of Medicine in Early Modern Portugal. The role and social status of the Fisico-mor and Surgião-mor", in Israel Katz (ed.), Libraries, History and Diplomacy and the Performing Arts. New York, Pendragon Press, 1991, pp. 143-145. 
D. João III e também na de D. Catarina. Sem dúvida um interlocutor atento das palavras de Dimas Bosque e um leitor interessado em Colóquios dos Simples. ${ }^{92}$

A seu respeito escreveu Rocha de Brito:

O Padre António Vieira num dos seus sermóes chama-lhe mesmo Grande Magnus Thomas - . [...] O remoto colega não fora apenas, à maneira de tantos mestres universitários de antanho, um teorisante, um repetidor de Hipócrates e Galeno, ou um comentador mais ou menos arguto e original dos autores gregos e árabes, mas espírito prático e ávido de saber, entretinha as horas de ócio, que lhe deixavam a clínica e o professorado, colhendo pelas colinas e campos do Mondego ervas e arbustos, que ia replantar nos seus hortos para os estudar in visu. ${ }^{93}$

A epístola latina redigida por Dimas Bosque — "Praestantissimo doctori Tomae Roderico in conimbricensi academia medicorum primo Dymas bosque medicus valentius. S.P.D.” encontra-se no final da obra, imediatamente antes da Errata. ${ }^{94}$ Nela, o médico, começou por enumerar os autores clássicos que tinham descrito a origem e virtudes das plantas. No entanto, como sublinhou o licenciado, Tomás da Veiga privilegiava um método de análise do mundo natural inovador. Dimas parecia seguro em relação à eficácia da dedicatória da obra de Orta a tão ilustre personalidade. Ciente da vasta teia de relaçôes na qual Tomás Rodrigues se inseria e que poderia assegurar a divulgação dos Colóquios na Europa, escreveu:

quando encontrei neste país o Doutor Garcia de Orta, [...] logo o aconselhei a que o colocasse [o Tratado sobre os Simples] sob a tua égide, como uma das mais

92 Para mais detalhes biográficos sobre o médico e a sua família vide Francisco Leitão FerReIRA, Notícias cronológicas da Universidade de Coimbra, [...]. Coimbra, Por ordem da Universidade, 1938, vol. 1, pp. 715-726 e Maximiliano Lemos, História da Medicina em Portugal: doutrinas e instituições. Lisboa, Dom Quixote/Ordem dos Médicos, 1991, vol. 1, pp. 250-252. Sobre a rede de relações familiares, científicas e comerciais que este físico mantinha na Europa vide António M. L. ANDRADE, O Cato Minor de Diogo Pires e a poesia didáctica do século xvı. Lisboa, Imprensa Nacional-Casa da Moeda, 2014, pp. 319-333 e Hans PoHL, Die Portugiesen in Antwerpen: (1567-1648). Wiesbaden, Franz Steiner, 1977, pp. 356-360.

93 Rocha de BRITO, "O Doutor Tomás Rodrigues da Veiga, ilustre ervanário", op. cit., pp. 408-409. Esta curta notícia parece-nos suficiente para justificar a oportunidade da Carta que Dimas Bosque dirigiu ao ilustre médico. Sobre o físico ver ainda: Francis DUTRA, "The practice of Medicine in Early Modern Portugal", op. cit., pp. 135-169.

94 Garcia de Orta incluiu este documento no final da obra, após o Colóquio 58. ․ Na sua edição, o Conde de Ficalho optou por colocar este texto no início do livro, imediatamente após a Carta ao leitor redigida por Dimas Bosque. Dado que a posição relativa dos diferentes paratextos dentro da obra nos parece ser relevante, pensamos que esta decisão de Ficalho não favorece a compreensão global do significado dos documentos. Por isso, optamos por nos referir ao texto incluído por Garcia de Orta no final da sua obra. Garcia de OrTA, Colóquios dos Simples, [1563], 1963, fl. 227 f. 
doutas, o que ele fez com o maior agrado. Bem sabia ele, venerando ancião, que és hoje na Europa, o patrono de todos os médicos e como és generoso para todos os estudiosos [...] Oxalá, portanto, sapientíssimo Doutor, que o livro, assim protegido pelo teu escudo e amparado na autoridade do teu nome, ouse caminhar sem medo dos zoilos, entre os sábios, e triunfe em todas as academias da Europa e deste modo possa a juventude colher os frutos e empregar os simples da Índia, pintados com as cores da virtude médica. ${ }^{95}$

Estrategicamente colocada ao lado da referida Errata, esta epístola latina aproximava o projecto científico de Orta da rota das redes eruditas europeias.

Um epigrama surgiu ainda nos Colóquios dos Simples logo a seguir a esta epístola. Trata-se de "Ad Gartiam ab horto medicum apud Indos...”, um curto epigrama redigido por Tomé Caiado. ${ }^{96}$ Sobre este latinista encontrámos muito pouca informação. Como escreveu Rui Manuel Loureiro,

Entre os eruditos portugueses que residiram na Índia durante o século Xvi, contase também Tomé Dias Caiado, que, em 1542, era incumbido de ensinar latim na Sé de Goa. Viveu ainda longos anos naquela cidade, onde proferiu várias orações solenes: em 1547, em honra de D. João de Castro, recém-chegado do cerco de Diu; em finais de 1557 ou princípios do ano seguinte, a propósito da morte de el-rei D. João III; e em 1564, à chegada de D. Antão de Noronha à capital do estado da Índia.

Sobre a sapiência do literato concluiu: "Em todas as oraçôes referidas revelava alguma erudição clássica, citando nomeadamente Homero, Plínio, Cícero e Santo Ambrósio.”97

Foi assim este letrado, a quem competia exaltar os feitos dos portugueses nomeados a desempenhar nobres funçôes no Oriente, que dirigiu um sonoro aplauso a Garcia de Orta. A redacção em latim tornava o seu louvor acessível a toda a comunidade erudita. Deste modo, o pequeno epigrama cantado por este cronista das elites deu visibilidade e crédito ao trabalho de Orta. O seu conteúdo laudatório, assegurou aos leitores mais cépticos o inegável valor da obra que tinham entre mãos. Tal como o privilégio do Vice-Rei e a Carta a Martim Afonso

95 A epístola redigida em latim foi publicada por Rocha de BRITO, "O Doutor Tomás Rodrigues da Veiga, ilustre ervanário", op. cit., pp. 408-409.

96 O epigrama foi vertido para português por Maria Helena Rocha PEREIRA, "Louvores latinos aos 'Colóquios dos Simples e Drogas". Porto, Centro de Estudos Humanísticos, Faculdade de Medicina do Porto, 1963. pp. 1-11. Para consultar o texto latino, ver Garcia de ORTA, Colóquios dos Simples, [1563], 1963. fl. 228 v.

97 Rui Manuel Loureiro, A biblioteca de Diogo do Couto, op. cit., p. 40. 
de Sousa garantiam aos ibéricos a credibilidade das notícias veiculadas nos Colóquios, estes textos finais, engastados entre o Colóquio 58. e a Errata, asseguravam aos letrados europeus a excelência das investigaçóes alcançadas pelo médico.

\section{NOTAS FINAIS}

Apoiada e protegida pelas cúpulas dirigentes do Estado Português da Índia, autorizada com o selo do Inquisidor, valorizada pelas elites eruditas destacadas no Oriente, a obra publicada em Goa, Colóquios dos Simples e Drogas he Cousas Medicinais da India, convinha aos negócios do império e defendia os interesses dos seus súbditos.

Pela multiplicidade de públicos que servia, não lhe conseguimos identificar um patrono único. Ao inequívoco interesse de D. João III e de D. Catarina em reconhecer o património natural da Ásia, há que aliar a relevância estratégica que estas notícias apresentavam no governo do Reino e do Estado da Índia.

Um nome em particular se destacou ao longo de Colóquios dos Simples: o de Martim Afonso de Sousa. Homem a quem Garcia de Orta ficou a dever a sua oportuna saída de Lisboa, ao serviço de quem, como médico privado, viajou no Oriente e ao lado de quem observou as tradiçóes e saberes locais, surgiu, ao longo da obra, como se de uma peça fundamental se tratasse.

Fidalgo educado e costumado no meio cortesão, desde cedo partilhou espaços e vivências com as elites do Reino. Com o desaparecimento, em 1557, de D. João III e o consequente afastamento do seu parente e protector D. António de Ataíde do meio cortesão; com a resignação, em 1562, de D. Catarina do seu cargo de regente, o nobre perdeu o apoio dos seus mais fortes aliados políticos.

Num momento em que as elites do Reino se preparavam para o esquecer, Colóquios dos Simples, publicado em Goa, em 1563, veio reavivar o seu nome, enaltecer os seus feitos e recordar a sua ligação com uma tradição.

Naquela época de transição de poderes, em que o apoio e investimento no desenvolvimento das ciências incentivado por D. João III arriscava não encontrar continuidade, o contributo de Orta não achava melhor interlocutor no Reino do que o deste seu amigo de longa data.

Ao longo da obra, a imagem de fidalgo de linhagem de Martim Afonso de Sousa saiu reforçada assim como foi valorizado o seu evidente contributo para a aquisição e circulação do novo saber.

Para além deste fidalgo, e apesar de surgir de uma forma mais discreta, também o nome de D. Constantino de Bragança, o Vice-rei cessante, que regressou ao Reino em 1561, sobressaiu como sustento do tratado apresentado por Garcia de Orta.

Através de Dimas Bosque, o médico privado de D. Constantino, o percurso de Garcia de Orta tomou forma e foi apresentado ao leitor. As leves correcçóes a aditamentos que Bosque introduziu na obra revelaram o suporte do Vice-Rei ao projecto de Orta. 
Com o apoio das elites, Colóquios dos Simples revelou-se um dos mais inovadores e arrojados contributos da medicina portuguesa para a ciência de Quinhentos.

A afirmação de Portugal enquanto autoridade nas Ciências era, afinal, parte de uma estratégia de afirmação de poder que, desde meados do século XVI, motivava e desafiava os sábios e os governantes portugueses. Naquela segunda metade da centúria, que todos adivinhavam conturbada, importava assinalar e destacar personalidades capazes de sustentar e dar continuidade a tão grandioso projecto.

\section{BIBLIOGRAFIA}

Albuquerque, Luís de, Introdução à história dos descobrimentos. Coimbra, Atlântida, 1962.

Albuquerque, Luís de, Martim Afonso de Sousa. Mem Martins, AlFA, 1989.

Andrade, A. Banha de, Novos mundos do Mundo. Panorama da difusão, pela Europa, de notícias dos Descobrimentos geográficos Portugueses. Lisboa, Junta de Investigaçóes do Ultramar, 1972, 2 vols.

Andrade, A. Banha de, "Drogas do Oriente", Arquivo do Centro Cultural Português 3 (1971), pp. 112-188.

Andrade, António M. L., O Cato Minor de Diogo Pires e a poesia didáctica do século xvi. Lisboa, Imprensa Nacional-Casa da Moeda, 2014.

Anselmo, António, Bibliografia das obras impressas em Portugal no século xvi. Lisboa, Biblioteca Nacional, 1977, [1926].

Barrera, Antonio, Experiencing nature. The Spanish American Empire and the Early Scientific Revolution. Austin, University of Texas Press, 2006.

Biagioli, Mario, Galileo cortesão. Lisboa, Porto Editora, 2003.

Bleichmar, Daniela, Science in the Spanish and Portuguese empires, 1500-1800. Stanford, Stanford University Press, 2009.

Boxer, Charles R., A tentative check-list of Indo-Portuguese imprints. Paris, Centro Cultural Português, 1975, pp. 567-599.

Boxer, Charles R., O Império Colonial Português 1415-1825. Lisboa, Edições 70, 2001.

Braga, Teófilo, A primeira poesia impressa de Luis de Camóes. Lisboa, Adolfo Modesto, 1867.

Buescu, Ana Isabel, D. João III, 1502-1557. Rio de Mouro, Temas e Debates, 2008.

Burke, Peter, A social history of knowledge. From Gutemberg to Diderot. Cambridge, Polity Press, 2008.

Calado, Adelino Almeida, (ed.), "Livro que trata das cousas da Índia e do Japão", Boletim da Biblioteca da Universidade de Coimbra, Vol. XXIV, pp. 1-138.

Cañizares-Esguerra, Jorge, "Iberian Science in Renaissance: ignored how much longer?”, Perspectives on Science 12, n. 1 (2004), pp. 86-124.

Carvalho, Augusto da Silva, "Garcia d’Orta", Revista da Universidade de Coimbra 12 (1934), pp. 61-246.

Carvalho, Joaquim Teixeira de, Homens de outros tempos. Coimbra, Imprensa da Universidade, 1924. 
Carvalho, Teresa Nobre de, "A apropriação de Colóquios dos Simples por dois médicos ibéricos de Quinhentos", in Palmira Fontes da Costa e Adelino Cardoso (orgs.), Percursos na história do livro médico (1450-1800). Lisboa, Ediçôes Colibri, 2011, pp. 59-72

Carvalho, Teresa Nobre de, "Invisible travelers and virtual tracks: knowledge construction in Colóquios dos Simples e Drogas da India of Garcia de Orta (Goa, 1563)", in Antoni Roca-Rosell (ed.), Proceedings of the 4th ESHS Conference. Barcelona, 2010, pp. 288-293.

Carvalho, Teresa Nobre de, "Os enigmas de uma edição goesa: Colóquios dos Simples de Garcia de Orta", in H. Leitão; L. Giurgevitch; T. N. de Carvalho (eds.), O livro cientifico lido de perto. Lisboa, BNP, 2015 (aceite para publicação).

Carvalho, Teresa Nobre de, O mundo natural asiático aos olhos do Ocidente. Contribuição dos textos ibéricos quinhentistas para a construção de uma nova consciência europeia sobre a Ásia. Lisboa, UL, 2012 (dissertação de doutoramento - texto policopiado).

Clusius, Carolus, Aromatum et simplicium. Antuérpia, Plantin, 1567.

Correia, Gaspar, Lendas da India, Rodrigo de Lima Felner (ed.). Lisboa, 1864.

Costa, Cristóvão da, Tractado de las drogas. Burgos, Martin de Victoria, 1578.

Costa, Palmira Fontes da; Carvalho, Teresa Nobre de, "Between East and West: Garcia de Orta's Colloquies and the circulation of medical knowledge in the sixteenth century", Asclepio, Revista de Historia de la Medicina y de la Ciencia 65, 1 (enero-junio 2013), pp. 1-13.

Cunha, José Gerson da, The origins of Bombay. Bombay, Society’s Library, Town Hall, 1900.

Dias, José S. Silva, A política cultural da época de D. João III. Coimbra, Universidade de Coimbra, 1969, 2 vols.

Ditos portugueses dignos de memória. História íntima do século xvi anotada e comentada por José Hermano Saraiva. Póvoa do Varzim, Publicaçóes Europa-América, 1980.

Domingues, Francisco Contente, Os navios do mar oceano. Teoria e empiria na arquitectura naval portuguesa dos séculos XVi e Xvir. Lisboa, CHUL, 2004.

Dutra, Francis, "The practice of Medicine in Early Modern Portugal. The role and social status of the Fisico-mor and Surgiāo-mor", in Israel Katz (ed.), Libraries, History and Diplomacy and the Performing Arts. New York, Pendragon Press, 1991, pp. 143-145.

Egmond, Florike, The world of Carolus Clusius: Natural History in the making: 1550-1610. Londres, Pickering \& Chatto, 2010.

Ferrâo, José Mendes, A aventura das plantas e os descobrimentos. Lisboa, Chaves Ferreira, 2005.

Ferreira, Francisco Leitão, Notícias cronológicas da Universidade de Coimbra, [...], Primeira edição publicada, revista e anotada por Joaquim de Carvalho. Coimbra, Por ordem da Universidade, 1938-1956, 3 volumes.

Ficalho, Conde de, Garcia de Orta e o seu tempo. Lisboa, Imprensa Nacional, 1886.

Fonseca, José Tello da, História da farmácia Portuguesa através da Legislação. Porto, Empresa Industrial Gráfica do Porto, 1935, 2 volumes.

Fragoso, Juan, Discurso de las cosas aromáticas. Madrid, Francisco Sanchez, 1572.

GÂndavo, Pêro Magalhães, História da Provincia de Santa Cruz. Lisboa, Antonio Gonsalvez, 1576. 
Goodman, David, Power and Penury: Government, technology and science in Philip II's Spain. Cambridge, Cambridge University Press, 1988.

Gschwend, Annemarie Jordan, "Catarina de Áustria: Colecção e Kunstkammer de uma princesa renascentista", Oceanos 16 (1992), pp. 62-70.

Gschwend, Annemarie Jordan, "Marvels of the East. Renaissance curiosity collections in Portugal» in Nuno Vassallo e SiLva (coord.), A herança de Rauluchantim. Lisboa, 1996, pp. 82-127.

Hooykaas, Reijer, "Science in manueline style. The historical context of D. João de Castro's Works", in Armando Cortesáo; Luís de Albuquerque, Obras Completas de D. João de Castro. Coimbra, Academia Internacional da Cultura Portuguesa, 1981, vol. IV, pp. 231-426.

Jordan, Annemarie, A rainha colecionadora. Catarina de Austria. Maia, Círculo de Leitores, 2012.

Jorge, Ricardo, La médecine et les médecins dans l'éxpansion mondiale des Portugais. Lisboa, Tip. Seara Nova, 1935.

Leitão, Henrique, "Um mundo novo e uma nova ciência”, in Henrique Leitão (ed.), $360^{\circ}$ Ciência Descoberta. Lisboa, Fundação Calouste Gulbenkian, 2013, pp. 15-40.

Lemos, Maximiliano História da Medicina em Portugal: doutrinas e instituiçōes. Lisboa, Publicações Dom Quixote/Ordem dos Médicos, 1991, 2 volumes.

López-Piñero, José-Maria, (dir.), Historia de la ciência y de la técnica en la corona de Castilla, Vol. III. Siglos Xvi y Xvir. Salamanca, Junta de Castilla y Léon, Consejeria de Educación y Cultura, 2002.

Loureiro, Rui Manuel, "Garcia de Orta e os Colóquios dos Simples: Observaçôes de um viajante sedentário”, in Anabela Mendes e Gabriela Fragoso (org.), Garcia de Horta e Alexandre von Humboldt. Errâncias, Investigaçôes e Diálogos entre Culturas. Lisboa, Universidade Católica Editora, 2008, pp. 135-145.

Loureiro, Rui Manuel, Animais Orientais: Fauna exótica dos descobrimentos. Lagos, Câmara Municipal de Lagos, 2008.

Matos, Manuel Cadafaz de, "Humanismo e evangelização no Oriente no século xvi", Revista ICALP, no 7-8 (1987), pp. 41-72.

Mundy, Barbara, The mapping of New Spain: indigenous cartography and the maps of the Relaciones Geograficas. Chicago, Chicago University of Chicago Press, 2000.

Orta, Garcia de, Colóquios dos Simples e Drogas da Índia, Edição fac-similada da dirigida e anotada pelo Conde de Ficalho. Lisboa, Imprensa Nacional, 1987 [1891-1895], 2 volumes.

Orta, Garcia de, Colóquios dos Simples, edição fac-similada da edição princeps. Lisboa, Academia das Ciências de Lisboa, 1963, [1563].

Pearson, Michael, "Hindu medical practices in Sixteenth-Century Western India: Evidence from Portuguese sources”, Portuguese Studies 17 (2001), pp. 100-113.

Pelúcia, Alexandra, Martim Afonso de Sousa e a sua Linhagem: Trajectórias de uma elite no Império de D. João III e D. Sebastião. Lisboa, CHAM, 2009.

Pereira, Maria Helena Rocha, "Louvores latinos aos 'Colóquios dos Simples e Drogas". Porto, Centro de Estudos Humanísticos, Faculdade de Medicina do Porto, 1963, pp. 1-11. 
Pina, Luís de, "As ciências na história do Império colonial português (séculos XV-XIX)" Extracto dos tomos dos anos 1937 a 1945 nos Anais da Faculdade de Ciências do Porto. Porto, Imprensa Portuguesa, 1945.

Pina, Luís de, "Garcia de Orta e o Magistério Universitário de Filosofia Natural em Lisboa", O Médico, vol. 636 (1963), pp. 3-26.

Pohl, Hans, Die Portugiesen in Antwerpen: (1567-1648). Wiesbaden, Franz Steiner, 1977.

Portuondo, Maria, Secret Science. Spanish cosmography and the New World. Chicago, The University of Chicago Press, 2009.

Puga, Rogério Manuel, “Os elementos paratextuais dos Colóquios de Garcia de Orta”, in: Anabela Mendes e Gabriela Fragoso (org.), Garcia de Horta e Alexandre von Humboldt. Errâncias, Investigaçôes e Diálogos entre Culturas. Lisboa, Universidade Católica Editora, 2008, pp. 119-134.

Ribeiro, Aquilino, Constantino de Bragança VII Vizo-Rei da Índia. Venda Nova, Bertrand Editora, 1987,

Sánchez-Martínez, Antonio, “Ciencia ibérica y el mundo Atlántico”, Dynamis 31 (2011), pp. 245-269.

SÁnchez-Martínez, Antonio, "La voz de los artesanos en el Renacimiento científico: cosmógrafos y cartógrafos en el preludio de la "nueva filosofía natural”, Arbor, CLXXXVI, 743 (Maio-Junho 2010), pp. 449-460.

SAntos, Catarina Madeira, "Goa é a chave de toda a Índia”, Perfil político da capital do Estado da Índia (1505-1570). Lisboa, CNCDP, 1999.

Schiebinger, Londa; Swan, Claudia, Colonial Botany. Science, Commerce and Politics in Early Modern Europe. Philadelphia, University of Pennsylvania Press, 2007.

Scholdberg, H., Bibliography of Goa and the Portuguese India. New Delhi, 1982.

Silva, Mário Justino, O rei e os nobres: imagens do quotidiano nos ditos portugueses dignos de memória (século xvi). Cascais, Patrimonia, 2004.

VeIga, Tomás Rodrigues da, Commentaria in Galenum, quibus complectitur interpretatio trium librorum Arti Medicae. Antuérpia, Plantin, 1564.

Veiga, Tomás Rodrigues da, Commentarij in libros Claud. Galeni duos De febrium differentiis. Coimbra, I. Barrerium, 1578.

VeIga, Tomás Rodrigues da, Commentariorum in Claudii Galeni Opera, medicorum principis complectens interpretationem Artis Medicae. Antuérpia, Plantin, 1566.

VesÁlio, André, De humani corporis fabrica libri septem. Basileia, ex of. J. Oporini, 1543.

Walter, Jaime, "Dimas Bosque e as sereias", Studia 12 (1963), pp. 260-271.

Walter, Jaime, "Simão Álvares e o seu rol das drogas da Índia”, Studia 10 (1962), pp. 117-149.

Županov, Ines, "Drugs, health, bodies and souls in the Tropics. Medical Experiments in Sixteenth century Portuguese India", The Indian Economic and Social History Review 39, 1 (2002), pp. 1-43. 


\section{As plantas na obra poética de Camões (épica e lírica) ${ }^{1}$}

JORGE PAIVA ${ }^{2}$

\section{RESUMO:}

Na época camoniana, as plantas mais conhecidas e citadas na literatura, não eram tanto as plantas comestíveis ou ornamentais, mas mais as plantas medicinais. Como Os Lusíadas foram escritos, quase na totalidade, no Oriente e centrados nos Descobrimentos, têm como base plantas asiáticas, particularmente especiarias e medicinais; a Lírica como foi, maioritariamente, escrita em Portugal e centrada no amor e paixão, as plantas referidas são europeias e ornamentais. Numa e noutra obra o poeta raramente cita as mesmas plantas, mas quando isso acontece, fá-lo com significados diferentes. Como Camões viveu a sua grande paixão durante os treze anos que esteve em Coimbra (1531-1544), de onde partiu aos vinte anos, a maioria das plantas referidas na Lírica são plantas dos campos do Mondego. O mesmo acontece n'Os Lusíadas nos episódios da "Ilha dos Amores" (Canto IX, 18 - X, 95) e de "Inês de Castro" (Canto III, 118-135).

Num trabalho sucinto, não é possível abranger a vasta obra completa de Luís de Camões. Assim, abordaremos algumas das plantas mais invulgares referidas n'Os Lusíadas e praticamente todas as citadas na Lírica. Aliás, é n'Os Lusíadas que o poeta mais plantas menciona (cerca de cinco dezenas), na maioria asiáticas e aromáticas. Na Lírica refere muito menos espécies de plantas (cerca de três dezenas e meia), maioritariamente, europeias campestres e ornamentais.

\section{PALAVRAS-CHAVE:}

Camões; poesia (Épica e Lírica); plantas.

1 Este trabalho foi desenvolvido no âmbito do projecto de I\&D "Dioscórides e o Humanismo Português: os Comentários de Amato Lusitano" (http://amatolusitano.web.ua.pt) do Centro de Línguas, Literaturas e Culturas da Universidade de Aveiro, financiado por Fundos FEDER através do Programa Operacional Factores de Competitividade - COMPETE e por Fundos Nacionais através da FCT - Fundação para a Ciência e a Tecnologia, no âmbito do projecto FCOMP-01-0124-FEDER-009102.

2 Centro de Ecologia Funcional da Universidade de Coimbra: jaropa@bot.uc.pt. 


\begin{abstract}
:
In Camões' time, the better known plants in literature were not necessarily the edible ones, but were rather the medicinal ones. The spices, being aromatic plants, are all included in the edible or medicinal plants. So, the study of plants referred by Camões must be based on the botanic knowledge of the 16th century, mainly on medicinal plants. Furthermore, as Os Lusíadas were written, almost in their totality, in the East and centered in the Discoveries, they have their basis on the Asian spices; in the lyric work, as it was mainly written in Portugal and centered in love and passion, the plants referred are European and ornamental. On both works the poet rarely refers to the same plant, but when it happens, he does it with different meanings. As Camões lived his great passion during the thirteen years he lived in Coimbra (1531-1544), which he left when he was twenty years old, the majority of plants referred in his lyric poems are plants from the Mondego river fields. The same happens in the "Ilha dos Amores" of Os Lusíadas (Canto IX, $18-95 ; X, 1-143)$.

In a concise work, it is not possible to include the vast work of Luís de Camões. So, we will approach some of the most uncommon plants referred in Os Lusiadas and practically all the lyric ones. Moreover, it is in Os Lusíadas that the poet refers to more plants (about fifty), mainly Asian and aromatic. In the lyric the poet mentions less species of plants (about thirty five), mainly European, from the countryside or ornamental.
\end{abstract}

\title{
KEYWORDS:
}

Camões; poetry (epic and lyric); plants. 


\section{PREÂMBULO}

Como se sabe, Luís Vaz de Camôes teve uma vida muito atribulada e escassamente documentada, pois segundo H. Saraiva "Documentos autênticos sobre a vida de Camôes, documentos originais e indiscutidos, daqueles que ninguém póe em dúvida, sabe-se de sete: o perdão do rei pela cutilada na cabeça de um empregado do Paço em dia do Corpo de Deus de 1552, o privilégio da publicação d'Os Lusíadas e o alvará da tença de 15000 réis durante três anos; os outros quatro são prorrogaçóes do prazo da tença."3

Por haver tão restrita documentação fidedigna sobre a vida de Camóes, actualmente não só se sabe muito pouco sobre factos reais, como também o que se pode elaborar são meras conjecturas conseguidas de interpretaçóes retiradas da sua obra poética (Épica e Lírica).

Era filho de Simão Vaz de Camóes e Ana de Sá e Macedo, mas pouco ou praticamente nada se sabe sobre a mãe. Não se conhece ao certo a localidade e dia do nascimento; apenas se sabe que foi em 1524. Também não se conhece com exactidão a data da morte. Faleceu na capital do país, em 1580, muito provavelmente a 10 de Junho.

Sabe-se que o poeta viveu treze anos em Coimbra (1531 a 1544), portanto dos sete aos vinte anos, onde, inicialmente, esteve ao cuidado do seu tio Bento Camóes, prior do Convento de Santa Cruz e chanceler da Universidade, que o recomendou, em 1535, para aio (escudeiro) de Francisco de Noronha e Violante de Andrade, acabados de casar, ele com trinta anos e ela com treze anos. Em 1540, quando Camóes tinha dezasseis anos e Violante dezoito, Francisco de Noronha vai para França como embaixador, até 1544. Nesse mesmo ano, o casal vai para Lisboa, tal como Camões. Em 1547 vai para Ceuta (desterrado?), regressando a Lisboa cego de um olho. Em 1550 vai para algures no Ribatejo, para um povoado junto às margens do Tejo. Regressa a Lisboa, e em 1552 é preso no dia do Corpo de Deus, indo para a prisão do Tronco. Em 1553 parte para Goa, em cumprimento da pena a que fora condenado, sendo, novamente preso em Goa. Esteve em Macau e sofreu um naufrágio no Estuário do rio Mekong. Em Dezembro de 1567, parte de Goa e, depois de uma estada na Ilha de Moçambique (1568-1570), chega a Cascais a 7 de Abril de 1570. Em 1572 é editada, em Lisboa, a 1. a edição d'Os Lusíadas, tendo sido censor o Padre Bartolomeu Ferreira e Inquisidor-geral o Cardeal D. Henrique. Morre em Lisboa em 1580 (10 de Junho?).

3 Cf. J. H. Saraiva, Vida ignorada de Camões. Mem Martins, Publicações Europa-América, ${ }^{2} 1982$, p. 17 (Estudos, Ensaios e Documentos 141). 


\section{INTRODUÇÃO}

Camóes, conhecia, seguramente, não só obras gregas sobre plantas, particularmente o tratado De materia medica (64 d.C.) de Pedânio Dioscórides (40-90 d.C.), como também os Coloquios dos simples, e drogas he cousas mediçinais da India (1563) de Garcia de Orta, por quem acalentava uma afectuosa amizade e admiração.

Aliás, a biblioteca do Convento de Santa Cruz, onde seu tio Bento Camóes era prior, era muito rica em obras da Antiguidade Clássica, que, muito provavelmente, o poeta consultou. Como Camóes refere muitas plantas europeias citadas por autores gregos e poetas anteriores a ele, alguns autores (ex. Joaquim Vieira Natividade, 1970 e Augusta F. G. Ventura, 1930-1943) admitem que Camóes refere essas plantas com o mesmo significado utilizado por esses poetas. $\mathrm{Na}$ minha opinião, Camões não foi um "plagiador". É natural que tenha utilizado algumas plantas já referidas por outros, particularmente as ornamentais, mas utilizou-as com significado bem diferente. $\mathrm{O}$ facto de Camóes referir muitas plantas nunca citadas por poetas anteriores, particularmente n'Os Lusíadas, onde refere muitas espécies asiáticas, constitui o melhor testemunho que o grande poeta não copiou ninguém.

Apesar de se saber isso, não é fácil determinar com exactidão todas as plantas referidas por Camóes na sua obra poética (Épica e Lírica), pois a maioria das vezes refere-as não só de forma poética, como também utilizando a sua admirável arte de derivar (ele próprio afirma que os seus versos são 'derivaçôes') com extraordinários malabarismos linguísticos.

Num trabalho sucinto não é possível explanar toda a flora da vasta obra poética de Luís de Camóes. Assim, abordaremos algumas das plantas mais invulgares referidas n'Os Lusíadas e as plantas que o poeta utilizou na Lírica, comparando as duas floras (Épica e Lírica) e explicitando as semelhanças e diferenças no significado que o poeta lhes confere n'Os Lusiadas e na poesia lírica. Aliás, é n’Os Lusiadas que o poeta mais plantas menciona (cerca de cinco dezenas), na maioria asiáticas e aromáticas. Na Lírica refere muito menos espécies de plantas (cerca de três dezenas e meia), maioritariamente, europeias campestres e ornamentais, particularmente as flores destas. Na parte final deste trabalho, apresentamos uma lista de nomes científicos das plantas mencionadas na Épica e outra das mencionadas na Lírica.

$\mathrm{Na}$ época camoniana, as plantas mais conhecidas e citadas na literatura não eram tanto as plantas comestíveis, mas mais as plantas medicinais. As especiarias, como todas são plantas aromáticas, estáo incluídas tanto numas como noutras. Por isso, o estudo das plantas citadas por Camóes deve ser feito com base nos conhecimentos botânicos do século XVI, maioritariamente circunscritos às plantas medicinais e campestres.

Comecemos por referir que quando se formou a nossa espécie, praticamente, a totalidade das outras espécies animais que hoje existem já habitavam o Globo Terrestre. Por isso, a espécie humana (Homo sapiens L.) aprendeu muito com a Natureza e com os outros animais. Assim, 
copiamos os outros animais na alimentação e, também, no uso de muitas das plantas medicinais que ainda hoje utilizamos. É disto exemplo, uma planta que em S. Tomé é designada por "aliba-cassô", que quer dizer planta do câo, que é uma erva, Eleusine indica (L.) Gaertn. [na Europa a grama-dente-de-cão é também uma erva da mesma família (Gramíneas), a Cynodon dactylon (L.) Pesrs.], que os cães comem quando têm desarranjos intestinais. Capacitando-se disso, os santomenses, quando têm disenterias tratam-se com infusóes dessa planta. Claro que também aprendemos com os outros animais a utilização das plantas tóxicas, como, por exemplo, a noz-vómica (Strychnos nux-vomica L.), cujas sementes contêm estricnina, sendo, por isso, que os símios não comem o fruto desta espécie de Strychnos, mas sim os frutos das espécies de Strychnos que não têm estricnina. É um fenómeno idêntico ao que acontece com os cogumelos.

A nossa espécie utiliza plantas alimentares e medicinais praticamente desde que apareceu na Terra. Conhecem-se documentos sobre plantas medicinais há mais de cinco mil anos, como são os documentados sistemas médicos chineses e o "ayurvédico" indiano. Antes da fabricação dos medicamentos pela indústria farmacêutica, que não tem mais do que século e meio, as enfermidades eram tratadas directamente com mezinhas das plantas ou dos animais. Foi, por isso, que a 5 de Outubro de 1773, o Marquês de Pombal escreveu ao então Reitor da Universidade de Coimbra (D. Francisco de Lemos), rejeitando o grandioso plano para o Jardim Botânico de Coimbra, que este lhe enviara, dizendo:

\begin{abstract}
Debaixo d'estas regulares medidas deve, V. Ex. ${ }^{a}$ fazer delinear outro plano, reduzido somente ao numero de hervas medicinais que são indispensáveis para os exercícios botânicos, e necessarias para se darem aos estudantes as instruçôes precisas para que não ignorem esta parte da medicina.... ${ }^{4}$
\end{abstract}

O Marquês não queria um Jardim Botânico sumptuoso, ornamental e muito dispendioso, mas um Jardim simples e fundamentalmente com plantas medicinais.

O tratado De materia medica (64 d.C.) de Pedânio Dioscórides (40-90 d.C.), célebre físico (cirurgião) grego, considerado uma das obras mais antigas sobre plantas, onde se descrevem os atributos (cerca de 1000) de cerca de 600 espécies de plantas, foi o guia da medicina ocidental durante mais de 16 séculos, o que implicou um reduzidíssimo progresso da fitoterapia, pois além da versão grega original, houve também traduçóes para várias línguas, algumas com erros graves que se repetiram durante séculos. Muitas publicaçóes (mesmo actuais) sobre plantas medicinais limitaram-se a parafrasear a obra de Dioscórides. Aliás, a maioria dos nomes utilizados por Dioscórides tinha sido utilizada por Hipócrates (ca. 460-370 a.C.) no seu catálogo De herbis com mais de 230 nomes de plantas, mais tarde descritas por Cratevas (120-60 a.C.)

4 Cf. J. Palva, "Jardins Botânicos. Sua origem e importância", Munda 2 (1981), pp. 35-44. 
em Rhizotomikon, assim como por Teofrasto (370-285 a.C.) no livro Xvi da sua Historia plantarum. O manuscrito de Rhizotomikon perdeu-se e, segundo alguns autores 5 , foi a fonte principal do "Herbário" de Séxtio Níger, no qual Plínio e Dioscórides basearam os seus trabalhos.

Portanto, a descrição dos atributos medicinais das plantas europeias e, em parte, asiática, é conhecida, está documentada e registada por escrito há muitos séculos.

Como se referiu, a obra de Dioscórides foi não só traduzida para diversos idiomas, entre os quais o latim, como até aumentada, alterada e iconografada, não correspondendo alguns dos desenhos às descriçóes dioscoridianas. Foi na obra de Dioscórides que não só Garcia de Orta, como também João Rodrigues de Castelo Branco, o Amato Lusitano, basearam os seus conhecimentos fitoterápicos, tendo, no entanto, Garcia de Orta acrescentado os conhecimentos da medicina "ayurvédica" indiana. Aliás, o título da obra de Amato Lusitano (In Dioscoridis Anazarbei De Materia Medica... Enarrationes Eruditissimae) é bem elucidativo de que assim foi.

Estas obras e outras sobre produtos naturais da Ásia, tal como o livro de Duarte Barbosa (1516) ${ }^{6}$ são cruciais para uma determinação, o mais exacta possível, das plantas referidas por Camóes, particularmente n'Os Lusíadas, escrito, quase na totalidade, durante a sua estada no Oriente.

Camóes acalentava uma afectuosa admiração por Garcia de Orta, resultante das relaçóes pessoais que mantiveram na Índia, a tal ponto que conseguiu do vice-rei D. Francisco de Sousa Coutinho, conde do Redondo, patrocínio para a publicação da célebre obra do eminente médico naturalista (Coloquios dos simples, e drogas he cousas mediçinais da Índia, 1563). O poeta conhecia certamente o Horto de Garcia de Orta, como é dedutível pela estrofe da ode ao Conde do Redondo, Viso-Rey da India, o primeiro poema a ver letra de forma, que antecede o texto da 1. ${ }^{\text {e }}$ edição dos Colóquios:

\footnotetext{
Olhai que em vossos annos

Produze hua Orta insigne varias ervas.

Nos campos indianos:

Has quaes, aquellas doutas e protervas

Medea, e Circe nunca conheceram.

Posto que as leis da Magica excederam.
}

5 A. G. MORTON, History of Botanical Science, an account of the development of Botany from ancient times to the present day. London, Academic Press, 1981.

6 Livro de Duarte Barbosa. Lisboa, Academia Real das Sciencias, 1813. 
Como já referimos, as plantas citadas n’Os Lusíadas são maioritariamente asiáticas e especiarias e na Lírica plantas dos campos do Mondego e Tejo. Por essa razáo, para determinados poemas polémicos, por haver (ou ter havido) críticos literários que os consideram camonianos e outros não, as plantas citadas n'Os Lusíadas e na Lírica poderão auxiliar na autoria camoniana ou não. É, por exemplo, o caso do "Vergel de Amor". Nesta poesia, citam-se, por vezes, muitas plantas por estrofe, o que não é característico de Camóes e mencionam-se muitas plantas que não encontramos citadas em toda a obra poética indubitavelmente camoniana, como, por exemplo, as boas-noites (Mirabilis jalapa L.), nativas do Peru e não conhecidas na Europa na época camoniana e o girassol (Helianthus annuus L.), também nativo do Continente Americano; assim como plantas dos montes, como as giestas (Cytisus spp.), e os rosmaninhos (Lavandula spp.).

\section{PLANTAS D'OS LUSÍADAS}

O coco das Maldivas ou coco-do-mar é um bom exemplo de plantas não dioscoridianas tratadas por Garcia de Orta nos seus Colóquios (Colóquio Décimo Sexto) e referida por Luís de Camóes (Canto X), tendo este utilizado a sua, já referida, admirável arte de derivar com extraordinários malabarismos linguísticos, quando menciona este coco na Lírica.

O coco-do-mar não é mais do que o fruto de uma palmeira (coqueiro) endémica (planta nativa apenas de determinado local ou região) da República das Seychelles. Por isso, é também, e mais correctamente, conhecido por coco das Seychelles. Por causa da forma do caroço, é também conhecido por coco-das-nádegas, coco-indecente, coco-gémeo ou coco-duplo e outros nomes, como coco-de-Salomão, coco-real, coco-da-escravatura e muitos outros epítetos vernáculos em idiomas asiáticos. Os frutos das palmeiras são cocos (drupas, como são os pêssegos, as ameixas, as cerejas, etc.) com uma camada fibrosa (geralmente oleosa) que envolve um caroço, no qual está a semente (amêndoa). Antes da descoberta do caminho marítimo para a Índia (1497-98), este coco não era conhecido na Europa, mas era já famoso na Ásia, onde conheciam apenas o caroço, que consideravam, erroneamente, como uma semente, sem nunca terem visto a palmeira que o produzia (assim o diz Garcia de Orta no referido colóquio "que nunqua pessoa alguma vio a arvore que dá estes coquos, senão o que o mar deita de si;”). É o maior $(30-50$ x 25-28 cm) e mais pesado $(15-20 \mathrm{~kg}$ ) caroço (portanto, também a maior e mais pesada semente) do Globo Terrestre. Por ser uma semente tão pesada, nem o respectivo coco, nem o caroço, flutuam facilmente, não sendo, portanto, transportados, com viabilidade, pelas correntes marítimas, como acontece com o fruto do coqueiro (Cocos nucifera L.). No entanto, como a parede do caroço é muito dura e dificilmente permeável, o caroço, depois de seco ou 
da perda da massa interna (embrião e albúmen, portanto a semente propriamente dita) fica muito mais leve e já é flutuante e transportável pelas correntes marítimas. Era assim, sem poder germinativo, que chegava às ilhas Maldivas (assim diz Ruano nos Colóquios "que dizem das Maldivas") e às costas da Índia, Indonésia e respectivas ilhas, onde os primeiros europeus deram conta da fama deste invulgar caroço, devido à sugestiva forma que apresenta (lembra formas anatómicas femininas).

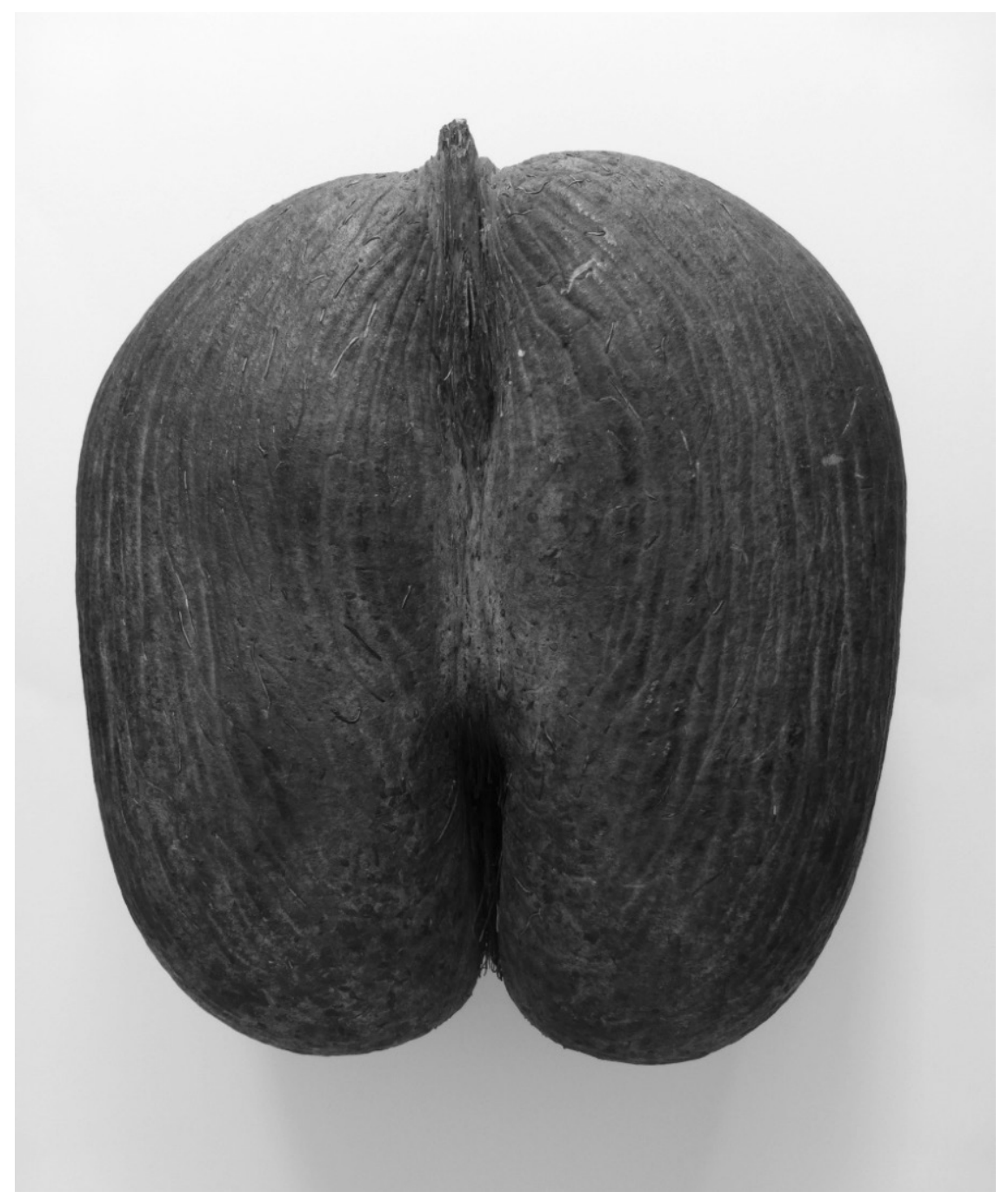

Figura 1 - Coco das Maldivas [Lodoicea maldivica (J. F. Gmel.) Pers.]. Museu da Ciência (Universidade de Coimbra) 
Por isso este caroço era, erroneamente, conhecido como coco das Maldivas, a tal ponto que o botânico que primeiro nomeou cientificamente a palmeira (Johann Friedrich Gmelin), em 1796, designou-a por Cocos maldivica, baseando-se apenas no caroço, pois não conhecia a planta. Quando se soube que afinal a palmeira não era nativa das Maldivas, mas das Seychelles, Jacques Julien Houtton de la Billardière, em 1801 (comunicação oral na Academia das Ciências Francesa, em Paris, mas só publicada validamente em 1807) ${ }^{7}$, designou-a por Lodoicea sechellarum. Porém, a primeira descrição científica da planta, feita por Pierre Sonnerat, é anterior (lida numa sessão da Academia das Ciências de França em 1773 e publicada em 1776) ${ }^{8}$ à de Billardière (1807), mas Sonnerat não lhe concedeu nenhum nome em latim. O género Lodoicea foi criado por Philbert Commerson (de Lodoicus, forma latinizada de Louis em homenagem ao rei Luís xv de França, pois as Seychelles eram, na época, uma colónia francesa) e descrito por Augustin Pyramus de Candolle em 1800. Neste género, mono-específico (só tem uma espécie), a planta teve várias designaçôes (L. callipyge Comm. ex J. St.-Hil.; L. humilis Pharm. ex Wehmer; L. maldavica Pers. ex H. Wendl.; L. seychellarum Labill. e L. sonnerati Baill.), mas o nome válido, segundo as Regras Internacionais de Nomenclatura Botânica, é Lodoicea maldivica (J. F. Gmel.) Pers.

Como os povos asiáticos nunca tinham visto a palmeira produtora de um coco tão grande e tão invulgar, consideravam (mais tarde, os navegadores europeus também) que era produzido por um coqueiro que vegetava nas profundezas do mar. Por outro lado, como o caroço tem uma forma bilobada ("que vem pegados dous em hum”, segundo Garcia de Orta nos Colóquios) que se assemelha às ancas e zona púbica da mulher, foi, por isso, considerado afrodisíaco e, como era muitíssimo raro e extremamente apreciado, era excessivamente dispendioso. Aliás, ainda hoje é caro e não é fácil adquiri-lo. Assim, nas ilhas Maldivas, arquipélago onde vinham, por vezes, caroços dar à costa, o direito de propriedade de todos os cocos-do-mar que apareciam nas praias destas ilhas, era pertença dos soberanos das mesmas, e qualquer pessoa que não entregasse algum desses achados era condenada à morte ou era-lhe sentenciada a ablação das mãos. Desta maneira, os primeiros exploradores europeus ao trazerem para a Europa este valioso caroço (geralmente considerado semente) enalteceram-lhe não só extraordinárias qualidades afrodisíacas, como também atributos místicos e medicinais (como o diz Ruano mais adiante "Dixeramme que a rainha, nossa senhora, mandava todo los anos por este coquo, e lho levam de cá; e por tanto não me negueis ser pêra a peçonha bom;"). Foi, por toda essa reputação que o coco tinha, que Rudolfo II dos Habsburgos (Imperador do Santo Império Romano), ofereceu, em vão, 4000 florins de ouro (uma fortuna para a época) por um coco desses, que

7 "Sur le Cocotier de Mer des Maldives", Annales du Muséum National d'Histoire Naturelle 9 (1807), pp. 140-145.

8 Voyage a la Nouvelle Guinée. Paris, Ruault, 1776. 
pertencia ao almirante holandês Wolfert Hermanssen, que o tinha recebido como presente do Sultão de Bantam (regiáo da ilha de Java), por ter defendido a capital do sultanato de um ataque da Armada Portuguesa, sob o comando de André Fortunato de Mendonça, em 16029. É por isso que há, actualmente, em museus europeus alguns destes caroços ocos, cobertos a ouro ou prata e ornamentados exteriormente com figuras decorativas, que serviam, geralmente, de vasilhas ou copos.

A primeira referência feita por um europeu a este coco e respectiva palmeira, aliás extraordinariamente fantasiosa, é de António Pigafetta, em 1519-22, quando relatou a passagem da frota de Fernão de Magalhães pelos mares da China e Sião, na sua viagem de circum-navegação. Aliás, a mais absurda, fantasiosa e romântica publicação sobre esta planta e respectivos atributos, foi feita pelo general inglês Charles Gordon, que visitou as Seychelles em 1881 e considerou que o Vallée de Mai (actualmente Parque Nacional na ilha Praslin, sendo a área onde vegeta naturalmente a maior quantidade de palmeiras do coco-do-mar) era o Jardim de Éden, onde vegetava a "Árvore da Ciência, do Bem e do Mal" (Lodoicea maldivica) e a "Árvore da vida" [a árvore-do-pão, Artocarpus insignis (Parkinson ex F.A. Zorn) Fosberg]. A fantasia foi tal que este general até se esqueceu que a árvore-do-pão foi introduzida nas Seychelles, pois é nativa da Malásia. Depois do italiano Pigafetta, os portugueses foram, naturalmente, outros europeus a referirem o coco-do-mar, como João de Barros, em 1553, que, como era habitual na época, considerou que o "pomo maior do que o coco" vinha de uma árvore que "nascia em algumas partes debaixo da água salgada”.

Outros europeus se seguiram nas referências a este legendário coco, como o holandês Jan Huygen van Linschoten que refere, em 1610, que o rei das Maldivas oferecia de presente este coco a soberanos locais e estrangeiros pelas suas propriedades contra peçonhas; o "fisico" holandês Antgers Cluyt (Augerius Clutius) publicou em Amesterdão (1634) a primeira monografia sobre o coco-do-mar, em que refere uma dúzia de doenças e outras enfermidades para as quais o coco era um bom remédio; o comerciante francês Pyrard de Laval que, por naufrágio em 1602, viveu vários anos numa das ilhas Maldivas, refere, mais uma vez, que este coco, que os nativos consideravam um tesouro pelas suas propriedades medicinais, era produzido por algumas árvores submarinas. Finalmente, o botânico Georg Eberhard Rumphius publicou um exaustivo estudo sobre o coco-do-mar, em 1750, em que descreve um conjunto de lendas sobre este coco e refere que os marinheiros chineses, malaios e indonésios acreditavam que as folhas do coqueiro-do-mar apareciam, por vezes, sobre o mar. Refere também que os soberanos das regióes onde o referido coco aparecia no litoral marítimo, não permitiam que se partissem os caroços, pois serravam-nos para fazerem caixas ou vasilhas e respectivas tampas para guardarem os ingredientes de mascar,

9 A.-A. Fauvel, "Le Cocotier de mer des lles Seychelles (Lodoicea Sechellarum)", Annales du Musée Colonial de Marseille, Sér. 3, 1 (1915), pp. 169-307. 
porque acreditavam que estes produtos, assim como a água potável, quando armazenados nestas caixas (vasilhas), adquiriam virtudes medicinais ou curativas para uma grande quantidade de enfermidades. Rumphius foi o primeiro botânico a admitir que a palmeira produtora de tais cocos crescia no Oceano Índico Ocidental.

Foi só em 1768, cerca de 26 anos depois de os franceses terem aportado às Seychelles [159 anos depois de os ingleses as terem descoberto (já eram conhecidas dos árabes, pelo menos, desde o ano 916)] que Brayer du Barré, um engenheiro francês integrado na expedição comandada por Nicholas Marion Dufresne (com a nau La Diguffe e a escuna La Curieuse), que foi da ilha Maurícia para as Seychelles, reconheceu a palmeira do coco-do-mar na ilha Praslin (ilha de Palma, na época). Atónito, não querendo acreditar no que os seus olhos viam, colheu cerca de uma trintena de cocos que levou para o botânico francês Pierre Poivre que se encontrava na ilha Maurícia (na época ilha de França) mais a Sul. Este pediu ao abade Alexis Rochon que trouxesse das Seychelles jovens coqueiros do coco-do-mar para a ilha Maurícia. A partir daqui, por iniciativa do Capitão Duchemin, que tinha participado na expedição de Marion Dufresne às Seychelles e que estava ao corrente da descoberta de Barré, deslocou-se à ilha de Praslin na nau L'Heureuse Marie, carregando-a de cocos que comercializou no mercado asiático, tendo, assim, descido, drasticamente e de modo definitivo, o valor económico deste fabuloso coco.

Apesar disso, esta palmeira e o respectivo coco não perderam a reputação, não só de virtudes afrodisíacas (além do caroço cluniforme, a forma da inflorescência masculina também se assemelha ao phallus humano e a fase inicial da germinação do caroço é cópulo-sugestiva), como também medicinais e místicas.

Assim, a colheita dos cocos foi tão intensiva que a planta, actualmente, apenas cresce, como espontânea, nas encostas e vales do interior de duas das 19 ilhas do Arquipélago das Seychelles [na ilha Praslin (Parque Nacional de Vallée de Mai, com cerca de 5000 exemplares, pois 59\% das árvores do Parque são Lodoicea maldivica) e na vizinha e pequena ilha Curieuse (primeiramente ilha Rouge)]. Além destes locais onde é nativa e espontânea, está cultivada em Jardins Botânicos, particularmente tropicais, onde a vimos nalguns, como no Jardin du Roi e Botanical Gardens em Victoria (capital da República das Seychelles na ilha Mahé), Pamplemousses Botanical Gardens (ilha Maurícia), Peradeniya Botanical Gardens em Kandy (Sri Lanka), Bogor Botanical Garden em Bogor (Indonésia), Singapore Botanical Gardens (Singapura), Darwin Botanic Gardens em Darwin (Austrália) e, em estufa aquecida (Palm House) dos Royal Botanic Gardens em Kew (Inglaterra).

Actualmente, nas Seychelles, a colheita e comercialização destes cocos é estritamente controlada pelo Estado, sendo uma importante fonte de receita local a venda aos turistas de peças de artesanato fabricadas com folhas, troncos e cocos desta palmeira. Porém, a população nativa não usufrui apenas da comercialização e da fama afrodisíaca e virtudes medicinais e místicas deste coco, pois o grande limbo flabeliforme das folhas é utilizado para cobertura das habitaçóes, 
para fabrico de esteiras, leques, cestos, caixas, estojos, chapéus, ramos de noiva e outros artigos de artesanato; a madeira e pecíolos foliares para tabiques, paliçadas e bebedouros para o gado; os caroços para pratos, vasilhas, copos, caixas, artigos de adorno e produção de marfim vegetal; os pêlos da parte inferior dos pecíolos das folhas jovens para encher almofadas e travesseiros. Dos cerca de 3000 destes cocos que são colhidos anualmente nas Seychelles (colheita controlada pelo Estado), apenas um pequeno número é consumido verde. Normalmente congelam a amêndoa (semente), para depois a servirem aos turistas como guloseima e, até, para produzirem uma bebida alcoólica (17\%), licorosa, que, como não podia deixar de ser, tem a designação de licor de coco d'amour e as garrafas têm a forma sugestiva do caroço.

Garcia de Orta, nos seus Colóquios, refere que o coco das Maldivas provinha de palmeiras que haviam sido submergidas quando as ilhas Maldivas se separaram do Continente Asiático por uma grande inundação e que a amêndoa deste coco era um excelente remédio. É importante referir que Garcia de Orta o cita como "um excelente remédio" e nunca faz qualquer alusão às apregoadas propriedades afrodisíacas deste coco. É fundamental não esquecer que nessa altura não só a Inquisição era poderosa, como também Garcia de Orta tinha que ter extremo cuidado, pois, sendo cristão-novo, era alvo de perseguição do Santo Ofício pela sua origem judaica.

Talvez pelo misticismo que conferiam a este coco, a palmeira "marinha" é uma das plantas que Luís de Camôes refere n'Os Lusíadas (Canto X, 136) ${ }^{10}$, também, cuidadosamente, sem qualquer alusão às célebres propriedades afrodisíacas do coco, pelas razóes que já referimos (Inquisição e Corte). É também importante referir que não só toda a obra de Camóes foi escrita entre 1540 e 1580, período de violentas perseguições aos Judeus; como também alguns autores modernos ${ }^{11}$ admitem uma origem bastarda e judaica de Camóes.

\footnotetext{
Nas Ilhas de Maldiva nace a pranta

No profundo das agoas soberana

Cujo pomo contra o veneno urgente

He tido por Antidoto excelente.
}

Camões também o refere na Lírica, obra centrada no amor e paixão, e aí utiliza eficazmente os seus, já referidos, malabarismos lexicológicos, para não ter qualquer consequência desagradável por parte dos censores e do Inquisidor-geral (Cardeal D. Henrique). É uma das poucas plantas asiáticas que Camões refere tanto na Épica, como na Lírica.

10 As citações dos versos camonianos feitas ao longo deste trabalho foram feitas a partir do texto fixado por Hernâni Cidade nas obras completas de Luís de Camões (I- Os Lusíadas; II-Rimas; III- Lírica).

11 Cf. J. H. Saraiva, Vida ignorada de Camões, op. cit. 
Assim, no soneto que, segundo J. H. Saraiva, é dedicado à recuperaçáo do valimento de D. António Pinheiro, bispo de Miranda, que fora obrigado, pelo Rei, a renunciar à diocese de Ceuta, tendo readquirido todo o valimento durante o reinado do cardeal D. Henrique, Camóes, na nossa opinião, utiliza aqui, de modo extraordinário, os seus malabarismos para exaltar a fama afrodisíaca deste coco:

Depois que viu Cibele o corpo humano

Do formoso Átis, seu verde pinheiro,

Em piedade o vão furor primeiro

Convertido, chorou seu grave dano.

E, fazendo a sua dor ilustre engano,

A Júpiter pediu que o verdadeiro

Preço da nobre palma e do loureiro

Ao seu pinheiro desse, soberano.

Mais lhe concede o filho poderoso

Que as estrelas, subindo, tocar possa,

Vendo os segredos lá do céu superno.

Oh! ditoso pinheiro! Oh! mais ditoso

Quem se vir coroar da folha vossa,

Cantando à vossa sombra verso eterno.

Ao ler-se com atenção repara-se que Camões refere as ditas propriedades afrodisíacas do coco. O "pinheiro" do formoso Átis estava com "grave dano". Aqui Camóes está a indicar que o órgão sexual de Átis fora "convertido" (deixara de ser "fálico", isto é, viril). Então, Cibele pediu a Júpiter que "o verdadeiro preço da nobre palma e do loureiro ao seu pinheiro desse, soberano". Isto é, que conferisse virilidade ao dito órgão de Átis. No que foi atendida Cibele, como se pode deduzir das últimas estrofes deste soneto "Oh! Ditoso pinheiro! Oh! Mais ditoso quem se vir coroar da folha vossa, cantando à vossa sombra verso eterno".

O mesmo se pode dizer na Redondilha "Carta a uma dama":

Da palma se escreve e canta

Ser tão dura e tão forçosa,

Que pena não a quebranta,

Mas antes, de presunçosa,

Com ele mais se levanta.

Co'o peso do mal que dais,

A constância que em mim vejo 
Não somente ma dobrais,

Mas dobra-se meu desejo,

Com que entáo vos quero mais.

Salientamos as palavras mais elucidativas do malabarismo camoniano: "Da palma se escreve e canta ser tão dura e tão forçosa que pena não a quebranta, mas antes, de presunçosa". $\mathrm{Na}$ nossa opinião, aqui refere os atributos afrodisíacos do coco. Depois "Com ele mais se levanta". Este "ele" é o órgáo sexual masculino. E depois "Co'o peso do mal que dais"... "Não somente ma dobrais". O que é que se dobra sem poder erectivo devido ao desgosto amoroso?

Aliás, já Cidália Alves dos Santos ${ }^{12}$ refere estas subtilezas do poeta na habilidosa evocação erótica da exibição e ocultamento do corpo da deusa Diana, utilizando plantas em metáforas com sentido erótico (hera) e ao referir o foco do desejo sexual, os lábios vulvares, como sendo "os roxos lírios" (Canto II, 36, 37):

Os crespos fios de ouro se esparziam

Pelo colo, que a neve escurecia;

Andando, as lácteas tetas lhe tremiam,

Com quem Amor brincava e não se via;

Da alva petrina flamas lhe saíam,

Onde o Menino as almas acendia;

Pelas lisas colunas lhe trepavam

Desejos, que como hera se enrolavam.

C'um delgado cendal as partes cobre,

De quem vergonha é natural reparo,

Porém nem tudo esconde nem descobre,

O véu, dos roxos lírios pouco avaro;

Mas, para que o desejo acenda e dobre,

Lhe põe diante aquele objeto raro.

Já se sentem no céu, por toda a parte,

Ciúmes em Vulcano, amor em Marte.

12 "Camões y Góngora; una lectura del erotismo en Los Lusíadas y en la Fábula de Polifemo y Galatea", Castilla. Estudios de Literatura 28-29 (2003-2004), pp. 23-46. 
Camóes, n’Os Lusiadas, refere ainda outras palmeiras. Uma no Canto I, 45, 46:

Eis aparecem logo em companhia

Uns pequenos batéis, que vêm daquela

Que mais chegada à terra parecia,

Cortando o largo mar com larga vela.

A gente se alvoroça, e de alegria,

Não sabe mais que olhar a causa dela.

-"Que gente será esta?” (em si diziam)

"Que costumes, que leis, que rei teriam?"

"As embarcações eram na maneira

Mui velozes, estreitas e compridas;

As velas com que vêm eram de esteira,

Dũas folhas de palma bem tecidas;

A gente da cor era verdadeira

Que Fáeton, nas terras acendidas,

Ao mundo deu, de ousado e náo prudente

(O Pado o sabe, e Lampetusa o sente).

Estas esteiras de folha de palma deviam ser feitas, muito provavelmente, das folhas flabeliformes de Borassus aethiopum Mart., uma palmeira relativamente comum nas baixas planícies do litoral central de Moçambique. Actualmente, as velas dessas embarcaçóes (pequenos batéis, os sambucos, de influência indo-árabe, de 2 velas e semelhantes às nossas caravelas) são feitas de "estopa" de sacos de farinha ou de pano. $\mathrm{Na}$ área de Matibane (cerca da ilha de Moçambique) são feitas das folhas flabeliformes de outras espécies de palmeiras pertencentes ao género Hyphaene, também comuns nessas regióes. Francisco Manuel de Mello (Conde de Ficalho, $1890)^{13}$ sugere que a palma usada para as velas pudesse também ser das folhas flabeliformes de Borassus flabellifer L., uma palmeira da Índia, utilizada para esse fim no litoral indiano. $\mathrm{Na}$ realidade, sabe-se que ainda há cerca de um século, os indianos, aproveitando os ventos das monções, iam em barcos à vela, aos mangais do litoral tanzaniano e moçambicano colher madeira para fabrico de habitações. Desta maneira, poderiam ter fornecido, por permuta, esteiras da palmeira indiana aos pescadores moçambicanos. É uma hipótese, mas pouco plausível. $\mathrm{Na}$ nossa opiniấo, os africanos copiaram as velas indianas, utilizando as palmeiras nativas de folhas flabeliformes (Borassus aethiopum Mart.) como as da palmeira indiana (Borassus flabellifer L.).

13 Conde de Ficalmo, Flora dos Lusiadas. Lisboa, Academia Real das Sciencias, 1880. 
Outra palmeira citada por Camóes (Canto VIII, 24 e Canto X, 42) é a tamareira (Phoenix dactylifera L.), já referida pelos "físicos" gregos, nos textos bíblicos, corânicos e por Garcia de Orta (Colóquio Quinquagesimo Terceiro), pela sua importância alimentar e religiosa:

\author{
A Dom Mateus, o Bispo de Lisboa, \\ Que a coroa de palma ali coroa. (VIII, 24) \\ "Que gloriosas palmas tecer vejo, \\ Com que Vitória a fronte lhe coroa, \\ Quando, sem sombra vã de medo ou pejo, \\ Toma a ilha ilustradíssima de Goa, (X, 42)
}

Como não podia deixar de ser, Camões refere também o aloé (Canto X, 137). Mas cita o aloé da ilha Socotra (Iémen) e não o Aloe vera (L.) Burm. f., o mais conhecido e citado aloé, desde a Antiguidade Grega e Tempos Bíblicos.

Verás defronte estar do Roxo Estreito

Socotorá, co’o amaro aloés famosa;

Este aloé de Socotra, já é referido por Aristóteles, que pretendeu que o Imperador Alexandre conquistasse esta ilha, por saber que ali havia muito aloé, de que necessitava para tratar as feridas dos soldados, pois é um bom cicatrizante. Na realidade, o Imperador, ao regressar da Índia, desterrou os habitantes da ilha de Socotra, fundando ali uma colónia grega para cultivarem os aloés.

Esta planta tem sido erradamente identificada como Aloe socotrina Lam. (ex Ficalho, 1890), aliás, um nome latino inexistente, por suporem tratar-se do Aloe succotrina Lam., que não é nativo de Socotra.

Mas, além de se confundir Aloe vera (L.) Burm.f. com os aloés da ilha de Socotra (Aloe perryi Bak. e Aloe forbesii Bak. f.), comercialmente utilizados para extrair a socotrina (tâyef, na ilha; saber ou sabr ou sabbara em árabe), também se tem confundido com Aloe succotrina Lam., nativo da província do Cabo da África do Sul, não só por se julgar que o restritivo específico é referente a Socotra, como também porque Philip Miller, em 1758, lhe chamou Aloe vera Mill. (non L.). O epíteto succotrina nada tem a ver com a ilha de Socotra; o termo deriva de sucocitrina, produto químico do suco das folhas deste aloé originário da África do Sul.

Desde que o frade franciscano Romano Zago, um brasileiro de São Francisco de Assis (Rio Grande do Sul, Brasil), na altura professor de Filosofia e de Latim no Convento de San Salvatore, em Jerusalém, deu a sua primeira grande entrevista à revista argentina "Florecillas de Tierra Santa”, por ter curado a leucemia de Geraldito, uma criança argentina, o cancro de Linda, irmã de 
uma amiga da freira Silvana, da Comunidade de Aida (Israel) e o cancro de Frei Rafael Caputo, director de uma Escola eclesiástica na Terra Santa, há cerca de uma dúzia de anos que se criou a panaceia do Aloe vera. Seguiram-se muitas mais entrevistas, conferências e curas milagrosas, tendo até o frade Romano Zago vindo a Portugal onde proferiu conferências no Porto, Coimbra, Odivelas e Lisboa, tendo sido entrevistado pelas emissoras de Rádio e Televisão.

A panaceia foi tal que em 1995-1996, quase desapareceram os aloés, que até não são Aloe vera (L.) Burm.f., mas, geralmente, Aloe arborescens Mill., dos jardins públicos de Portugal, pois as pessoas, tomadas de uma loucura colectiva, utilizavam o suco das folhas de qualquer aloé, na tentativa de tratarem qualquer tipo de doença e, até, apenas como uma espécie de vacina, mesmo sem estarem doentes. Formavam-se filas à porta do Convento dos Franciscanos em Lisboa, para compra do remédio milagroso. Não sei se esta romaria já parou, passados que são mais de uma dúzia de anos de muitas desilusões. Publicaram-se muitos artigos, plenos de erros, particularmente na identificação das espécies de Aloe, até recentemente, em revistas de divulgação e em livros sobre plantas medicinais, sendo alguns desses textos de autoria de pessoas com grandes responsabilidades, por efectuarem investigação científica com plantas medicinais.

Nessa altura alertei para o logro em que as pessoas tinham caído, através de entrevistas e vários artigos de divulgação e na televisão, mas sem grandes resultados. Indivíduos sem escrúpulos continuam a vender gato por lebre, comercializando outras espécies de aloés como sendo Aloe vera (L.) Burm.f., que é muito pouco cultivado nos jardins de Portugal. Apenas tenho conhecimento de exploraçôes agrícolas extensivas de Aloe vera (L.) Burm.f. em Portugal, no Algarve (concelhos de Portimão e de Vila do Bispo).

Como os aloés têm folhas suculentas (crassas), erroneamente, com muita frequência, designam-nos por cactos, um lapso "crasso". Os verdadeiros cactos, são, na realidade, plantas crassas (suculentas), geralmente afilas (sem folhas) e com espinhos, que constituem a família das Cactáceas, com cerca de 2000 espécies nativas das estepes americanas (América do Norte, Central e do Sul; apenas um género fora da América), tendo sido introduzidos, por cultivo, noutras regióes do Globo, onde algumas espécies se naturalizaram e adaptaram tão bem que se tornaram invasoras, como aconteceu, por exemplo, com a figueira-da-índia [Opuntia ficus -indica (L.) Mill.], uma cactácea originária do México e não da Índia, como erroneamente o epíteto específico leva a crer.

Há cerca de 350 espécies de aloés, das quais quase metade (140) é nativa de África, sendo as restantes de Madagascar, Socotra, Região Mediterrânica, Arábia, Índia e China.

O verdadeiro Aloe vera (L.) Burm.f. é nativo do Nordeste de África e, muito provavelmente, também da Arábia. É utilizado como medicinal há milhares de anos, havendo testemunhos disso desde 1500 anos a. C., no Egipto ("Papyrus Ebers", Universidade de Leipzig), referindo alguns autores que o encanto e beleza de Cleópatra se devia ao uso do "gel" de aloé. 
O Aloe vera foi muito apreciado, como planta medicinal, pelos "físicos" gregos, como refere Hipócrates (ca. 460-370 a. C.) no seu De herbis, Teofrasto (370-285 a. C.) em Historia plantarum e descrito por Dioscórides em De materia medica. O Aloe vera (L.) Burm.f., actualmente, está naturalizado na Região Mediterrânica, Macaronésia (Madeira, Açores, Canárias e Cabo Verde), América Central e do Sul.

Sendo utilizado desde antes de Cristo, não admira que o Aloe vera (L.) Burm.f. seja referido nos textos bíblicos. Mas, nem todas as referências a aloés nas diversas ediçôes da Bíblia são verdadeiros aloés. Os aloés citados no Antigo Testamento (Salmos 45:9; Provérbios 7:17; Cântico dos Cânticos 4:14) são plantas que não pertencem ao género Aloe. Aí são referidas como plantas aromáticas, conjuntamente com a mirra [Commiphora myrrha (Nees) Engl.], a caneleira do Ceilão (Cinnamomum vera Nees) e a caneleira da China [Cinnamomum cassia (L.) J.Presl], que até são referidas como árvores (Cântico dos Cânticos 4:14) e o Aloe vera é uma erva não aromática. Esse aloé citado no Antigo Testamento é uma árvore muito aromática, a Aquilaria malaccensis Lam. (ahaloth, em Hebraico), a que os gregos chamam xylaloe e a que Garcia de Orta dedica um Colóquio (Trigesimo; Do linaloes) e também chama agalugem e que, portanto, Camões também refere n'Os Lusiadas (Canto X, 129).

\footnotetext{
"Vês: corre a costa que Champá se chama,

Cuja mata é do pau cheiroso ornada;
}

Por isso, quando traduziram os textos em hebraico do Antigo Testamento para grego, à ahaloth chamaram (muito bem) xylaloe. Ao traduzirem a Bíblia do grego para latim, traduziram (erroneamente) xylaloe para aloe. Aloe vera é uma erva, não aromática, com propriedades cicatrizantes, e é o aloé referido no Novo Testamento (João 19:39). Aqui, refere-se que envolveram o corpo de Jesus com ligaduras e uma mistura de mirra [Commiphora myrrha (Nees) Engl.] e aloés [cerca de 100 libras (45-50 kg), levadas por Nicodemos], para o sepultarem, como era costume entre os judeus. Estes aloés são o Aloe vera (L.) Burm.f. ou, pouco provavelmente, Aloe perryi Bak. e Aloe forbesii Bak. f., nativos da ilha de Socotra e muito confundidos com o Aloe vera. Actualmente, ainda persiste esse hábito de envolverem (embalsamarem) os mortos com aloés e outras plantas (particularmente aromáticas, pois muitas delas são anti-sépticas), não só em Israel, como também entre os árabes.

Após os descobrimentos, o Aloe vera foi introduzido no Novo Mundo, provavelmente pelos espanhóis, a partir de plantas levadas das Canárias. Naturalizou-se rapidamente nas Índias Ocidentais (Barbados, Jamaica, Antígua, Porto Rico), na América Central (México, Nicarágua) e na América do Sul (Peru, Bolívia, Venezuela). Por isso, Philip Miller (1768) designou por Aloe barbadensis Mill., uma planta supostamente nativa da ilha dos Barbados, que não é mais do que o Aloe vera (L.) Burm.f. 
Infelizmente, essa confusão persiste ainda hoje, com a agravante de andarem a chamar Aloe barbadensis Mill. a um Aloe que não é o verdadeiro Aloe barbadensis Mill., isto é, que não é Aloe vera (L.) Burm.f. O pior é que essas confusôes até aparecem em livros sobre plantas medicinais de autores com grandes responsabilidades, por fazerem investigação cientifica na área química das plantas medicinais. Não admira, pois, que nesses livros se apresentem produtos químicos diferentes para o Aloe barbadensis Mill e para o Aloe vera (L.) Burm.f., pois Aloe barbadensis Mill. que referem não é o autêntico e, portanto, não é o Aloe vera (L.) Burm.f. ${ }^{14}$

$\mathrm{Na}$ África do Sul, começou, há já alguns anos, a utilizar-se como fonte comercial de produtos dos aloés, uma planta muito comum nos jardins desse país, o Aloe arborescens Mill. Inicialmente extraiam os produtos químicos do Aloe vera (L.) Burm.f., mas como o Aloe arborescens Mill. é não só largamente cultivado como ornamental, como também é nativo e bastante comum na Natureza daquele país, passaram a utilizar, para a obtenção do suco de aloé, este último em vez do Aloe vera (L.) Burm.f., que ali tinham que cultivar. Porém, não só a composição química do suco dos dois aloés é diferente, como também, como é evidente, as qualidades terapêuticas das duas espécies sejam igualmente diversas.

Aloe arborescens Mill. é nativo do sudoeste e sul de África (Zimbabwe, Malawy, Moçambique e África do Sul) e é muito utilizado como ornamental nas regiões temperadas do Globo, estando, actualmente, naturalizado em muitas regióes fora da respectiva área nativa, como no sudoeste da Região Mediterrânica (Sul de França, Espanha e Portugal).

Em Portugal (e não só), infelizmente, muita gente e herbanários sem escrúpulos, utilizam o Aloe arborescens Mill., como fonte do suco de aloé, para o comercializarem como se fosse o suco do verdadeiro Aloe vera (L.) Burm.f.

Gilbert Reynolds (1895-1967) foi o mais eminente especialista do género Aloe, tendo publicado duas excelentes monografias $\left(1950\right.$ e 1966) ${ }^{15}$, profusamente ilustradas com fotografias e desenhos a cores, pois ele observou vivas a maioria das espécies, muitas delas cultivadas nos jardins das suas residências na África do Sul e na Suazilândia. Este autor e Robert Compton (1886-1979), que foi director do Jardim Botânico de Kirstenbosch (África do Sul), durante a década de 70 do século passado, alertaram para o facto de se estar a comercializar gato por lebre, elucidando que o suco das folhas das duas espécies tinha composição química diferente e, portanto, propriedades medicinais também distintas. O suco das folhas dos aloés é um bom cicatrizante, virtude que nós próprios já constatamos e que é conhecida há muitos séculos, tanto que, na Antiga Grécia, Aristóteles utilizou as folhas de Aloe vera (L.) Burm.f. para tratamento dos ferimentos dos soldados gregos. Porém, enquanto o suco das folhas do Aloe arborescens Mill.

14 A. Proença da Cunha, A. P. da Silva, O. R. Roque, Plantas e produtos vegetais em fitoterapia. Lisboa, Fundação Calouste Gulbenkian, 2003.

15 G. W. ReYnolds, The Aloes of South Africa. Johannesburg, Aloes of South Africa Book Fund, 1950; Idem, The Aloes of Tropical Africa and Madagascar. Mbabane, The Trustees. The Aloes Book Fund, 1966. 
é eficaz no tratamento de queimaduras (até as devidas a Raios X), o do Aloe vera (L.) Burm.f. não o é. Como na literatura fitoterápica se têm confundido várias espécies de Aloe, têm sido atribuídas ao Aloe vera virtudes que não possui.

Encontram-se referências ao uso do Aloe vera no tratamento de cancros, mas, pessoalmente, não conheço nenhum trabalho científico demonstrativo de tal atributo desta planta. Por outro lado, também não conheço nenhum caso de cura de cancro de doentes que se trataram exclusivamente com o suco "milagroso", parando com todos os outros tratamentos que seguiam por indicação médica, como a quimioterapia e a radioterapia. Antes pelo contrário, conheci pessoas cancerosas, tanto em Portugal, como no estrangeiro, que se trataram com Aloe vera e morreram de cancro.

$\mathrm{Na}$ referida literatura encontram-se mencionadas muitas outras virtudes dos aloés, além das que acabamos de referir, tais como colagogas, emenagogas, vermífugas, repelentes de insectos, estimulantes, laxativas, no tratamento da meningite, conjuntivite crónica, blefarite, obstipação, ictiose, várias outras doenças cutâneas, úlceras e até, inimaginável, no tratamento da esterilidade. Enfim, os aloés curam todos os males!...A panaceia foi (e continua a ser) de tal ordem que, em 1996, até houve quem tivesse a desfaçatez de propor os aloés como as Plantas do Ano em Portugal.

Há imensas falsidades difundidas acerca destas plantas, como também, na grande maioria dos casos, se está a vender como Aloe vera (L.) Burm.f., outras espécies de Aloe, particularmente o Aloe arborescens Mill., que é o mais comummente cultivado nos nossos jardins, o que é grave, pois o suco deste último é laxativo e pode provocar reacçóes alérgicas.

Se o Aloe vera ou qualquer outra planta tivesse as propriedades oncológicas propagadas, as grandes multinacionais da indústria farmacêutica não deixavam de explorar tal filão, nem o deixavam entregue em mãos alheias. Aliás, a indústria sem escrúpulos, já explora este filão, pois encontram-se à venda produtos de cosmética (cremes, sabonetes, loções, águas de colónia, etc... até loções para a queda do cabelo...) fabricados por multinacionais como sendo à base de Aloe vera, não o sendo, na maioria dos casos.

O pior é que até na indústria alimentar já estão à venda alimentos com "Aloe vera". Considero um crime para a saúde pública, permitir-se a venda dos iogurtes com "Aloe vera". Não sei se têm suco do Aloe vera, mas se o têm, é criminoso permitir-se que crianças comam um alimento com um cicatrizante poderoso, sem terem qualquer infecção, fazendo com que o organismo da criança perca resistências a futuras infecçóes. A Organização Mundial de Saúde (OMS) e o Instituto Nacional de Farmácia e do Medicamento (INFARMED) não permitem a comercialização de medicamentos não comprovados cientificamente. Por isso, não há à venda medicamentos à base do "Aloe vera" para tratamento de cancros. A indústria de cosméticos é uma indústria sem regras que explora a vaidade das pessoas. A indústria de plantas medicinais e os "herbanários" também não têm regras e exploram a 
ingenuidade das pessoas. Mas a indústria alimentar é controlada pela Agência de Segurança Alimentar e Económica (ASAE). Por isso, não se entende como se encontram à venda iogurtes com "Aloe vera".

O verdadeiro Aloe vera (L.) Burm.f. distingue-se bem de todos os outros Aloe com os quais o confundem, deliberadamente ou não, pois tem flores amarelas e os outros não. Aloe perryi Bak. e Aloe forbesii Bak.f., nativos da ilha Socotra, têm flores cor de salmão, que amarelecem depois da antese (abertura das flores), amarelecendo da base para o cimo da inflorescência; Aloe succotrina Lam., da África do Sul, tem flores avermelhadas e Aloe arborescens Mill., do sudoeste e sul de África, tem flores escarlate. Além disso, o hábito das plantas e as inflorescências também são diferentes. Geralmente Aloe arborescens Mill. e Aloe succotrina Lam. são subarbustivos e têm as inflorescências simples (pedúnculos não ramificados), ao passo que Aloe vera (L.) Burm.f., Aloe perryi Bak. e Aloe forbesii Bak.f. são herbáceos e com as inflorescências 2-3-ramificadas. Na presença unicamente das folhas não é fácil distingui-los, daí as trapaças de muitos indivíduos gananciosos e sem escrúpulos.

A fundamental razão que levou os portugueses a desejarem a posse de Timor, uma das denominadas ilhas de sândalo, foi a riqueza das suas florestas em sândalo (Santalum album L.), uma árvore de madeira considerada preciosa, aromática e muito utilizada medicinalmente desde tempos remotos. Actualmente, ainda é muito apreciada e utilizada, particularmente nos países asiáticos, para o fabrico de produtos cosméticos aromatizados (sabonetes, loções, etc.). Garcia de Orta refere-a várias vezes nos seus Colóquios, assim como Camões n’Os Lusíadas (Canto X, 134):

"Ali também Timor, que o lenho manda

Sândalo, salutífero e cheiroso;

Durante a ocupação indonésia de Timor, as florestas de sândalo foram praticamente dizimadas, decorrendo, actualmente, um programa de cooperação portuguesa com reprodução de sândalos em viveiros. Não é fácil a produção de sândalo para reflorestação, por ser uma planta semi-parasita, necessitando, por isso de um hospedeiro lenhoso.

Finalmente, referimos apenas mais uma planta camoniana d'Os Lusiadas, não só por ser aromática e medicinal, como também e principalmente por ser do seu nome latino (Laurus

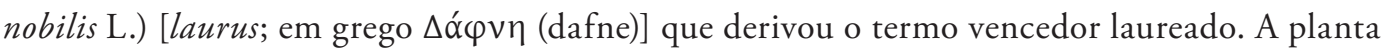
não só foi consagrada ao deus Apolo, como também era com ramos de loureiro que se coroavam os Imperadores romanos e os vencedores. Assim, tal como os ramos de oliveira simbolizam paz, os ramos de louro (Laurus nobilis L.) simbolizam vitória ou vencedor. É por isso que se representa quase sempre a figura de Camões com uma coroa de louros. É com essa simbologia que o poeta o refere n'Os Lusíadas (Canto III, 97): 
Quanto pode de Atenas desejar-se

Tudo o soberbo Apolo aqui reserva;

Aqui as capelas dã tecidos de ouro,

Do bácaro e do sempre verde louro.

Claro que é também uma planta referida pelo poeta na Lírica, mas com outro sentido, tanto no já referido soneto:

Depois que viu Cibele o corpo humano

Do formoso Átis, seu verde pinheiro,

Em piedade o vão furor primeiro

Convertido, chorou seu grave dano.

$E$, fazendo a sua dor ilustre engano,

A Júpiter pediu que o verdadeiro

Preço da nobre palma e do loureiro

Ao seu pinheiro desse, soberano.

Como na ode a D. Manuel de Portugal:

A quem daráo de Pindo as moradoras,

Táo doutas como belas,

Florescentes capelas

Do triunfante louro ou mirto verde,

Da gloriosa palma, que não perde

A presunção sublime,

Nem por força de peso algum se oprime?

Referimos algumas plantas invulgares e algumas curiosidades das plantas mencionadas por Camóes n'Os Lusíadas, mas muito mais há a dizer. Porém, resultaria um trabalho extremamente longo e preferimos apresentar uma lista com todas as plantas citadas na obra épica camoniana.

\section{PLANTAS DA LÍRICA}

$\mathrm{Na}$ Lírica, Camóes cita principalmente e como era previsível, flores e plantas campestres portuguesas, com a excepção de duas plantas asiáticas, o coco das Seychelles [Lodoicea maldivica (J. F. Gmel.) Pers.] e a árvore-triste (Nyctanthes arbor-tristis L.). 
Muitas dessas plantas ocorrem nos campos do Mondego, por onde Camóes, provavelmente, passeou quando esteve em Coimbra (1535-1544). Segundo J. H. Saraiva ${ }^{16}$, Camóes foi aio daquela que foi a sua grande paixão (platónica?), Violante de Andrade, casada com Francisco de Noronha e que residiam em S. Martinho do Bispo, povoação da margem esquerda do Mondego, fronteira a Coimbra. Que Violante tivesse constituído uma paixão marcante na vida do poeta, parece presumível pelo teor de alguns do seus poemas, embora ele devesse ter tido o cuidado de evitar citar o nome dela. Também é de referir que na época em que Camóes viveu (século xvi), os poetas referiam, por vezes, flores nos seus poemas amorosos (Natividade, 1970; Ventura, 1928-1936), como, por exemplo, Garcilaso de la Vega (1501-1536), que refere, por exemplo, a rosa e a açucena no soneto "En tanto que de rosa y azucena"; o lírio e a rosa na écloga a Salicio "el blanco lirio y colorada rosa" e até a violeta na ode "a la flor de gnido" (y cómo por ti sola,/ y por tu gran valor y hermosura,/ convertido en vïola,/ llora su desventura/ el miserable amante en tu figura.). Mas, Camóes não só o faz utilizando habilidades, transformando engenhosamente o termo viola em Violante, como refere várias vezes Violante nos seus poemas amorosos.

Há, pelo menos, dois sonetos onde Camóes revela, claramente, o nome da sua apaixonada. Num deles, utiliza os seus referidos malabarismos linguísticos:

Num jardim adornado de verdura,

A que esmaltam por cima várias flores,

Entrou um dia a Deusa dos amores,

Co’a Deusa da caça e da espessura.

Diana tomou logo ũa rosa pura,

Vénus um roxo lírio, dos melhores;

Mas excediam muito às outras flores

As violas na graça e fermosura.

Perguntam a Cupido, que ali estava,

Qual daquelas três flores tomaria,

Por mais suave, pura e fermosa.

Sorrindo-se, o Menino lhe tornava:

-Todas fermosas são; mas eu queria

Viol'antes que lírio, nem que rosa.

16 Cf. J. H. SARAIVA, Vida ignorada de Camões, op. cit., pp. 80-85; 121-136. 
Noutro soneto, escreve claramente o nome dela:

A violeta mais bela que amanhece

No vale, por esmalte da verdura,

Com seu pálido lustre e fermosura,

Por mais bela, Violante, te obedece.

Perguntas-me porquê? Porque aparece

Em ti seu nome e sua cor mais pura;

E estudar em teu rosto só procura

Tudo quanto em beldade mais florece.

Oh luminosa flor, oh Sol mais claro,

Único roubador do meu sentido,

Não permitas que Amor me seja avaro!

Oh penetrante seta de Cupido,

Que queres? Que te peça, por reparo,

Ser, neste vale, Eneias desta Dido?

Note-se que Camóes, neste último verso refere nitidamente o vale do Mondego, quando diz "neste vale".

O nome de Violante também está bem expresso num poema publicado pela primeira vez em 1861 e que Juromenha classificou como Écloga XIV (Nas ribeiras do Tejo, a uma areia...) e que muitas ediçóes modernas de obras de Luís de Camóes (e. g. Costa Pimpão, 2005; Hernâni Cidade, 2005) omitem com o fundamento de descoberta tardia:

No bosque a Violante vi um dia,

Doce princípio destas doces dores;

A flor caía nela e parecia

Dizer caindo: aqui reinam amores!

Humilde em tanta glória, ela se ria

E errando iam sobre ela várias flores.

$\mathrm{Eu}$, que vencido fui dum error cego,

Àquele honesto riso est'alma entrego.”

Aliás, a primeira vez que Camões refere o nome desta sua grande paixão, é num soneto escrito em galego e que talvez seja o mais antigo testemunho das iniciais tentativas literárias do poeta (Saraiva, 1982): 
A lá en Monte Rei, en Bal de Laça

A Biolante bi, beira de um rio,

Tão fermosa en berdá, que quedé frio

De ber alma imortal en mortal maça!

De um alto e lindo copo a seda laça

A pastora sacaba, fio a fio.

Quando the disse: Morro! Corta o fio!

Bolbeu: Não cortarei! Seguro passa!

- E como passarei, se eu acá quedo?

Se passar, respondi, não bou seguro

Que este corpo sem alma morra cedo!

- Com a minha, que lebas, te asseguro

Que não morras, Pastor! - Pastora hei medo,

O quedar me parece mais seguro!

Durante muitas dezenas de anos esta paixão de Camóes permaneceu desconhecida, pois a partir do primeiro biógrafo (Pedro de Mariz, vinculado à família Noronha) ela foi não só convenientemente ignorada (Mariz omitiu os primeiros 25 anos de vida de Camóes) devido à posição social do casal Noronha, como também houve biógrafos que inventaram amores inexistentes, de modo a desacreditar-se esta verdadeira paixão do poeta, como foi o caso de Diogo Paiva de Andrade, que pretendeu mostrar que a amante de Camóes não fora a sua tia Violante, mas uma Catarina de Ataíde.

Por se terem escrito muitas falsidades sobre a vida do poeta, actualmente não só se sabe muito pouco sobre factos reais, como também o que se pode elaborar são meras conjecturas conseguidas de interpretações retiradas da sua obra poética (Épica e Lírica), teatro e cartas.

Efectivamente, os tempos de Coimbra e essa paixão por Violante, parecem ter marcado profundamente a vida do poeta. A tal ponto, que em vários poemas ele refere saudosamente o Mondego e até n'Os Lusíadas, como no episódio de Inês de Castro (Canto III, 120):

Estavas, linda Inês, posta em sossego,

De teus anos colhendo o doce fruto,

Naquele engano da alma, ledo e cego,

Que a Fortuna não deixa durar muito;

Nos saudosos campos do Mondego,

De teus fermosos olhos nunca enxuto,

Aos montes ensinando e às ervinhas

$\mathrm{O}$ nome que no peito escrito tinhas. 
Claro que era ele que tinha saudades dos campos do Mondego (estava na Ásia, quando escreveu Os Lusiadas) e não Inês de Castro, assassinada em 1355 (7 de Janeiro). Reparar, também, que ele refere as "ervinhas" dos campos do Mondego, que ele cita em muitos poemas da Lírica, pois devia conhecê-las dos campos do Mondego, como, por exemplo as boninas (Bellis sp.) e as rosas das roseiras bravas (Rosa sp.) na Redondilha "A uma mulher que se chamava Grácia de Morais":

\footnotetext{
Vêem-se rosas e boninas,

Olhos, nesse vosso ver;

Vêem-se mil armas arder

No fogo dessas meninas.
}

E que também refere no episódio de Inês de Castro (Canto III, 134):

Assi como a bonina, que cortada

Antes do tempo, foi cândida e bela,

Sendo das mãos lascivas mal tratada

Da menina que a trouxe na capela,

O cheiro traz perdido e a cor murchada:

Tal está morta, a pálida donzela,

Secas do rosto as rosas, e perdida

A branca e viva cor co'a doce vida.

Há, pelo menos, duas espécies de boninas (actualmente designamo-las por margaridas), Bellis perennis L. e Bellis sylvestris Cirillo e duas de roseiras, Rosa canina L. e Rosa sempervirens L., nos campos que marginam o Mondego em S. Martinho do Bispo, onde residia Violante.

Há várias alusôes na Lírica a essa época apaixonante que o poeta viveu nos campos do Mondego, como, por exemplo, na canção da autobiografia poética:

Vão as serenas águas

Do Mondego descendo,

Mansamente, que até ao mar não param;

Por onde minhas mágoas,

Pouco a pouco crescendo,

Pera nunca acabar se começaram. 
Nesta florida terra

Leda, fresca e serena,

Ledo e contente para mim vivia,

Em paz, com minha guerra,

Contente com a pena

Que de tão belos olhos procedia...

Assim como no soneto em que refere o rio e a bela amada:

Doces águas e claras do Mondego,

Doce repouso de minha lembrança,

Onde a comprida e pérfida esperança

Longo tempo após si me trouxe cego;

De vós me aparto; mas, porém, náo nego

Que inda a memória longa, que me alcança,

Me não deixa de vós fazer mudança,

Mas quanto mais me alongo, mais me achego.

Bem pudera Fortuna este instrumento

D’alma levar por terra nova e estranha,

Oferecido ao mar remoto e vento;

Mas alma, que de cá vos acompanha,

Nas asas do ligeiro pensamento,

Para vós, águas, voa, e em vós se banha.

Outras flores de plantas que vegetam nos campos do Mondego, são frequentemente referidas por Camóes nos seus poemas, como, por exemplo, lírios (Iris sp.), cravos (Dianthus sp.), jasmim (Jasminum sp.), jacintos [Hyacynthoides hispanica (Mill.) Rothm.], andorinhas (Chelidonium majus L.), abrolhos (Tribulus terrestres L.) e violetas (Viola sp.).

Eis alguns exemplos na Lírica:

Sonetos (um dos dedicados a Violante)

Num jardim adornado de verdura,

A que esmaltam por cima várias flores,

Entrou um dia a Deusa dos amores,

Co’a Deusa da caça e da espessura.

Diana tomou logo ũa rosa pura, 
Vénus um roxo lírio, dos melhores;

Mas excediam muito às outras flores

As violas na graça e fermosura.

Perguntam a Cupido, que ali estava,

Qual daquelas três flores tomaria,

Por mais suave, pura e mais fermosa.

Sorrindo-se, o Menino lhe tornava:

-Todas fermosas são; mas eu queria

Viol'antes que lírio, nem que rosa.

\section{Éclogas (D. António de Noronha)}

Porque escondes a luz do Sol à gente,

Que nesses olhos trazes, bela e pura?

Mais bela, mais suave e mais fermosa,

Que o lírio, o jasmim, o cravo e a rosa?

\section{Éclogas (Duriano)}

Por ti, a noite escura me contenta;

Por ti, o claro dia me aborrece;

Abrolhos pera mim são frescas flores;

A doce filomela me entristece;

Todo contentamento me atormenta

Co'a contemplação de teus amores;

As festas dos pastores,

Que podem alegrar toda a tristeza.

\section{Odes}

Já a calma nos deixou

Sem flores as ribeiras graciosas;

Já de todo secou

Os cravos, lírios e as purpúreas rosas;

Fogem da calma grave os passarinhos

Pera o sombrio amparo de seus ninhos. 
O campo não o esmaltam

Flores, mas só abrolhos

$\mathrm{O}$ fazem feio; e cuido que lhe faltam

Ouvidos pera mim, pera vós olhos.

Mas faça o que quizer o vil costume;

Que o Sol, que em vós está,

$\mathrm{Na}$ escuridão dará mais claro lume.

\section{Elegias}

Se não tem as delícias de Corinto,

E se de Pário os mármores lhe faltam,

O piropo, a esmeralda e o jacinto;

Se suas casas de ouro não se esmaltam,

Esmalta-se-lhe o campo de mil flores,

Onde os cabritos seus, comendo, saltam.

\section{Redondilhas (carta a uma dama)}

Se alguém os olhos quiser

Às andorinhas quebrar,

Logo a mãe, sem se deter,

Ũa erva lhe vai buscar

Que lhe faz outros nascer.

Redondilhas (votas a mote alheio)

As flores me torna abrolhos,

A morte me determina

Quem eu trouxe de menina

Nas meninas dos meus olhos.

\section{Redondilhas (votas a mote)}

Vi terra florida

De lindos abrolhos

Lindos pera os olhos, 
Duros pera a vida;

Mas a rês perdida

Que tal erva pasce

Em forte hora nasce.

Que a flora dos campos do Mondego fazia parte da observação quotidiana do poeta, é também testemunhada pela referência nos seus poemas de árvores da floresta ripícola das margens do rio, como, por exemplo, salgueiros (Salix sp.), freixos (Fraxinus angustifolia Vahl), ulmeiros (Ulmus minor Mill.) e choupos ou álamos (Populus sp.), assim como as silvas (Rubus sp.) que orlam os nossos campos e florestas.

Redondilhas (Babel e Sião)

Assim, depois que assentei

Que tudo o tempo gastava,

Da tristeza que tomei,

Nos salgueiros pendurei

Os órgãos com que cantava.

Éclogas (Frondélio)

Aquele dia, as águas não gostaram

As mimosas ovelhas, e os cordeiros

O campo encheram de amorosos gritos.

Não se dependuraram dos salgueiros

As cabras, de tristeza, mas negaram

$\mathrm{O}$ pasto a si, e o leite aos cabreiros.

\section{Éclogas (Agrário)}

Estava o triste amante recostado,

Chorando ao pé de um freixo o triste caso

Que o falso amor lhe tinha destinado. 


\section{Éclogas (dos Faustos)}

Entre as ervas dos prados

Não há machos e fêmeas conhecidas,

E junto ũa da outra permanece?

Não estão carregados

Os ulmeiros das vides retorcidas,

Onde o cacho enforcado amadurece?

Destarte vão as Ninfas, que, deixando

De seu despojo os ramos carregados,

Nuas por entre as silvas vão voando.

Éclogas (Ao duque de Aveiro)

Embebido num longo esquecimento

De si e do seu gado e pobre fato,

Após um doce sonho e fingimento,

Rompendo as silvas hórridas do mato,

Vai por cima de outeiros e penedos,

Fugindo, enfim, de todo humano trato.

\section{Éclogas (Umbrano)}

Toca Frodélio, toca a doce lira;

Que, daquele verde álamo sombrio,

A branda filomela, entristecida,

Ao saudoso canto te convida.

\section{Éclogas (Agrário)}

Seus furiosos touros coroava,

E nos álamos altos escrevia

Teu nome, Enone, quando a ti só amava. 


\section{Odes}
Meneia os altos freixos
A branda viração, de quando em quando,
E, de entre os vários seixos,
O líquido cristal sai murmurando;
As gotas, que das alvas pedras saltam,
O prado, como pérolas, esmaltam.

Como também cita árvores características dos carvalhais, de que ainda existem resquícios em S. Martinho do Bispo, como carvalhos (Quercus sp.), castanheiros (Castanea sativa Mill.) e faia (Fagus sylvatica L.), alguns arbustos, como a murta ou mirto (Myrtus cummunis L.), a aveleira (Corylus avellana L.), o zambujeiro [Olea europaea L. var. sylvestris (Mill) Lehr] e as, já referidas, silvas (Rubus sp.):

Éclogas (Ao duque de Aveiro)

Que razão há, pastor, porque te saias

Pero nosso escamoso e vil terreno

Dos mil floridos mirtos e altas faias?

Fermosa Dinamene, se dos ninhos

Os implumes penhores já furtei

À doce filomela, e dos murtinhos

Pera ti, fera! As flores apanhei;

E quaisquer o seu vate coroaram

De capelas idónes e fermosas,

Que as Ninfas lhe teceram e ordenaram:

A Agrário, de murtinhos e de rosas;

Éclogas (À morte D. António de Noronha) (Frondélio)

Que vejo este carvalho, que queimado

Tão gravemente foi do raio ardente,

Não seja ora prodígio que declare

Que o bárbaro cultor meus campos are. 


\section{(Umbrano)}

Enquanto do seguro azambujeiro

Nos pastores de Luso houver cajados,

E o valor antigo, que primeiro

Os fez no mundo tão assinalados,

Não temas tu, Frondélio companheiro,

Que em nenhum tempo sejam subjugados,

Nem que a cerviz indómita obedeça

A outro jugo algum que se ofereça.

\section{Éclogas (dos Faustos)}

Porém a espessa mata, mensageira

Da futura cilada, co'o rugido

Dos raminhos dũa áspera aveleira,

Mostrando a um dos Deuses escondido,

Todas tamanha grita alevantaram,

Como se fosse o monte destruído.

\section{Sonetos}

A fermosura desta fresca serra

E a sombra dos verdes castanheiros,

O manso caminhar destes ribeiros,

Donde toda a tristeza se desterra;

O rouco som do mar, a estranha terra,

O esconder do sol pelos outeiros,

O recolher dos gados derradeiros,

Das nuvens pelo ar a branda guerra;

Assim como flores ornamentais já vulgarizadas na época, como a açucena ou cecém (Lilium candiduma L.) e rosas (Rosa sp,): 


\title{
Sonetos
}

\author{
Tornai essa brancura à alva açucena, \\ E essa purpúrea cor às puras rosas; \\ Tornai ao Sol as chamas luminosas \\ Dessa vista que a roubos vos condena. \\ Tornai à suavíssima Sirena \\ Dessa voz as cadências deleitosas; \\ Tornai a graça às Graças, que queixosas \\ Estão de a ter por vós menos serena;
}

$\mathrm{Na}$ Lírica refere ainda algumas (muito poucas) plantas utilizadas na alimentação como repolhos (Brassica oleracea L. var. capitata L.), alhos (Allium sativum L.), alface (Lactuca sativa L.) e condimentares como a manjerona (Origanum majorana L.) e hortelá (Mentha arvenses L.).

Redondilhas (a quarta, a João Lopes Leitão)

Tendes nem migalha assada,

Cousa nenhũa de molho,

E nada feito em empada,

E vento de tigelada,

Picar no dente em repolho,

De fumo tendes tassalhos;

Ave de pena que sente

Quem da fome anda doente;

Bocejar de vinho e de alhos,

Manjar em branco excelente.

Odes

Pelo moço escolhido,

Onde mais se mostravam as três Graças;

Que Vénus escondido

Pera si teve um tempo entre as alfaças,

Pagou co'a morte fria

A má vida que a muitos já daria. 


\section{Éclogas (dos Faustos)}

Ali se vêem os mirtos circunstantes

Que a cristalina Vénus encobriram

Da companhia dos Faustos petulantes;

Hortelá, manjerona ali respiram

Onde nem frio Inverno ou quente Estio

As murcharam jamais, ou secas viram.

Finalmente, Camóes refere na Lírica (Redondilhas) uma planta asiática e aromática, igualmente alusiva ao amor, mas que não encontramos referida n'Os Lusíadas, que é a árvore-triste (Nyctanthes arbor-tristis L.), cujas flores (brancas e aromáticas) só abrem à noite. Sendo uma planta aromática, os asiáticos usam-na em fitoterapia e aromatizam a comida com as flores. Por as flores abrirem apenas de noite, nalgumas regióes asiáticas tem algum significado mitológico, mas Camóes, na Lírica refere-a com o habitual sentimento amoroso.

(Carta a uma dama)

Ũa árvore se conhece

Que, na geral alegria,

Ela tanto se entristece

Que, como é noite, floresce,

E perde as flores de dia.

Escrevem vários autores

Que, junto da clara fonte

Do Ganges, os moradores

Vivem do cheiro das flores

Que nascem naquele monte.

(Glosa a mote alheio)

Por isso vós, arvoredos,

Que já nos meus olhos vistes

Mais alegrias que medos,

Se mos quereis fazer ledos,

Tornai-vos agora tristes. 


\title{
A ILHA DOS AMORES
}

É interessante que o poeta refere as plantas e flores dos campos do Mondego no episódio da Ilha dos Amores (Insula Divina) d'Os Lusíadas, quando, nesta obra ele normalmente refere, quase exclusivamente, plantas asiáticas. Alguns biógrafos tentaram localizar esta Ilha dos Amores, algures num dos arquipélagos do Oceano Índico ${ }^{17}$ e até na ilha de Santa Helena ${ }^{18}$. Ora isso não pode ser, pois ele cita plantas europeias e particularmente aquelas que lhe lembravam os campos do Mondego, onde viveu a sua grande paixão. Senão vejamos:

\section{Canto IX}

\author{
As árvores agrestes, que os outeiros \\ Têm com frondente coma enobrecidos, \\ Álamos são de Alcides, e os loureiros \\ Do louro Deus amados e queridos; \\ Mirtos de Citereia, co'os pinheiros \\ De Cibele, por outro amor vencidos; \\ Está apontando o agudo cipariso \\ Para onde é posto o etéreo Paraíso.
}

Nesta estância 57, cita os álamos (choupos) [Populus sp.; talvez o choupo-negro Populus nigra L., o mais comum nas margens do rio e não o choupo-branco (Populus alba L.), menos presente no campo], os loureiros (Laurus nobilis L.), os mirtos (murtas) (Myrtus communis L.), que são comuns, ainda hoje, nos campos do Mondego; o cipariso (cipreste) (Cupressus sempervirens L.) e o pinheiro de Cíbele (pinheiro de Alepo) (Pinus halepensis Mill.), árvores introduzidas talvez pelos romanos e comuns (ainda hoje) nos cemitérios e casas senhoriais da região. Uma das razóes que levaram Joáo Vidago a identificar a Ilha dos Amores com a Ilha de Santa Helena foi "em especial, a enumeração das espécies vegetais, flores e frutos, que nela abundavam". Realmente, as naus faziam escala na Ilha de Santa Helena para se abastecerem de água, frutas e vegetais que os portugueses ali haviam introduzido e cultivavam. Mas isso não é razão suficiente para se considerar que terá sido nesta ilha que o poeta baseara a Ilha dos Amores, pois ele refere plantas

17 Itha de Moçambique (Pedro de Marız, "Ao estudioso da lição poética" — Pedro Craesbeek, Os Lusíadas, comentados por Manoel Correa. Lisboa, 1613); Ilha do Ceilão (Manuel de Faria e SouSA, Lusíadas de Luís de Camões. Madrid; 1639); Itha de Bombaim (Luiz da Cunha GonçALVEs, Estudos Camonianos. Porto, 1947).

18 João VIDAGo, "Ilha de Santa Helena, Ilha dos Amores, Escala da "Carreira da Índia" (1502-1625)", Boletim da Sociedade de Geografia de Lisboa, Série 94ª, n.os 7-,10-12 (1976), pp. 153-175. 
e árvores europeias (álamos, loureiros, pinheiros, o cipreste, o cecém, as boninas, etc.) que não existiam, nem eram cultivadas, na Ilha de Santa Helena.

Nas estâncias 61 e 62 deste episódio (Ilha dos Amores) refere as flores [violas (violetas) (Viola sp; talvez a Viola riviniana Rchb., comum nos campos do Mondego ou o cultivado amor-perfeito, Viola tricolor L.), lírio roxo (Iris sp.; talvez o híbrido cultivado desde os tempos romanos, Iris $x$ germanica L. ou o espontâneo na região, Iris subbiflora Brot.), rosa (Rosa sp.), cecém (açucena) (Lilium candidum L.), manjerona (Origanum majorana L.), hiacintinas ${ }^{19}$ (jacintos) (provavelmente o jacinto cultivado, Hyacinthus orientalis L.; ou jacinto-dos-campos, Hyacinthoides hispanica (Mill.) Rothm.), boninas (margaridas) (Bellis sp., ocorrendo duas espécies nos campos do Mondego, Bellis sylvestris Cirillo e Bellis perennis L.], que também refere, como vimos, nos poemas líricos "amorosos" e que são flores de plantas comuns nos prados mondeguinos. Também cita o pomo, talvez referindo-se ao fruto da "perdição" de Adão, a maçã.

Para julgar, difícil cousa fora,

No Céu vendo e na terra as mesmas cores,

Se dava às flores cor a bela Aurora,

Ou se lhe dão a ela as belas flores.

Pintando estava ali Zéfiro e Flora

As violas da cor dos amadores ${ }^{20}$,

O lírio roxo, a fresca rosa bela,

Qual reluze nas faces da donzela;

A cândida cecém, das matutinas

Lágrimas rociada, e a manjerona;

Vêem-se as letras nas flores hiacintinas,

Táo queridas do filho de Latona;

Bem se enxerga nos pomos e boninas

Que competia Clóris com Pomona.

Pois, se as aves no ar cantando voam,

Alegres animais o chão povoam.

19 Augusta Faria Gersão Ventura (1928), pelo facto de Camões referir que se vêem letras nas flores hiacintinas, considera tratar-se de Delphinium ajacis L., cujo nome válido é Consolida ajacis (L.) Schur. (esporas-bravas ou ciúmes), planta de flores azuis, mas muito distinta das plantas de flores azuis vulgarmente conhecidas por jacintos e que é relativamente comum nos campos do Mondego.

20 Augusta Faria Gersão Ventura (1932) considera tratar-se de Matthiola incana (L.) R. Br. (goiveiro-encarnado), uma planta comum nos jardins. 
$\mathrm{Na}$ estância 58 são os frutos comuns, na altura, na região; as cerejas (Prunus avium (L.), as amoras (Morus nigra L.) e o pomo da Pérsia [pêssego; Prunus persica (L.) Batsch]:

Os dons que dá Pomona, ali Natura

Produze, diferente nos sabores,

Sem ser necessidade de cultura,

Que sem ela se dão muito melhores:

As cerejas purpúreas na pintura,

As moras, que o nome têm de amores,

O pomo que da pátria Pérsia veio,

Melhor tornado no terreno alheio;

Na estância 59 volta a citar frutos dessa altura [romãs (Punica granatum L.), pêras (Pyrus communis L.) e uvas (Vitis vinifera L.] e as vinhas de enforcado (as videiras são orientadas para treparem pelas árvores acima, afastando a ramada da geada do solo, podendo, assim dar uvas em cachos que ficam pendurados nos ramos das árvores, lembrando enforcados), que, actualmente, só se observam no Norte do país, mas que nessa altura devia ser a maneira usual de cultivarem a vinha. Aqui, o poeta diz que a vinha trepa pelos ulmeiros (árvores comuns nas margens do Mondego) (Ulmus minor Mill.), no Norte usam como árvores de suporte das vides, castanheiros, carvalhos, plátanos e até oliveiras (no Norte as oliveiras têm de ter porte arbóreo para a ramada estar longe da geada do solo e, assim, darem azeitona).

\footnotetext{
Abra a romá, mostrando a rubicunda

Cor, com que tu, rubi, teu preço perdes;

Entre os braços do ulmeiro está a jucunda

Vide, c'uns cachos roxos e outros verdes;

E vós, se na vossa árvore fecunda,

Peras piramidais, viver quiserdes,

Entregai-vos ao dano que co'os bicos

Em vós fazem os pássaros inicos.
}

O poeta refere também os narcisos neste episódio (estância 60), pois, de facto, existem muitas espécies de narcisos (Narcissus sp.) em Portugal, nomeadamente, nos campos do Baixo Mondego. É interessante notar que o poeta refere o pormenor de as flores destas plantas serem nutantes (“a cabeça a flor Cyfisia inclina”), como, na realidade, são na grande maioria das espécies de narcisos. 
Pois a tapeçaria bela e fina,

Com que se cobre o rústico terreno,

Faz ser a de Aqueménia menos dina;

Mas o sombrio vale mais ameno.

Ali a cabeça a flor cifísia inclina,

Sôbolo tanque lucido e sereno;

Florece o filho e neto de Ciniras,

Por quem tú, Deusa páfia, inda suspiras.

Das plantas mais interessantes referidas por Camóes na Ilha dos Amores, são os citrinos, que são plantas aromáticas de origem asiática (portanto, o normal n’Os Lusiadas) e já muito cultivados nessa altura na Europa Ocidental. Cita a laranjeira [Citrus sinensis (L.) Osbeck], a cidreira (Citrus medica L.) e o limão [Citrus limon (L.) Burm. f.]. Mas, como estamos na Ilha dos Amores, a referência "amorosa" tem de estar presente, quando diz que "A laranjeira tem no fruito lindo a cor que tinha Dafne nos cabelos;" e "Os fermosos limões ali, cheirando, estão virgíneas tetas imitando.” (estância 56).

Mil árvores estão ao céu subindo,

Com pomos odoríferos e belos:

A laranjeira tem no fruito lindo

A cor que tinha Dafne nos cabelos;

Encosta-se no chão, que está caindo

A cidreira co'os pesos amarelos;

Os fermosos limões ali, cheirando,

Estão virgíneas tetas imitando.

Da mesma maneira, com alusão "amorosa”, também cita o limão na Lírica, nas Redondilhas (Voltas a mote e alheio):

Verdes são os campos,

De cor de limáo;

Assim são os olhos

Do meu coração. 


\section{LISTA DAS PLANTAS D’OS LUSÍADAS}

As plantas indubitavelmente identificadas estão a negrito. Os casos que indicam apenas o nome do género, sem o restritivo específico (ex.: Rosa sp.), correspondem a casos em que não é possível identificar a espécie, como, por exemplo, no caso de Rosa sp., indica-se que ou se trata de rosas de roseiras cultivadas, normalmente cultivares resultantes de cruzamentos entre espécies diferentes (híbridos) e manipulação genética ou de roseiras silvestres e, neste caso, era preciso saber onde estava Camóes quando escreveu o poema (por exemplo, se estivesse nos campos do Mondego seria a Rosa sempervirens L. ou a Rosa canina L.). Os outros nomes correspondem a identificaçóes incorrectas encontradas na literatura camoniana, ou determinaçóes de exactidão impossível, ou a sinónimos de nomes a negrito. Para cada espécie indica-se um Canto e respectiva estância onde a planta é referida. Os nomes vulgares entre aspas, correspondem a nomes referidos por Camóes e, actualmente, em desuso ou nomes escritos, por conveniência elucidativa, em língua estrangeira.

Adonis annua L.

Adonis autumnalis L.

Aloe forbesii Bak.f.

Aloe perryi Bak.

Aloe succotrina Lam.

Aloe vera (L.) Burm.f.

Antiaris toxicaria (Rumph. ex. Pers.) Lesch.

Aquilaria malaccensis Lam.

Balsamodendrumn myrrha T. Nees

Bellis sp.

Bellis perennis $\mathrm{L}$.

Bellis sylvestris Cirillo

Borassus aethiopium Mart.

Borassus flabellifer L.

Boswellia sacra Flueck.

Caesalpinia echinata Lam.

Caesalpinia peltophoroides Benth.

Caryophyllus aromaticus L.

Cerasus avium (L.) Moench

Cinnamomum aromaticum Nees

Cinnamomum verum J. Presl

Cinnamomum zeylanicum Sin.

Citrus aurantium L.

Citrus limon (L.) Burm.f.

Citrus limomum Sin.

Citrus medica L.
Lágrimas-de-sangue; Olhos-de-perdiz; Casadinhos IX; 60

Lágrimas-de-sangue; Olhos-de-perdiz; Casadinhos IX; 60

Aloé de Socotra $\quad X ; 137$

Aloé de Socotra $\quad x_{;} 137$

Aloé $\quad X_{;} ; 137$

Aloé; Aloé-babosa; Erva-babosa; Erva-azebra $\quad X_{;} ; 137$

Árvore-de-upas; upas-antiar (veneno) $\quad X_{i} 44$

Pau-de-águia; "Aloé" (Biblia) X; 129

Mirra $\quad X ; 135$

Margaridas; "Boninas" IX; 62

Margaridas; "Boninas" IX; 62

Margaridas; "Boninas" IX; 62

Palmeira-leque; "Mevuma" (vandau) I; 46

Palmeira de Palmira $\quad$ I; 46

Incenso; Incenseiro; Olíbano; Árvore-do-incenso $\quad$ X; 101

Pau-brasil $x ; 140$

Pau-brasil $\quad x ; 140$

Cravinho; Cravinho da índia $\quad X ; 132$

Cerejeira; Cerdeira; cereja (fruto) IX; 58

Caneleira da China; Cássia da China $\quad$ X; 51

Caneleira do Ceilão; Caneleira da Índia $\quad$ X; 51

Caneleira do Ceilão; Caneleira da Índia $\quad$ X; 51

Laranjeira-amarga; laranja-amarga (fruto) IX; 56

Limoeiro; limão (fruto) IX; 56

Limoeiro; limão (fruto) IX; 56

Cidreira; cidra (fruto); cidrão (fruto) IX; 56 
Citrus sinensis (L.) Osbeck

Commiphora abyssinica Sin.

Commiphora myrrha (Nees) Engl.

Cupressus sempervirens $\mathrm{L}$.

Dryobalanops aromatica Gaërtn.

Dryobalanops sumatrensis (Gmel.) Kost.

Fagus sylvatica $\mathrm{L}$.

Gladiolus illyricus W.D.J. Koch

Gladiolus italicus Mill.

Gladiolus segetum Ker-Gawl.

Gnaphalium sanguineum $\mathrm{L}$.

Gossypium herbaceum L.

Hedera helix L.

Helichrysum sanguineum (L.) Kostel.

Hyacinthoides hispanica (Mill.) Rothm.

Hyacinthus sp.

Hyacinthus orientalis L.

Hyphaena obovata Furtado

Indigofera tinctoria L.

Iris sp.

Iris subbiflora Brot.

Jasminum sp.

Jasminum fruricans $L$.

Laurus nobilis L.

Lilium candidum $\mathrm{L}$.

Lodoicea maldivica (J.F. Gmel.) Pers.

Lodoicea sechellarum Labill.

Malus sylvestis (L.) Mill.

Matthiola incana (L.) R.Br.

Morus nigra $\mathrm{L}$.

Myristica fragans Houtt.

Myrtus communis L.

Narcissus sp.

Narcissus poeticus L.

Narcissus tazetta L.

Olea europaea L. var. europaea

Origanum majorana $\mathrm{L}$.

Persica vulgaris Mill.

Phoenix dactylifera $\mathrm{L}$.

Phoenix reclinata Jacq.

Pinus halepensis Mill.

Pinus pinea $\mathrm{L}$.
Laranjeira-doce; laranja-doce (fruto) IX; 56

Mirra X; 135

Mirra $\quad$ X; 135

Cipreste; "Cipariso" IX;57

Canforeira de Bornéu; Canforeira da Malásia $\quad$ X; 133

Canforeira de Bornéu; Canforeira da Malásia X; 133

$\begin{array}{ll}\text { Faia } & X ; 34\end{array}$

Espadana-dos-montes-de-folhas-largas $\quad I X ; 62$

Espadana-das-searas IX; 62

Espadana-das-searas IX; 62

Sangue-dos-macabeus III; 97

Algodoeiro-asiático; algodão (pêlo da semente) V; 76

Hera II; 36

Sangue-dos-macabeus III; 97

Jacinto; "hiacintina" IX; 61

Jacinto; "hiacintina" IX; 61

Jacinto; "hiacintina" IX; 61

"Matcheu" (vandau) I; 46

Anilerira; Índigo V; 76

Lírio II; 37

Lírio-roxo IX; 61

Jasmineiro; jasmim (flor) $X ; 1$

Jasmineiro-do-campo; jasmim (flor) $X ; 1$

Loureiro, Louro $\quad$ IX; 57

Açucena; "Cecém" ; "Susen" (árabe) IX; 62

Palmeira das Seicheles; coco-do-mar (fruto) X; 136

Palmeira das Seicheles; coco-do-mar (fruto) X; 136

Macieira-brava; maçã (fruto);"maçã-de-ouro" IV; 55

Goiveiro-encarnado IX;61

Amoreira-negra; "Mora"; amora (infrutescência) IX; 58

Moscadeira; noz-moscada (semente arilada) X;133

Murta; Murteira; "Mirto" IX; 57

Narciso; "Flor cifísia" IX; 60

Narciso-dos-poetas IX;60

Narciso-de-inverno; Mija-burro IX;60

Oliveira; azeitona (fruto) VI; 13

Manjerona IX; 62

Pessegueiro; pêssego (fruto); "pomo" (fruto) IX; 58

Tamareira; Palmeira-das-igrejas; tâmara (fruto) $\quad$ X; 42

"Matchindo" (vandau) I; 46

$\begin{array}{ll}\text { Pinheiro de Alepo } & I X ; 57\end{array}$

Pinheiro-manso; pinhão (semente) IX; 57 
Piper betle L.

Piper nigrum L.

Piper officinarum $\mathrm{L}$.

Piper retrofractum $\mathrm{L}$.

Populus sp.

Populus alba L.

Populus alba L.

Populus nigra $L$.

Prunus avium L.

Prunus persica (L.) Batsch

Punica granatum L.

Pyrus communis L.

Quercus sp.

Quercus robur L.

Rosa sp.

Rosa x centifolia L.

Santalum album L.

Strophanthus kombe Oliv.

Strophanthus petersianus Klotsch

Strychnos nux-vomica $\mathrm{L}$.

Strychnos tieute Lesch.

Strychnos toxifera R.H. Schomb. ex Benth.

Styrax benzoin Dryand.

Syzygium aromaticum (L.) Merr. \& Perry

Triticum sp.

Triticum aestivum L.

Triticum vulgare Vill.

Uhnus campestris auct., non L.

Ulmus minor Mill.

Viola sp.

Viola odorata L.

Viola riviniana Rchb.

Vitis vinifera $\mathrm{L}$.
Bétele

VII; 58

Pimenteira; pimenta-negra (semente) IX; 14

Pimenteira; pimenta-longa de Java (semente) X; 123

Pimenteira; pimenta-longa de Java (semente) X; 123

Choupo; Álamo; "Álemo"

IX; 57

"Faia"

X; 34

Choupo-branco; Álamo-branco; "Álemo"

IX; 57

Choupo-negro; Álamo-negro; “Álemo"

IX; 57

Cerejeira; Cerdeira; cereja (fruto)

IX; 58

Pessegueiro; pêssego (fruto); "pomo" (fruto)

IX; 58

Romãzeira; Romeira; romã (fruto)

IX; 59

Pereira; pêra (fruto)

IX; 59

Carvalho; bolota (fruto)

X; 34

Carvalho-comum; bolota (fruto)

$x ; 34$

Roseira; rosa (flor)

IX; 61

Roseira-pálida; rosa-pálida (flor)

IX; 61

Sândalo-branco; Pau-sândalo

X; 134

Estrofanto;"kombi" (veneno)

I; 86

Estrofanto;"kombi" (veneno)

I; 86

Árvore-da-noz-vómica; noz-vómica (fruto)

X; 44

"Upas tieuté" (veneno)

X; 44

$x ; 44$

X; 135

Benjoim

X; 132

X; 27

Trigo

IX; 27

Trigo; Trigo-mole

$1 X ; 27$

Trigo

IX; 27

Ulmeiro; Negrilho

IX; 59

Ulmeiro; Negrilho

IX; 59

Violeta; "Viola"

IX; 61

Violeta; Amor-perfeito; "Viola"

IX; 61

Violeta; "Viola"

IX; 61

Videira; "Vide"

IX; 59 


\section{LISTA DAS PLANTAS DA LÍRICA}

Os casos que indicam apenas o nome do género, sem o restritivo específico, como, por exemplo Salix sp., correspondem a casos em que não é possível identificar a espécie, pois, neste caso (Salix sp.), era preciso saber onde estava Camóes quando escreveu o poema. Os nomes vulgares entre aspas correspondem a nomes referidos por Camóes e, actualmente, em desuso ou nomes escritos, por conveniência elucidativa, em língua estrangeira. Para cada espécie indicase a composição poética lírica onde a planta é referida. Notar que as rosas são as únicas flores referidas em todas as formas líricas de composição poética.

Allium sativum $\mathrm{L}$.

Bellis sp.

Brassica oleracea L. var. capitata L. Castanea sativa L.

Chelidonium majus L.

Citrus limon (L.) Burm. f.

Corylus avellana $\mathrm{L}$.

Dianthus caryophyllus L.

Fagus sylvatica $\mathrm{L}$.

Ficus carica L.

Fraxinus angustifolia Vahl

Hedera helix L.

Hyacinthus sp.

Iris sp.

Jasminum sp.

Lactuca sativa L.

Laurus nobilis $\mathrm{L}$.

Lilium candidum $\mathrm{L}$.

Lodoicea maldivica (J. F. Gmel.) Pers.

Malus sylvestris (L.) Mill.

Mentha sp.

Myrtus communis L.

Nyctanthes arbor-tristis $\mathrm{L}$.

Olea europaea L. var. sylvestris (Mill.) Lehr

Origanum majorana L.

Pinus halepensis Mill.

Populus sp.

Quercus sp.

Rosa sp.

Rubussp.

Salix sp.

Tribulus terrestris $\mathrm{L}$.

Ulmus minor Mill.

Viola sp.

Vitis vinifera $\mathrm{L}$.
Alho

Margaridas; "Boninas"

Repolho

Castanheiro; castanha (fruto)

Erva andorinha; "Andorinha"

Limoeiro; limão (fruto)

Aveleira; avelã (fruto)

Craveiro; cravo (flor)

Faia

Figueira; figo (infrutescência)

Freixo

Hera

Jacinto; "Hiacintinas"

Lírio

Jasmim

Alface; "Alfaça"

Loureiro, Louro

Açucena; "Cecém"

Coco-do-mar; "Pomo"

Macieira-brava; macã (fruto); "pomo"

Hortelã

Murta; Murteira; "Mirto"

Árvore-triste

Zambujeiro; "Azambujeiro"

Manjerona

Pinheiro de Alepo

Choupo; Álamo; "Álemo"

Carvalho; bolota (fruto)

Roseira; rosa (flor)

Silva; Amora-da-silva (fruto); "moras"

Salgueiro

Abrolhos

Ulmeiro

Violeta; "viola"

Videira
Redondilhas

Red; Son; Écl; Odes

Redondilhas

Sonetos

Redondilhas

Redondilhas

Éclogas

Éclogas; Odes

Éclogas

Redondilhas

Éclogas; Odes

Éclogas

Elegias

Son; Écl; Odes

Redondilhas; Éclogas

Odes

Sonetos; Odes

Sonetos

Red; Son; Odes

Éclogas

Éclogas

Éclogas; Odes

Redondilhas

Éclogas

Éclogas

Sonetos; Éclogas

Éclogas

Éclogas

Red; Son; Écl; Od; El; Can

Éclogas

Redondilas; Éclogas

Red; Écl; Odes

Éclogas

Sonetos

Éclogas 


\section{BIBLIOGRAFIA FUNDAMENTAL}

Barbosa, Duarte, Livro de Duarte Barbosa. Lisboa, Academia Real das Sciencias, 1813.

Camốes, Luís de, Os Lusíadas. Fac-símile da edição de: Lisboa, Antonio Gốçaluez Impressor, 1572. Edição Fac-símile comemorativa dos 500 anos da Biblioteca da Universidade de Coimbra. [Lisboa], A Bela e o Monstro, 2013.

Cidade, H., "Luís de Camões e suas Afinidades com Garcia de Orta", Garcia de Orta, N. ${ }^{\circ}$ Especial (1972), pp. 155-163.

Cidade, H., Obras completas de Luis de Camôes. 1, Os Lusíadas. Mem Martins, Círculo de Leitores, 1980.

Cidade, H., Obras completas de Luís de Camóes. 2, Teatro e Cartas. Mem Martins, Círculo de Leitores, 1980.

Cidade, H., Obras completas de Luís de Camóes. 3, Lírica. Mem Martins, Círculo de Leitores, 1980.

Cunha, A. Proença da; Silva, A. P. da; Roque, O. R., Plantas e produtos vegetais em fitoterapia. Lisboa, Fundação Calouste Gulbenkian, 2003.

Pimpão, A. J. Costa, Luis de Camóes. Rimas. Coimbra, Almedina, ${ }^{5} 2005$.

Fauvel, A.-A., "Le Cocotier de mer des Iles Seychelles (Lodoicea Sechellarum)", Annales du Musée Colonial de Marseille, Sér. 3, 1 (1915), pp. 169-307.

Ferrão, J. E. M., A Aventura das Plantas e os Descobrimentos Portugueses. 3.a ed. Lisboa, Instituto de Investigação Científica Tropical; Fundação Berardo; Chaves Ferreira- Publicaçôes, S.A., 2005.

Ficalho, Conde de, Flora dos Lusiadas. Lisboa, Academia Real das Sciencias, 1880.

Labillardière, Jean-Jacques H., "Sur le Cocotier de Mer des Maldives", Annales du Muséum National d'Histoire Naturelle 9 (1807), pp. 140-145.

Lionnet, G., The Romance of a palm. Coco de Mer. Bell Village, L'ile aux Images, 1986.

Morton, A. G., History of Botanical Science, an account of the development of Botany from ancient times to the present day. London, Academic Press, 1981.

Moura, A. R., "Sobre os vandaus (Sofala - Moçambique)", in Moçambique: aspectos da cultura material. Coimbra, Instituto de Antropologia, Universidade de Coimbra, 1986, pp. 55-76, fig. 1-44 (Publicações do Centro de Estudos Africanos, 6).

Moura, A. R., "Contribuição para o conhecimento da cestaria de Moçambique", in Cestaria tradicional em África. Coimbra, Instituto de Antropologia, Universidade de Coimbra, 1988, pp. 13-34, fig. 1-64 (Publicações do Centro de Estudos Africanos, 9).

Natividade, J. V., "A flora da lírica de Camões", Memórias da Academia das Ciências de Lisboa 14 (1970), pp. 7-63.

Orta, Garcia de, Coloquios dos simples e drogas da India. Ed. Academia Real das Sciencias de Lisboa (dirigida e anotada por Conde de FicalHo) I. Lisboa, 1891.

Orta, Garcia de, Coloquios dos simples e drogas da India. Ed. Academia Real das Sciencias de Lisboa (dirigida e anotada por Conde de Ficalho) II. Lisboa, 1895.

PAIVA, J., “Jardins Botânicos. Sua origem e importância”, Munda 2 (1981), pp. 35-44. 
Reynolds, G. W., The Aloes of South Africa. Johannesburg, Aloes of South Africa Book Fund, 1950.

Reynolds, G. W., The Aloes of Tropical Africa and Madagascar. Mbabane, The Trustees. The Aloes Book Fund, 1966.

Santos, C. A. dos, "Camóes y Góngora; una lectura del erotismo en Los Lusíadas y en la Fábula de Polifemo y Galatea", Castilla. Estudios de Literatura 28-29 (2003-2004), pp. 23-46.

Saraiva, J. H., Vida ignorada de Camões. Mem Martins, Publicações Europa-América, 1982 (Estudos, Ensaios e Documentos 141).

Sonnerat, Pierre, Voyage a la Nouvelle Guinée. Paris, Ruault, 1776.

Ventura, A. F. G., "As Flores Hiacintinas de Camóes”, O Instituto 75 (1928), pp. 397-408.

Ventura, A. F. G., "O Adónis de Camóes" (Miscelânea de estudos em honra de D. Carolina Michaëlis de Vasconcelos), Revista da Universidade de Coimbra 11 (1933), pp 1009-1016.

Ventura, A. F. G., "Subsídio para o estudo da Flora Camoneana. III- A Viola”, O Instituto 83, 12 (1932), pp. 344-354.

Ventura, A. F. G., "Subsídio para o estudo da Flora Camoneana. IV- Boninas e rosas", Biblos 9 (1933), pp.128-138.

Ventura, A. F. G., "Subsídio para o estudo da Flora Camoneana. V- Lírios e legaçáo", O Instituto 85 (1933), pp. 180-185.

Ventura, A. F. G., "Subsídio para o estudo da Flora Camoneana. VI- O Bácaro e o louro", Biblos 11 (1935), pp.72-84.

Ventura, A. F. G., "Subsídio para o estudo da Flora Camoneana. VII- Fruta da Ilha dos Amores", Biblos 12 (1936), pp. 212-222.

Ventura, A. F. G., "O Côco da barca do Purgatório de Gil Vicente e o Jasmim dos Lusíadas e da Lírica de Camôes”, Liceus de Portugal 29 (1943), pp. 2329-2334.

Ventura, A. F. G., "Notas Camonianas", Brasilia 4 (1949), pp. 119-154.

Ventura, A. F. G., "Notas Camonianas", Brasilia 10 (1958), pp. 1- 37.

Ventura, A. F. G., "Notas Camonianas”, Brasilia 11 (1961), pp. 1-29.

Vidago, João, "Ilha de Santa Helena, Ilha dos Amores, Escala da "Carreira da Índia" (1502-1625)", Boletim da Sociedade de Geografia de Lisboa, Série 94a, n. ${ }^{\text {os }}$ 7-, 10-12 (1976), pp. 153-175.

Tavares, C. N., "Os Lusíadas e a Botânica”, Garcia de Orta, N.o Especial (1972), pp. 547-567. 
(Página deixada prepositadamente em branco.) 


\title{
Nicolás Monardes, John Frampton and the Medical Wonders of the New World
}

DONALD BEECHER ${ }^{1}$

\begin{abstract}
:
The Spanish discovery of the new world produced not only a supply of precious metals but of rare plants apt for study as potential drugs and the means to miraculous new cures. Early among those who pursued these botanical novelties was Nicolás Monardes of Seville, who collected, studied, catalogued, grew and integrated them into his medical practice. After many years, he wrote a singular treatise which was translated into several languages including English and Latin in several spirits at once: a botanical collection; a book of Pharmaceutical simples; a treatise on miraculous cures; a book of wonders; and a work promoting the commercial exploitation of overseas resources. These diverse rhetorical aspects become even more apparent in the work's translation into English by the merchant-trader John Frampton of Bristol. Monardes' treatise is not only scientific in its import, but a print culture phenomenon revealing how the new instruments for the mass dissemination of astonishing new data could reconstruct the popular imagination.
\end{abstract}

\section{KEYWORDS:}

new world; materia medica; Nicolás Monardes; Renaissance medicine; herbals and wonder books.

\section{RESUMO:}

O achamento do novo mundo pelos espanhóis produziu não só uma fonte de metais preciosos mas também de plantas raras, passíveis de ser objecto de estudo como drogas que pudessem levar a novas curas milagrosas. Nicolás Monardes de Sevilha conta-se entre os primeiros estudiosos destas novidades botânicas, tendo-as coleccionado, estudado, catalogado, plantado e integrado na sua prática médica. Após muitos anos escreveu um tratado singular que foi traduzido em várias línguas, incluindo o Inglês e o Latim, com múltiplas finalidades: uma colecção botânica; um livro de simples medicinais; um tratado sobre curas milagrosas; um livro de maravilhas; e um trabalho que promovia a exploração comercial de recursos ultramarinos. Estes diversos aspectos retóricos tornam-se ainda mais evidentes na tradução do livro para Inglês pelo mercador John Frampton de Bristol. $O$ tratado de Monardes não só tem significância científica mas é também um fenómeno da cultura impressa que revela como os novos instrumentos para a divulgação alargada de dados novos e surpreendentes conseguiram reconstruir a imaginação popular.

\section{PALAVRAS-CHAVE:}

Novo Mundo; materia medica; Nicolás Monardes; medicina renascentista; herbários e livros de maravilhas.

1 Department of English Language and Literature - Carleton University - Ottawa: Donald.Beecher@ carleton.ca. 
Upon their returns from the New World, the mariners and conquistadors first to explore the islands of the Caribbean, Florida, Mexico and Peru brought with them samples of the plants and minerals celebrated by the natives for their healing powers. Not only did the physicians and medical philosophers of Spain and Portugal take notice, but had made their requests for such materia medica as one of the potentially greatest rewards of the post-Columbian discoveries. Chief among them was Nicolás Monardes of Seville, who realized as early as the 1530 s that these simples might not only contain miraculous healing powers but fetch very high prices, prompting him to collect, classify, and even grow a goodly number of them for incorporation into his clinical practice. The account he at last published, after some thirty years of collecting and study, appeared in parts beginning in 1565 and 1569, and in its entirety in 1571 as the Primera y Segunda y Tercera partes de la Historia Medicinal de las Cosas que se traen de nuestras Indias Occidentales que sirven en Medicina. ${ }^{2}$ It became a seminal work in circulating news of these discoveries not only among botanists and apothecaries throughout Europe, but among common readers of the vernacular, for Monardes had chosen to publish in Spanish rather than the Latin of medical specialists. Therein is to be found the earliest accounts of sassafras, cannafistola, sarsaparilla, and the carlo sancto root, a scant four among the seventy-one simples comprising the work. Monardes' purpose was doubly tilted, not only toward the professionals interested in the location, preparation, and clinical administration of these drugs, but toward general readers potentially fascinated by the novelty of the plants, by their exotic powers and the promise of miraculous cures. In short, he had created two works in one, a botanical dictionary ultimately to be absorbed into the collective efforts of those assiduous botanists intent upon inventorying all the known plants of the planet, but simultaneously a book of wonders, a published "cabinet of curiosities," in keeping with the pursuit of mirabilia that had so incited and motivated the pre-conquest imagination and colored the accounts of the early explorers.

Concerning that mental frame of exoticism that preceded scientific measurement and investigation, one that suffused the mentalities of the early explorers, Margaret Hodgen has written, "if, on occasion, descriptions of New World topography, flora, fauna, or people crept into their narratives, the strange and bizarre was emphasized at the expense of the prosaic and carefully

2 The work is available in facsimile as La historia medicinal...de nuestras Indias Occidentales. Sevilla, Padilla Libros, 1988, as well as in a critical edition edited by José María López PIÑERo, La Historia Medicinal de las cosas que se traen de nuestras Indias Occidentales (1565-1574), de Nicolás Monardes. Madrid, Ministerio de Sanidad y Consumo, 1989. The original editions have been studied closely by Francisco Guerra in Nicolás Bautista Monardes, su vida y su obra [ca. 1493-1588]. México, Compañía Fundidora de Fierro y Acero de Monterrey, S.A., 1961). Two more accounts of his life may be found in Francisco Rodríguez Marín, La verdadera biografía de Nicolás Monardes. Sevilla, Padilla Libros, 1988 (first published in 1925), and in Javier LASSO DE LA VEGA, Biografía y estudio crítico de las obras del médico Nicolás Monardes. Sevilla, Padilla Libros, 1988 (first published in 1891). 
examined." Given the motivations of the early explorers to impress or bemuse, in conjunction with the misprision of what they had seen due to the prevailing myths about foreign lands circulating in the late Middle Ages, much of ethnographical, botanical, zoological, and medical value became obscured. The story of the persistence of medieval lore in discovery reports has been told many times over, but the willfulness of such accounts in order to amaze and incite their royal and fiscal sponsors through confabulatory rhetoric and inflated claims (especially involving potentially profitable commodities) should not be underrated. Monardes may have been somewhat credulous on these grounds, thus putatively generating a book of inflated claims. But if so, the reasons may ultimately be far more systemic and methodological. He was also a believer. As a physician he went about his work with a characteristic degree of skepticism and method, yet by professional training he was given to a credulousness typical of the investigative values and biases of sixteenth-century medical philosophy. This philosophy based on humoural medicine undergirded by an unchallenged deference to ancient authority on the eve of the scientific breakthroughs of the seventeenth century has also been thoroughly investigated by the historians of early modern science. Through such a mindset on Monardes' part, a book of wonders arose in pat keeping with the work of an enthusiastic botanical classifier and medical practitioner. In cyclical fashion, amazement among readers then created an industry of wonders in which practitioners were invited to participate on the best of professional grounds. In short, the marvelous brought from the shores of the New World was better press than the banal, and a better incentive to pursue the entire scientific enterprise of collecting and classifying these medical simples. This enthusiasm was simultaneously nourished by a deep-seated belief that a shortfall in efficacious medications would be repaired once the hidden miracles of the unknown world were brought forth to complete the pan-European medicinal arsenal. In the resulting double focus on the scientific and the miraculous, Monardes had played both a willing and unwitting part: he was not a patent medicine charlatan. Rather, after his years of study, he emerged a sincere believer in the clinical benefits achieved through the healing regimens into which had been incorporated the substances described in La historia. To his investigative satisfaction he had seen a goodly number of medical conditions cured through the sovereign operations of these plants, many of those conditions thought to be beyond the reach of medical treatment. His enthusiasm would have been but natural, once his own scientific criteria had been satisfied concerning the legitimate causal relationships between medications and their cures. The classification and description of these materials, hence, by default, became a form of rhetoric, an appeal apt to incite the imagination, and to create demand through the widening reach of an expanding print culture. Through the offices of print, Monardes himself, in a

3 Early Anthropology in the Sixteenth and Seventeenth Centuries. Philadelphia, University of Pennsylvania Press, 1971, p. 113. 
sense, had become a traveller, although he stayed close to Seville, in reducing medical exotica to clinical success, thereby claiming for himself the status of an explorer-benefactor through the cures that must, in turn, redound to his credit and fame.

To date, the bulk of the erudition dealing with Monardes has been devoted to his contribution to the development of Renaissance botany and pharmacognosy. ${ }^{4}$ To think of his work in rhetorical terms as an instrument for the shaping of the popular imagination through the power of print is therefore something of a novelty. But first to the historical and scientific side. Scholars have been much concerned with the earliest accounts of new world plants from tobacco and guaiacum wood to the rhubarb of Michoacan. They have examined every aspect of the physician's life through biographical studies, and specialists have examined all the related matters of nomenclature and taxonomy in order to compare his descriptions with their most recent scientific cognates. Others have been preoccupied with the Aztec medical components in his clinical applications and the degree to which Monardes was, himself, proactive in extending European herbals and pharmacology. C. R. Boxer styles him a pioneer in tropical medicine and a principal figure in the elaboration of sixteenth-century botany. ${ }^{5}$ Emily Walcott Emmart cites Monardes as a mediator of Aztec herbal practices in her study of the Aztec herbal of Martin de la Cruz. ${ }^{6}$ Both of these claims may be more circumstantial than demonstrable, given the

4 Among the many studies are those by Nicolás LEón, "El doctor Nicolás Monardes: sus servicios a la materia médica y terapéutica americanas," Gaceta Médica de México 57 (1926), pp. 553-68; E. ÁlvAREz López, "Nicólas Monardes y los botánicos europeos del siglo xvı", Las Ciencias 14 (1949), pp. 139-49; Ascensión MÁs-GuINDAL, "Datos históricos sobre los materiales farmacéuticos importados de América en el siglo XVI," Anales de la Real Academia de Farmacia 4 (1943), pp. 37-82; and Carlos PereyrA, Monardes y el exotismo médico en el siglo xVI. Madrid, Biblioteca Pax, 1936. See also Kurt STünZnER, Die Schrift des Monardes über die Arzneimittel Americas. Halle, Max Niemayer, 1895. Among the most important recent studies is that by José María LóPEz PIÑERo, "Las 'nuevas medicinas' americanas en la obra (1665-1574) de Nicolás Monardes", Asclepio 42.1 (1990), pp. 3-67. The Spanish physician, Francisco Hernández, had been sent to Spanish America by Philip II in 1558 to investigate the medical plants and medications of Mexico because this task "had been thoroughly neglected by the conquistadors." Frank J. ANDERSON, An Illustrated History of the Herbals. New York, Columbia University Press, 1977, p. 236. In what remains of Hernández' work, it would appear that he inventoried some 1000 plants, variously referred to by over 3000 names, many of them the Aztec names for native plants, most from the central plateau.

5 Two Pioneers of Tropical Medicine: Garcia d'Orta and Nicolás Monardes. London, Wellcome Historical Medical Library, 1963.

6 "Concerning the Badianus Manuscript. An Aztec Herbal, 'Codex Barberini, Latin 241' (Vatican Library)", Smithsonian Miscellaneous Collections 94.2 (1935), pp. 1-11. Nevertheless, Monardes' treatise gives no evidence that he had any direct knowledge of Aztec medicine, although their practices are implicit on the reports of the travellers treated abroad by native practitioners. This raises the entire question of Monardes' reading and what he could have drawn from printed works. No doubt he had reasons of his own for writing without the benefit of primary sources, although among the few to be considered are La natural... historia de las Indias of Gonzalo FERNÁNDEZ DE OVIEDo. Francisco Guerra asserts that Monardes knew only Garcia de ORTA's Coloquios dos simples, e drogas he cousas mediçinais da India, published in Goa in 1563. There is the writing of Bernardino de SAHAGún, Historia universal de las cosas de la Nueva España, but although it was written as early as 1555, it remained in manuscript (now in the Biblioteca del Palacio Real, Madrid, Sig. No. 1280). Concerning the Aztec Herbal, written at the 
lack of published materials available to him which dealt with such matters, but he did take close note of the lore accompanying the plants and minerals returned to him, including all that pertained to their medical uses among native practitioners as witnessed by his new world correspondents. It is important to add for the record, moreover, that Monardes was not alone in the search for new medical simples, and that ultimately even the rhetorical appeal of his treatise, together with his scientific claims, can be studied on a comparative basis with the work of a goodly number of contemporaries. ${ }^{7}$

With the publication of La historia, there can be no doubt of Monardes' faith in the healing powers of the simples presented therein, but he had not always endorsed their superiority. As a medical student at the Alcalá de Henares, from which he graduated in 1533, Galenic medicine was in vogue as it was throughout Europe, and his training in pharmacology was entirely traditional, largely derived from the Lexicon artis medicamentaria (1518) of Antonio de Nebrija - which was principally a commentary on the ancients, Dioscorides and Pliny. ${ }^{8}$ Hardly is it surprising, then, that Monardes' earliest work, the Diálogo llamado Pharmacodilosis o declaración medicinal (1536) reveals a strong preference for Greco-Roman sources, and that he gave an unquestioned pride of place to the medicinal plants native to the Iberian peninsula over imports from the West Indies, Florida, or Mexico. There was, in fact, a debate already in progress concerning the relative merits of old and new world plants, with Monardes still on the conservative side. His "conversion" can only be inferred as a matter of professional reflection and discussion. It would have been difficult, ultimately, for any practitioner to deny that a plethora of new plants, the creation of one God and the products of one planet, must be classified, with its component parts finding places in an orderly plan pertaining to healing, and man's role in divining all of the hidden secrets of

college in Tlatilulco in 1552 by the native writer Martín de la Cruz, the manuscript was presented to Don Francisco de Mendoza, the son of the Viceroy of Mexico, but it did not circulate. See Agnes ARBer, Herbals, their Origin and Evolution. Darien, Conn., Hafner Publishing Co., 1938, (rpt. 1970), pp. 104f, and Clara Sue KIDWELL, "Aztec and European Medicine in the New World, 1521-1600", in Lola Romanuccl-Ross et alii (eds), The Anthropology of Medicine from Culture to Method. New York, Praeger Publishers, 1983, pp. 20-31.

7 Among the most important are those by Juan FraGoso, Discursos de las cosas aromáticas, árboles y frutales y de otras muchas medicinas simples que se traen de la India Oriental y sirven al uso de la medicina. Madrid, Francisco Sánchez, 1572, now edited by José Luis Fresouet Febres and republished by the Fundación Marcelino Botín, Universitat de València, 2002. See also Juan de CárdenAs, Primera parte de los problemas y secretos maravillosos de las Indias. México, Pedro Ocharte, 1591; Francisco Bravo, Opera medicinalia. México, Pedro Ocharte, 1570; Gonzalo Fernández de Oviedo, La natural y general historia de las Indias. Huntington Library, MH 177 [ca. 1533]); Francisco HERNÁNDEZ, De historia plantarum Novae Hispaniae [ca. 1580], often reprinted and anthologized under variant names in the seventeenth and eighteenth centuries; Antonio de VILLASANTE, Memorial y Reales Cédulas referentes al bálsamo y demás drogas descubiertas por Antonio de Villasante en la Isla Española. Nov. 1526, Archivo General de Indias, Sevilla, Legajo No. 421; and Augustín FARFÁn, Tratado breve de medicina y de todas la enfermedades. México, Pedro Ocharte, 1592.

8 C. R. BOXER, Two Pioneers..., op. cit., p. 18. 
nature. Equally telling is that in the 1574 edition of La historia, Monardes confirms that he had, by then, been collecting new-world plants for 40 years, an interest reaching back to the time of his first publication. The paradox of that fact in relation to his book is patent. What had moved him can only be assumed, but the observations in his later study underscore the following perspectives: the role of travellers' accounts of the medicinal virtues of these new plants; the notion of planetary wholeness and symmetry which by definition includes new-world simples; the cures brought to his patients through his employment of these new materials on an experimental basis; the opportunity for the commercial exploitation of his new discoveries; and, not the least, the need to remain competitive in the drug trade in relation to Portuguese, Venetian and Genoese commercial ambitions. It was science to be sure, and yet as a book of wonders, who can deny that it also had patriotic and commercial overtones?? All of these primary and secondary layers are worthy of consideration, from science to rhetoric to markets. So what about the rhetorical stances of the treatise?

As a book-culture phenomenon, La historia is subject to diverse classifications. This is because sixteenth-century thinkers were actively pondering the nature of the book itself as a structured cultural artifact, a representation in codex form of the natural orders or cultural institutions they described. In this way, a book could become a memory theatre, a book of games even involving dice and player locations printed on the pages, a garden of pleasant devices, a book of emblems, an atlas, guide, or anatomy, a journey tantamount to an initiation rite or induction into a mystical cult, a museum of curiosities, a place of monuments, or civic and architectural planning, each one related to subject matter which the book could then dispose, set out, order, replicate, and turn into a kinetic process suggesting both place and time. ${ }^{10}$ At this juncture, we need not make a detour into the theory of the book as a chamber of mysteries which corresponds to the mind holding its secrets in ordered impressions and schemas, but by just such capacities for order and retention, the book (much like the modern computer) could serve as a tool in theorizing the nature of mind and memory before the age of the cognitive sciences: mind habits create the orders of books; books replicate the orders of the external world as orders of the mind. Quite simply, in that regard. Monardes' collection is a series of textual places, each one corresponding to a plant, which is the emblem, in pictorial form, providing the link to its remembered properties and promised benefits according to arcane processes. The curiosity cabinet thereby becomes more than a printed museum of oddities which creates the cognitive dissonance attached to those

9 Roderick CAmERon, Viceroyalties of the West. London, Weidenfeld and Nicolson, 1968, p. 14.

10 There is perhaps no better introduction to this complex component of Renaissance thought than Lina BoLzoni's The Gallery of Memory: Literary and Iconographic Models in the Age of the Printing Press, trans. Jeremy PARZEN. Toronto, University of Toronto Press, 2001. This is a translation of La stanza della memoria. Turin, Einaudi, 1995. In this complex study, Bolzoni discusses books as labyrinths, rhetoric machines, games, maps, theatres, chronological repertoires, topical place indexes, buildings, galleries, and the Wunderkammer as in "internal castle." 
intriguing things beyond our established categories of reference. It becomes more than an index of curios for passionate amateurs of the bizarre and marvelous — as it must seem at first glance. Yet that is where we must start. During the sixteenth century pottery, statuary, and fragments of ancient Roman buildings found their ways into humanist collections. Fossils and precious stones were assiduously collected. Regarding fauna and flora, a seminal example is the collection of Konrad Gesner; as a botanist and medical thinker, he created a private park full of exotic plants. ${ }^{11}$ The botanical garden might thereby become its own curiosity cabinet, and by extension the book in which it is catalogued. That provides the connection between gardens and mind places, and mind places and the ordering and storing of information, and thus of memory. Minds organized by such analogous associations (a large part of the humanist mindset) purposefully sought out these juxtapositions and affiliations and then assigned to them a degree of phenomenological depth. Francisco Guerra reminds us that Monardes, as well, maintained a private botanical garden in Seville in which he kept both indigenous and foreign plants. For a long time, as well, he was credited with having an extensive collection of natural objects and curiosities, which, although it proved to belong rather to Argate de Molina, does not diminish the ethos of the wonder cabinet as a category of thought and arrangement. ${ }^{12}$ The treatise, in the first instance, is a simple collection of wonders through which the reader travels from plant to plant, building up a library of specimens, each according to its history, properties, and medical uses. In the process, however, the book becomes the inventory of a collection arranged in a garden, and thus a memory space walked through as though in a horticultural setting as the pages are turned. Books so conceived were a Renaissance passion.

Concurrently, La historia medicinal solicited a place beside other popular scientific inventories of the era, such as Pierre Boaistuau's Certain Secrete Wonders of Nature, as it was called by its English translator, and Ambroise Parés Des monstres et prodiges, published in 1573. Boaistuau's treatise was translated into English as early as 1557, suggesting the level of interest already established among English readers concerning the occult properties of plants and minerals. There was hence a natural context for the translation of Monardes' work into English, which, in fact, followed the full Spanish edition by only a few years. It was the work of John Frampton, a Bristol trader to the Mediterranean ports in the 1560s; his work appeared in 1577 and more than ever fostered the spirit of wonder and a hopeful interest in miraculous healing, as featured in the title: Joyfull Newes out of the newe founde worlde. ${ }^{13}$ Frampton

11 Margaret Hodgen, Early Anthropology..., op. cit., p. 117.

12 Francisco Guerra, Nicolás Bautista Monardes..., op. cit., p. 80.

13 John Frampton, Joyfull Newes out of the newe founde worlde. London, Thomas Dawson for William Norton, 1580. Copies of the 1577 edition are now rare. The work was republished in two volumes in 1925, ed. Stephen GASELEE (London, Constable and Co. Ltd. - New York, Alfred A. Knopf). All citations are taken from this edition. 
came by his knowledge of Spanish the hard way in finding himself arrested and tried by the Inquisition, leading to a carefully planned escape from Cadiz in 1567 after several years of enforced residence wearing the heretic's sambenito. ${ }^{14}$ Just how much Frampton's rhetorically pitched and enthusiastically optimistic title is justified may be sampled in Monardes' account of "The tree that doth showe if one shall live or die." This anecdote came to the good doctor on the authority of the Earl of Niebe, who witnessed the phenomenon in Peru in 1562; upon such a basis, the account could hardly be omitted from the scientific record. According to report, the branches of this tree, held in the left hand, would instantly produce sensations of joy or sorrow when asked whether a sick spouse would live or die. (We must assume that joy signaled imminent health!) Tellingly, there is no differentiation in tone or commentary between this bit of ritual magic and the more studied presentations of pharmaceutical operations. Pains are taken to point out that the practice employing the tree's branches was that of "an Indian of greate reputation." Monardes reports his own reactions: "I was desirous to knowe if that it were soe, and a gentleman of the Peru that had been there many yeares, did certifie and saied unto mee that it was of trueth, that the Indians did this with their sicke people, [for which reason] it hath put mee in admiration, and in much consideration." ${ }^{15}$ Such is his skepticism in brief, and such is his inclination to credit authority on the basis of confirmed report. This is a touchstone example because it is a reminder that this book of marvels and botanical curiosities is also a complete dispensary in which historical anecdote becomes the basis for clinical and pharmaceutical doctrine. Always we come full circle from the science based on authority, to belief, and finally to practice and promise - from the marvelous to the clinic. Frampton, as a trader - in full anticipation of the days when such Englishmen as Sir Walter Raleigh would espouse the trade in New World simples - put forward the entire spirit of medical hope and pharmaceutical merchandising in his literary construction of "joyful news." The point must not be belaboured, but through Frampton's offices, in bringing Monardes to the attention of English readers, and in converting this Spanish pharmaceutical scripture into an English one, there may be seen the foundation for incentives behind the English colonization of Virginia on the basis of commodities formerly little to be imagined. The science of Monardes was self -promoting rhetoric apt for cultural expropriation and ensuing commercial rivalry in the age preceding the Spanish Armada.

Now, once more back to the design of the scientific treatise. The generic design of each article begins with a brief history of the plant, which then moves toward botanical description, then to the humoural classifications and to the degrees of heat or coldness requisite to align them

14 For more on the adventures of Frampton, see Donald BEECHER, "John Frampton of Bristol: Trader and Translator." In Carmine Di BIASE (ed.), Travel and Translation in the Early Modern Period. New York, Rodopi Press, 2006, pp. 103-122.

15 Joyfull Newes, op. cit., vol. II, p. 22. 
with the gradations and applications of the Galenic medical system. Monardes then turns to more clinical considerations, including the preparation and administration of the drugs derived from each simple in relation to the diseases each was disposed to treat. Here and there are to be found brief case studies of patients who had been treated with these new preparations. Monardes does not follow this plan with mechanical precision, often slighting some of the features, but his general purpose in combining history with botanical ordering and clinical reporting is to confirm the place and value of these simples in standard European medical practice. The anecdotal historian and the clinical investigator might have come into conflict, but Monardes harmonized them as parallel sources of authority behind his promotion of each simple, now considered according to the one-plant-one-medication formula (as opposed to the compound, multi-action recipes epitomized by theriaca). The motivations behind such a management of materials need not be rehearsed again in full, but the book's polytypic purposes remain concurrently in mind: a book of wonders, a horticultural inventory, a clinical manual, a book of botanical discoveries, and a book of pharmaceutical propaganda and patriotic promotion.

Monardes did not voyage to the Caribbean in order to build his collection based on personal observation and investigation, and thus he had no choice but to rely upon the scouting intuition and reporting of the returning explorers and soldiers. The selection of plants and minerals was made for him according to what attracted the attention of men otherwise very little interested in such matters. ${ }^{16}$ Peter Osma, one of the few who shared Monardes' vision, wrote to him from Peru, not only to praise his work, but to complain of the indifference to new-world medicications on the part of the colonial Spanish doctors, thus depriving patients of their many healing benefits. His letter was attached to a packet of medical materials from Peru for Monardes' collection, in which he offers several examples of remarkable indigenous cures. ${ }^{17}$ At the same time, he laments the secretiveness of the native practitioners and their unwillingness to share their lore. Monardes, in turn, praises Osma as a modern Dioscorides. More often, however, the materials were carried to Seville by those who had benefited from their use by native healers. Those fortunate enough to escape the threatening tropical disorders through specific herbs were, quite naturally, given to extolling their miraculous powers in deeply superstitious terms. One such herb was the Florida sassafras, the wood (actually the bark and leaves) of which, when steeped, produced a water credited with healing a great number of diseases. Often upon their returns, these men refused to be treated with any other medication, no matter the affliction. Monardes was clearly impressed by their accounts, for "thei began to praise so muche, to confirme the marvelous works of it, with so many examples of them that were there, that surely I gave great credite unto it, and this caused me to believe all that

16 Frank J. Anderson, An Illustrated History..., op. cit., p. 236.

17 Joyfull Newes, op. cit., vol. I, pp. 135-45. 
thereof I had heard." In consequence, he carried a piece of the wood on his person to protect himself from the contagions and pestilences he encountered as a practicing doctor — for which singular virtue he praised God for this marvelous plant. ${ }^{18}$

Monardes' enthusiastic account of this plant had a remarkable afterlife in the history of the earliest attempts by the English to found a colony in Virginia. Through Frampton's translation, the English came to prize the wood of this plant as a cure for many diseases, including syphilis. Thomas Harriot elaborated upon this report in conjunction with the discovery of this wonder-working tree in Virginia in his Briefe and True Report of the New Found Land of Virginia (1590). ${ }^{19}$ Because Monardes' illustration of the tree, replicated in the Frampton translation, also turns up on the famous 1650 map of the region by John Ferrar, the only such botanical feature on the document, it is now being considered as perhaps the best clue in explanation of the lost colony, for arguably its placement on the map marks the locale where the settlers had gone to harvest this tree - a commodity prized by their patron, Sir Walter Raleigh, and for which he held a monopoly. ${ }^{20}$ As stated by David L. Cowan, "The search for, cultivation of, and trade in drugs must take their place among the economic motives behind the building of the British empire in America. Sassafras was one of the most important drugs involved in the process of empire building. Sassafras attained a phenomenal repute." ${ }^{21}$ Little is it known that Raleigh, when he sent Samuel Mace to look for the lost colony in 1602, also commissioned him to ballast his ship, and more, with sassafras lumber. Less is it known that Mace, for want of finding the errant colonists, did just that, and netted a fortune for Raleigh-enough to outfit two new ships. In this historical by-way, all the strata of Monardes' book once again become visible: wonder products, hope for cures, especially of the dreaded syphilis, and mercantile commodification woven into a legendary tale of colonization and loss, and the prospect for enormous profits before illegal rivals broke into the trade and drove the prices down from over 1000 pounds per ton to values in two figures — but that is another story.

The book is, by default measure, an insight into the mental procedures of the sixteenth-century scientific investigator, teased out by inference from the procedures and biases it contains. There is no need to apologize for Monardes as a man of his age. He wore his many hats, as it were, with integrity: the curious collector, the medical historian, the horticulturalist, the physician, the author, the mercantilist, and the patriot. Yet it is recognized just how much these roles might have collided with one another under more rigorous analytical circumstances. The book is full

18 Joyfull Newes, op. cit., vol. I, p. 117.

19 Thomas HARriot, Briefe and True Report of the New Found Land of Virginia (1590). New York, Dover Publications, 1972, p. 9.

20 See Philip S. MCMulLan JR., "A Role for Sassafras in the Search for the Lost Colony", www.lost-colony/ Philpaper.pdf.

21 "Boom and Bust: Sassafras", Apothecary's Cabinet 8 (Fall, 2004), p. 9. 
of examples of his clinical testing, the purpose of which was not only to confirm the virtues and properties of each plant or stone, but to extend the reach of the clinic by extending the curative powers of these simples on a disease by disease basis, each case justified according to the Galenic principles of counteractive agents. A case in point involves the several experiments he carried out with the blood stone, whether in staunching the flow of blood or for curing kidney stones. That he found the stone uniformly efficacious in all instances, based on his clinical trials, ultimately provides the link between the taxonomist and the enthusiast. Description and method, for as long as he can contain himself, gradually gives way to the language of excitement and promotion. "My Ladie the Duchess," he reports, "for that she had in shorte tyme three times, excedying paines of the stone, she made a bracelet of them, and she used to wear it at her arme, and sithence she put them to her arme, she never had more paines of the stone...". ${ }^{22}$ Many other patients in his care reported similar effects so that the stone, in due course, became a much esteemed medicinal commodity. Tellingly, Monardes hints that the stone was rare, thus justifying the high price which made it accessible only to gentlemen. Innuendo follows from such hints: superlative clinical results create demand, rarity appeals to the elite, and hope creates high profits. There is a complex mind at work in the designing of this medical relation. Unconscious patterns are in the making; there are no medical failures; rarely if ever is there a word of doubt or disappointment unless it is a temporary hurdle to an ultimate proclamation of success. Never are there undesirable side effects, whatever is worn or ingurgitated. So many grand successes over a period of forty years is difficult to account for without resorting to matters of belief and intentionality coupled to enthusiasm (thus wonder), and the placebo effect in the clinical testing, for, in effect, there was very little by modern standards that held out any real pharmaceutical promise. It was, in fact, the failure of sassafras to eliminate the symptoms of syphilis that brought the medical world back to the use of mercury as the only functional cure in the later seventeenth- and eighteenth centuries, even though it shortened lives on a regular basis. Better in such cases, I suppose, to rely on faith, hope, and the placebo. But before we trumpet too loudly our skepticism concerning the blood stone, it might be mentioned in passing that mineral healing has staged a comeback in the second half of the twentieth century. Such weakly magnetic materials as haematite, Fe203, once it has been ramped up to Fe304, is still touted to bring relief from headaches, arthritis pain, and sports injuries, while building up the immune system through balancing the magnetic properties of the body's cells when worn as a bracelet of stones (magnetic medicine is currently endorsed in 45 countries); Mesmer is back. In recent years, there have likewise been lavish claims associated with neutraceuticals which promise enhanced memory, concentration, vision and pain relief while posing as super vitamins. My point is not to debunk, but to highlight the rhetorical component of newfound medical wonders with almost irresistible practical appeal. The point is

22 Joyfull Newes, op. cit., vol. I, p. 46. 
made to reduce the temptation to put Monardes on trial for his misconstructions of evidence or pre-modern methodologies. The Renaissance scientist was not merely the amazed and dazzled spectator of mysterious virtues in plants and minerals, but a philosopher who set out to find and harness the occult powers of nature. Healing for them was a miracle of nature based on faith in God's design for human relief through the hidden properties of plants which they could only discover and classify; that was the abiding faith behind every principle of pharmacognosy.

Already hinted at is an emergent received idea about the divine ordering of nature and the implicit symmetrical relationship between the hidden cures, catholicons, and panaceas of the natural world and the register of human diseases. This philosophical perspective, tantamount to a doctrine, held that a perfected knowledge of the natural order would ultimately provide physicians with a comprehensive dispensary for the treatment of all pathological conditions. Research was therefore renewed in view of a faith in the providential order of the universe, the legacy of a benevolent Creator. That faith was based upon the observable properties of plants to function as soporifics, emetics, expectorants and related physiological processes, thereby giving assurance of their secret powers. The virtues of plants aligned with less visible operations, however, had to be advanced on reasoned systemic grounds, having occult powers necessitated merely by their scientific classification, and relationships to body parts and organs largely on emblematic grounds. Yet such reasoning was essential to justify the benevolence of the Creator, whose plan for humankind included the comfortatives of a complete dispensary. The reasoning was circular in the end, insofar as diseases challenged God's love, necessitating man's participation in divining His gifts through research and exploration, which in turn drove the scientific vision of the sixteenth-century pharmacologists: rationalize new plants and justify the ways of God to man. The myth of a nature perfect in its provisions for human health supplied the new quest upon which the integrity of the profession might be restored. Medical credibility had been badly damaged by its failures in the face of such terrible trials as the bubonic plague. The new lease of life afforded to sixteenth century medicine was due largely to a bountiful new supply of untried simples. Hence the renewed botanical quests of the era which sextupled the count of catalogued plants within a period of a century. Even Doctor Faustus had caught the fever, for his final request of Mephistopheles, in Marlowe's celebrated play, after asking for a book of incantations and spells, and another on the motions and dispositions of the heavenly bodies, was a book "Wherein I might see all plants, herbs, and trees that grow upon the earth." Among his intellectual fantasies, through the help of secret powers, was a completed herbal for the entire world. ${ }^{23}$ The spirit of discovery thereby echoed in many fields, extending the spirit of rebirth invested in the label supplied to that age by nineteenth-century historians. With the gradual arrival of the new materials, the hopes for "joyful news" remained in the air.

23 Doctor Faustus, ed. David Scott KaStan. New York, W.W. Norton, 2005, II.1.169-171; p. 26. 
In the realm of practical research, this faith promoted the compilation of the great sixteenth-century herbals, the cumulative work of a number of indefatigable botanists: Mattioli, Foës, Lange, Fuchs, Gorraeus, Dodoëns, L'Obel, and L'Écluse. At the end of the fifteenth century scarcely 1,000 plants had been catalogued, most of them derived from the works of the classical herbalists, Theophrastus, Dioscorides, and Pliny the Elder. By 1623, Gaspar Bauhin could boast the careful description of some 6,000 plants in his monumental Pinax. Monardes' descriptions of new-world plants entered this collective enterprise through the offices of the Flemish naturalist Charles L'Écluse, who translated his work into Latin and incorporated it into his own monumental Atrebatis exoticorum liber decimus, a book that knew many editions and that circulated widely in the Latin-reading scholarly community. ${ }^{24}$ L'Écluse had performed much the same service for the work of Acosta on the medicinal plants of Peru, and of Garcia de Orta who, as a practicing physician in the Portuguese colony of Goa, spent a thirty-year period, roughly synonymous with the collecting years of Monardes, in the preparation of his Coloquios dos simples, e drogas he cousas mediçinais da India, published in 1563.

The doctrine of natural symmetry, made possible by occulting the powers of many medicinal plants, was widely endorsed by medical philosophers and was implicitly expressed by many works dealing with the virtues and properties of plants. Examples include De la faculté et vertu des medicamens simples of Ambroise Paré, ${ }^{25}$ and the widely popular Occulta naturae miracula of Levinus Lemnius, a work that was published in 1561, and that circulated not only in Latin but in several vernaculars (including in English, albeit only after 1658). Lemnius based his observations on the idea that many medicinal plants possess occult relationships with specific parts of the body, and that these plants collectively are part of a complex system of correspondences linking the plant world to pathological conditions. ${ }^{26}$ Lemnius was a serious and admired physician, but his investigation of the secret powers in natural agents whereby they were made useful in healing processes, in a sense linked to ritual magic, also made their appeals as mirabilia, generating the book of wonders for the common reader that brought him so much success as an author. Medicine and magic, description and wonder, once more joined forces in the popular imagination; Lemnius had pitched his work in precisely these terms. There was simply no escape from this doubly focused construction of the pharmaceutical world. As stated earlier, harnessing these occult powers was the work of researchers mandated philosophically by a divine purpose. Monardes expresses his mission in such terms at the close of his first book: "Seeyng that in the fields untilled, and in the Mountaines and Desertes, our

24 (Antwerp, Raphael Plantin, 1605). L'Écluse had translated the Dos libros as early as 1574 in epitomized form as De simplicibus medicamentis ex Occidentali India delatis, which was republished with the third part in 1582 and again in 1593.

25 Oeuvres complètes, ed. J.-F. Malgaigne. Paris, 1840-41 (rpt. Geneva, Slatkine Reprints, 1970).

26 See The Secret Miracles of Nature: In Four Books. London, Jo. Streater, 1658, p. 259. 
Indias doth geve them unto us, the fault is ours that wee doe not followe after it, nor seeke to doe the diligence that is conveniente, for to profite oure selves of these marveilous effects, the which I doe truste that the tyme being the discoverer of all thinges, and good diligence and experience will shewe it us unto our greate profite." ${ }^{27}$ Discovery, time, the marvellous, and the benefit of humankind forms a credo that conveys an optimism, a mood of promise that is but a short rhetorical step away from the credulous enthusiasm necessitated by the doctrine itself.

Perhaps, in completing the profile of the treatise in relation to its formulations and intentionalities, something might be said of its dimension of material self-interest. Uncharitable as it would appear, Monardes' enthusiasm for the flawless efficacy of his simples may also have stemmed in part from a subsumed motive of profit. After all, he had kept his findings hidden from published exposure for upwards of forty years, arguably not so much for the sake of scientific certainty or considered testing, but in order to reserve the exotica of his dispensary for his own exclusive practice, thereby controlling demand and prices in his own favour. Monardes' medical practice in Seville had been a lucrative one, by all circumstantial indications. It is certainly what we expect of him given the great wealth he was in possession of at the time of his death. He had indulged in the West African slave trade; he had made investments in houses and property; and he had been involved in the importation of high-priced drugs. He relates, for example, how the high demand for the rhubarb emetic from Michoacan had driven the price up to twenty ducats per pound, and how those prices in turn had caused the market to be flooded with inferior substitutes. Of these matters, he cared, and his concerns are true to form regarding the development of the drug trade generally. Such motives, by inference, seem even more relevant to Frampton by dint of his mercantile interests and his pitch to an English audience, patriotically predisposed to seek their advantage at the cost of Iberians generally. Where the Fuggers fit into this scenario is an intriguing question, insofar as they held the monopoly for guaiacum as the sovereign cure for syphilis. The importation of this precious Caribbean wood, fully described in La historia, produced high profits for as long as its reputation could be maintained. In that regard, with or without intention, Monardes' scientific endorsement served as advertisement for Fugger interests. ${ }^{28}$

Just where the divsions fell in Monardes' mind between science, medical practice, and commercial promotion is, of course, now beyond recovery, because all the parts are essential to the aspirations associated with any one part: demand through wonder; classification and cultivation; clinical experimentation; authorship and dissemination; and perhaps a quest for fame. Even his

27 Joyfull Newes, op. cit., vol. I, p. 170.

28 A. G. MORTON, History of Botanical Science. London, Academic Press, 1981, p. 120. An account in Aretino's Dialogues testifies to the implementation of guaiacum as a cure for this dreaded sexually transmitted disease when his courtesan speaks of having "to dose yourself with guaiacum" to retard its ravages. Trans. Raymond Rosenthal. New York, Stein and Day, 1971, p. 16. 
work as an historian of new world materials and practices served to raise curiosity, wonder, and demand. The remaining subtext in his enterprise is the role of Spanish traders and the guardianship of their interests as the sole suppliers of materials from their own empire. How those matters were balanced in Monardes' mind can only be imagined: the desire for secrecy to the benefit of his own practice; and the desire to share his findings through print. There must have been a debate. Self-interest, altruism, commercial calculations and purveyorships, or a desire for fame, who can say? And finally, where, does this treatise fit into the sentiments of a patriot anxious to abet his country in the exploitation of all of her colonial riches? The book, in its way, seeks to perpetuate the myth of the eternal bonanza by broadening the range of lucrative commodities. One tactic, as a writer, was to play upon the human fear of disease and a yearning for health through the celebrations of novel medical materials. After all, much of the politico-economic drive of sixteenth-century Spain had been defined by the promise of wealth, beginning with Columbus' obsession with gold. As Carl Saur explains, "Columbus had a genius for words, not as to their proper meaning but to cast a spell and to persuade." It was his habit to idealize everything he found, to describe desolate lands as resembling Andalusia in the spring, and above all as abounding in gold. From his accounts, "the sovereigns and people of Spain became imbued by his obsession, picturesquely and fantastically presented. The course of Spanish empire was first turned to its fateful search for gold by the idée fixe that dominated Columbus." ${ }^{29}$ We have come full circle to the realm of rhetoric and the propaganda of discovery through the generation of wonder and desire. Monardes could also be thought of as having an idée fixe that would extend the definition of new-world wealth to include its precious materia medica, materials which, in their capacity to bring cures, might attain values — indeed commercial values — equal to the yield of all the mines of Mexico. This could be achieved only through an assault upon the popular imagination in the form of an authoritative scientific appeal. It must rely upon the magic of words to construct both substance and hope. In this way, the doctrines pertaining to the provisional and providential design of the material world in relation to health, through indexation, practice, and praise, might be vulgarized in the collective consciousness. Such an assessment is merely an extension to the work of a collector and curiosity seeker eventuating in a book of wonders.

Through John Frampton's translation, Monardes' materials and subsumed themes are given one last dimension of rhetorical fashioning. It is curious to think how the gesture of translation itself from Spanish to English, and from culture to culture, carries an implicit degree of construction. Frampton, as an English merchant-turned-writer, we might suppose, was more interested in the exotic dimensions of the original than in its matter-of-fact accounts of botanical and mineralogical materials. That bias is made clear in his choice of a title, one that was adopted during a "stop press" in the first London printing. Here is that inspiration in full:

29 The Early Spanish Main. Berkeley and Los Angeles, University of California Press, 1966, pp. 290-291. 
Joyfull Newes out of the Newe founde Worlde wherein is declared the rare and singular vertues of diverse and sundrie hearbes, trees, oyles, plantes, and stones, with their aplications, aswell for phisicke as chirurgerie, the saied beyng well applied bryngeth suche present remedie for all deseases, as maie seme altogether incredible: notwithstandying by practize founde out, to bee true; also the portrature of the saied hearbes, very aptly described.

From the title onwards, Frampton structures reader expectations in terms of the "rare and singular" and the "incredible." Readers purchased to find bizarre tales, wonder drugs, and miracle cures. Just how much or little literal credence the Elizabethan reader gave to these claims, despite the sobriety of the evidence, is beyond direct demonstration. As Jonson suggests in The Alchemist, early moderns were as given to pseudo-science, inordinate desire, and gullibility as they were to good sense, principles of probability, and scepticism, and in proportions not unlike those of posterity. Perhaps they read Frampton as they watched plays with fabulous characters in fabulous lands, or read the romances of Palmerin and Amadis de Gaule. But with the fact of New Spain, the fact of new plants, and the established medical belief structures and principles of medicine, the enthusiasm for these putatively miraculous simples was altogether more phenomenally plausible than tales of fantasy. Those which are allowably true constitute the most intriguing wonders of all.

Moreover, there is one phrase in Frampton's dedication to his patron Sir Edward Dyer that gives further cause for reflection upon the materialization of dreams and desire. "And since the afore saied Medicines mentioned in the same worke of Doctour Monardes, are now by Marchauntes and others, brought out of the West Indias into Spaine, and from Spain hether into Englande, by suche as dooeth daiely trafficke thether..." ${ }^{30}$ we have it upon the word of a much-travelled and experienced Bristol trader that in 1577 these materials were actively imported to England on a daily basis, presumably for incorporation into English medicine; hope was at their doors for "all diseases." This is a bit of rhetorical assertion worth verification, for it goes against all that would seem possible. By 1577, diplomatic relations with Spain had been strained to the limit; the Queen's duplicity in encouraging Drake as a raider on the Spanish Main had become transparent. The treacherous attack by the Spanish in 1569 on the fleet of Sir John Hawkins while anchored in the Mexican port of San Juan Ulloa had been a turning point. By the end of the 1560s the Inquisition had made the residence of English merchants in Spain untenable. Not only owners and officials, but common seamen before the mast, had been its target. ${ }^{31}$ By then, the Barlows and the Thornes, also trading out of Bristol, had been

30 Joyfull Newes, op. cit., vol. I, p. 4.

31 E. M. TENISON, Elizabethan England, Being the History of this Country in Relation to All Foreign Princes, 13 vols.. Royal Leamington Spa, 1933, Vol. II, p. 120. 
forced to give up their Spanish trade, a salient fact, given that the Thornes, at one point, had been factors in the Canaries and the West Indies. Regarding Frampton's final sojourn in Spain, there were two differing accounts, according to Francisco Guerra, of how he had been arrested, imprisoned and tortured, and how he managed to escape some ten years before the appearance of his translation. ${ }^{32}$ For Guerra, there are hints, moreover, that his translations of Spanish books on navigation and exploration — on all subjects in fact - were a form of revenge insofar as they offered to the English raiders more explicit information about Spanish domains, commerce, and navigational savoir faire, and to the common reader an increased fascination for things commercially interdicted. But then, could Frampton have simply confabulated that daily commerce? That is work for others, for the embargo was lifted in 1573 for a time, and even during the period of relative non-communication during the 1580s, business may have remained business, and there may have been collusion among merchants to unload merchandise from Seville in the south of France and reload it into English bottoms. In a broader sense, the statement also expresses at least a provisional trade based on a very real belief in the unique medicinal value of Spain's imported materia medica. ${ }^{33}$ Whether his statement of daily trade is more to be regretted than real, it serves nevertheless, to impose probability upon the merely possible. Even though the turning of actual profits in Spanish materia medica seems unlikely, the statement fires the imagination. More research is, meanwhile, called for in terms of the use of these ingredients in actual English medical practice insofar as, to my knowledge, few were household items, and scarcely more than half a dozen of the seventy-one simples appear in the great Pharmacopoeia Londinensis of 1618, which was by far the most complete list of phamaceuticals then in use in England. Among the six to appear-and precisely those we would expect-are to be found the Michoacan root, sassafras, guaiacum wood, and nicotiana. Frampton, too, was a rhetorician to the ends already set out, namely the sale of books on the mirabilia of the discoveries, hope for miraculous cures, profit, and discomfiture of the Spanish navigators blended together, each one hiding the other in the guise of an at-home entertainment in the age of exploration. The very appeal of the book for the English reader may well have been the play of the possible at a time of expanding mercantilism. Spain was an increasingly forbidden world making news from its shores that much more appealing, and tales of wonder cures have always piqued the fancy. Rhetoric in that regard is an act of persuasion, if only to the suspension of disbelief. Monardes the scientist and Frampton the translator make their pitches to the curiosity cabinet of the mind where substance meets belief in a state of intellectual excitement.

32 Nicolás Bautista Monardes..., op. cit., pp. 97-8.

33 For a short history of Anglo-Spanish trade relations during the reign of Elizabeth, see Donald BEECHER, "John Frampton of Bristol...", op. cit., pp. 103-21. 


\section{BIBLIOGRAPHY}

\section{Manuscripts}

Fernández de Oviedo, Gonzalo, La natural y general historia de las Indias. Huntington Library, MH 177 (ca. 1533).

Sahagún, Bernardino de, Historia universal de las cosas de la Nueva España [ca. 1555]. Biblioteca del Palacio Real, Madrid, Sig. No. 1280.

Villasante, Antonio de, Memorial y Reales Cédulas referentes al bálsamo y demás drogas descubiertas por Antonio de Villasante en la Isla Española. Nov. 1526. Archivo General de Indias, Sevilla, Legajo No. 421.

\section{Printed sources}

Aretino, Pietro, Dialogues. Trans. Raymond Rosenthal. New York, Stein and Day, 1971.

Bravo, Francisco, Opera medicinalia. México, Pedro Ocharte, 1570.

Cárdenas, Juan de, Primera parte de los problemas y secretos maravillosos de las Indias. México, Pedro Ocharte, 1591.

Farfán, Augustín, Tratado breve de medicina y de todas la enfermedades. México, Pedro Ocharte, 1592.

Fragoso, Juan, Discursos de las cosas aromáticas, árboles y frutales y de otras muchas medicinas simples que se traen de la India Oriental y sirven al uso de la medicina. Madrid, Francisco Sánchez, 1572 (Ed. José Luis Fresquet Febres. Fundación Marcelino Botín, Universitat de València, 2002).

Frampton, John, Joyfull Newes out of the newe founde worlde. London, Thomas Dawson for William Norton, 1580 (Ed. Stephen Gaselee. 2 vols. London: Constable and Co. Ltd. - New York, Alfred A. Knopf, 1925). Harriot, Thomas, Briefe and True Report of the New Found Land of Virginia (1590). New York, Dover Publications, 1972.

L'Écluse, Charles. Atrebatis exoticorum liber decimus. Antwerp, Raphael Plantin, 1605.

Lemnius (Lemne), Levinus, The Secret Miracles of Nature: In Four Books. London, Jo. Streater, 1658.

Marlowe, Christopher, Doctor Faustus. Ed. David Scott Kastan. New York, W.W. Norton, 2005.

Monardes, Nicolás, Primera y Segunda y Tercera partes de la Historia Medicinal de las Cosas que se traen de nuestras Indias Occidentales que sirven en Medicina. Sevilla, Alonso Escribano, 1574 (facs. ed. Sevilla, Padilla Libros, 1988).

Orta, Garcia de, Coloquios dos simples, e drogas he cousas mediçinais da India. Goa, por Ioannes de Endem 1563.

Paré, Ambroise, Oeuvres complètes. Ed. J.-F. Malgaigne. Paris, 1840-41 (rpt. Geneva, Slatkine Reprints, 1970). 


\section{Secondary sources}

Álvarez López, E., "Nicólas Monardes y los botánicos europeos del siglo xvi”, Las Ciencias 14 (1949), pp. 139-49.

Anderson, Frank J., An Illustrated History of the Herbals. New York, Columbia University Press, 1977.

Arber, Agnes, Herbals, their Origin and Evolution. Darien, Conn., Hafner Publishing Co., 1938, (rpt. 1970.

Beecher, Donald, “John Frampton of Bristol: Trader and Translator", in Carmine Di Biase (ed.), Travel and Translation in the Early Modern Period. New York, Rodopi Press, 2006, pp. 103-22.

Bolzoni, Lina, The Gallery of Memory: Literary and Iconographic Models in the Age of the Printing Press. Trans. Jeremy Parzen. Toronto, University of Toronto Press, 2001.

Boxer, C. R., Two Pioneers of Tropical Medicine: Garcia d'Orta and Nicolás Monardes. London, Wellcome Historical Medical Library, 1963.

Cameron, Roderick, Viceroyalties of the West. London, Weidenfeld and Nicolson, 1968.

Cowan, David L., "Boom and Bust: Sassafras”, Apothecary's Cabinet 8 (Fall, 2004), p. 9.

Емmart, Emily Walcott, “Concerning the Badianus Manuscript. An Aztec Herbal, 'Codex Barberini, Latin 241' (Vatican Library)", Smithsonian Miscellaneous Collections 94.2 (1935), pp. 1-11.

Guerra, Francisco, Nicolás Bautista Monardes, su vida y su obra [ca. 1493-1588]. México, Compañía Fundidora de Fierro y Acero de Monterrey, S.A., 1961.

Hodgen, Margaret, Early Anthropology in the Sixteenth and Seventeenth Centuries. Philadelphia, University of Pennsylvania Press, 1971.

Kidwell, Clara Sue, “Aztec and European Medicine in the New World, 1521-1600”, in Lola Romanucci-Ross et alii, The Anthropology of Medicine from Culture to Method. New York, Praeger Publishers, 1983, pp. 20-31.

Lasso de la Vega, Javier, Biografía y estudio critico de las obras del médico Nicolás Monardes. Sevilla, Tipografia de la Revista de Tribunales, 1891 (facs. ed. Sevilla, Padilla Libros, 1988).

León, Nicolás, "El doctor Nicolás Monardes: sus servicios a la materia médica y terapéutica americanas", Gaceta Médica de México 57 (1926), pp. 553-68.

López Piñero, José María, “Las 'nuevas medicinas' americanas en la obra (1665-1574) de Nicolás Monardes”, Asclepio 42.1 (1990), pp. 3-67.

López Piñero, José María, La Historia Medicinal de las cosas que se traen de nuestras Indias Occidentales (1565-1574), de Nicolás Monardes. Madrid, Ministerio de Sanidad y Consumo, 1989.

MÁs-Guindal, Ascensión, "Datos históricos sobre los materiales farmacéuticos importados de América en el siglo xvi", Anales de la Real Academia de Farmacia 4 (1943), pp. 37-82.

McMullan Jr., Philip S., "A Role for Sassafras in the Search for the Lost Colony”, www.lost-colony/Philpaper.pdf.

Morton, A. G., History of Botanical Science. London, Academic Press, 1981.

Pereyra, Carlos, Monardes y el exotismo médico en el siglo xvi. Madrid, Biblioteca Pax, 1936. 
Rodríguez Marín, Francisco, La verdadera biografía del Doctor Nicolás Monardes. Madrid, Tip. de la «Rev. de Archivos», 1925 (facs. ed. Sevilla, Padilla Libros, 1988).

SAUR, Carl, The Early Spanish Main. Berkeley and Los Angeles, University of California Press, 1966.

Stünzner, Kurt, Die Schrift des Monardes über die Arzneimittel Americas. Halle, Max Niemayer, 1895.

Tenison, E. M., Elizabethan England, Being the History of this Country in Relation to All Foreign Princes. 13 vols. Royal Leamington Spa, 1933. 


\title{
Literatura e Medicina: alguns textos de Justo Lípsio e de dois doutores Luís Nunes ${ }^{1}$
}

\author{
ANTÓNIO GUIMARÃES PINTO²
}

\section{RESUMO:}

Pretendo neste artigo estabelecer, em primeiro lugar, a relação familiar, desatendida até hoje, que une três nomes ilustres na medicina dos séculos xVı e xVII, estabelecidos em Antuérpia, conquanto de confessa e orgulhosa origem portuguesa, e, em segundo lugar, cingindo-me ao viés literário, que é o que sobretudo me interessa, coligir e publicar alguns textos latinos do avô e neto homónimos (Luís Nunes) e duas peças epistolares de Justo Lípsio, que evidenciam a boa conta em que Álvaro Nunes e seu filho Luís eram tidos pelo prestigiado e bem conhecido polígrafo flamengo.

\section{PALAVRAS-CHAVE:}

Luís (sénior e júnior) e Álvaro Nunes; cristãos-novos; medicina e literatura; Justo Lípsio.

\begin{abstract}
:
In this article we tried to reach two main goals. On one hand, to establish the family connections between three well renowned Portuguese doctors of Hebrew ascent of xVI and xVII centuries, whose careers took place in the Flemish city of Antwerp: Luís Nunes the eldest, his son Álvaro Nunes and and his grandson Luís Nunes, whose portrait was painted by Rubens and is now at London's National Gallery. By the other hand, we present here the latin originals and Portuguese translations of some samples of the litteray legacy of the homonymous grandfather and grandson (Luís Nunes), and two letters by Justus Lipsius, that give evidence of the admiration and friendship of this prestigious Flemish author towards Álvaro Nunes and his son Luís.
\end{abstract}

\section{KEYWORDS:}

Luís (grand father and grandson) and Álvaro Nunes; Portuguese Hebrews; Medicine and Literature; Justus Lipsius

1 Este trabalho foi desenvolvido no âmbito do projecto de I\&D "Dioscórides e o Humanismo Português: os Comentários de Amato Lusitano" (http://amatolusitano.web.ua.pt) do Centro de Línguas, Literaturas e Culturas da Universidade de Aveiro, financiado por Fundos FEDER através do Programa Operacional Factores de Competitividade - COMPETE e por Fundos Nacionais através da FCT - Fundação para a Ciência e a Tecnologia, no âmbito do projecto FCOMP-01-0124-FEDER-009102.

Ao Dr. Arlindo Correia devo pronta e abundantíssima ajuda bibliográfica, sugestões pertinentes e palavras de alento que em grande parte mitigaram as forçosas limitações de quem pratica a investigação científica em pleno coração da região amazônica. Aqui publicamente se consigna a gratidão penhorada de quem tanto the deve.

2 Universidade Federal do Amazonas: aguimaraesp@gmail.com. 


\section{DE SANTARÉM A ANTUÉRPIA: TRÊS GERAÇÕES DE MÉDICOS HUMANISTAS}

No ano de 1983, em artigo intitulado “O 'Doctor Ludovicus Nonius' retratado por Rubens", ${ }^{3}$ o Professor Costa Ramalho ocupou-se, com suculenta brevidade, do percurso biográfico e literário (mais exatamente na vertente histórico-geográfica) do célebre médico luso-flamengo Luís Nunes, hoje conhecido como um dos patriarcas da dietética e, sobretudo, pelo retrato em que o imortalizou o célebre pintor seu conterrâneo, e que pode ver-se na National Gallery, de Londres. ${ }^{4}$ No sentido de determinar as raízes portuguesas do autor objeto da sua nótula erudita, Costa Ramalho colige e esmerilha uma série de textos literários e documentais que versam sobre as biografias de três médicos, de sobrenome Nunes e pertencentes a três sucessivas gerações: 1) um Luís Nunes, inequivocamente de Santarém e que floresceu na terceira, quarta e quinta décadas do século Xvi, 2) um Álvaro Nunes, largamente biografado por Barbosa Machado, 3) e um segundo Luís Nunes, retratado por Rubens, também biografado pelo abade de Sever e que as fontes impressas, sem exceção, dão como filho de Álvaro. No final do seu artigo, e perante a relativa escassez dos dados compulsados, Costa Ramalho, com a sua habitual sagacidade e sábia cautela, conclui nos termos seguintes: "Qual a relação entre este Luís Nunes 5 e o do retrato de Rubens, com quem já tem sido confundido? É difícil que não sejam parentes. Será este Luís Nunes o pai de Álvaro Nunes (Ludovici filius, no epitáfio)? Pode ser, mas não garanto. Se assim for, teremos uma linhagem de três médicos distintíssimos, verdadeiras sumidades na sua época, em que os dois mais conhecidos, e do mesmo nome, são avô e neto. Mas o parentesco não passa de hipótese."

Procurando alicerçar com elementos mais concretos esta hipótese, e fundando-me quase exclusivamente em fontes fidedignas e coetâneas das três personalidades visadas, penso que as pesquisas que empreendi, de que resultaram os elementos que a seguir se expendem, permitem afirmar, com a segurança possível neste tipo de estudos, que de facto o Dr. Luís Nunes, natural de Santarém e residente em Antuérpia na derradeira quadra da sua vida, foi pai do Dr. Álvaro Nunes e avô do Dr. Luís Nunes, cujas vidas e atividade profissional decorreram, se não totalmente (no caso de Álvaro), pelo menos na sua grande parte, naquela cidade portuária do sul dos então chamados Países Baixos.

3 Publicado na revista Mundo da Arte 16 (Dezembro de 1983), pp. 15-18.

4 A identificação do Dr. Luís Nunes com o médico representado neste retrato de Rubens só se fez em 1950, pelo crítico de arte L. Burchard, que apontou como terminus ad quem para a pintura do quadro 1627, ano no qual o médico antuerpiense publicou a sua obra mais importante, o tratado Diaeteticon siue de re cibaria libri IV. Veja-se o artigo de Marco Romano, "Rubens e l'erma ritratto di Ippocrate. La memoria dell'antico in un ritratto di Ludovicus Nonnius", Journal of History of Collections 22.1 (2010), pp. 15-27.

5 O santareno: cronologicamente, o primeiro da série.

6 "O 'Doctor Ludovicus...", op. cit., p. 18. 
Assim, se acudirmos ao imenso repositório de informaçóes sobre médicos portugueses da primeira metade do século Xvi, que é o In Dioscoridis Anazarbei de medica materia libros quinque, de Amato Lusitano, editado pela primeira vez em $1553,{ }^{7}$ verificamos que um Luís Nunes (ou, na forma latina, Ludovicus Nonius) aparece a dialogar com o Autor da p. 131 à 138, no decurso de três enarrationes ou comentários.

$\mathrm{Na} 1^{\mathrm{a}}$ aparição é identificado, na nota marginal, como Ludouicus Minius Sanctarensis, gralha no sobrenome que já se encontra correta na alusão que a ele se faz mais à frente, na p. 285, onde se lê a forma Nonius. É o seguinte o teor das palavras que o confrade lhe atribui:

LVDOVICVS: De iis praeceptores nostri Salmaticenses parum nos instruxere, imo eos, qui de simplicibus curam habebant, simplices appellabant.

LUÍS: Sobre este assunto os nossos professores de Salamanca pouco nos ensinaram, ou antes, chamavam 'simples' aos que se preocupavam com os símplices. ${ }^{8}$

Daqui se conclui que Luís Nunes, de Santarém, foi condiscípulo de Amato Lusitano nas aulas de medicina que este frequentou em Salamanca. Mais rico de conteúdo biográfico é o seguinte diálogo, entre Luís Nunes e Amato Lusitano, que podemos ler um par de páginas mais à frente:

LVDOVICVS: Hanc ipsam plantam quam Galenus intelligit et Dioscoridem intellexisse, scholasticis meis, cum publice Colimbriae interpretarer, saepe dixi. AMATVS: Scio certe, cum nos duo e Salmaticensi, nobili apud Hispanos gymnasio, in Lusitaniam reuerteremur, te publice medicinam apud Colimbricenses regis mandato legisse, imo ibidem tibi in eo munere primas delatas recordor. Sed ego, relicta Lusitania, ut qui, abhinc decem et octo annis, praesagieram quae nunc euenisse audio, regios contempsi honores et in Antuerpiam me recepi, ubi septennium egi, et inde illustrissimi ducis Ferrariae, Herculis secundi, iussu, Ferrariam ueni, sub cuius clientela sexennium moratus sum, ubi quoque publice artem medicam professi sumus et multa a uiris doctissimis in re anatomica et herbaria didiscimus. LVDOVICVS: Vtinam eo tempore tecum sentissem, nec in illo regno tam longam traxissem moram, ut Germanorum mores citius dinoscere potuissem, quibuscum hodie Antuerpiae felicissime deuersor.

LUÍS: Esta mesma planta, que Galeno conheceu, e eu muitas vezes, quando lecionava em Coimbra, disse aos meus alunos que Dioscórides conhecera. AMATO: Sei muito

\footnotetext{
7 Em Veneza, por Gualterus Scotus.

8 Op. cit., p. 132.
} 
bem que, quando nós os dois regressámos de Salamanca, nobre Academia na Espanha, para Portugal, tu foste lente de Medicina em Coimbra por nomeação régia, ou melhor, lembro-me de que te ofereceram no mesmo lugar uma posição vantajosa. Mas eu, depois de deixar Portugal, como alguém que há dezoito anos atrás previra aquilo que ouço que agora está a acontecer, desprezei as honrarias régias e acolhi-me a Antuérpia, onde vivi sete anos, e daí, obedecendo ao mandado do ilustríssimo duque de Ferrara, Hércules II, vim para esta cidade, permanecendo seis anos sob a sua proteção, onde também ensinei publicamente a arte médica e muito aprendi de anatomia e botânica com varôes de grande saber. LUÍS: Prouvera a Deus que nessa época tivesse pensado como tu, e não me houvesse demorado naquele reino durante tanto tempo, por forma a ter podido conhecer mais cedo os costumes das gentes germânicas, entre as quais mui venturosamente hoje vivo em Antuérpia. ${ }^{?}$

Daqui claramente se colige que Luís Nunes e Amato regressaram na mesma época de Salamanca para Portugal, donde o segundo, pouco tempo volvido, se retirou com destino a Antuérpia, tendo o primeiro permanecido durante mais alguns anos na pátria, na qual, por convite régio, desempenhou honroso cargo docente na Universidade de Coimbra. De forma mais ou menos sibilina, tanto Amato como Luís Nunes se referem aos difíceis momentos por que, na época pouco anterior à impressão do livro, e que corresponde ao tempo narrativo deste diálogo, passava a comunidade cristã-nova residente em Portugal: o primeiro, congratulando-se pela antevisão da perseguição desencadeada após a sua saída da pátria, e o segundo, lastimando por ter tardado tanto em aperceber-se da gravidade da situação, exprimindo porém este queixume sob a elegante (ou arteira) forma de reconhecer que esta tardança em desterrar-se o privara de, durante aqueles anos, gozar das delícias da hospitalidade flamenga, de que desfrutava em Antuérpia, onde "mui venturosamente hoje vivo."

Ora, para melhor estabelecermos as datas que balizam o percurso biográfico de Luís Nunes, recorde-se que Amato Lusitano abandonou Salamanca por volta do ano de 1532, permanecendo na pátria até 1534, data do seu estabelecimento em Antuérpia, três anos portanto antes de D. João III determinar a transferência da Universidade de Lisboa para Coimbra. ${ }^{10}$

9 Op. cit., p. 134.

10 Pouco depois da sua chegada a Antuérpia, para onde se deslocou a mando do mercador Henrique Pires, Amato Lusitano foi processado por permanência ilegal, em meados de outubro de 1534. Cf. António Manuel Lopes Andrade, "Ciência, Negócio e Religião: Amato Lusitano em Antuérpia", in Inês de Ornellas e CASTRO e Vanda ANASTÁCIo (coord.), Revisitar os Saberes - Referências Clássicas na Cultura Portuguesa do Renascimento à Época Moderna. Lisboa, Centro de Estudos Clássicos - Faculdade de Letras da Universidade de Lisboa, 2010, pp. 9-49. 
Escutemos agora novo diálogo travado entre os dois colegas médicos, a propósito da romã e de um episódio de contornos burlescos a que deu azo o desconhecimento do latim por parte de um boticário parisiense:

LVDOVICVS: Monendi hic pharmacopolae sunt ne per malum Punicum intelligant id quod seplasiarium quidam Parisiensis intellexit, cum medicus describeret suci malorum Punicorum siue malorum granatorum, ille crassae Mineruae, hebes ingenio et ignarus uocum, cum ex malis granatis, et illis quidem optimis, sucum extractum amandare debuerat, tantum abfuit ut optima aut bona intellexerit poma ut potius putrida et corrupta acciperet, ex quibus sucum putridum extractum ad miserum aegrotantem misit, credens utique per mala, non poma, sed mala, putrida, corrupta ac flaccida granata intelligi debere. AMATVS: Abhinc decem annis rem ita euenisse audiui, imo Petrus Fernandus amicus noster, qui magna cum gloria apud Anglos Londini medicinam excercuit et nunc prospere apud Venetos agit, mihi libellum ubi haec scripta erant Antuerpiae indicauit, quae tu postea, in ea epistola quam Lexico Nebrissensis Antuerpiae excusso apposuisti, ad memoriam reuocasti.

LUÍS: Aqui convém ter-se de sobreaviso os boticários, para que não entendam por romã ${ }^{11}$ o que entendeu certo droguista parisiense, que, tendo o médico prescrito suco de romãs, ele, por boçalidade, escassa inteligência e ignorância das palavras, quando lhe cumpria aviar o suco extraído de romãs, e estas das melhores, de tal maneira deixou de entender que se tratava das boas e melhores que antes entendeu que se tratava das podres e corruptas, de que extraiu um suco fétido e podre que mandou ao mofino do doente, cuidando que devia entender-se por mala não os pomos, mas as romãs ruins, podres, estragadas e murchas. AMATO: Há dez anos atrás ouvi dizer que isso aconteceu, e até o nosso amigo Pedro Fernandes, que com grande prestígio exerceu a Medicina em Londres, na Inglaterra, e agora trabalha com êxito em Veneza, me indicou em Antuérpia o livrinho onde se contava este episódio, a que tu depois te referiste naquela carta que antepuseste ao Dicionário de Nebrija, publicado nesta cidade. ${ }^{12}$

Antes, porém, de me ocupar desta alusão à participação de Luís Nunes numa edição do Dicionário de Nebrija, vejamos a última referência que Amato Lusitano faz na sua obra

11 Em latim malum Punicum. A confusão deu-se por o inepto boticário ter confundido o substantivo malum 'pomo' com a forma neutra do adjetivo malus, $a$, um 'mau'.

12 Op. cit., p. 137. 
In Dioscoridis enarrationes ao seu colega santareno. Surge ela no comentário de Rhapontico (uulgo rheubarbo da ponto), a propósito do qual escreve:

Proinde rhaponticum hoc Graecorum diuersum a uulgari rhabarbaro esse, non solum figura, sed uiribus ipsis certissimum est. Cum autem haec litteris mandaremus, huius radicis Ponticae partem ad Antonium Musam Brasauolam, uirum doctissimum, misimus, ueluti ad Antuerpienses, ut inde singularis doctrinae uir Ludouicus Nunius, Santarenensis, Lusitanus, in Hispaniam ad amicos transmittat.

Por isso não há dúvida alguma de que este rhaponticum dos Gregos é diferente do ruibarbo comum, não só no aspeto, mas nas suas propriedades específicas. Ora, ao registar isto por escrito enviei um pedaço desta raiz do Ponto a António Musa Brasavola, varão doutíssimo, e outro para Antuérpia, a fim de que daqui o português de Santarém Luís Nunes, homem de excecional saber, o remeta para os amigos na Península Ibérica. ${ }^{13}$

Com esta afirmaçáo ficamos certificados de que, no ano de 1553 , correspondente ao da impressão da obra de Amato, Luís Nunes, se não residia com caráter permanente, pelo menos estava de alguma forma vinculado a Antuérpia. Antes de avançarmos no tempo, convirá, porém, citar a documentação referente à sua carreira académica e atuação profissional na pátria.

Ora, Sousa Viterbo e Maximiano Lemos citam e transcrevem documentos, procedentes dos arquivos universitários, passados em nome de Luís Nunes, e que o dão como regendo, na Universidade de Lisboa, Filosofia Moral, a partir de 4 de dezembro de 1529, com a categoria de substituto, e como provido em Súmulas, em 30 de outubro de 1530, sendo reconduzido por mais três anos nesta cadeira no final do triénio, por provisão datada de 16 de outubro de 1533, fazendo, durante este período de tempo, exame privado para receber o grau de doutor em medicina. ${ }^{14}$ Se alguma dúvida poderia levantar-se sobre este Luís Nunes ser o mesmo de que nos ocupamos, ${ }^{15}$ penso que ela não terá cabimento em relação à pessoa do mesmo nome que, em 17 de outubro de 1541, é nomeada, em Coimbra, lente de Terça de Medicina, ou seja,

13 Op. cit., p. 285.

14 Maximiano Lemos, "Amato Lusitano. Correcções e aditamentos. Amato Lusitano nos Países Baixos", Revista da Universidade de Coimbra 10 (1927), pp. 5-38; Sousa VITERBO, Notícia sobre alguns médicos portugueses ou que exerceram a sua profissão em Portugal. Segunda série. Lisboa, 1895, pp. 12-13. Ambos estes autores podem ver-se citados em Francisco Leitão FerReIRA, Notícias Cronológicas da Universidade de Coimbra, edição publicada, revista e anotada por Joaquim de CARVALHO, $2^{\text {a }}$ parte, volume II. Coimbra, Imprensa da Universidade, 1940, pp. 182-189.

15 Sobretudo ocasionada por Amato se referir a uma docência universitária exclusivamente conimbricense e imediatamente posterior ao regresso à pátria, numa época em que a Universidade ainda funcionava em Lisboa: o que aliás, em boa verdade, é um deslize ou lapso de memória de somenos, explicável pelo já longo desterro do médico albicastrense. 
responsável pela regência de Avicena, e que é aquela mesma a cujo cargo universitário, aparentemente prestigiante, Amato Lusitano se referira. Três anos depois, em outubro de 1544, o Dr. Luís Nunes figura na lista dos ordenados pagos pela Universidade de Coimbra, cabendolhe o montante de 70.000 réis por ano. ${ }^{16}$

Com data de 11 de junho de 1545, Luís Nunes, de Santarém, endereça, de Antuérpia, a frei Diogo de Murça, reitor da Universidade de Coimbra, uma carta-dedicatória que vemos impressa à testa de nova edição do célebre Dicionário latim-espanhol, de Élio António de Nebrija, que, naquele mês e ano, o editor Steelsius fez sair dos seus prelos antuerpienses e, conforme prometia a página de rosto:

iam denuo innumeris dictionibus locupletatum. Cui praeter omnes editiones, Auctoris eiusdem acessit Medicum Dictionarium hactenus nondum typis euulgatum, a Ludouico Nunio philosopho ac doctore Medico peritissimo, a mendarum colluuie, qua scatebat, defaecatum.

agora de novo enriquecido com inúmeras palavras e acrescentado de um dicionário médico do mesmo autor que não figurava nas ediçôes anteriores e nunca foi impresso. Limpo da enxurrada de erros, que o inundava, por Luís Nunes, filósofo e doutor em Medicina, peritíssimo.

Esta interessante carta latina foi transcrita e traduzida pelo Professor Costa Ramalho, ${ }^{17}$ e dela respiguei os passos seguintes, de interesse para o escopo biográfico que é o nosso:

Italiam profecturus dum hac iter ago [...] loci cum amplitudine, tum et nobilitate allectus, plusculis quam decreueram diebus immoratus

De viagem para Itália, ao passar por aqui (...) demorei-me mais uns dias do que antes decidira, atraído pela grandeza e pela nobreza do lugar; ${ }^{18}$

cum Salmanticae discerem inibique publice docerem no tempo em que eu estudava em Salamanca e aí mesmo ensinava; ${ }^{19}$

qua diui Hieronymi collegio insigni, cui etiam praees, e tot unum me medicum adscripseras

16 Mário Brandão, Actas dos Conselhos da Universidade de 1537 a 1557, volume I. Coimbra, Imprensa da Universidade, 1941, p. 110.

17 Latim Renascentista em Portugal. Coimbra, C. E. C. H., 1985, pp. 160-173. As traduções que apresento do título do Dicionário e desta carta introdutória da edição de 1545 são da autoria do Professor Costa Ramalho.

18 Op. cit., p. 160

19 Op. cit., p. 162. 
Ao associares-me (...) como o único médico, ao insigne colégio de S. Jerónimo de que eras e continuas a ser o presidente. ${ }^{20}$

Como se vê, tendo, aparentemente, pensado em utilizar Antuérpia como mero ponto de passagem para viagem cujo destino era a Itália, Luís Nunes, em junho de 1545 sentiu-se cativado pelas comodidades e encantos que a cidade flamenga lhe oferecia, e decidiu protelar a partida. Confirma-nos também a sua anterior passagem por Salamanca, não só como aluno (conforme já ficáramos sabendo pelo texto dialogado inserto nas Enarrationes de Amato, atrás citado), mas igualmente como docente, e, finalmente, inteira-nos das boas relaçóes que entretivera em Coimbra com o reitor da Universidade, o ilustre hieronimita transmontano frei Diogo de Murça, relaçóes que com certeza se estreitaram pelo facto de o médico santareno prestar em exclusividade assistência clínica aos mestres e alunos do colégio universitário da Ordem religiosa a que frei Diogo pertencia.

Sou levado a pensar que, apesar da excelente impressão que Antuérpia lhe causara, Luís Nunes não assentou por então arraiais nesta cidade e decidiu tentar a sorte alhures. Se realmente chegou a rumar a Itália é algo que desconheço, mas a verdade é que parece indubitável a sua estância por alguns anos, talvez próximos dos dois lustros, em territórios de língua francesa. É que, entre janeiro e março de 1550, vêmo-lo dirigir, datada de Lausana, uma carta latina ao célebre humanista, tradutor do Novo Testamento para castelhano e reformador religioso Francisco de Enzinas, também residente em território helvético. O teor da carta, para além das gentilezas da praxe neste tipo de correspondência entre homens criados ao calor do humanismo, tem a ver sobretudo com a dificuldade em atinar com a correta nomenclatura das plantas: ao que cuido, Nunes, assoberbado com os seus afazeres médicos, promete para sazão mais desafogada os esclarecimentos relativos a dúvidas, presumo que relativas à designação vernácula para algumas plantas que punham problemas ao burgalês Enzinas, na empresa a que entáo se entregava de traduzir as Escrituras para a sua língua. ${ }^{21}$

Mais documentada nos aparece a sua estadia em França, ao serviço da rainha Catarina de Médicis, esposa de Henrique II. De facto, além do testemunho que constitui a carta-prefácio à $2^{a}$ edição antuerpiense do Dicionário de Nebrija, de 1553, que publico e traduzo neste artigo, que Luís Nunes escreveu 'no seu 'escritório de Paris', Andrés Laguna, na nota explicativa dirigida "Al benigno lector", que podemos ler no fl. Iiii vo do seu Dioscorides, saído dos prelos de Iuan Latio, de Antuérpia, no ano de 1555, informa: "Ayudaronme opportunamente para

20 Op. cit., p. 170.

21 Esta carta pode ver-se transcrita e traduzida para espanhol em Epistolario de Francisco de Enzinas. Texto latino, traducción española y notas de Ignacio J. García PINILLA. Genebra, Librairie Droz, 1995, pp. 508-511. O tradutor e anotador desta carta afirma, não sei com que base documental, que Nunes "se encontraba asentado en Lausana desde años antes." 
el tal negocio con muchos nombres Portugueses, de los quales yo no tenia entera noticia, El Doctor Luys Nuñez, Excellente Medico de la Serenissima Reyna de Francia: y Varon raro de nuestros tiempos."

Esta informação, em que parece fazer-se referência a um cargo que Nunes então ainda desempenhava, é corroborada e ampliada pelo passo seguinte de uma carta que o embaixador Francisco Pereira escreveu, de Bruxelas, ao rei D. João III, com data de 11 de novembro de 1558: "A rainha de Ingraterra está melhor das suas terçãs, como tenho escrito a Vossa Alteza, e per cima disto el-rei mandou agora o doutor Luís Nunes, português, que está assentado em Enveés, que cá tem nome de grandíssimo físico, e já de Paris veo com este nome, onde esteve alguns anos quando saiu desse reino." 22

Convém esclarecer que, apesar das melhoras aqui anunciadas, a rainha de Inglaterra, Maria Tudor, morreu a 17 de novembro de 1558, no palácio de St. James, em Londres, em consequência de uma epidemia de gripe, aqui designada por "terçãs", e que o 'rei' aludido na carta de Francisco Pereira é o então rei-consorte de Inglaterra, Filipe, em breve Filipe II de Espanha, que se encontrava nessa ocasiāo nos Países Baixos, donde, pelos vistos, enviou a Inglaterra o Dr. Luís Nunes para tratar da sua esposa: sem êxito, como os factos demonstraram. Também ficamos certificados de que em 1558 o Dr. Luís Nunes já estava “assentado” em Anvers (ou Antuérpia), cidade onde deve ter morrido em data que ignoramos.

Tal desconhecimento não se verifica com seu filho, o Dr. Álvaro Nunes, cujo epitáfio nos foi transmitido pelo seu contemporâneo Laurentius Beyerlinck, na obra Opus Chronographicum orbis uniuersi ab anno 1572 usque ad annum 1611, Antuerpiae, ex typographeio Hieronymi Verdussii, 1611. Com efeito, na secção consagrada aos varôes ilustres falecidos em 1603 nos Países Baixos, o antuerpiense Beyerlinck escreve o seguinte:

\begin{abstract}
Venio ad Aluarum Nonnium [...] magno in pretio apud magnos semper habitus et principum nostrorum archiater assiduus fuit. Bibliothecam habuit diuite librorum supellectile instructam, quam Ludouico Nonnio filio reliquit, qui, patriis uestigiis inhaerens, eruditionis merito Medicinae etiam lauream consecutus, uarios aliarum insuper scientiarum thesauros sibi comparauit. Sed et optimum parentem funeris tumulique pio honore affecit et ad D. Iacobi Antuerpiae (qua in urbe olim ille floruit) conditum, aeterno hoc elogio inter mortales aeternum superesse uoluit:
\end{abstract}

Vou agora ocupar-me de Álvaro Nunes (...) sempre tido em grande conta pelos grandes e que foi médico assistente dos nossos príncipes. Possuiu uma biblioteca ricamente ataviada de livros, que deixou a seu filho Luís Nunes, o qual, seguindo as pisadas de seu pai, depois

22 Apud Notícias cronológicas da Universidade de Coimbra, op. cit., p. 183. 
de merecidamente alcançar renome como médico e erudito, além disso enricou-se com os diversificados tesouros de outros saberes. Mas também como bom filho honrou o excelente pai com o funeral e o túmulo e, sepultando-o na igreja de S. Tiago, em Antuérpia (cidade na qual outrora brilhara) quis, mediante o seguinte eterno elogio, que eternamente ele sobrevivesse entre os mortais: ${ }^{23}$

Ora, curiosamente, é só bem mais à frente, na p. 294, que pode ver-se transcrito este epitáfio latino, que Barbosa Machado reproduz com exação da obra de Beyerlinck na entrada consagrada a Álvaro Nunes, e que damos em tradução de Américo da Costa Ramalho: "A Álvaro Nunes, filho de Luís, / De 60 anos de idade, falecido a 9 de dezembro de 1603, / Filósofo e médico da corte, / Ilustre por cultura e virtude, / Caro aos magnates. / A sua gentileza usou-a com todos, / Ele para quem nada foi mais caro na vida, do que dá-la aos outros, / Nada na morte mais agradável, que passar a uma vida melhor. / Mandaram colocar muito merecidamente (esta lápide) / a Mulher ao marido, os filhos ao pai." ${ }^{24}$ Convém referir que, no texto original, o numeral 60 está escrito em letras romanas, pelo que não será de descartar a possibilidade, mais verosímil para este tipo de numeração, de ter escapado alguma(s) letra(s), por exemplo um (ou dois) $X$. Parece militar a favor desta suposiçáo uma excelente gravura, da autoria do artista de Antuérpia Jan Wierix (1549-c.1618), de que existem exemplares nas coleçóes de vários museus (por exemplo, no Prentenkabinet do Museu Boimans van Beuningen, de Roterdão), e que representa, conforme reza a epígrafe: ALVARVS NONIVS LVDOI. F. H. N. ["Álvaro Nunes, filho de Luís"], a qual igualmente nos informa do ano em que o retrato foi executado: 1586. Além do nome do gravador (Johannis Wieriecx fecit), no lado esquerdo da legenda vê-se um brasão, com paquife e elmo encimado por cabeça de serpente, no qual se representa parte de antebraço, saindo de manga tufada, e uma mão segurando um livro. O retrato, aberto a buril, reproduz a cabeça e a parte superior do tronco de um homem de tipo mediterrânico, usando barba e bigode, com idade que acho poder estimar-se, sem grande margem de erro, entre os cinquenta e os sessenta anos, e que portanto orçaria a casa dos setenta à data do óbito.

23 Op. cit. no corpo do texto, p. 272.

24 Américo da Costa Ramalho, "O 'Doctor Ludovicus...", op. cit., p. 15. 


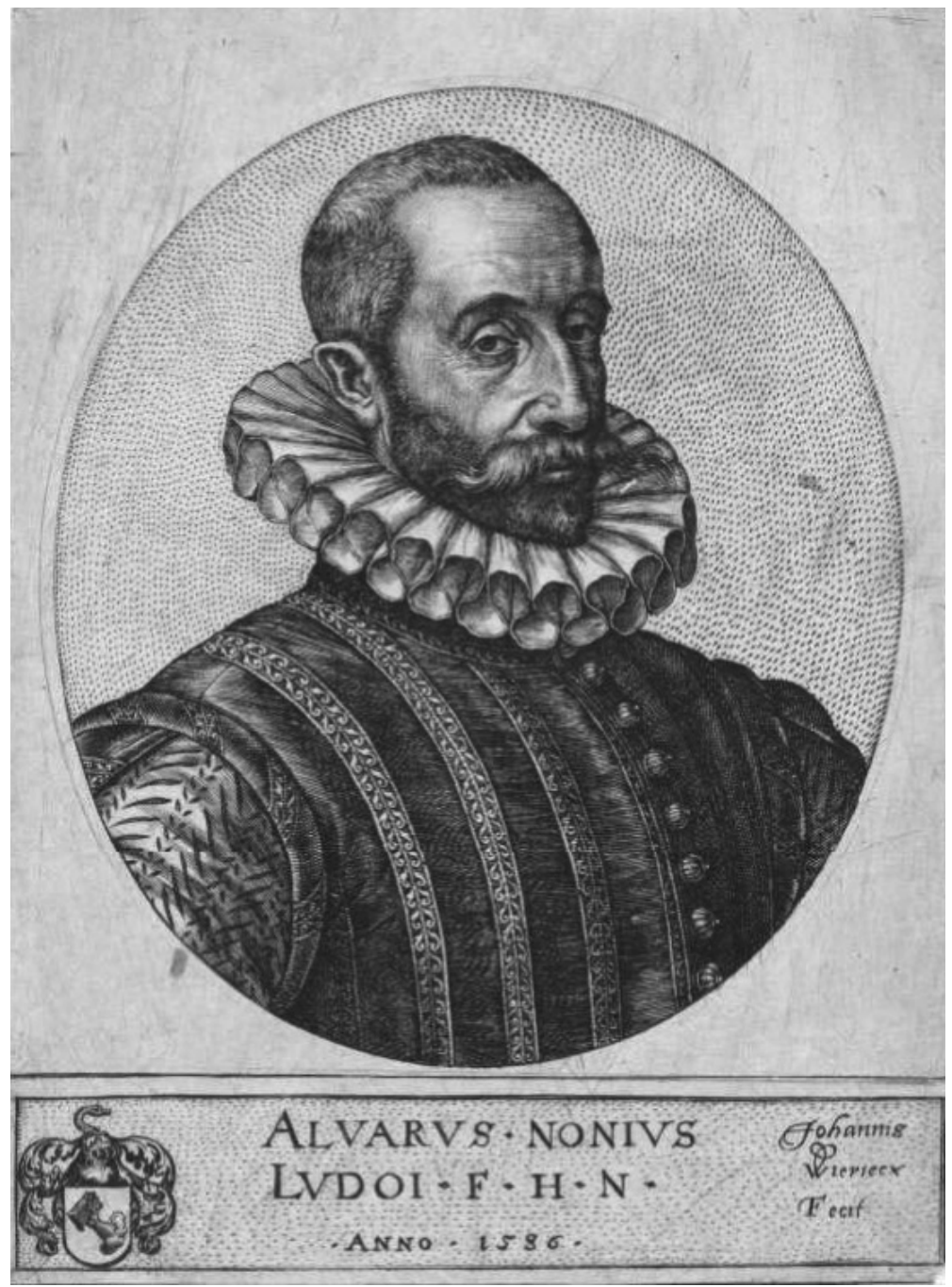

Figura 1 - O Dr. Álvaro Nunes. Gravura de Jan Wierix

Mais me corroboram na convicção de que se encontra mal transcrita por Beyerlinck a idade de Álvaro Nunes à data da sua morte as palavras que lhe consagra Benedito Arias Montano, no livro em que o nosso médico deixou o seu único legado científico-literário, as quais fazem supor um homem maduro que, em 1573, já estaria longe dos trinta que teríamos de atribuir-lhe, no caso de aceitarmos como corretos os sessenta em romano da inscrição transcrita no Opus Chronographicum. Com efeito, o célebre editor de Antuérpia, Cristóvão Plantino, entregou à luz 
da publicidade, no ano de $1574,{ }^{25}$ uma obra intitulada De recta curandorum unlnerum ratione et alii eius artis praeceptis libri II, da autoria do médico-cirurgião espanhol Francisco Arceo, na qual, da p. 3 à 11, podemos ler uma Prefação, da autoria de Benedito Arias Montano, escrita em Antuérpia, a 22 de abril de 1573, e onde o conhecidíssimo biblista, ademais de fazer a calorosa apresentação do autor, tal como ele natural de Fregenal de la Sierra, na atual província de Badajoz, se refere também nos termos seguintes ao Dr. Álvaro Nunes:

[8] Vt autem opus non sine digno ornamento, quamquam genio ipso suo ornatissimum esset, tamen cultius prodiret in publicum, uoluit doctissimus ac mihi suauissimus amicus Aluarus Nonnius, Hispanus, qui Antuerpiae litterarum ac disciplinarum uariarum studiis ingeniosissimam dat operam ac medicinam cum aegrotantium usu exercet, alteram partem, chirurgicam uidelicet, breuibus atque eruditis annotationibus illustrare, ut [9] ostenderet quam apte quamque diligenter antiquorum medicorum doctrinam Arcaeus noster persequatur [...].

ora, a fim de que esta obra não saísse a lume desprovida do merecido atavio, conquanto já por sua própria natureza estivesse muitíssimo bem ataviada, mesmo assim para que surdisse ainda mais elegante, quis o mui douto e meu prezadíssimo amigo Álvaro Nunes, hispânico, que em Antuérpia se dedica com imenso talento a estudos de letras e de variadas ciências e exerce a medicina com proveito dos doentes, ornamentar com breves e eruditas anotaçôes a primeira parte, ou seja, a consagrada à cirurgia, por forma a [9] mostrar o quão competente e desveladamente o meu conterrâneo Arceo segue os ensinamentos dos médicos da Antiguidade (...).

Logo depois deste texto preambular, da p. 12 até à p. 16 encontra-se uma carta com o seguinte cabeçalho: Ad Benedictum Ariam Montanum, theologum celeberrimum, Aluarus Nonnius. ["Álvaro Nunes ao mui afamado teólogo Benedito Arias Montano”], que infelizmente não encerra quaisquer achegas autobiográficas que aqui nos interessem, o mesmo sucedendo com as anotações médicas, ${ }^{26}$ às quais Arias se referira e que se apresentam no final dos capítulos da parte do livro consagrada à cirurgia (até à p. 210).

25 Conquanto no colofão se leia: pridie nonas Nouembris, anno Domini 1573.

26 Estas cartas proemiais, assim como todo o livro, foram recentemente publicados e traduzidos para espanhol em edição da responsabilidade de Andrés Oyola FABIÁn e José Miguel CoBos Bueno: Francisco ARCEO, Método verdadero de curar las heridas. Huelva, Servicio de Publicaciones de la Universidad de Huelva, 2009. Com o desplante habitual nos autores espanhóis (no caso vertente, supostamente versados em língua latina), os tradutores-comentadores expeditamente transformaram em 'espanhol' o Álvaro Nunes, que Arias Montano genérica e corretamente designara por 'hispânico' (hispanus). 
Finalmente, Florbela Veiga Frade, na sua dissertação de doutoramento, ${ }^{27}$ fundada em documentação original existente nos arquivos portugueses e flamengos, mostrou-nos a plena integração e posição de relevo do Dr. Álvaro Nunes dentro da nação ou comunidade portuguesa de Antuérpia. De facto, em 1571 e 1572 o seu nome consta da lista dos portugueses que residiam com suas famílias em Antuérpia; ${ }^{28}$ em 1584 vêmo-lo a gerir, de parceria com Rodrigo da Veiga, de Évora, o consulado português; ${ }^{29}$ consignando, enfim, um registo de 1591, que a assistência médica aos portugueses mais pobres era por ele assegurada.

Sabendo nós que o Dr. Álvaro faleceu em 1603, penso não haver dúvidas de que o Dr. Nunes que faz parte de uma lista, datada de 1604 e publicada pela investigadora que estamos a seguir, com os nomes dos membros da comunidade portuguesa residente em Antuérpia, ${ }^{30}$ não pode ser outro senão seu filho Luís, que já aparece com o título e nome completo num rol com as mesmas características do ano de 1611: ${ }^{31}$ com o que nos vemos chegados ao membro mais jovem e conspícuo desta ilustre família de médicos humanistas. No entanto, antes de prosseguirmos com a biografia do filho, cabe a pergunta sobre o lugar onde o pai veio ao mundo e a Universidade em que adquiriu tão grande e unanimemente reconhecido saber médico. Nada de concreto consegui apurar, e as afirmaçôes anacrónicas e infundamentadas de alguns escritores nem sequer merecem o trabalho da refutação. Ora, se atentarmos no que ficou dito sobre a vida mais ou menos errante do pai (designemo-lo por Luís Nunes 'Sénior') e a idade presumível do filho, penso não ser muito arriscado supor que o seu nascimento se deu em terras lusitanas e, quem sabe, em Lisboa, ${ }^{32}$ em cuja Universidade tudo indica que o Dr. Luís Nunes ensinou na década de 30 do século xvi. Podemos também conjeturar, no domínio da especulação, que tenha acompanhado o pai quando este abandonou a pátria e, se não ficou logo em Antuérpia ao cuidado de familiares ou amigos, não é inverosímil que tenha estanciado em terras de França e aí estudado Medicina. É também possível que seja ele o Alvarus Novius Lusitanus cuja inscrição se encontra consignada no registo de matrículas da Universidade de Lovaina com a data de 28 de agosto de 1560, mas a inexistência nos arquivos desta Universidade de quaisquer outras informaçóes curriculares ou pessoais deixa-nos a dúvida,

27 As relações económicas e sociais das comunidades sefarditas portuguesas. O trato e a família: 1532-1632, tese de doutoramento em História Moderna apresentada à Faculdade de Letras da Universidade de Lisboa, 2006 (policopiada).

Op. cit., pp. 369 e 371.

29 Op. cit., p. 279.

30 Op. cit., p. 375.

31 Op. cit., p. 377.

32 Berço que de resto Barbosa Machado the dá, para logo em seguida falhar de modo estrondoso ao afirmar que o Dr. Álvaro veio de Lisboa para os Países Baixos acompanhando como médico o arquiduque Alberto, que, conforme se sabe, entrou pela $1^{a}$ vez em Bruxelas em fevereiro de 1596: ou seja, Álvaro Nunes, na melhor das hipóteses, só teria vivido em Antuérpia os derradeiros sete anos da sua vida... 
não apenas sobre se se trata da mesma pessoa, como também sobre a existência anterior de quaisquer titulaçóes ou preparo académico. ${ }^{33}$

Sendo meu desígnio, na primeira parte deste artigo, de cariz mais histórico, como no começo ficou declarado, apenas estabelecer os laços de parentesco e a linhagem lusitana dos três médicos de sobrenome Nunes cuja vida e carreira se encontram também fortemente ligadas à cidade de Antuérpia, no caso do Dr. Luís Nunes 'Júnior' (nomeemo-lo assim para destrinçá-lo do avô homónimo) bastar-nos-á apontar os dados essenciais da sua biografia e coligir uma ou outra notícia, veiculada por autores seus contemporâneos, atinente aos aspetos que especificamente aqui me importam. Ora, a unanimidade dos autores mais recentes que do Dr. Luís Nunes se ocuparam estão acordes em relação aos seguintes dados biográficos: ${ }^{34}$ nasceu em Antuérpia em 1553, graduou-se em Medicina em Lovaina, em torno de 1577, e morreu na cidade natal com 92 anos, portanto em $1645 .{ }^{35}$

Quanto às referências de coetâneos e conterrâneos, em 1623 o professor do Colégio Trilingue, de Lovaina, Valerius Andreas, autor de um dicionário de autores naturais dos Países Baixos, assim lhe traça o perfil humano e intelectual

Ludouicus Nonnius, Aluari, medici Lusitani, filius, Antuerpiae natus, medicus, et ipse excellens, historicus, poeta. In singulis ostendit ingenii praestantiam, uariam doctrinam, antiquitatis notitiam non uulgarem. Ad haec, tractabilis et comis moribus: talem certe fatentur qui praesentem absentemque norunt aliquando. Scripsit hactenus:

Luís Nunes, filho do médico português Álvaro, natural de Antuérpia, médico, e como tal excelente, historiador e poeta. Em cada uma destas áreas mostra superior inteligência, saber variegado e um conhecimento incomum da antiguidade. Além disso, simpático e

33 Veja-se Arnold H. Schillings, Matricule de l'Université de Louvain, IV (1528-1569). Bruxelas, 1963, p. 606. Curiosamente, entre todos os estudantes matriculados entre 1545 e 1560, o outro único de nome próprio Álvaro que se nos depara, é um Alvarus Almaras, inscrito em 13 de agosto de 1554 , identificado como Antuerpiensis, ou seja, como natural da cidade onde o nosso compatriota constituiu família e desenvolveu toda a sua atividade profissional.

34 Nomeadamente os seguintes, que, a despeito de aqui e além claudicarem (sobretudo quando se referem a realidades ou nomes portugueses), nos pareceram mais bem informados: Leonard Jan BRUCE-ChwATt, "Ludovicus Nonnius, M. D., 1553-1645", Bulletin of the New York Academy of Medicine 60.9 (November 1984), pp. 938-943; A. R. FERRAZ, "The Portuguese background of Ludovicus Nonnius", Derde Symposium Geschiedenis der geneeskundige wetenschappen. Nonius en de 'dietetiek'. 2 december 1995. Academia Regia Belgica medicinae - Dissertationes - Series Historica, 5. Bruxelas, Kon. Akademie voor Geneeskunde, 1996, pp. 55-66; Hans PoHL, Die Portugiesen in Antwerpen, 1567-1648: zur geschichte einer Minderheit. Wiesbaden, Franz Steiner, 1977, pp. 108-109; Jean-Pierre TRICOT, Ludovicus Nonnius (1553-1645): humanistisch geneesheer, grondleger van de medische dietetiek. Beveren, Herman Cols, 1984.

35 De facto, a dedicatória que o autor escreveu para a $2^{a}$ edição do Diaeteticon, editada em Antuérpia, apud Petrum Bellerum, está datada pridie Idus Maiis 1645. 
de trato afável, como certamente confessam os que alguma vez o conheceram, ou diretamente ou de outiva. Escreveu até hoje:" segue-se a relação das obras publicadas até à data. ${ }^{36}$

A edição do mesmo livro, publicada em 1643, impressa também em Lovaina por Iacobus Zegers, na entrada correspondente a Luís Nunes, nas pp. 636-637, apresenta um texto idêntico, acrescentando apenas, às obras publicadas até entâo, o Diaeteticon, que saíra a lume em 1626. Dois anos depois, em 1628, o antuerpiense Franciscus Sweertius publica, na sua cidade natal e apud Guglielmum a Tungris, uma obra com o mesmo desígnio da acabada de citar, e sob a qual se lançou a acusaçáo de havê-la plagiado, intitulada Athenae Belgicae siue Nomenclator inferioris Germaniae scriptorum, na qual, nas páginas 521 e 522, se pode ler o seguinte:

Ludouicus Nonius, Aluari medici Lusitani filius, natus Antuerpiae, mihi a longo tempore, medicus elegans, poeta clarus, antiquarius sollers, utriusque linguae peritissimus, comis moribus

Luís Nunes, filho do médico português Álvaro, nascido em Antuérpia, meu íntimo amigo de longa data, médico distinto, poeta ilustre, perspicaz investigador de antiguidades, conhecedor a fundo do latim e do grego, de trato afável.

Enumerava em seguida as obras publicadas até então, acrescentando: Breui daturus: Elogia Hispanorum armis illustris, ["Em breve dará a lume Elogios de hispânicos ilustres na guerra"] obra esta que, ao que me foi possivel averiguar, nunca saiu à luz pública, pelo que o espólio literário de facto publicado por Luís Nunes 'Júnior' é aquele que o leitor interessado poderá encontrar minuciosamente descrito por Barbosa Machado.

\section{LITERATURA E MEDICINA: ORIGEM DOS NOSSOS TEXTOS}

Transcrevi e traduzi do latim cinco textos a que, segundo penso, a epígrafe 'Literatura e Medicina' assenta na perfeição. De facto, a carta-dedicatória a frei Diogo de Murça, do santareno Luís Nunes, é uma boa amostra das boas avenças que era possível existirem, e amiúde se davam no século Xvi, entre a medicina e o conhecimento das culturas e línguas grega e latina. Quanto às duas cartas de Justo Lípsio, endereçadas, uma a Álvaro Nunes, e a outra a seu filho Luís, pela sua qualidade intrínseca, que é a que seria de esperar por virem da pena de um dos maiores escritores em latim da segunda metade do século XVI, merecem o nosso apreço

36 Bibliotheca Belgica. Lovanii, apud Henricum Hastenium, 1623, p. 584. 
de amantes da boa latinidade, mas interessam-nos sobretudo por terem como destinatários dois médicos ilustres que nunca renegaram a sua origem portuguesa. Finalmente, no caso dos dois poemas de Luís Nunes 'Júnior', o próprio género escolhido pelo autor é índice inequívoco dos propósitos e pendores literários deste médico multifacetado, hoje sobretudo lembrado como um dos pioneiros da dietética.

1. A Carta-dedicatória a frei Diogo de Murça ocupa os fólios Aij-Aiij do Dictionarium latinohispanicum, et uice uersa hispanicolatinum, Aelio Antonio Nebrissensi interprete, nunc denuo ingenti uocum accessione locupletatum pristinoque nitori, sublata mendarum colluuie, Ioannis Belleri ope ac studio restitutum. Ad haec, Dictionarium propriorum nominum ex probatissimis Graecae et Latinae linguae auctoribus, addita ad calcem neoterica locorum appellatione concinnatum, Antuerpiae, in aedibus Ioannis Steelsius, 1553, longo título que, em vernáculo lusitano, quer dizer: "Dicionário de latim-espanhol e, vice-versa, de espanhol-latim, da autoria de Élio António de Nebrija, agora de novo enriquecido com um acréscimo de imensas palavras e, depois de alimpado da enxurrada de erros, restituído ao seu original primor graças ao desvelo e trabalho de João Bellerus. Além disso, aditou-se um dicionário de nomes próprios, a partir dos mais aprovados autores das línguas grega e latina, a que se ajuntaram no final as modernas designaçôes dos lugares. Em Antuérpia, nas oficinas de João Steelsius, 1554.”

Conforme atrás se disse, Luís Nunes no ano de 1545 já introduzira esta mesma obra e a colocara sob a proteção de frei Diogo de Murça, a quem se dirige de novo com o mesmo desígnio, informando do mesmo passo que esta nova edição se apresenta significativamente melhorada em relação à anterior. Como o leitor poderá verificar, neste breve escrito o autor revela-se um verdadeiro médico-humanista, em quem o conhecimento das línguas e autores greco-latinos vai de par com uma consciência aguda das responsabilidades sociais, no sentido da ampla difusão do saber, que impendem sobre o intelectual probo. Para cumprir com este imperativo ético escreve Nunes - , cumpre dar de máo a pequenas vaidades e orgulhos mundanos, proclives a ver com olho crítico e comentar com língua malédica o facto de um médico de renome perder o seu tempo com coisa aparentemente tão de somenos, como seja patrocinar e colaborar na edição melhorada de um dicionário.

2. A breve e elegantíssima carta que Justo Lípsio dirigiu, de Liège e com data de 24 de junho de 1592, ao Dr. Álvaro Nunes, faz parte do imenso espólio epistolar daquele polifacetado e conhecidíssimo polígrafo flamengo, e encontra-se impressa em Iusti Lipsii epistolarum selectarum centuria tertia ad Belgas, Antuerpiae, ex officina Plantiniana apud Ioannem Moretum, 1602. ["Terceira centúria de cartas seletas de Justo Lipsío, dirigidas a pessoas originárias dos Países Baixos, em Antuérpia, da oficina de Plantino, na casa de João Moretus"] Colige-se da leitura desta missiva que o Dr. Álvaro Nunes interviera como medianeiro do grão-duque da Toscana, 
que pretenderia estender a sua asa mecenática, e com certeza ter junto de si em Florença, o prestigiado homem de letras flamengo, que elegantemente se escusa, alegando motivos de saúde. O tom da carta e a referência a contactos pessoais, aquando de uma anterior visita de Lípsio a Antuérpia, legitimam a nossa convicção de que, à semelhança do pai e do filho, o Dr. Álvaro Nunes era, além de excelente médico, homem de pendores literários, como aliás já atrás vimos, ao citarmos os testemunhos de Arias Montano ("dedica-se com imenso talento a estudos de letras") e do cónego Beyerlinck ("possuiu uma biblioteca ricamente ataviada de livros”).

3. A carta que Justo Lípsio escreveu e remeteu de Lovaina, a 21 de setembro de 1604 , ao Dr. Luís Nunes 'Júnior', pode ver-se na página 5 do livro Iusti Lipsii epistolarum selectarum centuria quinta. Miscellanea postuma, Antuerpiae, ex officina Plantiniana apud Ioannem Moretum, 1607. ["Quinta centúria de cartas seletas de Justo Lipsío. Póstuma, a diversos destinatários, Em Antuérpia, da oficina de Plantino, na casa de João Moretus"] Trata-se de uma carta de conteúdo quase exclusivamente histórico-literário, na qual um dos homens do século XVI mais eruditos em história e cultura clássicas trata de igual para igual e se louva no discernimento e profundo saber do médico luso-flamengo. Forram-nos de aqui tecer mais comentários as anotaçóes que fizemos à carta de Lípsio e mediante as quais - através da transcrição de passos pertinentes do epítome histórico-geográfico de Nunes intitulado Hispania, pela primeira vez publicado em 1607 — ficará bem patente a profunda ciência e sólida independência de juízo do patriarca da dietética.

4. Em 1603 publica Rodrigo de Castro, célebre médico português residente na Alemanha, um tratado geral de ginecologia, o qual, entre as peças poéticas laudatórias, que era então da praxe colocar no início dos livros, nos apresenta um engenhoso poema, bem lardeado de saber clássico, da autoria de Ludouicus Nonius, e no qual este doctor medicus, Lusitanus, pede para a fronte do colega e compatriota ${ }^{37}$ os lauréis de uma eterna e merecida glória. Embora as bibliografias deem a $1^{a}$ edição deste livro como publicada em Hamburgo, ex Officina Frobeniana, typis Philippi Ohr, o exemplar de que me servi na página de rosto não indica qualquer nome de impressor ou editor, informando apenas que a obra se imprimiu cum gratia et privilegio Caesareae Maiestatis [“com autorização e privilégio do imperador”], Coloniae ["em Colónia”]. Os nove dísticos elegíacos que compóem a homenagem poética de Nunes encontram-se na p. 3 da obra, cujo longo título se inicia do seguinte modo: Roderici a Castro, Lusitani, philosophiae ac medicinae doctoris per Europam notissimi, de uniuersa mulierum medicina. ["Tratado geral

37 Embora presumivelmente nunca tenha saído dos Países Baixos, onde nasceu, o Dr. Luís Nunes, na sua qualidade de integrante da comunidade lusa de Antuérpia, considerava a nacionalidade portuguesa como a sua: estatuto que de modo algum lhe contestaremos. 
de ginecologia, por Rodrigo de Castro, português, doutor em medicina e filosofia, muitíssimo conhecido por toda a Europa"]

5. A obra mais suculenta e de propósitos mais evidentemente literários do conjunto que ofereço ao leitor é o epicédio ou poema fúnebre com o qual a musa do Dr. Luís Nunes pranteou o decesso do seu amigo Justo Lípsio, falecido em 23 de março de 1606, com 59 anos incompletos. Ocupa as páginas 52 a 56 de um volume, com 114 páginas numeradas, in memoriam do literato flamengo desaparecido. Integram-no apenas composições poéticas em latim e grego (estas em reduzido número) e leva por título Iusti Lipsii sapientiae et litterarum antistitis fama postuma, Antuerpiae, ex officina Plantiniana apud Ioannem Moretum, 1607. ["Fama póstuma de Justo Lípsio, mestre da sabedoria e das letras. Em Antuérpia, da oficina de Plantino, na casa de João Moreto, 1607"] Uma outra edição deste epicédio publicou-se em 1614, podendo ler-se, com o título de In Lipsii obitum, entre as páginas 695 e 698 da coletânea intitulada Deliciae c. poetarum Belgicorum, huius superiorisque aeui, tertia pars, collectore Ranutio Ghero. Francofurti, Tipis Nicolai Hoffmanni, sumptibus Iacobi Fischeri, anno MDCXIV. ["Primores dos poetas dos Países Baixos, de hoje e do passado, terceira parte, coligidos por Ranutius Gherus. Em Francoforte, às custas de Iacobus Fischerus e impresso por Iacobus Fischerus"] Neste mesmo florilégio e imediatamente antes do poema aqui traduzido pode ler-se, entre as páginas 693 e 695, outra amostra da inspiração poética, neste caso epitalâmica, do nosso autor, escrito in nuptias Ioan. Wouerii. ["para as bodas de João Woverus"]

Quanto à elegia dedicada a Lípsio, como o leitor poderá confirmar, Luís Nunes conseguiu apresentar nela um conspecto das mais significativas obras em que o homenageado revelou o seu imenso saber clássico, inteligentemente citadas mediante alusões que revelam também o à-vontade com que o médico luso-flamengo se movia nos domínios da cultura greco-latina. Não descurou tão-pouco a vertente ética e religiosa que Justo Lípsio cultivou com especial afinco, e até devoção, sobretudo na parte final da sua vida. 
TEXTOS

E TRADUÇÕES 
Dictionarium latinohispanicum, et uice uersa hispanicolatinum, Aelio Antonio Nebrissensi interprete, nunc denuo ingenti uocum accessione locupletatum pristinoque nitori, sublata mendarum colluuie, Ioannis Belleri ope ac studio restitutum. Ad haec, Dictionarium propriorum nominum ex probatissimis Graecae et Latinae linguae auctoribus, addita ad calcem neoterica locorum appellatione concinnatum, Antuerpiae, in aedibus Ioannis Steelsii, 1553

\section{[Aij]}

Optimo ac religioso uiro fratri Iacobo a Murça, Diuinarum Litterarum doctori clarissimo et Conimbricensis Academiae moderatori uigilantissimo, Ludouicus Nonius, a Sanctarena, medicae artis professor felicitatem

Cum superioribus annis, praesul amplissime, Antonii Lexicon in lucem esset proditurum, quibus ego causis impulsus illud tuae humanitati dedicandum existimauerim, facile, ut coniicio, ex nostra praefatione intelligere potuisti. Et, quamquam iam tum apud me satis erat constitutum nullum posthac eius generis librum, quantumlibet doctum et erudite conscriptum, cuiusquam patrocinio commendare, quippe qui essem expertus multos nominis mei studiosos iniquo animo tulisse me (a quo aliquid potius in re medica in dies exspectabant, quod illorum de studiis meis opinioni responderet) in id tempus insumere, quod nec hanc aetatem deceret, nec dignitati iam nostrae conueniret: cogebar tamen, Pater spectatissime, iure optimo hanc animi mei sententiam, tum ob publicum studiosorum commodum, tum etiam ob rei ipsius honestatem, mutare nec in proposito susceptoque consilio diutius permanere. Illa enim duo cum sint quae frugi hominem et probum ad omnem uitae actionem dirigere debeant, et quibus de omnibus quae fiunt ratio probabilis ostendi atque exponi possit, ubi me duplici illa ratione ad id officii genus adductum ostendero, amicis, ut arbitror, faciam satis, nec improborum hominum iudicia incurram.

Cum enim qui litterarum studiis fauent et earum studiosis prodesse cupiunt nihil praetermittere debeant quod e re ipsorum esse intelligant, etiamsi a grauioribus studiis aliquantulum ferientur, non uideo cur officium in Antonii Dictionario expoliendo, augendo et locupletando uitio dari cuiquam debeat, in praestantiore disciplina quamlibet uersato. Hic siquidem liber in tanto pretio ac existimatione, postquam semel in lucem editus est, apud Hispanos est habitus ut $\left[\mathbf{v}^{\mathbf{o}}\right]$ docti ad unum omnes ei non deteriorem locum in suis 


\section{[Aij]}

Ao excelente e piedoso varão frei Diogo de Murça, mui ilustre doutor em Sagrada Teologia e vigilantíssimo Reitor da Universidade de Coimbra, Luís Nunes, de Santarém, professor de Medicina, envia votos de felicidade

Quando, digníssimo Reitor, em anos recentes estava a ponto de ser publicado o Dicionário de António, eu, movido por certas razóes, pensei que deveria dedicá-lo à tua afabilidade, consoante conjeturo que facilmente pudeste entender pelo meu prefácio. E, embora já então eu tivesse firmemente decidido que a partir desse momento não recomendaria à proteção fosse de quem fosse nenhum livro deste género, por mais douto e eruditamente que tivesse sido escrito, visto como tinha experimentado que muitas pessoas que prezavam o meu prestígio suportavam de muito mau talante que eu (de quem de dia para dia estavam à espera de algo mais ligado com a Medicina que correspondesse à opiniáo deles acerca dos meus estudos) empregasse nisso o meu tempo: algo que nem ficava bem à minha idade nem quadrava já à minha posição, todavia, prezado Padre, sentiame obrigado a, com o melhor dos motivos, mudar esta opiniâo do meu espírito - não só por amor do proveito público dos estudiosos, mas também devido à bondade da própria coisa - e a não me manter fiel por mais tempo à decisão que me propusera e assumira. É que, sendo aqueles dois os critérios que devem dirigir o homem reto e probo em relação a todos os atos da vida, e com os quais se pode apresentar e dar a conhecer a razão provável de tudo que se faz, quando mostrar que esse duplo motivo me levou a cumprir tal espécie de dever, por um lado, segundo penso, terei satisfeito aos amigos, e por outro não me exporei aos juízos dos homens ruins.

De facto, uma vez que os que favorecem os estudos literários e vivamente almejam ser úteis aos estudiosos dos mesmos, não devem negligenciar nada daquilo que entenderem que é vantajoso para estes, ainda que repoisem algum tanto de estudos mais sérios, náo vejo por que motivo deva considerar-se como censurável o serviço prestado por alguém, por muito versado que seja em saberes mais alevantados, em acepilhar, acrescentar e enricar o Dicionário de António. Visto que este livro, desde a primeira vez que saiu a lume, é tão estimado e reputado entre os povos da Hispânia que [vo 
bibliothecis dederint. Quotus enim quisque doctorum apud eos est qui, nisi sit omnium ingratissimis, iis Antonii uigiliis non multum se fateatur adiutum et a graui quasi sopore excitatum? Quis non uidet post editum hoc Antonii opus apud nationes alias doctos homines auctorem hunc uehementer secutos, Dictionaria Latinogallica et Latinogermanica accurate etiam scripsisse? Nec umquam laborem hunc sponte subiissent nisi et auctoris nostri consilium multum probassent, et litteris litteratisque omnibus uberem fructum messuros se intellexissent.

Verum, cum abhinc annos septem tuis auspiciis Dictionarium hoc in publicum iret, dolui non potuisse me naeuos aliquot, qui iam impressi atque etiam inusti esse uidebantur, delere, nec item uoces multas, quae adiici possent, quod ad litteram $O$ liber iam typis esset excusus, addere. Namque eam libri partem uoculae nonnullae, candorem Latium minus referentes, foedauerant et Arabica plurima, leuem fortasse aliquem usum barbaris medicis afferentia, ueluti in alienum fundum ac possessionem irruperant. Cumque non minus inhonestum esset latinis admiscere barbara quam sacris profana, mundis impura ac demum optimis pessima, Arabicis uocibus tamquam iniuste sedem possidentibus in Libycas arenas ablegatis, Latiae et legitimae, quo iuuenibus abunde satisfieret, in noua editione, ut prior illa iactura magno cum fenore resarciretur, suffectae sunt. Atque ex hoc, Hispanolatinum quam plurima mutuatum, cum esset alioqui mutilum et inchoatum, perfectum et omnibus numeris absolutum, summa cum diligentia instauratum est.

Haec cum sint cumulate praestita facile intelligent qui, uel conniuentibus oculis, (absit modo fucus et liuor) librum ipsum semel percurrerint, adductae siquidem sunt innumerae propemodum uoces quae in alia editione desiderabantur, multarum quoque (quae tamen scriptae prius erant) alii significatus quam qui ab Antonio commemorati sunt, ex Latiniis

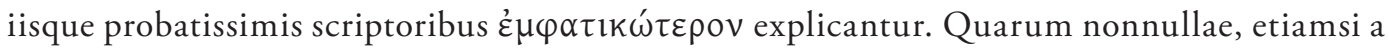
nostro usu recesserant, eoque nomine minus a rigidis et duris censoribus probari uidebuntur, meminerint uelim eleganter et uere illud scriptum esse:

\footnotetext{
Multa renascentur quae iam cecidere, cadentque

Quae nunc sunt in honore uocabula, si uolet usus,

Quem penes arbitrium est et uis et norma loquendi.
} 
todos os sábios sem exceção lhe reservaram o melhor lugar nas suas bibliotecas. É que, de entre os sábios hispânicos, qual é aquele que, a menos que se trate do mais desagradecido dos homens, não se reconhece muito ajudado pelos desvelos de António e como que despertado de um pesado sono? Quem é que não vê que, depois de editada esta obra de António, em outros países os homens sábios, seguindo com denodo este autor, também escreveram cuidadosamente dicionários de latim-francês e de latim-alemão? E tão-pouco de sua livre e espontânea vontade jamais se teriam abalançado a este trabalho, caso não só não tivessem aprovado assaz o desígnio do nosso autor, mas também não tivessem compreendido que haveriam de repartir abundante fruto por todas as letras e letrados.

Ora, é certo que, há sete anos atrás, ao publicar-se este dicionário sob a tua proteção, lastimei-me de não ter podido expungir algumas falhas, que já estavam impressas e até pareciam ter sido gravadas a ferrete, nem também acrescentar muitas palavras que poderiam aditar-se, porquanto o livro já tinha sido impresso até à letra $O$. Com efeito, desfiguraram esta parte do livro inúmeros vocábulos, pouco respeitadores da pura latinidade, e um sem número de palavras árabes como que violentamente se arrojaram sobre propriedades e terras alheias, oferecendo quiçá alguma fraca utilidade a médicos bárbaros. E uma vez que misturar termos bárbaros com latinos não era menos desonesto e impróprio do que misturar profanidades com cousas sagradas, sujidades com o que é limpo e enfim o ótimo com o péssimo, depois de desterrados para os areais da Líbia os vocábulos arábicos, como quem indevidamente se apropriara do lugar, foram substituídos nesta nova edição, para corrigir com grande vantagem aquele dano da primeira, pelos lídimos e latinos, por forma a satisfazer de sobejo à mocidade. E demais disto, o dicionário espanhol-latim, que se encontrava incompleto e iniciado, foi acrescentado com inúmeras palavras e com o máximo desvelo se oferece completo e totalmente aperfeiçoado.

De quão cabalmente isto se levou a bom termo facilmente se aperceberão os que, mesmo de olhos fechados (contanto que apartados da inveja e mentira), alguma vez os passaram por este livro, visto como se introduziu um quase sem número de palavras de que se sentia a falta na outra edição, e também de muitas que anteriormente constavam expóem-se com maior propriedade $^{38}$ outras significaçóes, extraídas dos mais aprovados escritores latinos, diferentes das registadas por António. Embora muitas destas tenham desaparecido do nosso uso, e por esse motivo hão de semelhar ser menos aprovadas por críticos duros e rigorosos, desejaria que eles se lembrassem de que com elegância e verdade se escreveu o seguinte:

\footnotetext{
Renascerão mil decaídos termos,

E mil decairão, hoje aplaudidos,

Se o uso assim quiser, de cujo arbítrio

O jus e a norma da linguagem pende. ${ }^{39}$
}

38 Em grego no texto original latino.

39 HorácIO, Arte poética, 70-72. Tradução do Visconde de Seabra. 
[Aiij] Ego etenim ita cum doctis semper sensi: "nouorum optima esse quae maxime uetera sunt, et ueterum quae noua", modo Latina lingua locupletior fiat et cum ceteris ausit de ubertate et copia suo iure contendere. Nec sola Latiarum uocum est ingens facta accessio, sed earum quae, passim excusae, in aliis omnibus circumferebantur, diligentissima animaduersio et castigatio. Quibus praeterea dicendi quaedam formulae Hispanis ipsis frequentes et usitatae, suis locis digestae, interseruntur, quo, mutua linguarum facta collatione, propius et elegantius multa pronuncientur quam uulgo dici ac proferri solent. Hoc omnia quantum sint et quam insignem usum studiosis allatura futurum spero legentes multo perspicacius et fructuosius suo commodo discant quam oratione mea consequi possint. Nam, praeter Hispanos, quibus hic liber potissimum esta elaboratus, exteras gentes, siue ipsius linguae peritiam spectent, siue auctorum cognitionem, qui praeclara multa Hispano sermone scripserunt, strenue iuuabit.

Cum igitur, Rector optime, te priori editioni, ob singularem eruditionem, insignem probitatem, amplissimam dignitatem, patronum adoptauerim tuaque existimatione ac nomine multum ponderis et auctoritatis apud lectores habuerit, adeo ut omnia illi fauste, feliciter prospereque euenerint, aequum est si officio tuo minime deesse uelis, ut certe deesse nolles, emendatissimam hanc, multo auctissimam ac utilitatis ubertate omnes, quae ad hanc diem prodiere, superantem, maiore animi alacritate tuearis. Consentaneum siquidem est, postquam etiamnunc Conimbricensem Academiam, nobile disciplinarum emporium, gubernas et moderaris, eorum labores tuo sinu excipias, foueas, probes et amplexeris qui secum quotidie certant, quo se ipsis facti meliores, rei publicae litterariae incrementum afferant. Sic enim tuum officium retinebis perficiesque ut ne minus studia tibi quam tu studiis debeant, et eorum ânimos excitabis qui nihil non sustinent, quo disciplinarum cultum suis sudoribus illustrent, ut remis

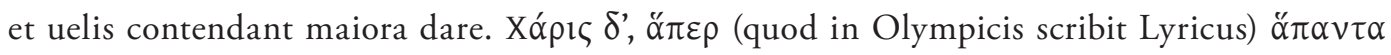
$\tau \varepsilon u ́ x \varepsilon ı ~ \tau \grave{\alpha} \mu \varepsilon i ́ \lambda ı \chi \alpha \theta v \alpha \tau o \tilde{c}$.

Vale, tui Ludouici non immemor

Parisiis, ex Museo nostro 
[Aiij] É que eu, em consonância com os sábios, sempre pensei que "das palavras novas as melhores são as mais velhas, e das velhas as novas", ${ }^{40}$ contanto que o latim se torne mais opulento e se atreva a com justo título rivalizar com as demais línguas no que tange a riqueza e abundância de léxico. Não houve apenas um acréscimo imenso de vocábulos latinos, mas fez-se uma acuradíssima correção e censura dos que, banidos de toda a parte, se continuavam a publicar em todas as outras ediçóes. Além disso, inseriram-se, repartidos pelos seus lugares, certos modos de falar frequentes e usuais entre os hispânicos, por forma a que, mediante a comparação entre ambas as línguas, se pronunciassem muitas palavras de modo mais elegante e correto do que vulgarmente se costumam dizer e pronunciar. Quão grande e quão extraordinário seja o proveito que tudo isto há de oferecer aos estudiosos tenho a esperança de que os leitores hão de, com proveito seu, aprendê-lo com muito maior evidência e fruto do que posso fazê-lo mediante as minhas palavras. É que, para além dos hispânicos, para os quais sobretudo este livro foi escrito, ajudará sobremaneira os estrangeiros, quer tenham em vista o domínio da língua propriamente dita, quer o conhecimento dos autores que escreveram em espanhol muitas coisas notáveis.

Por conseguinte, ó excelente Reitor, uma vez que, devido ao teu extraordinárioa saber, singular probidade e elevadíssima dignidade, te escolhi como patrono da primeira edição, e sendo certo que graças ao teu prestígio e reputação ela disfrutou de muito peso e autoridade junto dos leitores, a tal ponto que tudo lhe sucedeu a contento e de modo próspero e venturoso, é justo que, se não quiseres faltar à tua obrigação, como certamente não quererás faltar, protejas com o maior entusiasmo esta edição totalmente corrigida, muitíssimo aumentada e que, em riqueza de utilidade, se avantaja a todas as que até hoje se publicaram. Porquanto é razoável que, depois que governas e diriges a Academia de Coimbra, nobre empório das ciências, acolhas no teu seio, favoreças, aproves e abraces os trabalhos dos que todos os dias se esforçam por, tornando-se a si mesmo melhores, acrescentarem a república das letras. De facto, assim cumprirás com a tua obrigação e conseguirás que os estudos não te devam menos a ti do que tu deves aos estudos, e animarás aqueles que a tudo fazem frente, para que com o seu suor enobreçam o culto das ciências, por forma a "com unhas e dentes" se esforçarem por oferecer coisas maiores. O que

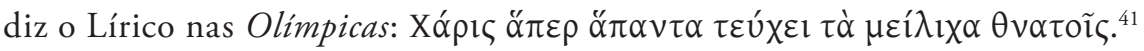

Fica de saúde, e não te esqueças do teu amigo Luís.

Em Paris, do nosso escritório.

40 Cf. QUINTILIANO, Institutio oratoria 1.g6.41: Ergo, ut nouorum optima erunt maxime uetera, ita ueterum maxime noua.

41 Píndaro, $1^{a}$ Ode Olímpica v. 31: "Uma graça que faz de todas as coisas um mel para os homens". 


\title{
Iusti Lipsii epistolarum selectarum centuria tertia ad Belgas,
}

Antuerpiae, ex officina Plantiniana apud Ioannem Moretum, 1602

\section{[3]}

\section{EPISTOLA III}

\author{
Antuerpiam
}

Alvaro Nonio, doctori medico, s. d.

Litteras tuas hodie accepi et in iis duo uidi: magni Etruriae ducis honestum de me iudicium et tuum in me amorem. Neutrum mihi nouum. Nam, et de munere ab eo proposito iamdiu inaudiueram, et tuus affectus olim mihi innotuit, cum ante decem plus minus annos haberet me urbs uestra. Sed quod ad ducem, ita me Deus amet, ut doleo non posse obsequi. Causa est non quaesita ulla aut affectata, sed ipsa ualetudo, sine qua numquam me admouerim iis ad quae desinamur. Iter longum est. Regio olim quidem mihi uisa, sed ad habitanionem nunc noua: et cum ibi ero, quid faciam? Languebo? Vmbram pro Lipsio ostentabo? Medicaea domus, et hic ipse princeps, mihi magnus est et uelim eius causa multa, sed supra uires nihil possum. Ipse Pontifex, caput nostrum, recenter nunc me Romam inuitauit, sed excusamus uerissimo illo ualetudinis pratextu. Sumus quidem in ea curanda, sed melancholici et chronici isti morbi, tu scis quam laneo pede ueniant, et plumbeo, ut sic dicam, recedant. Deus dedit mihi hanc sortem: ferenda est. Scripsi in similem sententiam ante menses tres ad Hieronymum Marcurialem, illustrem medicum et tibi notum, qui primus mihi aperuerat mentem serenissimi ducis. Scio illum accepisse et iam indicium fecisse ubi debebat. Ego te non celo animum mihi in patria esse, etsi afflicta. Deus hanc et me releuabit, cum ei uisum; et te stantem firmumque seruabit, uir clarissime.

Leodici, VIII Kal. Iul 1592 


\title{
[3]
}

\author{
Carta 3 \\ Para Antuérpia \\ Envia saudaçôes a Álvaro Nunes, doutor em Medicina
}

Recebi hoje a tua carta, e nela vi duas cousas: o honroso juízo do grão-duque da Toscana ${ }^{42}$ a meu respeito e o amor que nutres por mim. Nenhuma de ambas é novidade para mim. De facto, não só há muito tempo fora informado do favor com que ele me presenteia, como também no passado me ficou patente o teu afeto quando há cerca de dez anos estive na tua cidade. Mas no que toca ao duque, assim Deus me ame como me punge náo poder comprazê-lo. O motivo não é buscado nem afetado, mas a própria saúde, sem a qual não me teria aplicado ao cargo para que estou designado. A viagem é longa. É certo que se trata de uma região que em tempos visitei, mas nova para hoje lá morar: e quando aí estiver, que farei? Definhar-me-ei na inércia? Oferecerei uma sombra em vez de Lípsio? Tenho em grande apreço a casa dos Médicis e este príncipe em particular, e por amor dele desejaria muitas coisas, mas nada posso acima das minhas forças. O próprio Pontífice, nossa cabeça, recentemente me convidou para Roma, mas escusei-me com o pretexto totalmente verdadeiro do estado da minha saúde. Aplicamo-nos a tratar dela, mas sabes como essas moléstias melancólicas e crónicas vêm com pés de lã e se vão com pés de chumbo, por assim dizer. Deus deu-me este fadário: cumpre-me sofrê-lo. Neste teor escrevi há três meses a Girolamo Mercuriale, ${ }^{43}$ médico ilustre e que conheces: que fora o primeiro a revelar-me os sentimentos do sereníssimo duque. Sei que recebeu a carta e dela deu conta onde devia. Não te oculto que tenho o meu espírito na pátria, ainda que atribulada. Deus há de aliviá-la e a mim, quando Lhe aprouver; e a ti há de conservar-te fero e firme, ilustre varão.

Em Liège, 24 de junho de 1592

42 Era então grão-duque Ferdinando Medici (1549-1609).

43 Célebre médico italiano (1530-1606), conhecido sobretudo pela obra De arte gymnastica libri sex. Sobre ele veja-se o substancial artigo de Nancy G. SIRAISI, "History, Antiquarianism, and Medicine: The case of Girolamo Mercuriale", Journal of the History of Ideas 64.2 (April 2003), pp. 231-251. 
Iusti Lipsii epistolarum selectarum centuria quinta. Miscellanea postuma, Antuerpiae, ex officina Plantiniana apud Ioannem Moretum, 1607

\section{[51]}

EPISTOLA LIII

Antuerpiam

Ludouico Nonio, doctori medico, s. d.

"Diuam" nostram placuisse, tibi pietatis tuae in illam est, fortasse et in me affectus. Nam, a stilo aut ingenio meo [52] leuiter acessit quod commendaret. Gaudeo tamen grata haec esse (nam et ab aliis sic accipio) et excitor ad similes scriptiones. Similes dico, id est, historicas: et tu me eo uocas ualde inclinatum. Itaque iam nunc edo "Monita et exempla politica", in quibus quid nisi florem historiarum excerpo, et huic scriptioni uelut proludo.

Deus si uitam mihi seruat, illuc ibo, firmior sim modo, nam iam a tribus mensibus, mi Noni, ualde uirium et uigoris interni uacuus sum factus.

Te in "Hispania" illustranda pergere gaudeo, et in Marciani Capellae loco (inspexi et inquisiui) a tua correctione nihil muto. Vera et necessaria est: etsi temptabam illud "uniuersa" inuertere, sed non successit. 


\title{
3.
}

\section{[51]}

\author{
Carta 53 \\ Para Antuérpia \\ Envia saudações a Luís Nunes, doutor em Medicina
}

O ter-te agradado a minha $A$ Santa Virgem de Halle $e^{44}$ deve-se à tua devoçáo por ela ou talvez ao teu afeto por mim, pois do meu estilo ou capacidades intelectuais [52] pouco se ajuntou para recomendá-la. Todavia regozijo-me por ter agradado (de facto, também me dou conta de que outros a acolheram do mesmo modo) e sinto-me incitado a composiçôes do mesmo teor, ou seja, históricas: rumo para o qual também impeles quem para ele assaz se inclinava. E assim estou prestes a dar a lume os Monita et exempla politica, ${ }^{45}$ nos quais só extrato a nata das histórias e como que me exercito nesta casta de composições.

Se Deus me conservar a saúde, encaminhar-me-ei para aí, contanto que me sinta mais rijo, pois, meu caro Nunes, de três meses a esta parte que me sinto muito abatido de forças e desvigorado.

Regozijo-me por ver-te prosseguir no abrilhantamento da Hispania, ${ }^{46}$ e na passagem de Marciano Capela (que investiguei e esquadrinhei) não faço qualquer alteração à tua correção. É verdadeira e necessária: embora eu tenha tentado alterar a posição daquele uniuersa ${ }^{47}$ mas debalde.

44 Refere-se ao opúsculo piedoso I. Lipsi Diua Virgo Hallensis, beneficia eius et miracula fide atque ordine descripta. Antuerpiae, ex officina Plantiniana apud loannem Moretum, 1604, 86 pp., mais índices, licenças e privilégios.

45 Monita et exempla politica libri duo, qui uirtutes et uitia principum spectant. Paris, Petrus Chevalier, 1605. De 18 de janeiro deste ano está datada a dedicatória do Autor ao arquiduque Alberto de Áustria.

46 Refere-se à Ludouici Nonii HISPANIA siue Populorum, Vrbium, Insularum ac Fluminum in ea accuratior descriptio, cuja primeira edição saiu no ano de 1607, em Antuérpia, ex officina Hieronymi Verdussi, e que no ano seguinte o jesuíta André Schott incluiu no volume IV da Hispania Illustrata, publicado em Francoforte, apud Claudium Marnium et heredes loan. Aubrii: edição que seguimos para as transcrições, conquanto tenhamos feito o cotejo com o texto da $1^{\mathrm{a}}$. O prefácio-dedicatória de Nunes à sua Hispania, escrito em Antuérpia, tem a data do $1^{\circ}$ de março de 1607.

47 Vejam-se os termos em que Nunes formula a sua correção textual, aqui aprovada por Lípsio: Non praetereundum puto apud Martianum Capellam, ubi de Hispania agit, lib. VI, lacunam esse supplendam. Ita enim ait: 'At uniuersa prouincia habet conuentus septem, Carthaginensem, Tarraconensem etc'. Quae 
Quaeris super Strabonis loco de "Balearium laticlauia tunica”, et meretur quaeri. Ego autem simpliciter ita accipio, usos primum $\pi \lambda \alpha \tau v \sigma \eta ́ \mu o เ \varsigma \chi \tau \tilde{\omega} \sigma \mathrm{l}$, quas Romani senatores usurparunt, sed paulo aliter. Nam Baleares, opinor, in lino, non in lana, et ab iis haud dubio Hispani sumpserunt, sic propinqui. Sane de istis in Liuio est, lib. XxI, ubi de pugna Cannensi: "Hispani

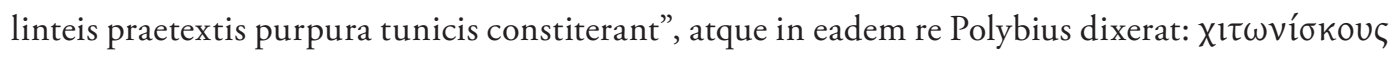

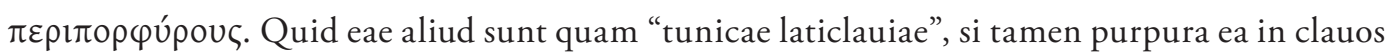
distincta? Haec ad Liuium olim notabam et Strabonis locum adiungebam: tu iudicabis.

enim uniuersa prouincia habet septem conuentus? An Hispania? Sed superius dixerat Baeticam duos habere conuentus, atque ita erunt nouem. Quare ita legendum puto: 'At uniuersa citerior prouincia conuentus habet septem.' Nam de Baetica et Lusitania egerat, restabat de Tarraconensi dicere.

["Penso que não deve deixar passar-se sem correção uma falta na obra de Marciano Capela, quando se ocupa da Hispânia, no livro $6^{\circ}$. É que diz o seguinte: 'Mas a província toda tem sete conventos: o Cartaginense, o Tarraconense' etc. Ora, que província tem sete conventos? Acaso a Hispânia? Mas mais atrás dissera que a Bética tem dois conventos, e desse modo serão nove. Motivo pelo qual considero que deve ler-se do modo seguinte: 'Mas a província citerior toda tem sete conventos.' Com efeito, ocupara-se da Bética e da Lusitânia, e faltava tratar da Tarraconense."] Hispania Illustrata, IV, p. 422 (c. 40). 
Perguntas-me sobre a passagem de Estrabão relativa à túnica com banda larga ${ }^{48}$ dos habitantes das Baleares, e é interessante a pergunta. Ora, eu simplesmente interpreto no sentido de que foram os primeiros a usarem as túnicas de banda larga ${ }^{49}$ que usaram os senadores romanos, mas com uma pequena diferença. É que, em minha opinião, as dos baleares eram feitas de linho, e não de lâ, e foi sem dúvida deles que os hispânicos, dada a grande proximidade, tomaram as suas. Destes fala Lívio no livro $21,{ }^{50}$ onde escreve, a propósito da batalha de Canas: Os hispânicos tinham-se disposto em linha com túnicas de linho bordadas a púrpura, e, escrevendo sobre o mesmo assunto, dissera Políbio: com túnicas curtas bordadas a púrpura. ${ }^{51}$ Por que são estas uma coisa diferente das túnicas de banda larga ou laticlavos, se também se distinguem pela púrpura nas bandas? Já no passado este detalhe despertava a minha atenção em Lívio e confrontava-o com o passo de Estrabão: tu ajuizarás. ${ }^{52}$

48 Ou laticlavos.

49 Em grego no original.

50 Este passo de Tito Lívio hoje identifica-se como pertencente ao c. 46 do livro 22.

51 Em grego no original. O passo de Políbio pertence ao c. 114 do livro $3^{\circ}$ das Histórias.

52 E de facto, no seu epítome histórico-geográfico, publicado menos de três anos depois desta carta, o Dr. Luís Nunes exerceu de alguma forma o seu juízo crítico sobre o material informativo que o compatriota aqui the ofereceu, e ele então transcreve e agradece, pois, ocupando-se, no c. 95, das ilhas Baleares, escreve o seguinte:

Memorat et Strabo, lib. III, primos omnium mortalium Baleares laticlauium induisse [...] mirorque apud rudes et incultos homines senatoriae dignitatis ornamentum primo repertum fuisse. Num uero hinc ad Romanos tunica laticlauia peruenerit, nulla mihi ratio suadet ut credam: praesertim cum Plinius, lib. IX, cap. $X X X I X$, refert latiore clauo Tullum Hostilium primum e regibus, deuictis Etruscis, usum fuisse, multis annis priusquam Baleares P. R. noti essent. Clarus lustus Lipsius, unicum rei litterariae (heu quondam) decus, suis ad me litteris credit Baleares $\pi \lambda \alpha \tau v \sigma \eta ́ \mu o เ \varsigma ~ x ı \tau \tilde{\omega} \sigma \mathrm{l}$ usos primum; quas Romani paulo aliter usurparunt, in lino nempe illi, non in lana: a quibus et Hispani ita uicini sumpserunt. De quibus Liuius, lib. xxı: 'Hispani

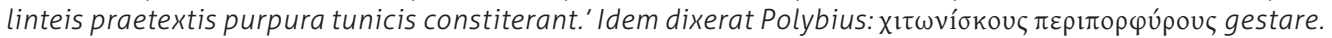
Non erat forsan purpura ea in clauos distincta, nec tam augusta ut senatorum laticlauus.

["Também regista Estrabão, no livro 30, que os primeiros homens a usarem laticlavos foram os habitantes das Baleares [...] e espanto-me de que entre homens boçais e rudes se encontrasse pela primeira vez o ornamento próprio da dignidade senatorial. De facto, nenhum motivo me convence de que tenha tido esta origem a túnica de bandas largas dos romanos: sobretudo sendo certo que Plínio, no livro 60, c. 39, conta que Tulo Hostílio foi o primeiro de entre os reis a, depois de vencidos os etruscos, usar a túnica de bandas largas, muitos anos antes de os romanos terem conhecimento do povo das Baleares. O ilustre Justo Lípsio, lustre e glória sem igual das letras (infelizmente, em dias que já lá vão!), em carta que me escreveu, afirma crer que os baleares foram os primeiros a usarem as túnicas de banda larga que usaram os senadores romanos, mas com uma pequena diferença: a saber, que aquelas eram feitas de linho, não de lã, sendo deles que os hispanos, dada a grande proximidade, as tomaram. Destes fala Lívio no livro 21: Os hispânicos tinham-se disposto em linha com túnicas de linho bordadas a púrpura. E o mesmo dissera Políbio: que levavam túnicas curtas bordadas a púrpura. Provavelmente esta púrpura não se destacava tanto nas bandas nem era tão majestosa como o laticlavo dos senadores."] Hispania Illustrata, IV, p. 471. 
Publica ualde me suspensum habent et uideo certamen omne in Flandria cernendum. Hostis copias auxisse, instruxisse dicitur, et recta ad nouam expeditionem ire. Nos quid? Quod tu scitissime a tua arte: in ueterno aut lethargo sumus, Nec ecxitati excitamur. Ades, o Deus, et patriam, aut certe religionem tuam, uindica et tuere!

\section{Vale, mi Noni}

Louanii, XI Kal. Octobris 1604 
Os negócios públicos deixam-me sobremaneira ansioso e vejo que toda a sorte de pelejas devem combater-se na Flandres. Corre a voz de que o inimigo aumentou as tropas e pôs-se em campo e se abalança diretamente para nova campanha. E nós que fazemos? Tal como mui a fundo conheces da tua arte, permanecemos em estado de modorra e letargia, e nem espicaçados reagimos. Acode-nos, ó Deus, e protege e defende a pátria: ou antes, a Tua religião!

Fica bem, meu caro Nunes

Em Lovaina, 21 de setembro de 1604 
4.

Roderici a Castro Lusitani (...) De uniuersa mulierum medicina (...), Coloniae, 1603.

\title{
[3]
}

\author{
D. Roderici a Castro, Lusitano, Ludouicus Nonius, \\ doctor medicus, Lusitanus
}

Ciuica si ciui seruato a morte corona

Sit data, et e lauro uirgine cincta coma

Si quibus hostili rorabant membra cruore

Contigit et multa caede triumphum erat:

Innumerae umbrabunt merito tua tempora lauri,

A Castro, et lambet multa corona caput,

Innumeros homines solus nam subtrahis Orco

Et facis inuita uiuere posse colo.

Ipse fugas imo latitantes corpore pestes,

Agmina morborum disiicis arte tua,

Disiicis arte tua Pandorae quidquid in orbem

Saeua tulit pyxis, quidquid et ira deum.

Mortaleis artus crebra ne tabe fatiscant

Efficis et diro soluis ab interitu.

Nec, Roderice, satis quod per te annosa Charontis

Cymba fuit totiens ludificata senis,

$\mathrm{Ni}$ postquam Lachesis rumpes subtegmina uitae

Sentiat ex calamo pluria damna tua. 


\section{4.}

\section{[3]}

\section{Ao Senhor Rodrigo de Castro, português, o doutor Luís Nunes, médico português}

Se a coroa cívica se concedia por da morte salvar

Um cidadão, e cingir as comas com puro louro

Em sorte coube aos que rociavam os membros com sangue imigo

E jus tinham ao triunfo por prémio de vasta matança:

Será justo que lauréis sem conto sombreiem tua fronte,

E que coroas muitas, ó Castro, te cinjam a cabeça,

Pois são sem conto os que tu só arrebatas à morte

E fazes que viver possam, em que pese à Parca.

Afugentas as pestes que no fundo do peito se rebuçam,

Com tu'arte desbaratas os esquadrôes de doenças,

Desbaratas com tu'arte tudo que sobre o mundo

Deixou cair a cruel caixa de Pandora e soltou a ira dos deuses.

Consegues que a galopante putrefação não desfaça

Os membros mortais e os livras da terrível morte.

Nem basta, ó Rodrigo, o teres tão amiúde logrado

A anosa barca do ancião Caronte,

Se Láquesis, depois de cortar o fio da vida,

Não sentir danos infindos por obra de tua pena. 
Iusti Lipsii sapientiae et litterarum antistitis fama postuma, Antuerpiae, ex officina Plantiniana apud Ioannem Moretum, 1607

\section{[52]}

In v. c. Iustum Lipsium epicedion

Ludouici Noni, doctoris Medici

Magna anima, aetherium quam supra euexit Olympum

Aeternus genitor solioque locauit auito:

$\mathrm{Da}$ faciles threnis aures, ne subtrahe uultum,

Nenia funereos mea dum persoluit honores

Et bustis extrema tuis epicedia cantat.

At quinam gemitus uel quae lamenta dolori

Sufficient? Claros cineres, quae praefica, Lipsi,

Perfundet lacrimis? An quae maestissima mater

In Sipylo queritur bis senas Tantalis urnas?

An fletu liquefacta suo Maeandria Byblis?

An Phaethonteo quae in funere diriguerunt

Heliades? Anne Eois emersus ab undis,

Ferales planctus Hyadum chorus occinet orbi?

Tu longaeua Themis, docta tu Pallas ab arce,

Dic tumulo lessos, et singultantia luctu

Plectra moue, et taxis crines et tempora uela:

Ante fores nullo frondescat culmine laurus,

Sed plorata tuos postes cyparissus obumbret.

Nam cecidit uates, Helicon, tuus! O ubi tristes

Siccabis lacrimas Grudium? Quanto undique questu 


\title{
5.
}

\section{[52]}

\author{
Epicédio à memória do varão Justo Lípsio, \\ por Luís Nunes, doutor em Medicina
}

Grande alma, que o eterno Criador elevou acima do étereo Olimpo

E colocou no trono de seus maiores:

Escuta de bom grado e não te esquives aos prantos,

Enquanto a minha nénia presta as honras fúnebres

E entoa às tuas cinzas o canto do adeus derradeiro.

Mas que gemidos ou que lástimas hão de bastar à dor?

Que carpideira, ó Lípsio, cobrirá de lágrimas os ilustres teus despojos?

Porventura a tristíssima mãe, filha de Tântalo,

Que no Sípilo pranteia as doze urnas?33

Porventura a meândrica Bíblis, liquefeita com o seu próprio choro? ${ }^{54}$

Acaso as Helíades ${ }^{55}$ que congelaram nos funerais de Faetonte?

Porventura soltará plangitivos trenos o coro das Híades, ${ }^{56}$

Assomando das levantinas ondas?

Tu, longeva Témis, tu, Palas, desde o alto da sábia Acrópole

Dize palavras de lástima ao túmulo,

E que o luto te arranque da lira suspirosos acordes,

E com teixos cobre melenas e têmporas:

Que diante da porta não frondeje o louro em nenhum viso,

Mas o choroso cipreste sombreie a tua soleira.

É que, ó Hélicon, tombou o teu vate!

Oh quando estancarás as tristes lágrimas dos Grúdios?57

53 Alusão a Níobe, pranteando os filhos mortos.

54 Como pode ver-se em OvíDıo, Metamorfoses 9, 446-665, Bíblis, filha de Meandro, loucamente apaixonada pelo irmão Cauno, acabou literalmente desfeita em pranto.

55 Filhas de Hélio e, por conseguinte, irmãs de Faetonte.

56 Ninfas, filhas de Atlas, que Zeus metamorfoseou na constelação que perpetua o seu nome.

57 Povo da Gália Belga a que Júlio César se refere em 5. 39, e que habitou na região de Justo Lípsio. 
Pulpita, Cecropiis certantia pulpita Athenis,

Maesta sonant? Vacuae lugent doctore cathedrae.

[53]Martia sic magni in Ciceronis funere Roma

Ingemuit quondam Latiaeque silentia linguae,

Vos septem colles, uos flestis rostra Quirini.

Sanctius ecquis enim coluit sacraria Phoebi?

Gorgoneo admouit quis dignius ora liquori?

Testis inexhausto est facundia pectore diues,

Seu libuit uincire modis effamina certis,

Seu libuit uoces animare lepore soluto.

Qualiter assurgis! Quam denso pondere mentes

Afficis et dulci perfundis nectare sensus!

Non tibi Nelides, non se tibi conferet heros

Dulichius, breuitate potens non frater Atridae.

Non tua Tellenis turgescit pagina nugis

Aut populo phaleras et inania cymbal uendit,

Sed solidae passim uirtutis semina spargit

Lectoremque auidum generoso replet honesto.

Nec tibi morosa dictatur epistola cura,

Ast facilis nulloque uenit impulsa labore.

Non ieiuna tamen, ridenda aut ilia ducit,

Cecropio sed melle madet Latioque lepore.

Tu miseros Belgas, afflatus turbine belli,

Erigis eloquio magnisque hortatibus imples.

Et tua nos docuit Constantia ferre pericla

Atque animum infirmum triplici firmare metallo 
Com quão grandes queixumes por toda a parte ressoam

Os contristados estrados, os estrados que emulavam a Cecrópia Atenas?

Desocupadas do mestre, as cátedras lacrimejam.

[53] Assim antanho no funeral de Cícero a marcial Roma

Gemeu de dor, e pranteastes o silenciar da língua latina,

Vós, ó sete colinas, e tu, ó tribuna de Quirino.

De feito, mais santamente cultuou alguém o santuário de Febo?

Quem mais dignamente libou a gorgónea leiva?

E disso é prova a fácil facúndia no peito nunca lasso,

Quer lhe tenha aprazido ligar as frases com ordem e medida,

Quer aviventar tenha querido as palavras com lépida graça.

Como avultas! Com quão densa carga provês os entendimentos

E com quão doce néctar impregnas os sentidos?

Nem o filho de $\mathrm{Neleu}^{58}$ nem o herói Dulíquio, ${ }^{59}$ senhor da concisão,

Nem do Atrida o irmão, ${ }^{60}$ contigo sofrem cotejo.

Os teus escritos náo se incham com nonadas frívolas

$\mathrm{Ou}$ arrebiques para engodar o povo; ${ }^{61}$ tão-pouco vendem ocos adufes,

Mas por toda a parte esparzem sementes de sólida moral

E ao leitor ávido colmam de generosa virtude.

Não redigias as cartas com detençoso cuidado,

Mas fáceis te fluiam e sem te exigir esforço algum.

Todavia, o seu conteúdo não é magro ou de somenos,

Mas ressuma mel ático e latina graça. ${ }^{62}$

Com tua eloquência, alentas os mofinos Belgas,

Batidos pelo turbilhão da guerra, e os esforças com exortaçóes de peso.

A tua Constância ${ }^{63}$ nos ensinou os perigos a suportar

$\mathrm{E}$ a fortificar com tríplice metal o esmorecido ânimo

\section{Nestor.}

59 Ulisses.

60 Menelau.

61 Cf. PÉRSIO, 3.30.

62 O nutrido epistolário seleto de Lípsio foi reunido em diversos volumes, intitulados Centúrias, dos quais o último de publicação póstuma (1607).

63 Alusão à obra talvez mais divulgada de Justo Lípsıo: De constantia libri duo, qui alloquium praecipue continent in publicis malis. Leiden, Plantino, 1584. 
Fortunae aduersus ludos et lubrica rerum.

Tu ueterum mores scabra robigine saecli

Eripis atque nouo cogis splendescere cultu.

Per te nigrantes Mauortia Roma fauillas

[54]Excutit et longae posito squallore senectae,

Ecce alios iterum melior iuuenescit in annos.

Iam priscas miratur opes et robora regni

Et modo Tarpeio Capitolia celsa Tonantis

Fulgere colle stupet, circum delubra deorum

Obtundunt trepidos oculos fulgore metalli.

Innumeri hinc arcus spoliisque ornata tropaea;

Hinc Thermae occurrunt; hinc admiranda theatra;

Deliciasque suas, saeuae spectacula arenae

Atque theatrales gaudet cognoscere plausus.

Consiliis monitisque tuis, uestigia regum

Lubrica componis, Consi penetralibus haustis,

Queis populos iustis ualeant compescere habenis.

Iam te quis Martis tenuit felicius artes?

Militiae dum prisca doces praecepta Quiritum;

Queis tectus ueniat telis in proelia miles;

Qua deceat fossa ualloue includere castra;

Moenia quam uario prosternat machina pulsu: 
Contra os caprichos do destino e as ciladas da vida.

Os costumes dos antigos tu os arrancas

$\mathrm{Da}$ áspera ferrugem do tempo

E a resplanderecem os obrigas com primor renovado.

Graças a ti, a mavórcia Roma as enegrecidas cinzas

[54] Sacode e, perdendo a sujidade da longa velhice,

Ei-la que melhorada se remoça para viver de novo.

Já olha com espanto para as antigas riquezas

E para o poderio do império, e em seguida vê com pasmo

No Tarpeio monte os tetos reluzirem do Capitólio do Tonante.

Em torno, com seu fúlgido metal os templos das divindades

Encandeiam os pasmados olhos.

De um lado, à vista se lhe presentam triunfais arcos sem conta

Ornados com despojos; do outro, as Termas;

Acolá, os admiráveis teatros; e se alegra

Ao reconhecer a menina dos seus olhos,

Os espetáculos da cruel arena e os aplausos teatrais. ${ }^{64}$

Depois de penetrares os recessos das decisóes secretas,

Corriges as incertas pisadas dos reis

Com teus conselhos e advertências, para que com estes possam

Os povos dirigir com rédeas justas. ${ }^{65}$

Quem, com mais felicidade do que tu,

As artes dominou de Marte?

Quando ensinas os antigos preceitos da milícia dos Quirites,

As armas com que o soldado se protege ao lançar-se à peleja;

Com que fossos ou valas convém rodear o arraial; ${ }^{66}$

Com quanta diversidade de tiros

Os bélicos engenhos derrubam as muralhas: ${ }^{67}$

64 Referência verosímil ao livro lipsiano Admiranda siue de magnitudine Romana libri quatuor. Paris, apud Ambrosium Drouard, 1598.

65 Talvez Nunes pretenda fazer aqui menção da mais importante obra de doutrinação política do polígrafo flamengo: Politicorum siue ciuilis doctrinae libri sex. Leiden, Plantino, 1589.

66 Tem aqui Nunes provavelmente em mente a obra Iusti Lipsii de militia Romana libri quinque, commentarius ad Polybium. Antuerpiae, ex officina Plantiniana apud uiduam et loannem Moretum, 1595.

67 Visa o nosso Autor com toda a probabilidade o livro lusti Lipsii Poliorceticon siue de machinis, tormentis, telis libri quinque. Antuerpiae, ex officina Plantiniana apud uiduam et loannem Moretus, 1596. 
Martis quae tantum pubes miratur, ut ultro

"Cedant arma togae, concedat laurea linguae."

Singula quid memorem? Non uestigata priorum

Ingeniis tenebrisque diu damnata profundis

Extrahis et primus luci committis apertae.

Te sine Zenonis latuissent scrinia. Magnum

Crantora quis nosset demorsoque ungue Cleanthem

$\mathrm{Ni}$ tu Stoicidum renouasses atria sectae?

Quid loca senta situ scriptorum aut mersa ueterno,

Vindice te, referam, solitum spirare decorem?

[55]Non Toto in Augeae stabulo exanclasse labores,

Eurysthi imperio, fertur Tyrinthius heros

Taedia quot passus, dum caeca nocte latentes

Eripis auctores, mendis blattisque fugatis.

Luce noua melior Tacitus Senecaeque coruscant,

Atque alii proceres, Latium quos uidit et Hellas,

Pileolo ornati, raso te uertice, Lipsi,

Sectantur cuncti: sic, libertate recepta,

Hostile fuerant quondam qui carcere clause,

Laeta triumphalis comitantur syrmata pompae.

Quam tibi blanditur Iessei germinis altrix?

Illa, cui extremos calamus seruauit honores, 
Então, com tanto espanto a márcia gente

Os olhos põe em teu saber, que livremente:

"As armas cedem à toga e à língua concede os louros." 68

Para quê em cada um tocar de teus títulos de glória?

Trazes à luz o que os passados não rastearam,

E o que por longo tempo ficou condenado a cerradas trevas

És o primeiro a restitui-lo à plena luz.

Não foras tu, e os tesoiros de Zenão teriam permanecido ocultos.

Quem teria tido conhecimento do grande Crantor ou de Cleante

$\mathrm{Se}$, depois de fadigas muitas, ${ }^{69}$ não tivesses restaurado

$\mathrm{O}$ átrio da seita dos Estóicos? ${ }^{70}$

Para quê referir como, salvas por ti, mostram seu nativo luzimento

Os passos, afeiados pelo desleixo dos copistas

Ou tragados pela longa idade?

[55]Diz-se que o herói Tiríntio, ${ }^{71}$ por ordem de Euristeu,

Nas cavalariças de Augias tanto trabalho não tivera

Quanto a fadiga que suportaste quando,

Rechaçando as faltas e as traças,

Os autores restauraste que se escondem na cega noite.

Tácito e os Sénecas ${ }^{72}$ melhorados brilham com nova luz,

E outros, de entre os grandes que o Lácio e a Hélade viram,

Ornados com pequenos píleos, a ti,

Que vais de cabeça raspada, ó Lípsio,

Te seguem num corpo só: tal como, após receberem a liberdade,

Os que outrora tinham estado encerrados em cárcere hostil,

Acompanham as alegres vestes roçagantes do cortejo triunfal.

Quanto te atrai a aleitadora do rebento de Jessé?73

Ela, para quem a pena reservou as derradeiras honras.

68 Cícero, De officiis 1. 22.

69 O Autor utiliza aqui uma expressão presente na sátira $1^{\text {a }}$ de Pérsio.

70 Alusão às obras lusti Lipsii Manductionis ad Stoicam philosophiam libri tres: L. Annaeo Senecae aliisque scriptoribus illustrandis. Antuerpiae, ex officina Plantiniana apud loannem Moretum, 1604, e Physiologiae Stoicorum libri tres: L. Annaeo Senecae aliisque scriptoribus illustrandis. Antuerpiae, ex officina Plantiniana apud loannem Moretum, 1604.

71 Hércules.

72 Como se sabe, a Justo Lípsio ficaram a dever os estudos clássicos edições criticamente depuradas e comentadas de inúmeros autores latinos, para além dos aqui expressamente nomeados pelo Dr. Nunes.

73 Is 11. 1-3. 
Dum quae Belga uidet, per te miracula uulgat,

Quaeque prius Hallis, nunc patrat Colle Sichemi:

Talia quae ueniens auida bibet aure uetustas

Iuratasque dabit fidei euanescere pestes.

Sed quid ego haec? Inopi sperem deducere uena,

Ingenii monumenta tui! Quae dicere fama

Nulla potest, quamuis centeno personet ore.

I, Musa, et cordis te per penetralia gyrans,

Arcanos animi penitus expende recessus.

An referes faciles et non sine pondere mores?

An niueum et nulla tinctum ferrigine pectus?

Quae probitas oris? Frontisque modestia quanta?

Illa dedit saeuas te sustentare procellas

Inuidiae et rabidae contemnere proelia linguae.

$\mathrm{Nec}$ tua in alterius iugulum facundia famae

Hac duce descendit dentesque armauit acutos,

[56] Sed cum alii plenis spargunt conuicia plaustris,

Innocuos tantum lusus sine felle reponis.

At quid in immenso laudum aequore naufragus erro?

Nam decus hoc, dignum meliori uiuere saeclo

(Ah dolor! Ah lacrimae!), mors inuida sustulit orbi,

Redderet ut caelo, caelestis particulam aurae

Vtque nouum patrio sociaret sidus Olympo.

Felix o nimium Lipsi, qui saxa dolosa

Et dubios uitae scopulos Syrtesque latentes

Emensus, tandem tuta in statione locaris. 
Enquanto o Belga os vê, divulga através de ti seus milagres,

Quer os que primeiro obrou em Hallen, ${ }^{74}$

Quer os que obra agora na colina de Zichem: ${ }^{75}$

Tais que com ávidos ouvidos há de vir a escutá-los a posteridade

E acreditará que se desvaneceram as pestes rogadas em praga.

Mas para quê estou a dizer estas coisas? Como se,

Com inspiração apoucada, esperasse apresentar

Os monumentos da tua inteligência! Que nenhuma fama

Pode jamais dizer, ainda que retumbe por um cento de bocas.

Vai, ó Musa, e girando pelos recessos do coração,

Examina a fundo os secretos penetrais da alma.

Darás acaso conta de um caráter acessível e ponderado?

Acaso de um peito cândido e sem mácula de inveja?

Quanta probidade transluz o semblante!

Quão grande comedimento que se revê na face!

Graças a este arrostaste com as cruéis tempestades do ódio

E desprezaste os ataques das línguas raivosas.

Nem, com este guia, a tua eloquência se rebaixou

A abocanhar a fama de outrem

Ou contra o próximo armou afiados dentes,

Mas, quando os outros espalham baldôes às carradas,

Retrucas apenas com inocentes gracejos sem fel.

[56]Mas por quê erro náufrago num imenso pego de louvores?

É que a esta glória, digna de viver em melhor século,

(Ah dor! Ah lágrimas), arrebatou-a ao mundo a invejosa morte,

Para restituir ao céu esta porção da luz celestial

E para associar um novo astro ao pátrio Olimpo.

Ó Lípsio deveras bem-aventurado,

Que, depois de atravessar os tredos arrecifes

E os escolhos incertos da vida e as ocultas sirtes,

Finalmente te encontras colocado em morada segura:

74 Alusão ao opúsculo piedoso atrás citado, no qual Lípsio historiava, coligia e exaltava os milagres da Virgem Negra cuja imagem se cultua naquela cidade flamenga.

75 Referência ao opúsculo piedoso I. Lipsii Diua Sichemiensis siue Aspricolis, noua eius beneficia et admiranda. Antuerpiae ex officina Plantiniana apud loannem Moretum, 1605, 75 pp. Nesta obrinha, como indica o título, relatam-se as mais recentes graças e milagres atribuídos à Virgem cultuada no santuário mariano da cidade flamenga de Zichem. 
Iam tenebris expers et uera luce refulges,

Illustres inter cuneos Manesque beatos,

Hic ubi perpetuo uia lactea lumine candet,

Vnde hominum miserans despectas uiuere inane

Et patriae ancipites casus et tristia fata.

Respice nos felix supremaque munera busti,

Quae tibi funesto soluit mens saucia luctu,

Suscipe, et affectus ne despice, Iuste, benignos.

Sic leuior semper tellus tibi uernet in urna,

Ossaque sic tumulo molli composta quiescant. 
Já livre estás das trevas e resplandeces com a verdadeira luz,

No meio dos luzentes esquadrôes e das almas bem-aventuradas:

Aí onde com luz perpétua alveja a via láctea,

Aí, donde olhas de alto e compassivo o vão viver dos homens

E os incertos sucessos e triste fado da pátria.

Venturoso, póe em nós os olhos e recebe as derradeiras homenagens

Que diante da tumba te presta um espírito abatido por funéreo luto,

E a desprezo não votes, ó Justo, um sentimento de lídimo afeto.

Que assim sobre a urna mais leve sempre te reverdeça a terra

E que assim descansem teus ossos, tranquilos em doce tumba. 


\section{BIBLIOGRAFIA}

Amato Lusitano, In Dioscoridis Anazarbei de medica materia libros quinque enarrationes eruditissimae. Venetiis, apud Gualterum Scotum, 1553.

Andrade, António Manuel Lopes, "Ciência, Negócio e Religião: Amato Lusitano em Antuérpia": in Inês de Ornellas e Castro, Vanda Anastácio (coord.), Revisitar os Saberes - Referências Clássicas na Cultura Portuguesa do Renascimento à Época Moderna. Lisboa, Centro de Estudos Clássicos - Faculdade de Letras da Universidade de Lisboa, 2010, pp. 9-49.

Andreas, Valerius, Bibliotheca Belgica. Lovanii, apud Henricum Hastenium, 1623; ibidem, typis Iacobi Zegers, 1643.

Arceo, Francisco, De recta curandorum uulnerum ratione et alii eius artis praeceptis libri II. Antuerpiae, Christophorus Plantinus, 1574.

Beyerlinck, Laurentius, Opus Chronographicum orbis uniuersi ab anno 1572 usque ad annum 1611. Antuerpiae, ex typographeio Hieronymi Verdussii, 1611.

Brandão, Mário, Actas dos Conselhos da Universidade de 1537 a 1557, volume I. Coimbra, Imprensa da Universidade, 1941.

Bruce-Chwatt, Leonard Jan, "Ludovicus Nonnius, M. D., 1553-1645”, Bulletin of the New York Academy of Medicine, 60.9 (November 1984), pp. 938-943.

Castro, Rodrigo de, Roderici a Castro Lusitani (...) De uniuersa mulierum medicina (...). Coloniae, 1603.

Enzinas, Francisco de, Epistolario de Francisco de Enzinas. Texto latino, traducción española y notas de Ignacio J. García Pinilla. Genebra, Librairie Droz, 1995.

Ferraz, Amélia Ricon, “The Portuguese background of Ludovicus Nonnius”, Derde Symposium Geschiedenis der geneeskundige wetenschappen. Nonius en de 'dietetiek'. 2 december 1995. Academia Regia Belgica medicinae - Dissertationes - Series Historica, 5. Bruxelas, Kon. Akademie voor Geneeskunde, 1996, pp. 55-66.

Ferreira, Francisco Leitão, Notícias Cronológicas da Universidade de Coimbra, edição publicada, revista e anotada por Joaquim de Carvalho, 2a parte, volume II. Coimbra, Imprensa da Universidade, 1940.

Frade, Florbela Veiga, As relaçôes económicas e sociais das comunidades sefarditas portuguesas. $O$ trato e a família: 1532-1632, tese de doutoramento em História Moderna apresentada à Faculdade de Letras da Universidade de Lisboa, 2006 (policopiada).

Laguna, Andrés, Pedacio Dioscorides Anazarbeo, Acerca de la materia medicinal y de los venenos mortiferos, traduzido de lengua griega, en la vulgar castellana. Anvers, Iuan Latio, 1555.

Lemos, Maximiano, “Amato Lusitano. Correcçôes e aditamentos. Amato Lusitano nos Países Baixos", Revista da Universidade de Coimbra 10 (1927), pp. 5-38.

Lípsio, Justo, Iusti Lipsii epistolarum selectarum centuria quinta. Miscellanea postuma. Antuerpiae, ex officina Plantiniana apud Ioannem Moretum, 1607.

Lípsio, Justo, Iusti Lipsii epistolarum selectarum centuria quinta. Miscellanea postuma. Antuerpiae, ex officina Plantiniana apud Ioannem Moretum, 1607. 
Lípsio, Justo, Iusti Lipsii epistolarum selectarum centuria tertia ad Belgas. Antuerpiae, ex officina Plantiniana apud Ioannem Moretum, 1602

Lípsio, Justo, Iusti Lipsii sapientiae et litterarum antistitis fama postuma. Antuerpiae, ex officina Plantiniana apud Ioannem Moretum, 1607.

Machado, Diogo Barbosa, Bibliotheca Lusitana, histórica, critica e cronológica na qual se comprehende a notícia dos authores portugueses e das obras, que compuserão desde o tempo da promulgação da ley da Graça até o tempo prezente. Lisboa, na officina de António Isidoro da Fonseca, 1741-1759, 4 vols.

Nebrija, Élio António de, Dictionarium latinumbispanicum. Antuerpiae, Iuan Steelsius, 1545 e 1553.

Nunes, Luís, Diaeteticon. Antuerpiae, apud Petrum Bellerum, 1645.

Nunes, Luís, Ludouici Nonii HISPANIA siue Populorum, Vrbium, Insularum ac Fluminum in ea accuratior descriptio, cuja primeira edição saiu no ano de 1607, em Antuerpie, ex officina Hieronymi Verdussi, 1607 (2a edição apud Hispania Illustrata, edição de André Schott, volume IV. Francoforte, apud Claudium Marnium et heredes Ioan. Aubrii, 1608).

PoHL, Hans, Die Portugiesen in Antwerpen, 1567-1648: zur geschichte einer Minderheit. Wiesbaden, Franz Steiner, 1977.

Ramalho, Américo da Costa, "O 'Doctor Ludovicus Nonius' retratado por Rubens", Mundo da Arte 16 (Dezembro de 1983), pp. 15-18.

Ramalho, Américo da Costa, Latim Renascentista em Portugal. Coimbra, Centro de Estudos Clássicos e Humanísticos, 1985.

Romano, Marco, "Rubens e l'erma ritratto di Ippocrate. La memoria dell'antico in un ritratto di Ludovicus Nonnius", Journal of History of Collections 22.1 (2010), pp. 15-27.

Siraisi, Nancy G., "History, Antiquarianism, and Medicine: The case of Girolamo Mercuriale", Journal of the History of Ideas 64, n. 2 (April 2003), pp. 231-251.

Sweertius, Franciscus, Athenae Belgicae siue Nomenclator inferioris Germaniae scriptorium. Antuerpiae, apud Guglielmum a Tungris, 1628.

TRICOT, Jean-Pierre, Ludovicus Nonnius (1553-1645): humanistisch geneesheer, grondleger van de medische dietetiek. Beveren, Herman Cols, 1984.

Viterbo, Sousa, Notícia sobre alguns médicos portugueses ou que exerceram a sua profissão em Portugal. Segunda série. Lisboa, 1895. 
(Página deixada prepositadamente em branco.) 


\title{
Ontologias e idiossincrasias dos Amantes, à luz da Archipathologia de Filipe Montalto. ${ }^{1}$
}

\author{
JOANA MESTRE COSTA2 \\ ADELINO CARDOSO 3
}

\section{RESUMO:}

Desde a Antiguidade Clássica, despertam os amantes o engenho do labor poético, a curiosidade do pensamento filosófico e, mesmo, o interesse da análise médica. A verdade é que, entregues a um imoderado sentimento, aqueles que amam nem sempre se mostram capazes de conciliar a razão e os sentidos, acabando por se deixar dominar por um espírito insano. É, precisamente, sobre este motivo que reflete Catulo, no seu carme 85, ou, antes dele, Anacreonte, no fragmento 46, conquanto se acerque já o poeta latino de uma apreciação mais idiossincrática.

Com efeito, da mesma excruciação se ocupa Filipe Montalto, ao deter-se, no Tratado Quinto da sua Archipathologia datada de 1614, sobre a "Insânia dos Amantes". Evidentemente que é médico o olhar de Montalto, e que este é um entre dezoito tratados que procuram a classificação das afeções neuropsiquiátricas. Assim, à semelhança das demais doenças elencadas, também no que à insânia dos amantes diz respeito, se investigam e procuram estabelecer as causas, a sintomatologia e uma terapêutica para a enfermidade. São estas ontologias e idiossincrasias dos Amantes, sobretudo as possíveis à luz da Archipathologia de Filipe Montalto, que pretende este trabalho explorar.

\section{PALAVRAS-CHAVE:}

Insânia dos Amantes; Topos Literário; Afeção Neuropsiquiátrica; Archipathologia; Filipe Montalto.

1 Este trabalho foi desenvolvido no âmbito do projeto «Arte médica e inteligibilidade científica na Archipathologia de Filipe Montalto» do Centro de História da Cultura da Universidade Nova de Lisboa, coordenado por Adelino Cardoso e que conta com o apoio da Fundação Calouste Gulbenkian.

2 Centro de Línguas, Literaturas e Culturas da Universidade de Aveiro: joanamestrecosta@ua.pt.

3 Centro de História da Cultura, Faculdade de Ciências Sociais e Humanas, Universidade Nova de Lisboa: cardoso.adelino@gmail.com. 


\section{ABSTRACT:}

Since Classical Antiquity, lovers arouse the ingenuity of the poetic work, the curiosity of the philosophical thought and even the interest of the medical review. The truth is that, handed over to an immoderate feeling, those who love do not always show themselves capable of reconciling reason and senses, eventually being dominated by an insane mind. It is precisely on this motive that ponders Catullus, in his carmen 85, or, prior to him, Anacreon, in the fragment 46, although being the Latin poet's approach a more idiosyncratic consideration.

Indeed, with the same excruciation is busied Filipe Montalto, while lingering over "Lovesickness", in the Fifth Treatise of his Archipathologia from 1614. Of course that it is medical the look of Montalto, and this is one among eighteen treatises seeking the classification of neuropsychiatric affections. Thus, approximating the other illnesses listed, also regarding the insanity of lovers, are the causes, symptoms and treatment for the disease investigated and established. Are these ontologies and idiosyncrasies of the Amantes, especially the conceivable under the light of the Archipathologia of Filipe Montalto, that this study intends to explore.

\section{KEYWORDS:}

Lovesickness; Literary Topos; Neuropsychiatric Affection; Archipathologia; Filipe Montalto. 


\begin{abstract}
Se Teletusa vier e os prometidos gozos me trouxer,
vou guardar para a minha bem-amada as quatro do teu nome, Rufo;

se indecisa estiver, com sete cíatos esperarei; se defraudar o amante,

para afogar as mágoas, a soma dos dois nomes beberei. ${ }^{4}$
\end{abstract}

Marco Valério Marcial, 8.50(51).23-26

Agraciado com um belíssimo copo cinzelado, presente de Istâncio Rufo, o poeta de Bílbilis conta, neste epigrama, que, à saúde do seu amigo e seguindo o costume, onze cíatos - um por cada letra do vocativo do nome celebrado, Istanti Rufe, neste caso - se tomarão, reservando, porém, a estreia para Teletusa, à mercê de quem o tem submetido o amor. E, acrescenta o epigramatista, se a sua bem-amada, indecisa, o fizer esperar, beberá sete dos onze, se, decidida a não comparecer, o fizer desesperar, embriagar-se-á, com os restantes quatro.

Não era, decerto, esta, nem ao tempo, a prescrição terapêutica mais adequada para o desassossego dos amantes; no entanto, esta solução, quotidianamente, praticada, no século I, não foi inovadora, nem viria a cair em desuso, com o porvir.

As curae - 'cuidados', 'inquietaçôes', 'tormentos de amor' ou 'mágoas' — de Marcial ou, pelo menos, de tantos amantes por ele observados, decorriam da discrepância dos comportamentos e, não raro, dos sentimentos entre o amante e a coisa amada, que, nas palavras do bilbilitano, assume o papel da domina - 'senhora' - a quem o amans, como um qualquer cliens, se sente subjugado.

E não se caia na errónea tentação de crer que os papéis do amante e da coisa amada estavam, a priori, destinados a pertencer ao género masculino, o primeiro, o derradeiro, ao feminino. Qualquer ser humano - homem ou mulher — se podia deixar tomar de um amor e de um desejo dominadores e doentios pelo objeto da sua afeição. Dido, a primeira rainha de Cartago, como é de todos cógnito e como no-lo rememora, na sua epopeia, Virgílio, deixou-se perder de curae por Eneias:

At non infelix animi Phoenissa, neque umquam soluitur in somnos oculisue aut pectore noctem accipit: ingeminant curae rursusque resurgens saeuit amor magnoque irarum fluctuat aestu. (En. 4.529-532)

4 Tradução de Paulo Sérgio Ferreira (C. S. Pimentel (introdução e notas); D. F. LeÃo; J. L. L. Brandão; P. S. FERREIRA (tradução), Marcial — Epigramas. Vol. III, Clássicos Gregos e Latinos. Lisboa, Edições 70, 2001), a partir da edição crítica de David Roy SChaCKLETon Bailey (D. R. SCHACKLETON Bailey, Martial — Epigrams. Vol. 2, Loeb Classical Library. Cambridge, Massachusetts and London, Harvard University Press, 1993):

si Telethusa uenit promissaque gaudia portat, seruabor dominae, Rufe, triente tuo;

si dubia est, septunce trahar; si fallit amantem, ut iugulem curas, nomen utrumque bibam.

5 G. P. Goold (revision); H. R. Fairclough (translation), Virgil - Eclogues, Georgics, Aeneid 1-6. Vol. 1, Loeb Classical Library. Cambridge and London, Harvard University Press, ${ }^{2} 1934$ (1998 reprint). 
Mas não a fenícia de espírito infeliz nunca repousa em sono

ou acolhe a noite com os olhos e o peito:

os cuidados redobram novamente o amor ressurgente,

enfurece-se e agita-se no grande furor das iras. ${ }^{6}$

Assim, se as mais canónicas relações amorosas ou o próprio amor sempre incentivaram a criação literária, quer lírica, quer heroica, quer dramatúrgica, entre os greco-latinos, a verdade é que aqueles que amam, entregues a um imoderado sentimento e, quase nunca, capazes de conciliar a razão e os sentidos, dominados que estão por um espírito insano, despertaram, desde a Antiguidade Clássica, não apenas o engenho do labor poético, mas também a curiosidade do pensamento filosófico e, mesmo, o interesse da análise médica.

É, precisamente, este motivo que intelectualiza a filosofia platónica e é sobre ele que reflete, ainda na Hélade, o lírico Anacreonte, no fragmento 46:

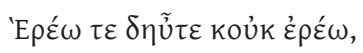

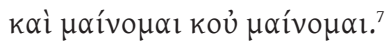

Amo e não amo,

Estou louco e não estou louco.

Depois dele, Catulo, em Roma, no seu carme 85, acerca-se mais ainda de uma apreciação idiossincrática, conquanto vática:

Odi et amo. Quare id faciam, fortasse requiris.

Nescio, sed fieri sentio et excrucior. ${ }^{8}$

Odeio e amo. Por que razão o faço, talvez te perguntes.

Não sei, mas sinto que sucede e excrucio-me.

6 Todas as traduções apresentadas, quer as de clássicos greco-latinos quer as da Archipathologia, são da autoria de Joana Mestre Costa, salvo, como indicado, a dos versos de Marcial em epígrafe.

7 B. GENTILI, Anacreonte - introduzione, testo critico, traduzione, studio sui frammenti papiracei. Lyricorum Graecorum quae exstant. Roma, Edizioni dell'Ateneo, 1958.

8 G. P. Goold (revision); F. W. CORNISH (translation of Catullus); J. P. Postgate (translation of Tibullus); J. W. Mackall (translation of the Peruigilium Veneris), Catullus, Tibullus, Peruigilium Veneris. Loeb Classical Library. Cambridge and London, Harvard University Press, ${ }^{2} 1913$ (1995 reprint). 
Com efeito, da mesma excruciação se ocupa Filipe Montalto, guiado, como o próprio assume, pelo testemunho das precedentes autoridades iátricas de Galeno, Haly Habbas ('Ali Ibn Al-'Abbas Al-Magusi), Abulcasis (Abu'l-Qasim Khalaf ibn 'Abbas al-Zaharawi) e Avicena, ao deter-se, sobre a "Insânia dos Amantes", no Tratado Quinto, da sua Archipathologia:

Amantium insania est solicitudo malancholica, ex immoderato amore profecta ac pendens, uariis subinde pathematibus animum exagitans. Dum enim laborans amoris inflictum uulnus alit uenis, et caeco carpitur igni, incessanter amatae rei fruendae ardentissimo desiderio cruciatur, ac modo inani spe ducitur; modo timore, aut desperatione premitur; modo graui tristitia conflictatur; modo prae laetitia delusorie gestit; ac demum uariorum animi pathematum uicissitudine fluctuat. ${ }^{9}$

A insânia dos amantes é um desassossego melancólico, motivado e dependente de um imoderado amor, que, por meio de sofrimentos vários, perturba, com frequência, o ânimo. Com efeito, em atividade, aumenta, benevolentemente, a ferida do amor infligida, e consome-se por um fogo cego, atormenta-se, sem cessar, por um ardentíssimo desejo de fruir da coisa amada, e guia-se, só, pela esperança vã; detém-se, só, pelo temor ou pelo desespero; choca-se, só, com a tristeza profunda; exulta, só, diante da alegria enganosa; e flutua, em suma, numa sucessão dos vários padecimentos do ânimo.

Evidentemente que é médico este olhar de Montalto, datado de 1614, e que, à semelhança do que sucede com as demais perturbaçôes neuropsiquiátricas, elencadas nos restantes dezassete tratados de que se compõe a obra, também, no que à insânia dos amantes diz respeito, se investigam e procuram estabelecer as causas, a sintomatologia e uma terapêutica para a enfermidade.

São estas ontologias e idiossincrasias dos Amantes, sobretudo, as possíveis à luz da Archipathologia de Filipe Montalto, que, neste contexto de trabalho, versando a questão médico-filosófica, suscitada pelo tema "Dioscórides e o Humanismo Português: os Comentários de Amato Lusitano", pretende explorar o presente labor.

Duas ordens de razóes — , uma firmada na sua origem e no seu percurso e uma outra (e, sem dúvida, a mais importante) de cariz meritório — , justificam o presente escrutínio do ponto de vista montaltino.

Montalto, à semelhança de Amato, possui ascendência judaica e, também ele, é de naturalidade albicastrense, tendo nascido em 1567. O percurso de ambos, como o de boa parte dos

9 F. MontAlto, Archipathologia, in qua internarum capitis affectionum: essentia, causae, signa, praesagia, et curatio accuratissima indagine edisseruntur. Lutetiae, Apud Franciscum lacquin, Sumptibus Caldorianae Societatis, 1614, p. 381. 
cristáos-novos portugueses ao tempo, corre em paralelo: a curiosidade humanista, a formação iátrica, máxime salmantina, e a jornada europeia, motivada pela pátria perseguição inquisitorial e acicatada pelos ensejos de negotium.

Antes ainda da viragem do século, Montalto acaba por rumar para a Europa transfronteiriça, onde abraça, aberta e definitivamente, o judaísmo e dá continuidade à prática clínica que exercera, outrora, em Portugal. No decurso do seu périplo europeu, centrado em Itália, a sua renomada conduta de esculápio dita que assista (e com auspicioso resultado, acrescente-se), em Paris, a italiana Leonora Galigai, aia e irmã de leite da Rainha Maria de Médicis, e que, segundo o próprio, haja sido o seu nome proposto para cátedras de Medicina em Bolonha, Messina, Pisa e Pádua.

Se alguma perplexidade ensombra estes últimos factos, quanto à sua próxima relação com família dos Médicis, não residem dúvidas: Filipe Montalto foi protegido do grão-duque Fernando I e as duas obras que dá à estampa, dedica-as, a primeira, Ad Sereniss. Hetruriae Principem D. Cosmum Medicem (Ao Serenissimo Príncipe da Etrúria D. Cosme de Médicis) ${ }^{10}$, a segunda, através de uma epístola introdutória, Christianissimae Gallarum et Nauarrae Reginae Regenti Maria de Medices (À Cristianissima Rainha Regente das Gálias e de Navarra, Maria de Médicis) ${ }^{11}$, sob a égide de quem, trocaria, aliás, em 1612, a Itália pela França, onde viria a sucumbir, em Tours, no ano de $1616^{12}$.

A primeva das empresas científicas montaltinas - Optica intra Philosophiae, et Medicinae aream, de uisu, de uisus organo, et obiiecto theoriam accurate complectens - , publicada, em 1606, em Florença, acabaria por conhecer, até aos nossos dias, mais larga difusão e mais aturados estudos do que a derradeira - Archipathologia, in qua internarum capitis affectionum: essentia, causae, signa, praesagia, et curatio accuratissima indagine edisseruntur —, cuja primeira edição parisiense data de 1614. No entanto, ao passo que, aquela, accurata — 'precisa', 'escrupulosa', 'completa' —, traria alguma depreciação ao seu autor; esta, accuratissima - 'muito precisa', 'muito escrupulosa', 'muito completa' —, conceder-lhe-ia a atenção dos investigadores.

Com efeito e segundo Alfredo Rasteiro, "Montalto procurou os fundamentos da visão num mundo em que o conhecimento estava limitado pela teoria dos quatro elementos e pela doutrina dos quatro humores e legou-nos uma Optica, 1606, que não acrescentará Kepler (1604) e será

10 F. Montalto, Optica intra Philosophiae, et Medicinae aream, de uisu, de uisus organo, et obiiecto theoriam accurate complectens. Florentiae, Apud Cosmum luntam, 1606, p. de rosto.

11 F. Montalto, Archipathologia..., op. cit., Epistola.

12 As mais relevantes informações sobre a biografia de Filipe Montalto sintetiza-as Herman P. Salomon, podendo, por exemplo, ser consultadas na edição do Tratado da Verdade da Lei de Moisés de Saul Levi Morteira, o rabino que terá, em 1612, acompanhado Montalto de Veneza para Paris (cf. H. P. SALomon (edição fac-similada e leitura do autógrafo (1659), introdução e comentário), Saul Levi Mortera - Tratado da Verdade da Lei de Moisés (escrito pelo seu próprio punho em português em Amesterdão, 1659-1660). Acta Universitatis Conimbrigensis. Coimbra, Universidade de Coimbra, 1988, pp. XL-XLIII). 
rapidamente ultrapassada por Scheiner (1619), Benito Daça de Valdes (1623) ou Descartes (1636)" ${ }^{13}$, conquanto possua o valimento, como também salienta o mesmo investigador, de ser "a única de autor "português" sobre este assunto, entre o De Oculo de Pedro Hispano (1220?1277) e os Elementos de Cirurgia Ocular (1793) de Joaquim José de Santa Anna (1735?-1814)"14. Já, através da Archipathologia, procura Filipe Montalto estabelecer a descrição e a classificação das afeçôes neuropsiquiátricas em dezoito tratados: sobre a dor, sobre a dor de cabeça, sobre a frenite e a parafrenite, sobre a melancolia, sobre a insânia dos amantes, sobre a mania ou furor, sobre a loucura lupina ou canina, sobre a demência e a fatuidade, sobre a perda e a fraqueza de memória, sobre o coma ou catáfora, sobre o coma em estado de vigília, sobre a letargia, sobre o caro, sobre a catalepsia, sobre as vertigens, sobre o íncubo, sobre a epilepsia e sobre a apoplexia. E muito embora Philippe Pinel seja, graças à concretização e à publicação, em 1801, do seu Tratado Médico-Filosófico sobre a Alienação Mental, considerado o fundador da moderna psiquiatria ${ }^{15}$, a verdade é que Montalto foi, avant la lettre, um clínico que consagrou parte (e uma parte importante) da sua atividade a esse porvindouro ramo da Medicina devotado às doenças e às perturbaçóes da mente e à respetiva terapêutica.

O pioneirismo de Filipe Montalto reside na abordagem das afeçôes mentais e, sobretudo, na confiança havida na Medicina como meio para o triunfo da natureza sobre os desvios de um organismo malsão que atestam o mérito da obra; o do seu autor assevera-o uma dedicação que pôde traduzir-se em resultados mais promitentes, no tocante às perturbaçôes neuropsiquiátricas, que os de coetâneos seus do humanismo europeu, como Felix Plater, com as Observaçôes de 1614, Robert Burton, com A Anatomia da Melancolia de 1621, ou Francisco Sanches, com as Obras Médicas de 1636.

Montalto arrisca, ao contrário de Sanches ${ }^{16}$ ou de Plater ${ }^{17}$, colocar o foco, exclusive, sobre as desordens da mente, e, consegue, ao contrário de Burton $^{18}$, um mais extensivo e estruturado produto dessa focagem.

13 A. RASteIRo, "Amato, Montalto e a Arte dos Olhos nos Séculos XVI e XVII", Medicina na Beira Interior da pré-História ao Século xx. Cadernos de Cultura 8 (1994), p. 6.

14 Ibidem.

15 Cf. P. Pinel, Tratado Médico-Filosófico sobre a Alienação Mental. Tradução de B. BARReiros, N. Melim e N. M. ProençA, Universalia, Série Ideias, 6. Lisboa, Colibri, 2011, passim.

16 Cf. F. SAnches, Opera Medica - his iuncti sunt tractatus quidam Philosophici non insubtiles. Tolosae Tectosagum, Apud Petrum Bosc, 1636, passim.

17 Cf. F. PLATER, Obseruationum, in hominis affectibus plerisq[ue], corpori et animo, functionum laesione, dolore, alia ue molestia et uitio incommodantibus, Libri Tres. Basileae, Ludovic König, 1614, passim e M. A. KatRItZky, Healing, Performance and Ceremony in the Writings of Three Early Modern Physicians: Hippolytus Guarinonius and the Brothers Felix and Thomas Platter. The History of Medicine in Context. Farnham, Ashgate Publishing, 2012, passim.

18 Cf. R. BURTON, The Anatomy of Melancholy, what it is, with all the kinds, causes, symptomes, prognostics, and several cures of it. In three partitions. With their several sections, members, and subsections, philosophically, medicinally, historically opened and cut up. London, Printed for J. CUTHELL et alii, ${ }^{12} 1821$, passim. 
O Quinto Tratado da Archipathologia, sobre o desassossego melancólico em que consiste a insânia dos amantes, é um bom exemplo da visão montaltina: revisitando a temática da amência amorosa, fá-lo, ao contrário do que sucede nos Diálogos de Amor ${ }^{19}$ de Leão Hebreu, à luz de uma conceção menos filosófica do que clínica ${ }^{20}$, e, de modo dissemelhante do proposto por Jacques Ferrand no seu Tratado sobre a Essência e a Cura do Amor ou sobre a Melancolia Erótica $^{21}$, numa perspetiva mais neuropsiquiátrica do que psicológica e escusando-se, ainda, a compor um cabinet de curiosités $^{22}$. Assim, conquanto seja o quinto dos mais breves entre os tratados da obra, não deixa, pela sua perspicuidade (não menos que pelo seu arrojo), de despertar a curiosidade e o interesse dos especialistas.

O autor principia a sua análise pela categorização desta patologia, determinando-lhe a essência e apontando-lhe as causas, com destreza na utilização da terminologia científica e clareza de discurso e concedendo especial atenção no que à legitimação das suas afirmaçóes diz respeito, como torna percetível o remate do primeiro capítulo:

Interna huius passionis causa humor est atrabiliarius cerebrum intemperans, animalesque spiritus uitians. Externa, immoderatus, aut diutinus amor. Huius enim uis tum per se, tum solicitudinis, ac uigiliarum interuentu, igneum, torridum, ac demum atrabiliarium sanguinem reddit; hic uero ad cerebrum delatus, insaniam parit [...]. Sic recte Auicennas lib. 3 canonis, eam melancholicis morbis adnumerat: minus recte, ut reor, alibi cholericis. ${ }^{23}$

A causa interna desta afeção é o humor atrabiliário, que destempera o cérebro e que adultera os espíritos animais. A [causa] externa [é] um amor excessivo ou que dura muito tempo. Com efeito, a força desta [afeção], tanto por si própria, como pela intervençấo da inquietação e das insónias, torna o sangue inflamado, ardente e, finalmente, atrabiliário; este, levado ao cérebro, com efeito, gera a insânia [...]. Assim, com validade, a enumera Avicena entre as doenças melancólicas, no terceiro livro dos cânones; com menos validade, segundo penso, noutra passagem, entre as coléricas.

19 Obra principal de Leão Hebreu, os Diálogos de Amor foram, a título póstumo, publicados em 1535.

20 L. Hebreu, Diálogos de Amor. Apresentação de J. VILA-Chã e Tradução de G. Manuppella. Lisboa, Imprensa Nacional Casa da Moeda, 2001, passim.

21 Titulada, no original, Traité de l'Essence et Guérison de l'Amour ou de la Mélancolie Érotique, esta obra de Jacques Ferrand foi, pela primeira vez, dada à estampa em 1610, numa edição que alguns críticos consideram superior à sucessiva e revista de 1623.

22 J. FerRAND, A Treatise on Lovesickness. Translated and Edited and with a Critical Introduction and Notes by D. A. Beecher and M. Ciavolella. Syracuse, Syracuse University Press, 1990, passim.

23 F. Montalto, Archipathologia..., op. cit., p. 382. 
O segundo capítulo dedica-o Montalto à descriçấo dos sintomas, cujo escrutínio, logo adverte, não é fácil, quando:

Affectionis speciem, et originem, quandoque insanientes ipsi propalant, quandoque celant; $\left[\ldots . .{ }^{24}\right.$

Os próprios dementes por vezes divulgam, por vezes escondem o tipo e a origem da paixão; [...].

Porém, elenca o autor uma série de manifestações físicas e de sinais psicológicos desta afeção: insónia, falta de apetite, magreza excessiva, atrofia corpórea, olhos cavos, indivíduos arrítmicos, suspirantes e incapazes de pensar, espíritos atidos só à forma, ainda que fantasiosa, da coisa amada ou desejada e que, dependendo da reciprocidade do sentimento, se mostram alegres e risonhos ou coléricos e desesperados. E o derradeiro dos sucessos desta afeçáo é a aniquilação do amente:

Quod ad praesagium attinet, in furorem, ferinaque deliramenta aliquando commigrat haec passio; quin et uisi sunt non pauci hac passione laborantes, qui prae desperatione et insania se ipsos interemerunt. ${ }^{25}$

No que diz respeito ao prognóstico, esta paixão muda-se, enfim, em furor e delírio ferino; e, ainda mais, são vistos não poucos que sofrem desta paixão que, por desespero e insânia, se matam a si próprios.

É com base na própria observação clínica, mas também (se não mesmo, sobretudo) na de terceiros - tomando, de forma particularmente expressiva, os exempla sobre as palpitaçóes cardíacas, proporcionados pelos estudos de Erasístrato e de Galeno, sobre o mítico caso de

24 F. Montalto, Archipathologia..., op. cit., p. 383.

25 F. Montalto, Archipathologia..., op. cit., p. 386. 
Antíoco e Estratonice ${ }^{26}$ e sobre a situação da mulher de Pílades ${ }^{27}$, na devida ordem - que encontra o fundamento científico para a sua descrição. E isto, de imediato, se torna evidente no início da sua exposição sintomatológica:

Vniuersum corpus gracile, et aridum in dies euadit, ut Galeni, Halyabbatis, Alzarauij, et Auicennae testimonio ratum est; prodit experientia; firmat ratio belle ab eodem amorum doctore decantata;

"Attenuant iuuenum uigilatae corpora noctes,

Curaque et immenso qui fit amore dolor." ${ }^{28}$

26 Ao amor de Antíoco por Estratonice, celebrizado pelas artes, da literatura à música, passando pela pintura, e ratificado pela autoridade de Estrabão ou de Plutarco, concede Montalto tratamento exemplar, salientado o papel do iátrico Erasístrato, na deteção deste célebre caso de insânia amorosa:

[...] quippe cum Antiochus Seleuci Regis filius, uesano Stratonices nouercae amore correptus, prae verecundia impium uulnus dissimularet, duo hi animo inclusi affectus, amor nempe, et uerecundia, miserum adolescentem divexantes pene contabefecerant; donec Erasistratus ingrediente Stratonice, auta ipsa obeunte, effatu dignam diversitatem in Antiochi uultu, in respiratione, et in pulso obseruans, dissimulanter iterum, atque iterum animaduertens, urentem Stratonices amorem, aegritudinis causam esse, penitius explorauit, remque totam Seleuco patri exposuit, qui charissima coniuge cedens, in filii medelam, ipsum ab imminenti morte uendicauit. (F. MonTALTo, Archipathologia..., op. cit., pp. 384-385)

[...] visto que Antíoco, filho do rei Seleuco, tomado por um louco amor pela madrasta Estratonice, teria ocultado, por pudor, o ímpio golpe, [e] estes dois conjugados no ânimo, a afeição, amor sem dúvida, e o pudor, quase teriam consumido, devastadores, o jovem infeliz; então, Erasístrato, observando, no semblante, na respiração e no pulso de Antíoco, uma diferença digna de menção, aproximando-se Estratonice ou estando a mesma distante, [e], várias vezes, em segredo, verificando que o amor por Estratonice era a causa da aflição, examinou mais profundamente e expôs todo o caso ao pai, Seleuco, que, afastando-se da caríssima cônjuge para a cura do filho, roubou o mesmo à morte iminente.

27 À semelhança do seu predecessor Erasístrato, que, a partir da observação da condição de Antíoco, pôde dar um contributo significativo para o dealbar do estudo da arritmologia, também Galeno procurou a compreensão dos ritmos cardíacos, examinando a mulher de um certo Pílades; e sobre as conclusões do segundo dos esculápios se pronunciaria, de novo, Montalto:

Haud multo aliter Galenus, iusti uxorem Pyladis amore captam deprehendit, non uiso, sed solum nominato Pylade praedictam turbationem considerans, ut apud ipsum lidere est, lib. de praenotione ad Posthumum, quo loco etiam nugas appellat eorum opinionem, qui credunt arterias amatorie pulsare, seu certam quandam esse pulsus differentiam amoris indicatricem; sed sicut in concertationibus et pauoribus animum ex improuiso turbantibus, pulsum immutari accidit; sic et in uesano amore, re amata subito occurente, aut eiusdem facta mentione; [...]. (F. MonTALTo, Archipathologia..., op. cit., p. 385)

De modo não muito diferente, Galeno, com fundamento, descobriu, tomada pelo amor, a mulher de Pílades, nunca divisado, mas, apenas, designado por Pílades, considerando o predito tumulto, como no próprio está patente, no livro De praenotione ad Posthumum, nesse passo também chama [Galeno] bagatelas à opinião daqueles que creem que as artérias pulsam amorosamente, ou que uma certa diferença no pulso é sinal do amor; mas sucede que assim como o pulso se altera por causa de um conflito e de uma agitação que, de improviso, perturbam o ânimo, assim por causa de um louco amor, inesperadamente presente a coisa amada ou dela feita menção; [...].

28 F. Montalto, Archipathologia..., op. cit., p. 383. 
O corpo todo se torna, de dia em dia, magro e mirrado, como está determinado pelo testemunho de Galeno, Haly Habbas, Abulcasis e Avicena; [como] mostra a experiência; [como] estabelece o argumento pelo mesmo doutor dos amores belamente declamado:

"As noites de vigília enfraquecem os corpos dos jovens; e o cuidado e a dor nascem deste imenso amor." ${ }^{29}$

Aparentemente inusitado poderá parecer este último convocado: trata-se do poeta Ovídio este encantador mestre dos amores. A perícia que, neste domínio, reconhece o iátrico ao vate, adviria, decerto, da reflexão proporcionada pela redação das páginas da sua Arte de Amar e não menos dos seus Remédios de Amor, das suas Heroides ou dos seus Amores.

A verdade é que cedendo a literatura à ciência exempla completivos dos testemunhos das autoridades médicas e da experiência clínica - assim corroboram estes escritos de Ovídio, como os de Marcial, os de Virgílio, os de Anacreonte ou os de Catulo, antes, citados —; acabaria a ciência por conceder à literatura uma certa competência no seio da sua especialidade.

E não apenas quanto aos sintomas da insânia dos amantes indagou Montalto as obras ovidianas, como também no tocante à cura, como, depressa, permite perceber o dealbar do capítulo terceiro do seu tratado:

Vesani amoris curatio mox circa initia aggredienda, antequam ille altius radices defigat, ut et magnus ille amorum magister belle cecinit.

Dum nouus est, coepto potius pugnemus amori;

Flamma recens parua sparsa resedit aqua.

Et alibi:

Dum licet, et modici tangunt praecordia motus,

Si piget, in primo limine siste pedem.

Opprime, dum noua sunt subiti mala semina morbi,

Et tuus incipiens ire resistat equus.

Nam mora dat uires:

Et rursum:

Principiis obsta, sero medicina paratur,

Dum mala per longas conualuere moras. ${ }^{30}$

29 A tradução de OV., A. A., 1.735-736 supôs confronto com a edição crítica de George P. Goold e J. H. Mozley (G. P. GooLd (revision); J. H. MozLey (translation), Ovid - The Art of Love and Other Poems. Loeb Classical Library. Cambridge and London, Harvard University Press, ${ }^{2} 1979$ (1999 reprint)).

30 F. Montalto, Archipathologia..., op. cit., p. 386. 
A cura do amor louco deve ser empreendida de imediato, antes que aquele fixe raízes muito profundamente, e assim bem cantou aquele grande mestre dos amores:

"Enquanto é novo, lutemos contra um amor que começámos a sentir; uma chama recente extingue-se, quando salpicada com pouca água."31

E numa outra obra:

"Enquanto é possível, e são ligeiros os movimentos que agitam o teu coração, se te deixam pesaroso, mantém o pé no primeiro limiar.

Esmaga, enquanto são novas, as funestas sementes de uma súbita doença e que, desde a partida, o teu cavalo se recuse a avançar.

Pois a demora dá forças." ${ }^{32}$

E, em seguida:

"Resiste aos começos, demasiado tarde é preparado o remédio, quando a doença ganhou força por uma longa demora." ${ }^{3}$

Cedo ou tarde combatida, esta afeção para ser debelada, conclui Montalto, na senda científica de Hipócrates, Galeno, Paulo Egineta, Avicena, Haly Habbas ou Oribásio (mas, também, na literária de Ovídio), carece de procedimentos específicos, capazes de harmonizar o espírito (como o afastamento relativamente à coisa amada, o evitamento da solidão, a promoção da conversação elevada, a contemplação das coisas divinas, a dedicação às leituras sagradas, o entretenimento quer pela caça, quer pela pesca, quer pelos jogos, espetáculos e distraçóes de toda a sorte, a ocupação por meio de um qualquer ofício ou, mesmo, a busca de um novo amor e, até, a corretiva sujeição a chicotes e varas) e de regular o corpo (como os preparados e as beberagens, os sonos retemperadores, os banhos ou mais dúbias purgas de heléboro ou de lápis-lázuli), perturbados por esta vera afeção.

Um inegável intento de eficácia curativa acompanha a tentada classificação exaustiva das patologias neuropsiquiátricas, central no estudo montaltino, assim, a mais óbvia das curas para insânia dos amantes teria de constituir a primeira proposta deste elenco terapêutico:

[...] si licet amata re potiri, id sufficiens plerunque fuerit praesidium, tum pro amouenda insania, tum pro omni corporis damno resarciendo. ${ }^{34}$

31 A tradução de Ov. H. 17.189-190 supôs confronto com a edição crítica de George P. Goold e Grant Showerman (G. P. Goold (revision); G. SHowerman (translation), Ovid - Heroides, Amores, Loeb Classical Library. Cambridge and London, Harvard University Press, ${ }^{2} 1973$ ).

32 A tradução de Ov. Rem. vv. 79-83 supôs confronto com a edição crítica de George P. Goold e J. H. Mozley (G. P. Goold (revision); J. H. Mozley (translation), Ovid — The Art of Love..., op. cit.). O mesmo aconteceu no passo seguinte.

33 Ov. Rem. vv. 91-92.

34 F. Montalto, Archipathologia..., op. cit., p. 387. 
[...] se é permitido possuir a coisa amada, isto terá, geralmente, sido socorro suficiente, tanto diante da insânia que deve ser banida, como diante de todo o dano do corpo que deve ser reparado.

Filipe Montalto constitui, pois, uma referência entre os humanistas portugueses e, mesmo, entre os europeus, e este Tratado Quinto da sua Archipathologia disso mesmo faz prova, pela forma como recupera a tradição platónica e a recoloca à luz das narrativas de sucessivas gerações de homens das ciências e das letras, mas, sobretudo, do saber médico do seu tempo, conceptualizando doutrinalmente a insânia dos amantes:

Haec porro effraenata, disformis, inconstans, ac caeca appetentium facultatum motio, prauam facultatum principum functionem sequitur. Non solum enim dilectae, desiderataeque rei formam multo pulchriorem, uenustioremque phantasia ementitur; sed et ipsam nunc praesentem, nunc absentem, fugientemue confingit; nunc uotis annuentem, nunc abnuentem; nunc aduersam et acriter infensam: quale uero phantasiae figmentum, talis appetitus passio. Cogitatiua, ratiocinatrixue non modo phantasiae mendacia non corrigit, sed et seducta ipsis assentitur [....$^{35}$

[...] este impulso desenfreado, disforme, inconstante e cego das faculdades apetitivas resulta num vicioso funcionamento das faculdades principais. Com efeito, a imaginaçáo não mente apenas quanto à forma, muito mais bela e muito mais encantadora, da coisa amada e desejada, como também a supóe ora presente, ora ausente ou fugidia; ora anuente, ora resistente, relativamente aos desejos; ora desfavorável e fortemente hostil: na verdade, tal a representação da imaginação, tal a paixão do apetite. A [faculdade] cogitativa ou raciocinativa não só não corrige as ilusóes da imaginação, como, seduzida, lhes dá a sua anuência [...].

Ora, do ponto de vista montaltino, só através da ciência médica se revelava ser possível controlar o desassossego que afeta os amantes, sanando as faculdades cupidinosas e assegurando às faculdades principais o são funcionamento e a devida soberania.

35 F. Montalto, Archipathologia..., op. cit., pp. 381-382. 


\section{BIBLIOGRAFIA:}

Burton, R., The Anatomy of Melancholy, what it is, with all the kinds, causes, symptomes, prognostics, and several cures of it. In three partitions. With their several sections, members, and subsections, philosophically, medicinally, historically opened and cut up. London, Printed for J. Cuthell et alii, ${ }^{12} 1821$.

Ferrand, J., A Treatise on Lovesickness. Translated and Edited and with a Critical Introduction and Notes by D. A. Beecher and M. Ciavolella. Syracuse, Syracuse University Press, 1990.

Gentili, B., Anacreonte - introduzione, testo critico, traduzione, studio sui frammenti papiracei. Lyricorum Graecorum quae exstant. Roma, Edizioni dell'Ateneo, 1958.

Goold, G. P. (revision); Cornish, F. W. (translation of Catullus); Postgate, J. P. (translation of Tibullus); Mackail, J. W. (translation of the Peruigilium Veneris), Catullus, Tibullus, Peruigilium Veneris. Loeb Classical Library. Cambridge and London, Harvard University Press, ${ }^{2} 1913$ (1995 reprint).

Goold, G. P. (revision); Fairclough, H. R. (translation), Virgil-Eclogues, Georgics, Aeneid 1-6. Vol. 1, Loeb Classical Library. Cambridge and London, Harvard University Press, ${ }^{2} 1934$ (1998 reprint).

Goold, G. P. (revision); Showerman, G. (translation), Ovid - Heroides, Amores, Loeb Classical Library. Cambridge and London, Harvard University Press, ${ }^{2} 1973$.

Goold, G. P. (revision); Mozley, J. H. (translation), Ovid - The Art of Love and Other Poems. Loeb Classical Library. Cambridge and London, Harvard University Press, ${ }^{2} 1979$ (1999 reprint).

Hebreu, L., Diálogos de Amor. Apresentação de J. Vila-Chã e Tradução de G. Manuppella. Lisboa, Imprensa Nacional Casa da Moeda, 2001.

Katritzky, M. A., Healing, Performance and Ceremony in the Writings of Three Early Modern Physicians: Hippolytus Guarinonius and the Brothers Felix and Thomas Platter. The History of Medicine in Context. Farnham, Ashgate Publishing, 2012.

Montalto, F., Optica intra Philosophiae, et Medicinae aream, de uisu, de uisus organo, et obiiecto theoriam accurate complectens. Florentiae, Apud Cosmum Iuntam, 1606.

Montalto, F., Archipathologia, in qua internarum capitis affectionum: essentia, causae, signa, praesagia, et curatio accuratissima indagine edisseruntur. Lutetiae, Apud Franciscum Iacquin, Sumptibus Caldorianae Societatis, 1614.

Pimentel, C. S. (introdução e notas); Leão, D. F.; Brandâo, J. L. L.; Ferreira, P. S. (tradução), Marcial - Epigramas. Vol. III, Clássicos Gregos e Latinos. Lisboa, Edições 70, 2001.

Pinel, P., Tratado Médico-Filosófico sobre a Alienação Mental. Tradução de B. Barreiros, N. Melim e N. M. Proença, Universalia, Série Ideias, 6. Lisboa, Colibri, 2011.

Plater, F., Obseruationum, in hominis affectibus plerisq[ue], corpori et animo, functionum laesione, dolore, alia ue molestia et uitio incommodantibus, Libri Tres. Basileae, Ludovic König, 1614.

Rasteiro, A., "Amato, Montalto e a Arte dos Olhos nos Séculos xvi e xviı", Medicina na Beira Interior da pré-História ao Século xx. Cadernos de Cultura 8 (1994), pp. 6-10. 
SAlomon, H. P. (edição fac-similada e leitura do autógrafo (1659), introdução e comentário), Saul Levi Mortera - Tratado da Verdade da Lei de Moisés (escrito pelo seu próprio punho em português em Amesterdão, 1659-1660). Acta Universitatis Conimbrigensis. Coimbra, Universidade de Coimbra, 1988.

Sanches, F., Opera Medica - his iuncti sunt tractatus quidam Philosophici non insubtiles. Tolosae Tectosagum, Apud Petrum Bosc, 1636.

Shackleton Bailey, D. R., Martial - Epigrams. Vol. 2, Loeb Classical Library. Cambridge, Massachusetts and London, Harvard University Press, 1993. 
(Página deixada prepositadamente em branco.) 


\title{
Gabriel da Fonseca. A New Christian doctor in Bernini's Rome.
}

\author{
JAMES W. NELSON NOVOA ${ }^{1}$
}

\section{RESUMO:}

Esta comunicação apresenta novos dados, através da edição e análise de documentos arquivísticos, sobre o médico lamecense Gabriel da Fonseca (1586?-1668), professor de medicina nas universidades de Pisa e de Roma e médico pessoal do papa Inocêncio $X$. A documentação evidencia as diversas estratégias usadas por Gabriel da Fonseca para se integrar na Roma do séc. xVII. O seu estudo permite-nos compreender melhor as actividades do médico originário de Lamego nos anos em que aí viveu, a sua actividade mecenática em relação a Gian Lorenzo Bernini e os seus vínculos familiares, enfim, as estratégias usadas para alcançar uma inserção plena no tecido social romano do período barroco.

\section{PALAVRAS-CHAVE:}

Medicina; mecenato; cristão-novo; Portugal.

\section{ABSTRACT:}

This article presents new information, through the edition and analysis of archival documents, concerning the doctor from Lamego Gabriel da Fonseca (1586?-1668), a professor of Medicine in the Universities of Pisa and Rome and personal physician to Pope Innocent $X$. The documents demonstrate the different strategies used by Gabriel da Fonseca to integrate in the Roman society of the seventeenth century. Their study allows us to better understand the activities of this doctor from Lamego during the years in which he lived in Rome, his patronage of Gian Lorenzo Bernini and his family ties which all played into his strategies of insertion into the social world of Baroque Rome.

\section{KEYWORDS:}

Medicine; patronage, New Christian; Portugal.

1 Cátedra de Estudos Sefarditas «Alberto Benveniste»_Universidade de Lisboa: jwnovoa@gmail.com. 
At some point between 1662 and 1665 work was undertaken in earnest on a chapel in the Roman church of San Lorenzo in Lucina, which years later would known as the Cappella dell'Annunziata or more commonly, the Fonseca chapel, according to the design of Giovan Lorenzo Bernini (1598-1680), engaged in this enterprise by the physician from Lamego, in the north of Portugal, Gabriel da Fonseca (1586?-1668) ${ }^{2}$. The work in the chapel which is best known, and indeed, is associated with the name of its patron is a bust, which depicts Fonseca dressed in a doctor's robes, holding a rosary enrapt in a devotional pose and is rightly hailed by art historians as one of the pivotal works in the late production of the Neapolitan painter and sculptor. Few, however, have rarely delved into the complexities of the man behind the commission or what could have been, at least in part, the motives behind the decision to have himself and his family interred in the church. Here I will address some of these issues, relying on hitherto unpublished documents, chief among them Fonseca's will, in order to provide some background to man behind the construction of the chapel and how learning, medicine and patronage all played into the pursuit of social integration and ascendancy in Baroque Rome.

The work on the decoration of the chapel itself employed some of the most well known artists of the day. The altarpiece, a depiction of the Annunciation, the work of Ludovico Gimignani (1643-1697) was executed sometime before 1663 and the following year Ludovico's father, Giacinto (1606-1681), signed the painting of Elisha pouring salt into the waters of Jericho in order to purify them. The work on the chapel also involved the talents of other important artists of the moment such as Guillaume Courtois (1628-1679) who contributed a painting of King Ahab and the prophet Elija on Mount Carmel which is now lost and the sculptor Antonio Raggi (1624-1686) along with lesser known people active in Baroque Rome's artistic life. ${ }^{3}$

Suffice it to say that the initial design for the chapel itself can be dated around 1663, when Bernini was commissioned by Fonseca to undertake plans for its construction. ${ }^{4}$ Gimignani's altarpiece is central to the overall scheme of the chapel for which Fonseca had planned. The later addition of Bernini's bust of Fonseca, participates in the whole scene, almost seeming to face the event of the annunciation as though paying homage to the scene. ${ }^{5}$ The whole is a clear indication of Fonseca's attention to leaving a stamp on the church in the form of a chapel dedicated to himself and his

2 The most recent dating of the work on the chapel is to be found in Fabio BARRY, "New documents on the decoration of Bernini's Fonseca Chapel", The Burlington Magazine 146 (June 2004), pp. 396-399.

3 Ibid.

4 Giovanni CARERI, Bernini. Flights of Love, the Art of Devotion, trans. Linda LAPPIn. Chicago, The University of Chicago Press, 1995, pp. 11-22.

5 On the iconography in the chapel see Judy DoBIAS, "Gian Lorenzo Bernini's Fonseca Chapel in San Lorenzo in Lucina", The Burlington Magazine 120, no. 899 (Feb. 1978), pp. 65-71; Giovanni CARERI, "Il busto di Gabriele Fonseca nel "bel composto" di Bernini", in Augusto GenTILI, (a cura di), Il ritratto e la memoria, 3. Roma, Bulzoni, 1993, pp. 195-204; Giovanni CARERI, Bernini..., op. cit., pp. 11-22; Margaretha Rossholm LagerlöF, "Life Transformed: Performative Meaning, Analogy, and the Art of Bernini's Funeral Decorations", Konsthistorisk Tidscrift 81 (2012), pp. 9-11. 
Portuguese family. His will, published here, indicates very clearly just how the chapel fit into an overall desire to commemorate, celebrate and ensure the ensconcing of his family in Rome, by providing a resting place for those of them who had already died and for those who were to die in the future.

Gabriel da Fonseca made out his will on March 27, 1668, before a notary and in the house of a lawyer, one Eusebii de Eusebiis. According to an autobiographical account he had prepared several years before, in 1657, for the University of Rome where he was employed as a professor of Medicine he was then over eighty years old. ${ }^{6} \mathrm{He}$ apparently had worked in that capacity for some twenty years, a position he was surely confirmed in thanks to his proximity to Popes Urban VIII (1623-1644) and Innocent X (1644-1655), having worked as a physician to the conclaves which elected both popes and for the latter from his election until Innocent's abrupt dismissal of Fonseca in 1654 and literally working until the year of his death, which occurred in December 1668. ${ }^{7}$ It was during his tenure as a professor of medicine in Rome that he prepared his autobiographical account, intended as an exercise in self-promotion in which fact and fiction easily overlap. In it he claimed to have been a permanent fixture in the Spanish community in Rome of the seventeenth century, linked to men of power in both the church and the state, in the employ of several Spanish ambassadors as their personal physician, chief among them Gaspar de Borja y Velasco (1580-1645) whom he followed on to Naples when he was viceroy there briefly. ${ }^{8}$ That a Portuguese physician should make such inroads into these

6 According to the account he was born in Lamego at the end of the month of February in 1586. The account is published in James Nelson NOVOA, "Medicine, learning and self representation in seventeenth century Italy. Rodrigo and Gabriel da Fonseca", in António ANDRADE, João TORRÃo, Jorge Costa, Júlio COSTA (orgs.), Humanismo, Diáspora e Ciência (séculos XVI e XVII): estudos, catálogo, exposição. Porto, CMP-BPMP; UA-CLC, 2013, pp. 227-229.

7 "12 dicembre 1668: Il signor Dottor Gabriele Fonsecha, portoghese in età di anni 63, figlio del quondam signor Diego dal medesimo loco, fu marito della quondam signora Caterina Comes romana, morì nella parrocchia di San Tomaso in Parione di subito et il suo corpo fu seppellito in questa nostra Chiesa il dì seguente." San Lorenzo in Lucina, Morti (vol. VII), 1668, fol. 19 r. Archivio Storico del Vicariato di Roma. This contradicts the date of Fonseca's death which has been given by Diogo Barbosa Machado of 20 May 1668. Diogo Barbosa MACHADO, Bibliotheca Lusitana, histórica, crítica e cronológica na qual se comprehende a notícia dos authores portugueses e das obras, que compuserão desde o tempo da promulgação da ley da Graça até o tempo prezente. Lisboa, na officina de Ignacio Rodrigues, 1747, tomo II, pp. 313-314.

8 On Spain and Rome see Thomas James DANDELET, Spanish Rome 1500-1700. New Haven, Yale University Press, 2001; Michael, J. LeVIN, Agents of Empire. Spanish Ambassadors in Sixteenth-Century Italy. Ithaca, Cornell University Press, 2005; Valentina Favarò, "Un hombre al servicio del rey: Francisco de Lemos, conde de Castro (1601-1620", Saitabi 60-61 (2010-2011), pp. 189-202; Isabel EnCISo, "La embajada de obediencia del VI Conde de Lemos: ceremonial diplomático y política virreinal", in Carlos José Hernando Sánchez (ed.), Roma y España. Un crisol de la cultura europea en la Edad Moderna. Vol. 1. Madrid, Sociedad estatal para la acción cultural exterior, 2007, pp. 471-513; David García Cueto, "Mecenazgo y representación del Marqués de Castel Rodrigo durante su embajada en Roma", in Carlos José Hernando Sánchez (ed.), Roma y España. Un crisol de la cultura europea en la Edad Moderna. Vol. 2. Madrid, Sociedad estatal para la acción cultural exterior, 2007, pp. 695-716; Silvano Giordano, "Gaspar Borja y Velasco rappresentante di Filippo III a Roma", Roma moderna e contemporanea 15, 1-3 (gennaio-dicembre 2007), pp. 157-186. 
Spanish contexts there should come as no surprise. From 1580 to 1640 Portugal found itself governed by the Habsburg monarchy of Spain under a shared crown. It was natural to try to curry favor with Portugal's overseers given the advantages these could bring to one in a place like Rome.

While he himself frequented the circles of Spanish power within the city he himself chose to marry a Portuguese woman. On September 14, 1618 he wed one Catarina Gomes, the daughter of António Gomes, from Elvas receiving a dowry of 4,000 julios and 500 scudi in property and goods. ${ }^{9}$ He chose to settle in the parish of San Tommaso in Parione, in the quarter in Rome where the Fonsecas from Lamego would first seemed to have settled upon arriving in Rome in the middle of the sixteenth century. One of them, António da Fonseca (1515?-1588), a prominent merchant-banker, had a family chapel built in the church of San Giacomo degli spagnoli, the national church of the Castilians in Rome, in Piazza Navona in 1583 in which he, his wife and son were buried. It was a tangible sign of the presence of the family hailing from the north of Portugal in the city. ${ }^{10}$

Perhaps in an effort to distance himself from the family which had preceded him in the Rome or from the Spanish church, especially after Portugal had gained its independence from Spain in 1640, other members of Gabriel's immediate family chose to be interred in San Lorenzo in Lucina. His sister, Violante, had chosen to be buried there, a wish which was manifested in her will, opened after her death in 1657 as her mother Isabel Cardoso, had been before. Both were buried in the church but awaiting a chapel which was to be built for the family, a project which Gabriel da Fonseca already was nurturing, according to Violante's will. ${ }^{11}$ It was shortly after his sister's death in fact that Gabriel requested the priests of the Clerics Regular Minor, the religious order which, since the beginning of the seventeenth century, had taken possession of the church, to have a family chapel built. They responded favorably in April 1661, allowing for a chapel to built and administered by the Fonseca family, in invocation of the Annunciation. ${ }^{12}$

At his death Gabriel himself was solidly in place in Rome, a figure known to all. He could flaunt the credentials of any well to do Romanized foreigner, becoming a Roman citizen in 1638, purchasing a villa in Frascati in 1640 and family palace in Parione, in 1653, in which he

9 The contract is published as doc. 2 in the documentary appendix.

10 On the Fonseca's in Rome see Susana Bastos Mateus and James Nelson NovoA, "A Sixteenth Century Voyage of Legitimacy. The Paths of Jácome and António da Fonseca from Lamego to Rome and Beyond", Hispania Judaica 9 (2013), pp. 169-192, and James Nelson NovoA, "Unicorns and bezoars in a Portuguese house in Rome: António da Fonseca's Portuguese inventories", Ágora, Estudos Clássicos em Debate 14.1 (2012), pp. 91-112; IDEM, "Gusti e saperi di un banchiere portoghese a Roma nel Rinascimento", Giornale di Storia 10 (2012) (http://www.giornaledistoria.net/index.php?Articoli=557D0 301220A740321070500777327).

11 Bruno ContARd, "Precisazioni sul Bernini nella cappella Fonseca", Studi di storia dell'arte 1 (1991), p. 275.

12 B. ContARDI, "Precisazioni...", op. cit., pp. 275-276. 
had built up a fine art collection. ${ }^{13}$ The fact that cardinals Benedetto Odescalchi (1611-1689) and Lorenzo Imperiali (1612-1673) are named the protector of his heirs in his will is a further indication of his integration in Rome and familiarity with important members of Roman society. Aside from his teaching and his practice of medicine to prestigious patrons he had gained renown as one of the advocates and users of quinine in Rome to treat malaria. His Roman career followed his university training (1603-1609) and teaching (1609-1611) in Pisa, to which he led by his prestigious uncle, Rodrigo da Fonseca (1550 ca-1622), the author of more than twenty medical works and a professor in Pisa (1575-1615) and later in Padua (1615-1622). ${ }^{14}$ These Tuscan years were evoked in Fonseca's 1657 autobiographical account and shortly after his death by his son, Gaspare, who, writing on December 22, 1668 to Granduke Ferdinando II de' Medici (1610-1670), in an obvious bid to ingratiate himself with him, informing of this father's recent death while he offered his Christmas greetings. ${ }^{15}$

\section{GABRIEL DA FONSECA'S LAST WILL AND PROVISIONS}

The existence of the will and itself and its contents have been known for some time, having been discovered by the art historian Irving Lavin in the late 1970's and having been subsequently alluded to and partially published by scholars who have worked on Fonseca's commission to Bernini. ${ }^{16}$ The provisions in the will were rendered public on December 12, 1668, the same day as his death. ${ }^{17}$ The terms of the will were carefully crafted so as to make sure his name and memory would be conserved and preserved in Rome as well as those of his offspring, doing all that was possible to have them make inroads into Roman society. It is a reflection of the important ties with that society that he had been able to establish, links which had been forged during the decades in which he had been recognized as a prestigious physician, linked to the Spanish political and ecclesiastical presence in the Eternal City and to the papacy. The document cites some of the members of the upper echelons of Roman society with whom Gabriel was in contact in a variety of capacities. It is a telling demonstration of the position of prestige which he had attained by the time of his death there.

13 B. CONTARDI, "Precisazioni...", op. cit., p. 276. On the villa in Frascati, obtained from his brother-in-law Luís Gomes see Maria Barbara Guerrieri Borso "Il 'palazetto' di Frascati. Il casino dei Gomez, Fonseca, Silva, oggi Mergè, opera di Francesco Peparelli", Palladio 43 (2009), pp. 104-110.

14 James Nelson Novoa, "Medicine, learning and self representation...", op. cit., pp. 216-219.

15 The letter is published as document 3 in the documentary appendix.

16 Judy Dobias, "Gian Lorenzo Bernini's...", op. cit., p. 65.

17 San Lorenzo in Lucina, Mort, v. VII, 1668, fol. 19R, Archivio Storico del Vicariato di Roma. I thanks my colleague Bruno Pomara Saverino for having transcribed this document for me. 
Judging from the information we can glean about them in the document all his children, presumably born in Rome, had all either made successful marital alliances or entered the Church. He had two daughters, one Antonia Fonseca Argoli, married to Prospero Argoli, and Olimpia Fonseca Galli, married with three boys and left them one hundred scudi each. Another, Isabella Fonseca, a religious at a convent in Campo Marzio, who took upon the name donna Maria Helena, was left one hundred scudi, a year. One son was a priest, Baldassarre Fonseca, a canon of Santa Maria Maggiore, to whom he left 20,000 scudi, in a censo shared with the Duke of Bracciano, along with investments in papal debt (Monti), allowing him, in addition, to live in Gabriel's house after his death. From the 1657 autobiographical account we learn that Baldassare had been made a knight of Saint Peter before the canonry in the Roman basilica and had been granted Spanish naturalization in order to receive ecclesiastical benefices in Spain. ${ }^{18}$ Another son, Gaspare Francesco Fonseca, is named as his universal heir.

Gaspare was entrusted with the administration of the family chapel which Gabriel had ordered to be erected, claiming, in the will, that it was to be amovibile ad nutum di Gaspare Francesco Fonseca mio figlio e suoi descendenti or, in lieu of him, his cleric son, Baldassarre and that it was to be administrated by his descendants. A mass was to be said each day in the chapel for his soul, that of his ancestors, wife, uncles, aunts, brothers and sisters and other relatives, preferably by a priest which is a member of the family. In addition four masses a month are to be said for the repose of the soul of his sister, Violante Fonseca, something which she had apparently established in her will, for which she had provided funds.

Yet it was not only in stone and through masses that he wanted to be remembered and evoked. His will provided detailed instructions to assure that the the Fonseca name would be passed on, insisting that Giuseppe, the son of a deceased daughter of his, Anna Fonseca, who had been married to one Ludovico Panizza, should maintain the Fonseca name and arms if he wanted to receive some of Gabriel's inheritance. The same provisions were made out to the oldest son of his daughter Olimpia Fonseca Galli. He had left his native land and made a name for himself through his hard work, meticulously organized self promotion and cultivation of important social relations. After his death he was concerned not only that his name and his activities be remembered but that the Fonsecas of Lamego remain in Rome, something which was to be obtained by doing all possible to perpetuate the family name. Gabriel had thus chosen Science, Medicine and social capital as a means to ensure that his New Christian family from Portugal could become Roman, all the while never forgetting his origins.

18 James Nelson Novoa, "Medicine, learning and self representation...", op. cit., p. 228. 


\section{DOCUMENTARY APPENDIX}

\section{Document 1}

Archivio Storico Capitolino di Roma, Trenta Notai Capitolini, Sez. 19, Not. J. B. Rondinus, Busta 56, Testamenta \& Donationes ab anno 1667 usque 1672.

Aperitio testamenti bone memorie Gabrielis Fonseche.

Die decima decembris 1668

Coram perillustri et excellentissimo domino Vincentio Candido, notario illustrissimi et reverendissimi domini alme Urbis gubernatoris in civilibus causis, locumtenente in Romana curia eiusque districtu, iudice ordinario et competente et ad interponendum decreta in contractibus voluntarie iurisdictionis a sanctissimo domino nostro papa specialiter deputato pro tribunali sedente super quadam sede lignea coramine ornata in loco infrascripto posita et existente, quam sedem et quem locum pro sitis iuridico et congruo tribunali, quoad hunc actum tantum valide peragendum elegit et deputavit, me notario ac testibus etc., presentes et personaliter constituti perillustris dominus Gaspar ac perillustris et reverendissimus dominus canonicus Baldassar, germani fratres de Fonsechis, filii bone memorie Gabrielis, mihi cogniti, asserentes nuper dictum dominum Gabrielem eorum patrem de hac ad meliorem vitam migrasse, prout ego notarius cum infrascriptiis testibus illius cadaver super quadam tabula extensum in propria eius domo vidi et recognovi, condito prius per eum testamento clauso et cosigillato et mihi etc. sub die 27 martii proximi preteriti consignato cum facultate illum, sequto eius obitu, aperiendi et publicandi, quod ego notarius pro manibus habebat sanum, integrum, illesum, nullaque in parte vitiatum, ideo predicti domini fratres de Fonsechis|stante obitu dicti bone memorie Gabrielis eorum patris ad hoc ut per eum disposita debite executioni demandentur, petirerunt et institerunt a dicto domino iudice dictum testamentum per me notarium aperiri et publicari mandari premisso et omni alio meliori modo etc.

Qui perillustis et excellentissimus dominus iudex ut supra sedens etc., auditis etc., cum iustum petenti non sit denegandus assensus, dictum testamentum aperiri, desigillari et publicari mandavit omnibus etc. prout ego idem notarius ad mandatum dicti domini iudicis utendo facultatibus mihi a domino quondam Gabriele in eiusdem testamenti consignatione attributis idem testamentum aperiri, desigillari, publicari et de verbo ad verbum perlegi tenori etc. in quibus omnibus et singulis tamquam rite, recte et legitime gestis et factis dictus dominus iudex suum ius suique officii iudiciariam auctoritatem pariter et decretum interposuit, supplendo si qui etc. et alterius quomodolibet folium eiusdem testamenti in principio et calce propria manu signavit et lineavit omni etc. rogante etc. 
Actum Rome, domi solite habitationis dictorum dominorum de Fonsechis in regione Parionis, presentibus perillustre et excellente domino Petro Andree soprano, filio quondam Ascanii Senogalliensi et illustri Francisco Carilli magistri Marci Romano testibus etc.

Die vigesimaseptima martii 1668

In mei etc. perillustris et excellentissimus dominus Gabriel Fonseca, filius bone memorie Didaci Lusitanus, medicus phisicus in Urbe mihi etc. cognitus, sanus Dei gratia mente, sensu, loquela ac visu, auditu et in-|tellectu ac etiam corpore, timens casum sue future mortis, cum nil (sic) sit certius ea nilque incertius hora et puncto illius volensque diem sui obitus testamentaria dispositione prevenire, deliberavit facere, prout fecit, suum ultimum nuncupativum testamentum quod de iure civili dicitur sine scriptis in presentibus foliis serio consuetis et septem sigillis sigillatis eius etc. propria manu, ut dixit, subscriptis et manu persone sibi fide scriptisque mihi etc. tradidit et consignavit, in eisque contineri dixit suum ultimum testamentum suamque ultimam voluntatem, quod et quam valere voluit iure testamenti nuncupativi sine scriptis, donationis causa mortis, codicillorum et alias omni etc. cassans, irritans et annullans omne aliud testamentum, codicillos et alias quasvis dispositiones per eum hactenus quemlibet forsan factas sub quibusvis verbis et derogatoriis vel derogatoriorum derogatoriis et hoc ceteris omnibus preferri et prevalere voluit non solum etc. sed omnibus tribuitque mihi facultatem illum statim sequuto eius obitu ad instantiam cuiusvis persone etc. aperiendi et publicandi propter auctoritatem et absque alicuius domini iudicis decreto premissis et alias omnibus super quibus etc.

Actum Rome, domi solite habitationis illustrissimi domini advocati Eusebii de Eusebiis in via Acqueductorum regionis Campimartii, presentibus infrascriptis testibus, nempe perillustre et admodum eccellenti domino Iohanne, perillustre Baptista Pasqualino filio quondam Philippi de Accumulo Ausculane diocesis, perillustre et adomodum excellente domino Paulo Mattheo, filio domini Laurentii Reatino, perillustre et admodum excellente domino Augustino Gri-|sono filio quondam Nicolai Romano, illustre et excellente domino Bonaventura Ciaffarello filio quondam Dominici de Ispello, Spoletane diocesis, illustre et excellente domino Alexandro Nerio filio domini Iohannis de Camaiono Luccensis diocesis, domino Francesco Maria filio quondam Bernardini Guasturini de Aretio in Etruria et magistro Bernardo de Carolis filio quondam Iohannis Luccensi testibus, qui sese propriis manibus subscripsere ut infra.

Io Giovanni Battista Pasqualoni fui testimonio quanto sopra etc.

Paolo Mattei fui testimonio

Io Agostino Grisoni fui testimonio

Io Bonaventura Ciaffarelli fui testimonio

Io Alessandro Neri fui presente etc. 
Io Francesco Maria Guastarini fui testimonio

Io Bernardo Carli fui testimonio

In Dei nomine amen. Anno salutis 1668, die vero vigesimaseptima mensis martii, tempore pontificatus sanctissimi in Christo patris domini nostri domini Clementis pape noni, anno eius primo.

Io Gabrielle Fonseca, figlio della bona memoria del signore Diego Luigi della città di Lamego di Portugallo, da molti anni in qua commorante in Roma, famigliare e medico secreto della felice memoria della santità di nostro signore papa Innocentio X e lettore già nello studio di Pisa, e al presente nella Sapienza di Roma publico lettore di pratica di medicina, sano per grazia di Dio, di corpo, mente, sensi, loquela et intellecto, sapendo che ogni creatura|nata deve morire e che nessuno può sapere l'hora et il giorno estremo della sua vita, ho voluto - mentre mi trovo in questo essere - disporre delli beni temporali concessimi da sua divina maestà in questa vita et ho deliberato di fare il presente testamento nuncupativo sine scriptis e perchè desidero che la mia dispositione non si sappia se non seguita la mia morte. Lo fo chiuso e sottroscritto [sic] di mia propria mano nel modo che segue.

E prima - con tutto il cuore — raccomando l'anima mia a nostro signore Giesù Christo supplicando humilmente che per l'infinita bontà e misericordia sua si degni farla degna delli meriti della sua santissima passione, e divotamente prego la gloriosissima vergine Maria madre di Dio, tutti li santi e angeli del cielo che sempre e nell'hora della mia morte intercedano per me.

Dopo che sarò morto voglio che il mio corpo sia seppellito nella venerabile chiesa di San Lorenzo in Lucina nella quale chiesa è sepellita la bona memoria della signora Isabella Cardosa Fonseca, mia carissima e dilettissima madre, e la signora Isabella Cardosa Violante Fonseca, mia dilettissima sorella, nella sepoltura della mia cappella della Santissima Annuntiata che nuovamente ho fatto construere e perfettionare, et ordino che quelle siano trasportate nella medesima sepoltura della mia cappella sudetta accedente il placet di chi occorre in quanto sia di bisogno, sopra la quale sepoltura si dovrà fare nella lapidell'inscrittione del mio nome, cognome, patria, età et anco specificare gl'honori e cariche concessemi dalla felice memoria di Innocenzo X e la lettura di pratica da me esercitata nella Sapienza di Roma. Volendo di più che il mio corpo sia trasportato in detta chiesa privatamente et in quella dovrà stare esposto con quella quantità di torcie e pompa funerale che parerà che parerà $[$ sic] alli miei heredi et essecutori testamentarii, alla quale chiesa lascio quel che di raggione li verrà per la sepoltura.

Item voglio e commando che nel giorno seguente della mia morte — non si potendo nel medesimo per impedimento di festa o altro - sia recitato in canto funerale il mattutino de' morti con le laudi e cinquanta messe de' defonti per l'anima mia in detta chiesa e di più cento altre messe basse in tutto e da distribuirsi ne' monasterii e chiese di Roma tra quelli, trenta 
nella chiesa della Pace et il resto in altre chiese o monasterii che pareranno a detti miei heredi et essecurtori testamentarii, fra le quali nel monasterio di San Gregorio e sua chiesa [et se] debbiano celebrare diece messe, di dette cento per l'anima mia come sopra.

Item voglio e commando che al trigesimo giorno della mia morte — non essendovi impedimento di festa che in tal caso voglio che sia il giorno seguente - si celebri in detta chiesa di San Lorenzo in Lucina un altro offittio de' morti|con le laudi e mattutino come sopra ordinato nel giorno della mia morte con venticinque messe basse per l'anima mia, de' mio padre, madre, zio, sorelle e parenti.

Inoltre dichiaro che doppo l'anno 1642 essendo partito di Roma doppo la morte della bona memoria di Luigi Gomez, suo fratello maggiore, e signore Ferdinando Gomez Estella, mio cognato, restando questi debitori della Camera per la Tesoreria di Portugallo da loro amministrata, io per loro di mia propria volontà per riparare alla subhastatione della loro villa di Frascati, pagai alla Reverenda Camera seimila scudi moneta in più volte - come costa dalle ricevute da lei fatte — e da poi pure in più volte due altri mila et ottocento scudi con la cessione delle raggioni di detta Camera e per li primi seimila scudi fu da me compra la villa di essi posta in Frascati cum pacto redimendi fra cinque anni che, non havendola mai riscossa in tanti anni, restò per me libera e, restando creditore di maggior somma per altri debiti per essi pagati ad altri creditori per sodisfatione di detti denari pagati, riscossi la pigione della casa posta a Sant Eustachio e li frutti di un lavatore che possedevano alla fontana di Trevi, havendo però pagato a donna Maria Susanna e a donna Maria Alessandra lıannue entrate assegnateli da essi fratelli e zii di detta donna Maria Alessandra, loro nipote, però ordino che, se a caso fossero creditori o debitori facendosi li detti conti, si aggiustino ancorchè io in coscienza non creda doverli cosa alcuna, anzi stimo essere|creditore, non volendo però cos'alcuna da loro per questo particolare, havendomi detto signor Ferdinando Gomez fatto con le sue lettere la dichiaratione di esser saldati et aggiustati li conti di dare et havere fra di noi, come apparisce dalle lettere e scritte che sono appresso il signore Gasparo mio figliolo.

Item dichiaro che, stando da molto tempo in qua in mia casa la signora Dionisia Gomez quale, volendo continuare in mia casa, ordino e commando si debba tenere nella forma che io la tenevo vivendo con li miei heredi amorevolmente e, non volendo loro tenere in casa overo non volendo hora tenere in casa lei stante, li debbano dare detti heredi - mentre vive - cinque scudi il mese per l'amorevolezza che sempre ha usato meco, alla quale non voglio se li domandino conti di quello che ha tenuto in mano, ma si stia a quello che lei dirrà et tantomeno havendoci io revisti li conti che stanno benissimo e ne sono restato sodisfattissimo et io adesso per allhora li fo piena et assoluta quietanza e mi chiamo totalmente sodisfatto di quanto essa dirà.

Item dichiaro che ho due figlie maritate, una cioè la maggiore chiamata Antonia Fonseca Argoli, maritata al signor Prospero Argoli senza figlio, quale ha havuto seimilla scudi di moneta 
consegnateli in tanti luoghi de' monti, e l'altra si chiama Olimpia Fonseca Galli, la quale si trova con tre figli maschi: per la loro amorevolezza lascio ad esse Antonia et Olimpia, mie figliole, cento scudi a ciascheduna di loro per una sol volta|et in questi scudi cento l'instituisco heredi e voglio che non possino pretendere altro dalla mia heredità, se non quanto da me sarà disposto nel presente testamento et, in evento che non si acquietassero a questo mio testamento, ma che oltre alle cose da me disposte volessero molestare li miei heredi et heredità, in tal caso privo le medesime e chi di loro contraverrà, non solo nel presente legato, ma ancora dell'infrascritte sostitutioni havendole io in vita condecentemente dotate.

Item dichiaro e voglio che, in caso che la sudetta signora Antonia, mia figlia maritata al signore Argoli, restasse vedova con la sola dote di scudi seimila che io li diedi et il quarto dotale, perchè non gli basterà a vivere et a mantenersi conforme al suo grado, voglio che li miei heredi gli diano ogni due mesi anticipatamente la rata parte di cento scudi moneta l'anno che ci lascio mentre viverà e non oltre, e questo legato non habbia luogo quando il suo marito li lasciasse qualche simile portione.

Item dichiaro havere un'altra figliola chiamata al secolo Isabella Fonseca et al presente monaca in Campo Marso, professa, che hora si chiama donna Maria Helena alla quale, mentre si fece monaca, consegnai sessanta scudi l'anno d'entrata mentre viveva per li suoi bisogni et hora titulo institutionis et in ogn'altro miglior modo e titolo voglio e commando che, dopo la mia morte, se li ereschino $[s i c]$ quaranta scudi di moneta l'anno che in tutto saranno scudi cento di moneta l'anno mentre vive e non più oltre, e se li assegnino mentre vive detti scudi cento in tanti frutti de' luoghi de' monti esigibili od pighioni di botteghe o altra entrata|esigibile come ad essa più parerà e piacerà, dando ad essa donna Maria Helena amplissima facoltà di poterne pigliare subbito il possesso et esigere et far esigere tutta detta somma ogni anno mentre vive di sua propria auctorità et, in evento che i luoghi de' monti fossero estratti o ridotti, se li debbiamo assegnare altri, in modo che sempre abbia pieni et intieri li cento scudi l'anno e, seguita la mia morte, voglio che di più se li diano scudi centomila per una sola volta con espressa prohibitione che nè lei nè il monastero possi alcun'altra cosa pretendere dalla mia heredità per qualsivoglia ragione e di legittima o per supplemento di essa, perchè così voglio e dispongo in questo et in ogn'altro miglior modo.

Item dichiaro che, havendo io un altro figlio ecclesiastico chiamato Baldassare Fonseca, canonico di Santa Maria maggiore, titulo institutionis et in ogn'altro miglior modo lo lascio et instituisco parimente herede nella somma di scudi ventimila durante la sua vita solamente e non più, e questi scudi ventimila li dovrà pigliare parte in censo che ho con il signore duca di Bracciano, e parte in tanti luoghi de' monti - cioè del Sale e della Fede - tantum ipsius vita durante, con conditione però che del frutto deli detti ventimila scudi debba dare per mantenimento delle spese della casa quattrocento scudi l'anno, quali debbono essere per la parte al medesimo spettante, al quale parimente lascio che habiti nella casa mia e se li dia il suo appartamento dove al 
presente habita con le sue stanze che hora gode e, bisognando altre commodità nell'appartamento di sopra principalmente se entrasse in prelatura, se le diano le due stanze nell'appartamento di mezzo, restando la sala communele dichiaro che li quattrocento scudi sopradetti serviranno per il vitto e servitù et altre spese, eccetto che per le carozze e cochieri voglio che ogn'uno proveda alle sue con le proprie entrate, pregando detto Baldassare, mio figlio, voglia approvare e ratificare questa mia ultima volontà et alla medesima quietarsi senza contradittione alcuna et in ogni miglior modo, volendo e commandando di più che, nascendo qualche differenza o lite tra essi miei figli, non debbano in alcun modo litigare, ma che ogni differenza venghi decisa dalli monsignori due auditori di Rota spagnoli che pro tempore saranno in Roma e, se non vi fossero o non volessero fare questa parte, si rimetta la differenza a quel che deciderà monsignor decano della Rota opure, se così li parerà al signore avocato Eusebio, quali estragiuditialmente faranno gratia di acquietare ogni interesse di lite e pretensione senza proporle in Rota, dandoli per quest'effetto ogni facultà paterna e di arbitratori et amicabili compositori, imponendo et espressamente commandando a detti miei figli che debbano stare taciti e contenti a quel che sarà da detti signori lodato et arbitrato et, in evento che esso Baldassarre non volesse restar quieto e sodisfatto a questa mia dispositione, ma che volesse pretendere la legitima, adesso per allhora l'instituisco in essa legitima, ordinando espressamente che non possi pretendere altro dalla mia heredità per qualsivoglia causa e prestesto.

Item alla mia cappella della Santissima Annuntiata, posta nella venerabile chiesa di San Lorenzo in Lucina, lascio che si eregga una capellania amovibile ad nutum di Gaspare Francesco Fonseca mio figliole suoi descendenti in infinito et in difetto di esso signore Gaspare proveda detta cappella l'altro mio figlio Baldassarre e questi ancora mancando debbano provedere tutti gli heredi che succederanno nella mia heredità sino che ve ne saranno, e detta cappella sia sempre ad eorum nutum, amobivile, perpetua con entrata di scuti trentasei moneta da assegnarsi da me e, caso ciò non succedesse, se li assegni subbito dall'infrascritto mio herede con conditione che il sacerdote che terrà detta cappella dica ogni giorno una messa per l'anima mia de' miei ascendenti, di mia moglie, zii e zie, come anco di fratelli e sorelle e poi d'altri miei parenti, e voglio però che se vi sarà qualche sacerdote parente mio o de' miei heredi e di tutti li sostituti in questa eredità, debbano essere eletti e preferiti ad ogn'altro e di più voglio e dichiaro che nelle sudette messe si comprendano le quattro messe il mese che ho fatto celebrare per il passato sino al presente in esecutione di una lascita fatta dalla bona memoria della signora Violante Fonseca, mia sorella, per l'anima sua nel suo testamento, nel quale lascia che dette messe si comprendano in quelle che io lasciarò per l'anima mia in detta mia cappella e, quando non vi fosse nel suo testamento, voglio che siamo comprese in queste messe che io lascio quotidiane nella mia cappella e non si possino più pretenedere le dette quattro messe stante questa compretensione da me ordinata in questo testamento. 
Item ad una figlia del signor Ludovico Panizza chiamata Agata, che sta in educatione nel monastero di Campo Marzo, maritandosi o|monacandosi gli lascio scudi cinquecento moneta per una sol volta che gli servì per agiuto di dote.

Item lascio alla signora Gratia Gomez Checci, commorante in Terni mia nipote carnale, scudi cento moneta per una sol volta e, maritandosi una figlia che ha, li lascio scudi duecento per aiuto, il che voglio se li dia anche monacandosi.

Item lascio a tre sorelle del signor Ferdinando Gomez, residenti in Fiorenza monache nell'istessa città due in un monastero, l'altra nel monastero dell'Ape fuori di Fiorenza scudi trenta per ciascheduna di esse, e questo una sol volta acciò preghino Dio per me.

Item lascio ad Angelo Gomez e Gerolamo Gomez, miei nepoti carnali, luoghi cinque de' monti Camerali non vacabili e della Fede o Sussidio Quarto ad elettione del mio herede, i frutti de' quali luoghi siano la metà per uno d'essi Angelo e Girolamo e mancando uno, succeda l'altro e, se in caso ambedue loro mancassero senza figli legitimi e naturali, dichiaro che li detti scudi cinquecento con li frutti tornino al mio infrascritto erede Gasparo o suoi figli legittimi e naturali che, se a caso non vi fossero detto Gasparo e suoi figli nè Baltassarre, mi contento che detti miei nepoti Angelo e Girolamo Gomez ne siano legitimi padroni e dispositori, intendendo in questo caso non solo de' frutti, ma anco della sorte principale de' luoghi de' monti.

Item lascio che l'offitii vacabili e luoghi de' monti vacabili di S.|Spirito che sono a dispositione mia si debbiano fra sei anni vendere e comprarne tanta entrata non vacabile o in luoghi de' monte Camerali o in censi o altri stabili boni, non intendendo però di quelli offitii che sono alla dispositione de' miei figli, compri da loro, de' quali voglio che ogn'uno di essi che li haverà compri n'habbia il pieno et assoluto dominio senza haverne a dare ricompensa alcuna all'altro fratello che non n'havesse compri.

Item lascio a due miei nepoti carnali, figlie della bona memoria della signora Anna mia sorella, monache in Santa Susanna che si chiama una donna Maria Teresa e l'altra donna Maria Deodata, scudi dodeci l'anno tra tutte due, cioè scudi sei per ciascheduna di loro che, con altri dodeci lasciateli dalla bona memoria della signora Violante, sono ventiquattro e questi durante la lor vita e non altrimenti e, caso che una di loro mancasse, voglio che questo mio legato ritorni all'altra, e mancando ambedue ritorni all'infrascritto mio herede, non volendo che il monastero possa havere alcuna pretensione.

Item lascio alli servitori che si trovaranno in casa per una sola volta scudi diece moneta, et a Giovanni Maria, quale per molto spatio di tempo ha servito in casa, benchè di presente non serva, lascio scudi quindeci ritrovandosi però in Roma e questi per una sol volta, et a Giovanni Battista, cocchiero vecchio che mi serve, scudi venti per una sol volta ancorchè non si ritrovasse al|servitio e, caso fosse morto, voglio che detta quantità di scudi venti si diano alla sua moglie che seli goda assieme con i suoi figli, et agli altri cocchieri che si trovaranno al servitio 
di casa lascio scudi diece per una sola volta, et al signore Michelangelo, bracciero della signora Catarina, ritrovandosi al servitio lascio, scudi quindeci per una sol volta.

Item lascio che in tutti e singuli miei beni tanto mobili come stabili, raggioni, crediti, luoghi de' monti, nome de' debitori et attioni in qualsivoglia modo e luogo posti et esistenti appartenenti a me testatore e sotto qualsivoglia titolo spettanti et in avvenire mi potessero spettare et appartenere, sia et essere debba mio universale herede Gasparo Francesco Fonseca, mio figlio legitimo e naturale, e per tale l'instituisco e di propria bocca nomino, al quale sostituisco in infinito et in perpetuo per conservatione della mia casa Fonseca li suoi figlioli maschi, legitimi e naturali e dal proprio corpo nati in infinito, sempre con questa qualità e non altrimenti, volendo che in detti figlioli maschi e descendenti in infinito si conservino sempre i miei beni nella famiglia mascolina Fonseca senza potersi mai alienare in alcun tempo fuor di quella parte alcuna benchè minima della mia heredità et ciò per qualsivoglia urgente o urgentissima causa et ogni alienatione, etiam late sumpto vocabulo, sia nulla e di nessuna fermezza anzi possa da chiamati successivamente dopo l'alienante rivocarsi con facoltà di poterne prender possesso, etiam senza decreto di giu|dice e di propria autorità, dichiarando che questa prohibitione sia repetita eque pricipaliter et de per se in tutti quelli che possederanno la mia heredità in infinito et aggiungendo che l'alienante sia e si intende privato ipso facto et ipso iure alienando in tutto $\mathrm{o}$ in parte da quella portione e parte della mia heredità che alienarà, e questo perchè sempre interamente si conservi nei chiamati a questo mio perpetuo fideicommisso.

Item dichiaro e voglio che la villa di Frascati, trovandosi a vendere per giusto prezzo, si possi vendere et investire il prezzo o in altra vigna in Roma o suoi suburbii pure di giusto prezzo o in luoghi de' monti o in altri stabili di giusto prezzo $^{19}$ e, non vendendosi, possino i signori Gaspare e Baldasssarre andarci a dimorare egualmente. Il frutto però di essa spetti al signore Gaspare, al quale toccarà la spesa del mantenimento di essa villa.

E morendo in qualsivoglia tempo Gasparo Francesco Fonseca, mio figlio, senza figli legitimi e naturali e di proprio corpo nati voglio che, essendoci di detto Gaspare figlie femine legitime e naturali, succedano esse et i detti loro figlioli maschi legitimi e naturali e di loro proprio corpo nati et $\mathrm{i}$ loro descendenti in infinito in stirpes et non in capita con questo, che siino obligati ritenere il cognome et arme della famiglia Fonseca senza misura di altro cognome et arme, e quello possino mai lasciare anche con dispensa del principe, volendo in tal caso che decadano dalla mia heredità e vada come disporrò a quelli che osservaranno la mia volontà, cioè all'altri maschi delle femine sudette descendenti et, in difetto loro, come sostituirò appresso e, mancando le sudette figlie|femine del detto signore Gasparo Francesco, mio figlio, senza figlioli maschi come sopra, sostituisco e voglio succedano le di loro figlie femine legitime e naturali nate e da nascere di loro proprio corpo e loro descendenti in infinito maschi sempre in stirpes

19 prezzo added in at the margin. 
et non in capita con li pesi sudetti del cognome et arme della casa Fonseca come ho detto con questo che sempre siino preferiti i maschi in concorso et in difetto di maschi le femine e mancando Gasparo, mio figlio, senza figli legitimi e naturali tanto maschi quanto femine come sopra e loro descendenti finita la sua linea masculina e feminina e loro descendenti come sopra, opur morendo esso Gasparo senza figli legitimi e naturali, in tal caso sostituisco e voglio che succeda prima nell'usufrutto e nella proprietà ancora il sopradetto mio figlio Baldassarre Fonseca sua vita durante e doppo la di lui morte, o anche premorendo a Gasparo Francesco Fonseca, mio figlio, detta mia heredità e beni tanto nell'usufrutto come nella proprietà, voglio che succedano e sostituiscano tanto a Baldassarre quanto a Gaspare Fonseca tanto a' maschi quanto a' femine come sopra chiamati et ultimo di loro per la metà il figliolo maggiore d'età della buona memoria di Anna Fonseca, mia figliola maritata al signor Ludovico Panizza che si chiama signor Gioseppe, e per l'altra metà li figlioli maschi del signor Francesco Galli e loro descendenti maschi in infinito con le medesime conditioni come sopra, volendo che sempre uno di loro, cioè il figlio sudetto di detto signore Panizza come dal signore Galli e loro descendenti chiamati a questa mia heredità in|infinito, debba portare il cognome et arme della casa Fonseca e, mancando qualcheduno di loro, voglio che succeda l'altro con dette conditioni e, mancando loro maschi, succedano le femine e loro descendenti in infinito con le sopradette conditioni e, mancando loro maschi, succedano le femine e loro descendenti in infinito con le sopradette conditioni, salva sempre la prerogativa del sesso mascolino in stirpe e non in capita, con li medesimi pesi di arme e cognome come sopra nella metà che li toccarà e, mancando li maschi e femine tanto del signor Panizza come del signor Galli da me chiamati e, finita la linea di essi, succedano gl'altri sempre in stirpes et non in capita reciprocamente e, caso della total mancanza dell'una e dell'altra linea tanto mascolina quanto feminina in infinito, mancando in qualsivoglia tempo la linea de' Galli e di Panizza tanto de' maschi come de' femine, voglio che succedano et habbiamo la mia heredità li figlioli della bona memoria della signora Anna Fonseca e loro descendenti in infinito come sopra con l'istesso peso e conditioni che si impone agl'altri. Chiamando Girolamo et Angelo Gomez suoi figli maschi e descendenti in infinito come sopra et in difetto de' maschi le femine e descendenti delle femine in infinito sempre prima li maschi et in difetto di essi le femine come sopra, et in mancanza di tutti li sopranominati, sostituisco li figlioli e descendenti in infinito come sopra della signora Gratia Gomez Checci figlia di detta signora Anna, maritata già in Terni, con i medesimi ordini e pesi che sopra sempre in|stirpes et non in capita.

Item voglio e dichiaro che, in evento che il signore Giovanni Panizza altro figlio del signore Ludovico Panizza mio genero applicasse alli studi e vivesse con rettitudine con ubbidienza al padre e nel modo che conviene ad un buon gentilhomo, in tal caso lo sostituisco ugualmente con il fratello e, se in lui concorrino tali qualità, la dichiaratione la rimetto alla bontà et arbitrio di monsignor decano pro tempore della Rota et delli due signori auditori di Rota spagnoli, se 
vi saranno in Roma o chi di essi votarà pro tempore, e questa dichiaratione la possino fare e disfare più e diverse volte e quante bisognerà e che altro arbitrio e dichiaratione si stia tante volte quante occorrerà.

Item ordino e dichiaro e voglio che la prohibitione dell'alienatione da me sopra fatta sia e s'intenda nel più stretto modo che far si possa per conservare li beni nei chiamati al fideicommisso e, perchè si conservino integri e senza diminutione alcuna in perpetuo, volendo che s'intenda etiam late sumpto vocabulo e che sotto nome d'alienatione venga etiam de locatione ad longum tempus hipoteca, pegno et ogn'altra e, perchè so che per nulla di meno si trovano pretesti e colori per defraudare la mente de' testatori, dispongo che li miei heredi e ciaschuno di essi e tutti quelli che possederanno la mia heredità per mia ordinatione e dispositione|non possino vendere nè li frutti durante la lor vita, nè la commodità, nè altro quantunque minimo, particolarmente ne' luoghi de' monti, case et altri effetti esistenti in Roma, volendo che chiunque contrafarrà alienando li frutti o commodità alla vita del medesimo o in altro minor tempo sia e s'intenda irremissibilmente decaduto e privato ipso facto et ipso iure da ogni commodo della mia heredità, la quale spetti alli chiamati doppo di essi e, venendo il caso che li chiamati fossero figlioli de alienante, voglio e dichiaro che durante la vita dell'alienante e contraveniente quelli non devano essere ammessi, ma subentrino gli altri chiamati quali, venendo la morte dell'alienante, siano tenuti restituire a detti figli e più prossimi dell'alienante e non altrimenti, e questo senza eccetione alcuna, dando facoltà di pretendere possesso propria aucthoritate etiam senza decreto di giudice.

Item voglio, ordino e commando che ciascheduno de' miei heredi che vorrà succedere nella mia heredità, sia obligato fare inventario distinto di tutti li miei beni, mettendo la quantità etiam con la misura da farsi da un perito da elegersi da monsignor decano della Rota, notando tutti li confini distintamente et ogn'altra dimostratione e questo inventario debba farsi da ciaschuno che succederà quante volte la mia heredità passarà da uno in altro, volendo|di più che detto inventario debba dentro il termine di due mesi esser compito et esibito nell'archivio Urbano e, perchè questo non si trascuri e non si dia caso che li possessori della mia heredità alleghino ignoranza, voglio che siano obligato ciascheduno di loro che succederà obligarsi di ostentare tutto il contenuto in questo testamento che dovrà legersi et inserirsi de verbo ad verbum dell'obligo solenne e giustamente da farsi et effettuarsi avanti con l'assistenza di monsignore decano della Rota pro tempore quale prego a voler prendere questo peso.

Supplico l'eminentissimi signori cardinali Odescalchi et Imperiale a degnarsi d'esser protettori de' miei heredi e sostituti, supplicandoli degnarsi ad accettar un quadro per ciascheduno di loro da darseli dal signor Gaspare, mio figliolo et herede.

Essecutori di questo mio testamento e dispositione nomino e lascio il signor Eusebio Eusebii, avvocato concistoriale e de' poveri, e monsignor Giacomo Emense, nuovo auditore di Rota, 
eletto ultimamente e nepote di monsignor Giovanni Emense, alli quali tre lascio parimenete un quadro per ciascheduno di loro da darseli dal detto signor Gasparo mio figlio et herede.

Item voglio et ordino che li miei heredi e sostituti sudetti siano obligati ogni anno la vigilia della santissima Annunziata a dare in mano del sacristano pro tempore di San Lorenzo in Lucina acciò alla detta mia cappella dell'Annuntiata si possa|mantenere la lampada accesa scudi quattro moneta l'anno et inoltre in detta vigilia lascio per la detta mia cappella sei candele d'altare.

E questo voglio che sia il mio ultimo testamento et ultima volontà quale voglio che vaglia per ragione di testamento nuncupativo sine scriptis e, se per detta ragione non valesse, voglio che vaglia per raggione di donatione causa mortis o per raggione di codicilli per ultima volontà et in ogn'altro miglior modo, cassando, annullando ogn'altro testamento, codicilli e qualisivoglia ultima volontà sino al presente giorno da me fatta etiam se fosse con qualsivoglia clausola derogatoria e derogatorie di derogatoria per qualsivoglia notaro rogato et in fede l'ho fatto scrivere a persona a me fida e poi l'ho sottoscritto di mia propria mano.

Io Gabrielle Fonseca testo e dispongo come sopra manu propria

Ego Vincentius Candidus interfui ut supra

Iohannes Baptista Rondinus notarius rogatus 


\section{Document 2}

Archivio di Stato di Roma, Trenta Notai Capitolini, Not Q, Prot. 129, fols. 290r-291r. Acta spo(n)salia ill(ustrem) d(ominam) [Catherinam] Gomez et ill(ustrem) dominum Gabriele(m) Fonsecca(m)

Die 14 septembris 1618

In mei etc. presentia personaliter constitutus illustris Antonius Gomez Sueri quondam domini Gomez Philippi, pater et legitimus administrator illustris domine Catherine Gomez eius filie legitime et naturalis ex illustri domina Anna Fonseca coniuge procreata, vice et nomine dicti illustris domine Catherine ex una et illustris dominus Gabriel Fozecca Lamacensis partibus ex altera que partes sponte etc. omni meliori modo etc. devenerunt ad actum parentele et pacta sponsalia in Dei nomine pactata et stabilita in hunc modum (videlicet).

Dictus illustris dominus Antonius pater et legitimus administrator predicte illustris domine Catherine eius filie legitime et naturalis promisit predicto illustri domino Gabrielli presenti et acceptanti se facturum et curaturum omni exceptione remota quod dicta illustris domina Catherina eius filia legitima et naturalis previis denunciis ex forma Concilii Tridentini requisitis accipet in eius et legitimum sponsum dictum illustrem dominum Gabrielem et cum eo contrahet matrimonium de presenti vis et volo iuxta ritum Sancte Romane Ecclesie.

Et vice versa presentis illustris dominus Gabriel promisit presenti illustri domino Antonio patri et legitimo administratori predicte domine Catherine presenti et pro ea acceptanti previis dictis denunciis ex forma Sacri Concilii Tridentini requisitis accipere eius in veram et legitimam sponsam dictam illustrem dominam Catherinam et cum eam matrimonium contrahere per verba de presenti vis et volo iuxta ritum Sancte Romane Ecclesie.

Cui illustri domino Gabrieli presenti et acceptanti predictus illustris dominus Antonius pater et legitimus administrator predicte illustris domine Catherine pro illius dote promisit et convenit scuta quatuor milia monete ad iulios $\mathrm{x}$ pro scuto in pecunia numerata et alia scuta quingenta similia in tot bonis mobilibus extimatis quam dotem ipse illustris dominus | Antonius solvere et respective assignare ac tradere promisit hoc modo videlicet: scuta quingenta in tot mobilibus extimatis tempore quo ipse illustris dominus Gabriel eamdem illustrem dominam Catherinam eius futuram uxorem ad eius domum traducet et residuum in pecunia numerata infra duos menses a die consumationis matrimonii decurrentes libere.

Declarans tamen ipse illustris dominus Antonius in huiusmodi dote comprehendi debere legatum scutorum .600. vel .800. eidem illustri domine Catherine factum per illustrem dominam Violantem de Fonseca in suo ultimo testamento ut dixit rogato in civitate Pisarum per publicum notarium. 
Et convenerunt dicti illustres domini contrahentes quibus supra respective nominibus quod inter dictos futuros coniuges censeatur et sit facta donatio propter nuptias iuxta formam statuti urbis super lucratione, quibus ambe partes se subiecerunt et supposuerunt.

Quam dotem unam cum donationem propter nuptias aliisque variis dotalibus predictus illustris dominus Gabriel ex nunc pro tunc secuta solutione et satisfactione et pro ea summa que sequetur cautelavit et assicuravit in et super omnibus et singulis suis bonis mobilibus, immobilibus, iuribus, actionibus et nominibus debitorum presentibus et futuris ubicumque existentibus et extituris dictaque bona et iura similiter ex nunc pro tunc tam in genere quam in specie ita tam quod specialitas generaliter non deroget nec extra obligavit et hipotecavit eamdem dotem unam cum donatione propter nuptias aliisque iuribus dotalibus reddere et restituere promisit eidem illustri domine Catherine vel suis etc. aut cui vel quibus de iure restitutio facienda erit libere. |

Dans et concedens eidem illustri domine Catherine suisque etc. ac cui vel quibus restitutio facienda erit plenam licentiam et omnimodam potestatem, facultatem et auctoritatem in quocumque casu restitutionis dotis constante vel soluto matrimonio capiendi et apprehendendi realem, corporalem et attualem possessionem dictorum bonorum et iurium propria auctoritate sine alicuius iudicis vel curie licentia, decreto vel mandato aut vitio spolii seu iurium suorum lesione captamque et apprehensam retinendi et continuandi usque quo eidem illustri domine Catherine vel suis etc. aut cui vel quibus restitutio facienda erit de dicta dote donationeque propter nuptias aliisque iuribus dotalibus fuerit integre satisfactum et donec ipse illustris dominus Gabriel pro se suisque etc. constitutis etc. que omnia etc. alias etc. de quibus pro quibus se ipso etc. eorumque heredes etc. de bona etc. in ampliori forma Camere Apostolice cum clausulis etc. citra etc. ad invicem obligavit etc. renuntiandum approvationi etc. consentientes in mandatum executivum unica citatione precedente relaxandum etc. iuravit tactis etc. super quibus etc.

Actum Rome domi solite habitationis dicti illustris domini Antonii regionis predictis, presentibus domino Ludovico filio domini Angeli Picchi de Peschio Terre Marsicane diocesis planellano in Urbe apud ecclesiam Beate Marie de Pace et domino Johanne Baptista filio domini Matthie Cospini Anconitano testibus etc. ex quibus illustris Antonius est mihi notus. 


\section{Document 3}

Archivio di Stato di Firenze, Mediceo del Principato 1082, fol. 1533.

22 dicembre 1668

Serenissimo Signore et patrone mio illustrissimo.

Gli effetti d'una devota et ossequiosa gratitudine mi rendono ardito dar parte a Vostra Altezza Serenissima della morte della bona memoria di Gabbriello Fonseca, mio padre, che dal principio della sua gioventù sino all'ultimo della sua vita fu continuamente honorato dal serenissima sua casa. Partì dall'Amego (sic), sua patria, nel Regno di Portogallo, chiamato in Fiorenza da Rodrigo Fonseca, suo zio, lettore primario di medicina prattica nella celebre università di Pisa, et medico della gloriosa memoria del Gran Duca, Ferdinando, avo di Vostra Altezza Serenissima. La sorte del zio fu ben tosto communicata al nipote, vinendo provisto d'una lettura di filosofia nel medesimo studio: e si come in ogni loco ambidue goderno di continui honori conferitili dall'innata e somma generosità e beneficenza degli antenati e fratelli e di Vostra Altezza Serenissima, così vive sempre conservarne le rimembranze di ricevuti benefiti. Assalito questo ultimo pochi giorni sono da un improvviso accidente, passò a miglior vita et io come figlio et erede delle innumerabili obligationi del Padre ambisco et devo esserne perpetuo fortunatissimo debitore a Vostra Altezza Serenissima, suplicandola assieme del suo stimatissimo e gloriosissimo patrocinio Vostra Altezza Serenissima come sole egualmente benefico non sdegnarò conferire il lume delle sue gratie a servire, benché inutili et in tutto inhabili. Retribuisca, sua Divina Maestà, con concedere a Vostra Altezza Serenissima tutte le imaginabili proprietà, contentezze come con l'intimo del mio core gl'auguro in queste santissime feste natalizie di Nostro Signore Giesù Cristo che dopo molti e molti lustri e perpetuata per molti secoli la sua gloriosa prosapie dispensi a Vostra Altezza serenissima in questa vita il fonte di tutte le contentezze e poi l'aeterna gloria nell'altra compatisca Vostra Altezza Serenissima la mia temerarietà humilmente vivenendola et bacionadoli il lembo delle sue sue gloriose porpore rimango di Illustrissima Altezza Serenissima.

Roma, li 22 xbre 1668.

Humilissimo Devotissime et Obbligatissimo servitore.

Gasparo Fonseca. 


\section{BIBLIOGRAPHY}

Barry, Fabio, "New documents on the decoration of Bernini's Fonseca Chapel", The Burlington Magazine 146 (June 2004), pp. 396-399.

Careri, Giovanni, "Il busto di Gabriele Fonseca nel "bel composto" di Bernini", in Augusto Gentili (a cura di), Il ritratto e la memoria, 3. Roma, Bulzoni, 1993, pp. 195-204.

Careri, Giovanni, Bernini. Flights of Love, the Art of Devotion, trans. Linda Lappin. Chicago, The University of Chicago Press, 1995.

Contardi, Bruno, "Precisazioni sul Bernini nella cappella Fonseca", Studi di storia dell'arte 1 (1991), pp. $273-283$.

Dandelet, Thomas James, Spanish Rome 1500-1700. New Haven, Yale University Press, 2001.

Dobias, Judy, “Gian Lorenzo Bernini's Fonseca Chapel in San Lorenzo in Lucina”, The Burlington Magazine 120, no. 899 (Feb. 1978), pp. 65-71.

Enciso, Isabel, "La embajada de obediencia del VI Conde de Lemos: ceremonial diplomático y política virreinal”, in Carlos José Hernando Sánchez (ed.), Roma y España. Un crisol de la cultura europea en la Edad Moderna. Vol. 1. Madrid, Sociedad estatal para la acción cultural exterior, 2007, pp. 471-513.

Favarò, Valentina, "Un hombre al servicio del rey: Francisco de Lemos, conde de Castro (1601-1620", Saitabi 60-61 (2010-2011), pp. 189-202.

García Cueto, David, "Mecenazgo y representación del Marqués de Castel Rodrigo durante su embajada en Roma”, in Carlos José Hernando Sánchez (ed.), Roma y España. Un crisol de la cultura europea en la Edad Moderna. Vol. 2. Madrid, Sociedad estatal para la acción cultural exterior, 2007, pp. 695-716.

Giordano, Silvano, "Gaspar Borja y Velasco rappresentante di Filippo III a Roma", Roma moderna e contemporanea 15, 1-3 (gennaio-dicembre 2007), pp. 157-186.

Guerrieri Borsoi, Maria Barbara, "Il 'palazetto' di Frascati. Il casino dei Gomez, Fonseca, Silva, oggi Mergè, opera di Francesco Peparelli”, Palladio 43 (2009), pp. 103-118.

Levin, Michael, J., Agents of Empire. Spanish Ambassadors in Sixteenth-Century Italy. Ithaca, Cornell University Press, 2005.

Machado, Diogo Barbosa, Bibliotheca Lusitana, histórica, critica e cronológica na qual se comprehende a noticia dos authores portugueses e das obras, que compuserão desde o tempo da promulgação da ley da Graça até o tempo prezente. Lisboa, na officina de António Isidoro da Fonseca, 1741-1759, 4 vols.

Mateus, Susana Bastos and Nelson Novoa, James, "A Sixteenth Century Voyage of Legitimacy. The Paths of Jácome and António da Fonseca from Lamego to Rome and Beyond”, Hispania Judaica 9 (2013), pp. 169-192.

Nelson Novoa, James, "Medicine, learning and self representation in seventeenth century Italy. Rodrigo and Gabriel da Fonseca", in António Andrade et alii (orgs.), Humanismo, Diáspora e Ciência (séculos xvi e xviI): estudos, catálogo, exposiçâo. Porto, CMP-BPMP; UA-CLC, 2013, pp. 213-232. 
Nelson Novoa, James, “Unicorns and bezoars in a Portuguese house in Rome: António da Fonseca's Portuguese inventories", Ágora, Estudos Clássicos em Debate 14.1 (2012), pp. 91-112.

Rossholm Lagerlöl, Margaretha, "Life Transformed: Performative Meaning, Analogy, and the Art of Bernini's Funeral Decorations", Konsthistorisk Tidscrift 81 (2012), pp. 2-30. 
2

\section{DIOSCÓRIDES \\ E O HUMANISMO \\ PORTUGUÊS: \\ OS COMENTÁRIOS \\ DE AMATO LUSITANO}


(Página deixada prepositadamente em branco.) 


\section{Léxico científico português nos Comentários de Amato: antecedentes e receção ${ }^{1}$}

ANA MARGARIDA BORGES²

\section{RESUMO:}

Em finais do século xv e princípios do século xVı são publicadas, com o impulso da imprensa, um grande número de obras do domínio da Medicina, da Botânica e da Farmácia, como é o caso das edições, traduções e comentários do tratado grego de Dioscórides, mais conhecido por De materia medica. Estas e outras obras, sobre estes domínios da ciência, constituem um importante testemunho das origens e da evolução das línguas nacionais, pois, embora tenham sido preponderantemente elaboradas nas línguas clássicas, apresentam os primeiros apartados plurilingues em línguas vulgares, fundamentais para a correta identificação das plantas.

De entre o grande número de traduções e comentários ao tratado grego, debruçar-nos-emos, neste breve estudo, sobre a obra do médico português Amato Lusitano, onde se verifica um registo abundante de aparatos plurilingues, com o objetivo de averiguar a sua importância no aparecimento e difusão de novos vocábulos nas línguas vulgares, em geral, e no léxico português, em particular.

\section{PALAVRAS-CHAVE:}

Amato Lusitano; vocabulário científico; Andrés Laguna; Conrad Gesner; Pietro Andrea Mattioli; lexicografia portuguesa e espanhola.

1 Este trabalho foi desenvolvido no âmbito do projeto de I\&D "Dioscórides e o Humanismo Português: os Comentários de Amato Lusitano" (http://amatolusitano.web.ua.pt) do Centro de Línguas, Literaturas e Culturas da Universidade de Aveiro, financiado por Fundos FEDER através do Programa Operacional Factores de Competitividade - COMPETE e por Fundos Nacionais através da FCT - Fundação para a Ciência e a Tecnologia, no âmbito do projeto FCOMP-01-0124-FEDER-009102.

2 Centro de Línguas, Literaturas e Culturas da Universidade de Aveiro: amborges@ua.pt. 


\section{ABSTRACT:}

In the late fifteenth and early sixteenth cgentury are published, with the encouragement of the press, a large number of works in the domain of medicine, botany, and pharmacy, such as the endless translations and commentaries on the Greek treatise of Dioscorides, better known by De materia medica. These and other works on these domains of science are an important witness of the origins and evolution of national languages, because, though they were predominantly written in the classical languages, they present some innovating articles written in various modern languages.

Among these translations and commentaries on the Greek treatise, we will focus, in this study, on the work of the Portuguese doctor Amato Lusitano, where we can find an abundant number of innovating articles, along with annotations in the vernacular languages, in order to evaluate its importance in emerging and consolidating the various modern vocabularies, in general, and the Portuguese vocabulary, in particular.

\section{KEYWORDS:}

Amato Lusitano; scientific vocabulary; Andrés Laguna; Conrad Gesner; Pietro Andrea Mattioli; Portuguese and Spanish lexicography. 


\section{INTRODUÇÃO}

A Medicina e outras ciências mais diretamente a ela associadas, como a Botânica e a Farmácia, constituíram os âmbitos temáticos que mais potenciaram, com o impulso da imprensa, a publicação de obras nos finais do século Xv e princípios do século XVI, que correspondem, na sua grande maioria, à recuperação dos textos clássicos greco-latinos.

Os vocabulários especializados foram preponderantemente elaborados em latim e dentro de um quadro de conjugação entre a herança medieval árabe e a erudição lexical greco-latina, apresentando, contudo, alguns apartados plurilingues em línguas vulgares fundamentais para a correta identificação das matérias. Embora a terminologia utilizada nos meios eruditos fosse essencialmente a latina, a pressão crescente que exerceram as línguas vulgares sobre as línguas eruditas durante este período originaria que médicos e botânicos tivessem que encontrar designaçôes em vernáculo apoiando-se nas línguas clássicas.

Estudar estas obras supõe, portanto, adentrar em território filológico e esquadrinhar as origens das línguas nacionais, utilizando estes textos como um complemento dos dicionários para compreender a realidade linguística da época.

Uma menção especial merecem as inumeráveis edições, traduçôes e comentários do tratado grego de Dioscórides, mais conhecido por De materia medica. Do abundante número de traduçôes e comentários ao tratado grego, debruçar-nos-emos, neste estudo, sobre a obra do médico português Amato Lusitano, onde se verifica um registo abundante de aparatos plurilingues, com o objetivo de averiguar a sua importância no aparecimento e difusão dos novos vocábulos em línguas vulgares, em geral, e do léxico português e espanhol, em particular. Para tal, faremos uma revisão do registo dos vocábulos das línguas vulgares nas principais obras médicas e botânicas de maior difusão nos circuitos culturais europeus e nas traduçóes e comentários à obra de Dioscórides antes e depois de Amato. Além disso, e considerando o carácter precursor da obra de Amato em relação ao registo de termos portugueses, pretendemos, com esta análise panorâmica de carácter comparativo, avaliar o impacto dos aparatos metalinguísticos da obra do médico albicastrense na consolidação do vocabulário técnico-científico através dos exemplos português e espanhol.

\section{VOCABULÁRIOS COM APARATOS PLURILINGUES: BREVE PANORAMA CRONOLÓGICO}

Entre as várias manifestaçóes da revolução científica e linguística do Renascimento está, como já referimos, o aparecimento de um grande número de obras do âmbito da Medicina e da Botânica, considerada esta última, desde o seu nascimento, como uma parte da Medicina. Se é certo que em 
outros ramos da ciência se publicaram numerosas obras, igualmente favorecidas pela tipografia, o número de obras botânicas e médicas ultrapassa em muito o de outros domínios científicos.

Entre estas últimas, merecem destaque tanto as inumeráveis ediçôes, traduções e comentários à obra De materia medica de Dioscórides como as obras de maior difusão nos circuitos culturais europeus. Pedro Parrado 3 e Telmo Verdelho ${ }^{4}$ dão-nos notícia dos numerosos dicionários e obras afins de orientação médica com maior circulação na época: De Medicina (1478) de Celso; Margarita Philosophica (1503) de Gregório Reisch; Vocabulorum medicinalium et terminorum difficilium explanatio (1508) de Symphorien Champier; Officina (1532) de Ravisius Textor; Thesaurus Linguae Latinae (1530) de Mario Nizoli; Herbarum vivae eicones (1530) de Otto Brunfels; Thesaurus Linguae Latinae (1531) de Robert Estienne; Onomastikon medicinae, continens omnia nomina herbarum, fruticum (1534) de Otto Brunfels; Methodus anathomicus seu de sectione humani corporis contemplatio (1535) de Andrés Laguna; De humani corporis fabrica libri septem (1543) de André Vesálio; Latinae Linguae Universae Promptuarium (1545); Historia animalium (1551-1558) de Conrad Gesner; Dictionarium medicum (1564) de Henri Estienne.

Seguindo uma longa tradiçâo que tem como pontos de referência, na Antiguidade, os nomes de Teofrasto, Dioscórides, Plínio e Galeno, destacam-se, no século xvi, entre muitas outras, as obras de António Musa Brasavola (Examen omnium simplicium medicamentorum, 1536), de Jean de Ruel (De natura stirpium, 1536), de Escalígero (De plantis, 1556), assim como outros compêndios enciclopédicos que recompilavam obras anteriores ao século XIV, como os Herbario latino (1484), Herbario germanico (1485), Ortus sanitatis (1491), Macer Floridus (ca. 1500).

No que diz respeito ao tratado grego, desde a Antiguidade até ao Renascimento publicaram-se inumeráveis traduções (latim e árabe) e comentários à obra de Dioscórides. Entre a infinidade de editores tradutores e comentadores, evidenciam-se, no Renascimento, os nomes de: Aldo Manuzio, Marcelo Virgílio, Jean de Ruel, Hermolao Barbaro, Jano Cornario, Otto Brunfels, Conrad Gesner, Leonard Fuchs, Amato Lusitano, Giovanni Manardo, Valério Cordo, Melchior Guilandino, Andrés Laguna e Pietro Andrea Mattioli, apenas para referir os mais célebres.

O percurso cronológico por todas estas obras confirma a ideia da escassez, nas primeiras décadas do século XVI, de vocabulários que apresentassem aparatos plurilingues, apesar de se verificar já na Idade Média (porém antes da imprensa) uma tendência para registar a terminologia médica numa língua vulgar. Vários estudos ${ }^{5}$ centrados nos glossários e léxicos medievais reforçam e apoiam esta ideia:

3 Pedro Conde Parrado, Hipócrates Latino: El de Medicina de Cornelio Celso en el Renacimiento. Valladolid, Secretariado de Publicaciones e Intercambio Editorial, 2003, pp. 155-169.

4 Telmo Verdelho, As Origens da Gramaticografia e da Lexicografia Latino-Portuguesas. Aveiro, Instituto Nacional de Investigação Científica, 1995, pp. 276-279.

5 Cf. Jacqueline HAMESSE; José MeIRINhos, (eds.), Glossaires et lexiques médiévaux inédits. Bilan et perspectives. Porto, Fédération International des Instituts d'Études Médiévales, 2011. 
Les glossaires dont il a été question au cours de cette journée s'inscrivent tous dans des circonstances historiques précises entre le $\mathrm{IX}^{e}$ et le $\mathrm{XV}^{\mathrm{e}}$ siècle: ils attestent d'une façon ou d'une autre la pression grandissante des langues vernaculaires sur les langues savantes pendant cette période afin d'obtenir, en prenant appui sur elles, le statut de langue écrite et on les voit, petit à petit, atteindre leur objectif. Cette pression est sensible non seulement à travers des glossaires bilingues, mais même à travers les glossaires unilingues, dans lesquels parfois se glissent en sus du terme latin glosant une terme technique et une traduction en vernaculaire $[\ldots]^{6}$.

Apesar dessa escassez, a primeira publicação de Amato Lusitano, Index Dioscoridis (1536), apresenta, embora de forma embrionária e incipiente, a tradução de algumas entradas latinas em diversas línguas modernas, encabeçando, portanto, a lista de catálogos plurilingues de inícios do século XVI.

Antes do Index de Amato só encontramos uma outra obra que regista as entradas em línguas vernaculares. Trata-se do livro de Otto Brunfels (1488-1534), intitulado Herbarum vivae eicones (Estrasburgo, 1530), que incorpora, juntamente com as línguas grega e latina, os nomes em "Germanice" e, por vezes, "Theutonice" sob o título "Nomenclaturae".

Porém, importa salientar que não se trata de um registo que abarque várias línguas modernas, mas sim apenas duas. Com magníficas ilustraçôes do mundo natural, Otto Brunfels escreveu também uns comentários ao De materia medica que incluiu no tomo segundo dos seus Novi herbarii (Estrasburgo, 1531), que tem por título Exegema omnium simplicium quae sunt apud Dioscoridem, que prima sobretudo pela grande preocupação lexicográfica em identificar com exatidão as plantas e os animais descritos por Dioscórides (apenas dos livros I-IV). Além disso, acrescenta, também, informação de outras fontes antigas como Teofrasto, Plínio ou Galeno, e testemunhos de comentaristas de Dioscórides como Bárbaro ou Marcelo Virgílio.

6 Luis Holtz, "Conclusions" in Jacqueline HAMESSE; José MeIRINHOS (eds.), Glossaires et Lexiques médiévaux inédits. Bilan et perspectives. Porto, Fédération Internationale des Instituts d'Études Médiévales, Textes et Études du Moyen Âge, 59, 2011, pp. 271-74. 


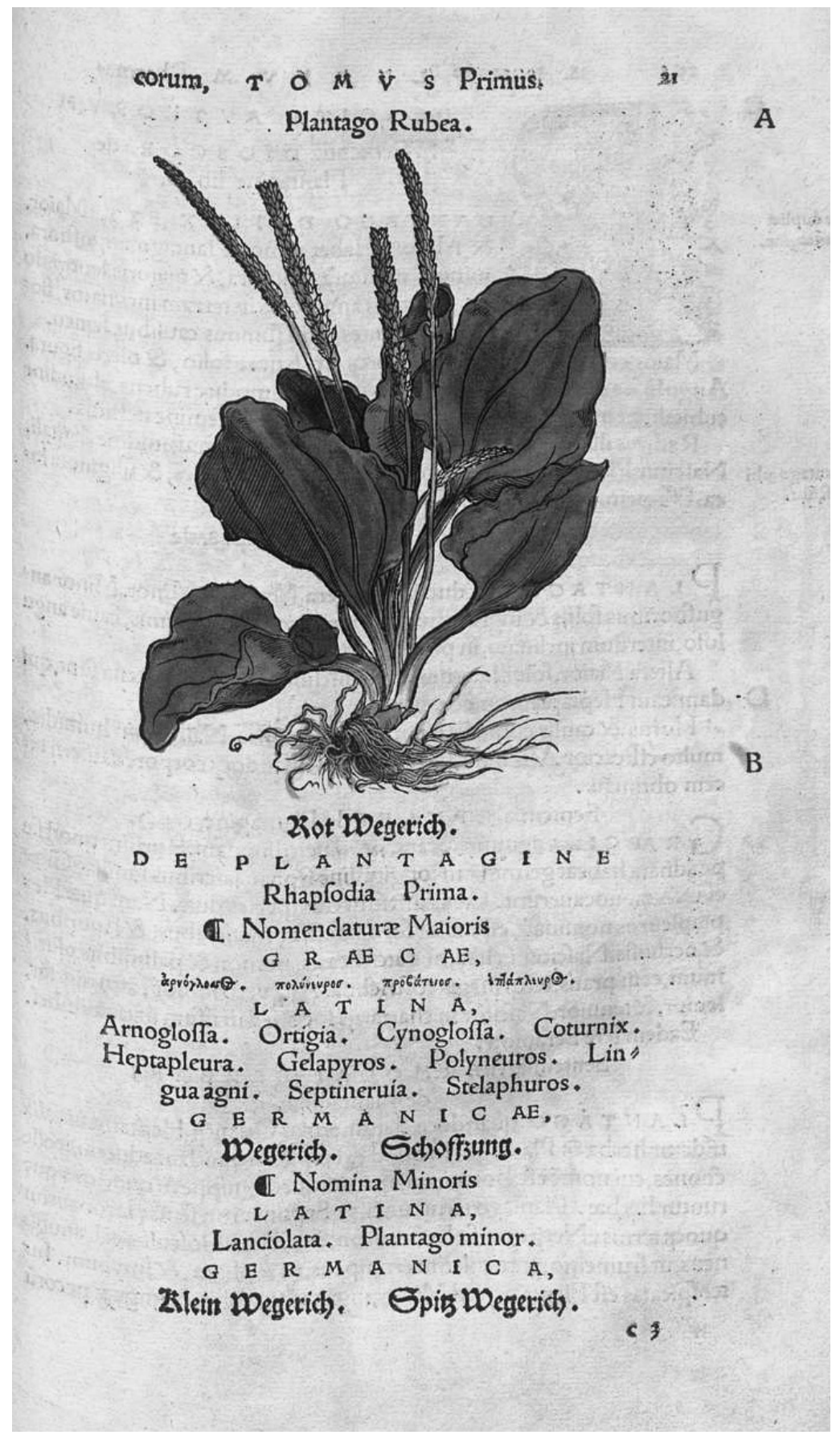

Figura 1 - Exemplo de uma glosa plurilingue de Herbarum vivae eicones, de Otto Brunfels (tomo I, 1530) 
A partir da década de quarenta do século XVI assiste-se a uma crescente circulaçáo de vocabulários plurilingues que propiciam o contacto interlinguístico de um grande número de denominaçôes especializadas, em particular do âmbito da Botânica, da Farmacognosia, da Medicina e da Zoologia. Os descobrimentos, com a subsequente ampliação dos circuitos comerciais e culturais entre países e continentes diversificados, propiciaram em simultâneo o surgimento de novas designaçóes de plantas, produtos exóticos e animais, até entâo desconhecidos, e a prática da tradução para as várias línguas modernas:

Moreover, the growth of European commerce required merchants willing to acquire at least a beginner's knowledge of the languages of the countries with which they were trading a need which travellers also experienced. So far the vocabularies remained simple lists and hardly more than a single equivalent for each word was provided?

As traduçóes latinas de Jean Ruel e de Marcelo Virgílio são agora reeditadas com a preocupação em oferecer os nombres nas diversas línguas modernas. A edição de Ruel de Francoforte 1543, apresenta os comentários de Walther Ryff, centrados na identificação das plantas e nos problemas lexicais relacionados com as suas designaçôes nas línguas modernas. Na mesma edição latina de Ruel (Frankfurt de 1543) também são publicados os comentários Nova scholia a Dioscórides de Johann Lonitzer.

O comentário abarca uma série de correçóes a Jean Ruel a partir da versão latina de Marcelo Virgílio, com observaçôes maioritariamente filológicas e relacionadas com os problemas de nomenclatura. A edição apresenta muitos vocábulos em "Latinis", "Ebraice/Ebraeis", "Graecis", "Germanice", "Gallice" e, ocasionalmente, "Denmark".

7 Robert Lewis Collison, A History of Foreign-Language Dictionaries. Londres, Deutsch, 1982, pp. 60-61. 


\section{PEDANII DIOSCO=}

RIDIS ANAZARBEI DE MEDICI= NALI MATERIA LIBRI SEX, IOANNE RVELLIO SVESSIO nenfi interprete, Singulis cùm ftirpium, tum animantium hiftorijs, ad natura rmulationem expreffis imaginibus, feu uiuis picturis, ultra millenarium mumerum adiedtis: non fine multiplici peregrinatione, fum. ptu maximo, ftudio atque diligentia fingulari, ex diuter/is regionibus con. quifitis. Additis etiam Annotationibus fue Scbolijs bre. ui Simis quidem, qua tamen de medicinali materia omnem controuer fiam facile tollant. Per G V A L T H E R VM H, RYFF, Argentinum, Medicum, o Cbirurgum,

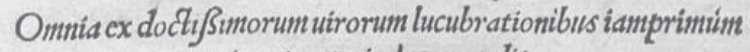
concinnata, o in lucem adita.

Cum Indice quintuplici, copiofiflimo:quorum primus omnium fere fimplicium, quibus paffim utuntur Medici, nomenclaturas Graecas: alter Latinas:tertius Officinis, Herbarijs, \& Arabum fami. liauulgares:quartus Germanicas:quintus Gallicas,miro ordine complectitur.

ACCESSERE IN EVNDEM AVTOREN Scholia noud, cum nomenclaturis Grecis, Latinis, Hebraicis or Gera manici, IOANNE LONI CERO autore.

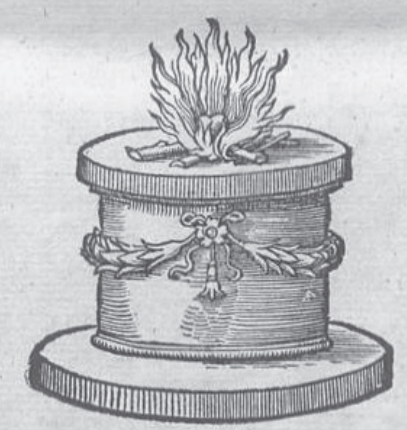

Cum Gratia \& Priuilegio Imperiali。 FRA N C. Apud Chr.Egenolphum.

Figura 2 - Página de rosto da edição de Ruélio (Franckfurt, 1543), com os comentários de Walther Ryff e Johann Lonitzer 
Uma década mais tarde seria publicado o segundo trabalho de Amato, In Dioscoridis Anazarbei [...] Enarrationes (1553), que regista, com mais regularidade do que o primeiro - Index Dioscoridis, 1536 - um considerável número de vocábulos nas línguas modernas europeias. Esta evolução em nada nos surpreende, especialmente tendo em conta que a segunda metade do século XVI constitui um momento privilegiado na emergência das linguagens de especialidade que começam, agora, a brotar em diferentes línguas. Integradas nos circuitos comerciais e culturais, a obra de Amato e outras do mesmo âmbito são um exemplo interessante do cruzamento do comércio com a ciência e refletem o trânsito interlingue de nomes de especiarias, drogas e substâncias originárias de todo o mundo. Em várias partes da Europa, muitos botânicos e médicos produzem grandes obras pluridisciplinares e com aparatos plurilingues, que renovam e ampliam o panorama do saber científico e filológico, em que sobressaem, entre outros, os nomes de Conrad Gesner, Amato Lusitano, Andrés Laguna e Pietro Andrea Mattioli.

Também a composição em diálogo da autoria do português Garcia de Orta - Colóquios dos Simples e Drogas he cousas mediçinais da India (Goa, 1563) - constitui um dos mais apreciáveis documentos sobre materia medica, pelo significativo registo de novas substâncias, pelo rigor científico da sua descrição e pela copiosa informação metalinguística, como elucidam estes breves exemplos:

[...] Estes nomes vos direy, pois o perguntei em malaio e malavar, e decanim e pérsio, e arábio e turco [...] [...] Sac he nome corruto [...]

[...] O coquo tem nomes em todas as lingoas [...]

[...] Do aloes ha poucas cousas que dizer que sejâo notaveis, e porém fazervosey a vontade, e digo que o aloes ou aloa he latino e grego, e os Arabios o chamão cebar, e os Guzarates e Decanins areá, e os Canarins (que são os moradores desta fralda do mar) o chamão catecomer, e os Castelhanos acibar, e os Portuguezes azevre: fazse de çumo de huma herva depois de seco, e he chamada em portuguez herva-babosa, da qual herva ay muita quantidade em Cambaya e em Bengala e em outras muitas partes, mas a de Çocotora he muito mais louvada, e he mercadoria pera a Turquia, a Persia e Arabia, e pera toda a Europa; e por isso o chamam aloes çocotorino ${ }^{8}$.

Outro importante léxico renacentista de carácter plurilingue é o Nomenclator omnium rerum propria variis linguis explicata (1567) do médico holandês Adriano Júnio, famoso pela sua

8 Garcia de ORTA, Colóquios dos Simples e Drogas he cousas mediçinais da Índia, 1563. Edição publicada por deliberação da Academia Real das Ciências de Lisboa. Dirigida e anotada pelo conde de Ficalmo, da mesma academia, volume II. Lisboa, Imprensa Nacional, 1895. 
dedicação à medicina e pelo seu domínio de várias línguas. A sua obra recolhe termos latinos seguidos dos correspondentes em grego, alemão, francês, italiano, espanhol e, por vezes, inglês.

Uma análise de carácter comparativo centrada em todas estas obras do Renascimento demonstra-nos não só a importância da obra de Amato para o estudo das origens da linguagem científica, mas também o contributo dos aparatos plurilingues para a redação de outras glosas noutras obras, sobretudo no que diz respeito à inclusão de termos científicos em português e em espanhol.

\section{APARATOS PLURILINGUES NOS COMENTÁRIOS DE AMATO A DIOSCÓRIDES}

\subsection{Index Dioscoridis (1536)}

Os comentários à obra de Dioscórides da autoria do médico português Amato Lusitano (1511-1568), publicados no estrangeiro, por força do seu exílio, mas conhecidos e divulgados em Portugal, alcançariam uma auspiciosa fortuna editorial, com várias reedições nas principais cidades europeias.

Amato iniciou o seu tirocínio comentarista em 1536, publicando com o seu nome de batismo João Rodrigues de Castelo Branco o Index Dioscoridis (Antuérpia), em que comenta apenas os dois primeiros livros de Dioscórides.

A segunda obra de Amato, publicada em 1553 sob o título In Dioscoridis Anazarbei de medica materia [...] enarrationes (Veneza), compreenderia, desta vez, os comentários aos cinco livros do tratado grego, com consideráveis ampliaçóes e correçóes do Index.

Além da manifesta preocupação em identificar e descrever com detalhe as substâncias, baseando-se nas suas próprias experiências de médico, botânico e mercador, Amato corrige e atualiza formulários anteriores.

O seu primeiro trabalho, Index Dioscoridis, oferece já alguma informação referente à designação de cada espécie nas diversas línguas europeias. Depois de cada capítulo original acrescenta um comentário dividido em três partes: a identificação de cada elemento com o respetivo nome nas diferentes línguas ("Philologia”); a descrição de Dioscórides ("Dioscoridis historia”); o comentário propriamente dito ("Iuditium nostrum”), onde tece várias consideraçóes, com assíduas referências e críticas a fontes antigas e modernas. 


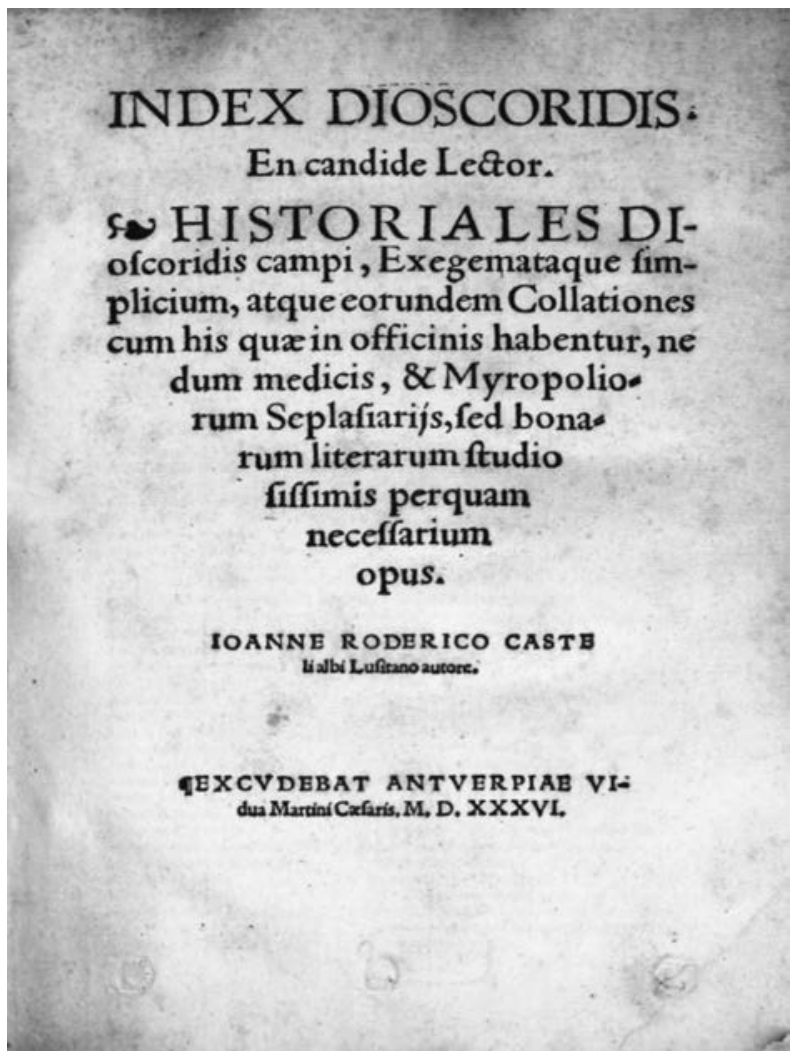

Figura 3 - Página de rosto dos primeiros comentários de Amato a Dioscórides (1536)

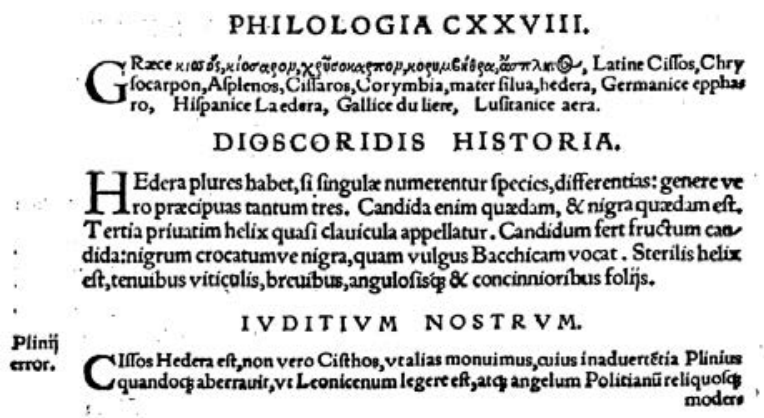

Figura 4 - Aparato plurilingue e estruturação dos conteúdos - fragmento retirado do primeiro trabalho de Amato (Index Dioscoridis, 1536) 
No que concerne ao aparato metalinguístico, somente em 20\% das Philologiae são apresentadas as equivalências dos termos nas diversas línguas, com um registo mais frequente na parte inicial do livro I. Anotam-se em Graece, Latine, Gallice, Hispanice, Lusitanice, Germanice, Theutonice. Ao longo dos dois livros, só aparece duas vezes o correspondente italiano Italice? Observa-se a falta de metodologia no registo dessas equivalências, bem evidente na inexistência de um registo sistemático e contínuo em todas as línguas supracitadas, e na inclusão de comentários eminentemente filológicos no Iuditium nostrum.

Em relação ao português, importa destacar que o percurso pela lexicografia plurilingue dos séculos XV e XVI sustenta a perceção de que é no Index Dioscoridis que a língua portuguesa figura pela primeira vez num repertório plurilingue impresso.

\subsection{In Dioscoridis Anazarbei de Medica Materia [...] Enarrationes (1553)}

Embora o primeiro trabalho de Amato nos ofereça já alguns termos nas diversas línguas vernaculares, é nas suas obras posteriores que esse registo passa a ser uma prática recorrente. Esse propósito é, desde logo, enunciado na carta dedicatória que introduz e apresenta a obra, reproduzida nas páginas iniciais de todas as reedições dos comentários de Amato:

[...] atque ideo herbarum et caeterarum rerum nomenclaturas, non solum Graece, et Latine, sed Italice, Hispanice, Gallice, et Germanice, expressimus, ut unus quisque tanquam e penu, quod sibi conducat depromere possit: Dioscoridi antiqua adiecta nomina: ut pote hodie inutilia: consulto detraximus $[\ldots]^{10}$.

9 Livro II, Philologia LXXXIX. Livro II, Philologia CXXXVI.

10 AmATo LUSITANo, In Dioscoridis Anazarbei de medica materia libros quinque enarrationes eruditissimae doctoris Amati Lusitani medici ac philosophi celeberrimi [...]. Venetiis, apud Gualterum Scotum, 1553, pp. 4-5. 


\section{IN DIOSCORIDIS}

\section{ANAZARBEI DE MEDICA}

\section{MATERIA LIBROS QVINQVE}

ENARRATIONES ERVDITISSIMAE

DOCTORIS AMATI LVSSTTANI MEDICI

A. FHILOSOPHI. C.EPEDERIMI,

quibus non folum Officinarum Seplafia-

rüs,fed bonarum etiam literarum itus

diofis utilitas adfertur, quum paf-

fim fimplicia Grace, Latine,

Italice, Hifpanice, Germa.

viee, \& Gallice proponantur.

Cum-Priwilegio Illufrij. Senatus Veneti ad decennium.
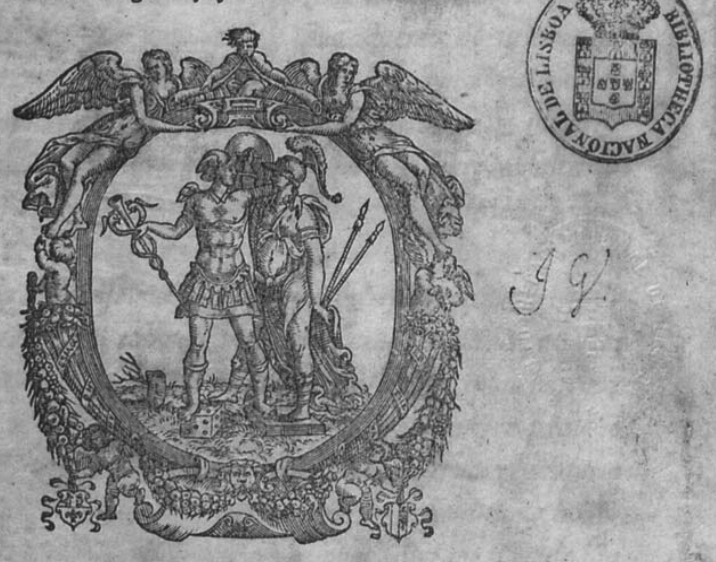

VENETIIS. MD LIII.

Figura 5 - Página de rosto da segunda obra de Amato (1553)

Após a enunciação de cada entrada em latim, a edição princeps dos comentários de Amato (1553) aos cinco livros do tratado grego apresenta a notaçâo plurilingue em $85 \%$ das entradas, com apontamentos menos regulares na parte inicial do livro V.

Relativamente ao Index Dioscoridis, a edição de 1553: integra com frequência os termos em Italice; faculta mais termos em Gallice e, por vezes, em Arabice; apresenta apenas 5 entradas sob a marca Theutonice: 


\begin{tabular}{|c|c|c|}
\hline \multicolumn{3}{|c|}{ Entradas sob a marca Theutonice } \\
\hline Latim & Index Dioscoridis (1536) & $\begin{array}{c}\text { In Dioscoridis Anazarbei de Medica Materia } \\
\text { Enarrationes (1553) }\end{array}$ \\
\hline iris & lelie & Theutonice seu Germanice lelie \\
\hline acorum & geheel lelien & ---ー----- \\
\hline celticum nardum & lavendola & --------- \\
\hline asarus & plumbe ubbidenardus & plumbe ubbidenardus \\
\hline valeriana & valeriaen & ---------- \\
\hline lignum aloes & aloes hout & ---------- \\
\hline iuniperus & geniver & Germanice geniver \\
\hline thure & --------- & ---------- \\
\hline sabina & savelboom & --------- \\
\hline laurus & bakeler & --------- \\
\hline macer macis & foulie & ---ー-ー---- \\
\hline Erica & heye & ---------- \\
\hline rhamnus & stekelbesie & -ー-ー-ー-ー- \\
\hline ebenus graiacum & hout vut Indien & --------- \\
\hline agnus/lignus & vvater mulghe & vvater mulghe \\
\hline salix & wilgenboom & Theutonice et Germanice wilgenboon \\
\hline orobus & vitsen & -ー-ーーーーーー \\
\hline rapa/napum & rape & rape \\
\hline rumex/lapathum & partike & ---------- \\
\hline malva & maluwe & ---------- \\
\hline portulaca & porceline & ---------- \\
\hline arnoglosa & wegebree blaren & -ー-ー-ー-ー- \\
\hline chicorium & cicoreie & --------- \\
\hline tuber terrae & eertnot & --------- \\
\hline piper & peper & ---------- \\
\hline dracunculus maior & draken hals de groote & --------- \\
\hline aros & calfs voent & --------- \\
\hline scilla & wile cammijn & ---------- \\
\hline celidonium maius & ghelu wortel & -----ー-ー- \\
\hline myosota altera & muysooren & --------- \\
\hline isatis sativa & vuou vuerde & ---------- \\
\hline
\end{tabular}

Tabela 1: Registo de vocábulos sob a marca Theutonice. 
Os nomes geniver, vvater mulghe, wilgenboom, witsen, registados na obra de 1536 sob a marca Theutonice, aparecem nos comentários de 1553 sob a marca Germanice.

Comparativamente às ediçóes de 1553 e de 1557, onde a marca Germanice aparece frequentemente associada às marcas Belgice, Gallice, Italice, a edição de 1554 faculta uma entrada autónoma para o nome dos simples em alemão, grafados com tipos de desenho gótico.

É sobretudo na edição de 1558 que se observa um abundante registo de termos botânicos nas diferentes línguas modernas. Esta edição incorpora a língua árabe sob a marca Arabice e apresenta mais entradas em alemão, italiano e francês, como exemplifica a entrada De cancris:

\begin{tabular}{|c|c|}
\hline $\begin{array}{l}\text { In Dioscoridis Anazarbei de Medica Materia [...] } \\
\text { Enarrationes (1553) }\end{array}$ & $\begin{array}{l}\text { In Dioscoridis Anazarbei de Medica Materia [...] } \\
\text { Enarrationes (1558) }\end{array}$ \\
\hline 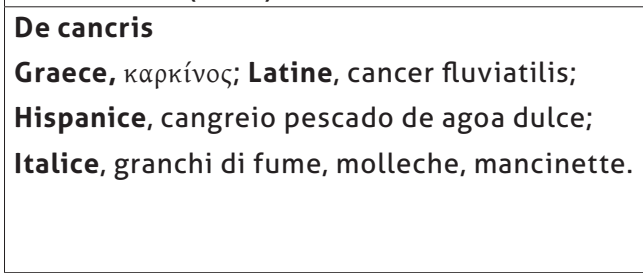 & 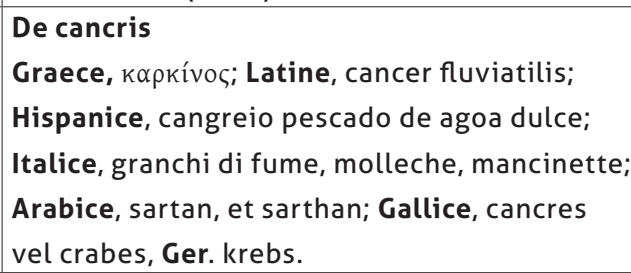 \\
\hline
\end{tabular}

Tabela 2: Exemplo da crescente incorporação de termos das diferentes línguas europeias modernas nas obras de Amato.

Em relação ao português e ao espanhol, não se podem fazer leituras independentes, pois, tal como nos corrobora Pilar Salas Quesada, quando rastreamos os inícios da lexicografia hispano-portuguesa deparamo-nos, no século xvi, com um abundante número de obras plurilingues em que se notam grandes dificuldades na diferenciação de vocábulos portugueses e espanhóis ${ }^{11}$. Porém, a utilização das marcas Lusitanice e Hispanice nos comentários de Amato leva-nos a deixar de lado a ideia equivocada de alguns autores de que o português era considerado apenas um dialeto do espanhol. O registo da marca Lusitanice, em concreto, é um indício de que na Europa se podia estar consciente das diferentes línguas que se falavam na Península. Efetivamente, o seu primeiro trabalho, Index Dioscoridis, apresenta uma série de vocábulos sob a marca Lusitanice: lirio cor de ceo, espadana, raiz de iunca de cheiro, spica nardo, alfazema, cardo machis, ortelaa romana, pallia damequa, palha de Chamelos, aguila paoo, alacar, tamargueira, urzes urgueira, tamargueirinhas, carrasco, roseira brava, amieiro, stebam, pultegras, esteban, salamantegua, rabaon guallisco, labaca, sparraguos, tamchagem, linguoa dovellha, lenguoa

11 Pilar Salas Quesada, "La Marca Hisp. en los diccionarios plurilingües. En busca de los inicios de la lexicografía hispano-portuguesa", Res Diachronicae Virtual: El Contacto de Lenguas 4 (2005), pp. $137-52$. 
de carnero, genero de mentrastos, agriois, perexxil do mar, serralha, almeirois, serralha endive, leitugas, bisnagua, alfavaqua, feijois, erva xabonera, erva cobreira maior, folha de yaro, gamois, guamonitos, cebolha alavarrana, papoulas, era, herva das andorinhas [...].

Apesar da distinção efetuada através da marca de língua portuguesa Lusitanice, observa-se alguma confusão entre o português e o espanhol com o registo de grafemas do alfabeto português que correspondem a fonemas da língua espanhola: pallia damequa, sparraguos, guallisco, yaro, cebolha.

Embora o seu primeiro trabalho nos faculte já alguns vocábulos portugueses, quer sob a marca Lusitanice, quer sob a marca Hispanice, é essencialmente nos seus trabalhos posteriores que se observa o registo de um grande número de vocábulos portugueses. Apesar da existência de casos em que as duas línguas estão totalmente diferenciadas (1), uma análise atenta e detalhada do registo dos vocábulos nas Enarrationes (1553) demonstra-nos que a distinçáo não se observa na generalidade das entradas, em que a marca Hispanice ora abarca simultaneamente vocábulos portugueses e espanhóis (2), ora integra o termo de somente uma língua (3):

(1) De Apio Sativo [...] Hispanice, perexil; Lusitanice, salsa [...];

(2) De Malo Punico [...] Hispanice, granadas, romanas [...];

(3) De Amygdalis [...] Hispanice, almendras [...]; De Erinaceo Terrestri [...] Hispanice, orico quacheiros [...].

A contabilização das designaçôes apresenta-nos um total de 281 designações portuguesas, mas apenas $22 \%$ destas aparece catalogada sob a marca Lusitanice. A aglutinação das duas línguas sob uma mesma marca teve algumas repercussões na receção do léxico científico de Amato nas obras de autores coetâneos, como observaremos seguidamente.

\section{RECEÇÃO DO LÉXICO CIENTÍFICO DE AMATO NAS OBRAS DE HISTÓRIA NATURAL POSTERIORES}

\subsection{Historia animalium (1551-1558) de Conrad Gesner}

Tendo em conta não só a grande inovação de Amato relativamente ao registo dos vocábulos portugueses, mas também a sua própria origem portuguesa, certamente os seus coetâneos consideravam-no uma fonte fidedigna onde pudessem coligir o léxico português a incluir nas glosas metalinguísticas das suas obras. 
No âmbito da Botânica e de outros domínios de especialidade, há que destacar a obra do médico suíço Conrad Gesner (1516-1565), onde se observa uma prática lexicográfica constante, que está na génese da taxonomia moderna das linguagens científicas. Trata-se de um dos monumentos mais notáveis do fundo terminológico, que se apresenta nesta breve resenha cronológica: Enchiridion historiae plantarum (1541); Catalogus plantarum latine, graece, germanice, et gallice (1542); Bibliotheca universalis (1545, ed. J. Simler 1574); Pandectarum sive partitionum universalium libri xxI (1548); Historia animalium (1551-1558); Thesaurus Euonymi Philiatri (1552); Corpus Venetum de Balneis (1553); Mithridates de differentis linguis (1555); De omni rerum fossilium genere (1565).

De entre esta vasta produção que, em geral, apresenta índices com as nomenclaturas nas línguas eruditas e em diversas línguas vernaculares, a Historia animalium é a única obra que reúne vocábulos portugueses.

A Historia animalium recolhe os saberes da época e as observaçóes directas do autor sobre os animais. A obra divide-se em cinco tomos ${ }^{12}$, publicados ao longo de vários anos, que se ocupam, respetivamente, de cada uma das grandes classes da conceção aristotélica: os quadrúpedes vivíparos (1551); os quadrúpedes ovíparos (1554); as aves (1555); os peixes e os animais aquáticos (1558); as serpentes (1587). Todos estes tomos ostentam à cabeça umas tabelas que contêm os nomes dos animais em várias línguas (persa, grego, hebraico, alemão, francês, italiano, espanhol, português, inglês, russo e polaco) e a respetiva página em que se encontram. No que concerne ao português, não encontramos vocábulos portugueses nem referências a Amato Lusitano no tomo I. Curiosamente só encontramos vocábulos portugueses a partir do tomo II, que surge depois da publicação das Enarrationes (1553), a mais importante obra de Amato.

Náo obstante, Conrad Gesner, à semelhança de outros autores do século xvi, não diferencia o espanhol do português e apresenta os vocábulos portugueses e espanhóis do tomo II sob a mesma epígrafe: Hispanica. Os tomos seguintes (III e IV) agrupam as duas línguas sob o título Hispanica et Lusitanica, mas a língua portuguesa só aparece com identidade própria no tomo III, onde os vocábulos portugueses se registam através da marca Lusit.. Contudo, há que ter em conta que o autor suíço, apesar do seu intuito de diferenciação entre as duas línguas, não foi bem sucedido, pois apresenta como espanhóis uma série de vocábulos portugueses.

O cotejo entre os nomes registados em Amato e os registados em Gesner indica-nos que os erros de identificaçáo por parte deste último se devem especialmente ao facto de uma das fontes

12 Tomo I (1551): Historice Animalium Liber I de Quadripedibus uiuiparis. Opvs Philosophis, Medicis, Grammaticis, Philologis, Poëtis, \& omnibus rerum linguarumque studiosis, utilissiimum simul incumdissimumque futurum, Zurich, Crist. Froschoverum; Tomo II (1554): Historice Animalium Liber II de Quadrupedibus ouiparis, Zurich, C. Froschovervs; Tomo III (1555): Historice Animalium Liber III qui est de Auium natura [...], Zurich, Christoph. Froschoverum; Tomo IV (1558): Historice Animalium Liber IIII qui est de Piscium \& Aquatilium animantium natura [...], Zurich,Christoph. Froschoverum; Tomo V (1587): Historice Animalium Lib. V qui est de Serpentium natura, Zurich, Officina Froschoviana. 
de Gesner ser Amato Lusitano, a quem cita frequentemente. No total, contabilizamos mais de cinquenta referências às obras de Amato, não só ao Dioscórides (mais abundantes no tomo IV), mas também às Centúrias de Curas Medicinais (mais abundantes no tomo III) ${ }^{13}$. Considerando aqui os comentários de Amato como principal objeto deste estudo, apresentaremos de seguida algumas transcriçôes com referências à sua obra:

Tomo IV, De Aquatilibus

Página 282: [...] Halzum Serapioni commune est nomen marinae et terrestri. Buovalo similiter Italis commune est: non tamen dicitur, Amatus Lusitanus, ab aliis Almeia, vel caracol de la mar $[\ldots]$.

Página 292: Cochleae terrestres quae in altioribus et montanis locis inveniuntur [...] Quandoquidem absinthium depasta, amaritudinem reddunt: sicuti quae serpylium, pulegium, calamintham, origanum, (petroselinum, foenichulum stichadem, Amatus Lusit.) aliasque;

Página 293: Nonnulli hodie cochleas hecticva febri laborantibus concedunt, non contennendo auxilio, Amatus Lusitanus. Qui phthsi afficiuntur, maritima loca vitare debent: atque; illic maxime, ubi pix conficitur. commorari, ibique; cochlearum carne cum vino excoctarum adsidue vesci, Marcellus Empiricus.

Página 494: [...] certo velint hippocampum esse pisciculum illum, vel potius marinum monstrum, qui quibusdam dracunculus, aliis vero equiculus marinus vocant, cuius nullus in cibis usus, Matthiolus. [...] Hispanice, ut Amatus Lusitanus scribit, vocatur Cavalinho marino. Italice Cavalin marino, Cavalin ritorto, Dragonetto, Gallice, Draconeto [...]

Página 1042: [...] Sturionis vetus nomen quaerendum sit, multo maior est Tursionis cum Sturione, quam Siluri cum Sulio affinitas, quo Sulii nomine Sturionem Hispani hodie nuncupant: unica litera 1 , ex medio in principium translata, ex Tursione, Sturionem efficies. Illam tamen Iovii opinionem libenter amplexus est in suis in Dioscoridem commentariis Amatus Lusitanus, et facile cum Iovio credit Silurum Graecorum nostrum esse Sturionem, quod Hispanicum nomen multum ei favere videatur [...].

13 Encontramos referências a Amato nas seguintes partes da Historiae animalium de Gesner: tomo II - páginas 57, 76, 109; tomo III - páginas 144, 220, 223, 282, 343, 363, 394, 395, 404, 432, 533. 535, 717; tomo IV — páginas 282, 292, 293, 294, 407, 494, 507, 508, 509, 540, 593, 595, 1042, 1292 ; tomo V - páginas $12,19,72,74,75,76,77$. 
A utilização da marca Hispanice por Amato Lusitano para abarcar simultaneamente vocábulos portugueses e espanhóis levou Gesner a identificar como espanholas palavras portuguesas. Com efeito, e apenas para citar um exemplo, Amato não diferencia na sua obra os vocábulos "andorinha" e "golondrina", anotando estes termos sob uma mesma marca Hispanice. Gesner oferece, sem especificações, a forma espanhola e a portuguesa, de modo que a palavra "andorinha" aparece como sinónima de "golondrina", sem qualquer diferenciação.

\subsection{Acerca de la materia medicinal (1555) de Andrés Laguna}

Os mesmos erros de identificação de Gesner não se observam na tradução do tratado médico grego da autoria do médico espanhol Andrés Laguna (1511-1560) - Acerca de la materia medicinal y de los venenos mortiferos (1555) - que escolheu um método diferente do seu, atribuindo ao português uma entrada independente, assinalada sob a marca Por. ou Port.

\begin{tabular}{|l|l|l|l|l|}
\hline & $\begin{array}{l}\text { Amato } \\
\text { In Dioscoridis Anazarbei de Medica Mate- } \\
\text { ria [...] Enarrationes (1553) }\end{array}$ & $\begin{array}{l}\text { Laguna } \\
\text { Acerca de la materia medicinal [...] } \\
\text { (1555) }\end{array}$ \\
\hline Entrada latina & Hispanice & Lusitanice & Cast. & Por. \\
\hline De lauro arbore & laurel, loureiro & --- & Laurel & loureiro \\
\hline De cydoniis & membrillos, marmelos & --- & membrillos & marmelos \\
\hline De altero sisymbro & berros, agriois & --- & cilantro & agroens \\
\hline De coriandro & culantro, cilantro & ---- & golondrina & andorinha \\
\hline De hirundine & golandrina, andorinha & --- & romero & alecrin \\
\hline $\begin{array}{l}\text { De libanotide, } \\
\text { id est rosmarino }\end{array}$ & romero, alichri & & & \\
\hline
\end{tabular}

Tabela 3: Exemplo do confronto entre Amato e Laguna no que diz respeito à diferenciação entre o português e o espanhol.

Na página 617 da edição que nos ocupa, o médico Laguna introduz uma nota $A$ l benigno lector, onde justifica o procedimento seguido para a sua edição castelhana e informa-nos detalhadamente sobre o registo das várias línguas modernas, entre elas, o português. Deste modo, sabemos que este labor esteve a cargo de dois portugueses: o médico Luís Nunes e o boticário Simão de Sousa: 
Acabada la traduction parecionos ser convenible, para que el fructo d'este nuestro trabajo, se communicasse a las otras nationes, añadir a la fin de cada capitulo, seis ò siete, y aun algunas vezes ocho, nueve, y diez nombres varios de cada simple: conviene a saber, el Griego, el Latino, el Arabico, el Barbaro que es el que se usa por las boticas, el Castellano, el Catalan, el Portugues, el Italiano, el Frances, y el Tudesco. Ayudaron me opportunamente para el tal negocio con muchos nombres Portugueses, de los quales yo no tenia entera noticia, El doctor Luys Nuñez, Excellente Medico de la Serenissima Reyna de Francia; y Varon raro de nuestros tiempos: y Simon de Sousa, Espejo de boticarios, y diligentissimo escudriñador de los simples Medicinales ${ }^{14}$.

O percurso biográfico de Luís Nunes ${ }^{15}$, amigo e colega de Amato em Salamanca, comprova a idoneidade deste médico para levar a cabo o labor lexicográfico de registar os termos portugueses na obra de Andrés Laguna.

Para além de documentar vocábulos portugueses que são de grande interesse para a fixação do léxico especializado, esta inovação permite-nos, em confronto com a obra do médico português, estabelecer uma distinção entre vocábulos portugueses e vocábulos espanhóis, agrupados frequentemente sob a marca Hispanice em Amato. Náo obstante, importa esclarecer que Amato foi para Luís Nunes uma fonte valiosa para anotar os nomes portugueses, pois indica-nos (através da acotação "segun Amato") o autor que não raras vezes lhe serviu de informação.

\subsection{Os comentários de Pietro Andrea Mattioli}

Se o médico Andrés Laguna teve o discernimento, pouco comum na época, de diferenciar o português do espanhol, evitando muitos erros de identificação dos vocábulos e inovando ao incluir na sua obra palavras portuguesas que as obras de Amato não integram, o mesmo não verificamos nas obras do célebre médico italiano Pietro Andrea Mattioli (1501-1578).

Os primeiros comentários de Pietro Andrea Mattioli ao texto de Dioscórides - Di Pedacio Dioscoride Anazarbeo libri cinque - Il Dioscoride gli suoi discorsi - foram publicados em língua

14 Andrés LAGUNA, Pedacio Dioscorides Anazarbeo, Acerca de la materia medicinal y de los venenos mortíferos, traduzido de lengua griega en la vulgar castellana e illustrado con claras y sustantiales annotationes, y con las figuras de innumerables plantas exquisitas y raras. Amberes, Juan Latio, 1555, p. 617.

15 Luís Nunes, condiscípulo de Laguna e de Amato en Salamanca, também fez a revisão do dicionário médico deixado por Nebrija - Dictionarium Aelii Antonii Nebrissensis iam denuo innumeris dictionibus locupletatum. Cui praeter omnes aeditiones, autoris eiusdem accessit Medicum Dictionarium hactenus nondum typis euulgatum [...]. Sobre a saga da família dos três médicos Nunes, veja-se o trabalho de António Guimarães PINTo, "Literatura e Medicina: alguns textos de Justo Lípsio e de dois doutores Luís Nunes", presente neste volume. 
italiana em 1544, mas só incluiriam glosas plurilingues a partir da edição de 1557, isto é, depois da publicação dos trabalhos de Amato. Relativamente à versão latina dos comentários de Mattioli - P. A. Matthioli, commentarii in lib. VI Pedacii Dioscoridis Anazarbei, de medica materia (1554), a inclusão dos nomes das substâncias nas línguas modernas observa-se unicamente a partir da terceira edição, ou seja, a partir de 1558, quando se acrescenta a Apologia adversus Amathum Lusitanum, com quem manteria uma acesa disputa profissional e pessoal ${ }^{16}$.

A análise comparativa entre as glosas plurilingues das versôes italiana e latina de Mattioli e a obra de Amato indica-nos curiosamente que o médico albicastrense foi a única fonte do médico senense, particularmente no que concerne à anotação dos vocábulos portugueses e espanhóis. Seguem-se alguns exemplos retirados ao acaso de cada uma das obras:

\begin{tabular}{|l|l|l|l|}
\hline \multicolumn{2}{|l|}{$\begin{array}{l}\text { Amato } \\
\text { In Dioscoridis Anazarbei de Medica Materia }\end{array}$} & $\begin{array}{l}\text { Mattioli } \\
\text { P. A. Matthioli, commentarii } \\
\text { in lib. VI Pedacii Dioscoridis } \\
\text { Anazarbei [...] (1558) }\end{array}$ \\
\hline Entrada latina & Hispanice & Lusitanice & Hispanis \\
\hline De fraxino & fresno, frexo & & fresno, et frexo \\
\hline De lauro arbore & laurel, loureiro & & laurel, sive loureiro \\
\hline De ladano & Xara & esteba & xara \\
\hline De prunis & $\begin{array}{l}\text { prunas, andrinas, } \\
\text { amexeas }\end{array}$ & milho, miyo & prunas, andrinas, amexeas \\
\hline De milio & Romero & alichri & milho, myio \\
\hline De rosmarino coronaria & serraya, serralha & & romero \\
\hline De soncho & $\begin{array}{l}\text { leitugas, lechugas } \\
\text { dentre los planos }\end{array}$ & $\begin{array}{l}\text { leitugas, lechugas dentre } \\
\text { los planos }\end{array}$ & $\begin{array}{l}\text { leitugas, lechugas dentre } \\
\text { los planos }\end{array}$ \\
\hline De condrilla & &
\end{tabular}

Tabela 4: Anotação do léxico português e espanhol nas obras de Amato e Mattioli.

A análise desta tabela é concludente quanto à fonte de Mattioli. Verifica-se que nos casos em que Amato apresenta uma entrada para a marca Hispanice e uma entrada para a marca Lusitanice, Mattioli elimina a palavra portuguesa anotada sob a marca Lusitanice e copia a espanhola: observa-se o registo de xara e de romero e a eliminação de esteba e de alichri. Porém, como já tínhamos analisado antes, Amato regista quase sempre os vocábulos portugueses e espanhóis

16 António Guimarães PInto, "Ciência e Preconceito: O ataque de Pietro Andrea Mattioli a Amato Lusitano", Humanitas 65 (2013), pp. 157-182. 
sob a marca Hispanice. À semelhança do que já tinha acontecido com Gesner, este facto originaria que Mattioli identificasse como espanhóis vocábulos portugueses: frexo; loureiro. Estes são apenas dois ou três exemplos das centenas de casos em que observamos a cópia exata das anotações de Amato referentes ao léxico português e espanhol. Considerando o excelente trabalho de Luís Nunes na obra de Andrés Laguna, não só diferenciando bem as duas línguas, mas também anotando com mais exatidão os termos, poderíamos interrogar-nos acerca das opções de Mattioli quanto às suas fontes e, inclusive, quanto à essência das suas disputas com Amato.

\section{CONSIDERAÇÕES FINAIS}

O estudo da trajetória das principais obras de Historia Natural do Renascimento sensibilizou-nos para a importância do conhecimento dos fundos terminológicos que integram estes patrimónios linguísticos nacionais.

O conjunto de informação indagada em torno da estrutura e dos conteúdos das obras publicadas antes de Amato deu-nos o reconhecimento do espaço de destaque da sua obra na história das línguas de especialidade e deixou bem evidente a sua importância no aparecimento, difusão e consolidação dos vocábulos nas línguas vulgares, especialmente no português e no espanhol.

Depois de Amato, abundam as referências aos seus comentários e é imenso o caudal de termos recuperados da sua obra pelos médicos coetâneos, o que nos permite inferir que o médico português era considerado uma autoridade pelos eruditos do seu tempo. O êxito editorial destas obras, manifesto nas numerosas reedições ao longo do século, constitui por si só um testemunho irrefutável da difusão e consolidação do léxico científico português e espanhol. No que concerne ao português, trata-se da primeira publicação impressa com um avultado número de vocábulos, grande parte deles nunca antes catalogados em língua portuguesa.

\section{BIBLIOGRAFIA}

Alvar Ezquerra, Manuel, "Léxico Español en la Historia animalium de Conrad Gesner”, Archivo de filología aragonesa 59-60 (2002-2004), pp. 149-168.

Alvar Ezquerra, Manuel; Nieto Jiménez, Lidio, "Léxico castellano en el Dioscórides de Laguna”, in Ignacio Ahumada (coord.), Diccionarios y lenguas de especialidad, VSeminario de Lexicografía Hispánica. Jaén, Universidad de Jaén, Servicio de Publicaciones, 2002, pp. 143-195.

Амato Lusitano (João Rodrigo Castelo Branco), Index Dioscoridis. En, candide lector, Historiales Dioscoridis campi, exegemataque simplicium, atque eorundem collationes cum his quae in officinis habentur... Ioanne Roderico Castelli albi Lusitano auctore. Antuerpiae, excudebat Vidua Martini Caesaris, 1536. 
Amato Lusitano, In Dioscoridis Anazarbei de medica materia libros quinque enarrationes eruditissimae doctoris Amati Lusitani medici ac philosophi celeberrimi [...]. Venetiis, apud Gualterum Scotum, 1553 (1. a edição); 1554 (2.a edição); Venetiis, ex officina Iordani Zilleti, 1557 (3.a edição); Lugduni, apud Gulielmum Rouillium, 1558 (4.a edição).

Andrade, António Manuel Lopes, "Ciência, Negócio e Religião: Amato Lusitano em Antuérpia": Inês de Ornellas e Castro, Vanda Anastácio (coordenação), Revisitar os Saberes - Referências Clássicas na Cultura Portuguesa do Renascimento à Época Moderna. Lisboa, Centro de Estudos Clássicos - Faculdade de Letras da Universidade de Lisboa, 2010, pp. 9-49.

Collison, Robert Lewis, A History of Foreign-Language Dictionaries. Londres, Deutsch, 1982.

Conde Parrado, Pedro, Hipócrates Latino: El de Medicina de Cornelio Celso en el Renacimiento. Valladolid, Secretariado de Publicaciones e Intercambio Editorial, 2003.

Cortesão, Armando, A Suma Oriental de Tomé Pires e o Livro de Francisco Rodrigues. Coimbra, Acta Universitatis Conimbrigensis, 1978.

Gouvera, António Jorge Andrade de, Garcia d' Orta e Amato Lusitano na ciência do seu tempo. Lisboa, Instituto de Cultura e Língua Portuguesa, 1985.

Guerrero Ramos, Gloria, “Anotaciones de Nebrija a Dioscórides: voces españolas”, Boletín de la Real Academia Española 72 (1992), pp. 6-50.

Holtz, Luis, “Conclusions”, in Jacqueline Hamesse; José Meirinhos (eds.), Glossaires et Lexiques médiévaux inédits. Bilan et perspectives. Porto, Fédération Internationale des Instituts d’Études Médiévales, Textes et Études du Moyen Âge, 59, 2011, pp. 271-74.

Laguna, Andrés, Pedacio Dioscorides Anazarbeo, Acerca de la materia medicinal y de los venenos mortiferos, traduzido de lengua griega en la vulgar castellana e illustrado con claras y sustantiales annotationes, y con las figuras de innumerables plantas exquisitas y raras. Amberes, Juan Latio, 1555.

Orta, Garcia de, Colóquios dos Simples e Drogas he cousas mediçinais da Índia, 1563. Edição publicada por deliberação da Academia Real das Ciências de Lisboa. Dirigida e anotada pelo conde de Ficalho, da mesma academia, volume II. Lisboa, Imprensa Nacional, 1895.

Pinto, António Guimarães, "Ciência e Preconceito: O ataque de Pietro Andrea Mattioli a Amato Lusitano”, Humanitas 65 (2013), pp. 157-182.

Ruel, Jean, Pedanii Dioscoridis Anazarbei de Medicinali Materia libri sex, Ioanne Ruellio Suessionensi interprete [...] cum nomenclaturis Graecis, Latinis, Hebraecis, et Germanicis, Ioanne Lonicero autore. Franc[ofurti], apud Chr. Egenolphum, 1543.

Salas Quesada, Pilar, "La Marca Hisp. en los diccionarios plurilingües. En busca de los inicios de la lexicografía hispano-portuguesa”, Res Diachronicae Virtual: El Contacto de Lenguas 4 (2005), pp. 137-52.

Verdelho, Telmo, As Origens da Gramaticografia e da Lexicografia Latino-Portuguesas. Aveiro, Instituto Nacional de Investigação Científica, 1995. 
(Página deixada prepositadamente em branco.) 


\title{
Usos medicinais das plantas, em Amato Lusitano: o bálsamo ${ }^{1}$
}

\author{
ANTÓNIO MARIA MARTINS MELO²
}

\section{RESUMO:}

"Amigo fiel é bálsamo de vida" lê-se no Antigo Testamento, no livro Eclesiástico ou de Ben Sirá (6.16). Uma frase que nos remete para a preciosidade deste perfume na Antiguidade. Depois desta breve introdução, estudam-se os dois textos de Amato Lusitano que tratam do bálsamo: um no Index (I.18) e outro nas Enarrationes (I.18).

\section{PALAVRAS-CHAVE:}

Bálsamo; Amato Lusitano; Humanismo; Judeus.

\begin{abstract}
:
"A loyal friend is the elixir of life" we read in the Old Testament, on the Book Ecclesiasticus or Filius Sirach (6.16). This phrase reminds us to the preciousness of this perfume in Antiquity. After this brief introduction, we study two texts of Amatus Lusitanus which theme is the balsam: one on the Index (I.18) and another at Enarrationes (I.18).
\end{abstract}

\section{KEYWORDS:}

Balsam; Amatus Lusitanus; Humanism; Jews.

1 Este trabalho foi desenvolvido no âmbito do PEst-OE/FIL/UI0683/2014, projeto estratégico do Centro de Estudos Filosóficos e Humanísticos, financiado pela Fundação para a Ciência e Tecnologia (FCT) e do projeto de I\&D "Dioscórides e o Humanismo Português: os Comentários de Amato Lusitano" (http:// amatolusitano.web.ua.pt) do Centro de Línguas, Literaturas e Culturas da Universidade de Aveiro, financiado por Fundos FEDER através do Programa Operacional Factores de Competitividade - COMPETE e por Fundos Nacionais através da FCT - Fundação para a Ciência e a Tecnologia, no âmbito do projeto FCOMP-01-0124-FEDER-009102.

Para a elaboração deste artigo, pudemos contar com os comentários, sugestões e críticas de António Andrade, João Torrão, Carlos de Miguel Mora e Jorge Paiva, a quem manifestamos a nossa gratidão.

2 Universidade Católica Portuguesa — Braga: antmelo@braga.ucp.pt. 


\section{O ELOGIO DA SABEDORIA}

A sociedade contemporânea, contrariando a tradição de gerações, com raízes nos primórdios da humanidade, tem sistematicamente desvalorizado o elogio da sabedoria. Não querendo subalternizar a tradição milenar da cultura oriental, permita-se que a primeira referência se situe na Cultura Grega; e aqui, que o pensamento voe, quase de imediato, até à tradição dos Sete Sábios: Tales de Mileto, o mais antigo dos filósofos pré-socráticos (625-545 a. C.), será um dos seus primeiros nomes, incontestavelmente.

Desta cultura, dita pagã, recorda-se, aqui, o elogio da sabedoria de um filósofo pré-socrático, natural de Cólofon, antiga cidade grega na região da Lídia, na Ásia Menor, hoje território da Turquia. Chamava-se ele Xenófanes (sécs. VI-V a. C.), o qual apresentou este elogio contraposto às honrarias que acompanham sempre os vencedores em Olímpia, que, apesar de serem mais ilustres à vista dos seus concidadãos, em nada são mais dignos do que ele,

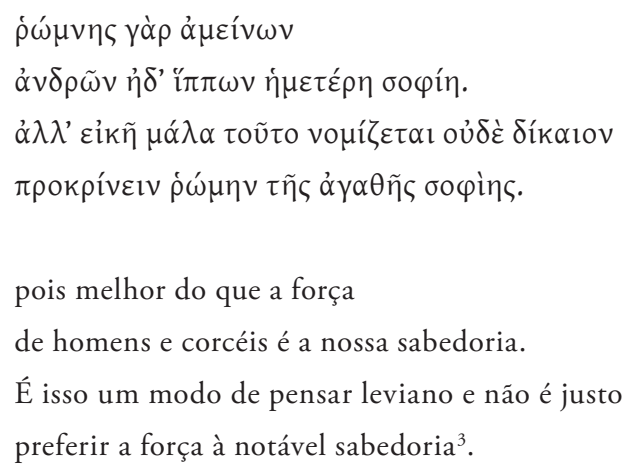

Os textos da Sagrada Escritura também reservaram um grande apreço à reflexão sapiencial, com origens na regiáo do Próximo Oriente e tradicionalmente relacionada com a figura do rei Salomáo. A recolha dos antigos provérbios e das reflexóes sapienciais do povo de Israel, a seguir ao seu exílio da Babilónia, resulta num conjunto de sete livros do Antigo Testamento, denominados de Sapienciais.

\section{O BÁLSAMO, NA BÍBLIA}

Num destes livros, isto é, no livro dos Salmos (45.8), pode ler-se este passo:

3 Xenoph., fr.2 Diels, in Maria Helena da Rocha Pereira, Hélade. Antologia de Cultura Grega, organizada e traduzida do original. Coimbra, Faculdade de Letras da Universidade de Coimbra - Instituto de Estudos Clássicos, ${ }^{7} 1998$, p. 131. 
dilexisti iustitiam et odisti iniquitatem;

propterea unxit te Deus Deus tuus

oleo laetitiae

prae consortibus tuis ${ }^{4}$.

Amas a justiça e odeias a injustiça;

por isso, Deus, o teu Deus, te ungiu

com o óleo da alegria,

preferindo-te aos teus companheiros ${ }^{5}$.

Esta metáfora remete-nos para a preciosidade em que era tido em conta este perfume na Antiguidade. E, em consequência, para o comércio desta e doutras plantas, tal era a relevância do seu uso na vida das pessoas e dos povos. Com efeito, enquanto perfume, também é tomado como símbolo do amor entre namorados e esposos, como sucede no livro sapiencial Cântico dos Câticos (Canticum Canticorum). Depois de o homem declarar o seu amor à mulher, socorrendo-se de diferentes árvores aromáticas (Cant. 4.13-14):

\author{
13 propagines tuae paradisus malorum punicorum \\ cum optimis fructibus, \\ cypri cum nardo. \\ 14 Nardus et crocus, \\ fistula et cinnamomum \\ cum universis lignis turiferis, \\ myrrha et aloe \\ cum omnibus primis unguentis ${ }^{6}$.
}

4 Liber Psalmorum in Nova Vulgata Bibliorum Sacrorum Editio. Sacrosancti Oecunemici Concilii Vaticani II Ratione Habita Iussu Pauli PP. VI Recognita Auctoritate Ioannis Pauli PP. II Promulgata. Edito typica altera. Constitutio Apostolica. Praefatio ad Lectorem. Praenotanda. Vetus Testamentum. Novum Testamentum. Appendix. URL: http://www.vatican.va/archive/bible/ nova_vulgata/documents/novavulgata_index_lt.html (última consulta: 2013.11.18).

5 Bíblia Sagrada, para o Terceiro milénio da Encarnação, versão dos textos originais, coordenação geral de Herculano Alves (ofmcap). Lisboa, Difusora Bíblica, 2003, p. 885.

6 Canticum Canticorum in Nova Vulgata..., op. cit. 


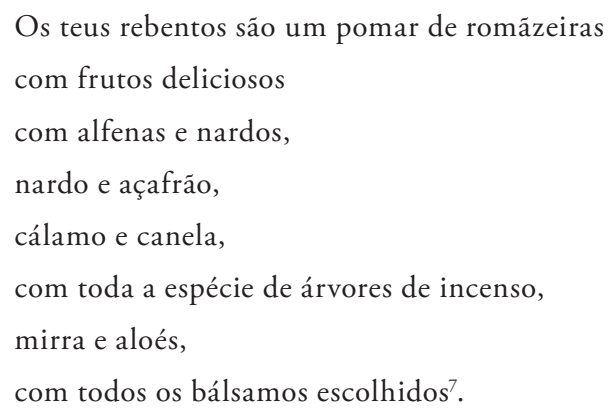

Neste contexto, não deixará de se revelar útil uma pequena nota hermenêutica. Com efeito, a leitura do livro Cântico dos Cânticos, de natureza poética e à maneira de um epitalâmio, quase sempre esteve marcada por uma transposição de sentido, que faz dele uma alegoria, em que o amado é Deus ou o Messias, novo Salomão, e a amada é Israel ou a Igreja, como nova comunidade de Israel $^{8}$.

Segundo a opinião autorizada de Santiago Segura Munguía, no seu monumental tratado Historia de las Plantas en el mundo antiguo, capítulo "Las plantas en la Biblia", o balsameiro ou bálsamo, actualmente conhecido por bálsamo de Gileade ou mirra de Meca, referenciado neste livro sapiencial é a espécie Commiphora gileadensis ${ }^{9}$. E traz à colação este passo do capítulo quinto, versículo primeiro deste livro bíblico:

\footnotetext{
Veni in hortum meum, soror mea, sponsa;

messui myrrham meam cum aromatibus meis,

comedi favum cum melle,

bibi vinum cum lacte meo.

Comedite, amici, et bibite

et inebriamini, carissimi ${ }^{10}$.

Entrei no meu jardim, minha irmã e minha esposa,

colhi a minha mirra e o meu bálsamo,

do meu favo de mel,

bebi o meu vinho e o meu leite.
}

7 Cf. Bíblia Sagrada... op. cit., p. 1055.

8 Cf. Bíblia Sagrada..., op. cit., p. 1051.

9 Santiago Segura Munguía y Javier Torres Ripa, Historia de las plantas en el mundo antiguo. Bilbao, Universidad de Deusto; Madrid, Consejo Superior de Investigaciones Científicas, 2009, p. 41.

10 Canticum Canticorum..., op. cit. 
Comei, ó companheiros, bebei

e embriagai-vos, ó bem-amados! $!^{11}$

Se se recuar ao primeiro livro do Pentateuco, o Génesis (43.11), lá se poderá ler a decisão de Jacob prendar seu ignorado filho José com os melhores produtos do seu país e, de entre eles, menciona-se o bálsamo. Um facto que testemunha a possibilidade de este artigo de comércio ser exportado para o Egipto, já no tempo dos Patriarcas, conforme menção a "uma caravana de ismaelitas que vinha de Guilead. Os camelos estavam carregados de aroma, bálsamo e láudano, que levavam para o Egipto"12 (Ismaelitas viatores venire de Galaad et camelos eorum portantes tragacanthum et masticem et ladanum in Aegyptum $)^{13}$, como se lê num passo anterior deste mesmo livro (37.24-25). Talvez por isso, este seja o bálsamo bíblico mais afamado, assim como de todo o Próximo Oriente Antigo. Chegando a valer o dobro do seu peso em ouro, em tempos imemoriais, segundo a tradição, este perfume era uma resina balsâmica extraída de uma planta, possivelmente a Commiphora gileadensis, segundo outras opiniōes, como adiante se verá. E não faltam, nas Sagradas Escrituras, referências às suas propriedades medicinais, nomeadamente como adjuvante na cicatrização das feridas, como se pode ler num passo do livro do profeta Jeremias $(51.8)^{14}$, ainda que, neste caso, de forma metafórica, pois o profeta busca remédio para curar as feridas de uma Babilónia arruinada:

\footnotetext{
Subito cecidit Babylon

et contrita est. Vlulate super eam.

Tollite resinam ad dolorem eius

si forte sanetur ${ }^{15}$.

De repente, caiu a Babilónia

e ficou arruinada. Chorai por ela!

Procurai o bálsamo para a sua ferida,

a ver se ainda pode sarar ${ }^{16}$.
}

\footnotetext{
11 Bíblia Sagrada..., op. cit., p. 1055.

12 Bíblia Sagrada..., op. cit., p. 77.

13 Liber Genesis, in Nova Vulgata..., op. cit.

14 Para além destes passos citados, há outros da Bíblia Sagrada que nos remetem para a identificação da Commiphora gileadensis: Exod. 30.23; 1Reg. 10.10; 2Reg. 20.13; Esth. 2.12; Prov. 2.12, 7.17; Cant. 1.13, 4.6, 5.1, 5.5, 5.13; Is. 39.2; Ier. 8.22, 46.11, 51.8; Ezech. 27.17; Mtth. 2.11; Marc. 15.23; Ioh. 19.39; Apoc. 18.13. Abreviaturas segundo o Thesaurus Linguae Latinae.

15 Liber Genesis, in Nova Vulgata..., op. cit.

16 Bíblia Sagrada..., op. cit., p. 1318
} 


\section{DA NATUREZA DO BÁLSAMO}

Depois da imagem bíblica acima mencionada, será oportuno explicar o que se entende por bálsamo. De facto, numa consulta ao dicionário de Houaiss, o leitor vai deparar-se com uma entrada subdividida em treze apartados. No primeiro, adianta-se a etimologia (balsamum < $\beta \alpha ́ \lambda \sigma \alpha \mu o v)$ e uma primeira acepção, registando-se que é uma "substância aromática exsudada por muitas plantas, composta de resinas, óleos essenciais, ácido benzoico, cinâmico e seus ésteres; muito us. em perfumaria e farmácia". Numa segunda acepção, fala-se "na medicina caseira, infusão de plantas narcóticas em óleo, com que se friccionam regiôes doloridas do corpo" (bálsamo-tranquilo). Por derivação metonímica, temos aroma agradável e penetrante; no sentido figurado, como já se viu acima, significa consolo, alívio; depois, segue-se a indicação de um arbusto (Cotyledon orbiculata) e de uma erva (Othonna cylindrica). Nesta sequência, abre-se agora o nosso entendimento à consideração de cinco árvores: bálsamo-de-tolu (Myroxylon balsamum) ou bálsamo-do-peru (Myroxylon balsamum var. pereirae); cabriúva-do-campo (Myrocarpus fastigiatus); copaíba (Copaifera officinalis), copaíba-vermelha (Copaifera langsdorffi) e copaíba-jutaí (Copaifera martii). No dicionário de Michaelis, vai encontrar-se a menção ao famoso bálsamo-de-gilead, não só no sentido de uma pequena árvore (Commiphora gileadensis) ${ }^{17}$, de cujas folhas se desprende um cheiro aromático forte, quando pisadas, mas também como oleorresina aromática, amarela ou esverdeada, com gosto algo amargo, obtida dessa árvore e apreciada especialmente em tempos bíblicos como unguento e cosmético; acrescenta, depois, que é o mesmo que bálsamo-judaico ou bálsamo-de-meca. Quer o dicionário de Michaelis, quer o de Aulete, registam a palavra balsameiro para designar a árvore que produz o bálsamo.

\section{O BÁLSAMO EM AMATO LUSITANO}

E assim se foi fazendo o caminho até aos textos do humanista albicastrense, respectivamente no Index ${ }^{18}$ e nas Enarrationes ${ }^{19}$, livro primeiro: em ambos os tratados ${ }^{20}$, a entrada coincide com

17 Como sinónimos: amyris gileadensis.

18 INDEX DIOSCORIDIS. / En candide Lector. / HISTORIALES DI- / oscoridis campi, Exegemataque sim- / plicium, atque eorundem Collationes / cum his quae in officinis habentur, ne / dum medicis et Myropolio- / rum Seplasiarijs, sed Bona / rum literarum studio / sissimis perquam / necessarium / opus. / IOANNE RODERICO CASTE / li albi Lusitano autore. I EXCVDEBAT ANTVERPIAE VI-/ dua Martini Caesaris. M.D.XXXVI.

19 IN DIOSCORIDIS / ANAZARBEI DE MEDICA / MATERIA LIBROS QVINQVE / ENARRATIONES ERVDITISSIMAE I DOCTORIS AMATI LVSITANI MEDICI / AC PHILOSOPHI CELEBERRIMI, / quibus non solum Officinarum Seplasia- / riis, sed bonarum etiam literarum stu- / diosis utilitas adfertur, quum pas- / sim simplicia Graece, Latine, I Italice, Hispanice, Germa- / nice, \& Gallice pro- / ponantur. I Cum Priuilegio Illustriss. Senatus Veneti ad decennium. / VENETIIS. MD LIII.

20 Para um conhecimento aprofundado das várias edições das obras do médico humanista albicastrense, 
o número xviII / 18. No primeiro texto, publicado em Antuérpia, em 1536, é este o registo:

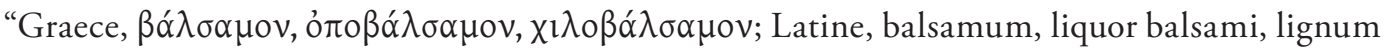
balsami; Vulgo, balsamo”. Nas Enarrationes, que são publicadas já em Itália, na cidade de Veneza, corria o ano de 1553, o texto que se ocupa das diferentes designaçóes desta planta já se apresenta mais desenvolvido, talvez um reflexo da sua experiência acumulada de mercador, como irá ser referido mais abaixo, a que se aliou a de professor na Universidade de Ferrara ${ }^{21}$ :

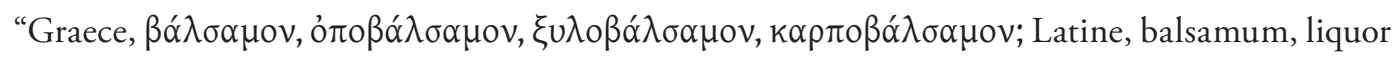
balsami, lignum balsami, fructus balsami; Vulgo, balsamo, olio de balsamo, legno de balsamo, semente de balsamo". Como se pode depreender, às diferentes designaçóes váo corresponder, por sua vez, diferentes naturezas do bálsamo. E com isso, Amato Lusitano desvela a sua faceta tão característica de médico e filólogo do Renascimento ${ }^{22}$, um humanista "não apenas por ter escrito em bom latim as suas obras, mas por toda a sua educação e cultura que iam muito além da formação profissional do médico”, como havia de registar o Professor Costa Ramalho ${ }^{23}$.

Para além de mais desenvolvido, também se nota que a explanação dos assuntos se faz segundo um estilo mais cuidado, revelador de um domínio crescente, por parte de Amato, da língua latina, o grande veículo universal da cultura da época. Ora esta evolução parece denunciar as dificuldades que o movimento humanista havia de vencer paulatinamente para se impor no reino de Portugal, a partir de influências vindas de Itália, como há pouco havia de sublinhar Nair Castro Soares:

\footnotetext{
A grande abertura ao Humanismo de matriz italiana, ao longo de sucessivas décadas, não bastaria para comprovar a afirmação e difusão do Humanismo em Portugal. Necessária se tornava a renovação dos estudos, segundo o programa humanista, os métodos pedagógicos da educação nova, que caracterizam este movimento, tanto na Gramática como na Retórica, como na produção de textos literários.
}

vide João José Alves DıAs, Amato Lusitano e a sua obra: séculos xvı exvII. Lisboa, Biblioteca Nacional de Portugal, 2011.

21 A propósito da viagem de Amato até esta cidade italiana e da diáspora sefardita, vide António Manuel Lopes ANDRADE, "De Antuérpia a Ferrara: o caminho de Amato Lusitano e da sua Família", Medicina da Beira Interior. Da Pré-História ao século xxı — Cadernos de Cultura 25 (2011), pp. 5-16.

22 Virgínia Soares PereIRA, "Relato hagiográfico e memória clínica. Afinidades na organização discursiva de André de Resende e de Amato Lusitano", in José A. Sánchez Marín y Ma Nieves Muñoz Martín (eds.), Retórica, Poética y Géneros Literarios. Granada, Universidad de Granada, 2004, pp. 289-312.

23 Mario Santoro, Amato Lusitano ed Ancona. Coimbra, Centro de Estudos Clássicos e Humanísticos da Universidade de Coimbra, 1991, p. 3 (Prefácio). 
Apesar do ambiente favorável da corte portuguesa, decisivo para a propagação do Humanismo, estes novos métodos pedagógicos impuseram-se não sem algum conflito, ou mesmo resistência da instituição universitária, tanto em Portugal como em Espanha ${ }^{24}$.

Seguem-se, agora, as autoridades citadas por Amato Lusitano e o pensamento delas. Por último, as propriedades do bálsamo, segundo a opinião do cristão-novo português.

\subsection{Teofrasto (c. $371-$ c. 287 a. C.)}

Ao contrário do que sucede no Index, o médico humanista vai fazer referência, nas Enarrationes, ao tratado da História das Plantas de Teofrasto, filósofo grego que havia de suceder a seu mestre Aristóteles na direcção do Liceu, corria o ano de 322 a. C. Depois de dizer que “o bálsamo é uma espécie de arbusto, que tem ramos de videira flexíveis e delgados, do comprimento de três côvados" 25 (Balsamum, arbuscula quaedam est, tricubitales uirgas, et illas quidem viticosas habens), ele acrescenta que

... nec ab hac magnitudine multum recedit, mali punici arbor, cui Theophrastus libro 9 de Plantarum historia, capite 6 similem fecit: nam folia ut ibidem inquit, perpetua illi sunt, nec unquam decidunt, virentia rutae foliis perquam simillima, multo tamen candidiora ${ }^{26}$.

... não se afasta muito deste tamanho a árvore da romãzeira, a que Teofrasto, no livro

9 Da história das plantas, capítulo 6, reconhece uma mesma semelhança: pois as folhas, como ele diz aí mesmo, são perenes, isto é, nunca caem, são verdes e muito semelhantes às folhas da arruda, mas muito mais brancas.

E se Amato, já no Index, aponta como berço do bálsamo a região da Judeia e o Egipto, agora vai socorrer-se da opinião do autor de Os Caracteres para afirmar que ele cresce exclusivamente na Síria (Nascitur arbor haec, ut refert Theophrastus, in Syria tantum). A consulta feita a esta fonte leva-me a afirmar que o humanista omite, por agora, como se verá mais abaixo, a informação de

24 Nair de Nazaré Castro SoARes, "O primeiro humanismo ibérico", in Italo PonTANI, Margarida MiRAnda \& Henrique MANSO (coords.), Aires Barbosa na Cosmopólis Renascentista. Coimbra, Imprensa da Universidade de Coimbra / Classica Digitalia Vniversitatis Conimbrigensis / Centro de Estudos Clássicos e Humanísticos da Universidade de Coimbra; Roma, Sapienza, Universidade de Roma, 2014, p. 21 (Série Humanitas Supplementum).

25 Medida antiga de comprimento, equivalente a $66 \mathrm{~cm}$.

26 Amato Lusitano, In Dioscoridis Enarrationes..., op. cit., p. 33. 
que esta planta se cultiva exclusivamente nas hortas (Thphr., HP 9.6.1). Segundo a sua opinião, em parte alguma se encontra o bálsamo silvestre (Thphr., HP 9.6.4). Por outro lado, Teofrasto refere explicitamente que está a caracterizar a Commiphora gileadensis ${ }^{27}$.

Pode ainda acrescentar-se que Amato reconhece no criador da Botânica científica na Antiguidade uma fonte de informação de Plínio-o-Velho, como se verá abaixo, ao tratar deste historiador e cientista romano.

\subsection{Pedânio Dioscórides (? - c. 56 d. C.)}

No Index, Amato Lusitano vai dar-lhe destaque na entrada, ao intitular um dos três parágrafos com Historia Dioscoridis ${ }^{28}$. É esta a súmula apresentada:

Balsamum arbuscula est quae violae aut licii, quod pyxacantha id est buxea spina etiam dicitur magnitudine crescit, rutae folia habet, multo tamen candidiora perpetuaque. Fronde magis virentia in Iudaea eiusque convalle quadam tantum et in Aegypto nascitur ${ }^{29}$.

O bálsamo é um arbusto que cresce até à altura da violeta ou do lício ${ }^{30}$ e é também designado por escambroeiro ${ }^{31}$, isto é, buxo espinhoso; tem folhas parecidas com a arruda, mas muito mais brancas e perenes e mais viçosas na sua copa; nasce na Judeia, apenas num certo vale, e no Egipto.

A leitura deste passo revela uma evolução de pensamento do texto do Index para as Enarrationes. Com efeito, na descrição apresentada nos Comentários, o humanista albicastrense vai comparar a altura do balsameiro com o lício pixacanto (licium pixacanthem) e deixa para trás

27 TeOfRAsto, Historia de las plantas, introducción, traducción y notas por José María Díaz-ReGañón López. Madrid, Editorial Gredos, 2008, p. 453. Aqui fala-se do bálsamo-de-meca, embora se possa afirmar que se trata da Commiphora gileadensis, referida na Bíblia como mirra-de-meca ou bálsamo-de-gileade.

28 Neste século XVI, para além de João Rodrigues de Castelo Branco, outros nomes importantes se dedicaram ao estudo do tratado De materia medica de Dioscórides, como João Ruélio, Hermolao Bárbaro, Andrés Laguna, Pietro Andrea Mattioli, Marcelo Virgílio... Acerca da influência deste último médico humanista no pensamento de Amato Lusitano, vide João Manuel Nunes Torrão, "Marcelo Virgílio e Amato Lusitano: a utilização do saber alheio para a lenta construção de um saber próprio (breves indicações)", in Maria Cristina Pimentel, Paulo F. Alberto (eds.), Vir bonus peritissimus aeque. Estudos de homenagem a Arnaldo do Espírito Santo. Lisboa, Centro de Estudos Clássicos, 2013, pp. 601-609.

29 Amato Lusitano, Index Dioscoridis..., op. cit., p. $7 \mathrm{v}$.

30 Arbusto espinhoso, provavelmente por ser citado por Dioscórides, Rhamnus catartica L., o espinheirocervina.

31 O mesmo que catapereiro, isto é, pereira silvestre (Pyrus bourgaeana Decne.) em que se enxertam pereiras cultivadas (Pyrus communis L.). 
a sua comparação com outra planta, uma espécie de buxo espinhoso (buxea spina), o que nos parece indiciar uma maior preocupação de rigor na designação. Diz ele:

\begin{abstract}
Balsamum, arbuscula quaedam est, tricubitales uirgas, et illas quidem viticosas habens, huius enim proceritatis ac magnitudinis, albam violam, uel licium pixacanthem, nasci novimus, quibus Dioscorides eam similem facit ${ }^{32}$.
\end{abstract}

O bálsamo é uma espécie de arbusto, que tem ramos de videira flexíveis e delgados, do comprimento de três côvados, e contudo sabemos que desta altura e desta grandeza há a violeta branca ou o lício pixacanto, semelhante aos quais Dioscórides considera esta espécie de arbusto.

Em contrapartida, vai citar agora, por comparação, uma outra árvore, a romãzeira (Punica granatum L.) (Thphr., HP 9.6.1), como já vimos acima, no apartado dedicado a Teofrasto, o que atesta uma preocupação de maior rigor na consulta das fontes. Mas Amato não se esquece de dizer, a propósito, numa advertência ao leitor, que Dioscórides discorda desta opinião (in quam sententiam Dioscoridem in praesenti ire animadvertimus).

Quanto à regiāo onde ele é cultivado, lá vem, uma vez mais, o recurso ao médico grego, que muito provavelmente assistiu as legióes romanas no oriente, para sustentar a afirmaçáo de que esta planta nasce não só no vale da Judeia, mas também no Egipto, o que é uma novidade relativamente ao pensamento de Teofrasto:

Dioscorides vero non solum in convalle Iudaeae quadam, sed Aegypto quoque; nasci fatetur, quod ita esse certi sumus ${ }^{33}$.

Com efeito, Dioscórides reconhece que ele nasce não só num vale da Judeia fechado por todos os lados, mas igualmente no Egipto, coisa de que estamos certos que assim é.

Quanto à maneira de colher o suco do bálsamo, o opobálsamo, também se aponta o processo descrito pelo médico grego (I.19) ${ }^{34}$, que é comum ao mencionado por Teofrasto (HP 9.6.2), ou seja, a partir de uma incisão feita na árvore com um gancho de ferro:

32 Amato Lusitano, In Dioscoridis Enarrationes..., op. cit., p. 33.

33 Amato Lusitano, In Dioscoridis Enarrationes..., op. cit., p. 33.

34 Dioscórides, Plantas y remedios medicinales (De materia medica), introducción, traducción y notas de Manuela García Valdés, Tomo I. Madrid, Editorial Gredos, 1998, pp. 127-129. 
Vocant vero opobalsamum, balsami liquorem, ardentissimo canis aestu exceptum, qui eo tempore, vulnerata arbore, fluit non ut Theophrasti, aut Dioscoridis temporibus, ferreis unguibus, fiebat, sed ... ${ }^{35}$

$\mathrm{Na}$ verdade, chamam-lhe opobálsamo, o suco do bálsamo, extraído pelo calor muito ardente da canícula, que nesse tempo flui da árvore rasgada com um gancho de ferro em forma de unha, não como sucedia nos tempos de Teofrasto e de Dioscórides, mas ...

A colheita deste opobálsamo, ainda nos anos mais fartos, nunca ultrapassaria os vinte e um litros por ano; daí, pois, a inflação do seu preço, condicionado pelas leis de mercado, como é hábito dizer-se hoje:

Deprehenditur autem optimum opobalsamum si laneae vesti instillet maculam non relinquant, si lacti instilletur coagulet aquae aut lacti infusum: quamprimum disiiciat et lactis modo albescat, vetustate crassescit, sed generositatem amittit, interdum enim novum est sive mustum; colorem habet candidum et oleo crassiori simile est, deinde rubescit, postea durescit, et translucidum sit; optimum modice ruffum esse debet, secundum bonitatis locum obtinet album, tertium viride, peius nigrum; nec illius copiosius quotannis sex septemue congiis, ut Dioscorides tradit colligebatur. (...) Item, inquit Dioscorides, rependitur quo loco nascitur, duplo ad pondus eius argento... ${ }^{36}$

Descobre-se, contudo, que o melhor opobálsamo, se ele se derramar num tecido de lá, não deixará mancha; se ele se derramar no leite, coagulá-lo-á. Derramado sobre a água ou o leite, espalha-se quanto antes e começa a ficar branco à maneira do leite, torna-se espesso com o tempo, mas perde a sua boa qualidade, pois, entretanto, fica fresco ou adocicado; tem uma cor branca e é parecido com um óleo mais espesso; em seguida, fica vermelho, depois torna-se duro e poderá ser transparente; o melhor deve ser medianamente vermelho; o branco ocupa o segundo lugar de boa qualidade; o verde ocupa o terceiro lugar; o pior é o negro; nem se colhia, de forma mais copiosa, todos os anos, seis ou sete côngios dele, como conta Dioscórides. (...) Do mesmo modo, como diz Dioscórides, no lugar em que nasce, compensa-se o seu peso com o dobro da prata ...

35 Amato Lusitano, In Dioscoridis Enarrationes..., op. cit., p. 34.

36 Amato LUsitano, In Dioscoridis Enarrationes..., op. cit., pp. 34-35. 
No texto, destacou-se o passo que se deve exclusivamente à inspiração de Plínio-o-Velho $(12.54 .120)^{37}$, outra das autoridades invocadas e da qual se irá tratar logo de seguida.

Falando do carpobálsamo, isto é, da semente do bálsamo, Amato vai instruir os leitores a distingui-lo da sua falsificação, a semente do hipericão ou hipérico, como também se pode designar:

Secundas vero, carpobalsamum bonitate obtinet, quod ut bonum dicatur, decet russum plenum grande ponderosum fervidae cuiusdam in gustu mordacitatis, et odoratum sit; unde facile diiudicari potest, quod hoc tempore in officinis granum pro semine balsami receptum, balsami semen non est, cum oppositas omnino in eo qualitates videamus; nam subnigrum est leve evanidum nec gustui mordax imo parum aut nihil odoratum, ut facile inclinet animus credere, hoc officinarum carpobalsamum, non balsami, sed verius semen illud hyperico simile, quod ex Petra Palestinae oppido affertur, quo olim (testante id Dioscoride) adulterabatur ${ }^{38}$.

Com efeito, o carpobálsamo obtém pela sua qualidade as segundas escolhas e para que ele se possa chamar bom, convém que seja vermelho, grosso, grande, pesado, de um sabor picante e ardente, e aromático; daí que pode ser fácil distinguir-se o grão que, nesta altura, se recebe nas boticas em vez da semente de bálsamo; não é a semente de bálsamo, visto que vemos nele qualidades completamente opostas. De facto, ele é um tanto negro, leve, sem consistência, sem sabor picante e, pelo contrário, pouco ou nada aromático, de tal maneira que o espírito facilmente se inclina a acreditar que este carpobálsamo das boticas não é a semente do bálsamo, mas é mais verdadeiramente uma outra semente parecida com o hipérico (Hypericum, muito provavelmente o Hypericum androsaemum L.), que é trazido da cidade de Petra, na Palestina, com o qual outrora se falsificava, testemunhando Dioscórides esta informação.

$\mathrm{Na}$ continuidade, o médico humanista albicastrense vai falar do xilobálsamo, isto é, dos ramos ou da própria madeira do balsameiro. Observa, depois, que Dioscórides se esqueceu de referir o seu valor para os medicamentos:

Tertias vero bonitatis dotes ad Dioscoridis mentem xylobalsamum obtinet, quod tam a vero illo quod officinae illius loco monstrant, abest, quantum peniculum ab arca differre

37 Pline L'AnCIEn, Histoire Naturelle, Livre XII, texte établi, traduit et commenté par A. ERnout. Paris, Les Belles Lettres, 1949, pp. 57-58; Plinio el VIejo, Historia Natural. Madrid, Editorial Gredos, 1995.

38 Amato Lusitano, In Dioscoridis Enarrationes..., op. cit., p. 35. 
animadvertimus, cum praeter gracile esse, nihil cum ligno balsami veri habeat; hoc vero ut tradit Plinius in unguentis coquitur, et pro succo ipsum substituere officinae. Corticis etiam ad medicamenta pretium est, quod Dioscorides siluit, praecipua autem (subdit) gratia, lachrimae; secunda semini; tertia cortici; minima ligno... ${ }^{39}$

No pensamento deste, conserva as terceiras escolhas o xilobálsamo pelos seus dotes de qualidade, o qual está tão afastado daquele, que as boticas mostram em substituição daquele mesmo, quanto para nós vemos que uma vassoura é diferente de uma arca, porque para além de ser miúdo, nada tem em comum com o lenho do verdadeiro bálsamo; realmente, como diz Plínio, este prepara-se nos unguentos e as boticas substituíram-no pelo suco do bálsamo. Além disso há o valor da casca para os remédios, que Dioscórides passou em silêncio, mas o primeiro reconhecimento é da lágrima (ver também abaixo); o segundo é da semente; o terceiro pertence à casca; o mais pequeno é do lenho ...

E aos poucos foram evoluindo três conceitos distintos: o opobálsamo, o carpobálsamo e o xilobálsamo.

\subsection{Plínio-o-Velho (c. $24-79$ d. C.)}

$\mathrm{Na}$ descrição da planta do bálsamo, já Teofrasto e Dioscórides, como se viu acima, falam na semelhança das suas folhas com as da arruda (Ruta graveolens L.), o que sucede também com Plínio-o-Velho. Contudo, Amato parece estar equivocado quanto à identificaçáo do passo na obra deste escritor romano, natural de Como, uma comuna italiana da região da Lombardia:

... nec Plinius libro 12. capite 25. ubi de ea tanquam de re sibi conspecta iudicium fert, ab illis dissentit; quin imo folium proximum rutae, perpetua coma, habere affirmat ${ }^{40}$.

... nem Plínio, no livro 12, capítulo 25, onde dá o seu parecer acerca dela, como se o desse acerca de uma coisa vista por si, discorda deles, pois até afirma que ela tem uma folha mais próxima da arruda, uma folhagem perene.

39 Amato LUsitano, In Dioscoridis Enarrationes..., op. cit., p. 35.

40 Amato Lusitano, In Dioscoridis Enarrationes..., op. cit., p. 33. 
Com efeito, neste passo, nas edições usadas actualmente, Plínio fala do costo arábico (costus arabicus / adix costi); só no capítulo 25, parágrafo $112^{41}$, mesmo no fim, se identifica esta frase a propósito do bálsamo: folium proximum tuburi, perpetua coma, isto é, de folha muito parecida com a da azaroleira. Ou será que se pode traduzir por arruda, como nos indica a versão francesa? Por outro lado, Amato ao usar a expressão "de uma coisa vista por si", eventualmente está a recordar-se que Plínio esteve na Síria, no tempo do imperador Vespasiano, seu amigo, numa missão militar e administrativa, entre os anos 69 e $70 \mathrm{~d}$. C.

No que se refere ao local do seu cultivo, retoma o pensamento dado a conhecer no Index, no parágrafo intitulado Iudicium nostrum; por isso transcrevemos a partir das Enarrationes:

\begin{abstract}
Nascitur arbor haec, ut refert Theophrastus, in Syria tantum, unde Plinius eleganter ut solet libro 16. capite 32. Fastidio balsamum (inquit) alibi nasci natura, quam in Syria noluit ferre: subscribens vero ille Theophrasti verbis libro 12. Ita quoque, inquit, balsamum uni terrae Iudaeae concessum, quondam in duobus tantum hortis utroque; regio, altero iugerum viginti non amplius, altero pauciorum ${ }^{42}$.
\end{abstract}

Esta árvore cresce, como menciona Teofrasto, somente na Síria, daí que Plínio, com o discernimento que lhe é habitual, no livro 16, capítulo 32, diga que o bálsamo, por desdém, não quis nascer em outro lugar, por uma razão natural, e não quis produzir senão na Síria”, subscrevendo, na verdade, com as palavras de Teofrasto, no livro 12. Assim, do mesmo modo - diz ele — que o bálsamo é atribuído à única terra da Judeia, outrora em apenas duas hortas; numa, que pertence ao rei, com vinte jeiras e não mais, noutra de poucas.

De novo se coloca a questão há pouco mencionada: uma consulta às ediçóes modernas revela que, em vez da indicação do capítulo 32, se devia ter registado o capítulo 59, parágrafo 135 . A esta distância, com naturalidade se aceita que a edição humanista consultada por Amato apresentasse estas discrepâncias na identificação dos passos citados.

41 Pline L'Ancien, Histoire Naturelle..., op. cit., pp. 55-56.

42 Amato Lusitano, In Dioscoridis Enarrationes..., op. cit., p. 33. 
Amato $^{43}$ socorre-se ainda da autoridade de Plínio para afirmar que o aroma do bálsamo era, de longe, o mais preferido $(12.54 .111)^{44}$. Mais acrescenta que o suco, o denominado opobálsamo, deve ser extraído a partir de uma incisão feita na árvore com um vidro $(12.54 .115)^{45}$, ao contrário do que afirmaram Teofrasto e Dioscórides, como já se viu acima:

... reconditae (...) tantum suavitatis, ac iucundissimi odoris, ut merito Plinius omnibus
odoribus balsamum praeferri dixerit: vocant vero opobalsamum, balsami liquorem, ardentis-
simo canis aestu exceptum, qui eo tempore, vulnerata arbore, fluit (...) sed potius ut Plinius
testatur, vitro, lapide, osseisve cultellis, cum ferro laedi vitalia odit, et protinus emoritur ${ }^{46}$. ... é de uma tão grande e recôndita suavidade e de um aroma tão agradabilíssimo que Plínio teria dito que o bálsamo, por seu merecimento, era preferido a todos os outros aromas. Na verdade, chamam-lhe opobálsamo, o suco do bálsamo, extraído pelo calor muito ardente da canícula, que nesse tempo flui da árvore rasgada (...) de preferência, como atesta Plínio, com um vidro, com uma pedra ou então com pequenas facas de osso, já que receia que as partes vitais sejam feridas com o ferro e acabe por morrer logo de seguida.

Na verdade, Plínio (12.54.115) ainda fala do uso de uma pedra ou de instrumentos cortantes de osso (inciditur uitro, lapide osseisue cultellis). Como ele adianta, as árvores não suportavam ser tocadas, nas suas partes vitais, com o ferro, pois morriam imediatamente; contudo, a sua poda já podia ser feita com instrumentos de ferro (ferro laedi uitalia odit, emoritur protinus, eodem amputari superuacua patiens).

\subsection{Juniano Justino (c. séc. II d. C.)}

Trata-se de um historiador romano, muito provavelmente da época do imperador Adriano (117-138), conhecido pelo epítome que fez dos 44 livros das Historiae Philipicae, obra de um

43 Com propósitos distintos dos seus, até porque a história the haveria de reservar um lugar destinado a porventura um dos maiores poetas do nosso humanismo quinhentista, Diogo Pires, poeta eborense e seu parente, com formação médica, também se vai ocupar de plantas medicinais e a ervas aromáticas. Para mais pormenores, vide Virgínia Soares PereIRA, "Plantas de uso terapêutico e alimentar em Amato Lusitano e Diogo Pires", in António ANDRADE, João ToRRÃo, Jorge Costa e Júlio Costa (orgs.), Humanismo, Diáspora e Ciência (séculos xvı exvı): estudos, catálogo, exposição. Porto, Câmara Municipal do Porto, Biblioteca Pública Municipal; Aveiro, Universidade de Aveiro, Centro de Línguas e Culturas, 2013, pp. 313-326.

44 Pline L'Ancien, Histoire Naturelle..., op. cit., p. 55.

45 Pline L'Ancien, Histoire Naturelle..., op. cit., p. 56.

46 Amato Lusitano, In Dioscoridis Enarrationes..., op. cit., p. 34. 
outro historiador romano, Pompeio Trogo, de quem pouco se sabe. Apenas que viveu na época de Augusto, tendo sido natural da Gália Narbonense, e do qual há escassas informaçóes veiculadas por Plínio-o-Velho e por um tal Carísio ${ }^{47}$. Também a sua autoridade é chamada por Amato à colação, com menção ao enriquecimento dos habitantes de Jericó:

Quo vero in loco Iudaeae balsamum proveniat, Iustinus historicus e Pompeio Trogo tradit libro 36. qui post multa et varia citata nugamenta in hunc modum inquit: opes genti ex vectigalibus opobalsami crevere, quod in iis tantum regionibus gignitur, est namque; vallis, quae continuis montibus velut muro quodam cincta instar hortorum clauditur, spatium loci ducenta millia iugera nomine Hierico dicitur; in ea valle silva est, et ubertate et amoenitate insignis, siquidem palmeto et opobalsamo distinguitur, et arbores opobalsami formam similem pineis arboribus habent, nisi quae sunt humiles magis, et in vinearum morem excoluntur: haec certo tempore anni balsamum sudant. Haec Iustinus. In quibus inquit, balsamum in Hiericho Iudaeae nasci, quod ita esse tradidit Iosephus Hebraeorum magnus historicus ${ }^{48}$.

Com efeito, por isso o bálsamo pode crescer neste lugar da Judeia, como o historiador Justino conta a partir de Pompeio Trogo, no livro 36, o qual depois de muitas e variadas ninharias ligeiras diz deste modo: as riquezas desta gente cresceram à custa dos impostos do opobálsamo, porque se produz tão-somente nestas paragens; na verdade, este vale que, rodeado por uma cordilheira de montanhas como se fosse um muro fortificado, à semelhança das hortas, tem uma extensão de duzentas mil jeiras e é denominada Jericó. Neste vale há uma floresta, notável pela sua fertilidade e pela sua amenidade, visto que se distingue por um palmar e pelo opobálsamo; as árvores do opobálsamo têm uma forma semelhante às árvores de pinho, embora sejam mais baixas e se cultivem à maneira das videiras; estas árvores destilam bálsamo numa determinada época do ano. Estas palavras são ditas por Justino e nelas diz que o bálsamo nasce em Jericó da Judeia, o que José dos Hebreus, o grande historiador, transmitiu como foi dito.

E não falta a referência a um outro grande historiador, desta feita judeu, Flávio Josefo (c. 38 - 103 d. C.), por vezes também designado por Flávio José.

47 Cf. Ettore Paratore, História da Literatura Latina, tradução de Manuel LosA, S. J.. Lisboa, Fundação Calouste Gulbenkian, 1987, p. 517.

48 Amato Lusitano, In Dioscoridis Enarrationes..., op. cit., p. 33. 


\subsection{Galeno (129 - 199 d. C.)}

Um dos maiores médicos da Antiguidade, e texto obrigatório na Universidade Medieval, a autoridade de Galeno também aqui é invocada a propósito da falsificação do bálsamo. É que Amato queixa-se de que, no seu tempo, raramente lhe chegava às mãos o verdadeiro:

Raro hodie pretiosissimus liquor iste opobalsamum dictum ad nos verum et sincerum affertur: imo multis mixtum, adulterinum et falsum e Graecia delatum, cuius causa Galenus, ut verum a falso dignosceret, in Iudaeam navigavit ut libro de Antidotis legitur, ad hunc modum dicens: inde opobalsami et cinnamomi in praedictis versibus Andromachus meminit, in quibus post traditas a Dioscoride notas, maximum est ea prius inspexisse, in qua regione unum quodque; ipsorum praestantissimum gignitur, quemadmodum ego conatus sum, sciens opobalsamum variis adulterari modis, ut aegre possit dignosci, ipse videre quomodo id liquorem fundat, ac inde ceu regulam quandam aliorum obtinere: porro didici multas ipsius adulterationes, ut etiam exercitatissimos lateant, quas publicare scientes non dignum aestimo, ne praui ipsas in transcursu discentes, in opere ad malas actiones transferant. Haec ille ${ }^{49}$.

Hoje, raras vezes, este suco preciosíssimo, designado opobálsamo verdadeiro e puro, é trazido até nós; pelo contrário, misturado com muitos unguentos, adulterado, falsificado e trazido da Grécia, e por causa dele Galeno, com a intenção de distinguir o falso do verdadeiro, viajou por mar até à Judeia, como se lê no livro Dos antídotos, falando deste modo: "Andrómaco nos versos atrás referidos lembra-se do opobálsamo e do cinamomo e neles, depois dos sinais transmitidos por Dioscórides, o mais importante é ter examinado antes estas coisas: em que regiáo cada um deles se produz e se torna mais notável e de que maneira eu próprio, ao saber que o opobálsamo é falsificado de várias maneiras e para poder fazer a custo o diagnóstico, me esforcei por ver como este derrama o líquido e ainda como obter uma certa regra dos outros. Assim, descobri muitas falsificaçóes dele, embora escapem aos mais experientes, e não me julgo digno de as tornar públicas para que os corruptos as não aprendam na narração e as não transcrevam numa obra para as más actividades.” Estas são as suas palavras.

Para além de Galeno, é citado Andrómaco de Creta, médico de Nero (37-68 d. C.), que ficou famoso por ter transformado o célebre Mitridaticum, um antídoto universal do rei do Ponto, Mitridates VI Eupator (c. 130-63 a. C.), na teriaga (ou triaga), introduzindo um novo

49 Amato Lusitano, In Dioscoridis Enarrationes..., op. cit., p. 34. 
componente, considerado de grande importância, a carne de víbora; além disso, aumentou o número de ingredientes, de 54 para 63. Esta composição e o modo de preparação foi fixada em verso, para facilitar a sua memorização ${ }^{50}$.

Retomando novamente o texto, Amato vai introduzir outra variedade de bálsamo, proveniente de uma nova terra das descobertas, o Peru, mas que é diferente do da Judeia ou daquele que é proveniente do Egipto:

Quod vero opobalsamum e Peru noua regione adfertur, purum et sincerum esse crediderim, cum tantae sit refragantiae aut odoris, ut omnes alios praestantissimos odores antecellat; quod ut tradunt ii qui arborem illic viderunt, ex arbore pino persimilli non adeo tamen procera effluit colligiturve quod ut superioribus diebus deprehendimus, gustu pingue est, acutum diu in ore saporem retinens odoris suavissimi, ad belzuinum tendentis, nam color et illius substantia tanquam aquae mellis spissae erant, ut manifesto appareat, opobalsamum hoc non esse eiusdem speciei cum Iudaico, aut Aegyptio; quanquam Trogus Pompeius, ut diximus, arbores opobalsami, quae in Iudaea nascebantur pineis similes fecit, ita ut has herbusculas Peru delineasse visus sit ${ }^{51}$.

Na verdade, o opobálsamo que é trazido da nova região, do Peru [Myroxylon balsamum (L.) Harms, a que Lineu chamou Toluifera balsamum L.], eu poderei acreditar que ele é puro e não adulterado, embora seja de tão grande fragrância ou aroma que supera todos os outros aromas mais notáveis. Como dizem os que viram lá a árvore; dessa árvore muito semelhante ao pinheiro, mas nem, por isso, alta flui ou colhe-se aquilo que, como descobrimos nos dias anteriores, possui um paladar viscoso, que conserva na boca um sabor penetrante durante muito tempo, possui também um aroma suavíssimo, que pende para benjoim, pois a cor e a natureza dele eram espessas como se de uma água de mel se tratasse; como poderá saltar à vista de forma evidente que este opobálsamo não é da mesma espécie daquele da Judeia ou do Egipto. Ainda que Pompeio Trogo, como dissemos, tenha considerado as árvores do opobálsamo, que nasciam na Judeia, semelhantes às árvores do pinho, de tal maneira que pareceu ter desenhado estas pequenas plantas, vindas do Peru.

A referência ao tema candente da sua época, a empresa dos descobrimentos, é feita com o apelo ao sentido da vista, "como os que viram lá a árvore". Mais acima, a propósito da descrição de Plínio, também usa uma expressão que denuncia a mesma ambiência epocal, “de uma coisa

50 Cf. "Seitas ou escolas médicas em Alexandria", in A. Tavares de SousA, Curso de História da Medicina. Das origens aos fins do Século xvı. Lisboa, Fundação Calouste Gulbenkian, 21996, pp. 83-86.

51 Amato Lusitano, In Dioscoridis Enarrationes..., op. cit., p. 34. 
vista por si”. Esta é uma atitude que, indubitavelmente, faz recordar dois célebres episódios, embora em vernáculo, descritos por Luís de Camóes, mais tarde, na sua epopeia, sob a provável influência do Roteiro da viagem que D. João de Castro fez a primeira vez que foi à India, no ano de 1538, mais conhecido por Roteiro de Lisboa a Goa (1538) de D. João de Castro (1500-1548) ${ }^{52}$, de que terá tido conhecimento a partir de cópias manuscritas. O primeiro desses episódios é a referência ao fogo-de-santelmo, no Canto V (18.1-2) de Os Lusiadas ${ }^{53}$ :

Vi, claramente visto, o lume vivo

Que a marítima gente tem por Santo.

Na estrofe seguinte (V.19.1-3), a descrição da tromba de água:

Eu o vi certamente (e não presumo

Que a vista me enganava): levantar-se

No ar um vaporzinho e sutil fumo.

Este conhecimento empírico, prático, na linha de pensamento de Duarte Pacheco Pereira (c. 1460-1533) ${ }^{54}$, que nos é transmitido ao longo da sua única obra escrita que chegou até nós, o Esmeraldo de Situ Orbis, de 1508, é ainda reforçado pela experiência pessoal do médico humanista, judeu português, ao dizer-nos que ele próprio provou a nova substância vinda desse novo mundo, "um paladar viscoso", "um sabor penetrante" "como descobrimos nos dias anteriores". Mas desta experiência pessoal fica ainda o registo do sentido apurado do olfacto — "um aroma suavíssimo, que pende para benjoim" — ou da visão, como nesta expressão, "pois a cor e a natureza dele eram espessas como se de uma água de mel se tratasse". Com efeito, aquando da sua passagem por Antuérpia, onde terá chegado porventura ainda nos últimos meses do ano de $1534^{55}$. Amato envolve-se directamente nas actividades comerciais desta Feitoria da Flandres,

52 Armando Cortesão e Luís de Albuqueroue (eds.), Obras Completas de D. João de Castro, edição crítica. Coimbra, Academia Internacional da Cultura Portuguesa, 1968-1982, 4 vols.

53 Luís de CAMÕes, Os Lusíadas, prefácio e fixação do texto de Hernâni CIDADE, il. Lima de Freitas. Lisboa, Círculo de Leitores, ${ }^{12} 1984$.

54 Cf. Luís de Albuqueroue, "Duarte Pacheco Pereira - O saber de experiência feito", in Navegadores, Viajantes e Aventureiros Portugueses Sécs xv e xvı. Lisboa, Círculo dos Leitores, 1987, pp. 157-173; Joaquim Barradas de CARVALho, Esmeraldo de Situ Orbis de Duarte Pacheco Pereira, édition critique et commentée. Lisboa, Fundação Calouste Gulbenkian, 1991.

55 Acerca das tribulações que o acompanharam à chegada a este empório, nas margens do rio Escalda, vide António Manuel Lopes ANDRADE, "As tribulações de Mestre João Rodrigues de Castelo Branco (Amato Lusitano) à chegada a Antuérpia, em 1534, em representação do mercador Henrique Pires, seu tio materno", in Medicina na Beira Interior: Da Pré-História ao século xx। - Cadernos de Cultura 23 (2009), pp. 7-14 (reprodução disponível em http://www.historiadamedicina.ubi.pt/cadernos_medicina/ vol23.pdf). 
aonde chegavam não só as especiarias mais vulgares, como as drogas mais raras. Mas também demandavam este porto produtos portugueses vindos da metrópole, como o azeite, vinho, sal, figos e passas, atum, entre outros. A este propósito, podem ser referenciados alguns testemunhos, na sua obra, como já foi escrito por Ricardo Jorge, no seu magnífico ensaio Amato Lusitano. Comentos à sua vida, obra época $(1962)^{56}$, o que demonstra o conhecimento, em particular, que o nosso médico humanista tinha acerca da exportação de produtos algarvios para a Europa ${ }^{57}$.

No apartado dedicado a Dioscórides, mais acima, já se falou da maneira como se identifica o verdadeiro bálsamo.

Como também já se viu atrás, o médico de Anazarbo elaborou uma escala valorativa das diversas espécies de bálsamo. Nessa continuidade, vem à colação a opinião de Galeno:

... de quibus Galenus libro 6. Facultatibus simplicium medicamentorum ita posteritati scriptum reliquit: balsamum desicat et excalfacit secundo excessu; est autem et tenuium partium, adeo ut odoratum sit, sed liquor eius subtiliorum etiam partium est, quam planta ipsa, non tamen adeo calidus, ut quidam existimant, tenuitate partium falsi: porro fructus eius persimilis facultatis est, ceterum longe in subtilitate partium inferior. Hactenus Galenus ${ }^{58}$.

... acerca destes valores, Galeno deixou escrito para a posteridade, no livro Dos poderes dos medicamentos simples ${ }^{59}$, estas palavras: "o bálsamo seca e aquece na segunda retirada, logo é próprio das partes finas, para que seja aromático; porém, o suco das suas partes é mais subtil do que a própria planta, todavia não tão cálido, como alguns pensam, pela subtileza das partes; até o seu fruto é de poder muito semelhante, com tudo isso ele é de longe inferior na finura das suas partes." Estas são as palavras de Galeno.

56 Nesta obra editada pelo Instituto de Alta Cultura, em Lisboa, são estes os passos identificados: figos (Ficus cariaca L.) e passas (Vitis vinifera L.) do Algarve, vendidas para a Europa Central e Setentrional (pp. 185-186; Enarrationes IV.158); a polpa bolbosa das palmeiras-anãs (Chamaerops humilis L.), frequente no Algarve, exportada para Antuérpia (pp. 196-197; Enarrationes I.137); o atum, pescado no Algarve e exportado para toda a Europa (pp. 201-202; Enarrationes II.30). Para mais pormenores, vide J. A. Romero MAGALHÃES, Para o Estudo do Algarve Económico durante o século xvı. Lisboa, Edições Cosmos, 1979, pp. 125-149.

57 Para mais pormenores acerca das actividades comerciais de João Rodrigues de Castelo Branco, vide António Manuel Lopes ANDRADE, "Ciência, negócio e religião: Amato Lusitano em Antuérpia", in Inês Ornelas e CASTRO \& Vanda ANASTÁCIO (coords.), Revisitar os Saberes. Referências clássicas na Literatura Portuguesa do Renascimento à Época Moderna. Lisboa, Centro de Estudos Clássicos. Lisboa, IELT Universidade Nova de Lisboa, 2010, pp. 9-49.

58 Amato Lusitano, In Dioscoridis Enarrationes..., op. cit., p. 35.

59 O estudo deste manual de Galeno foi introduzido na Università degli Studi di Padova em 1594, pelo médico e botânico italiano Prospero Alpino (1553-1617), conforme se lê em Regina Andrés Rebollo, "A Escola Médica de Pádua: medicina e filosofia no período moderno", História, Ciências, Saúde - Manguinhos 17-2 (abr.-jun. 2010), pp. 307-331, maxime p. 312. Neste contexto, vem a propósito a menção a duas datas referenciadas neste estudo: em 1533, inicia-se o ensino da botânica, com Bonafede; para as práticas de botânica, havia de nascer um horto ou jardim público em 1545. 
Sem dúvida que os Descobrimentos implementaram as trocas comerciais, em parte justificadas pela procura de especiarias e, com isso, alarga-se o conhecimento com o acesso a novas espécies animais, vegetais e minerais. Conhecimento e mercadorias essas que aportavam a Lisboa através do Tejo, rio tão celebrado por poetas e geógrafos, pelas suas auríferas areias, entretanto desaparecidas. Em compensação, no século Xvi, as suas águas quantas frotas lançaram no largo oceano, diz o escritor Gaspar Barreiros, sobrinho de João de Barros, o autor das Décadas. E acrescenta ele na sua Chorographia, publicada em 1561:

Quâtas strellas nouamente achadas? Quătas ilhas \& segredos da natureza descobertos? Quâta diversidade de fontes, de rios, de lagos \& de mares? Quáta nouidade de pedras, heruas, peixes, $\&$ outros animaes ignotos? Que maravilhosa qualidade de terras, de aruores, de plantas, fructos, legumes, \& outros mătimẽtos? Que drogas? Que aromatas? E quăto numero de simples, em que Aristoteles, Theophrasto, Dioscorides \& Galeno, teueram copiosa matéria para comporẽ historias naturaes? Que nouos costumes de gẽtes? Que abominaueis ritos de nefandas religiôes para mais confirmação da nossa? E en quátas d' estas cousas poderam redarguir muitas q tam excelentes Philosophos \& Geographos por certas screuêrã, cuja verdade acharam nestas armas \& descobrîrã nossas navegaçóes? E o melhor de tudo quanto nobre sangue derramado, para q o de Christo se oferecesse a Deos nos lugares, onde nã somente o dos brutos animaes, mas inda o dos rationaes se oferecia ao demonio? 60

\subsection{Os médicos contemporâneos}

Neste apartado, vai apresentar-se o bálsamo de uma nova proveniência, agora do Peru, nas Américas, e apresenta-se uma súmula das propriedades do bálsamo, no âmbito da medicina curativa.

\section{O bálsamo do Peru [Myroxylon balsamum (L.) Harms, a que Lineu chamou Toluifera balsamum L.]}

Amato, à história tradicional acerca do lugar onde é cultivado, vai acrescentar a novidade que lhe é oferecida pela azáfama da empresa dos descobrimentos: o bálsamo proveniente do

60 Gaspar BARREIROS, Chorographia de alguns lugares que stam em hum caminho que fez Gaspar Barreiros ó anno de MDXXXXV] começa[n]do na cidade de Badajoz em Castella te á de Milam em Italia; co[m] algu[m]as outras obras cujo catalogo vai scripto com os nomes dos dictos lugares na folha seguinte, por Ioã Aluarez, \& por mandado do doctor Lopo de Barros do Desembargo d'el rei nosso senhor \& conego da Se d'Euora, em Coimbra,1561, fl. 42r. 
Peru, nas Américas; contudo, depois de experimentado e observado pelo próprio, ele é diferente do da Judeia, como se observou atrás; uma forma de estar típica da mentalidade quinhentista, como perpassa nas palavras de Vasco da Gama dirigidas no âmbito da sua narração ao Rei de Melinde, a propósito das tormentas vencidas e dos "rudos marinheiros / que tem por mestra a longa experiência" ${ }^{1}$, experiência essa que conduz os homens às "puras verdades" através de “casos tão diversos", como acabará por confessar o Poeta algures nos seus sonetos. A descoberta desta terra das Américas ficou a dever-se ao espanhol Francisco Pizarro González, que iniciou a sua ocupação em Setembro de 1532. Agora, as palavras do médico humanista português:

Ceterum hodie alibi balsamum, quam in iis regionibus nasci novimus, ut experientia compertum habemus, videntes, opobalsamum apud eos qui e Peru noviter inventa regione, reversi sunt, et inter thesauros suos tanquam rem pretiosissimam reconditae asportant ${ }^{62}$.

De resto, hoje sabemos que o bálsamo nasce noutro lugar, naquelas regióes de que temos a certeza pela experiência, nós que vemos o opobálsamo junto daqueles que regressaram do Peru duma regiáo de novo descoberta e entre os seus tesouros como se fosse coisa preciosíssima, o transportam.

\section{Propriedades terapêuticas do bálsamo}

Amato Lusitano, ao longo do texto que estou a traduzir, cita vários médicos contemporâneos, nomeadamente Hermolau Bárbaro (1434-1493), patriarca de Aquileia, Jean de la Ruelle (Ruellius) (1474-1537) e Pietro Andrea Mattioli (1500-1577), médico de Siena, que acusa o médico português de ter fugido de Portugal em razão da sua condição de cristão-novo e, com isso, o empurra, definitivamente, para o exílio de Salónica, na Grécia, no império Otomano. Uma polémica que foi objecto de estudo aturado recente, pela mão de António Guimarães Pinto, que acaba de traduzir, deste médico italiano, o seu tratado Apologia aduersus Amathum, publicado em $1558^{63}$. Tudo isto nos pode fazer recordar que, bem cedo, e por ser cristão-novo,

61 Luís de CAMÕes, Os Lusíadas V.17.1-2.

62 Amato Lusitano, In Dioscoridis Enarrationes..., op. cit., p. 35.

63 Cf. António Guimarães PInTo, "Ciência e Preconceito: o ataque de Pietro Andrea Mattioli a Amato Lusitano", Humanitas 65 (2013), pp. 157-182. Para informação complementar, vide dois estudos de J. M. VALDERAS, "La polémica en la investigación botânica del siglo xvı. Mattioli contra Lusitano", Collectanea Botanica 25, 2 (2000), pp. 255-304 e "Mattioli contra Lusitano.II. Las 'censuras' y la interpretación de Dioscórides", Collectanea Botanica 26 (2003), pp. 181-226. Também em Espanha, o médico e humanista Andrés Laguna, na sua tradução castelhana e comentário ao tratado de Dioscórides (Pedacio Dioscorides Anazarbeo, Acerca de la matéria medicinal, y de los venenos mortíferos, traduzida de len- 
foi obrigado a abandonar o Reino, rumo ao empório de Antuérpia, como acima já foi referido, numa altura em que a Inquisição se aprestava para lançar âncora entre nós. Muitos cristãosnovos, como este, se distinguiram na Diáspora pela excelência da obra em diferentes áreas do conhecimento, como se pode ler numa obra de sumo interesse para o tema, Humanismo, Diáspora e Ciência ${ }^{64}$.

O médico albicastrense, quando se vai ocupar da enumeração das mais variadas virtudes do bálsamo, apontando-lhe as propriedades curativas, sublinha que, entre as muitas que lhe são atribuídas, os modernos atribuem-lhes outras propriedades, que não são muito diferentes das que são consagradas pela tradição. Assim, ele vai mencionar a sua importância para a cicatrização das feridas, para a garganta e os ouvidos; que ele faz desaparecer as sardas, no rosto das mulheres, ou o tamanho das pedras nos rins e na bexiga ${ }^{65}$ :

At ultra tam multas balsamo vires tributas recentiores plures alias eidem attribuunt facultates: primam, quod vulnera citissime curat, et ea absque; cicatrice relinquat: secundam, ad sibilum, obtusumque; auditum, instillata in aurem opobalsami gutta, multum valet: tertiam, mulierum lentigines e facie delet, et eam perpolitam, claram ac formosam reddit: quartum, lapillos renum et vesicae ita celeriter frangit et minuit, ut opus incantamento simile esse videatur, quod et Abinzoar medicus doctissimus expertus fuit, ut apud ipsum est legere libro 2. Sui Theifir sectione secunda capite $7^{66}$.

Mas para além das muitas virtudes atribuídas ao bálsamo, os modernos atribuem ao mesmo outras faculdades: a primeira, porque cura muito rapidamente as feridas e pode deixá-las sem cicatriz; a segunda, porque tem muito valor para o assobio enfraquecido; para o ouvido, onde uma gota de opobálsamo nele derramada tem muito poder; a terceira,

gua grega, en castellana ... por el Doctor Andrés de Laguna... En Anvers, En casa de luan Latio, 1555) havia de mencionar o seu colega português. Para uma análise dessas relações entre os dois colegas de profissão, a partir das citações que ambos fazem, nas suas obras, vide M. Á. GonzÁLEz MANJÁRRES - M. J. Pérez IBÁÑEz, "Andrés Laguna e Amato Lusitano, el desencuentro de dos humanistas médicos", in Ferran Grau Codina (ed.), La Universitat de Valência i l'Humanisme: Studia Humanitatis i renovació cultural a Europa i al Nou Món. València, Universitat de València - Departament de Filologia Clàssica, 2003, pp. 689-711.

64 António Andrade, João Torrão, Jorge Costa e Júlio Costa (orgs.), Humanismo, Diáspora e Ciência..., op. cit.

65 Para um conhecimento da prática clínica deste médico português, vide Amati Lusitani Doctoris Medici praestantissimi Curationum medicinalium centuriae septem, varia multiplicique rerum cognitione refert[a] e \& in hac ultima editione recognitae \& valde correct[a]e...: ex typographia Gilberti Vernoy, 1620. Há uma tradução portuguesa: Amato Lusitano (João Rodrigues de Castelo Branco), Centúrias de Curas Medicinais, prefácio e tradução de Firmino CRESPO, Lisboa, Centro Editor Livreiro da Ordem dos Médicos, 2010, 2 vols.

AmATO LUSITANo, In Dioscoridis Enarrationes..., op. cit., p. 35. 
porque faz desaparecer as sardas do rosto das mulheres e deixa-o muito polido, claro e formoso; a quarta, porque rapidamente faz em pedaços e diminui de tamanho as pequenas pedras dos rins e da bexiga, de tal maneira que pareça ser uma obra semelhante a um encantamento, uma obra, que o muito douto médico Avenzoar ensaiou, como se pode ler nele, no livro 2. Al-Theisir, na secção 2, capítulo 7.

Natural de Sevilha, Avenzoar ou Abenzoar (Ibn Zuhr) viveu na primeira metade do século XII (1091-1162) e a sua obra mais famosa, Kitab al-Taysir fi 'l-Mudawat wa-'l-Tadbir (Livro que facilita o estudo da terapêutica e da dieta ou Livro da Simplificação), citada abreviadamente por Amato neste excerto, é uma colectânea de observaçôes médicas, escrita na língua arábica, mas que nunca foi publicada. A sua tradução para a língua latina, impressa em Veneza, corria o ano de 1490 , fez-se a partir do hebraico ${ }^{67}$.

Mesmo a terminar esta entrada, Amato vai ocupar-se daquilo que hoje é conhecido por "medicamentos genéricos", isto é, vai dar a conhecer diversos sucedâneos, como se lê:

Verum Galenus libro succidaneorum suadet deficiente balsamo, eius loco utamur stacte, id est myrrhae pretiosissima gutta, quam hodie officinae, storacem liquidum, ut opinor, appellant; vel oleo irino; vel ut Paulus tradit liquore myrti: nam loco ligni balsami, utendum est albae violae radice. In quodam vero tractatu, qui absque auctoris alicuius nomine, circumfertur, quem recentiores. Quid pro quo appellant, legitur, loco balsami utendum esse terebinthinae oleo, vel oleo laurino, aut gummi hederae: et carpobalsami loco, hederae corymbis, et xylobalsami vice, ipsius hederae ligno: multi praeterea moliuntur balsamum parare artificiale, quorum compositiones consulto praetermittimus ${ }^{68}$.

Na verdade, Galeno, no livro dos sucedâneos, exorta a que na falta do bálsamo usemos a stacte, essência de mirra, isto é, uma gota muito preciosa de mirra, a que hoje as boticas chamam líquido de estoraque, creio eu, ou então usemos o óleo de irino (não será o óleo de irione, em italiano, pois este é de uma planta muito utilizada há séculos, o Sisymbrium officinale (L.) Scop., a que Lineu chamou Erysimum officinale L.) ou o líquido de murta

67 Para mais pormenores, vide "A medicina no Islão Ocidental", in A. Tavares de SousA, Curso de História..., op. cit., pp. 170-171. Ali se pode ler, num parágrafo anterior (pp. 167-168): "Sob o governo de califas como Abd Al-Rahman III (de 912 a 961) e do seu sucessor Al-Hakam II (961-976), grandes patronos da arte e da ciência, Córdova tornou-se, com o seu milhão de habitantes, na maior cidade da Europa, logo a seguir a Constantinopla, e no mais importante centro cultural do Ocidente, procurado por estudiosos de várias origens e crenças religiosas. Hrosvita, freira beneditina de Grandersheim (no ducado de Brunswick), rara figura de intelectual, poetisa e dramaturga, escrevendo naquela época, chamava à cidade 'a jóia do mundo'".

68 Amato Lusitano, In Dioscoridis Enarrationes..., op. cit., p. 35. 
(Myrtus communis L.), como diz Paulo; com efeito, em lugar do lenho do bálsamo deve usar-se a raiz de violeta branca [Matthiola incana (L.) R. Br.]. Na verdade, num certo tratado, que se divulgou com um nome de um outro autor a que os modernos chamam quid pro quo, lê-se que em lugar do bálsamo deve usar-se o óleo de terebinto (Pistacia terebinthus L.) ou óleo de loureiro (Laurus nobilis L.) ou goma de hera (Hedera helix L.); que em lugar do carpobálsamo, deve usar-se os cachos de hera, e que em vez do xilobálsamo, passe a usar-se o lenho da própria hera; além disso, muitas pessoas fazem um esforço para preparar o bálsamo artificial, e, por nossa decisão, omitimos as suas preparaçóes.

De referir que neste excerto é citado Paulo Egineta ou Paulo de Egina (625-690 d. C.), médico grego, associado à medicina bizantina, a par de outros nomes célebres, nomeadamente este, também citado por Amato, noutras passagens, Écio (Aetius) de Amida (502-575), médico do imperador Justiniano, na corte de Constantinopla ${ }^{69}$.

De notar, ainda, no fim deste excerto, a preocupação de Amato com as contrafacçôes do bálsamo, omitindo as suas preparações, a fim de não tornar acessíveis tais conhecimentos.

\section{PALAVRAS FINAIS: A PANACEIA DO BÁLSAMO}

O bálsamo de Gilead, como se viu acima, era exportado para o Egipto, destinando-se a uso na medicina, no culto às divindades ou ainda na preparação dos corpos para a mumificação e, daí, o vocábulo embalsamar para designar o processo de conservação do cadáver.

Contudo, sem sombra de dúvida que o mais famoso será o bálsamo de Ferrabrás, celebrizado por El Ingenioso Hidalgo Don Quijote de la Mancha.

O escudeiro Sancho Pança observa ao seu senhor, o cavaleiro D. Quixote, montado em seu Rocinante, que a orelha dele se esvaia em sangue, depois de um pequeno recontro, à maneira de uma batalha. E logo colocou à disposição do seu senhor fios e um pouco de unguento branco que trazia nos alforges, afivelados no seu burro. Mas logo lhe responde D. Quixote, dizendo que tudo aquilo seria escusado se ele se tivesse lembrado de preparar uma redoma de bálsamo de Ferrabrás, pois uma só gota dele lhes pouparia mais tempo e curativos.

À pergunta de Sancho Pança, que o inquiria acerca da natureza desse bálsamo, segue-se esta resposta:

“- É um bálsamo - respondeu D. Quixote — de que eu tenho a receita na memória, com o qual ninguém pode ter medo da morte, nem se morre de ferida alguma; e as-

69 Cf. "A medicina bizantina", in A. Tavares de SousA, Curso de História..., op. cit., pp. 147-152. 
sim, quando eu o tiver feito e to entregar, não tens mais nada que fazer: em vendo que nalguma batalha me partem por meio corpo, como muitas vezes acontece, a parte do corpo que tiver caído no chão tomá-la-ás com muito jeito e com muita subtileza, e, antes que o sangue se gele, a porás sobre a outra metade que tiver ficado na sela, por modo que acerte bem à justa; e dar-me-ás a beber só dois tragos do dito bálsamo, e ver-me-ás ficar mais são que um pêro"70.

Resta explicar que este Ferrabrás era um gigante sarraceno das canções de gesta francesas da Idade Média, particularmente de uma com esse nome, do fim do séc. XII. Segundo reza a lenda, este herói, convertido ao cristianismo, durante o saque de Roma, juntamente com o seu pai, Balão, arrebatara da Igreja de São Pedro algumas relíquias de Jesus Cristo, entre elas o óleo usado para untar o corpo morto do Senhor. Daqui as propriedades milagrosas que se lhe atribuíam.

\section{BIBLIOGRAFIA}

Albuquerque, Luís de, "Duarte Pacheco Pereira - O saber de experiência feito", in Navegadores, Viajantes e Aventureiros Portugueses Sécs xv e Xvi. Lisboa, Círculo dos Leitores, 1987, pp. 157-173.

Amato Lusitano, (João Rodrigues de Castelo Branco), Centúrias de Curas Medicinais, prefácio e tradução de Firmino Crespo. Lisboa, Centro Editor Livreiro da Ordem dos Médicos, 2010, 2 vol.

Amato Lusitano, INDEX DIOSCORIDIS. / En candide Lector. / HISTORIALES DI- / oscoridis campi, Exegemataque sim- / plicium, atque eorundem Collationes / cum his quae in officinis habentur, ne / dum medicis \& Myropolio- / rum Seplasiarijs, sed bona- / rum literarum studio / sissimis perquam / necessarium / opus. / IOANNE RODERICO CASTE / li albi Lusitano autore. / EXCVDEBAT ANTVERPIAE VI-/ dua Martini Caesaris. M.D.XXXVI.

Amato Lusitano, IN DIOSCORIDIS / ANAZARBEI DE MEDICA / MATERIA LIBROS QVINQVE / ENARRATIONES ERVDITISSIMAE / DOCTORIS AMATI LVSITANI MEDICI / AC PHILOSOPHI CELEBERRIMI, / quibus non solum Officinarum Seplasia- / riis, sed bonarum etiam literarum stu- / diosis utilitas adfertur, quum pas- / sim simplicia Graece, Latine, / Italice, Hispanice, Germa- / nice, \& Gallice pro- / ponantur. / Cum Priuilegio Illustriss. Senatus Veneti ad decennium. / VENETIIS. MD LIII.

Andrade, António Manuel Lopes, "As tribulações de Mestre João Rodrigues de Castelo Branco (Amato Lusitano) à chegada a Antuérpia, em 1534, em representação do mercador Henrique Pires, seu tio materno",

70 Miguel de Cervantes, D. Quixote de La Mancha, Primeiro Volume, tradução dos Viscondes de Castilho e de Azevedo. Mem Martins, Círculo de Leitores, 2005, p. 92. 
in Medicina na Beira Interior: Da Pré-História ao século XxI — Cadernos de Cultura 23 (2009), pp. 7-14 (reprodução disponível em http://www.historiadamedicina.ubi.pt/ cadernos_medicina/vol23.pdf).

Andrade, António Manuel Lopes, "Ciência, negócio e religião: Amato Lusitano em Antuérpia", in Inês Ornelas e Castro \& Vanda Anastácio (coords.), Revisitar os Saberes. Referências clássicas na Literatura Portuguesa do Renascimento à Época Moderna. Lisboa, Centro de Estudos Clássicos; Lisboa, IELT Universidade Nova de Lisboa, 2010, pp. 9-49.

Andrade, António Manuel Lopes, "De Antuérpia a Ferrara: o caminho de Amato Lusitano e da sua Família", in Medicina da Beira Interior. Da Pré-História ao século XxI — Cadernos de Cultura 25 (2011), pp. 5-16.

Barreiros, Gaspar, Chorographia de alguns lugares que stam em hum caminho que fez Gaspar Barreiros ó anno de MDXXXXVJ começa[n]do na cidade de Badajoz em Castella te á de Milam em Italia; co[m] algu[m]as outras obras cujo catalogo vai scripto com os nomes dos dictos lugares na folha seguinte, por Ioã Aluarez, \& por mandado do doctor Lopo de Barros do Desembargo d'el rei nosso senhor \& conego da Se d'Euora, em Coimbra, 1561.

Bíblia Sagrada, para o Terceiro milénio da Encarnação, versão dos textos originais, coordenaçáo geral de Herculano Alves (ofmcap). Lisboa, Difusora Bíblica, 2003.

Carvalho, Joaquim Barradas de, Esmeraldo de Situ Orbis de Duarte Pacheco Pereira, édition critique et commentée. Lisboa, Fundaçáo Calouste Gulbenkian, 1991.

Cortesão, Armando e Albuquerque, Luís de (eds.), Obras Completas de D. João de Castro, edição crítica. Coimbra, Academia Internacional da Cultura Portuguesa, 1968-1982, 4 vols.

Dioscorides Anazarbeo, Pedacio, Acerca de la matéria medicinal, y de los venenos mortíferos, traduzida de lengua grega, en castellana ... por el Doctor Andrés de Laguna... En Anvers, En casa de Iuan Latio, 1555.

Dioscórides, Plantas y remedios medicinales (De materia medica), introducción, traducción y notas de Manuela García Valdés, Tomo I. Madrid, Editorial Gredos, 1998.

González Manjárres, M. Á. - Pérez Ibáñez, M. J., “Andrés Laguna e Amato Lusitano, el desencuentro de dos humanistas médicos", in Ferran Grau Codina (ed.), La Universitat de Valência i l'Humanisme: Studia Humanitatis i renovació cultural a Europa i al Nou Món. València, Universitat de València Departament de Filologia Clàssica, 2003, pp. 689-711.

Nova Vulgata Bibliorum Sacrorum Editio. Sacrosancti Oecunemici Concilii Vaticani II Ratione Habita Iussu Pauli PP. VI Recognita Auctoritate Ioannis Pauli PP. II Promulgata. Edito typica altera. Constitutio Apostolica. Praefatio ad Lectorem. Praenotanda. Vetus Testamentum. Novum Testamentum. Appendix. URL: http://www.vatican.va/archive/bible/ nova_vulgata/documents/ nova-vulgata_index_lt.html (última consulta: 2013.11.18).

Pereira, Maria Helena da Rocha, Hélade. Antologia de Cultura Grega, organizada e traduzida do original. Coimbra, Faculdade de Letras da Universidade de Coimbra - Instituto de Estudos Clássicos, ${ }^{7} 1998$.

Pereira, Virgínia Soares, "Plantas de uso terapêutico e alimentar em Amato Lusitano e Diogo Pires", in António Andrade, João Torrão, Jorge Costa e Júlio Costa (orgs.), Humanismo, Diáspora e Ciência 
(séculos XVI e XVII): estudos, catálogo, exposição. Porto, Câmara Municipal do Porto, Biblioteca Pública Municipal; Aveiro, Universidade de Aveiro, Centro de Línguas e Culturas, 2013, pp. 313-326.

Pinto, António Guimarães, "Ciência e Preconceito: o ataque de Pietro Andrea Mattioli a Amato Lusitano", Humanitas 65 (2013), pp. 157-182.

Pline L'Ancien, Histoire Naturelle, Livre XII, texte établi, traduit et commenté par A. Ernout. Paris, Les Belles Lettres, Paris, 1949.

Plinio el Viejo, Historia Natural. Madrid, Editorial Gredos, 1995.

Santoro, Mario, Amato Lusitano ed Ancona. Coimbra, Centro de Estudos Clássicos e Humanísticos da Universidade de Coimbra, 1991.

Segura Munguía, Santiago y Torres Ripa, Javier, Historia de las plantas en el mundo antíguo. Bilbao, Universidad de Deusto; Madrid, Consejo Superior de Investigaciones Científicas, 2009.

SoAres, Nair de Nazaré Castro, "A História Opus Oratorium e Espertador do entendimento", in Nair Castro Soares, Margarida Miranda \& Carlota Miranda Urbano (coords.), Homo eloquens homo politicus. A retórica e a construção da cidade na Idade Média e no Renascimento. Coimbra, Centro de Estudos Clássicos e Humanísticos da Universidade de Coimbra / Classica Digitalia Vniversitatis Conimbrigensis, 2011, pp. 117-152.

Soares, Nair de Nazaré Castro, "O primeiro humanismo ibérico", in Italo Pontani, Margarida Miranda \& Henrique Manso (coords.), Aires Barbosa na cosmopólis renascentista. Coimbra, Imprensa da Universidade de Coimbra / Classica Digitalia Vniversitatis Conimbrigensis / Centro de Estudos Clássicos e Humanísticos da Universidade de Coimbra; Roma, Sapienza, Universidade de Roma, 2014 (Série Humanitas Supplementum).

Teofrasto, Historia de las plantas, introducción, traducción y notas por José María Díaz-Regañón López. Madrid, Editorial Gredos, 2008.

Torrão, João Manuel Nunes, "Marcelo Virgílio e Amato Lusitano: a utilização do saber alheio para a lenta construção de um saber próprio (breves indicaçóes)", in Maria Cristina Pimentel, Paulo F. Alberto (eds.), Vir bonus peritissimus aeque. Estudos de homenagem a Arnaldo do Espirito Santo. Lisboa, Centro de Estudos Clássicos, 2013, pp. 601-609. 


\section{Amato Lusitano e a importância da ilustração botânica no século XVI. Em torno das edições lionesas das Enarrationes (1558) ${ }^{1}$}

CARLOS A. MARTINS DE JESUS²

\section{RESUMO:}

0 presente estudo revisita a polémica questão da reedição das Enarrationes de Amato em Lyon (França), em 1558, encargo compartido por quatro casas editoriais. Mais especificamente, busca averiguar as circunstâncias em que essa reedição recebeu, pela primeira vez, a inclusão de gravuras, reproduções à escala das placas das gravuras do De historia stirpium de Fuchs (1542). Naquilo que pretende ser uma discussão sobretudo do âmbito das políticas e práticas da edição científica da segunda metade de Quinhentos, o caso da obra de Amato é sem dúvida paradigmático, seja pela ausência, seja pela presença (cada vez mais necessária) de gravuras.

\section{PALAVRAS-CHAVE:}

Amato Lusitano; ilustração botânica; P. A. Mattioli; Dioscórides.

\section{ABSTRACT:}

This paper aims to revisit the polemics around the 1558' edition of Amato's Enarrationes in Lyon (France), an assignment made by four publishers. In a more strict way, it aims to look for the circumstances that made this edition the first one to include pictures, scale-made reproductions of the engraves produced to Fuchs' De historia stirpium (1542). In a paper that intents to be a discussion on the political and practical contexts of scientific edition in the second half of the sixteenth century, Amatus' work is indeed paradigmatic, both for the absence and the (more and more necessary) presence of pictures.

\section{KEYWORDS:}

Amatus Lusitanus; bothanical engravings; P. A. Mattioli; Dioscorides.

1 Este trabalho foi desenvolvido no âmbito do projecto de I\&D "Dioscórides e o Humanismo Português: os Comentários de Amato Lusitano" (http://amatolusitano.web.ua.pt) do Centro de Línguas, Literaturas e Culturas da Universidade de Aveiro, financiado por Fundos FEDER através do Programa Operacional Factores de Competitividade - COMPETE e por Fundos Nacionais através da FCT - Fundação para a Ciência e a Tecnologia, no âmbito do projecto FCOMP-01-0124-FEDER-009102.

2 Investigador de Pós-doutoramento pela FCT — Centro de Estudos Clássicos e Humanísticos da Universidade de Coimbra: carlosamjesus@gmail.com. Referência: SFRH/BPD/84291/2012. 
Nos anos em que desenvolveram a sua atividade de médicos e intelectuais botânicos figuras como Amato Lusitano ou Garcia de Orta, qualquer discussão séria sobre botânica medicinal contemplava já, enquanto objeto científico e não meramente estético ou lúdico, a observação e comparação de ilustrações das plantas e substâncias naturais em causa. A obra de Dioscórides (e nesta categoria se incluem as traduções e comentários, tantas vezes extensíssimos, ao texto grego), mas também um vasto conjunto de herbários e textos críticos contemporâneos sobre a matéria eram frequentemente acompanhados de amplos repertórios iconográficos, tarefa que, como bem se compreende, muito lucrou com a implantação da imprensa. Como tal, é correto considerar a conjugação do livro impresso com a estampa científica um factor decisivo para o desenvolvimento, em termos gerais, da ciência moderna. O certo, contudo, é que nenhuma destas obras - às Enarrationes de Amato e aos Colóquios de Orta nos referimos —, num primeiro momento, foi dada à estampa acompanhada de gravuras, naquilo que constituiu, para o tempo da sua edição e impressão (1553 e 1563, respetivamente), no mínimo uma prática pouco comum.

O presente estudo debruça-se sobre o caso concreto das Enarrationes, os extensos comentários de Amato Lusitano à obra de Dioscórides que, em 1558, saíram dos prelos de quatro casas editoriais lionesas acompanhadas de gravuras. Buscaremos, por via desse exemplo, averiguar a lógica editorial (que é sobretudo economicista) da impressão de gravuras científicas em meados de Quinhentos. Antes, porém, algumas considerações gerais se impóem.

Sabemos que o próprio Dioscórides, para estes médicos e botânicos quinhentistas o modelo ao qual era impossível não recorrer, já se terá servido das ilustrações de Cratevas, que anos antes tinha elaborado um tratado sobre plantas medicinais que incluía desenhos das principais espécies ${ }^{3}$. No mesmo século, Plínio (História Natural 25.8) menciona diversos autores antigos que, trabalhando e escrevendo sobre as plantas e as virtualidades terapêuticas que lhes são inerentes, "reproduziram a cores as plantas para escrever, por baixo, os seus efeitos". Mas acrescenta: "[é que] a pintura é enganosa (verum et pictura fallax), já que são imensas as cores a utilizar, em especial se se pretende rivalizar com a natureza, e esta resulta muito alterada pelos acasos da cópia.” Assim, aquilo que inicialmente procurou ser um instrumento de clarificação - à ilustração botânica nos referimos —, ditariam as limitaçôes técnicas que se tornasse um impedimento à boa interpretação e ao conhecimento de determinada planta.

Apenas a criação da imprensa, e com ela a possibilidade de reproduzir em série também as gravuras, ultrapassaria este problema. Os desenhos e pinturas de artistas ativos já em finais do século xv como Da Vinci (1452-1519) e Dürer (1471-1528) demonstram já, no dealbar de Quinhentos, como se buscava um aperfeiçoamento, em simultâneo científico e artístico, na representação da natureza, da sua fauna e flora, tendência cedo aproveitada pelos editores, tradutores e comentadores de Dioscórides. Uma das obras mais marcantes a este nível foi o

3 M. García Valdés, Dioscórides. Plantas y Remedios Medicinales. Madrid, Gredos, 1998, 2 vols., p. 27. 
De historia stirpium commentarii insignes que, em 1542, Leonhart Fuchs fez sair em Basileia (fig. 1). Tratava-se de uma obra monumental em tamanho fólio, adornada de ricas ilustraçóes que ocupavam por vezes duas páginas inteiras. Diferente de outras edições, as ilustraçóes de Fuchs ${ }^{4}$ buscam ser esquemáticas e reduzir-se aos traços e cores essenciais, tentando, pelo uso de traços finos e pela recusa de sombreados, uma maior clareza descritiva.

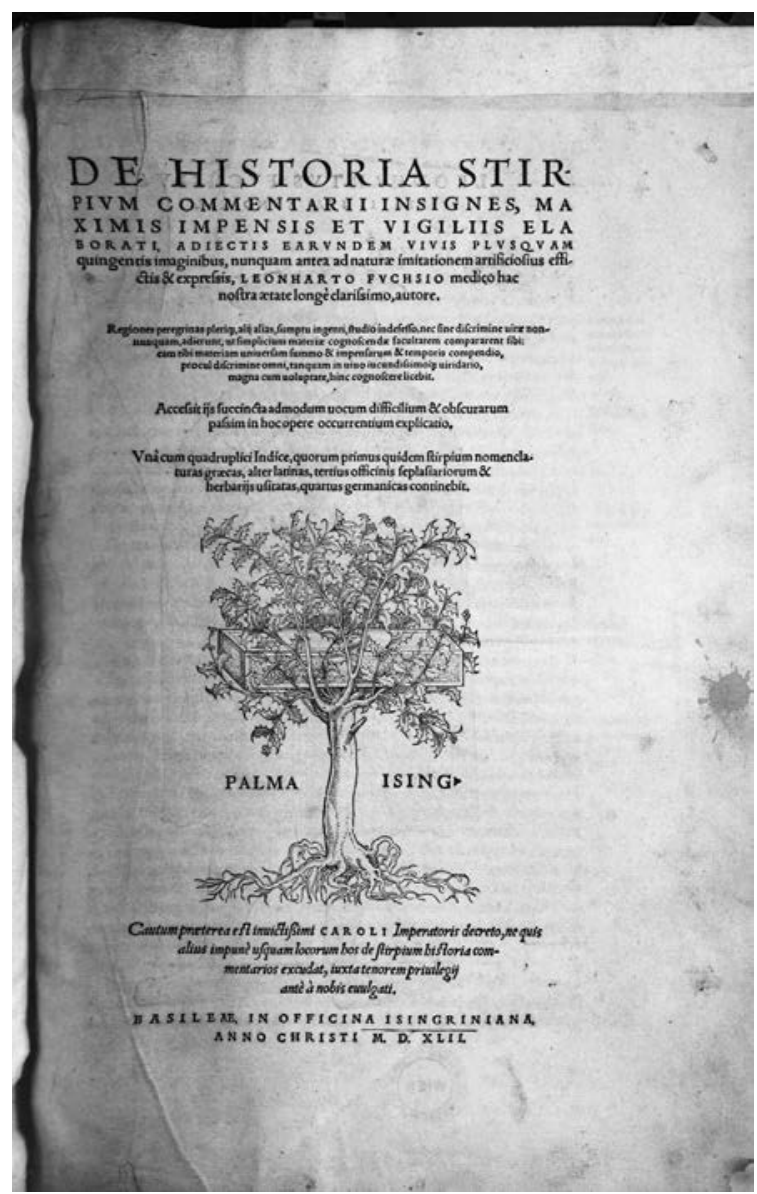

Figura 1

4 Sabemos da imensa fortuna destas ilustrações por toda a Europa, elas que, como as de outras edições, foram incluídas em distintas edições em diversos idiomas e mesmo publicadas isoladamente enquanto índices iconográficos (sem o texto). Isto, claro, tornou-as muito conhecidas e fez com que, por exemplo, ainda em 1574, fossem reproduzidas na obra Anleitung zu der Pflanzenkenntniss de Salomon ScHINz. 
Não menos importante, a própria natureza das ediçóes que se iam sucedendo torna claro que os seus autores tinham consciência do uso de que seriam alvo, ou seja, de que cada vez mais o assunto da botânica medicinal importava a um maior número de gente, especialistas e simples interessados, pelo que importava tornar materialmente mais acessíveis estas edições. O monumental volume de Fuchs conheceria, pela mão da mesma casa editorial que pela primeira vez o publicou, uma série de edições mais ligeiras em formato de quarto e oitavo de fólio, as mais das vezes com o texto reduzido ou mesmo publicando, em exclusivo, o índice das plantas em vários idiomas, sempre acompanhado das ilustraçôes. Ciência, alta cultura e artes plásticas caminhavam, portanto, de mãos dadas, naquilo que também constitui um dos muitos reflexos da importância que os intelectuais renascentistas passam a conferir à natureza, ao homem e sobretudo à experimentação.

As Enarrationes de Amato Lusitano (In Dioscoridis Anazarbei de medica materia libros quinque enarrationes, esse o título da primeira edição), como é sabido, foram por primeira vez editadas em Veneza em 1553, edição que nessa cidade, segundo J. Alves Dias (2011: 71), conheceu três impressóes ou "estados de venda": a referida (e pouco rigorosa) edição de 1553 na casa editorial de Gualtiero Scoto, uma reimpressão desta com portada renovada, na casa de Giordano Ziletti, em 1557 e, pelo mesmo editor, outra edição no mesmo ano. A obra voltou a ser impressa, desta feita em Estrasburgo, pela casa de Wendelin Rihel, em 1554 — o mercado e a academia alemães eram, obviamente, do interesse de Amato —, antes de, em 1558, conhecer quatro impressóes em quatro casas editoriais distintas de Lyon, em França - aquelas sobre as quais nos debruçaremos. Nestas, a principal novidade são as gravuras que são acrescentadas ao texto, cuja importância (e investimento) as torna merecedoras de figurar no título impresso: In Dioscoridis Anazarbei De medica materia libros quinque, Amati Lusitani doctoris medici ac philosophi celeberrimi enarrationes eruditissimae. Accesserunt huic operi praeter correctiones Lemmatum, etiam adnotationes $R$. Constantini, necnon simplicium picturae ex Leonharto Fuchsio, Jacobo Dalechampio, atque aliis.

Este título é, com efeito, comum aos quatro estados de impressão da obra, nas quatro casas editoriais que, nesse mesmo ano, terão dividido os seus elevados custos de produção e incertos lucros de venda (apud J. Alves Dias 2011: 9): apud viduam Balthazaris Arnoleti (fig. 2a), apud Gulielmum Rouillium (fig. 2b), apud Theobaldum Paganum (fig. 2c) e apud Mathiam Bonhomme (fig. 2d). O exame que nos foi possível fazer destes quatro estados de impressão comprovou, a nossa vista, que apenas a portada e o aditamento (e, necessariamente, a paginação do primeiro caderno) foram alterados, mantendo-se os textos e as ilustraçóes os mesmos ao longo da obra. Todas as impressóes, de resto, apresentam no último fólio, antes do caderno com o apêndice iconográfico de 30 gravuras de Daléschamps, a referência "Lugduni excudebat Vidua Balthazaris Arnolleti" - o que, desde logo e com a concordância de dados que em seguida forneceremos, confere à casa editorial de Arnoleto, no mínimo, a iniciativa de editar e imprimir a obra em Lyon. 

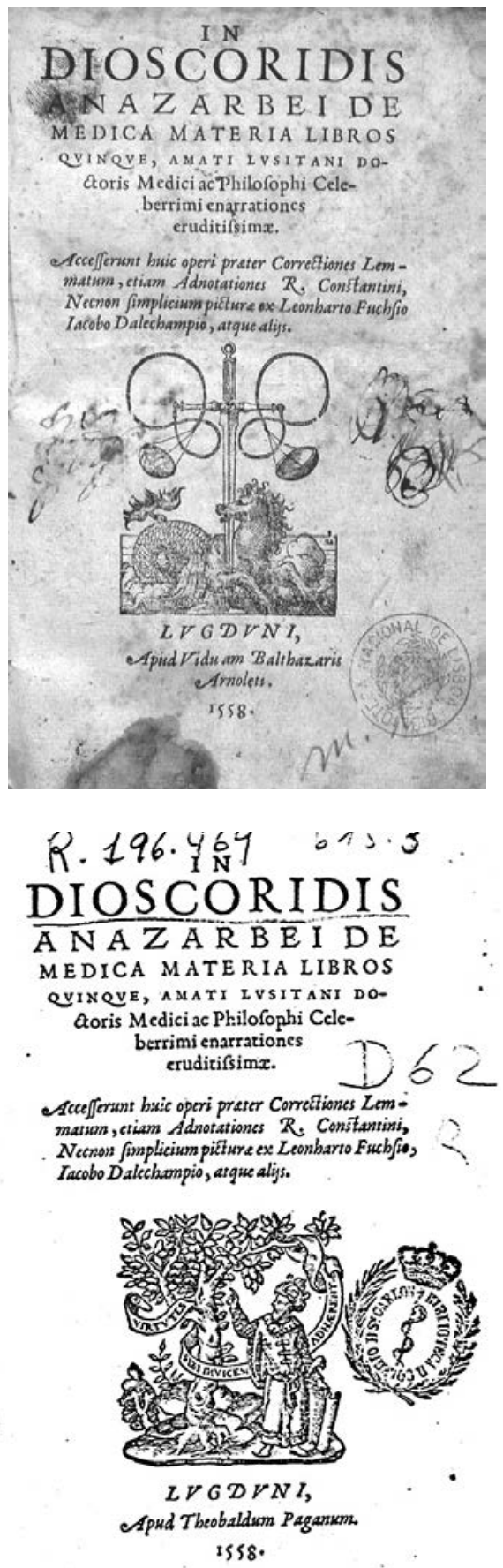

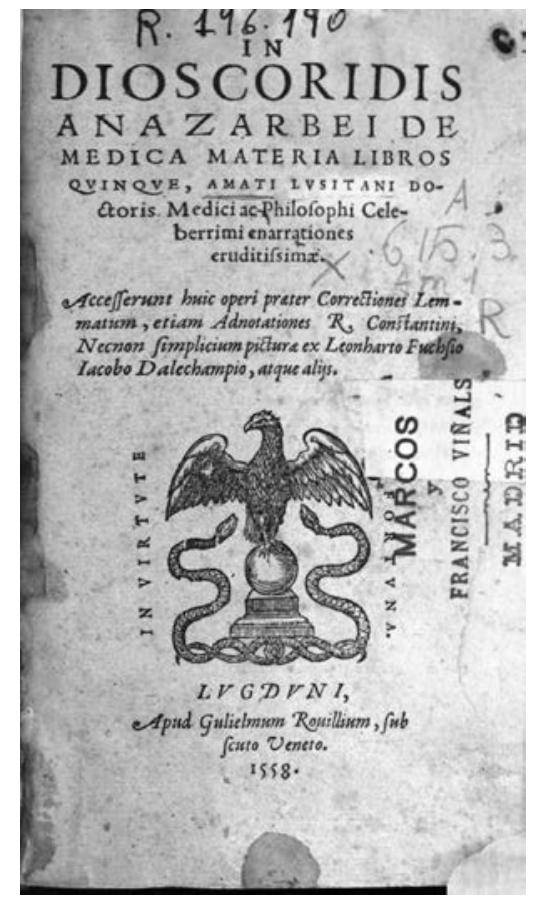

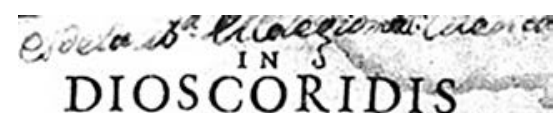
A N A Z A R B E I DE MEDICA MATERIA LIBROS CYNCEx, ANATI LSITANT DOQoris Mediciac Philofophi Celce. 3. berrimi cnartationes cruditifsimx.

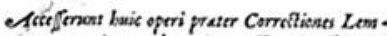
mation, etion Adnocationes $R$. Cenftentini, Necron finglicion pillare co Lesnharto Facb fo

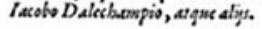

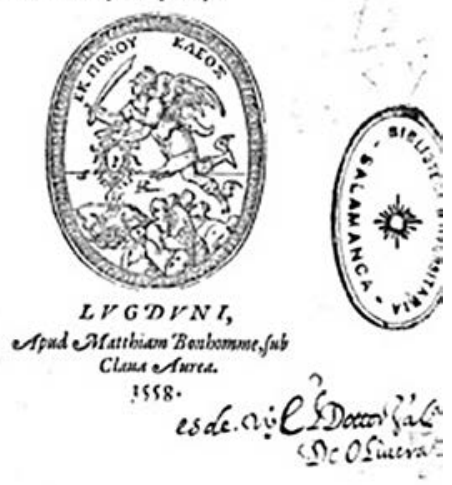

Figura $2[a, b, c, d]$ 
O novo e extenso título que a obra de Amato recebe em terras lionesas (e que os quatro impressores reproduzem sem alteraçáo) anuncia a participaçáo, enquanto corretor e anotador, do médico francês Robert Constantin (1530?-1605), ele que, nesse mesmo ano de 1558, publicaria isoladamente umas Annotationes et correctiones lemmatum in Dioscoridem, extant cum Amati Lusitani ad eundem commentaria. A profundidade da sua intervenção e comentários ao texto de Amato, bem assim a extensão dos seus comentários - evidente na organização visual do fólio -, além de ter justificado a impressão de um volume isolado, leva-nos a suspeitar que o que estava em causa não seria, simplesmente, imprimir o texto de Amato, antes aproveitá-lo para fazer publicar também a obra de um famoso e reconhecido médico francês.

Mas anuncia o título, de igual forma, a inclusão de gravuras de Leonhardt Fuchs, de quem acima já falámos, e de Jacques Daléschamps. Do último, médico que se tornaria um dos mais importantes botânicos franceses do século XvI, sobretudo a partir da publicação do seu Historia generalis plantarum (1586-87; 1616), fazem-se imprimir no final da obra 30 gravuras (fig. 3) de espécies regra geral não ilustradas ao longo do volume (ou mesmo pela ediçáo de Fuchs). O que, ao que sabemos, não foi até agora notado, é que a edição apud Theobaldum Paganum — ou, pelo menos, um conjunto de exemplares seus, entre os quais os que nos foi dado consultar - é a única que não imprime este apêndice. Não sendo claras as razốes desta discrepância na edição de Paganum, o certo é que os fólios com o apêndice iconográfico de Daléschamps constituiriam um caderno à parte, fácil de imprimir ou náo em determinado momento. Ainda assim, como se disse já e facilmente se compreende, o título impresso mantém-se inalterado.

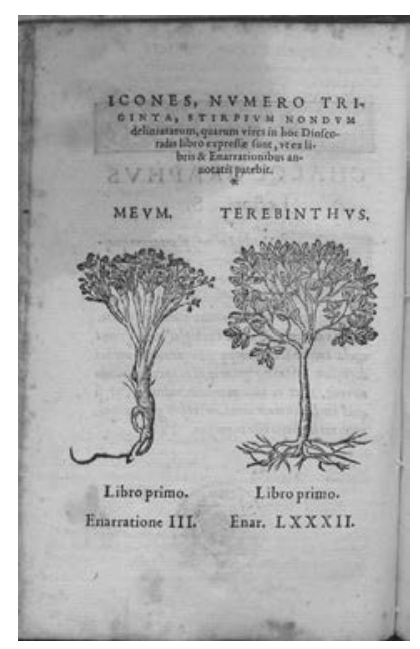

Figura 3 
Não obstante, é às outras, às gravuras que acompanham os comentários e que confessamente são retiradas da obra de Fuchs que pretendemos reportar-nos. O título é claro e honesto, diríamos, ao anunciar que a obra que agora se imprime contém "simplicium picturae ex Leonharto Fuchsio", pelo que não há qualquer pretensão de ocultar a origem das gravuras. O sintagma "ex Leonharto Fuchsio", no contexto editorial e de impressão que era o destas obras, nesses meados do século XVI, indica claramente não a "inspiração em” (nesse caso seria apud a preposição utilizada), antes a cópia desse modelo original, a abertura de novas gravuras na madeira (de igual formato ou à escala, as mais das vezes) e a sua utilização a propósito da impressão de outra obra, mais frequentemente ainda num conjunto de obras ou em diversas reimpressões de um mesmo título 5 .

Um exame minimamente atento dos quatro estados de impressão da "obra de Amato" em 1558 basta para concluir que são as mesmas as gravuras e, mais em pormenor, que muito provavelmente foram as mesmas as placas de madeira utilizadas pelas quatro casas editoriais. Sobre estas, sabemos que foram abertas por Clément Boussy a pedido do editor Arnoleto, que com esse gravador parisiense firmara em 1547 um contrato de colaboração, segundo informa a Bibliographie lyonnaise (Recherches sur les imprimeurs, libraires, relieurs et fondeurs de lettres de Lyon au XVI siècle). Boussy, é de crer, teria sido contratado para iniciar a reprodução à escala das gravuras do De historia stirpium de Fuchs (1542), trabalho concluído em 1549, data em que as referidas gravuras (precedidas de um retrato à escala do próprio alemão) foram incluídas na edição lionesa de Arnoleto do herbário de Fuchs (fig. 4).

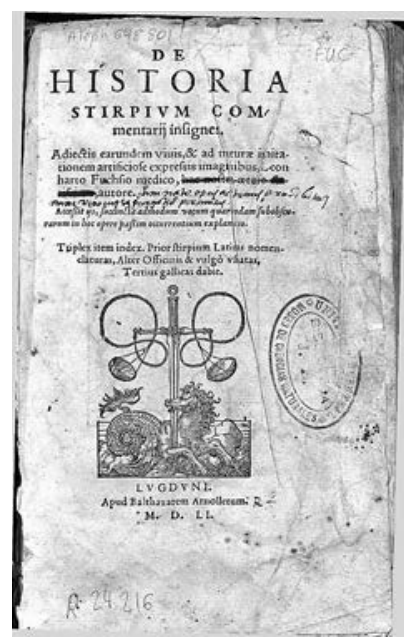

Figura 4

5 Sobre os processos, técnicas, custos e reutilizações das gravuras científicas ao tempo vd. o estudo recente de S. KusukaWA, Picturing the Book of Nature. Image, Text, and Argument in Sixteenth-Century Human Anatomy and Medical Botany. Chicago, University of Chicago Press, 2012, pp. 26-97. 
$\mathrm{Na}$ realidade, a casa de Arnoleto fez um aproveitamento múltiplo do investimento monetário e de tempo (ambos por certo elevados) implicado na execução destas gravuras: além da edição do herbário de Fuchs, em tamanho de quarto de fólio (232 x $168 \mathrm{~mm}$.), as gravuras foram impressas em volume de oitavo de fólio, no mesmo ano e sem qualquer texto (apenas o nome da planta em várias línguas), no Plantarum effigies e Leonartho Fuschio ac quinque diversis linguis redditae (fig. 5), sendo depois reutilizadas para a edição dos comentários de Amato ao De materia medica de Dioscórides, de si mesmos comentados por Constantin, em $1558^{6}$. A partir daqui, as placas de madeira terão circulado pelas demais três casas editoriais que no mesmo ano de 1558 imprimiram a obra.

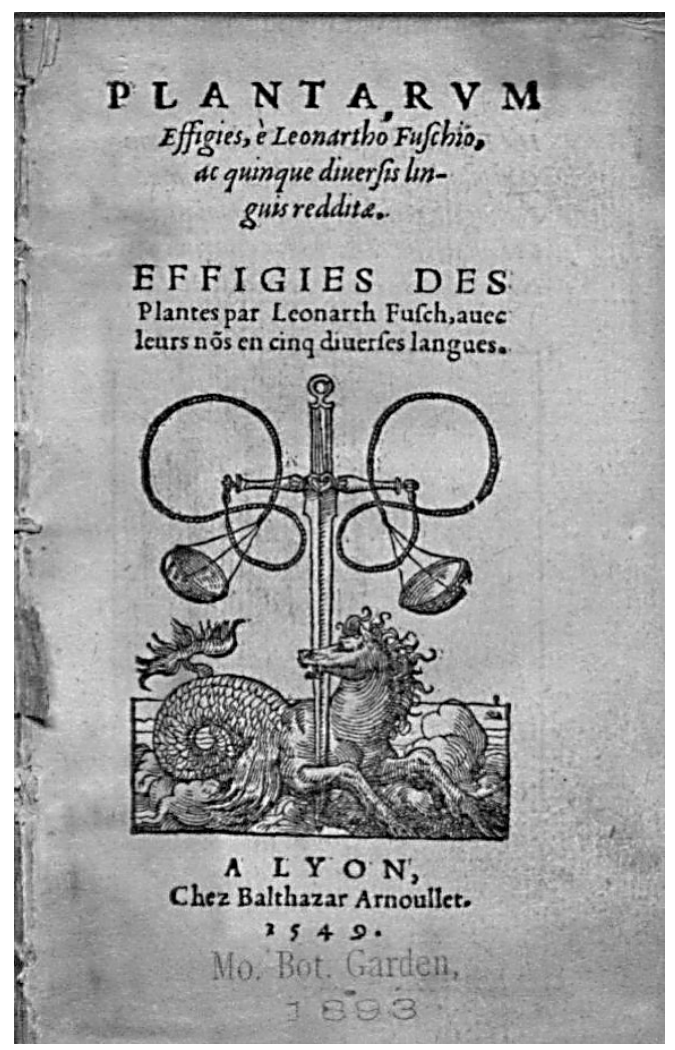

Figura 5 6 As gravuras foram também utilizadas na versão francesa do herbário de FucHS, que a casa de Arnoleto
fez sair em 1550 sob o título L'Historie des plantes mis en commentaires. 
Uma comparaçấo simples das gravuras nos referidos seis estados de impressão (a reimpressão do herbário de Fuchs, o Plantarum effigies ${ }^{7}$ e as quatro impressóes da obra de Amato) basta para perceber que são as mesmas as gravuras e, mais em detalhe, que algumas marcas de impressão denunciam mesmo a utilização das mesmas placas pelas quatro casas editoriais envolvidas. A prática era de facto frequente, e parecem ser os elevados custos envolvidos na feitura de novas placas (sobretudo as de ilustraçóes) os responsáveis: era necessário, no mínimo, a colaboração de um desenhador (que esboçava as ilustraçôes à vista da planta original, ou, em alguns casos, por via das descriçóes dela conhecidas) e de um gravador, figuras (três, no seu caso) às quais Fuchs quis prestar homenagem - por via da arte que eles mesmo dominavam ao incluir o seu retrato na última página do De historia stirpium (fig. 6). No caso, dois indivíduos (os de cima) recebem a designação latina de pictores, nomeadamente Albrecht Meyer e Heinrich Füllmaurer; mas é a figura de baixo, Veit Rudolf Specklin, especialista na abertura de gravados em placas de madeira, o artista mais considerado pelo próprio Fuchs. Sabemos que a sua tarefa era paga entre duas e cinco vezes mais cara do que a dos desenhadores ${ }^{8}$, pelo que a ele era atribuída a autoria artística das ilustraçóes.

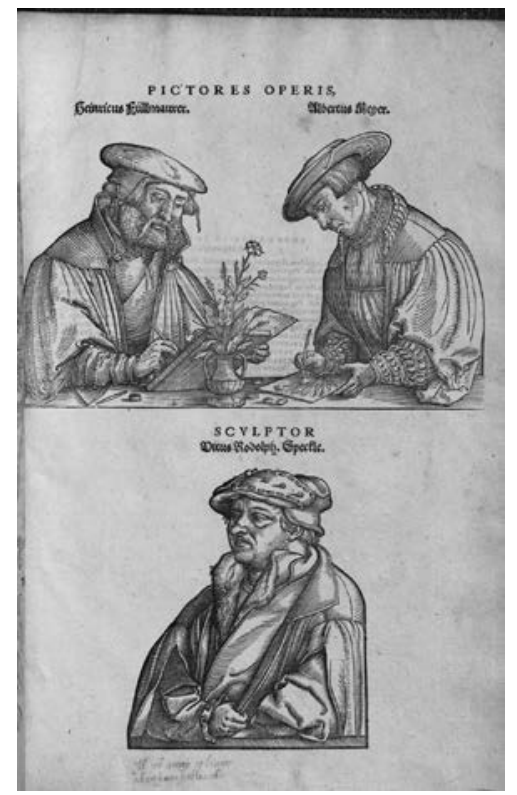

Figura 6

7 No mesmo ano de 1549, conheceu o prelo a versão francesa.

8 Cf. S. Kusukawa, Picturing..., op. cit., p. 45 e n. 62. 
Em rigor, como notou S. Kusukawa ${ }^{9}$, a reprodução das gravuras de Fuchs, a partir da gravação de novas placas de madeira, em tamanho reduzido, depois utilizadas em todos os momentos editoriais que vimos, estava em princípio coberta pela legalidade. $\mathrm{O}$ autor alemáo havia obtido um privilégio imperial com data de 27 de maio de 1554, por cinco anos, que cobria também os direitos de reprodução das placas de madeira das suas gravuras ${ }^{10}$. Ou seja, ao contratar Clément de Boussy em 1547, o editor Arnoleto (que morreria antes de ver a tarefa concluída) estava a prever o tempo necessário para a execução das placas, de forma a imprimir o volume já expirado o privilégio imperial de cinco anos de que estas gozavam, no decurso do ano de 1549.

Não que isto fosse necessário para justificar Amato. Dito de outra forma, nem é nosso propósito justificá-lo, nem há, em rigor, qualquer necessidade de o fazer. Com efeito, sabemos que o português não estaria sequer perto de França aquando da reimpressão da sua obra em Lyon, pelo que é opinião generalizada que não terá acompanhado a preparação da obra. Como tal, as críticas que lhe são tecidas, por Mattioli e outros (e já teremos ocasião de ler uma), a propósito do mau entendimento ou simples desconhecimento de Fuchs, não têm que ver com a escolha das gravuras do alemão, antes com o entendimento dos comentários deste. A escolha das figuras, como dos comentários de Constantin é de responsabilidade editorial, nesta categoria se enquadrando a possível atividade de seleção iconográfica que Daléschamps terá feito sobre o corpus pictórico da obra de Fuchs. Daí que, naquilo que A. Rasteiro (2006: 33) considera terem sido "ediçôes piratas", executadas à pressa e "contra o tempo" — opiniáo sobre a qual em breve diremos algumas palavras —, seja natural encontrarmos erros, não tão pequenos quanto isso, na relação comentário-gravura. Por exemplo, das duas gravuras que ilustram o verbete "De tritico", uma corresponde na realidade à cevada, além de vir depois repetida no capítulo "De hordeum".

Amato não era, em terras francesas, um autor desconhecido ${ }^{11}$. Em Lyon, editara já em 1556 a Terceira e Quarta Centúrias, além de que a Primeira e Segunda Centúrias haviam sido editadas em Paris, entre 1552 e 1554 . Pouco se sabe da relação que teria o Albicastrense com os indivíduos envolvidos na empresa editorial lionesa, mas um ou outro dado conservamos que, no mínimo, nos leva a repensar a teoria difundida de que as edições lionesas de Amato teriam sido "piratas", completamente à margem da vontade de Amato. Se, na Memória 66a da Terceira Centúria (concluída em 1552), quando alude ao encontro com um médico poliglota e alemão de nome Constantino, não é de crer que Amato esteja a referir-se ao comentador francês ${ }^{12}$,

9 Cf. S. KusukaWa, Picturing..., op. cit., pp. 85-86.

10 Vd. S. Kusukawa, Picturing..., op. cit., pp. 84-89 para os detalhes e motivações deste privilégio.

11 Vd. J. Alves DiAs, Amato Lusitano e a sua obra: séculos xvi exvii. Lisboa, Biblioteca Nacional de Portugal, Centro de Estudos Históricos e Centro Editor Livreiro da Ordem dos Médicos, 2011, p. 72.

12 Acerca deste indivíduo pergunta A. RASTEIRo, "Escorbuto, pepinos, inquisição e opúncias na época de Amato Lusitano (1511-1568)", Medicina na Beira Interior. Da Pré-História ao Século xx. Cadernos 
a experiência editorial em terra francesas a que já aludimos, bem como essa outra, posterior a 1558, em especial com a casa editorial de Guilherme Rouillium, uma das responsáveis pela impressão lionesa das Enarrationes na qual saíram, a partir de 1564, as Centúrias, todos estes dados nos parecem apontar no sentido de que Amato, ainda que exilado do outro lado do Adriático, fosse um autor conhecido e respeitado por essas paragens.

O que estamos a defender é que, se por um lado parece de aceitar que Amato não terá procedido ao controlo e revisão da obra que aí era editada - algo que, no panorama editorial em causa, sequer constituiu um caso isolado ou especial — , por outro a opção destas casas editoriais por editar os comentários a Dioscórides do autor português - aos quais se acrescentava a revisão e os comentários de um médico francês de renome, Robert Constantin — buscava mais do que publicar um comentário barato, por não ser do conhecimento do seu autor. A prosa de Amato merecera as maiores críticas (logo, necessariamente, a maior atenção) de Mattioli, talvez o maior especialista em botânica medicinal do tempo. Mattioli, no ano de 1558, passou a fazer imprimir uma Apologia adversus Amathum Lusitanum na abertura da sua edição latina amplamente comentada de Dioscórides, texto que sabemos que vinha já a preparar há algum tempo ${ }^{13}$. Publicar os comentários de Amato, portanto, era também publicar um dos estados mais completos da discussão científica botânica em torno de Dioscórides, assunto tão em voga e gerador de polémicas tão acesas.

A questão está na legitimidade desta responsabilização (a do uso das gravuras de Fuchs), que não pode cair sobre o autor, nem sequer sobre os editores. Como se viu, a elaboração de novas placas a partir das ilustrações de Fuchs, por primeira vez impressas em 1549, era legal. Depois, a prática de reutilização de gravuras por decisão editorial e à margem da vontade e do controle do autor do texto era de facto frequente, sobretudo com estes autores religiosamente comprometidos e por isso mesmo geograficamente mais inacessíveis (mais inacessíveis ainda do que estaria qualquer pessoa de outro país, no século XVI). Depois, a questão sequer se põe. Em 1558, quando lançou a Apologia (que sabemos, como acima se disse, estar a ser preparada há já bastante tempo), Mattioli não tinha como ter visto uma edição ilustrada (pelas reproduçôes

de Cultura 20 (2006), p. 34: "será o comentador das edições de Lyon e se terá alguma ligação com a tipografia de Baltasar Constantino, de Veneza, que em 1557 editou as primeiras quatro Centúrias". Se a primeira hipótese nos parece pouco provável, como dissemos, a propósito da segunda tampouco tivemos como chegar a conclusões seguras.

13 Mattiolı, que utiliza como mote para a sua Apologia uma carta de aviso que acabara de receber da parte de Partini, preparava já desde 1553, ano da primeira edição das Enarrationes, a resposta a Amato. Isso se depreende de uma carta sua a Ulisse Aldrovandi, de 21 de Novembro de 1553, na qual confessa estar ocupado com as "risposte et obiettioni al lusitano". Ao que nos foi dado saber, o primeiro a notar a importância desta carta a Aldrovandi foi Harry FrIEDENWALD, "Amatus Lusitanus": Bulletin of the Institute of the History of Medicine 5 (1937), p. 622. Vd. J. M. VALDERAS, "La polémica en la investigación botánica del siglo xVI. Mattioli contra Lusitano", Collectanea Botanica 25.2 (2000), p. 268 e n. 67. 
de Fuchs) da obra de Amato. Não obstante, a interpretação da imagem plástica, descrita ao pormenor mesmo nas obras não acompanhadas de ilustraçóes, era algo corrente.

Quando por exemplo, na 16a calúnia refutada por Mattioli na Apologia, o italiano critica o desconhecimento de Fuchs a propósito da sideretis, fá-lo apenas e só pelo que a propósito de si próprio (Mattioli) dissera Amato no texto das Enarrationes, já desde a primeira edição de 1553; estaria irritado, sobretudo e como bem denuncia, pelo facto de o Albicastrense o acusar de afirmar que Fuchs desconhecia essa espécie:

\begin{abstract}
E não refutarei com muitas palavras o que objetas acerca da sideritis, a propósito da qual cada vez mais póes a nu a tua ignorância da botânica, ao escreveres assim: "Encontra-se esta sideritis em muitos vales, tem folha áspera, do tamanho da da salva e esbranquiçada como a do marrubius e dentada em volta como a do carvalho, e esfregada exala de si um odor semelhante ao que vemos provir dos marmelos muito maduros, que Dioscórides subentende ao dizer que tem um gosto não desagradável, com alguma adstringência. Parece que Fuchs, no seu Herbarium, a conheceu, embora Mattioli sustente o contrário. Mas a verdade é que Mattioli nunca a viu, porque, se a tivesse conhecido, [ $\left.\mathbf{v}^{\mathbf{o}}\right]$ nunca teria omitido o seu odor muitíssimo agradável.” (...) De facto não ignoro esta espécie, consoante cuida o Lusitano, mais com o seu desatino do que ciência. Mas provavelmente não se desviaria do alvo quem dissesse que o Lusitano em lugar algum viu a sideritis de Fuchs, a náo ser pintada, pelo que falsamente escreve que esta sideritis nasce nos vales, onde ordinariamente o solo costuma ser húmido, ao passo que tanto Fuchs como Dioscórides dizem que em lugares sáfaros, fragosos e incultos. ${ }^{14}$
\end{abstract}

Dito de outro modo, parece-nos que a riqueza do texto de Mattioli, nos pontos em que alude à má interpretação de Fuchs por parte dos comentários de Amato, reside na perfeita síntese que faz da natureza e dos processos da mais alta investigação científica em botânica medicinal, nesses meados de Quinhentos. As descriçōes de botânicos de diversas origens são comparadas ao mais ínfimo detalhe, cotejadas com as ilustrações disponíveis, na mais perfeita fusão entre artes plásticas, literatura e ciência. A tudo isto se acrescenta o imenso valor da experiência, o contacto direto com a espécie, o seu cheiro, textura, sabor e sensação ao tacto.

Nos Coloquios dos simples, e drogas he cousas mediçinais da India, publicados além-mar em 1563, escutamos Garcia de Orta afirmar, a propósito do Amomo (Col. 4: vol. 1, p. 60):

14 Agradecemos a António Guimarães PINTo a cedência desta parcela de tradução da Apologia, fruto do trabalho realizado no âmbito do projeto de I\&D «Dioscórides e o Humanismo Português: os Comentários de Amato Lusitano», cuja publicação está prevista futuramente sob a chancela da Fundação Calouste Gulbenkian. 
E derãome huma mostra de amomum, que eu trouxe a Goa, mostreya aos boticários, e cotejeya com huns debuxos dos simples de Dioscorides; e a todos nos pareceu conforme ao debuxo, e aos ditos dos escritores, e ainda que estava seca, bem parecia feita á feição de pé de pomba.

Orta, investigando e escrevendo na Índia, lidava com ediçôes de debuxos dos simples, como lhes chama, muito anteriores a meados de Quinhentos. Sabemos da riquíssima edição do herbário de Fuchs, em 1542, mas há que olhar para este último já como um marco importante na reforma e desenvolvimento da gravura botânica científica, como especialista que contava já, detrás de si, com uma longa tradição. Daí que tanto o seu livro (o de Orta), como o de Amato (os de Amato, aliás), pela primeira vez editados sem ilustraçôes, tivessem nisso mesmo um calcanhar de Aquiles no que à divulgação das suas investigaçôes diz respeito.

Ainda assim, por um lado, foram muito lidos e levados em conta pelos mais afamados especialistas europeus; e sobretudo por isso, por outro, ambos conheceriam reediçôes "ilustradas" ainda em anos de sua vida (Orta em 1567, na versão latina de Charles de l'Écluse; Amato nas impressōes lionesas de 1558). Pouco se sabe, é certo, da participaçâo de ambos nestas reedições. O próprio adjetivo 'ilustradas', inevitável, deve ser tomado com cautela, porquanto sabemos que nem sempre era óbvio ou sequer existente uma relaçáo direta texto/ imagem. Contudo, colocado este pouco ao lado do muito (algo mais) que sabemos da cotação científica europeia de ambos, e pese embora a situação religiosa no mínimo limitadora e desconfortável que lhes era igualmente comum, tampouco nos convence a radical exclusão da sua participação nestas empresas editoriais. Sobretudo a de Amato, demasiado relacionado editorialmente com o território francês e lionês em concreto, demasiado conhecido e comentado ao mais alto nível na Europa culta; um intelectual maduro e em final de vida (pelos anos de 1558), com a mais ampla rede de contactos perfeitamente constituída; muitos demasiados afinal para que aceitemos, sem mais, a sua total marginalidade no processo editorial lionês. 


\section{BIBLIOGRAFIA CITADA}

Dias, J. Alves, Amato Lusitano e a sua obra: séculos Xvi e Xvir. Lisboa, Biblioteca Nacional de Portugal, Centro de Estudos Históricos e Centro Editor Livreiro da Ordem dos Médicos, 2011.

Friedenwald, H., "Amatus Lusitanus", Bulletin of the Institute of the History of Medicine 5 (1937), pp. 603-653.

García Valdés, M., Dioscórides. Plantas y Remedios Medicinales. Madrid, Gredos, 1998, 2 vols.

Kusukawa, S., Picturing the Book of Nature. Image, Text, and Argument in Sixteenth-Century Human Anatomy and Medical Botany. Chicago, University of Chicago Press, 2012.

Orta, Garcia de, Colóquios dos Simples e Drogas da India [Goa, 1563], dir. e notas por Conde de Ficalho, 2 vols. Lisboa. Academia Real das Ciências de Lisboa/Imprensa Nacional, 1891-1895.

Rasteiro, A., “Escorbuto, pepinos, inquisição e opúncias na época de Amato Lusitano (1511-1568)", Medicina na Beira Interior. Da Pré-História ao Século xx. Cadernos de Cultura 20 (2006), pp. 23-36.

Valderas, J. M., "La polémica en la investigación botánica del siglo xvi. Mattioli contra Lusitano", Collectanea Botanica 25.2 (2000), pp. 255-304. 


\title{
Sobre la identificación entre ébano y guayaco en una entrada del Index Dioscoridis de Amato Lusitano ${ }^{1}$
}

\author{
CARLOS DE MIGUEL MORA²
}

\section{RESUMEN:}

En el presente artículo pretendemos descubrir cómo se encuadra el primer comentario de Amato Lusitano a la materia médica de Dioscórides, el Index Dioscoridis, en el proceso de confusión entre el guayaco y el ébano que se sabe que se produjo a principios del s. xVI. Para ello, intentamos revisar en primer lugar cómo surge la enfermedad del mal francés, para llegar a la conclusión de que la novedad del mal exigió, en cierto modo, un tratamiento también novedoso, en este caso por guayaco, madera procedente de las llamadas Indias occidentales. Aunque la información sobre plantas iba llegando del nuevo mundo, el desconocimiento del guayaco y, lo que es más sorprendente, el aparente desconocimiento del ébano a no ser por las descripciones de los autores antiguos, permitió una confusión que fue acentuada por cuestiones económicas (el control de unas pocas familias sobre el mercado del guayaco) y las propias características de la historia natural en el Renacimiento. A continuación, se analizan paso a paso algunos textos que permiten comprender la evolución de la comparación entre el guayaco y el ébano, para llegar al texto del Index de Amato, que supone un cambio de paradigma por la convicción y los argumentos con que defendió la postura de la identidad entre ambas especies.

\section{Palabras clave:}

Humanismo médico; mal francés; sífilis; guayaco; ébano; plantas del nuevo mundo; Amato Lusitano.

1 Trabajo realizado en el ámbito del proyecto de I+D "Dioscórides e o Humanismo Português: os Comentários de Amato Lusitano" (http://amatolusitano.web.ua.pt) del Centro de Línguas, Literaturas e Culturas de la Universidad de Aveiro, financiado por Fondos FEDER a través del Programa Operacional Factores de Competitividade - COMPETE y por Fondos Nacionales a través de la FCT - Fundação para a Ciência e a Tecnologia, en el ámbito do proyecto FCOMP-01-0124-FEDER-009102.

2 Centro de Línguas, Literaturas e Culturas da Universidade de Aveiro: cmm@ua.pt. 


\begin{abstract}
:
In this article we explore how the Index Dioscoridis, the first commentary by Amatus Lusitanus on Dioscorides' work on materia medica, contributes to the confusion between guaiac and ebony which, as is well known, was produced at the beginning of $16^{\text {th }}$ century. To do this, we first endeavour to explore how the French disease appears, to conclude that the novelty of the disease demanded, in like measure, an equally novel treatment, in this case the application of guaiac, from the so-called West Indies. Although information on plants was arriving from the new world, the unavailability of guaiac and, what is more surprising, the apparent lack of knowledge about ebony, but for the descriptions provided by ancient authors, allowed for a confusion which was further intensified by economic issues (the control of the guaiac market by a few families) and the characteristics of natural history in the Renaissance. We then analyze some texts that allow us to understand the evolution of the comparison between guaiac and ebony, step by step, in order to arrive at the Index of Amato, which represents a radical paradigm shift due to his convictions and to the arguments with which he defends the position of the identity of the two species.
\end{abstract}

\title{
KEYWORDS:
}

Medical Humanism; French disease; syphilis; guaiac; ebony; plants from de new world; Amatus Lusitanus. 


\section{LA APARICIÓN DEL MAL FRANCÉS}

En la última década del s. xv proliferan las descripciones de una enfermedad que casi todos, tanto los expertos como el público en general, consideran nueva. Los testimonios de que disponemos sitúan la primera aparición de este mal en el año 1494, y muy probablemente en el entorno de Nápoles, en el momento en que esta ciudad se hallaba asediada por las tropas del monarca francés Carlos VIII, al inicio de lo que después se conoció como Guerras Italianas. Que la enfermedad, rápidamente extendida por todo el mundo, fuese catalogada como 'nueva' suponía un serio problema para el estamento médico. Los médicos, a diferencia de empíricos, cirujanos, barberos y otros sanadores sin estudios teóricos, basaban su prestigio en unos conocimientos heredados de la antigüedad y recientemente purgados del oscurantismo medieval por el movimiento humanista (al menos, esta era la imagen que interesaba transmitir); este conocimiento y el manejo de vocabulario y conceptos complejos, como las teorías galénicas de los temperamentos, garantizaban el control en exclusiva de los complicados y caros procedimientos terapéuticos que se debían aplicar en determinadas enfermedades. Sin embargo, a despecho de algunas voces disonantes que reclamaron que la enfermedad ya era conocida desde la Antigüedad grecolatina, lo cierto es que la mayor parte de los primeros textos pregonaba la novedad de la misma. Así, por ejemplo, en septiembre de 1496, Piero di Marco Parenti, en el segundo tomo de sus Istorie Fiorentini, dice "Non sarà inconueniente far memoria della nuoua malattia uenuta in Italia a questi tempi, chiamata rogna franciosa la quale in tutte le parti del mondo si distese."3 Segismundo Titio, en el tomo VI (p. 439 sub anno 1497) de sus Historiarum Senensium ab initio Urbis Senarum usque ad annum 1528, afirma: "Advenere praeterea hoc anno 1497 novi ac insoliti hominibus morbi pustulis primum in facie, modo vero in toto corpore... (...) Quem egritudinem aevo nostro amplius non visam, ex adventu Gallorum morbum gallicum appellant." 4

Se podrían multiplicar los ejemplos de este tipo de afirmaciones, pero nos fijaremos tan solo en otros dos textos que demuestran que la novedad estaba muy relacionada con la falta de reconocimiento por parte de los médicos. El hecho de no identificar una enfermedad anulaba

3 Fuente de inapreciable valor para estudiar los primeros testimonios sobre el mal francés es la obra de Alfonso CORRADI, Nuovi documenti per la storia delle malattie veneree in Italia dalla fine del Quatrocento alla metà del Cinquecento. Milano, Tipografia Fratelli Rechiedei, 1884. En ella se encuentra un buen número de documentos inéditos y publicados sobre esta temática. Aunque con posterioridad a la obra de Corradi se han publicado algunos de los inéditos, esta sigue siendo imprescindible para una aproximación a las primeras reacciones ante el mal francés. La obra de Parenti estaba inédita entonces, aunque en la actualidad ha sido publicada por Andrea Matucci (Piero di Marco PARENTI, Storia fiorentina, I, 1476-1478, 1492-1496, a cura di A. MatuccI. Firenze, Leo S. Olschki Editore, 1994; Piero di Marco ParentI, Storia fiorentina, II, 1496-1502, a cura di A. MATUCCI. Firenze, Leo S. Olschki Editore, 2005). La cita está tomada de Alfonso CorRADI, Nuovi documenti..., op. cit., p. 56. La cursiva es nuestra.

4 Ibidem. 
por completo la competencia del médico, ya que su saber estaba directamente vinculado a la aplicación de remedios específicos adecuados para un tipo particular de dolencia. El desconocimiento provoca la falta de esperanza en la cura y, por lo tanto, un agravamiento de índole psicosomático en la condición del paciente, aparte de un sentimiento alarmista en la sociedad en general. El primero de estos textos, escrito en 1501, es de Nadi Gaspare, de su Libro per tenere Ricordo dal 1418 al 1501: "Rechordo, chome uenne uno Morbo a Bologna, e per el quale ueniua alle persone una malatia doglie in le chonzeture e bole per adosso portauano una grandissima passion specialmente la notte, cridauano che iera (era) una gran passion, non se trouaua medise (medico) che lo conoscesse, se chiamaua male franzoso comezò dell'anno 1495, e ancora iera dell'anno 1496 e dell'anno 1497." 5 El segundo, de Friano degli Ubaldini, lo extrajo Corradi de la Cronaca dalla creazione del mondo fino all'anno di N. S. 1513, nella quale non lascia di scrivere tutta l'istoria della sua Patria, T. III dall'anno 1492 fino a tutto il 1513, p.717, y en él se puede leer lo siguiente: "Esendo uenuto el Re Charlo de Franza in Italia chome e dito per andare a piare el Reamo de napuli chomenzo auenire aliomeni e ale done una strania et oribile malatia la quale non era archognessuta (riconosciuta) da medico alchuno e le persone dezevano che li franzoxi aueano portado la dicta malatia in italia e fuli posto nomo male franzoxo." La idea de que le enfermedad era totalmente nueva y, por ende, incurable (al no poderse encontrar un remedio apropiado) se encuentra en muchos otros textos. Pero vale la pena mencionar dos textos literarios espańoles, escritos por estudiosos de la medicina, que se hacen eco de esta idea. El primero, de 1498, es de Francisco López de Villalobos, quien, en la tercera estrofa de su Sobre las contagiosas y malditas buvas estoria y melecina, poema incorporado a su Sumario de la medicina en romance trovado con un tratado sobre las pestiferas bubas por el licenciado Villalobos, estudiante en el estudio de Salamanca hecho a contemplación del muy magnifico y ilustre señor el marques de Astorga, publicado en Salamanca, dice:

\footnotetext{
Fue una pestilencia no vista jamas

en metro ni en prosa ni en sciencia ni estoria

muy mala y perversa y cruel sin compas

muy contagiosa y muy suzia en demas

muy brava y con quien no se alcanza vitoria

la qual hace al hombre indispuesto y gibado

la qual en mancar y doler tiene extremos

la qual escurece el color aclarado
}

\footnotetext{
5 Alfonso CoRRADI, Nuovi documenti..., op. cit., pp. 58-59. El autor informa que recoge el texto de un manuscrito de la Biblioteca de la Universidad de Bolonia. Las cursivas que no están entre paréntesis son nuestras.

6 Alfonso CorRADI, Nuovi documenti..., op. cit., p. 59.
} 
es muy gran vellaca y asi á comenzado

por el mas vellaco lugar que tenemos ${ }^{7}$

El segundo es de Francisco Delgado, quien, en su Lozana Andaluza, obra publicada en Venecia en $1528^{8}$, indica en un diálogo la poca confianza que tiene el pueblo en poder sanar de esta dolencia:

COR. ¿Qué podria decir como ignorante?

LOZ. Di que sanarás el mal frances, y te judicarán por loco del todo, que ésta es la mayor locura que uno puede decir. ${ }^{9}$

Los médicos, evidentemente, no podían aceptar sin más la novedad del mal, lo que hubiera significado, como se deduce claramente de los textos, la imposibilidad de tratarlo. De hecho, el debate que se originó en un principio, y que fue el motivo principal de la llamada "disputa de Ferrara" 10 , fue determinar si lo que empezaba a ser conocido principalmente bajo la denominación de 'mal francés' se correspondía en realidad con alguna enfermedad antigua ya conocida o si, por el contrario, había surgido como algo totalmente nuevo. Las conjeturas sobre su procedencia y, desde luego, la teoría del origen americano, solo vendrían posteriormente, cuando se acabe por imponer la tesis de su novedad ${ }^{11}$.

7 Extraido de Anastasio CHINCHILLA, Anales históricos de la medicina en general y biográfico-bibliográficos de la española en particular, Tomo I. Valencia, Imprenta de López y Compañía, 1841, p. 105-106. He corregido el final del tercer verso, donde aparece copas por evidente errata, ya que incluso impide la rima. Existe una edición moderna de María Teresa Herrera, publicada en Salamanca en 1973. Chinchilla transcribe todo el poema entre las páginas 105 y 126.

8 En el finis el autor fecha la conclusión de la obra en 1524, pero los certeros vaticinios de acontecimientos de 1527 sugieren más de una redacción. Cf. Tatiana BuBnova, "Delicado en la Peña de Martos", en Jules WHICKER, Actas del XII Congreso de la Asociación Internacional de Hispanistas 21-26 de agosto de 1995, Vol. 2: Estudios áureos I. Birmingham, University of Birmingham, 1998, pp. 70-78.

Disponible en http://cvc.cervantes.es/literatura/aih/pdf/12/aih_12_2_011.pdf.

9 Mamotreto 55. Cito por Francisco DeLGADo, Retrato de la lozana andaluza. Madrid, Imprenta y Estereotipia de M. Rivadeneyra, 1871, p. 280.

10 Como demostró Jon Arrizabalaga, "Sebastiano dall'Aquila (c. 1440 - c. 1510), el 'mal francés' y la 'disputa de Ferrara' (1497)", DYNAMIS. Acta Hispanica ad Medicinae Scientiarumque Historiam Illustrandam 14 (1994), pp. 227-247, esta disputa se realizó de forma física, es decir, como una reunión y no como un intercambio de escritos, tuvo lugar en alguna de las dependencias de la corte de los duques de Este, en lugar de las tradicionales reuniones en un Studium generale dentro del ámbito académico, y tuvo como esencial propósito debatir si el mal francés que asolaba la ciudad podía ser identificado, como algunos decían, con la elefantiasis.

11 Cf. Jon Arrizabalaga, John Henderson \& Roger French, The Great Pox. The French Disease in Renaissance Europe. New Haven and London, Yale University Press, 1997, pp. 24-25. 
De hecho, Villalobos y Delgado muestran posiciones diferentes. El primero, en su calidad de médico, afirma la novedad solo de forma aparente, pues más adelante en su tratado, en la estrofa 27 , acaba por identificar la enfermedad con otra antigua, la sarna egipcia: ${ }^{12}$

\footnotetext{
Y pues tan probado esta mi propuesto no quiero altercar mas en esta escritura y de aqueste morbo questa presupuesto agora sea puesto en scabie o no puesto el nombre dire y la passion y la cura aquesta segun mi razon corta y flaca que alos que pecaron tan crudo condena debemos nombrarla la sarna egipciaca que asi es tan perversa y vellaca enbiada de Dios por castigo y por pena. ${ }^{13}$
}

De ese modo puede, a continuación, recomendar las recetas y los cuidados que se han de tener para mejorar en esta enfermedad. En cambio, el práctico (médico empírico) Delgado, no tiene necesidad de identificarla con otra. Lo que hace es proponer en su obra, por un lado, remedios caseros y, por otro, el tratamiento a base de leńo santo o guayaco ${ }^{14}$, cosa que le interesa, por haber sido probablemente uno de los primeros que lo introdujo en Italia y por ser autor de un opúsculo sobre el tratamiento del mal francés por medio de ese producto americano. ${ }^{15}$

En realidad, una de las características más notorias de este mal, la profusión de nombres con que se lo conoce, deriva en parte de esta controversia inicial y del intento de identificarlo con otras enfermedades conocidas, lo que llevó a términos como elephantiasis, lichen, mentagra carbonem o ignem persicum. Pero incluso aquellos que veían en ella una enfermedad totalmente nueva multiplicaron los intentos de nombrarla, en parte para evitar el término que se había extendido de forma vulgar, mal francés, puesto que suponía una comprensible ofensa para los

12 Por cierto, el mencionado Segismundo Titio afirma que el mal francés es diferente y peor que la piaga egiziaca y que la mentagra di Plinio. Cf. Alfonso CoRRADI, Nuovi documenti..., op. cit., p. 57.

13 Anastasio ChINCHILLA, Anales históricos..., op. cit., pp. 112-113.

14 Cf. Ma Cruz Herrero Ingelmo; Enrique Montero Cartelle, "El Morbus gallicus o Mal francés en La Lozana andaluza de Francisco Delicado", Asclepio 65, 2 (julio-diciembre 2013), p021. http://dx.doi. org/10.3989/asclepio.2013.21. De hecho, el texto completo de la intervención de la lozana andaluza que hemos transcrito anteriormente, es el siguiente: "Di que sanarás el mal frances, y te judicarán por loco del todo, que ésta es la mayor locura que uno puede decir, salvo que el legño es salutífero."

15 El modo de adoperare el legno de India Occidentale. Salutífero remedio a ogni piaga et mal incurabile, Roma 1525. Hemos consultado la edición de Bruno M. DAMIANI, "Francisco Delicado El modo de adoperare el legno de India Occidentale. A critical transcription", Revista Hispánica Moderna 36, no 4 (1970/1971), pp. 251-271. 
franceses ${ }^{16}$. Esta búsqueda de un término neutro originó las denominaciones más variopintas, ya se decantasen por hacer referencia a una enfermedad con que se pareciera (como crassiora variola), ya por mencionar una parte del cuerpo (como mentulagra o inguinagra), ya por alguna característica de su contagio (como mal de siment) ${ }^{17}$, ya por el supuesto origen astrológico (como saturninum morbum), etc. ${ }^{18}$

El nombre más curioso fue, con toda probabilidad, el que le atribuyó el médico, filósofo y filólogo Girolamo Fracastoro, sifflis, que fue el que a la postre acabaría por triunfar ${ }^{19}$. Pero para ello tendrían que pasar siglos, pues esta designación no se empezó a usar hasta bien entrado el siglo Xviri. En cualquier caso, es necesario emplear esta terminología con cautela cuando se habla de la historia de una enfermedad pues, tal como alertan los autores Arrizabalaga, Henderson y French ${ }^{20}$, no se puede decir que la sífilis actual sea la misma enfermedad que el mal francés. Una enfermedad es un concepto abstracto fruto del cruce de varios elementos (formas de contagio, posible parásito -en caso de las enfermedades infecciosas-, etiología, síntomas, pacientes...). La medicina actual aplica unos criterios de definición que no son idénticos a los de épocas anteriores y, por lo tanto, a lo más que podemos aspirar es a estudiar el concepto de sífilis y no la enfermedad en sí $^{21}$.

16 Hutten, por ejemplo, siente la necesidad de disculparse por utilizar ese nombre en aras de la claridad: Ulrich von HUTTEN, De guaiaci medicina et morbo Gallico liber unus. [Parisiis], Ex typis Petri Vidoue, 1519, fol. aiii (De morbi Gallici ortu et nomine Caput I): "nos hoc opusculo Gallicum dicemus, non inuidia quidem gentis clarissimae et qua uix alia sit hoc tempore ciuilior aut hospitalior, sed ueriti ne non satis intelligant omnes, si quolibet alio nomine rem signemus."

17 Aunque en este caso es dudoso que se refiera a simiente. Para una sólida justificación de que se podría estar haciendo referencia a un santo bretón, saint-Méen-le-Grand, ver Germán Colón DOMÉNECH, "Filología y sífilis. Sobre el mal de simiente o mal de sement", Revista de Filología Española $78,3^{\circ}-4^{\circ}$ (julio-diciembre de 1998), pp. 275-308.

18 Para hacerse una idea de la multiplicidad de nombres usados para designar esta afección, se puede ver, por ejemplo, el texto reciente de Danielle GOUREVITCH, "La syphilis, une maladie aux noms multiples" en Jerôme FrACASTOR, La syphilis ou le mal français. Syphilis sive Morbus Gallicus, Texte établi, traduit, présenté et annoté sous la direction de Jacqueline Vons, avec la collaboration de Concetta PenNuto et Danielle Gourevitch et le concours du Dr. Jacques Chevallier. Paris, Les Belles Lettres, 2011, pp. XV-XXXVII. Aunque sea más antiguo, parece más claro en su exposición el artículo de Ma Jesús PÉrEZ IBÁÑEZ, "Un problema médico y terminológico (sífilis en el s. XVI)", Voces 6 (1995), pp. 61-79. La misma autora trabaja sobre un término eufemístico en "Galli vocant istum morbum morbum eius cuius est. Otra designación para el 'mal francés'", Asclepio. Revista de Historia de la Medicina y de la Ciencia $40-n^{\circ} 1$ (enero-junio 2008), pp. 267-280. Un estudio también reciente es el de Antonio TAGARELLI, Giuseppe TAGarelli, Paolo Lagonia, Anna PIRo, "A Brief History of Syphilis by Its Synonyms", Acta Dermatovenerol Croat 19- 4 (2011), pp. 228-236, aunque no introduce algunas conclusiones de Pérez Ibáñez.

19 Hieronymus Fracastorius, Syphilis siue Morbus Gallicus. Verona [Stefano Nicolini da Sabbio e fratelli] 1530. La edición con traducción más reciente es la citada Jerôme FRACASTOR, La syphilis ou le mal français.

20 Jon Arrizabalaga, John Henderson \& Roger French, The Great Pox..., op. cit., pp. 1-3.

21 Jon Arrizabalaga, "Syphilis", The Cambridge World History of Human Disease. $1^{\text {st }}$ ed. Cambridge, Cambridge University Press, 1993, pp. 1025-1033. Cambridge Histories Online. Accedido el 14 de marzo de 2013. http://dx.doi.org/10.1017/CHOL9780521332866, maxime p. 1029. 


\section{LOS TRATAMIENTOS DE LA ENFERMEDAD}

No aceptar la novedad de la dolencia, como decíamos, facilitaba la posibilidad de tratarla, pues al identificarla con otra se podían prescribir los mismos remedios transmitidos por la tradición. Es el caso de Gaspar Torrella y Pere Pintor, médicos valencianos en la corte de Alejandro VI. Jon Arrizabalaga ${ }^{22}$ demostró que ambos, a raíz de su identificación con diferentes enfermedades (una especie de aluhumata o viruela corruptiva en el caso de Pere Pintor, sarna — scabies - para Torrella), consideraron diferentes modos de contagio y aplicaron tratamientos diferenciados. Cuando, poco a poco, se empezó a hacer evidente que el llamado 'mal francés' no podía ser asimilado con propiedad a ninguna de las enfermedades de que se tenía constancia en la historia de la medicina, también los médicos de prestigio anunciaron su carácter novedoso. Por poner un ejemplo que contrasta claramente con los médicos valencianos Torrella y Pintor, unos años más tarde otro médico de la corte papal, en este caso médico personal del papa Julio II, Giovanni de Vigo, quien introduce unos comentarios sobre el mal francés en su Practica in arte chirurgica copiosa continens nouem libros (Romae, per S. Guillireti et H. Bononiensem, 1514), afirma: "Et propterea sicut ista aegritudo est incognita et nunquam a doctoribus uisa prout nunc est" Por ese motivo, tiene que declarar más adelante que para su curación fue necesario investigar métodos terapéuticos nuevos, y que si alguna cosa trajo provecho fue más a raíz de nuevos experimentos que de antiguos remedios: "Ideo pro eius curatione operae precium fuit noua auxilia et pharmaca indagare. Et in rei ueritate, si quid salutis inuentum fuerit in isto morbo, fuit id potius ex nouis experimentis, quam ex antiquis auxilijs." Un poco más adelante anunciará ese nuevo método, producto de los recientes experimentos. Junto a complejos brebajes y regímenes especiales transmitidos por la tradición, se puede sanar a partir de una simple untura reforzada con un poco de mercurio ("ex simplici unctione cum modico argenti uiui roborata") ${ }^{24}$.

Este caso específico nos sirve de ejemplo de aquello que se dio en general en todo el ambiente médico de la época a la hora de enfrentarse al mal francés. A unos primeros tratamientos basados en las recetas tradicionales (sangrías, baños de vino y hierbas o de aceite, regímenes, cauterización, estufas de calor, emplastos y diversos brebajes) se siguió, como remedio más específico, el tratamiento por mercurio, normalmente en unciones ${ }^{25}$. En realidad, el mercurio

22 Jon ArrizabalaGa, "Práctica y teoría en la medicina universitaria de finales del siglo xv: el tratamiento del mal francés en la corte papal de Alejandro VI Borgia", Arbor 153, n 604-605 (Abril-Mayo 1996), pp. 127-160.

23 Giovanni de Vico, De morbo gallico en Luisinus, 1566, vol. I, p. 387. Cito por la edición de Aloysius LUISINUS, De morbo gallico omnia quae extant apud omnes medicos cuiusque nationis, tomus prior. Venetiis, apud lordanum Zilettum, 1566.

24 Ibidem.

25 Se puede ver un buen resumen de estos tratamientos en Jon ARRIZABALAGA, John Henderson \& Roger FRENCH, The Great Pox..., op. cit., pp. 28-32 y después, centrado en la corte papal pero con mucho mayor detalle, en 131-142. 
era un tratamiento ya usado para enfermedades que producían llagas en la piel, como la sarna, y gozaba de tradición galénica, por lo que en realidad se trataba de la aplicación de un tratamiento antiguo por aproximación, por la semejanza entre los síntomas externos de las dolencias.

Como en un principio parecía el único remedio que surtía algún efecto, pronto se convirtió en el tratamiento por antonomasia contra el mal francés ${ }^{26}$, para suplicio de los enfermos, pues los terribles dolores que causaba, la hediondez del aliento, la pérdida de dientes, eran un castigo tan terrible que muchos afirmaban que preferían morir por el mal francés que vivir con el mercurio. Además, como notaron muchos médicos ${ }^{27}$, la enfermedad había cambiado durante las primeras dos décadas, y ya no era tan mortal. Sirvan de ejemplo estas palabras de Fracastoro, escritas en 1546:

\begin{abstract}
Abinde enim annis fere viginti coeperunt pauciores videri pustulae, gummositates vero plures, quum e contrario primis annis fuisset, factae item fuere pustulae (si quae apparebant) sicciores, ac dolores (si qui accedebant) cuivis sunt acerbiores. Porro et annis labentibus, annis iam fere sex in quibus nunc sumus, magna rursus mutatio facta est eius morbi; quippe quum in valde paucis pustulae iam visantur, et dolores fere nulli, aut multo leviores, gummositates vero multae, et, quod mirum omnibus visum est, capillorum, et reliquorum pilorum casus homines fere ridiculos facit, aliis sine barba, aliis sine superciliis, aliis glabro capite in conspectum venientibus, quod infortunium prius putabatur ex medicaminibus evenire, praesertim ex argento vivo. ${ }^{28}$
\end{abstract}

Pues desde hace unos veinte años se han empezado a ver menos pústulas, pero mayor número de gomas, mientras que sucedía al contrario en los primeros años: es decir, que las pústulas que se formaban (si es que aparecían algunas) eran más secas, y los dolores, si se daban, eran en cada caso más agudos. Pero sucede que con el paso de los años, más o menos en los últimos seis, se ha producido de nuevo un gran cambio en esta enfermedad. En efecto, ya se ven muy pocas pústulas y no hay casi ningún dolor

26 Lo seguía siendo a principios del siglo xx, antes de que el bacteriólogo alemán Paul Ehrlich descubriera, en 1910, el modo de acabar con la espiroqueta causante de la sífilis. En algunos carteles americanos de propaganda para evitar el contagio (los soldados americanos fueron los más afectados por esta enfermedad infecciosa durante la Primera Guerra Mundial) se podía leer la frase que aún suena en los tratados sobre la sífilis: "one night with Venus, a lifetime with Mercury."

27 Cf. John Henderson, "Fracastoro, il legno santo e la cura del 'mal francese'", en Alessandro Pastore e Enrico Peruzzi (eds.), Girolamo Fracastoro. Fra medicina, filosofia e scienze della natura. Atti del Convegno internazionale di studi in occasione del 450 anniversario della morte. Verona-Padova 9-11 ottobre 2003. Firenze, Leo S. Olschki, 2006, pp. 73-89, maxime 75-79.

28 Hieronymus Fracastorius, De contagione et contagiosis morbis et eorum curatione, libri III. Translation and notes by Wilmer Cave WrIGHT, Ph.D.. New York-London, G. P. Putnam's Sons, 1930, pp. 138-140. Hemos alterado las grafías ' $j$ ' por ' $i$ '. 
o este es muy leve; en cambio hay muchas gomas y, lo que a todos maravilla, la caída del cabello y de los restantes pelos torna a los hombres casi ridículos, llegándose a ver a unos sin barba, a otros sin cejas y a otros con la cabeza pelada, desgracia que antes se creía que derivaba de los tratamientos, especialmente del mercurio. ${ }^{29}$

Ante los graves daños que producía el mercurio en el organismo y los terribles padecimientos que tenían que soportar los que a tal cura se sometían, no es de admirar que la llegada de un nuevo producto que presuntamente curaba la enfermedad sin los dañinos efectos de la plata viva tuviese una aceptación prácticamente inmediata. El nuevo producto venía de las Indias occidentales; se trataba del guayaco, guayacán, palo santo o palo índico.

\section{EL GUAYACO}

Contrariamente a lo que sucedió con otros productos americanos, la difusión del guayaco fue inmediata. Se calcula, sin ninguna precisión, que su uso se extendió por España y Portugal entre 1506 y $1516^{30}$. Como bien indicaron Pardo Tomás y López Terrada ${ }^{31}$, ninguno de los investigadores que han estudiado la aparición del guayaco en el panorama médico del s. XVI y su difusión posterior parece haber dado importancia a esta ausencia de datos, lo que no deja de ser curioso, pues se trata de un asunto que merecería mayor atención. Los primeros textos de que disponemos ya indican que su uso es conocido, al menos en la península Ibérica, por lo que algunos de ellos no se explayan en una explicación que resultaría superflua al lector.

Tenemos noticia de que en 1516 o 1517 el obispo y canciller imperial de Maximiliano I Matthäus Lang, ya designado cardenal aunque aún no en posesión de su cargo, envió una comisión de médicos a Espańa y Portugal, con el objetivo de estudiar un nuevo producto de las Indias occidentales que estaba siendo empleado con bastante éxito contra el mal francés en los territorios peninsulares ${ }^{32}$. Es muy probable que, de entre los textos que tenemos, el más antiguo

29 Todas las traducciones que presentamos en el presente trabajo son de nuestra autoría.

30 Cf. Robert S. Munger, "Guaiacum, the Holy Wood of the New World", Journal of the History of Medicine and allied Sciences 4 (1949), pp. 196-229, maxime 197. Agradezco aquí la amabilidad de Jon Arrizabalaga, del CSIC de Barcelona, quien me hizo llegar copia de este artículo.

31 José PARDO TOMÁs y María Luz LóPEZ TERRADA, Las primeras noticias sobre plantas americanas en las relaciones de viajes y crónicas de Indias (1493-1553). Cuadernos valencianos de Historia de la medicina y de la ciencia XL. Serie A (monografías). Valencia, Instituto de Estudios Documentales e Históricos sobre la Ciencia, 1993, p. 222.

32 Cf. Munguer, "Guaiacum, the Holy Wood...", op. cit., p. 197; José María López PIÑero y María Luz López TERRADA, La influencia española en la introducción en Europa de las plantas americanas (1493-1623). Cuadernos valencianos de Historia de la medicina y de la ciencia LIII. Serie A (monografías). Valencia, Instituto de Estudios Documentales e Históricos sobre la Ciencia, 1997, p. 27. Disponible en http:// 
sea el del doctor Nikolaus Poll, físico imperial, (De cura morbi gallici per lignum guaiacum libellus), editado en 1535 pero escrito muy posiblemente en 1517. En su inicio nos da cuenta de la embajada de la que hemos hablado:

\begin{abstract}
Incipit modus curandi Alemanorum corpora morbo Gallico infecta cum ligno quodam Indico guycanum appellato secundum varias atque diversas receptarum descriptiones quas reverendissima et illustrissima Sua Dignitas ex diversis Hyspaniarum locis, ubi talem curam expertam habent, non parvis impensis neque sine magnatum ibidem favoribus singularibus ad nos usque etiam pro sua tuenda valitudine proferri procuravit, extractus per Nicolaum Pollucem, medicine professorem sacre Caesaris Maiestatis physicum. ${ }^{33}$
\end{abstract}

Comienza el modo de curar los cuerpos de los alemanes infectados por el mal francés por medio de cierto leño índico llamado guycano, según varias y diversas descripciones de recetas que Su Reverendísima e Ilustrísima Dignidad ha hecho que lleguen a nuestras manos, también para protección de su salud, procedentes de diversos lugares de las Españas donde tienen experiencia en tal remedio, con gastos no pequeños y no sin favores particulares de los grandes de allí, extraído por Nikolaus Poll, profesor de medicina y físico de la Sagrada Majestad del Emperador.

Aunque el texto de Nikolaus Poll haya sido probablemente el primero que se escribió de los que aún conservamos, la primera noticia publicada ${ }^{34}$ podría ser una receta titulada Eyn bewert Recept wie man das holtz Guagacan fur die kranckheyt Frantzosen brauchen sol etcetera. Se trata de un texto breve, pues la receta se indica en cinco páginas, especificando cómo se debe preparar y en qué momentos hay que beber la decocción de guayaco. Hubo dos ediciones, una en Ausburg y otra en Nuremnberg. En la de Nuremberg (Nürnberg, Hieronymus Höltzel, 1518), al principio del documento se indica la fecha de 24 de diciembre de $1518^{35}$, pero la de Ausburg es de 1 de diciembre, lo que hace a este texto anterior al que, el 17 de diciembre de ese mismo ańo, publicó el físico de Salzburgo Leonard Schmaus ${ }^{36}$, donde afirma que reunió diecinueve informes

digital.csic.es/bitstream/10261/88589/1/P_AMER_completo.pdf, accedido el 19-11-2013; PARDO TOMÁs y López TERRADA, Las primeras noticias..., op. cit., p. 221.

33 Max Harold FISCH and Dorothy May SCHullian, Nicolaus Pol doctor 1494: with a critical text of his guaiac tract. New York, Herbert Reichner for Cleveland Medical Library Association, 1947, p. 56.

34 Al menos, es la opinión de Munguer, "Guaiacum, the Holy Wood...", op. cit., p. 198 y de López PIÑERo y López TERrAda, La influencia española..., op. cit, p. 27.

35 La Biblioteca Digital de Múnich pone a disposición de los investigadores un ejemplar en la página http://daten.digitale-sammlungen.de/bsb00083987/image_1, en la que he realizado mis consultas.

36 Esta es la fecha que se indica al final del texto, donde después del fin, escrito en griego ( $\tau \varepsilon \lambda$ oo), se dice: In officina Sigismundi Grimm medicine doctoris atque Marci Wyrsung Auguste Vindelicorum anno etc. 
y estudios sobre el guayaco que le habían mandado algunos príncipes y señores de Alemania. En opinión de López Piñero y López Terrada ${ }^{37}$, Schamus confunde los territorios americanos con los territorios de las Indias orientales, error nada fuera de lo corriente en esta época, pues afirma haber recibido informes ex India et Portugalia. Nosotros no estamos tan seguros de ello, pues anteriormente dice de forma clara: de ligno quodam in occidentali India in insula Spagnola nouiter reperta. ${ }^{38}$ No sería imposible que lo que estuviese queriendo decir Schmaus es que los informes (y no el guayaco, que viene de las Indias occidentales) los recibieron desde Portugal y las Indias, y no desde España. Aunque este asunto merece mayor atención, puede ser que los primeros textos sobre el uso del guayaco hayan estado deliberadamente envueltos en un halo de misterio y sigilo para transmitir la idea de que se trataba de recetas secretas y de este modo potenciar su venta. Incluso antes de que los ricos banqueros Fugger controlasen gran parte del mercado de guayaco ${ }^{39}$, era de interés de mercaderes y de médicos conseguir que la preparación de este producto se hiciese según unas recetas médicas complejas, al estilo galénico de las medicinas tradicionales. En efecto, si se aceptase de modo natural que el guayaco producía una mejora del sufrimiento causado por el mal francés, o incluso su completa curación, como algunos afirmaban, mediante cualquier tipo de preparación, los médicos perderían buena parte de su credibilidad y de sus clientes, ya que cualquier particular podría comprar el producto y aplicárselo. Por otro lado, si los médicos publicasen y divulgasen la información de que el guayaco no producía ningún efecto práctico en los pacientes, los mercaderes podrían perder el lucrativo negocio que suponía la venta de un producto bastante caro, por su procedencia americana. Por lo tanto, era de interés común aceptar y hacer pública la información de que el guayaco funcionaba, pero solo si se consumía preparado de forma preceptiva, es decir, según el modo indicado por expertos médicos, al estilo de las complejas recetas para la preparación de otros productos medicinales. ${ }^{40}$

El espaldarazo definitivo al guayaco lo dio el humanista Ulrich von Hutten, con su obra De guaiaci medicina et morbo Gallico liber unus. ${ }^{41} \mathrm{Su}$ prestigio como humanista reconocido

MDXVIII, die vero XVII Decembris. Cf. Leonard Schmaus, Lucubratiuncula de morbo Gallico et cura eius nouiter reperta cum ligno Indico Leonardi Schmaus medicine professoris. Augsburg, Grimm \& Wirsung, 1518.

37 Op. cit., p. 27.

38 Schmaus, Lucubratiuncula, fol. $1 \mathrm{v}$.

39 Pero sin tener propiamente un monopolio, como muchas veces se ha dicho. Cf. Mark HäBERLEIN, The Fuggers of Augsburg. Pursuing Wealth and Honor in Renaissance Germany. Charlottesville \& London, University of Virginia Press, 2012 (= Die Fugger: Geschichte einer Augsburger Familie, 1367-1650. Stuttgart, W. Kohlhammer $\mathrm{GmbH}, 2006)$, p. 82, y la bibliografía allí citada en nota 23.

40 Cf. Jon Arrizabalaga, John Henderson \& Roger French, The Great Pox..., op. cit., p. 102.

41 La editio princeps fue publicada en Maguncia en abril de 1919. Así se dice en la anotación del editor al final del libro: Maguntiae in Aedibus Joannis Scheffer Mense Aprili, Interregni vero Quarto. Anni M.D.xIX. Cum Privilegio Caesareo sexennii. Cf. F. F. A. PotTon, Livre du chevalier allemand Ulric de Hutten sur la maladie fançaise et sur les propriétés du bois de Gayac. Orné d'un portrait de l'auteur, précédé d'une notice 
y poeta laureado, junto a la elegancia de su latín, contribuyó enormemente al éxito de su opúsculo, que se difundió rápidamente. Hutten no era médico, sino alguien afectado por la enfermedad que hablaba de sus padecimientos en primera persona. Pero, al contrario de los médicos, él afirma que no se detendrá en cuestiones inútiles, diríamos nosotros que bizantinas, sobre el origen de la enfermedad; estas disquisiciones no llevan a ninguna parte. Su falta de esperanza en los remedios propuestos por los médicos venía de experiencia propia, pues estos experimentaron con él mezclando remedios exóticos y dándole muchos tratamientos que no sirvieron para nada. ${ }^{42}$

Hutten, en cambio, habla desde la posición de un hombre letrado con sentido común y que se ha visto personalmente afectado por este tormento. Y habla con el entusiasmo de quien se juzga curado por un nuevo fármaco milagroso. Su obra se vio pronto traducida a varias lenguas vulgares $^{43}$, especialmente alemán, inglés y francés, probablemente por influencia de la familia Fugger. Jacob Fugger, apodado El Rico, financió la coronación del emperador Carlos V en 1519, por lo que, en ese momento, era de suponer que las relaciones entre la familia de banqueros y la corona española se mantendrían durante varios años. A partir de 1521 los préstamos a esa corona serían muy elevados, cinco millones y medio de ducados entre esta fecha y 1555, lo que representaba una quinta parte del total de los préstamos recibidos por Carlos $\mathrm{V}^{44}$. Como en ese mismo año de 1521 los Fugger abrieron su 'casa del leño's5 (se la solía llamar de ese modo, Holzhaus, porque el remedio administrado era esencialmente el leño santo o guayaco), podemos suponer que ya tenían el control del producto y por lo tanto el máximo interés en que se divulgase su uso.

A partir de entonces se dio una importante controversia entre los partidarios del guayaco y los del mercurio ${ }^{46}$, animada por los escritos de Paracelso, quien escribió ocho libros sobre el mal francés recomendando el uso del mercurio (mezclándolo con otros productos, pues no ignoraba su toxicidad) y condenando el del guayaco, por parecerle inútilil ${ }^{47}$. Naturalmente, incurrió en las iras de los Fugger y del decano de la facultad de medicina de Leipzig, Heinrich Stromer,

historique sur sa vie et ses ouvrages. Lyon, Imprimerie de Louis Perrin, 1865, p. xvi. Hemos manejado la edición citada en la nota 16, del mismo año.

42 [Medici] ausi tamen sunt exotica miscere nobis et multa quae minime oportuit inculcare. Ulrich von HuTTEN, De guaiaci medicina..., op. cit., fol. b (De causis morbi huius Caput II).

43 Se puede ver un estudio bibliográfico, interesante a pesar de su antigüedad, sobre la repercusión de esta y otras obras de Hutten, en Josef BENZING, Ulrich von Hutten und seine Drucker: eine Bibliographie der Schriften Huttens im 16. Jahrhundert, mit Beiträgen von Heinrich Grimm. Wiesbaden, Otto Harrassowitz, 1956. Hay otras obras más modernas, pero se centran más en el papel de Hutten en las controversias religiosas y en el triunfo de la reforma protestante en Alemania.

44 HÄBERLEIN, The Fuggers of Augsburg..., op. cit., p. 76.

45 HÄBERLEIN, The Fuggers of Augsburg..., op. cit., p. 82.

46 En este debate se centra el estudio de Mariano CIPRIANI, "Mercurio e mercurialisti, guaiaco e guaiacofili e "fenomeno Fugger"", Rivista di Storia della Medicina 6 (1962), pp. 87-113.

47 Cf. Jon Arrizabalaga, John Henderson \& Roger French, The Great Pox..., op. cit., p. 103. 
muy vinculado a esta familia y amigo de Hutten, a quien había ayudado con asesoramiento médico en la redacción de su obra sobre el guayaco.

En cualquier caso, la extensión del uso del guayaco fue imparable. Cuando Garcia de Orta parte para la India, en 1534, entre el equipaje debía cargar algo valioso con lo que poder comerciar a su llegada; decide entonces llevar cinco quintales de guayaco. ${ }^{48}$ En la colección de Luigi Luisini de 1566, gran parte de los autores seleccionados optan por aconsejar el leño santo, y este remedio es el que aparece en primer lugar en el frontispicio, cuando se hace mención de los remedios ${ }^{49}$. En fecha tan tardía como 1613 el hospital de S. Giacomo en Roma compraba 100 libras de carbón, 60 de leña para quemar y 5.000 de leño santo ${ }^{50}$. En términos generales, el consumo de guayaco para los hospitales de incurables era elevadísimo, y estos solían tener afluencia de enfermos que no estaban normalmente internados en los períodos en que administraban las curas de leño santo ${ }^{51}$.

\section{EL GUAYACO Y EL ÉBANO}

El movimiento humanista de finales del s. XV tenía como una de sus principales aspiraciones el desarrollo de la Historia Natural, es decir, la descripción de la naturaleza. Pero esta descripción estaba encuadrada en un objetivo más amplio de recuperación de los saberes clásicos. La firme creencia de que los autores griegos y latinos formaban un marco de referencia irreprensible para el estudio de cualquier materia y de que la principal tarea de cualquier estudioso era purgar los textos de la corrupción entrañada en ellos desde la Edad Media llevó a una especie de adoración de los clásicos, por lo menos de algunos autores. La creencia de que estos autores constituían un modelo que se debía seguir sin fisuras y un criterio incuestionable para evaluar el mundo se convirtió en una verdad asumida y no en una postura que debía ser defendida. Por el contrario, lo que hubo que defender en ocasiones era la posición contraria, es decir, los momentos de

48 Garcia de ORTA, Colóquios dos simples e drogas da Índia, ed. Conde de FICALHO, 2 vols.. Lisboa, Imprensa Nacional, 1985, vol. 2, p. 260 (Colóquio 47): "Eu vim de Portugal hum anno antes, e trouxe pouca fazenda (como se acontece a muytos), entre a qual trouxe cinquo quintaes do páo chamado guaiacam." La cursiva es del texto.

49 Aloysius LuIsInUs, De morbo gallico..., op. cit. Comienza el título del frontispicio diciendo DE | MORBO GALLICO | OMNIA OVAE EXTANT | APVD OMNES MEDICOS | CVIVSCVNOVE NATIONIS, | Qui vel integris libris, vel quoquo alio modo huius affectus curationem I methodice aut empirice tradiderunt, diligenter hincinde conquisita, | sparsim inuenta, erroribus expurgata, \& in vnum I tandem hoc corpus redacta. | In quo de Ligno Indico, Salsa Perillia, Radice Chynae, Argento uiuo, I caeterisque rebus omnibus ad huius luis profligationem inuen- / tis, diffusissima tractatio habetur. La cursiva es del documento.

50 Cf. John Henderson, "Fracastoro, il legno santo...", op. cit., p. 86.

51 Cf. Jon Arrizabalaga, John Henderson \& Roger French, The Great Pox..., op. cit., pp. 145-233. 
desacuerdo con los textos clásicos ${ }^{52}$. La primera generación de humanistas médicos, la que va desde finales del siglo Xv hasta los años 30 del siglo Xvi, se preocupó sobre todo de identificar las materias médicas que habían descrito los autores antiguos, de conciliar los textos de estos cuando mostraban discrepancias ${ }^{53}$ y de edificar una medicina que estuviese de acuerdo con las enseñanzas de esos autores, especialmente Galeno y Dioscórides, sin olvidar a Plinio.

Teniendo en cuenta esta actitud, no es de extrañar que la incorporación al saber botánico de las nuevas plantas, tanto orientales, llegadas a través del comercio portugués, como occidentales, transportadas desde las Indias occidentales por los españoles, se realizase de forma deficitaria. A principios del s. XVI, cuando se dio una importante proliferación de traducciones y comentarios a la obra de Dioscórides ${ }^{54}$, los comentaristas incluyeron pocas plantas nuevas en sus listas (una de las pocas excepciones era precisamente el guayaco, muy probablemente por las razones económicas apuntadas anteriormente) y, cuando lo hacían, normalmente incurrían en importantes errores. ${ }^{55}$ Claro está que tener que respetar el riguroso catálogo dioscorídeo, con una serie bien definida de plantas, minerales y animales que tratar y en un orden de igual modo muy bien determinado por la tradición ${ }^{56}$ y al mismo tiempo incluir nuevas especies no tratadas por ningún estudioso de la antigüedad era una tarea que exigía no poco esfuerzo y mucha audacia.

Cuando los humanistas quieren tratar esas realidades venidas de nuevas tierras, a oriente u occidente, necesitan describirlas. No podemos olvidar que la preocupación principal de la historia natural del Renacimiento es la descripción ${ }^{57}$. Pero, como es inevitable partir de los propios paradigmas conceptuales cuando damos de bruces con una realidad que no se deja encasillar fácilmente en nuestras categorías mentales, cuando los humanistas encontraban nuevas materias que describir, inevitablemente buscaban un parangón con la realidad europea, y especialmente mediterránea, que conocían. En una época en que la ilustración, es decir, el dibujo, aún no ha asumido un papel preponderante, aunque el público exija cada vez más su

52 Cf. Brian W. OLGILVIE, The Science of Describing. Natural History in Renaissance Europe. Chicago and London, The Universtity of Chicago Press, 2006, pp. 11-12.

53 Brian W. OLGILVIE, The Science of Describing..., op. cit., p. 29.

54 Para comprobarlo no hay más que echar un vistazo al tamaño del artículo de Riddle dedicado a Dioscórides dentro de la colección del Catalogus Translationum et Commentariorum. Cf. John M. RIDDLE, "Dioscorides", en F. Edward Cranz (ed.), Paul Oskar Kristeller (assoc. ed.), Catalogus Translationum et Commentariorum: Mediaeval and Renaissance Latin Translations and Commentaries. Annotated Lists and Guides, Vol. IV. Washington D. C., The Catholic University of America Press, 1980, pp. 1-144.

55 Cf. José María López PIÑERo, Medicina e historia natural en la sociedad española de los siglos xVI y xVII. Valencia, Universitat de València, 2007, p. 104.

56 Sobre el orden antiguo y el nuevo orden alfabético, probablemente realizado en el s. XI por Constantino el Africano, ver John M. RIDDLE, Dioscorides..., op. cit., p. 7.

57 Son palabras de Brian W. OLGILVIE, The Science of Describing..., op. cit., p. 6: "It is no exaggeration to say that description, as both process and result, is the central concern of Renaissance natural history." 
presencia y su importancia vaya en aumento ${ }^{58}$, lo primero al describir un objeto o un ser vivo insólito es decir a qué se parece. González Bueno recuerda que Hernán Cortés llamaba mezquitas a los templos náhualt. ${ }^{59}$ Este mismo autor, cuando analiza en otro trabajo la introducción de las plantas americanas en el comentario a Dioscórides más famoso del s. Xvi, el del italiano Pietro Andrea Mattioli, explica que las va incluyendo dentro de las entradas correspondientes a las plantas dioscorídeas, aproximándolas normalmente por alguna semejanza, y confundiéndolas en ocasiones. ${ }^{60}$ En realidad, Mattioli no hacía sino seguir una tradición que se fue poco a poco instituyendo, de modo que las materias nuevas tenían que introducirse en el lugar en que lo había hecho otro comentarista anterior, de lo contrario los lectores tendrían dificultad en encontrar la entrada correspondiente a lo que querían buscar. Ahora veremos este asunto en relación al guayaco que, como dice González Bueno, se hallaba en el tratado de Mattioli en la entrada del ébano.

Si bien es cierto que los comentaristas de Dioscórides introdujeron deficientemente, de forma general, otros productos diferentes a los transmitidos por la tradición libresca, el hecho de que el caso de Amato Lusitano era algo diferente ya fue visto por el siempre perspicaz López Piñero, quien indica que el autor albicastrense supo incluir noticias de primera mano debido

58 Sobre la relevancia de las imágenes en los tratados médicos y botánicos, véase Sachiko Kusukawa, Picturing the Book of Nature. Image, Text, and Argument in Sixteenth-Century Human Anatomy and Medical Botany. Chicago, University of Chicago Press, 2012, y el artículo de Carlos de Jesus, "Amato Lusitano e a importância da ilustração botânica no século xvI. Em torno das edições lionesas das Enarrationes (1558)", en este mismo volumen.

59 Antonio González Bueno, "La flora del paraíso: recepción de las plantas americanas en la literatura científica europea del Renacimiento" en Alfredo BARATAS (ed.), Memorias de la Real Sociedad Española de Historia Natural. Tomo III. $2^{a}$ época. El libro de la Naturaleza. Madrid, Facultades de Biología y Geología - Ciudad Universitaria, 2004, pp. 5-33, maxime 10. También Oviedo compara las cabañas del poblado Thamara con mezquitas, diciendo: "Allí se halló un buhío á manera de mezquita ó casa de oraçion desta gente". Gonzalo FERNÁNDEZ DE OVIEDO, Historia general y natural de las Indias, islas y Tierra-Firme del mar Océano, editada por D. José Amador de los Ríos para la Real Academia de la Historia. Tomo primero de la segunda parte. Madrid, Imprenta de la Real Academia de la Historia, 1852, p. 277.

60 Antonio González Bueno, "El Descubrimiento de la Naturaleza del Nuevo Mundo: Las Plantas Americanas en la Europa del siglo XvI", Circumscribere. International Journal for the History of Science 2 (2007), pp. 10-25, http://revistas.pucsp.br/index.php/circumhc/article/view/569/1028, p. 18. Merece la pena transcribir el fragmento: "el guayaco pasa, sin apenas precisión, como una suerte de ébano pero al que se le reconocen virtudes antisifilíticas y sudoríferas, como a la zarzaparrilla americana, que es claramente identificada con la mediterránea, siguiendo la opinión que, años atrás, hubiera defendido Luca Ghini, profesor de la Universidad de Padua; un "piper in India nasci...", de pequeños frutos en forma de cuernos, figura junto a la pimienta y el clavo. Apenas dos líneas merecen los tomates, denominados "pomi d'oro" o "mala aurea", de frutos dorados y rojos, aproximados en éste, y confundidos en otros textos renacentistas, con las berenjenas. Algo más añade sobre unas calabazas de Indias, conocidas en la península italiana desde algún tiempo atrás, cultivadas sobre semillas de procedencia americana y de las que señala la ventaja de poder ser conservadas durante todo el invierno. También tienen su sitio los "claveles de Indias", rápidamente extendidos por los jardines europeos; y por supuesto el maíz, planta ya bien conocido en estos años centrales del siglo xvı." 
a su conocimiento de las plantas de la península Ibérica y de algunos productos ultramarinos, venidos de las Indias orientales y de América. ${ }^{61}$ António Andrade demostró recientemente que los conocimientos que João Rodrigues de Castelo Branco (más tarde conocido tan solo como Amato Lusitano) poseía sobre los productos orientales le venían no solo de su actividad como médico y de su mirada atenta, sino de los negocios familiares en los que se involucró cuando salió de Portugal rumbo a Amberes en 1534, pues formaba parte de la familia de mercaderes judíos Pires-Cohen, sobrino como era de Henrique Pires, elemento nuclear de una de las redes familiares extendidas por toda Europa dedicadas al comercio. ${ }^{62}$

Amato Lusitano publicó el primero de sus comentarios a Dioscórides, el Index Dioscoridis, ${ }^{63}$ dos años después de su llegada a Amberes. Era obra de juventud, pues el autor contaba tan solo con 25 años de edad, y por ello con bastante errores, no solo tipográficos, como el propio autor denuncia en su prólogo al lector, lo que casi lo lleva, según sus palabras, a detener su publicación, sino incluso algunos fruto de una mala comprensión de los textos de que se sirvió. Muy diferente es su comentario a Dioscórides publicado en la madurez, a los 42 años de edad, las Enarrationes. ${ }^{64}$ Ahí hace gala de la originalidad que López Piñero apunta en su revisión de los comentaristas de Dioscórides. Sin embargo, en este trabajo nos vamos a detener en su primera obra, de la que espero sacar algunas conclusiones interesantes. Dejaremos para un estudio posterior la curiosa evolución experimentada entre la publicación de una obra y la de la otra.

Cuando se habla de esta obra, no se tiene en consideración, o al menos no se da importancia al hecho de que la entrada del ébano es, con un amplio margen, la más extensa de los dos libros de Dioscórides que incluye. Bastante más extensa que, por ejemplo, la primera entrada, sobre el iris, sobredimensionada porque el autor la usa para realizar una presentación del libro y dirigirse a los lectores, dejando de hecho un espacio cuando va a empezar a hablar propiamente de la planta que le ocupa. ${ }^{65} \mathrm{La}$ del ébano comienza en la página $23 \mathrm{v}$ y acaba en la $26 \mathrm{r}$, con texto corrido, algo curioso si tenemos en cuenta que algunas páginas contienen hasta cinco entradas. Evidentemente, el motivo de esta extensión fuera de lo común para un producto que no merece la misma atención en el texto del autor griego radica en que, en realidad, la entrada

61 José María López PIÑEro, Medicina e historia natural..., op. cit., p. 98.

62 António Manuel Lopes Andrade, "Ciência, Negócio e Religião: Amato Lusitano em Antuérpia", en Inês de Ornellas CASTRO e Vanda AnASTÁcio (coord.), Revisitar os Saberes - Referências Clássicas na Cultura Portuguesa do Renascimento à Época Moderna. Lisboa, Centro de Estudos Clássicos - Faculdade de Letras da Universidade de Lisboa, 2010, pp. 9-49.

63 Amatus Lusitanus (João Rodrigues de Castelo Branco), Index Dioscoridis. Antuerpiae, excudebat Vidua Martini Caesaris, 1536.

64 AmATUS LUSITANUS, In Dioscoridis Anazarbei de medica materia libros quinque enarrationes eruditissimae. Venetiis, apud Gualterum Scotum, 1553. Para conocer las vicisitudes de las diferentes ediciones de los textos de Amato Lusitano, ver João José Alves DIAS, Amato Lusitano e a sua obra: séculos XVI exVII. Lisboa, Biblioteca Nacional de Portugal, 2011.

65 Amatus Lusitanus, Index Dioscoridis..., op. cit., p. 2 r. 
se aprovecha para hablar del guayaco. O, mejor dicho, João Rodrigues trata del ébano, que identifica plenamente con el leño santo.

Al tratar los nombres que recibió el guayaco, Munger afirma que, al principio, unos pocos escritores lo identificaban con el ébano. ${ }^{66}$ Uno de ellos fue Amato Lusitano, y con mucha mayor rotundidad en el Index, de fecha tan temprana como 1536. Las cuestiones que se nos plantean son: ¿cómo se produjo esa identificación?, ¿en quién se fijó Amato para relacionar ambos productos?, ¿qué papel juega el texto de Amato en el debate sobre el guayaco y el ébano?

En 1550 se publica en Lyon una edición de la traducción de Dioscórides de Jean Ruel (la editio princeps es de 1516, publicada en París) con comentarios añadidos, de la autoría de H. B. M. En su exhaustiva obra, Riddle, basándose en la identificación del estudioso DuPetitThouars, indica que estas iniciales se refieren posiblemente a Johannes Bruyerinus. Ignoramos si esta atribución de autoría ha sido rebatida por alguien. Sin haber comprobado su fiabilidad, hemos visto que una notación manuscrita del ejemplar de la Biblioteca Complutense indica que el autor es Huberto Barlando, médico belga que fue profesor en Lovaina. En esta obra, al final de la traducción de Ruel en la entrada del ébano, se incluye un pequeño comentario en el que se dice: Quidam guayacum ebeni speciem putant; istud nec affirmare nec negare ausim, cum a nullo veterum scriptorum praedictum sit qualia folia, flores et fructus ebenus producat. ${ }^{67}$ Podemos deducir de aquí dos cosas: que ya era común, aunque no todo el mundo lo compartía, pensar que el guayaco fuese una especie de ébano, y que este último producto ya era menos conocido que el americano, pues el autor del comentario no se atreve a manifestar su opinión por la ausencia de descripciones de las hojas, flores y fruto del ébano. Una década antes los comentaristas se quejaban de no conocer las del guayaco, porque no se enviaban desde las Indias occidentales, ya que solo interesaba el lucro de la madera (solo esta se usaba para el tratamiento del mal francés) y no el conocimiento científico.

Pero si el autor incluye esta duda en su comentario al ébano es porque otros comentaristas de Dioscórides ya lo están haciendo. En efecto, las mismas dudas vemos ya en los comentarios de Pietro Andrea Mattioli y Andrés Laguna. Mattioli introduce la siguiente consideración en su comentario al ébano:

\footnotetext{
Sunt qui lignum ex Indijs petitum, quod quidam GVAIACVM, nonnulli Guaiacanum, plerique uero Lignum sanctum appellant, cuius aduersus Gallicam luem praecipus est usus, ebeni genus esse crediderint. Quod quidem nec asserere nec negari ausim: quandoquidem
}

66 Munguer, "Guaiacum, the Holy Wood...", op. cit., p. 204.

67 [Hubertus Barlandus], Pedanii Dioscoridis Anarzabei de medicinali materia libri sex, loanne Ruellio Suessionensi interprete, cuilibet capiti additae annotationes, eruditae et compendiariae e selectiori medicorum promptuario. Lugduni, Apud Balthazarem Arnolletum, 1550, p. 105 
nusquam inuenerim apud quenquam tum ueterum, tum recentiorum scriptorum, quas frondes, quos flores, quosque fructus proferat ebenus. ${ }^{68}$

Hay quienes piensan que el leño que se trae de las Indias, que unos llaman guayaco, algunos guayacano, pero que la mayoría conoce como leño santo, y sobre todo se emplea contra la peste francesa, pertenece a la especie del ébano. Esto no me atrevería yo a afirmarlo ni a negarlo, ya que nunca he encontrado en ningún autor, ni entre los antiguos ni entre los modernos, qué hojas, flores y frutos da el ébano.

Parece clara la influencia del texto de Mattioli en Barlando. Como vemos, el humanista sienense tampoco quiere afirmar la identidad entre uno y otro. A continuación de este fragmento, Mattioli comenta pormenorizadamente las formas de preparación del guayaco, ya que era una materia de clarísimo interés para sus lectores. ${ }^{69}$

En cuanto a Andrés Laguna, ${ }^{70}$ en su comentario latino de 1554 nada dice sobre el guayaco cuando corrige algunos errores de la traducción de Ruel. ${ }^{71}$ En cambio, lo trata con profundidad en su traducción comentada de Dioscórides al español, publicada un año después. Su opinión, menos prudente que la de Mattioli, abraza sin miedo la teoría de que el guayaco es una especie de ébano:

Hallanse muchas especies del Ebano, entre las quales es una, y la mas excellente, aquel bendito y sancto madero, llamado vulgarmente Guayaco, el qual por la diuina bondad y misericordia fue communicado à los hombres. ${ }^{72}$

68 Pietro Andrea MAttıolı, Commentarii in libros sex Pedacii Dioscoridis Anazarbei de medica materia. Adiectis quam plurimis plantarum et animalium imaginibus, eodem authore. Venetiis, in officina Erasmiana, apud Vincentiu Valgrisium, 1554, p. 107

69 Mattioli ya había escrito un Morbi Gallici novum ac utilissimum opusculum, publicado en 1534 (o 1530, fecha que ha sido propuesta por algunos investigadores), que fue reeditado al año siguiente en el Liber de morbo Gallico in quo diversi celeberrimi in tale materia scribentes medicine continentur auctores. Veneza, [Giovanni Padovano \& Venturino Ruffinelli], 1535. Tras consultar esta edición, no he encontrado niguna relación con el ébano en las pocas ocasiones que Mattioli habla del guayaco.

70 Para un cabal conocimiento de las características de la obra del humanista segoviano, resulta esencial la obra de Miguel Ángel González MANJARRÉs, Andrés Laguna y el Humanismo médico. Salamanca, Junta de Castilla y León, 2000.

71 Andrés LAGUNA, Annotationes in Dioscoridem Anazarbeum, per Andream Lacunam Segobiensem Medicum Iulii III Pont[tificis] Max[imi] iuxta vetustissimorum codicum fidem elaboratae. Lugduni, Apud Gulielmum Rouillium, 1554, pp. 46-47.

72 Andrés LAGUna, Pedacio Dioscorides Anazarbeo, acerca de la materia medicinal y de los venenos mortíferos. Anvers, Casa de Juan Latino, 1555, p. 81. 
A lo cual sigue una serie de alabanzas ensalzando las virtudes de este leño milagroso y una pormenorizada descripción de su preparación, como se veía en Mattioli.

Tanto la obra de Mattioli como la de Laguna son bastante posteriores al Index de Amato, por lo que no nos sirven para resolver las cuestiones que planteábamos.

Intentaremos ahora atar los cabos que hemos ido dejando sueltos en nuestro razonamiento, para procurar comprender cómo se introdujo el guayaco en el espacio del ébano.

Decíamos antes que cuando los humanistas encontraban nuevas materias que describir, inevitablemente buscaban un parangón con la realidad europea y especialmente mediterránea que conocían o, aún mejor, con la cultura libresca de los clásicos, verdadero modelo donde se debe encajar la nueva realidad. En la que podría ser la primera descripción del guayaco escrita (no se llega a decir el nombre de la madera) ya se menciona al ébano, aunque sea de forma más o menos indirecta. Nos referimos a un texto del libro quinto de la primera década de las $D e$ orbe nouo decades de Pedro Mártir de Anglería. Debe de haber sido escrito bastante pronto, pues se calcula que Anglería empezó a escribir esa primera década hacia 1493, habiéndola finalizado en $1510 .^{73}$ Puesto que las tres primeras décadas fueron publicadas en 1516, es natural que lo que cuenta Anglería sobre cierta madera fuese conocido antes de la publicación conjunta de las ocho décadas, en 1526. Mucho más si tenemos en cuenta que gran parte de los textos de Anglería circulaban manuscritos antes de su publicación, o incluso en traducciones no autorizadas por él, como el opúsculo Libretto de tutta la navigatione de' re de Spagna de le isole et terreni nuovamente trovati, traducción al italiano de la primera década (que no coincide con la que posteriormente sería la primera, pues Anglería reunió dos décadas en una), realizada por Angelo Trivigiano y publicada mucho antes que el original latino ${ }^{74}$. El texto en cuestión al que nos referimos es el siguiente:

\footnotetext{
Itinere autem medio, in uico quod est ipsius regiae sororis gazophylacium pernoctatum est. Illius uero thesauri non aurum, non argentum, non gemmae, sed utensilia tantum resque ad humanum usum attinentia, utputa sedilia, paropsides, lances, pelues, patellae ex ligno nigerrimo, lubrico, lucido (quod hebenum eximius artium et medicinae doctor tuus Ioannes Baptista Elisius esse contendit) confectae et arte mira laboratae. ${ }^{75}$
}

73 Cf. José Torre Revello, "Pedro Mártir de Anglería y su obra De orbe nouo", Thesaurus: boletín del Instituto Caro y Cuervo 12 (1-3), pp. 133-153, maxime 150.

74 Cf. José Pardo Tomás y María Luz López Terrada, Las primeras noticias..., op. cit., p. 50.

75 La cita está tomada de Petri MARTYRIS AB ANGLERIA Mediolanensis oratoris clarissimi Ferdinandi et Helisabeth Hispaniarum quondam regum a consiliis de rebus Oceanicis et Orbe nouo decades tres (=Petrus MARTYR AB ANGLerIA, De rebus Oceanicis et Orbe nouo decades tres). Basileae, apud loannem Bebelium, 1533, p. 14 r. 
Pero se pernoctó a mitad de camino, en un poblado que es una sala de tesoro de la propia hermana regia. Pero no era oro, ni plata ni piedras preciosas lo que formaban aquel tesoro, sino tan solo utensilios y enseres de uso corriente, como por ejemplo sillas, bandejas, platos, vasijas, ensaladeras hechas de un leño negrísimo, pulido, brillante (que tu doctor en medicina y eximio cultivador de las artes Juan Bautista Elisio defiende que es ébano) y talladas con admirable industria.

Por lo tanto, teniendo en cuenta lo que hemos dicho sobre la difusión de la obra de Anglería, desde los primeros tiempos, antes de conocerse el nombre del producto descrito, los eruditos ya podían saber que había quien sostuviese la opinión de que era ébano.

Al mismo tiempo, como vimos, en los primeros tiempos tras la aparición del mal francés el debate se estableció sobre si la enfermedad era nueva o no; de los que pensaban que era nueva, algunos aceptaban que se hubiera producido espontáneamente en Europa por diversos motivos, entre los que no estaba excluido el castigo divino o la confluencia astral; otros, los menos, buscaban un origen externo, en África o Asia. La teoría del origen americano del mal francés apareció tardíamente en relación al surgimiento de la enfermedad. Es opinión de Munger ${ }^{76}$ y Cipriani ${ }^{77}$, que nosotros compartimos, que esta teoría solo ganó fuerza cuando interesaba vender el guayaco, y esto porque la teoría natural del Renacimiento era que de donde viene el mal, viene la curación. Es decir, si Dios permite, para castigar a los hombres, que surja determinada enfermedad en una zona del mundo, para compensar y premiar el esfuerzo de los hombres les concede que el medio para sanar se encuentre en el mismo sitio. Cuando el negocio del guayaco se estaba haciendo lucrativo, la convicción de que el mal francés provenía de las islas donde se producía el guayaco era un modo de reforzar su consumo. Ya en 1519, Hutten, una de las fuentes de Amato -como el propio João Rodrigues nos dice al final de la entrada del ébano y se torna evidente ante el mínimo cotejo de los textos-, había dicho que los indígenas de la isla Española padecían el mal francés de forma endémica como los europeos la viruela ${ }^{78}$, aunque esto no significase, ni se pudiese interpretar que hubiera surgido allí. Más bien al contrario, la descripción de Hutten parece sugerir que la enfermedad es diferente, no solo 'con la misma frecuencia que la viruela' sino también 'tan inconsecuente como la viruela' (en comparación con la enfermedad mortal del mal francés en Europa). Además, una prueba fehaciente de que reconocer la antigüedad de la dolencia en las Indias occidentales y pensar que el origen de este mal provenía de allí eran dos cosas distintas nos la da Schmaus quien, un año antes que Hutten, ya había indicado esa antigüedad ${ }^{79}$ para, acto

76 Munguer, "Guaiacum, the Holy Wood...", op. cit..

77 Mariano CIPRIANI, "Mercurio e mercurialisti...", op. cit..

78 Ulrich von HUtTEn, De guaiaci medicina..., op. cit., fol. biii (Guaiaci descriptio et eius inuentio ac nomen Caput VI): Ipsius Insule omnes morbo Gallico aliquando laborant accolae, quemadmodum variolis nos.

79 Leonard SchmaUs, Lucubratiuncula ... op. cit., p. aii v.: quippe compertum est iam omnibus occidentales 
seguido, exponer una larga lista de conjeturas sobre el surgimiento de la enfermedad sin que se le ocurriese la posibilidad de que viniera del continente americano.

Cuando aparecen ya referencias específicas en los textos sobre el supuesto origen americano es en 1526, en el Sumario de la natural historia de las Indias que publicó en Toledo el cronista Gonzalo Fernández de Oviedo. El capítulo 75 está dedicado al palo santo y en él se dan unas informaciones interesantes, sobre todo cuando se comparan con las que el propio Fernández de Oviedo da en otra obra posterior, la Historia general y natural de las Indias, de 1535. En el Sumario describe el palo santo o guayacán, como lo llaman los indígenas. Se detiene algo más en la descripción de aquellas partes que no se conocen en Europa, es decir, de todo lo que no es el tronco, y explica cómo lo toman los nativos, alertando de que en las Indias, por el hecho de tomar el producto recién cogido y por estar situados en una zona de diferente temperatura que España, la forma de preparación y administración no será igual, y por eso sus lectores no deben guiarse por sus explicaciones. Vemos aquí el cuidado de no entrometerse en terreno de médicos con una receta excesivamente sencilla por comparación a las recetas de los doctores en medicina. Pero una parte bastante relevante es la que se refiere al origen del mal francés:

\footnotetext{
"Puede V. Magestad tener por cierto que aquesta enfermedad vino de las Indias y es muy comun a los Indios, pero no peligrosa tanto en aquellas partes como en estas, antes muy facilmente los indios se curan en las yslas con este palo y en tierra firme con otras yeruas o cosas que ellos saben porque son muy grandes eruolarios. La primera vez que aquesta enfermedad en España se vido fue despues quel Almirante don Christoual Colom descubrio las Indias y torno a estas partes, y algunos christianos de los que con el vinieron que se hallaron en aquel descubrimiento, y los que el segundo viaje hizieron, que fueron mas, truxeron esta plaga y dellos se pego a otras personas. Y despues, el año de mil y quatro cientos y nouenta y cinco, que el gran capitan don Gonçalo Fernandez de Cordoua passo a Ytalia con gente en fauor del rey don Fernando, jouen de Napoles, contra el Rey Charles de Françia, el de la cabeça gruessa, por mandado de los Catholicos reyes don Fernando y dońa Ysabel de inmortal memoria, abuelos de V. S. M. passo esta enfermedad con algunos de aquellos Españoles y fue la primera vez que en Ytalia se uido y como era en la sazon que los Franceses passaron con el dicho rey Charlo, llamaron a este mal los ytalianos, el mal frances, y los françeses le llaman el mal de Napoles porque tan poco le auían visto ellos hasta aquella guerra. Y de ay se desparzio por toda la christiandad." 80
}

Indos per plurimos annos hoc morbo grauiter laborasse, medicinamque qua semper usi sunt contra hunc morbum nostris mercatoribus iam indicarunt.

80 Gonzalo FERnÁNDEZ DE OVIEDo, Sumario de la natural y general historia de las Indias. Toledo, Ramón de Petrás, 1526, pp. 38r-38v. 
Se trata, probablemente, de un momento importante para el comercio del guayaco. Se está vendiendo a buen ritmo, como indican las cifras que dimos anteriormente, pero existen voces críticas: en esa fecha Paracelso se establece en Basilea, y muchos estudiantes están dispuestos a seguir sus opiniones mercuriales. Además, la muerte de Hutten por el mal francés, pocos años antes (1523), a despecho de su exultante regocijo por haber hallado la cura milagrosa, suponía un revés para los defensores del guayaco como remedio sobre el mercurio. Conviene, así pues, insistir en la idea de que la cura por guayaco se produce en el mismo sitio del que proviene la enfermedad. ${ }^{81}$

Cuando Gonález de Oviedo retoma el asunto en su Historia general y natural de las Indias, publicada en 1535, aunque escrita antes y con una divulgación inmediata, insiste de forma aún más clara y contundente en el origen americano de la enfermedad e introduce una nueva cuestión: lo que se llama palo santo o guayaco está compuesto en realidad por dos especies, que él propone diferenciar usando un nombre para cada una (se trata de Guaiacum officinale L. y Guaiacum sanctum L.):

Dos árboles hay muy notables y exçelentes en estas islae é aun en la Tierra-Firme; porque assi como es comun el mal de las buas en todas estas partes, quiere la misericordia divina que assi sea el remedio comunicado, é se halle para curar esta dolençia. Pero aunque en otras partes se halle esta enfermedad, el origen donde los chripstianos vieron las buas, y experimentaron é vieron curarlas y experimentar el árbol del guayacan fué en esta Ista Española. El otro se llama palo sancto, y este hay en la isla de Boriquen, llamada agora por los españoles Sanct Johan; é quando della se hable, se dirá del palo sancto. ${ }^{82}$

La divulgación de las obras de Mártir de Anglería, Francisco Delicado y Fernández de Oviedo por la Italia de los humanistas fue inmediata y extensa, como demuestra Pardo Tomás ${ }^{83}$ y también López Piñero y López Terrada ${ }^{84}$, no solo por medio de traducciones y ediciones,

81 Es probable que la mejoría que experimentaban los que tomaban guayaco se debiese esencialmente al abandono de las nocivas curas mercuriales, aunque también podía contribuir a ello el riguroso régimen de vida que acompañaba a la receta del tratamiento por leño santo.

82 Gonzalo Fernández de OVIEdo, Historia general y natural de las Indias, islas y Tierra-Firme del mar Océano, editada por D. José Amador de los Ríos para la Real Academia de la Historia. Primera parte. Madrid, Imprenta de la Real Academia de la Historia, 1851, p. 363.

83 José PARDo TOMÁs, "Obras españolas sobre historia natural y materia médica americanas en la Italia del siglo xvı", Asclepio 43.1 (1991), pp. 51-94, maxime 52-53. Allí explica como el famoso humanista Andrea Navagero, que era embajador veneciano en Toledo, volvió a Venecia en 1528 con, entre otras obras, un ejemplar del Sumario de Oviedo.

84 José María López Piñero y María Luz López TerRadA, La influencia española..., op. cit., pp. 19-22. Destaca especialmente las relaciones que mantuvieron los humanistas Pietro Bembo y Girolamo Fracastoro con los autores españoles a través de Navagero. 
sino por las relaciones personales entre eruditos que intercambiaban correo. Podemos asumir, así pues, que las informaciones pasaron inmediatamente a las obras de autores italianos, sobre todo aquellas que se relacionaban con un tema tan candente como eran los remedios para el mal francés. Por lo tanto, las informaciones sobre el guayaco se extenderían rápidamente por toda Europa a través de los autores italianos cuando no lo hicieron directamente por la lectura de los textos publicados en España. ${ }^{85}$

\title{
5. ¿EL GUAYACO ES ÉBANO?
}

Pero no creemos que fuera directamente Oviedo quien puso en comparación el guayaco y el ébano. Afirma Munger ${ }^{86}$ que el cronista, en su Historia Natural de 1530, dice que algunos prefieren llamar ébano al guayaco. Como no indica dónde lo dice, hemos buscado esta afirmación de Oviedo, pero en vano. La única referencia que hemos encontrado que pudiera hacer pensar en esta identificación es la siguiente, cuando habla del pueblo de Thamara en el capítulo 2 del libro 25 :

\begin{abstract}
Los veçinos deste pueblo por la mayor parte labran oro, é tienen sus forjas é yunques é martillos, que son de piedras fuertes: algunos dicen que son de un metal negro á manera de esmeril. Los martillos son tamaños como huevos ó mas pequeños, é los yunques tan grandes, como un quesso mallorquin, de otras piedras fortíssimas: los fuelles son unos canutos tan gruessos como tres dedos ó mas, y tan luengos como dos palmos. Tienen unas romanas sotiles con que pessan, y son de un hueso blanco, que quiere paresçer marfil; y tambien las hay de un palo negro, como ébano. ${ }^{87}$
\end{abstract}

Si fuera este el fragmento a que hace referencia Munger, sería demasiado aventurado pensar que el cronista está designando el guayaco, dado que en el capítulo en que trata específicamente este árbol, cuyo inicio hemos transcrito más arriba en este trabajo, lo llama siempre guayacán o palo santo. No tendría por qué decir 'un palo negro'.

Pero, sin duda, las noticias de Pedro Mártir y de Fernández de Oviedo allanaban el camino para la comparación o identificación del guayaco y el ébano.

85 Amato Lusitano podría haber manejado los textos de Oviedo, a juzgar por unos comentarios sobre el plátano que trataremos en otro lugar.

86 Op. cit., p. 204.

87 Gonzalo Fernández de Oviedo, Historia general....Tomo primero de la segunda parte, op. cit., p. 274. La cursiva es nuestra. 
Vamos a intentar rastrear esta comparación en los textos que conservamos, sin pretensiones de exhaustividad, ni mucho menos, pero fijándonos en algunos hitos importantes bien de la botánica en general bien de los tratamientos contra el mal francés en particular, hasta llegar al Index de Amato Lusitano, para responder a las preguntas que planteábamos más arriba.

Nada sobre el guayaco encontramos en el Corolario de Hermolao Bárbaro editado por Egnacio $^{88}$. Aunque era de esperar, considerando la fecha en que fue compuesto y publicado, intentamos leer entre líneas la entrada del ébano, teniendo en cuenta las palabras de Amato: Nobis hac de re Hermolaus Barbarus astipulatur, si quis nucleum non tantum verborum corticem spectet. ${ }^{89}$ Sin embargo, la única coincidencia se halla en las propiedades curativas que se atribuyen al ébano, semejantes en ambos autores.

Tampoco encontramos nada en la obra de Benedicto Textor, publicada en París dos ańos antes que la de Amato. ${ }^{90}$ Esta obra es muy interesante porque se aparta de los comentarios dioscorídeos al uso, dividiendo las plantas de una forma muy práctica, con lo que respeta lo prometido en el título, guiándose más por la experiencia que por la tradición. Comienza con una moderna tabla de definiciones para el vocabulario que va a utilizar y agrupa las plantas según semejanzas y diferencias a partir de diversas propiedades cuantitativas y cualitativas, tiempo de maduración, sustancia, utilización, etc. A pesar de esto, no parece haber tenido interés en hablar del ébano y mucho menos del guayaco.

Creemos que una de las primeras comparaciones explícitas entre estos dos productos que se pueden leer en los textos humanistas (dejando aparte el comentario de Mártir de Anglería, escrito, como dije, antes de especificar el nombre de la madera americana) es la de Fracastoro en su poema Syphilis. Como hemos dicho más arriba, este médico, poeta y poetólogo tenía un buen conocimiento de las plantas americanas por los contactos con las publicaciones y los autores hispanos a través de su amigo y también miembro del círculo veneciano Andreas Navagero. No le faltaba, por tanto, material con que escribir su poema sobre el mal francés, que él denominó artísticamente sífilis. Este poema en hexámetros, a medio camino entre la poesía épica y la didáctica, se compone de tres libros de algo más de 400 versos cada uno. Tras acabar el segundo libro con una desagradable visión de los sacrificios que hay que soportar al someterse a las diferentes curas contra la sífilis, empieza el tercero de forma exultante, cantando como un don de los propios dioses - pues la obra, como es normal en la épica del

88 Ioannis Baptistæ EGNATII, In Dioscoridem ab Hermolao Barbaro tralatum annotamenta. [Venetiis], Aloisius \& Franciscus Barbari \& loannes Bartholomaeus Astensis, [1516], maxime XVIIIV. Es una edición catalogada como dudosa por Riddle. Cf. John M. RIDDLE, Dioscorides..., op. cit., p. 16.

89 Amatus Lusitanus, Index Dioscoridis..., op. cit., p. 24r: "En este asunto Hermolao Bárbaro coincide con nosotros, si se mira al meollo de sus palabras y no solo a lo externo."

90 Hemos manejado la editio princeps, Benedictus Textor, Stirpium differentiae ex Dioscoride secundum locos communes. Opus ad ipsarum plantarum cognitionem admodum conducibile. Parisiis, Apud Simonem Colinaeum, 1534. 
Renacimiento, se reviste de un manto de mitología pagana que el fervor religioso de la época acepta por su halo de simbolismo- la llegada del palo santo (Hyacum, v. 35). Inmediatamente, llega su descripción, donde podemos leer:
Materia indomita est, duro et pene aemula ferro
robora, quae resinam sudant incensa tenacem.
Dissectae color haud simplex. In cortice, lauri
exteriore uiret leuor, pars altera pallet
buxea, at interior nigro suffusca colore est,
iuglandem ebenumque inter. Quod si inde ruberet,
iam poterat uarijs aequare coloribus Irim. ${ }^{91}$
Es su madera indomable, casi igual su reciedumbre
que el hierro duro y transpira tenaz resina a la lumbre.
El color, al corte, es doble. En la corteza verdea
un bruñido de laurel. La otra parte se blanquea
como boj. Mas su interior morenamente negrea
entre el ébano y nogal. Si también enrojeciera,
por sus variados colores igualar a Iris pudiera.

Un año más tarde edita Otto Brunfels su Noui herbarii en Estrasburgo. Aunque se trata de una obra que sigue la lista de Dioscórides sin una exégesis tan exhaustiva como será la de los comentaristas posteriores como Amato, Mattioli o Laguna, destaca su preocupación por la correcta identificación de las plantas. La entrada del ébano, como muchas otras, no aparece en el corpus principal de la obra, sino en el De uera herbarum cognitione appendix, que reinicia la numeración, y dice lo siguiente:

Hebaenus: iuxta omnia signa et notas quibus hanc describunt Hermolaus Barbarus et Plinius apparet quiddam habere nostro Guaiaco simile, aut certe eius genere esse; sed non habeo cur id certo affirmem. ${ }^{92}$

91 Fracastoro, Syphilis, 3.40-46. Cf. Jerôme Fracastor, La syphilis ou le mal français..., op. cit., p. 63.

92 Otto Brunfels, Noui Herbarii Tomus II, per Oth[o] Brunf[elsio] recens editus. Argentorati, Apud loannem Scottum, 1531, p. 8 (tras comenzar una nueva numeración en el appendix). En la edición de 1536 realizada también en Estrasburgo y en misma casa editorial de Juan Escoto, el texto, idéntico, aparece en la página 102. 
ÉBANO: A juzgar por todos los signos y características con que lo describen Hermolao Bárbaro y Plinio, parece tener algo semejante a nuestro guayaco, o sin duda es de su mismo género, pero no tengo cómo afirmar esto de forma segura.

Como vemos, Brunfels ha ido un paso más allá de Fracastoro pues, aparte de constatar el parecido, ya plantea la posibilidad, bastante firme aunque no con rotundidad por la falta de pruebas, de que ambas maderas sean del mismo genus. Merece la pena destacar que, tal como sucederá más tarde, en los textos de Mattioli y en los comentarios a la obra de Ruel, la confusión entre las dos maderas, guayaco y ébano, se da por el desconocimiento de este último, y no del producto americano, como podría pensarse en un principio También querríamos destacar que Brunfels comienza ya a usar nomenclaturas en diferentes lenguas para catalogar bien los productos, algo que Amato mejorará al poner estos nombres en un epígrafe aparte ${ }^{93}$, por lo que no es difícil pensar en un conocimiento de esta obra por parte de Amato.

En 1535 aparecen publicadas en Basilea las epístolas de Giovanni Manardo, pero la que nos interesa para el asunto que estamos tratando, la $3^{\text {a }}$ epístola del $17^{\circ}$ libro, está datada en la vigilia de S. Mateo (21 de septiembre) de $1532,{ }^{94}$ un año después de la obra de Brunfels. El título de la carta (De Ebeni Indici electione et usu) es elocuente por dos motivos: porque se hace explícita la importancia de la elección de la madera para tratar el mal francés y porque se la denomina ebeni indici. La confusión ya es bastante evidente en Manardo, una de las fuentes de Amato, pues este lo cita explícitamente. En ese momento ya se veía en las boticas guayaco de dos tipos - los que iba a describir Oviedo en su obra aún no publicada en ese momento que probablemente también se confundía en ocasiones con el palo de Brasil ${ }^{95}$. No podemos olvidar, además, que de la tradición pliniana venía el conocimiento de que había una especie de ébano llamado precisamente índico. De modo que Manardo, ante las informaciones confusas, explica lo siguiente:

Tria ad nos hactenus huius ligni genera peruenere. Primum, quod guaiacum uocant, densius, grauius, crassius, interiore parte nigricantius, exteriore subpallida et ueluti lineis

93 Véase, en este mismo volumen, el trabajo de Ana Margarida BorGES, "Léxico científico português nos comentários de Amato: antecedentes e receção".

94 Confirma, además, la fecha, el inicio de la carta, cuando dice que hace 38 años que se padece la enfermedad del mal francés (recuérdese que se suele fechar sus comienzos en 1494, tal como se hacía desde poco después de su aparición): Quum igitur anno hunc duodequadragesimo, ad coercenda humani generis delicta, luem pessimam Gallicam uocatam, ueluti multicipitem hydram, in nos grassari [Deus] premisisset. Cf. Ioannis MANARDUS, Epistolarum medicinalium libri duodeuiginti. Basileae, Hieronymus Artolphus, 1535, p. 377.

95 De hecho, en Johannes Ruellius, De natura stirpium libri tres. Parisiis, Ex officina Simonis Colinaei, 1536, p. 161, Jean Ruel comienza a tratar el palo de Brasil en la entrada del ébano después de haber hablado extensamente del guayaco. 
quibusdam ad fuscum inclinantibus, in aeque distantibus per longum interfecta. Alterius ad albius magis uergit exterior pars, neque est tam manifestis lineis distincta: nigrum tamen et ipsum colorem intrinsecus ostendit, sed minore orbe quam praecedens. Tertium quod sanctum praecipue uocatur, tam intrinsecus quam extrinsecus albicantem colorem prae se fert, exilibusque ualde lineis eius distinguitur longitudo. Ex tribus hisce generibus ego in casu nostro primum praetulerim, quod procul dubio hebenum esse Indicum puto, nec ab eo secundum, nisi forte natalibus, diferre. Tertium ualentius esse non dubito, quoniam et acrius est et odoratius. ${ }^{96}$

Hasta ahora nos han llegado tres tipos de este leño. El primero, al que llaman guayaco, es más denso, más pesado, más grasiento, pero tirando al negro en la parte interior, con la parte externa ligeramente pálida y cortada longitudinalmente, a intervalos regulares, como con ciertas estrías que tienden al moreno. La parte exterior del segundo tiende a una mayor blancura y no está marcada por estrías tan señaladas; sin embargo, muestra una parte interna del mismo color negro, solo que de un diámetro menor que el anterior. El tercero, que es aquel al que de forma especial se llama santo, tanto en la parte interna como en la externa lleva un color blancuzco y su longitud está marcada por hendiduras muy estrechas. De estos tres tipos, para lo que nos ocupa yo preferiría el primero, que sin duda creo que es el ébano índico, y no me parece que el segundo difiera de él a no ser en sus orígenes. No tengo dudas de que el tercero es más fuerte, ya que es más agrio y aromático.

Manardo ya ha identificado, así pues, una especie de guayaco que se encuentra en las boticas con el ébano índico. A partir de este momento se genera una época de confusión en que se bifurcan dos líneas de pensamiento, que podrían estar bien ejemplificadas por dos obras que aparecieron el mismo año, el siguiente a la publicación de las epístolas de Manardo. En 1536 sale publicado, por un lado, el De natura stirpium libri tres de Jean Ruel que ya hemos comentado, y, por otro, el Index Dioscoridis de Amato.

Ruel usa la entrada del ébano para hablar del guayaco y del palo de Brasil, pero solo porque es el único lugar donde será encontrado por sus lectores, que se han ido habituando a buscar esos productos en ese lugar. Ruel es muy consciente de que la semejanza de los dos leños es superficial, y niega categóricamente que se trate de la misma especie (genus) ${ }^{97}$.

En cambio, Amato seguirá la línea opuesta, para afirmar rotundamente que el guayaco es ébano. Puede ser que los motivos económicos no fueran ajenos a esta identificación. Como hemos dicho, el negocio de guayaco movía mucho dinero y ponía en juego sobre el tablero

96 Ioannis MANARDUS, Epistolarum ..., op. cit., p. 378.

97 Cf. Johannes Ruellius, De natura stirpium..., op. cit., p. 161. 
económico de Europa muchos intereses. Los médicos que estuviesen fuera de los circuitos de venta del guayaco, que no sacasen provecho, o miembros de familias de mercaderes, como Amato Lusitano, veían que una mercancía tan valiosa quedaba fuera de su alcance. En ningún otro autor anteriormente se afirma esta identidad con tal pasión, con tal acumulación de argumentos, con tan minuciosa comparación de propiedades. De la extensísima entrada del ébano podemos entresacar algunos fragmentos que nos permitirán ver la convicción de Amato:

Quantum ergo superis de gaiaci beneficio nos debemus, simul et de hebeni nos debere omnes sciant, cum gaiacum lignum vulgo notum antiquorum ebenus est, cum omnia, acsi acu pingerentur, ebeno, quae gaiaco insunt, respondent. ${ }^{98}$

De modo que cuanto debemos a los cielos por los beneficios del guayaco, que todos sepan que lo debemos de igual modo por los del ébano, porque lo que se conoce vulgarmente como palo guayaco es el ébano de los antiguos, ya que todo lo que hay en el guayaco corresponde al ébano como si lo bordaran.

Est vero lignum illud durissimum, ut vix secabilis eius duricies fit, atque ponderosissimum, ut nulla eius quanquam minutissima pars in aqua fluitat aut supernatat, sed omnino mergitur et subcidit, boni (si prunis incendatur) est odoris, a quo gummi subnigrum provenit; nec a se minorem in ebullitione: mittit odorem, boni saporis est atque iucundi, ut tradunt assuetis. His iam verbis manifeste deprehenditur gaiacum lignum antiquorum ebenum esse, cum in omni Dioscoridis descriptioni in praesenti respondet, tam in eius colore quam in reliquis omnibus guaiaco tributis, ut legenti manifestum est. ${ }^{99}$

Este leño es durísimo, tanto que su dureza hace que apenas se pueda cortar, y muy pesado, al punto que ninguna porción de él, ni siquiera la más diminuta, flote en el agua o emerja, sino que se sumerge totalmente y se hunde; si se quema con brasas desprende grato aroma, y de él proviene una resina negruzca; y no es menor lo que sale de él cuando se hierve: emite aroma, es de sabor gustoso y agradable, como se dice en los sitios habituales. Por estas palabras se deduce claramente que el palo guayaco es el ébano de los antiguos, ya que se corresponde totalmente con la descripción de Dioscórides que aquí se presenta, tanto en su color como en todas las demás propiedades atribuidas al guayaco, como le será evidente a quien lo lea.

98 Amatus Lusitanus, Index Dioscoridis..., op. cit., p. 24 r.

99 Amatus Lusitanus, Index Dioscoridis..., op. cit., p. $24 \mathrm{v}$. 
Nec enim ab hac nostra opinione te retrahat id quod in omnium ore est, multa nunc gaiacum possidere, quae minime ebeno prisci tribuerunt. Nam licet notitiam de eo olim habuere, non tamen exactam ut nos. ${ }^{100}$

Y que no te aparte de esta opinión nuestra lo que está en boca de todo el mundo, que el guayacán posee ahora muchas propiedades que los antiguos no atribuyeron en absoluto al ébano. Porque si bien tuvieron entonces noticia de aquel, no con precisión, como nosotros.

Creemos que esta pequeña muestra de fragmentos de esta entrada basta para demostrar lo que decíamos. La opinión de Amato es, así pues, tajante, decidida, diríamos que valiente, a pesar de su error. El joven de 25 años quiere parecerse a Leoniceno y Manardo, sus maestros, y por eso no tiene miedo de lanzar sus opiniones, aunque sean osadas:

Quibus heroibus quicquid scimus, si modo quid scimus, acceptum referentes atque $a b$ ipsorum perennibus fontibus, parvos nostros cantharos adimplentes, hoc opus componere sumus aggressi. Sed quum ipsi non sine ingenti laude quid de unaquaque re sentirent audacter nec minus erudite praeferrent, non video quur mihi vitio sit vertendum, si quid de hebeno nostrum iuditium aperiamus, cum ille ab omnibus ferme prae manibus habeatur, nec tamen quid apud antiquos fuerit sciatur. ${ }^{101}$

Señalando que hemos recibido todo lo que sabemos, si es que sabemos algo, de estos héroes, y llenando nuestros pequeños cántaros de sus fuentes perpetuas, nos decidimos a componer esta obra. Pero dado que ellos reciben grandes alabanzas cuando presentan lo que opinan de cada cosa de forma audaz y no menos erudita, no veo por qué se habría de considerar en mí un defecto si mostramos un poco nuestra opinión sobre el ébano, ya que casi todos lo manipulan pero no se sabe qué era para los antiguos.

Poco después, algunos médicos eruditos reaccionarán con decisión y de forma contundente contra esta opinión. En 1538, Alfonso Ferri, el cirujano mayor del papa Pablo III ${ }^{102}$ y en 1540 Antonio Gallo ${ }^{103}$, publican sendos textos que incluyen demostraciones contundentes sobre la diferencia entre el ébano y el guayaco. No sería imposible que el texto de Amato hubiera tenido algo que ver con esta reacción. Como hemos visto, el texto de Ruel no identificaba ambos

100 Amatus Lusitanus, Index Dioscoridis..., op. cit., p. 25v.

101 Amatus Lusitanus, Index Dioscoridis..., op. cit., p. $24 \mathrm{r}$.

102 Alfonsus FERRI, De ligni sancti multiplici medicina et vini exhibitione libri quatuor. Basileiae, Johannes Bebelius, 1538.

103 Antonius Gallus, De ligno sancto non permiscendo. Parisiis, Apud Simonem Colinaeum, 1540. 
productos, como tampoco lo hizo en 1537 Antonio Musa Brassavola, ${ }^{104}$ por lo que no pueden haber provocado los escritos de corrección. Es probable que el prestigio de Manardo y la escuela de Ferrara, y ver que un joven seguidor ${ }^{105}$, ciertamente prometedor, se alzaba como adalid de la causa de la identificación, desencadenase esta reacción científica que intentó poner las cosas en su sitio y evitar que se vendiera ébano en lugar de guayaco. Lo cierto era que, irónicamente, ninguno de los dos tendría más éxito en el tratamiento del mal francés que el otro.

La ciencia se va construyendo así paso a paso, e incluso cuando esos pasos van en la dirección equivocada, no por ello se deja de construir ciencia, pues las conclusiones y el debate posterior servirán para un avance más. Hemos visto que la confluencia de diversos factores: la aparición de una nueva enfermedad, las dificultades en describir esa nueva dolencia, las características de la historia natural, las descripciones de nuevos productos, determinados intereses económicos, la circulación de la información, etc., va determinando el momento en que se produce la identificación, científicamente comprobada, aunque equivocada, entre dos especies de árboles de características semejantes. En ese proceso, el joven João Rodrigues de Castelo Branco, aún no Amato Lusitano, tuvo un papel relevante que merece tenerse en consideración.

\section{BIBLIOGRAFÍA}

Amatus Lusitanus (João Rodrigues de Castelo Branco), Index Dioscoridis. Antuerpiae, excudebat Vidua Martini Caesaris, 1536.

Amatus Lusitanus, In Dioscoridis Anazarbei de medica materia libros quinque enarrationes eruditissimae. Venetiis, apud Gualterum Scotum, 1553.

Andrade, António Manuel Lopes, "Ciência, Negócio e Religiâo: Amato Lusitano em Antuérpia”, en Inês de Ornellas e Castro, Vanda Anastácio (coord.), Revisitar os Saberes - Referências Clássicas na Cultura Portuguesa do Renascimento à Época Moderna. Lisboa, Centro de Estudos Clássicos - Faculdade de Letras da Universidade de Lisboa, 2010, pp. 9-49.

104 Antonius Musa Brasavolus, Examen omnium simplicium medicamentorum quorum in officinis usus est. Lugduni, Apud Ioannem et Franciscum Frellaeos, fratres, 1537. Cf. p. 328: Quandoque hebeni speciem esse suspicabamur, sed postea autores considerantes, a suspicione liberati sumus.

105 Unos años más tarde, Amato mantendría estrechas relaciones con los miembros de la escuela de Ferrara, sobre todo tras su llegada a esta ciudad a mediados de 1540, donde ejercería, a partir del año siguiente, funciones de profesor de medicina teorica en su Estudio. Cf. António Manuel Lopes ANDRADE, "Dioscórides renovado pela mão dos humanistas: os comentários de Amato Lusitano", en Carmen SOARES (Coord.), Espaços do Pensamento Científico da Antiguidade. Volume I. Coimbra, Imprensa da Universidade de Coimbra, 2013, pp. 71-90. 
Andrade, António Manuel Lopes, "Dioscórides renovado pela mão dos humanistas: os comentários de Amato Lusitano”, en Carmen Soares (Coord.), Espaços do Pensamento Cientifico da Antiguidade. Volume I. Coimbra, Imprensa da Universidade de Coimbra, 2013, pp. 71-90.

Arrizabalaga, Jon, "Práctica y teoría en la medicina universitaria de finales del siglo xv: el tratamiento del mal francés en la corte papal de Alejandro VI Borgia”, Arbor 153, no 604-605 (Abril-Mayo 1996), pp.127-160.

Arrizabalaga, Jon, “Sebastiano dall'Aquila (c. 1440 - c. 1510), el 'mal francés' y la 'disputa de Ferrara' (1497)”, DYNAMIS. Acta Hispanica ad Medicinae Scientiarumque Historiam Illustrandam 14 (1994), pp. 227-247. Arrizabalaga, Jon, "Syphilis", The Cambridge World History of Human Disease. $1^{\text {st }}$ ed. Cambridge, Cambridge University Press, 1993, pp. 1025-1033. Cambridge Histories Online. Accedido el 16 de marzo de 2013. http://dx.doi.org/10.1017/CHOL9780521332866.

Arrizabalaga, Jon, Henderson, John \& French, Roger, The Great Pox. The French Disease in Renaissance Europe. New Haven and London, Yale University Press, 1997.

[Barlandus, Hubertus], Pedanii Dioscoridis Anarzabei de medicinali materia libri sex, Ioanne Ruellio Suessionensi interprete, cuilibet capiti additae annotationes, eruditae et compendiariae e selectiori medicorum promptuario. Lugduni, Apud Balthazarem Arnolletum, 1550.

BenzInG, Josef, Ulrich von Hutten und seine Drucker: eine Bibliographie der Schriften Huttens im 16. Jahrhundert, mit Beiträgen von Heinrich Grimm. Wiesbaden, Otto Harrassowitz, 1956.

Brasavolus, Antonius Musa, Examen omnium simplicium medicamentorum quorum in officinis usus est. Lugduni, Apud Ioannem et Franciscum Frellaeos, fratres, 1537.

Brunfels, Otto, Noui Herbarii Tomus II, per Oth[o] Brunf[elsio] recens editus. Argentorati, Apud Ioannem Scottum, 1531.

Bubnova, Tatiana, "Delicado en la Peña de Martos", en Jules Whicker, Actas de XII Congreso de la Asociación Internacional de Hispanistas 21-26 de agosto de 1995, Vol. 2: Estudios áureos I. Birmingham, University of Birmingham, 1998, pp. 70-78. Disponible en http://cvc.cervantes.es/literatura/aih/pdf/12/ aih_12_2_011.pdf.

Delgado, Francisco, Retrato de la lozana andaluza. Madrid, Imprenta y Estereotipia de M. Rivadeneyra, 1871.

Chinchilla, Anastasio, Anales históricos de la medicina en general y biográfico-bibliográficos de la española en particular, Tomo I. Valencia, Imprenta de López y Compañía, 1841.

Cipriani, Mariano, "Mercurio e mercurialisti, guaiaco e guaiacofili e 'fenomeno Fugger”, Rivista di Storia della Medicina 6 (1962), pp. 87-113.

Colón Doménech, Germán, "Filología y sífilis. Sobre el mal de simiente o mal de sement", Revista de Filología Española 78, 30-4o (julio-diciembre de 1998), pp. 275-308.

Corradi, Alfonso, Nuovi documenti per la storia delle malattie veneree in Italia dalla fine del Quatrocento alla metà del Cinquecento. Milano, Tipografia Fratelli Rechiedei, 1884.

Damiani, Bruno M., "Francisco Delicado El modo de adoperare el legno de India Occidentale. A critical transcription”, Revista Hispánica Moderna 36, no 4 (1970/1971), pp. 251-271. 
Dins, João José Alves, Amato Lusitano e a sua obra: séculos xvi e Xvir. Lisboa, Biblioteca Nacional de Portugal, 2011.

Egnatil, Ioannis Baptistæ, In Dioscoridem ab Hermolao Barbaro tralatum annotamenta. [Venetiis], Aloisius \& Franciscus Barbari \& Ioannes Bartholomaeus Astensis, [1516].

Eyn bewert Recept wie man das holtz Guagacan fur die kranckheyt Frantzosen brauchen sol etcetera. Nürnberg, Hieronymus Höltzel, 1518. http://daten.digitale-sammlungen.de/bsb00083987/image_1.

Fernández de Oviedo, Gonzalo, Historia general y natural de las Indias, islas y Tierra-Firme del mar Océano, editada por D. José Amador de los Ríos para la Real Academia de la Historia. Primera parte. Madrid, Imprenta de la Real Academia de la Historia, 1851.

Fernández de Oviedo, Gonzalo, Sumario de la natural y general historia de las Indias. Toledo, Ramón de Petrás, 1526.

Ferri, Alfonsus, De ligni sancti multiplici medicina et vini exhibitione libri quatuor. Basileiae, Johannes Bebelius, 1538.

Fisch, Max Harold and Schullian, Dorothy May, Nicolaus Pol doctor 1494: with a critical text of his guaiac tract. New York, Herbert Reichner for Cleveland Medical Library Association 1947.

Fracastor, Jerôme, La syphilis ou le mal français. Syphilis sive Morbus Gallicus, Texte établi, traduit, présenté et annoté sous la direction de Jacqueline Vons, avec la collaboration de Concetta Pennuto et Danielle Gourevitch et le concours du Dr. Jacques Chevallier. Paris, Les Belles Lettres, 2011.

Fracastorius, Hieronymus, De contagione et contagiosis morbis et eorum curatione, libri III. Translation and notes by Wilmer Cave Wright, Ph.D.. New York-London, G. P. Putnam’s Sons, 1930.

Gallus, Antonius, De ligno sancto non permiscendo. Parisiis, Apud Simonem Colinaeum, 1540.

González Bueno, Antonio "El Descubrimiento de la Naturaleza del Nuevo Mundo: Las Plantas Americanas en la Europa del siglo xvi", Circumscribere. International Journal for the History of Science 2 (2007), pp. 10-25, http://revistas.pucsp.br/index.php/circumhc/article/view/569/1028.

González Bueno, Antonio, "La flora del paraíso: recepción de las plantas americanas en la literatura científica europea del Renacimiento” en Alfredo Baratas (ed.), Memorias de la Real Sociedad Española de Historia Natural. Tomo III. 2a época. El libro de la Naturaleza. Madrid, Facultades de Biología y Geología - Ciudad Universitaria, 2004, pp. 5-33.

González Manjarrés, Miguel Ángel, Andrés Laguna y el Humanismo médico. Salamanca, Junta de Castilla y León, 2000.

Gourevitch, Danielle, "La syphilis, une maladie aux noms multiples" en Jerôme Fracastor, La syphilis ou le mal français. Syphilis sive Morbus Gallicus, Texte établi, traduit, présenté et annoté sous la direction de Jacqueline Vons, avec la collaboration de Concetta Pennuto et Danielle Gourevitch et le concours du Dr. Jacques Chevallier. Paris, Les Belles Lettres, 2011, pp. Xv-XXXVII.

Häberlein, Mark, The Fuggers of Augsburg. Pursuing Wealth and Honor in Renaissance Germany. Charlottesville \& London, University of Virginia Press, 2012 (= Die Fugger: Geschichte einer Augsburger Familie, 1367-1650. Stuttgart, W. Kohlhammer GmbH, 2006). 
Henderson, John, "Fracastoro, il legno santo e la cura del 'mal francese", en Alessandro Pastore e Enrico Peruzzi (eds.), Girolamo Fracastoro. Fra medicina, filosofia e scienze della natura. Atti del Convegno internazionale di studi in occasione del 450 anniversario della morte. Verona-Padova 9-11 ottobre 2003. Firenze, Leo S. Olschki, 2006, pp. 73-89.

Herrero Ingelmo, Ma Cruz; Montero Cartelle, Enrique, "El Morbus gallicus o Mal francés en La Lozana andaluza de Francisco Delicado", Asclepio 65, 2 (julio-diciembre 2013), p021. http://dx.doi. org/10.3989/asclepio.2013.21.

Hutten, Ulrich von, De guaiaci medicina et morbo Gallico liber unus. [Parisiis], Ex typis Petri Vidoue, 1519.

Kusukawa, Sachiko, Picturing the Book of Nature. Image, Text, and Argument in Sixteenth-Century Human Anatomy and Medical Botany. Chicago, University of Chicago Press, 2012.

Laguna, Andrés, Annotationes in Dioscoridem Anazarbeum, per Andream Lacunam Segobiensem Medicum Iulii III Pont[tificis] Max[imi] iuxta vetustissimorum codicum fidem elaboratae. Lugduni, Apud Gulielmum Rouillium, 1554.

Liber de morbo Gallico in quo diversi celeberrimi in tale materia scribentes medicine continentur auctores. Veneza, [Giovanni Padovano \& Venturino Ruffinelli], 1535.

López Piñero, José María y López Terrada, María Luz, La influencia española en la introducción en Europa de las plantas americanas (1493-1623). Cuadernos valencianos de Historia de la medicina y de la ciencia LIII. Serie A (monografías). Valencia, Instituto de Estudios Documentales e Históricos sobre la Ciencia, 1997. Disponible en http://digital.csic.es/bitstream/10261/88589/1/P_AMER_completo.pdf.

López Piñero, José María, Medicina e historia natural en la sociedad española de los siglos XVI y XviI. Valencia, Universitat de València, 2007.

Luisinus, Aloysius, De morbo gallico omnia quae extant apud omnes medicos cuiusque nationis, tomus prior. Venetiis, apud Iordanum Zilettum, 1566.

Manardus, Ioannis, Epistolarum medicinalium libri duodeuiginti. Basileae, Hieronymus Artolphus, 1535.

Martyr ab Angleria, Petrus, De rebus Oceanicis et Orbe nouo decades tres. Basileae, apud Ioannem Bebelium, 1533.

Mattioli, Pietro Andrea, Commentarii in libros sex Pedacii Dioscoridis Anazarbei de medica materia. Adiectis quam plurimis plantarum et animalium imaginibus, eodem authore. Venetiis, in officina Erasmiana, apud Vincentium Valgrisium, 1554.

Munger, Robert S., "Guaiacum, the Holy Wood of the New World", Journal of the History of Medicine and allied Sciences 4 (1949), pp. 196-229.

Olgilvie, Brian W., The Science of Describing. Natural History in Renaissance Europe. Chicago and London, The Universtity of Chicago Press, 2006.

Orta, Garcia de, Colóquios dos simples e drogas da Índia, ed. Conde de Ficalho, 2 vols. Lisboa, Imprensa Nacional, 1985.

PArdo Tomás, José, “Obras españolas sobre historia natural y materia médica americanas en la Italia del siglo xvi”, Asclepio 43.1 (1991), pp. 51-94. 
Pardo Tomás, José y López Terrada, María Luz, Las primeras noticias sobre plantas americanas en las relaciones de viajes y crónicas de Indias (1493-1553). Cuadernos valencianos de Historia de la medicina y de la ciencia XL. Serie A (monografías). Valencia, Instituto de Estudios Documentales e Históricos sobre la Ciencia, 1993.

Pérez IbáŃñez, Ma Jesús, "Galli vocant istum morbum morbum eius cuius est. Otra designación para el 'mal francés', Asclepio. Revista de Historia de la Medicina y de la Ciencia 40, no 1 (enero-junio 2008), pp. $267-280$.

Pérez Ibáñez, Maa Jesús, “Un problema médico y terminológico (sífilis en el s. Xvi), Voces 6 (1995), pp. 61-79.

Pоттоn, F.F.A., Livre du chevalier allemand Ulric de Hutten sur la maladie fançaise et sur les propriétés du bois de Gayac. Orné d'un portrait de l'auteur, précédé d'une notice historique sur sa vie et ses ouvrages. Lyon, Imprimerie de Louis Perrin, 1865.

Riddle, John M., “Dioscorides”, en F. Edward Cranz (ed.), Paul Oskar Kristeller (assoc. ed.), Catalogus Translationum et Commentariorum: Mediaeval and Renaissance Latin Translations and Commentaries. Annotated Lists and Guides, Vol. IV. Washington D. C., The Catholic University of America Press, 1980, pp. 1-144.

Ruellius, Johannes, De natura stirpium libri tres. Parisiis, Ex officina Simonis Colinaei, 1536.

Schmaus, Leonard, Lucubratiuncula de morbo Gallico et cura eius nouiter reperta cum ligno Indico Leonardi Schmaus medicine professoris. Augsburg, Grimm \& Wirsung, 1518.

Tagarelli, Antonio; Tagarelli, Giuseppe; Lagonia, Paolo; Piro, Anna, "A Brief History of Syphilis by Its Synonyms", Acta Dermatovenerol Croat 19-4 (2011), pp. 228-236.

Textor, Benedictus, Stirpium differentiae ex Dioscoride secundum locos communes. Opus ad ipsarum plantarum cognitionem admodum conducibile. Parisiis, Apud Simonem Colinaeum, 1534.

Torre Revello, José, "Pedro Mártir de Anglería y su obra De orbe nouo", Thesaurus: boletín del Instituto Caro y Cuervo 12 (1-3), pp. 133-153. 
(Página deixada prepositadamente em branco.) 


\title{
Os partos distócicos em Amato Lusitano e em Rodrigo de Castro: fontes, doutrinas e terapias greco-romanas
}

CRISTINA SANTOS PINHEIRO ${ }^{1}$

\section{RESUMO:}

Configurando-se tradicionalmente o parto como um acontecimento conduzido por parteiras, em que só excepcionalmente e perante dificuldades extremas se apelava a um médico, nos casos em que ambos estavam presentes manifestava-se uma distinção fundamental entre as práticas médicas utilizadas por uns e outros. Tendo esta divergência em mente, analisamos nas Curationum medicinalium centuriae de Amato Lusitano e no De universa mulierum medicina de Rodrigo de Castro Lusitano, as fontes gregas e romanas que os autores referem ao descreverem os partos distócicos - em especial, os tratados hipocráticos De mulierum affectibus e De superfetatione e os Gynaikeia de Sorano - e como o discurso de ambos reforça a importância do saber médico no contexto das dificuldades que é forçoso enfrentar nestas circunstâncias.

\section{PALAVRAS-CHAVE:}

História da Medicina; textos de ginecologia; medicina renascentista; obstetrícia; ginecologia.

\begin{abstract}
:
By tradition, childbirth was an event conducted by midwives, when only exceptionally and in face of extreme difficulties a doctor was called for. When the midwife and the doctor attended, a fundamental distinction emerged between the medical practices used by one and by the other. Having this difference in mind, we analyze in Amatus Lusitanus' Curationum medicinalium centuriae and in Rodericus a Castro Lusitanus' De universa mulierum medicina the Greek and Roman sources that the authors use to treat dystocia - in particular, the Hippocratic treatises De mulierum affectibus and De superfetatione, as well as Soranos' Gynaikeia - and how the discourse of these authors reinforces the importance of medical knowledge in the context of the difficulties they must face under these circumstances.
\end{abstract}

\section{KEYWORDS:}

history of medicine; gynaecological texts; Early Modern medicine; obstetrics; gynaecology.

1 Universidade da Madeira; Centro de Estudos Clássicos da Universidade de Lisboa: polybios@uma.pt. 
As dificuldades que podiam surgir no decorrer do nascimento de uma criança são tema de exposições detalhadas nos textos gregos e romanos sobre medicina. Já no Corpo Hipocrático ${ }^{2}$, as referências a fetos mortos ou em posição anormal in utero e a substâncias e técnicas que

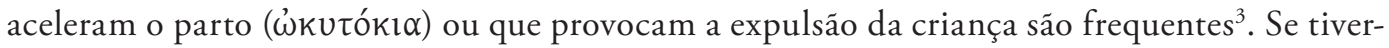
mos igualmente em consideração o pormenor com que se descrevem intervençóes cirúrgicas como a que tinha como finalidade desmembrar e extrair do ventre materno, parte por parte, um feto morto ou inviável, podemos com alguma legitimidade concluir que se tratava de uma situação frequente, que permitiu o desenvolvimento de um conjunto mais ou menos consistente de técnicas e saberes. Nestas ocasióes, em que, por alguma razáo, o parto não se desenrolava

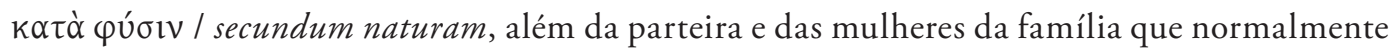
prestavam assistência, apelava-se ao médico.

Nancy Demand considera que no século V a. C. os autores dos tratados hipocráticos de ginecologia retiraram do domínio exclusivo das mulheres as questôes médicas relacionadas com a gravidez e o parto: «(...) childbirth was medicalized, and male doctors came to exercise a degree of control over female reproductivity as they created a Hippocratic gynecology.» ${ }^{4}$. Afirmações semelhantes a esta são frequentes para explicar o incremento notável na publicação de obras sobre ginecologia a que se assistiu na Europa entre as últimas décadas do século XVI e o século $\mathrm{XVII}^{5}$. Este interesse masculino numa área tradicionalmente associada às mulheres tem sido entendido como consequência da divulgação dos tratados hipocráticos sobre estas

2 O Corpo Hipocrático é constituído por cerca de seis dezenas de tratados atribuídos a Hipócrates, mas de autores incertos e com temáticas diversas. Não representa, portanto, uma colectânea uniforme ou um qualquer sistema de teorização médica coerente. Sobre doenças das mulheres, o Corpo Hipocrático inclui De mulierum affectibus 1 e 2 (Mul.); De sterilibus (Ster.); De natura muliebri (Nat. Mul.); De uirginum morbis (Virg.). Têm interesse também nesta matéria os tratados: De semine (Genit.), De natura pueri (Nat. Puer.), De septimestri partu (Septim.), De octimestri partu (Oct.), De foetus exsectione (Foet. Exsect.) e o De superfetatione (Superf.).

3 Vejam-se, a título de exemplo, alguns excertos que, no livro 1 do De mulierum affectibus, descrevem

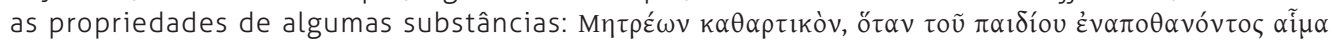

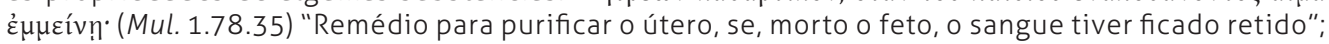

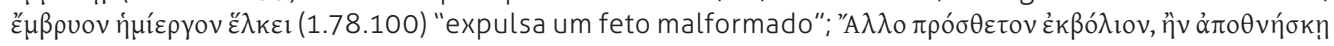

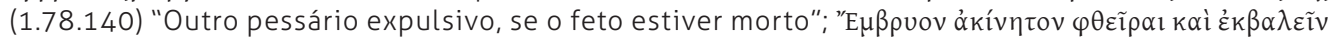

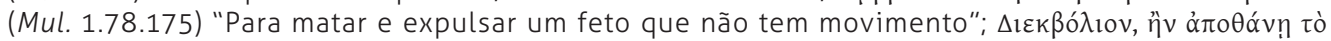

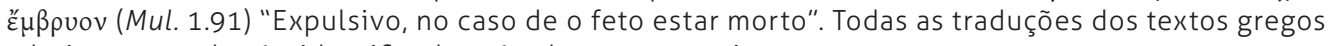
e latinos, quando não identificadas, são da nossa autoria.

4 Nancy Demand, "Monuments, midwives and gynaecology", in Ph. J. van der EIJK, H. F. HoRSTMANSHOFF, \& P. H. SCHRIJVERS (eds.), Ancient medicine in its socio-cultural context. Amsterdam, Rodopi, 1992, pp. 285-287.

5 Michael StolberG, "A woman down to her bones: the anatomy of sexual difference in the sixteenth and early seventeenth centuries", Isis 94 (2003), p. 288; Helen KING, Midwifery, obstetrics and the rise of gynaecology: the uses of a sixteenth-century compendium. Aldershot, Hants \& Burlington, Ashgate Publishing, 2007, p. 29. 
matérias, especialmente porque Galeno, à excepção de alguns tratados breves como o De uteri dissectione, não compusera um texto especificamente a elas dedicado ${ }^{6}$.

Assim, se, por um lado, se apresenta nestes textos um nível de conhecimento de índole popular, fundamentado principalmente na transmissão de receitas e associado ao desempenho das mulheres — parteiras e não só — , por outro lado, parece-nos evidente, na exuberância dos pormenores e numa certa tendência para mostrar capacidades técnicas alheias ao domínio feminino, a demonstração da proeminência do saber do médico que, especialmente numa situação desesperada como um parto difícil, se apresenta como superior e imprescindível. Recordemos que a presença do médico só se tornaria necessária precisamente quando o parto se desenrolava de forma anormal.

Os partos distócicos são tema recorrente nos tratados médicos da antiguidade relacionados com as doenças femininas e, na nossa opinião, parecem ter-se configurado como um tópico de cariz mais ou menos estável, que se repete quase sempre com as mesmas classificaçóes e características, mas que denota um interesse e uma sofisticação crescentes ${ }^{7}$. Nos tratados de ginecologia do século Xvi, títulos de capítulos como «Difficultas partus» (Nicholas de la Roche, De morbis mulierum curandis liber, 1542), "De praeceptis et medicaminibus partus moram et difficultatem allevantibus» (Jakob Ruff, De conceptu et generatione hominis, 1554) ou "Quibus praesidiis partum acceleremus et foetum mortuum pellamus» (Luigi Bonacciuoli, Muliebrium liber, 1505) são indício seguro de que se mantinha o entendimento dos partos distócicos como uma área fundamental na medicina dedicada às doenças femininas.

É objectivo desta pesquisa a procura de traços comuns aos tratados médicos antigos e a duas obras de autores portugueses - as Curationum medicinalium centuriae de Amato Lusitano e o De universa mulierum medicina de Rodrigo de Castro Lusitano - no que concerne à definição e ao tratamento dos partos difíceis. Náo se trata de uma pesquisa exaustiva nem diacrónica, mas apenas de uma identificação preliminar de tópicos comuns. Tomamos, assim, como ponto de partida para este estudo um corpus constituído por textos gregos e romanos que se debruçam sobre partos distócicos, em especial os tratados hipocráticos De mulierum affectibus e De superfetatione $e^{8}$ e o tratado de ginecologia de Sorano de Éfeso, os Gynaikeia. Este autor de origem grega terá exercido medicina em Roma nos principados de Trajano e Adriano e teve uma importância notável, ainda que indirecta, na literatura acerca das doenças e condiçóes femininas, uma vez que o seu tratado foi cedo

6 Também por esta razão omitimos nesta pesquisa a obra galénica. O facto de circular sob o nome de Hipócrates um conjunto de tratados sobre condições femininas parece ter concedido uma certa autoridade aos autores que, especialmente por influência da tradução latina de CALVI, publicada em 1525. invocavam o pai da medicina para legitimar as suas obras. Veja-se, a este respeito, Helen KING, Hippocrates' woman: reading the female body in ancient Greece. London \& New York, Routledge, 1998, p. 13.

7 Veja-se, por exemplo, Ann E. HANSON, "A division of labor: roles for men in Greek and Roman births", Thamyris 1.2 (1994), pp. 157-202.

8 Os partos difíceis são também referidos em tratados médicos de carácter mais geral, como as Epidemias. 
abreviado e traduzido em língua latina ${ }^{9}$. Estas versóes simplificadas, em especial a Genecia, de um autor desconhecido, identificado nos manuscritos como Muscio ou Mustio (? c. 500), foram muito divulgadas na Europa. Apesar da problemática tradição manuscrita da obra de Sorano — chegou até nós um único manuscrito, e incompleto, dos Gynaikeia, encontrado já em pleno século xIx ${ }^{10}$ —, o livro IV dos seus Gynaikeia, dedicado às patologias ginecológicas a serem tratadas pelo recurso a substâncias medicinais ou a intervenções cirúrgicas, constitui uma fonte importante acerca da tradição médica dedicada aos partos distócicos. Autores de enciclopédias médicas como Aécio de Amida (séc. V-VI), ou Paulo de Egina (séc. VII), retomando a tradição, incluem também nas suas obras consideraçóes consistentes acerca deste assunto e por este motivo os incluímos também aqui.

Constituem uma segunda componente do corpus em análise as já referidas obras de Amato Lusitano e de Rodrigo de Castro Lusitano, ambas fundamentais na história da medicina em Portugal: as Curationum medicinalium centuriae, publicadas em 1556, e o De universa mulierum medicina de Rodrigo de Castro. No contexto do presente volume, Amato dispensa apresentaçóes. Dele analisamos um conjunto de casos reais em que o autor descreve a terapia a que recorreu quando chamado a ajudar mulheres em sofrimento devido ao que ele designa de partus diffciles. O De universa mulierum medicina é um tratado de ginecologia, publicado pela primeira vez em 1603 e em 1604, em dois tomos, em Hamburgo, onde o seu autor se instalara para fugir da Inquisição, e que foi reeditado durante décadas. Os dois volumes - um, De natura mulierum, especialmente teórico; o segundo, De morbis mulierum, de natureza prática — com quatro livros cada, tratam, de forma abrangente e documentada, condiçóes femininas como a concepção, a menstruação, a gravidez, o parto, o aborto, a infertilidade, etc., e constituem um reportório monumental acerca do estado da ciência do seu tempo, especialmente no diálogo que estabelece entre tradiçôes díspares, como a clássica e a escolástica, mas também e não menos importante, pela proeminência das novas ideias que por então enformam a medicina.

Abordamos hoje os elementos que nestas duas obras entroncam na tradição grega e romana acerca dos partos distócicos e como a reelaboração destes elementos no contexto da medicina dos séculos XVI e XVII permite distinguir e fundamentar o saber médico numa área maioritariamente reservada às mulheres.

A definição de parto distócico que é hoje em dia comummente aceite («parto difícil, causado por anomalias no feto ou na mãe» ${ }^{11}$ ) não anda muito longe das definições antigas, que associam

9 Sobre a pervivência da obra de Sorano na medicina ocidental, cf. Ann E. HANson \& Monica H. GREEN, "Soranus of Ephesus: Methodicorum princeps", ANRW II.37.2 (1994), pp. 968-1075, maxime pp. 1042 ss., e Yves Malinas, "Modernité de Soranos", in P. BurguiÈRe, D. GourevitCh \& Y. MALInAs, Soranos d'Éphèse. Maladies des femmes I. Paris, Les Belles Lettres, 2003², pp. LXVII-LXXIV.

10 Sobre a descoberta do Parisinus Graecus 2153 por Friedrich Dietz, cf. P. BuRGUIÈrE, "Histoire du Texte", in P. Burguière, D. Gourevitch \& Y. Malinas, Soranos d'Éphèse..., op. cit., 2003², pp. XLVII-LXV.

11 Veja-se, a título de exemplo: «Dystocia - difficult birth, caused by abnormalities in the fetus or the mother (...). Dystocia may arise due to uterine inertia, which is more common in a first labour; abnor- 
a difficultas pariendi a três, por vezes a quatro causas. Nos tratados hipocráticos, é de preferência

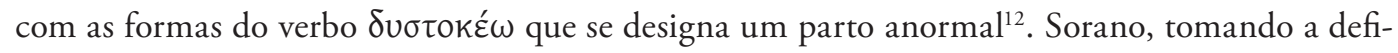
nição de Demétrio de Apameia, como o próprio Sorano seguidor de Herófilo de Alexandria e da escola metódica ${ }^{13}$, define distocia como um parto penoso ( $\left.\delta v \sigma \chi \varepsilon \rho \tilde{\eta}\right)$ ou difícil ( $\left.\mu \varepsilon \tau \grave{\alpha} \delta v \sigma \varepsilon \rho \gamma \varepsilon i ́ \alpha \varsigma\right)$ :

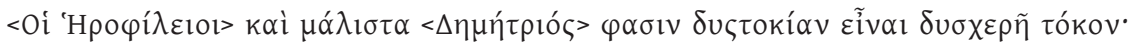

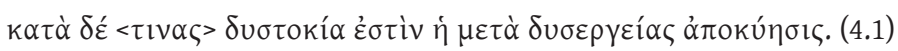

Os seguidores de Herófilo e especialmente Demétrio dizem que parto distócico é um parto penoso; para alguns, parto distócico é dar à luz entre dificuldades.

E prossegue com uma longa recensão das causas propostas para os partos distócicos por autores que o precederam (Díocles de Caristo, Cleofanto, Herófilo, Demétrio...), que vai citando e comentando. Na Genecia, Múscio reduz todas as consideraçóes de Sorano acerca das causas propostas pelos seus antecessores, abreviando-as e organizando-as de forma mais simplificada e acessível:

Quot sunt enim causae quibus laboriosus vel difficilis partus efficitur?

Plurimi duas causas esse dixerunt, unam apud eam quae parit, alteram apud ipsum infantem qui nasci habet. Alii vero iam tertiam causam addunt quae extrinsecus venire consuevit. Apud alios etiam quarta causa emergit, quae ex omnibus praedictis causis miscetur. (2.17.1)

Quantas são as causas de um parto penoso ou difícil?

A maioria dos autores disse que existem duas causas, uma relacionada com a parturiente, outra com a própria criança que nasce. Outros, porém, acrescentam uma terceira causa

mal fetal lie or presentation; absolute or relative cephalo-pelvic disproportion; (...)», Oxford Concise Medical Dictionary. Oxford University Press, $2010^{8}$, s. v. "Dystocia".

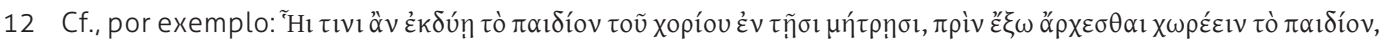

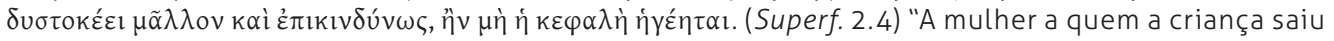
da placenta dentro do útero antes de começar a sair, tem um parto extremamente difícil e perigoso, se

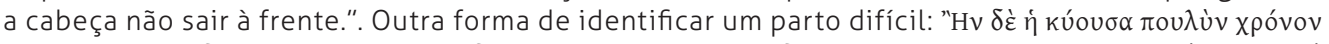

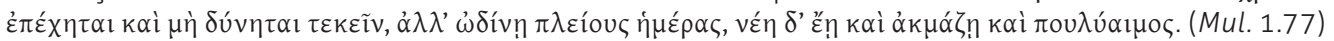
"Se uma mulher grávida depois de muito tempo não é capaz de dar à luz, mas tem dores durante muitos dias, é jovem e forte e tem muito sangue (...)".

13 Sobre a obra de Demétrio de Apameia, cf. H. von StAden, Herophilus: the art of medicine in early Alexandria. Cambridge-New York, Cambridge University Press, 1989, pp. 506 ss. 
que costuma vir do exterior. Na obra de outros surge ainda uma quarta causa, que é composta por todas as causas referidas antes.

Aécio de Amida (Iatricorum liber 16.22) divide em três tipos os factores que podem difi-

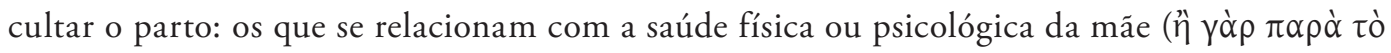

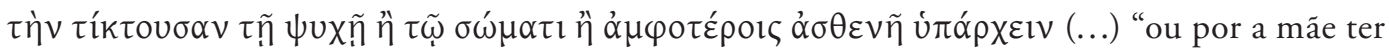

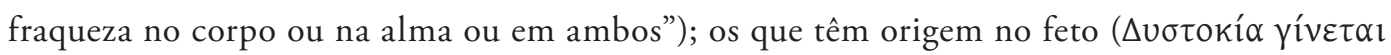

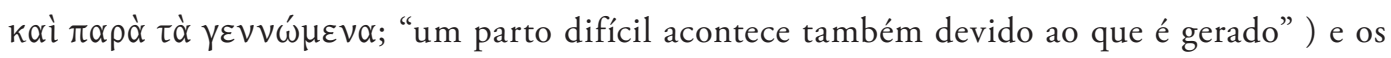

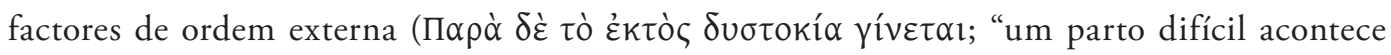
devido ao exterior"). Paulo de Egina (Epitomae Medicae 3.76) apresenta quatro causas:

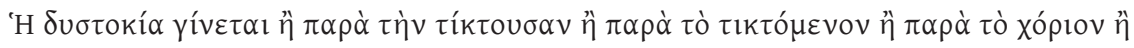
$\pi \alpha \rho \dot{\alpha} \tau \dot{\alpha} \check{\varepsilon} \xi \omega \theta \varepsilon v^{.}$

Um parto distócico acontece ou devido à parturiente, ou devido ao feto, ou devido à placenta, ou devido a causas externas. ${ }^{14}$

Nos textos em análise, distinguem-se efectivamente e de um modo geral as causas relacionadas com a saúde materna, as que são causadas pelo estado do feto e as condiçóes externas que podem condicionar o decorrer normal do parto, como condiçóes climatéricas adversas ou mesmo a inexperiência da parteira ou do médico que orienta o parto.

Amato recorre principalmente ao vocabulário associado à diffcultas ou ao labor para designar um parto demasiado longo e penoso ${ }^{15}$. Rodrigo de Castro, pelo contrário, tem uma abordagem sistemática e fundamentada na distinção entre um parto natural, assunto que explora no primeiro capítulo desta secção, e os seus opostos, que trata nos capítulos subsequentes. Esta oposição é apresentada logo no início quando justifica a inclusão de um capítulo sobre partos normais no volume da obra que dedica às condiçôes patológicas. Para que um parto seja designado como um parto normal deve obedecer, segundo Castro, a cinco condiçóes:

14 Nas Definitiones Medicae 19.456, uma obra atribuída a GALENo, mas de autoria duvidosa, afirma-se

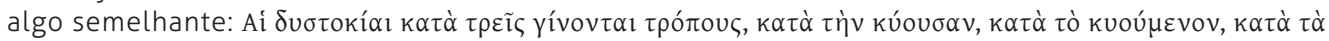
$\tilde{\varepsilon} \xi \omega \theta \varepsilon v$. "Os partos distócicos acontecem de três maneiras: devido à grávida, devido ao feto, devido a causas externas.".

15 Apenas alguns exemplos: (...) difficulter pariebat (Cent. VI, curas 51 e 86) refere-se em ambos os casos ao parto de fetos mortos; ut plerunque partum difficilem habentibus evenit (Cent. I, cura 93) cum per triduum in emittendo foetu, graviter laboraret (Cent. V, cura 34) designam o parto de gémeos. 
(...) ad naturalem partum quinque requiri conditiones. Prima est, ut fiat profecto iam foetu; Secunda ut debito tempore; Tertia ut debita figura; Quarta ut levibus symptomatibus; Quinta ut evacuationibus debitis. (2.4. cap. 1, pp. 445-446)

(...) para um parto natural são necessárias cinco condições: a primeira, que aconteça quando o feto está formado; a segunda, que aconteça no tempo oportuno; a terceira na posição conveniente, a quarta com sintomas toleráveis; a quinta com evacuaçóes convenientes.

Qualquer parto em que não se verifique uma destas situaçóes é um parto que não é natural: o nascimento de um feto morto ou um aborto (náo se cumprem a primeira e a segunda), o parto de um feto em posição anormal (não se cumpre a terceira), um parto difícil e penoso (não se cumpre a quarta), e, por fim, um parto seguido de retenção da placenta (não se cumpre a quinta). Uma distinção fundamental no De universa mulierum medicina, que não está presente em nenhuma das obras em análise, é a que o autor estabelece entre partus vitiosus e partus difficilis et laboriosus: o primeiro é o nascimento de um feto em posição anormal, o segundo um parto com sofrimento prolongado e que representa um risco para a mãe:

Dicitur autem difficilis partus ille, qui cum foetus vel matris periculo accidit, vel quia cum gravissimis fit symptomatibus, vel quia tardius procedit, ita ut longo tempore prematur mulier. (2.4. cap. 6, p. 478)

Diz-se um parto difícil aquele que acontece envolvendo perigo para o feto ou para a máe, quer porque se desenrola com sintomas muito graves, quer porque avança de forma muito lenta, de modo a que a mulher seja atormentada por muito tempo.

Entre as causas relacionadas com a saúde materna, os autores são mais ou menos unânimes ao referir que não só a condição física da parturiente, mas também o seu estado psicológico podem originar dificuldades no parto. Sorano, reproduzindo o pensamento do já citado Demétrio, realça efectivamente a importância do equilíbrio mental e emocional da paciente:

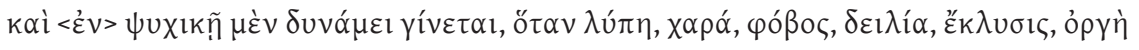

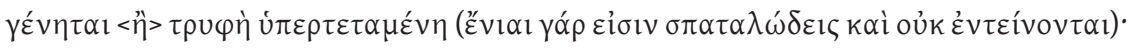

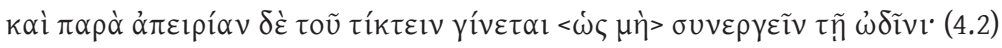

O parto difícil deve-se também à força psíquica quando acontece a dor, a alegria, o medo, a timidez, a fraqueza, a ira, ou uma vida de luxo exagerado (pois algumas mulheres são 
indulgentes e não fazem esforços). Acontece também por falta de experiência em dar à luz: [a parturiente] não colabora no trabalho de parto.

O bem-estar psicológico da mãe é factor essencial no momento em que se prepara o parto ${ }^{16}$, mas é absolutamente determinante se este se complicar. Entre as causas de distocia relacionadas com a parturiente, Sorano adverte a parteira para que tenha sempre cuidado de modo a que os seus gestos, o seu olhar, as suas palavras não assustem a parturiente, com frequência demasiado jovem para entender o que se passa à sua volta. Esta falta de experiência é, aliás, enumerada entre os factores que podem condicionar o desenrolar do parto, por poder originar a retracçáo do corpo da mãe, que deixa de colaborar com a parteira. A primípara é, normalmente, uma paciente a ter sob vigilância ${ }^{17}$. Veja-se, por exemplo a afirmação do tratado De mulierum affectibus:

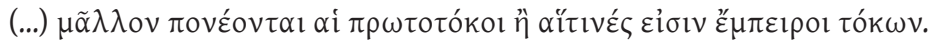

(...) Sofrem mais as primíparas do que as que têm experiência no parto.” (Mul. 1.72)

Sorano refere também a falta de experiência das primíparas como um obstáculo a um parto

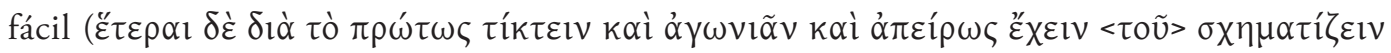

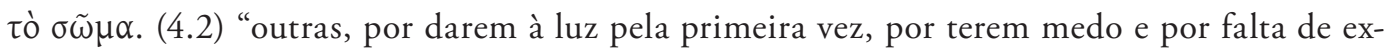
periência em colocar o corpo na posição certa"), mas assinala igualmente as jovens que casam demasiado cedo, cujo corpo não está ainda preparado para o parto:

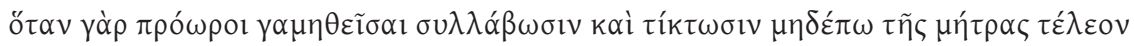

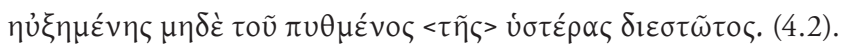

Pois, casadas antes do tempo adequado, engravidam e dáo à luz quando o útero ainda não atingiu o seu crescimento máximo nem o fundo da matriz se abriu.

Entre os factores de ordem física, assumem relevo, além das patologias do útero ou do colo do útero, que dificultam ou impossibilitam a passagem do feto, a extrema magreza ou, em

16 Rodrigo de Castro, por exemplo, aconselha as parteiras que dêem ânimo à parturiente consolando-a com a esperança de um parto de um rapaz: Parientem obstetrix (...) etiam verbis consoletur cum bona spe felicis ac masculi partus, eo enim mulieres sese gaudent (...). "Que a parteira (...) anime a parturiente com a esperança de um parto fecundo e de um rapaz, porque as mulheres alegram-se com isso." (II. 4. cap. 1, p. 448).

17 Cf. também a observação de Rodrigo de Castro: parturiens puella (...) ob imperitiam corpus apte praeparare ignorat. "A jovem parturiente (...) por falta de experiência não sabe como preparar convenientemente o corpo." (II. 4. cap. 6, p. 472). 
oposição, a obesidade da mãe. Os problemas relacionados com o peso são aliás frequentemente assinalados como obstáculo a todo o ciclo de procriação, já que tanto as mulheres obesas como as magras em demasia têm, de acordo com os tratados médicos antigos, dificuldade em engravidar, ou, se engravidam, são incapazes de levar a gravidez a termo ${ }^{18}$. Sorano refere igualmente a obesidade da mãe entre as causas relacionadas com a condição física da parturiente ${ }^{19}$.

É também notado por estes autores que o facto de a mulher grávida ter uma vida sedentária e inactiva dificulta o parto, enquanto o exercício é benéfico, não apenas porque favorece um parto normal, mas também porque contribui para a saúde da criança.

Entre as causas relacionadas com o feto, todos os autores referem o seu tamanho, na totalidade ou numa parte do corpo, um feto morto, o nascimento de gémeos ou a posição anormal no útero materno. Veja-se o que diz Sorano:

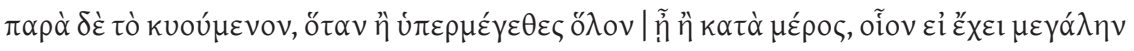

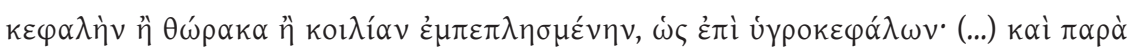

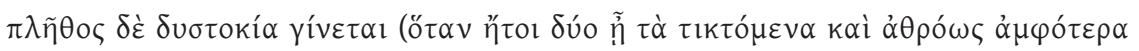

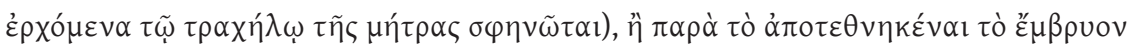

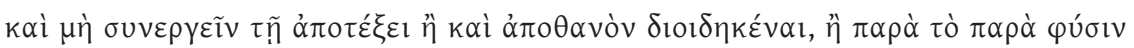
$\dot{\varepsilon} \sigma \times \eta \mu \alpha \tau i ́ \sigma \theta \alpha$ l. (4.2)

Causas relacionadas com o feto: quando é demasiado grande quer no corpo inteiro quer numa das partes, como quando tem a cabeça ou o tórax grandes ou o ventre inchado, como acontece nos hidrocéfalos. (...) Ocorre também um parto distócico devido ao número (quando são dois e ambos se aproximam em conjunto do colo do útero causando uma obstrução), ou por o feto estar morto e não colaborar no parto ou por, visto estar morto, estar intumescido, ou por se apresentar numa posição anormal. ${ }^{20}$

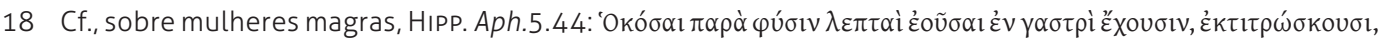
$\pi p i v$ ทे $\pi \alpha \chi v v \theta \tilde{n} v \alpha$. "As mulheres grávidas que são anormalmente magras abortam enquanto não ficarem mais fortes.". Ideias semelhantes em HIPP. Ster. 237 e Nat. Mul. 19. Sobre mulheres obesas, cf. Aph.

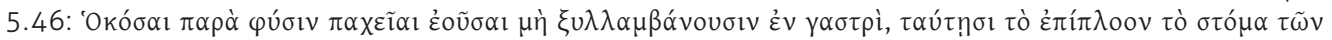

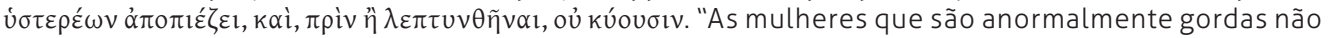
concebem no seu ventre, pois a estas a gordura pressiona-lhes a entrada do útero e, enquanto não emagrecerem, não engravidam.". Em HIPP. Ster. 229 e Nat. Mul. 20 fazem-se afirmações idênticas.

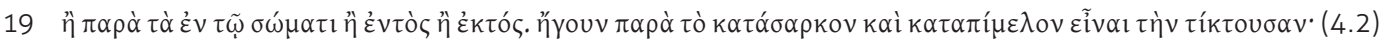
"Há ainda causas físicas, internas ou externas, como a parturiente ser extremamente corpulenta e gorda.". Esta ideia é repetida verbatim por AÉcıo de AMIDA (lat. 16.22).

20 As causas relacionadas com o feto não são muito diferentes nos outros autores: "Hv $\delta \dot{\varepsilon} \gamma u v \alpha \iota k i ̀ ~ \varepsilon ́ v ~ \gamma \alpha \sigma \tau \rho i$

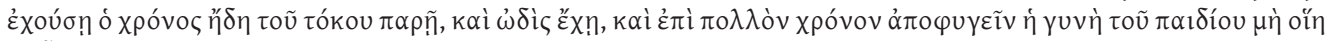

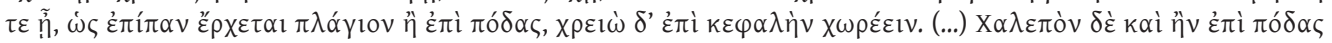

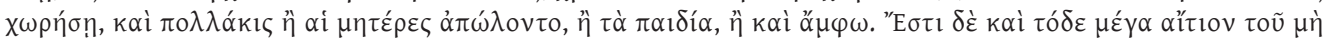


Rodrigo de Castro, repetindo uma ideia que remonta aos tratados hipocráticos, afirma que dificulta o parto um feto maior do que o normal ou, pelo contrário, demasiado pequeno, porque este náo consegue romper as membranas e àquele o útero náo consegue adaptar-se. A criança é deste modo vista como incapaz de desencadear o parto e de fazer o seu próprio caminho em direcção à vida:

Ex parte foetus causae sunt, si inusitatae magnitudinis existat, aut exiguus nimis, qui nec vincula disrumpere queat: nec uterus ei adaequetur. Aut si magni capitis, vel admodum exigui, hic enim non aperit vias, nec ab obstetrice apprehendi potest; ille difficulter egressum invenit. Similiter si parvi ponderis aut debilis sit, quia tunc seipsum adminiculantem non praestat. (2.4. cap. 6, p. 472)

Da parte do feto as causas são: se tem um tamanho grande inusitado ou demasiado pequeno que nem consegue romper os vínculos nem o útero a ele se adequa. Ou se tem a cabeça grande ou muito pequena, pois este não abre o caminho nem pode ser puxado pela parteira; aquele dificilmente encontra a saída. Do mesmo modo, se tiver pouco peso ou se for débil, porque não é capaz de se auxiliar a si próprio.

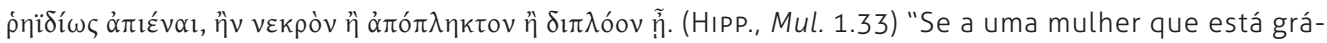
vida passou já o momento do parto e sente dor, e depois de ter passado muito tempo a mulher não foi capaz de expulsar a criança, em geral está em posição lateral ou podálica, sendo necessário que saia de cabeça. (...) É também causa de dificuldades se sair de pés, e muitas vezes morrem as mães ou as crianças ou ambos. Existe outra razão importante que o impede de sair facilmente: quando

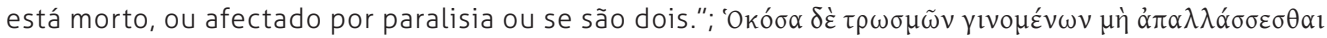

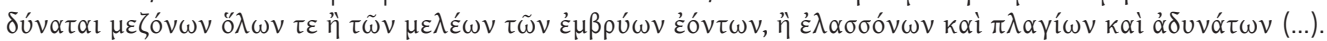
(Mul. 1.68) "No caso de, tendo ocorrido um aborto, não se poder expulsar o feto por ser demasiado grande no todo ou num dos membros, ou por ser pequeno, estar de lado e fraco (...)"; Quomodo dicunt per infantem qui nasci habet difficilimum partum dari? Scilicet qui naturaliter grande caput habeat vel omne corpus, vel tres manus, aut certe hydropicus sit vel gibberosus vel languidus aut inflatus vel mortuus aut positione contra naturam. (Múscio, Genecia 17.3) "Como dizem que o parto se torna muito difícil devido à criança que vai nascer? Seguramente aquele que tem por natureza a cabeça grande ou todo o corpo, ou três mãos, ou se é hidrópico, corcovado, fraco, ou se estiver intumescido ou morto ou em

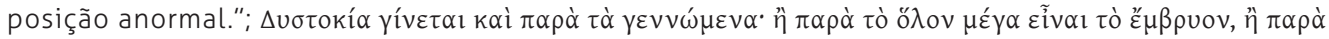

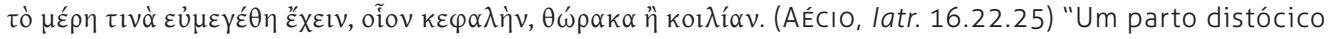
acontece também devido ao que é gerado: ou por o feto ser todo ele grande, ou por ter alguma parte

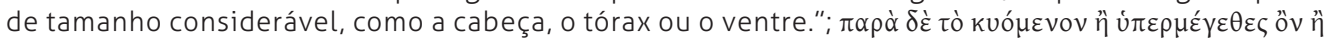

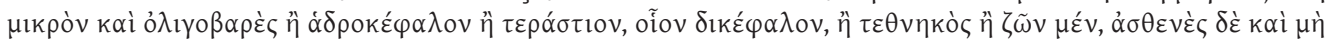

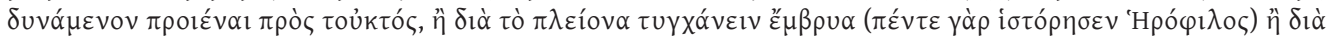

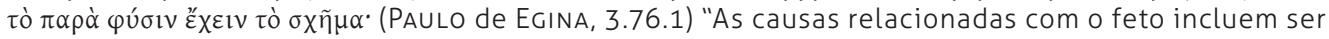
demasiado grande ou pequeno e leve, hidrocéfalo ou monstruoso, como ter duas cabeças, ou estar morto ou ter ainda vida mas ser fraco e incapaz de avançar para o exterior, ou acontecer serem muitos fetos (Herófilo registou cinco) ou estar uma posição anormal.". 
A gestação de um feto monstruoso é igualmente uma das causas apontadas para um parto difícil ${ }^{21}$. Diga-se que este tema gerará grande interesse na literatura do período renascentista, com a publicação de vários tratados, alguns com representaçóes de seres deformados e entendidos como nascimentos prodigiosos ou como uma punição divina ${ }^{22}$. Amato, por exemplo, descreve um monstro nascido no terceiro ou quarto mês de gestação de uma mãe habitante de Ancona. Não é certo se ele próprio o terá visto, mas descreve-o com pormenor:

\begin{abstract}
Mulier Anconitana monstrum quoddam peperit: nam tertio vel quarto mense impregnationis informe quoddam carneum corpusculum emisit, quod omnino hirsutum erat et pilosum, quatuor habens óculos, duas nares, quatuor aures, labra vero deformia, ut omnibus esse admirationi. (Cent. III, cura 57)

Uma mulher anconitana deu à luz um monstro. No terceiro ou quarto mês da gravidação deitou fora um corpúsculo carnoso, informe, totalmente hirsuto e cabeludo, com quatro olhos, dois narizes, quatro orelhas e lábios disformes. A todos causava espanto. ${ }^{23}$
\end{abstract}

Diz ainda que enquanto escreve (cum haec scribo), chegou a Ancona um rapaz da Ilíria, com seis anos, aparentemente normal, mas trazendo consigo (ou em si?) um monstro que lhe ocupava o espaço entre o umbigo e o tórax e tinha a forma de outro corpo de criança, sem cabeça, mas com braços e pernas, ainda que imóveis ${ }^{24}$.

A morte do feto in utero deve ter sido muito frequente. Expressões com o significado de "para expulsar um feto morto" são repetidas à exaustão para introduzir uma panóplia de receitas e terapêuticas que aparecem desde os textos hipocráticos a Plínio-o-Velho ${ }^{25}$ e se mantêm na tradição. Nas curas 51 e 86 da Centúria VI, Amato descreve precisamente dois casos em que fetos mortos no ventre materno originaram partos prolongados e dolorosos. Recordemos apenas a situação

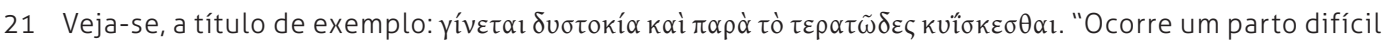

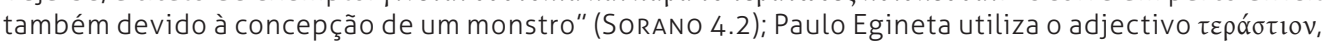
que significa "monstruoso" ou "prodigioso". Rodrigo de Castro refere-se a um foetus monstruosus como causa de dificuldades no parto.

22 Veja-se Lorraine DASTON \& Katherine PARK, Wonders and the order of nature, 1150-1750. New York, Cambridge, Mass., Zone Books, 1998.

23 Amato Lusitano, Centúrias de curas medicinais, vol. II (trad. Firmino CRespo). Lisboa, Universidade Nova de Lisboa, s. d., p. 267.

24 Amato Lusitano, Centúrias..., op. cit., p. 268. Para dar veracidade ao seu relato Amato termina o texto com a data: Fuit autem hoc monstrum Anconae, anno 1552. "Este monstro esteve em Ancona no ano de 1552.".

25 Cf. supranota 2. De Plínı, vejam-se, por exemplo, Nat. 23.62; 24.22; 24.102; 26.152; 26.153; 26.154; $26.157 ; 26.158 ; 26.161 ; 27.30 ; 28.252$. 
desesperada de Aloísia, a quem só depois de três dias de sofrimentos atrozes e quando já todos a davam como morta, conseguiram extrair, em pedaços, o filho sem vida. Rodrigo de Castro, repetindo o que se escreve no De superfetatione, diz que um feto morto se identifica se a máe se deitar de lado. Se o feto já não tiver vida, mover-se-á como uma pedra ${ }^{26}$. A este assunto dedica todo um capítulo nesta secção da sua obra, que faz seguir por outro acerca da prática da cesariana, uma novidade do seu tempo, divulgada por François Rousset, na sua obra Traité nouveau de l'hysterotomotokie ou enfantement Caesarien, publicada em Paris em 1581 e posteriormente traduzida para língua latina e incluída nos Gynaeciorum libri, um compêndio monumental de obras dedicadas a doenças e condiçóes femininas, muito divulgado na Europa.

Também os partos múltiplos são enumerados entre os partos difíceis. Herófilo, citado por Sorano e Paulo de Egina, teria descrito o caso de uma mulher que, em cada um de três partos, tinha tido cinco filhos, ou seja, um total de quinze crianças ${ }^{27}$.

De Amato citamos a cura 34 da Centúria V, a das meninas amarelas, as puellae luteae, irmãs gémeas que nasceram amarelas devido ao açafrão que era um dos ingredientes da medicação aconselhada por Amato, depois de um parto que se prolongou também por dias. Os partos

26 Cognosces foetum in utero mortuum esse, si admota manu amplius moveri non percipitur, sed decumbente foemina in latus, in id devolvitutr etiam infans, veluti immobile quoddam saxum. "Saber-se-á que o feto está morto no útero se colocando a mão [i. e. no ventre] se perceber que já não se move, mas, deitando-se a mulher de lado, para esse lado vira-se também a criança, imóvel como uma qualquer pedra.". Veja-se

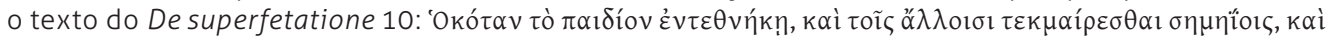

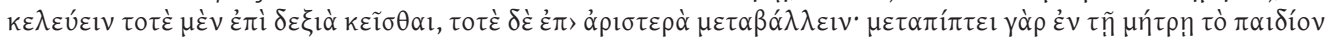

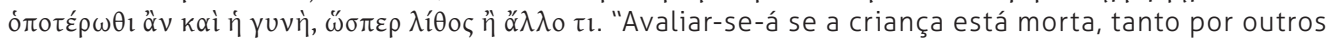
sinais como pedindo [à mãe] que se deite primeiro sobre o lado direito, depois que mude para o lado esquerdo, pois a criança no útero vai para a direcção para a qual se virou a mãe, como uma pedra ou algo assim.".

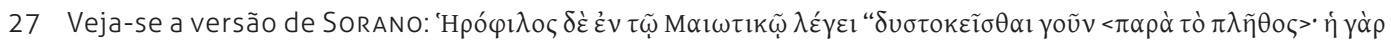

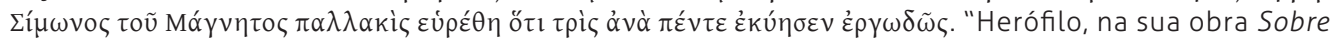
os Partos afirma: "acontecem partos difíceis devido ao número [de fetos]: deu-se o caso da concubina de Símon da Magnésia que em três vezes deu à luz cinco filhos entre dificuldades.". Cf. o texto de PAULo de EGINA, supra n. 17. Veja-se também o texto de Aristóteles: "Na maior parte dos casos e na generalidade dos países, as mulheres dão à luz uma só criança; mas é também frequente e ocorre por toda a parte que tenham duas, como é o caso do Egipto. Podem até ter três ou quatro gémeos, em certas regiões bem definidas (...). O máximo é cinco, situação que já se verificou várias vezes. Houve um único caso de uma mulher que, em quatro partos, deu à luz vinte filhos; teve, de facto, cinco gémeos de cada vez, e conseguiu criar a maior parte." ARISTóteles, História dos Animais II (tradução de M. F. Sousa e SILVA). Lisboa, Imprensa Nacional-Casa da Moeda, 2008, p. 215. De acordo com Aulo Gélio, o imperador Augusto terá mandado erigir uma estátua a uma sua escrava que deu à luz quíntuplos: Sed et diuo Augusto imperante, qui temporum eius historiam scripserunt, ancillam Caesaris Augusti in agro Laurente peperisse quinque pueros dicunt eosque pauculos dies uixisse; matrem quoque eorum non multo, postquam peperit, mortuam, monumentumque ei factum iussu Augusti in uia Laurentina, inque eo scriptum esse numerum puerperii eius. (Gel. 10.2.2). "Mas também no reinado do divino Augusto, dizem aqueles que escreveram a história do seu tempo, uma escrava de César Augusto deu à luz no campo de Laurento cinco rapazes e que eles viveram poucos dias; a mãe deles morreu também não muito depois do parto. Por ordem de Augusto, foi construído em memória dela um monumento na via Laurentina, e nele estava escrito o número dos filhos dela.". 
de gémeos suscitaram sempre alguma surpresa, ora acolhidos como sinal de fecundidade e prosperidade, ora interpretados como símbolo de crise e de carestia ${ }^{28}$.

A causa de distocia mais comentada é, todavia, a apresentação anormal do feto no ventre

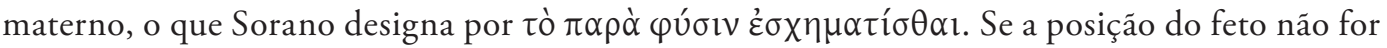
a cefálica, unanimemente apresentada nestes textos como a posição natural e conveniente ao parto, ou a podálica, deve tentar-se corrigi-la, manipulando interna e externamente o corpo da criança ${ }^{29}$. No livro 1 do De mulierum affectibus explicam-se as dificuldades geradas por um feto em posição anormal recorrendo a uma imagem muito sugestiva: como acontece com um caroço de azeitona dentro de um lekytos, de um vaso de gargalo alto e estreito, que não se consegue tirar se náo estiver alinhado com a abertura, o mesmo sucede com uma criança numa posição que não a cefálica ou a podálica ${ }^{30}$.

As apresentações que um feto podia assumir dentro do útero seriam tema de uma série de gravuras que acompanhariam o texto de Sorano. Lamentavelmente, o único manuscrito que o conserva, o Parisinus Graecus, apresenta os espaços correspondentes em branco. Os manuscritos da Genecia de Múscio, bem mais numerosos, apresentam estas ilustraçóes, que foram divulgadas na Europa desde muito cedo. De facto, circularam mesmo separadamente do texto e chegaram, por vezes, a ser incluídas como anexo em textos de autores posteriores ${ }^{31}$. Podemos observar estas imagens num manuscrito do século Ix, que mostra as posiçóes secundum naturam e depois as praeter naturam ${ }^{32}$.

Amato Lusitano aconselha o seu leitor, especialmente se for Hispanicus e considerar sacrilégio cortar um cadáver, a procurar informações sobre as apresentações do feto in utero nos modernos livros de anatomia. Esta referência, entendida como uma alusão a Vessálio, pode, no entanto, remeter o leitor para as muitas versóes das imagens da Genecia de Múscio que circulavam por então também na obra de autores contemporâneos como Eucharius Rösslin, uma vez que na obra de Vessálio não se representa o feto dentro do útero materno ${ }^{33}$. Rodrigo de Castro referese precisamente a estas imagens ao descrever as posiçóes da criança:

28 Sobre os nascimentos múltiplos, veja-se V. DASEN, "Multiple Births in Graeco-Roman Antiquity", Oxford Journal of Archaeology 16.1 (1997), pp. 49-63.

29 Para algumas descrições destas manobras, cf., por exemplo, Sorano 4.4; Múscio, Genecia 2.18.11.

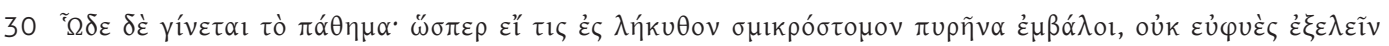

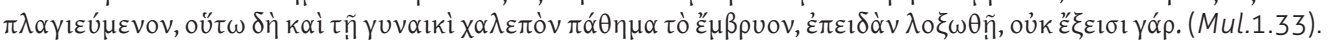
"O sofrimento acontece pelo seguinte: como se alguém tivesse colocado dentro de um vaso de entrada pequena um caroço de azeitona, que não tem uma forma adequada para ser retirado de lado, assim também o feto, se estiver de lado, é causa de grande sofrimento para a mulher, pois não sai.".

31 Cf. Hanson \& Green, "Soranus...", op. cit., pp. 1023-1024, e Monica H. Green, "The sources of Eucharius Rösslin's Rosegarden for Pregnant Women and Midwives (1513)", Medical History 53 (2009), pp. 167-192.

32 As imagens podem ser visualizadas em http://wellcomeimages.org/indexplus/image/M0007236.html.

33 Afirma Amato: Caeterum, quomodo gemini in utero ex adversa figura sedeant, et quo modo singulus singulis involucris et membranis circumvolvatur, ad anatomicos libros hodiernos, miris depictos figuris, 
(...) quas omnes figuras Hippocrates posuit, eas vero, ac plures ad easdem reducendas depinxit Eucharius Rodion. (2.4. cap. 5, p. 468)

(...) todas estas apresentaçôes foram expostas por Hipócrates, mas a estas e a muitas que podem ser resumidas a estas representou-as Eucharius Rösslin.

A descrição das manobras necessárias para colocar o feto na posição indicada para nascer é longa nestes textos ${ }^{34}$, mas acompanhada normalmente pela afirmação de que, se não se consegue extrair a criança de modo nenhum, deve recorrer-se a uma cirurgia, já descrita nos tratados hipocráticos e que consistia em desmembrar o feto morto, retirando-o posteriormente por partes ${ }^{35}$. Também Celso, que terá vivido na primeira metade do século I d. C., autor do De medicina, parte integrante da sua obra enciclopédica que abrangeria outros assuntos, descreve com pormenor esta cirurgia, desde as partes do corpo do feto que se devem ir amputando e extraindo até aos instrumentos mais indicados para o fazer (7.29). Trata-se, todavia, e todos os autores o afirmam, de uma cirurgia de riscos elevados para a mãe, cuja vida se pretende salvar, e que não deve ser realizada antes de a informar dos perigos que corre (4.9). No De superf. 7 , recomenda-se que se cubra a cabeça da parturiente, de modo a que esta não se atemorize. Na cura 51 da Centúria VI, depois de dois dias de sofrimentos intoleráveis, da aplicação, aconselhada por Amato perante a desistência das parteiras, de fomentaçóes e de substâncias esternutatórias, saiu do útero da jovem Aloísia o braço enegrecido do seu filho morto. Depois de partido o braço, um dexter chirurgus introduziu as mãos no ventre da mãe e extraiu a criança. Diz Amato que se isto não tivesse sido eficaz, teria de recorrer-se a um instrumento conhecido pela designação de "espéculo da matriz" para retirar o feto, inteiro ou por pedaços ${ }^{36}$.

recurrite, si modo vobis praesertim Hispanis, quibus piaculum est cadaver considere, non contingat aliter experire. (Cent. VI, cura 51) "Como é que os gémeos estão colocados no útero, em posição adversa, e como estão envolvidos cada um com as suas membranas ou invólucros recorra-se aos modernos livros de anatomia, com gravuras de admirável desenho, se, no entanto (especialmente aos hispânicos, para quem é crime retalhar um cadáver) não calhar experimentar de outro modo." AMATo LusitANo, Centúrias..., vol. IV, op. cit., p. 84.

34 SORANO 4.4.

35 SORANO 4.9-13; MúsCIO 2.18.26ss.; AÉCIO 16.23. A embriotomia é já descrita nos tratados hipocráticos, por exemplo em Mul. 1.68-70; Foet. Exsect. 1 e Superf. 7, o que atesta a antiguidade da sua prática.

36 Rodrigo de CASTRO, sobre a possibilidade de desmembrar um feto vivo no ventre materno afirma: ac etiamsi nulla medicamenta prosint, puer tamen vivus dissecari nulla ratione debet, quamvis Avicenna, Aëtius, \& Moschio id praecipiant, non enim licet unum interficere, alterius vitae gratia, sed implorato divino auxilio medicamentis, insistendum. (2.4. cap. 6, p. 477) "E ainda que nenhum medicamento seja eficaz, todavia por nenhuma razão se deve dilacerar uma criança viva, mesmo que Avicena, Aécio e Múscio o aconselhem. É que não é lícito matar uma pessoa por causa da vida de outra, mas, depois de implorar a ajuda divina, deve-se continuar com o uso de medicamentos.". 
Não cabe no âmbito desta pesquisa uma análise das substâncias cujo uso se recomenda para acelerar o parto. Não podemos, porém, deixar de referir a utilização de substâncias que provocam o espirro, como o heléboro e a pimenta, especialmente porque a utilização destas substâncias está relacionada com o muito citado Aforismo 5.35 de Hipócrates:

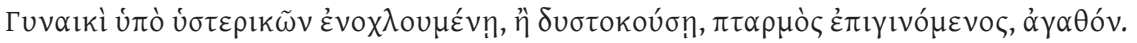

A uma mulher afectada por patologias uterinas ou num parto difícil, se lhe sobrevier um espirro, é bom. ${ }^{37}$.

O espirro era uma forma de sacudir o corpo da paciente que poderia levar a uma mais fácil expulsão do feto. No De mulierum affectibus afirma-se:

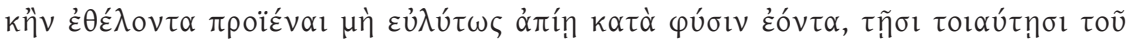

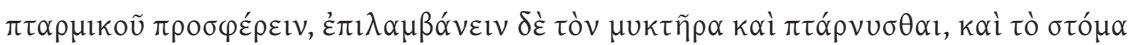

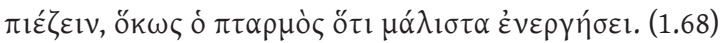

e se [o feto] querendo avançar e estando em posição normal, não sai facilmente, nestas circunstâncias aplicar algo que provoque o espirro, fechar o nariz e espirrar e fechar a boca para que o espirro seja o mais forte possível.

Amato é defensor desta prática, louvando - mas nunca o bastante, segundo o próprio Hipócrates, senex ille, naturae verus minister, e citando o aforismo 5.35. Afirma ter ele próprio visto muitas vezes um espirro acelerar um parto difícil ${ }^{38}$.

37 Veja-se a tradução de CELSO: Quae locis laborat aut difficulter partum edit, sternumento leuatur. ("Aquela que sofre devido aos órgãos genitais ou que dá à luz num parto difícil é aliviada por um espirro."). Sobre as referências hipocráticas ao espirro como forma de facilitar o parto, cf. Ann Elis Hanson, "Continuity and change: Three Case Studies in Hippocratic Gynaecological Therapy and Theory", in Sarah Pomeroy (ed.), Women's History and Ancient History. Chapel Hill, University of North Carolina Press, 1991, pp. 91ss..

38 Porro interim haec agebamus, sternutationem ciebamus condiso, hoc est, struthio, sive lanaria dicta herba, helleboro, pipere, euphorbio, et similibus, prout, nos docuit agendum, nunquam satis laudatus senex ille, naturae verus minister, libro quinto suorum aphorismorum, aphor. 35. dicens mulieri, quae uterinis molestatur, aut difficulter parit, superveniens sternutatio, bonum. Vidimus autem nos difficulter parientes, a repetita sternutatione, brevi parere, quia vehementiore concussu, atque fervore, partim quidem naturam excitat, partim vero excernit, quae partibus corporis firmiter infixa adhaerent. (Cent. V, cura 34) "Entretanto, enquanto trabalhávamos nisto, provocávamos o espirro com struthion, isto é, saponária, a chamada erva-dos-pisoeiros (lanária), heléboro, pimenta, eufórbio e semelhantes, conforme nos ensinou a fazer aquele nunca assaz louvado Ancião, verdadeiro ministro da natureza, no livro $5^{\circ}$ dos seus Aforismos, aforismo 350, ao dizer: "À mulher que é molestada por estrangulações uterinas ou tem parto difícil, é bom sinal o sobrevir-lhe espirro". Nós temos visto parturientes difíceis darem à luz 
Se isto não for eficaz, torna-se necessária uma intervenção mais violenta que consistia também em sacudir o corpo da paciente, mas de forma bem mais vigorosa. É o que se afirma no mesmo tratado hipocrático, logo de seguida: a paciente deve deitar-se numa cama sólida a que será atada, cama que será sacudida por dois homens. Em De exsect. 4, a parturiente deve ser colocada por cima de um lençol e, agarrada pelos pés e pelos braços por mulheres, deve ser sacudida pelo menos dez vezes. Depois será sacudida alternadamente pelos braços e pelas pernas. Aqui as manobras têm como finalidade fazer com que o feto numa posição anormal tenha espaço no útero para se reposicionar de forma adequada ${ }^{39}$.

Nos casos descritos nas Centúrias, por exemplo, estas duas formas de terapia são constantes. O recurso a substâncias esternutatórias constitui, a par da sucussão, o método mais utilizado por Amato para acelerar um parto difícil. Na cura 21 da Centúria VI, que se refere a uma mulher primípara em sofrimento, ordenou que se agarrasse a parturiente a uma corda suspensa do tecto e que fosse sacudida por um homem robusto. Receitou igualmente substâncias para provocar o espirro, o que acabou por permitir que expulsasse a criança no espaço de um dia.

Amato parece até, por vezes, acreditar que estes métodos causam uma certa impressão nas pessoas que assistem, incluindo nas parteiras. Veja-se por exemplo o parto antes citado das chamadas meninas amarelas:

Pinta uxor Pharasii, musici insignis, cum per triduum in emittendo foetu, graviter laboraret, ad eam iuvandam accersiti sumus. Ac post multa ob obstetricibus adhibita, et machinata, hoc illi ebibendum dedimus medicamentum. (...) Hoc enim epoto et repetito medicamento, duas peperit puellas, omnino luteas, ob quem colorem assistentes mulieres admirabantur. Caeterum, nos colorem hunc, a croco ebibito contractum esse docuimus. (Cent. V, cura 34)

A esposa do insigne músico Pharasi, de nome Pinta, há já três dias que procurava dar à luz uma criança com sofrimento e, para lhe darmos o nosso auxílio, chamaram-nos. Depois de muitos tratamentos feitos e engendrados pelas parteiras, demos-lhe a beber o seguinte remédio (...). Tendo tomado e repetido este medicamento, deu à luz duas meninas completamente amarelas. A cor causou grande admiração às mulheres assistentes. Por isso esclarecemos que esta cor tinha sido causada pelo croco bebido. ${ }^{40}$

rapidamente após repetidos espirros, visto que, pela sacudidela ou agitação mais veemente, por um lado se excita a natureza, por outro se desagrega aquilo que aderia com firmeza a partes do corpo." Amato Lusitano, Centúrias..., vol. III, op. cit., p. 224.

39 A mesma intervenção no texto de Rodrigo de CASTRo (2.4. cap. 5, p. 472).

40 amato Lusitano, Centúrias..., vol. III, op. cit., p. 225. 
Note-se que a relação entre o médico e as parteiras que podemos reconstituir a partir destes textos denota, com frequência, uma certa desconfiança dos médicos em relação a estas. Admonições como "cuida para que as parteiras não dilacerem o útero", ou "que as parteiras não recorram a práticas supersticiosas" são muito frequentes ${ }^{41}$. Também Amato mostra uma certa desconfiança em relação às práticas destas, que considera prejudiciais ${ }^{42}$. Rodrigo de Castro afirma que uma das medidas que a grávida deve tomar antes do parto é precisamente a escolha de uma boa parteira, arte que, segundo afirma, não é conveniente para os homens:

Igitur ante partum eligenda obstetrix prudens, muliebrium affectionum docta, \& obstetricandi exercitatione perita, nam haec ars viros dedecet. (2.4. cap. 1, p. 447)

Por esta razão antes do parto deves escolher-se uma parteira previdente, instruída acerca das condições femininas e versada no exercício da obstetrícia, pois esta arte não convém aos homens.

De facto, a imperícia das parteiras é algo pernicioso: torna os rapazes eunucos (1.2. cap. 6, pp. 63-64), leva-as a cortar antes do momento certo o cordão umbilical (2.4. cap. 7 , p. 478); está associada a superstiçóes absurdas (1.1. cap. 8, p. 32).. O mesmo afirmara Sorano, séculos antes. Se em toda a descrição de um partus naturalis é a parteira que age e toma decisóes, acompanhada, quando muito por "ajudantes com experiência e que deram à luz muitas vezes ou o próprio marido da mulher [i. e. da parturiente]"(ministrae peritae et quae saepius pepererunt aut ipse foeminae maritus (2.4. cap. 1, p. 448)), quando o parto se complica é o chirurgus quem desempenha as acções mais sensíveis, na presença do médico (accersitus chirurgus, praesente etiam medico).

Quanto mais desesperada fosse a situação, podemos afirmar, tanto mais pessoas que não a parteira seriam necessárias para desempenhar toda uma série de tarefas, das mais científicas às mais braçais: do médico que orientava, a homens ou mulheres da família, robustos o suficiente

41 Cf. Jean Le Bon, Therapia Puerperarum, in Gynaeciorum libri, 1586, vol. 2, p. 387: Dilaniari enim non paucas gravidas mulieres a chirurgis, obstetricibus et tonsoribus, multosque semivivos infantulos ab iisdem dilacerari, saepius quam voluissemus, vidimus. Vimos, mais vezes do que teríamos desejado, serem dilaceradas não poucas mulheres grávidas por cirurgiões, parteiras e barbeiros, e muitas criancitas mal vivas serem desmembradas por estes.

42 Veja-se, por exemplo: (...) nec enim obstetrices permisimus unquam, manibus violentum aliquod tractarent, prout illis moris est, quando ex illa violenta attractione, multa vitia, et foedae affectiones oriuntur. (Cent. VI, cura 21) "(...) e não permitimos nunca que as parteiras usassem de algo violento com as mãos, conforme é o seu costume, visto que por causa dessa violenta actuação se originam muitos males e afecções desfeantes." Amato Lusitano, Centúrias..., vol. IV, op. cit., p. 33. Curabis tu, sapiens medice, ut obstetrices omni ingenio ac arte in hanc naturalem figuram, hoc est, in caput, foetum deducant (...) "Tu, médico sabedor, procurarás que as parteiras tirem o feto com o maior engenho e habilidade pela forma natural, isto é, pela cabeça (...)". Amato Lusitano, Centúrias..., vol. IV, op. cit., p. 84. 
para segurarem a parturiente e a sacudirem, passando pelo cirurgião que operava e pela parteira que fazia a versão do feto e examinava o corpo da paciente. É precisamente no meio desta multidão que sobressai o saber do médico, baseado nas autoridades antigas que como um alicerce fundamentam e legitimam práticas e terapêuticas.

\section{BIBLIOGRAFIA}

\section{Edições e Traduções}

Amato Lusitano, Curationum medicinalium Centuriae II. Priores. Lugduni, apud Guglielmum Rouillium, 1567. Amato Lusitano, Curationum medicinalium Centuriae Duae. Tertia et Quarta. Lugduni, apud Guglielmum Rouillium, 1565.

Amato Lusitano, Curationum medicinalium Centuriae Duae. Quinta et Sexta. Lugduni, apud Guglielmum Rouillium, 1576.

Amato Lusitano, Centúrias de curas medicinais, vol. I, II, III e IV (trad. Firmino Crespo). Lisboa, Universidade Nova de Lisboa, s. d.

Aristóteles, História dos Animais II (tradução de M. F. Sousa e Silva). Lisboa, Imprensa Nacional-Casa da Moeda, 2008.

Burguière P., Gourevitch, D. \& Malinas, Y., Soranos d'Éphèse I, II, III, IV. Paris, Les Belles Lettres, $2003^{2}$.

Castro, Rodrigo de, Philosophiae et Medicinae Doctoris De universa muliebrium morborum medicina, tertia editio auctior et emendatior. Hamburgi, ex Bibliopolio Frobbeniano, 1628.

Radicchi, R., La Gynaecia di Muscione: manuale per le ostetriche e le mamme del VI sec. d. C. Pisa, Giardini, 1970.

(Para os restantes textos usaram-se as edições do Thesaurus Linguae Graecae e do Packards Humanities Institute Latin Corpus)

\section{Estudos}

Burguière, P., "Histoire du Texte", in P. Burguière, D. Gourevitch \& Y. Malinas, Soranos d'Éphèse. Maladies des femmes I. Paris, Les Belles Lettres, 2003², pp. XLVII-LXV.

Dasen, V., "Multiple Births in Graeco-Roman Antiquity", Oxford Journal of Archaeology 16.1 (1997), pp. 49-63.

Daston, Lorraine \& PARK, Katherine, Wonders and the order of nature, 1150-1750. New York, Cambridge, Mass., Zone Books, 1998. 
Demand, Nancy, "Monuments, midwives and gynaecology", in Ph. J. van der Eijk, H. F. Horstmanshoff, \& P. H. Schrijvers, (eds.), Ancient medicine in its socio-cultural context. Amsterdam, Rodopi, 1992, pp. $275-290$.

Gourevitch, Danielle, "La gynécologie et l'obstétrique”, ANRW 37.3 (1996), pp. 2083-2146.

Gourevitch, Danielle, "La mort de la femme en couches et dans les suites de couches", in F. Hinard (ed.), La mort, les morts et l'au-delà dans le monde romain: Actes du Colloque de Caen, 20-22 novembre 1985. Caen, Centre de publications de l’Université de Caen, pp. 187-193.

Hanson, Ann E. \& Green, Monica H., "Soranus of Ephesus: Methodicorum princeps", ANRWII.37.2 (1994), pp. 968-1075.

Hanson, Ann E., "Continuity and change: Three Case Studies in Hippocratic Gynaecological Therapy and Theory", in Sarah Pomeroy (ed.), Women's History and Ancient History. Chapel Hill, University of North Carolina Press, 1991, pp. 73-110.

Hanson, Ann E., "A division of labor: roles for men in Greek and Roman births", Thamyris 1.2 (1994), pp. 157-202.

KInG, Helen, Hippocrates' woman: reading the female body in ancient Greece. London \& New York, Routledge, 1998.

KING, Helen, Midwifery, obstetrics and the rise of gynaecology: the uses of a sixteenth-century compendium. Aldershot, Hants \& Burlington, Ashgate Publishing, 2007.

Malinas, Yves, "Modernité de Soranos", in P. Burguière, D. Gourevitch \& Y. Malinas, Soranos d'Éphèse. Maladies des femmes I. Paris, Les Belles Lettres, 2003², pp. LXVII-LXXIV.

Stolberg, Michael, "A woman down to her bones: the anatomy of sexual difference in the sixteenth and early seventeenth centuries", Isis 94 (2003), pp. 274-299.

Von Staden, H., Herophilus: the art of medicine in early Alexandria. Cambridge-New York, Cambridge University Press, 1989. 
(Página deixada prepositadamente em branco.) 


\section{Do carvalho ao castanheiro: usos e propriedades medicinais de fagáceas nas Enarrationes de Amato Lusitano ${ }^{1}$}

EMÍLIA OLIVEIRA²

\section{RESUMO:}

Amato Lusitano dedica os comentários 131-133 do livro primeiro das Enarrationes a árvores como o carvalho, a azinheira, o sobreiro, a faia e o castanheiro. 0 presente artigo tem como objectivo explorar os variados usos e propriedades terapêuticas destas fagáceas.

\section{PALAVRAS-CHAVE:}

Amato Lusitano; Fagáceas; Quercus; Fagus; Castanea.

\section{ABSTRACT:}

Amato Lusitano devotes Comments 131-133 of the first book of Enarrationes to trees such as the oak, the holm oak, the cork oak, the beech and the chestnut tree. This paper aims to explore the varied uses and medicinal properties of these Fagaceae.

\section{KEYWORDS:}

Amato Lusitano; Fagaceae; Quercus; Fagus; Castanea.

1 Este trabalho foi desenvolvido no âmbito do projecto de I\&D "Dioscórides e o Humanismo Português: os Comentários de Amato Lusitano" (http://amatolusitano.web.ua.pt) do Centro de Línguas, Literaturas e Culturas da Universidade de Aveiro, financiado por Fundos FEDER através do Programa Operacional Factores de Competitividade - COMPETE e por Fundos Nacionais através da FCT - Fundação para a Ciência e a Tecnologia, no âmbito do projecto FCOMP-01-0124-FEDER-009102.

2 Centro de Línguas, Literaturas e Culturas da Universidade de Aveiro e Centro de Estudos Clássicos da Faculdade de Letras da Universidade de Lisboa: emilia.oliveira@ua.pt. 
No livro primeiro das Enarrationes de Amato Lusitano, mais concretamente, nos comentários 131-133, o humanista reflecte sobre os usos e propriedades medicinais de algumas árvores pertencentes à família Fagaceae ${ }^{3}$.

Assim, na enarratio $1.131^{4}$, consagrada à descrição das características e virtudes do carva1 ho ${ }^{5}$, Amato inclui outras fagáceas, a saber, a faia ${ }^{6}$, a azinheira ${ }^{7}$ e o sobreiro ${ }^{8}$. Na verdade, como se percebe pelo próprio texto de Dioscórides ${ }^{9}$, o nome grego usado para designar o carvalho, $\delta \rho \tilde{u} \varsigma$, que, em Amato, tem como correspondentes latinos quercus e robur, é um termo genérico que designa não apenas essa, mas outras espécies de árvores produtoras de glande (ou bolota), chamadas glandíferas ${ }^{10}$. Amato confirma-o, dizendo:

3 Agradecemos ao Prof. Doutor Jorge Paiva as informações relativas à classificação das fagáceas que são objecto deste estudo, bem como outras sugestões que tão gentilmente nos foram facultadas. Sobre estas plantas, leia-se Antoine Kremer [et alii], "Genomics of Fagaceae", Tree Genetics 8 Genomes 8 (2012), pp. 583 e seg., onde se diz que as Fagaceae são uma lata família de angiospérmicas (pertencentes à ordem Fagales), que abarca mais de 900 espécies distribuídas por 8-10 géneros, maioritariamente presentes nas zonas temperadas do Hemisfério Norte. Os géneros do carvalho (Quercus), do castanheiro (Castanea) e da faia (Fagus) são os únicos que se encontram distribuídos pela Ásia, Europa e América do Norte e os mais relevantes do ponto de vista económico, já que constituem recursos florestais com inúmeros usos (biomassa, fibra, produtos de madeira e alimentares). Sobre os diferentes géneros e espécies de fagáceas, vide também Antoine KrEMER [et alii], "Fagaceae Trees", in Chittaranjan Kole (ed.), Genome mapping and molecular breeding in plants, vol. 7, Forest Trees. Heidelberg, Springer, 2007, pp. 161 e seg.; Paul. S. Manos, Zhe-Kun Zhou e Charles H. Cannon, "Systematics of Fagaceae: phylogenetic tests of reproductive trait evolution", International Journal of Plant Sciences 162 (2001), pp. 1361 e segs.

4 O nosso estudo centrar-se-á, por conseguinte, na análise das enarrationes 131-133 do Livro I das In Dioscoridis Anarzabei De Materia Medica libros quinque Enarrationes Eruditissimae. Veneza, Gualtiero Scoto, 1553.

5 Quercus robur L., carvalho-comum ou carvalho-roble. Para o estabelecimento dos nomes científicos das espécies botânicas citadas neste estudo, consultámos o manual de Francisca Maria FERnANDES e Luís Mendonça CARvalho, Portugal Botânico de A a Z: plantas portuguesas e exóticas. Lisboa, Lidel, 2003.

6 Fagus sylvatica L. subsp. sylvatica.

7 Quercusilex $L$.

8 Quercus suber $L$.

9 Cf. Diosc. 1.106-106.3.

10 Em especial, as que pertencem ao género Quercus L., mas também o castanheiro (Castanea sativa Mill.). A este propósito, leia-se o comentário de Hermolau BÁRBARO em Hermolai Barbari patricii Veneti \& Patriarchoe Aquileiensis Corollarium libris quinque Absolutum. Veneza, Oficina dos irmãos De Gregori, 1516, f. 20v, onde se diz que os Gregos designavam com um único termo (drys) diferentes espécies de árvores glandíferas. Por sua vez, Marcelo VIRGílıo, em Pedacii Dioscoridae Anarzabei De medica materia libri sex. Florença, Herdeiros de Fillippo Giunta, 1518, f. 65v, afirma congregar no mesmo capítulo aquilo que a natureza e, posteriormente, o próprio Dioscórides já haviam congregado, ou seja, as árvores glandíferas: Oniunximus unoque et eodem clausimus capite quae natura primum in eodem genere, mox in historia hic scriptor, postremo melliores graecorum codices coniuncta esse voluerunt. 
Drys vox aequivoca est, omnem arborem glandiferam comprehendens, ut ex Dioscoride in praesentia comprehenditur, cum dicat: astringendi vires quercus omnis habet.

Drys é um termo ambíguo que compreende toda a espécie de árvore glandífera, como se depreende de Dioscórides neste capítulo"11, quando afirma: "Toda a espécie de carvalho tem propriedades adstringentes." 12

Mas se as virtudes das glandíferas podem justificar a sua pertença ao mesmo género, o mesmo não se pode dizer em relação à sua morfologia:

Cuius Dioscorides, tanquam species fagum et ilicem numerat, quod intelligas velim, viribus, secus autem figura, cum multum inter se differant.

Gostaria que soubesses que Dioscórides considera como espécies daquele a faia e a azinheira ${ }^{13}$, por causa das suas propriedades, de forma diferente, no entanto, no que diz respeito ao seu aspecto, pois diferem bastante entre si. ${ }^{14}$

A faia ${ }^{15}$, de facto, apesar de glandífera, produz um fruto diferente da bolota do carvalho, bastante apreciado por alguns animais e outrora consumido pelos homens:

11 Diosc., loc. cit.

12 Na mesma linha de pensamento, defende Pietro Andrea MAtTIOLI, em I discorsi di M. Pietro And. Matthioli sanese, medico del sereniss. principe Ferdinando archiduca d'Austria \& c. ne i sei libri di Pedacio Dioscoride Anazarbeo Della materia medicinale. Veneza, Vincenzo Valgrisi, 1563, p. 145: "Ma perche drys vocabulo Greco, il quale noi interpretiamo quercia nel nostro volgare, serve universalmente et alla quercia, et ad ogni altra specie d'alberi ghiandiferi, comprese Dioscoride sotto questo vocabulo tutte le specie delle piante, che ne producono le ghiande. Et imperò disse egli nel principio del presente capitolo: "Ogni quercia ha virtù costrettiva", quasi volendo dire "Ogni pianta ghiandifera è costrittiva". Il che da ad intendere esser questo capitolo commune à tutti gli alberi sopradetti." Também Andrés LAGUNA, em Pedacio Dioscorides Anarzabeo. Acerca de la materia medicinal y de los venenos mortíferos. Antuérpia, Casa de Juan Latio, 1555, p. 92, afirma: "Este Griego vocabulo drys, que propriamente significa el roble, llamado de los Latinos robur, y quercus, es aqui general y commun à todos aquellos arboles, que produzen bellota. De suerte que lo que aqui atribuye al roble Dioscorides, se deve entender de todas las glandiferas plantas, de las quales ay innumeras differentias."

13 Cf. Diosc. 1.106.2. Na verdade, Dioscórides aplicou o nome de origem indo-europeia da faia, $\varphi \eta \gamma o ́ \varsigma$ (lat. fagus), a qual não existia no espaço geográfico grego, a uma variedade de carvalho nativa do sul da europa (Quercus aegilops L. ou Quercus macrolepsis Kotschy). No seu comentário, porém, Amato parece referir-se à faia (Fagus sylvatica L. subsp. sylvatica), tendo em conta o nome apresentado em diferentes línguas europeias (em Espanhol, 'haia arbore'; em Italiano, 'faggio', 'faggivola'; em Francês, 'faus') e a descrição que faz do respectivo fruto (uma glande triangular).

14 Cf. A. Laguna, op. cit., loc. cit.

15 Fagus sylvatica L. subsp. sylvatica. 
Nam fagus arbor est, quae licet fructum glandi figura et forma similem non habeat, glandiferis tamen annumeratur arboribus, cum fructum ferat viridem aculeatum, intra quem glans dulcissima, triangulari figura includitur, subtili quodam cortice ad rufedinem, cum quodam splendore, veluti in castaneis videtur, cooperta, quam glires et mures avidissime comedunt, et a turdis maxime expetitur; qua quoque homines in victu tantum assumpta diu vixisse feruntur.

Com efeito, a faia é uma árvore que, embora não tenha um fruto semelhante no aspecto e na forma à bolota, se inclui, todavia, no número das árvores glandíferas, já que produz um fruto verde com espinhos dentro do qual se encontra encerrada uma glande dulcíssima de forma triangular, envolta numa fina casca de cor arruivada, um tanto brilhante, tal como a que se vê nas castanhas; os arganazes e os ratos comem-na com muita avidez e é bastante procurada pelos tordos. Diz-se que os homens também se alimentaram exclusivamente dela durante muito tempo. ${ }^{16}$

Por sua vez, a azinheira ${ }^{17}$ apresenta semelhanças com o carrasco (ou carrasqueira ${ }^{18}$ ), mas, por ser maior, segundo Amato, é muitas vezes confundida com outra fagácea, o sobreiro ${ }^{19}$ :

Ilex vero arbor est similis granam ferenti, quae ut diximus procere crescit. Nonnulli tamen illicem maius suber esse crediderunt, sed falso, cum maius suber arbor magnae proceritatis sit, et ex qua cortices virides et sicci, variis rebus accommodati extrahantur. Nam medius cortex, quem viridem appello, colore rubrum, a coriariis Hispaniae pro praeparandis bubulis coriis usurpatur; exteriores vero cortices sive sicci, pro cooperiendis domibus tegularum loco variis in locis accipiuntur, veluti pro conficiendis alvearibus et crepidis ac soccis ornandis.

16 Em P. A. MATTIOLI, op. cit., pp. 145 seg., encontramos a mesma justificação para a inclusão da faia no grupo das glandíferas. $\mathrm{O}$ comentador descreve o fruto desta árvore em termos muito semelhantes aos de Amato, fazendo igualmente referência ao seu consumo por diversas espécies de roedores (arganazes, ratos e esquilos) e aves (tordos, melros...), assim como pelo homem, em períodos de carestia. A. LaGUNA (op. cit., loc. cit.) descreve desta forma a faia e o respectivo fruto: "Cuentase tambien la haya entre los arboles que produzen bellota, dado que su fructo es de differente figura y forma, el qual se muestra por defuera redondo, velloso, y vestido de muy aspera cascara, dentro de la qual se encierra un meollo duro, y triangular, cubierto de otra cascarilla lisa, y subtil, de color castaño. El qual fructo es dulce y de grato sabor, aunque estiptico al gusto."

17 Quercus ilex L.

18 Quercus coccifera L.

19 Quercus suber $L$. 
A azinheira, na verdade, é uma árvore parecida com a que produz a grã-dos-tintureiros ${ }^{20}$; conforme dissemos, cresce em altura ${ }^{21}$. Alguns, porém, julgaram que a azinheira era um sobreiro de maior dimensão, mas sem razão, já que um sobreiro de maior dimensão é uma árvore de grande porte da qual são extraídas cascas verdes e secas, próprias para diversas $\operatorname{coisas}^{22}$. Com efeito, a casca do meio, de cor vermelha, a que chamo verde é arrancada pelos curtidores de peles da Hispânia para o curtimento de peles bovinas ${ }^{23}$; já as cascas

20 Amato refere-se, muito provavelmente, ao arbusto chamado carrasco ou carrasqueira (Quercus coccifera L., da família das fagáceas), hospedeiro do Kermes vermilio Planchon, também conhecido como grãdos-tintureiros, grã-de-carrasco ou cochonilha-do-carmim. Este, na verdade, é "um insecto do grupo das cochonilhas, que foi utilizado em tinturaria, para dar a cor carmesim a tecidos valiosos, fabricados desde a antiguidade clássica em toda a Europa, principalmente na zona mediterrânica. Em Portugal era vulgar na Arrábida e no Barrocal algarvio, com grandes populações, que permitiram a sua exploração comercial, tendo sido exportado, como matéria corante preciosa, para muitos centros têxteis europeus. Hoje é raríssimo, não só em Portugal, sendo uma espécie em extinção, mas também noutras zonas onde antes era abundante." (M. A. FerReIRA, "Grã-dos-tintureiros - Kermes vermilio Planchon", Boletim Técnico do UIPP-BT/O6 (2010), p. 1). As fêmeas ressequidas de cochonilhas tipo quermes (coccus) vermilio tomam por hospedeiro o arbusto Quercus coccifera L. (chamado, como já referimos, carrasco ou carrasqueira), que se dá no Sul de França, em Espanha e na Grécia. Os machos alados do quermes morrem pouco depois de cópula. As fêmeas, sem asas, quando ainda larvas, fixam-se nas folhas e nos ramos, sugando-os. Crescem rapidamente até ao tamanho de ervilhas (daí, também, os nomes 'baga de quermes', 'baga carmésios', 'grão escarlate', grana chermes, 'quermes tinctorius', etc.). Triturada em pó, esta "baga" é solúvel em água. $\mathrm{O}$ tingimento em escarlate com quermes alcançou grande tradição, existindo, na idade média, em algumas cidades de França e Itália, corporações de tintureiros de escarlate. Na antiguidade era muito caro, mas muito mais barato que a púrpura, que foi suplantada pelo quermes a partir da conquista de Constantinopla, no ano de 1453, pelos turcos (José Miguel F. P. FIADEIRO, O tingimento de materiais têxteis: de arte a ciência (Oração de Sapiência proferida no Dia da Universidade, em 30 de Abril de 1993). Covilhã, Universidade da Beira Interior, 1993, p. 26).

21 Por oposição ao carrasco (ou carrasqueira), que é uma árvore de baixo porte. A propósito, leia-se a enarratio 4.51, dedicada à grã-dos-tintureiros (De grano quod tingendo est), na qual Amato refere que esta é colhida de uma azinheira pequena (quod lentis magnitudine ex ilice quadam parva colligitur); cf. Diosc. 4.48. Para uma descrição mais pormenorizada das características da azinheira e do respectivo fruto, leia-se, por exemplo, A. LAGUNA, op. cit., pp. 92 seg.: "La enzina es arbol harto crecido, y produze hojas semejantes à las del lauro, empero por el ennes blanquezinas. Tiene la corteza castaña, y la madera maciça, dura, fuerte, y algun tanto bermeja. Sus bellotas son mas pequeñas, y mas austeras que las del roble." Este autor também compara a azinheira ao carrasco (loc. cit.): "Hallase una suerte de enzina muy baxa, la qual llaman en Castilla 'carrasco'. La coscoja llamada de Plínio cusculium, tambien es especie de enzina: y cogese della grana, la qual se haze en unas vexiguillas pequeñas, llamadas cocos."

22 P. A. Mattioli (op. cit., p. 146) estabelece ainda uma comparação entre o sobreiro e a azinheira: "Il sovero di frutto, et di frondi è simile all'elice, (...) ma ha la scorza grossissima, ne cresce tanto à un gran pezzo, quanto fa l'elice." Leia-se a mesma comparação em A. LAGUNA, op. cit., loc. cit.: "El alcornoque, de los Latinos llamado suber, es una especie de roble, que ansi en el fructo, como en las hojas, se parece à la enzina. Empero no es tan poblado de ramos, y tiene la corteza sin comparation mas gruessa, de la qual se hazen aquellos andamios, que en castilla suelen llamarse alcorques (...)".

23 A casca dos sobreiros é muito rica em taninos, razão pela qual tem sido usada como adstringente e, sobretudo, no curtimento de peles; em tempos idos, este foi o uso mais rentável do sobreiro, e por esse facto foram destruídas enormes extensões de sobreirais. 
exteriores ou secas são colhidas, em diversos locais, para cobrir, em lugar de telhas, as casas, assim como para construir cortiços e fabricar alcorques e socos. ${ }^{24}$

Amato relembra, pois, que a utilidade desta e de outras árvores que produzem bolota não se resume à alimentação do homem e de outros animais. As diferentes espécies de glandíferas têm, na realidade, propriedades cicatrizantes, reconhecidas, aliás, pelo próprio Galeno:

Haec vero admodum glandifera est, ut plures aliae arbores, porcis dicatae, ut sunt cerrus, aegilops dicta, aesculus, platyphyllos et roboris varia genera, quae omnia constringendi vires habent, adeo ut Galenus roboris foliis vulnus securi inflictum glutinasset, cum eo tempore nullum aliud ad manus adesset medicamen. Sic enim ille tradit libro sexto De facultatibus simplicium medicamentorum.

Esta árvore, na verdade, é, efectivamente, glandífera, à semelhança de muitas outras árvores destinadas aos porcos, como são o cerrus chamado aegilops ${ }^{25}$, o aesculus ${ }^{26}$, o platyphyllos ${ }^{27}$ e as diversas espécies de carvalho ${ }^{28}$, as quais, sem excepção, têm propriedades constringentes, a ponto de Galeno ter cicatrizado com folhas de carvalho um golpe infligido por uma foice, pois naquele momento não havia à mão nenhum outro medicamento. Assim conta, de facto, no livro sexto Sobre as propriedades dos medicamentos simples. ${ }^{29}$

24 Sobre a utilização da cortiça no fabrico de calçado, leiam-se os comentários de A. LAGUNA (op. cit., loc. cit.) e P. A. MATTIOLI (op. cit., loc. cit.). Este evoca também a utilização de bóias de cortiça nas redes de pesca. A primeira tirada da cortiça ocorre entre os vinte e os trinta anos do sobreiro. A extracção do tecido suberoso faz-se mais ou menos de nove em nove anos. Antigamente a cortiça utilizava-se sobretudo na cobertura dos telhados, no fabrico de calçado, na construção de colmeias (cortiços), etc. A madeira de sobro era usada no fabrico de utensílios agrários. Actualmente a casca é o principal aproveitamento do sobreiro, sendo objecto de múltiplas aplicações na indústria e no artesanato. É usada no fabrico de rolhas, colmeias, isolantes, parqué e outros materiais de construção, juntas para automóveis, calçado, papel de cortiça, manufactura de roupa e outros objectos de uso diário. A cortiça queimada (ou carvão de cortiça) é usada no fabrico de tintas e na medicina.

25 Possivelmente, o Quercus cerris L., carvalho-da-Turquia, ou o Quercus aegilops L.

26 Porventura, o Quercus esculus L. Sin. Quercus petraea (Matt.) Liebl., carvalho-pétreo.

27 Talvez se trate do Quercus petraea f. platyphylla (Lam.) O. Schwarz Sin. Quercus petraea (Matt.) Liebl., carvalho-pétreo.

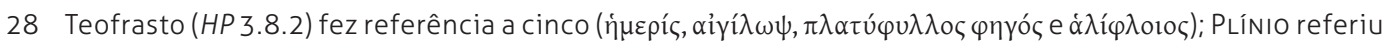
quatro (Nat. 16.16-17: quercus, robur, aesculus e cerrus), mas a identificação das espécies está longe de ser consensual. Leia-se, a este propósito, o comentário de H. BárBARo (op. cit, f. 20v), onde se diz que aos quatro nomes latinos designativos de espécies de carvalho, quercus, robur, aesculus e cerrus, cor-

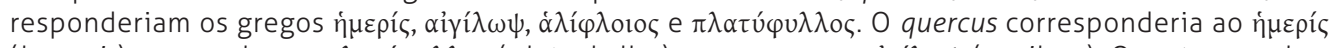
(hemeris), o aesculus ao $\pi \lambda \alpha \tau u ́ \varphi v \lambda \lambda$ os (platyphyllos), e o cerrus ao aỉíi $\omega \psi$ (aegilops). Quanto ao robur, o comentador afirma não ter percebido se corresponderia ou não ao á $\lambda$ í $\varphi \lambda$ oloc (haliphloeos).

29 Cf. Galeno, De simplicium medicamentorum temperamentis ac facultatibus 6.4.11 (Kühn 11.866). 
O carvalho tem, na verdade, propriedades que favorecem a cicatrização de ferimentos:

Exsiccandi, astringendique possidet facultatem cum mediocri quadam tepidaque caliditate:

Tem faculdades dessecativas e adstringentes e uma temperatura um tanto mediana e tépida.

Algumas partes da árvore e do respectivo fruto são, todavia, mais adstringentes do que outras, do mesmo modo que algumas espécies de glandíferas o são relativamente a outras, proporcionando aplicaçóes terapêuticas diversas:

Caeterum plus caeteris eius partibus astringit, quae in trunci cortice membrana subest, tum quae ipsius fructus convestit carnem. Quamobrem ad profluvium muliebre, sanguinis expuitiones, dysenterias et diuturnos ventris fluxus eam esse credunt accommodam. Valentius autem astringunt fagus et ilex.

De resto, mais do que as outras partes deste, adstringe a película que se encontra sob a casca do tronco, tal como a que reveste a carne [sc. semente] do próprio fruto. Por esta razão é que se crê ser apropriada para a hemorragia ginecológica, expectoraçôes de sangue, disenterias e fluxos persistentes do ventre ${ }^{30}$. Contudo, a faia e a azinheira são mais adstringentes. ${ }^{31}$

Já a virtude dessecativa destas árvores é mais concentrada nas folhas e no fruto:

Quarum plantarum folia tenella illita non instrenue desiccant, nec non vulnera glutinant. Eandem foliis vim habet et fructus roboris, eoque medici nonnulli utuntur ad incipientes atque crescentes phlegmonas.

Esfregadas, as folhas um tanto tenras destas plantas secam fortemente e também cicatrizam as feridas ${ }^{32}$. O fruto do carvalho tem a mesma virtude que as folhas

30 Cf. Diosc. 1.106, onde se advoga que o decocto de ambas as partes (o tecido membranoso que se encontra entre a casca e o tronco e o que envolve a bolota debaixo da casca) se deve administrar a quem sofre do ventre, de disenterias e cospe sangue; moídas, aplicam-se em supositório vaginal às mulheres com fluxos menstruais excessivos.

31 Cf. Galeno, op. cit., loc. cit. (Kühn 11.865 e seg.); Diosc. 1.106.1.

32 Cf. Diosc. 1.106.2, onde se diz que as folhas de todas as espécies, uma vez cortadas e moídas, são eficazes contra os inchaços e tonificam as partes afectadas de atonia. 
e, por essa razão, alguns médicos usam-no para as inflamações incipientes e até em desenvolvimento. ${ }^{33}$

Seguindo a tradição botânica que vem desde Teofrasto, na enarratio dedicada ao bugalho (1.133), declara o médico de Castelo Branco:

Fert quercus et eius species glandem et gallam.

O carvalho e as suas espécies produzem a bolota, mas também o bugalho. ${ }^{34}$

Amato distingue três espécies de bugalho ${ }^{35}$. A primeira a que faz referência provém da Síria e tem características muito peculiares:

Quae Syria praecipue affertur, parva, rotunda, in longum tendens, crebis foraminibus perforata, atramento scriptorio conficiendo aptissima.

33 Cf. Galeno, op. cit., loc. cit. Segundo este autor, as inflamações em estado mais avançado não reagem à adstringência do carvalho. Segundo Diosc. 1.106.1, moídas cruas e aplicadas em forma de cataplasma, as bolotas aliviam as inflamações. Misturadas com gordura de porco salgada, revelam-se eficazes contra as indurações rebeldes e úlceras malignas. Pela sua virtude, são mais eficazes as de azinheira que as de carvalho.

34 Segundo este autor (HP 3.7.4), todo o carvalho ( $\delta \rho \tilde{c} \varsigma)$ produz, além da bolota, o bugalho; Cf. Plin. Nat. 16.26, onde se afirma que as árvores glandíferas produzem também o bugalho, e Diosc. 1.107, que defende que o bugalho é fruto do carvalho ( $\delta \rho \tilde{u} \varsigma)$. Leiam-se ainda os comentários de H. BÁrbaro, op. cit., f. 22 r (erradamente numerada como 24), A. LAGUnA, op. cit., p. 95 e P. A. MATTIOLI, op. cit., p. 148. Os bugalhos (ou galhas) são, na verdade, excrescências arredondadas que se formam nos ramos, folhas e inflorescências de algumas espécies de carvalhos, como reacção à picada de um insecto que aí deposita os seus ovos. Com o desenvolvimento da larva, dá-se a proliferação e hipertrofia dos tecidos vegetais e a consequente formação de taninos. As galhas dos ramos dos carvalhos são inicialmente verdes, tornando-se, depois, acastanhadas e volumosas como nozes; as das folhas são verdes e esféricas como ervilhas; as das inflorescências são vermelhas e cilíndricas como pequenos amendoins.

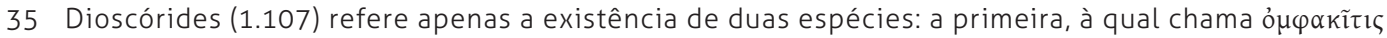
(isto é, 'semelhante ao sumo de uva verde', devido à sua acritude), é pequena, rugosa, maciça e não perfurada, correspondendo à segunda espécie descrita por Amato); a outra é lisa, leve e perfurada, não sendo certo que corresponda à primeira espécie de bugalho descrita pelo médico albicastrense. P. A. Mattioli (op. cit., p. 149) refere a existência de dois tipos de bugalho: o maior é grande como uma noz, leve e esponjoso; o menor, do tamanho de uma avelã, é rugoso, duro e fechado. Segundo A. LAGUNA, op. cit., p. 95, "Pone aqui dos especies de agallas tan solamente Dioscorides, à las quales se pueden reduzir todas las otras suertes y differentias." Plínio (Nat. 24.9; cf. 16.26), à semelhança do que fizera Teofrasto (HP 3.7.4), foi mais longe, considerando a existência de mais espécies: Nec pauciora gallae genera fecimus, solidam perforatam, item albam nigram, maiorem minorem. A este propósito, leiam-se os comentários de H. BÁrBARO, op. cit., f. 22 r (erradamente numerada como 24) e M. VIRGílio op. cit., f. 65v. Ambos referem a existência de todas essas espécies de bugalho, no entanto, Marcelo Virgílio acrescenta que Teofrasto refere a existência de muitas espécies e que Plínio as retoma a todas, atribuindo nomes latinos a cada uma delas. 
Este [sc. o bugalho] provém principalmente da Síria; é pequeno, redondo, a tender para o alongado, crivado de numerosos furos, muito apropriado para o fabrico de atramento para escrever.'

O segundo tipo de bugalho, apontado como o melhor de todos, tem proveniência e características diferentes:

Nam optima, succosa sit oportet, plena, gravis, styptica, qualis Anconae apud Italos et Castello Albo propria patria nostra apud Hispanos nascitur: unde suaderem, cum galla uti opus fuerit, hac potius recenti quam siccata illa syriaca, uterentur, cum recens omphacitis acerbior et valentior ad omnia, ut diximus, sit.

Na verdade, o melhor [sc. bugalho] convém que seja sucoso, maciço, pesado, adstringente, tal como o que nasce em Ancona, em Itália, e em Castelo Branco, a nossa terra natal, na Hispânia ${ }^{36}$, donde eu aconselharia a que usem, de preferência, sempre que for preciso usar bugalho, este verde em vez daquele seco, da Síria, pois o [bugalho] omphacitis verde é mais acre e eficaz, conforme dissemos, para tudo. ${ }^{37}$

O terceiro tipo de bugalho difere dos anteriores sobretudo na forma:

Est praeterea gallae alia species, magna, circulo veluti corona circundata, caput vitulinum figura repraesentans, non adeo tamen ut altera acerba, ex qua pauperes coronas pro numerandis preculis conficiunt.

36 Amato faz com alguma frequência referências de índole botânica a Itália e à Península Ibérica, em especial, aos locais por onde passou, como Ancona e Castelo Branco.

37 Segundo A. LAGUNA, op. cit., loc. cit., "La agalla omphacitis es aquella pequeñita, y mas estimada que todas, de la qual se haze la tinta fina, yà la qual por este respecto deven mucho todas las disciplinas, y los cultores dellas: la otra es la commun agalla." Os bugalhos são muito ricos em taninos, mais ainda se colhidos antes da saída dos insectos nascidos no seu interior. Os mais célebres tinham origem em Alepo, na Síria, e na Turquia. O ácido gálico deles extraído permitia o fabrico de tintas de muito boa qualidade (os bugalhos, depois de moídos, eram fervidos ou deixados a macerar num líquido ácido: água terçada de vinagre, vinho branco, ou simples vinagre). Por serem ricos em taninos (o seu principal componente é o ácido tânico), os bugalhos também eram usados no curtimento de couros. Apesar de já não terem utilidade na medicina humana, continuam a ser utilizados na indústria de curtumes e corantes. Sobre a utilidade dos bugalhos nos curtumes, na tinturaria, na medicina e na escrita, leiam-se os comentários de H. Bárbaro, op. cit., f. 22 r e M. VIRGílio, op. cit., f. 65v. 
Existe, além disso, outra espécie de bugalho, grande, circundada por um anel semelhante a uma coroa, cuja forma representa a cabeça de um bezerro, mas que não é tăo acre como a outra, e com a qual os pobres fazem coroas para contar as oraçóes ${ }^{38}$.

No intuito de corroborar a caracterização que fez dos diferentes tipos de bugalho, evoca a autoridade de Galeno:

De quibus omnibus Galenus libro 7 De facultatibus simplicium medicamentorum memoriam facit, dicens: galla, quae omphacitis dicitur, admodum acerbum est medicamen, pleraque sui parte essentiae terrenae et frigidae, valde desiccat, repercutitque fluxiones. (...) Esto vero tertii in desiccando, secundi autem in refrigerando, ordinis. Altera autem galla, flava illa et magna, laxaque, et ipsa dessicat quidem, sed tanto minus, quanto minus acerbae qualitatis est particeps.

Galeno recorda-as a todas, quando, no livro sétimo Sobre as propriedades dos medicamentos simples, afirma: "o bugalho a que chamam omphacitis é um medicamento bastante acre, na sua maior parte, de essência terrosa e fria, fortemente dessecativo e que repele os fluxos. (...) Na verdade, pode dizer-se que é do terceiro grau dos que dessecam, mas do segundo dos que arrefecem ${ }^{39}$. O outro bugalho, porém, o amarelo, grande e pouco consistente, é também dessecativo, mas tanto menos quanto menos partilha da qualidade acre."

Por fim, explica a utilidade farmacológica do bugalho, decorrente das suas propriedades adstringentes, anti-inflamatórias e hemostáticas:

Cocta itaque ipsa per se in aqua, aut si magis astringere vis, in vino aliquo austero, ac dein trita, cataplasma est non instrenuum sedi inflammatae, procidentique. Gallae combustae, extinctaeque in aceto aut vino, sanguinis reprimendi facultatem acquirunt.

Assim, cozida esta, por si só, em água, ou, se se quiser adstringir mais, num vinho acre, e, em seguida, moída, constitui uma cataplasma eficaz para o ânus inflamado e prolapso. Os bugalhos incendiados e apagados com vinagre ou vinho adquirem a faculdade de estancar o sangue. ${ }^{40}$

38 Amato refere algo semelhante aos actuais terços.

39 Cf. A. Laguna, op. cit., loc. cit., onde se afirma: "Es toda suerte de agalla, seca en el grado tercero, y en el segundo fria."

40 Cf. Galeno, op. cit., loc. cit. Em suma, o bugalho, rico em taninos, tem propriedades adstringentes e dessecativas, sendo variados os seus usos farmacológicos: por via externa, tem uma acção cicatri- 
$\mathrm{Na}$ enarratio consagrada à castanha ${ }^{41}$ (1.132), depois de a descrever em termos muito genéricos, Amato explica a origem de um dos nomes atribuídos pelos Gregos a este fruto:

Castanea echinis inclusa nascitur fructus ubique notus, cuius differentiae plures habentur, quas persequi supervacaneum arbitror, dicitur tamen castanea, glans sardiana a Graecis, quia primum Sardibus urbe Asiae inventa.

A castanha, fruto conhecido em toda a parte, nasce encerrada em ouriços; dela encontramos muitas variedades que julgo desnecessário enumerar. Seja como for, a castanha é chamada 'bolota de Sardes' pelos Gregos ${ }^{42}$, porque foi primeiramente descoberta na cidade asiática de Sardes ${ }^{43}$.

Segundo Amato, já Galeno considerava este fruto um alimento bastante nutritivo:

Haec vero, ut tradit Galenus, Libro de cibis boni et mali succi, si in ventriculo concoquatur, efficaciter nutrit, crassique, nunquam tamen mali succi est.

Esta, na verdade, como diz Galeno no Livro sobre os alimentos que provocam bom e mau humor, se é digerida no estômago, nutre eficazmente e provoca humor espesso, mas nunca mau. ${ }^{44}$

Apesar de flatulenta, pode ser bastante saborosa, desde que devidamente condimentada:

Flatuosa tamen castanea est, quae sub cineribus cocta flatum amittit, et optimum, licet siccum, praebet nutrimentum, modo vel saccharo, aut pipere, vel sale comedatur.

zante, hemostática (estanca as hemorragias), protectora e reepitelizante; por via interna, um efeito antidiarreico. Tem ainda uma acção anti-inflamatória e antiséptica; Dioscórides (1.107) aconselha o seu uso, depois de moído, no tratamento de aftas e úlceras da boca, males das gengivas, garganta, anginas e úvula. Segundo o autor, o bugalho, quando introduzido na cárie dos dentes, tem também um efeito analgésico.

41 Fruto do castanheiro-comum (Castanea sativa Mill.), outra árvore da família das fagáceas. Cf. Diosc. 1.106.3.

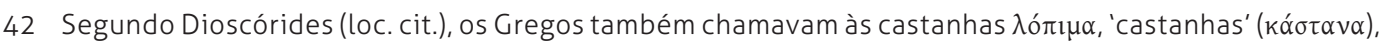

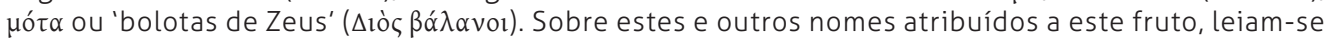
os comentários de H. BÁrbaro, op. cit., f. 21v e M. VIRGílio, op. cit., f. 65v.

43 A capital da Lídia foi uma das mais importantes cidades do império persa. Em 498 a. C., durante a revolta das cidades gregas da Jónia contra os Persas (que teve lugar entre 499 e 493 a. C.), os Jónios, apoiados por tropas de Atenas e de Erétria, capturaram e incendiaram Sardes.

44 Cf. GALENo, De provis pravisque alimentorum succis liber 6.8 (Kühn 6.792 sq.). 
A castanha é, todavia, flatulenta; cozida sob cinzas, liberta gás ${ }^{45}$ e constitui um óptimo alimento, ainda que seco, contanto que seja comida com açúcar, pimenta ou sal. ${ }^{46}$

Seco ao fumo, este fruto tem virtudes medicinais no tratamento de hemorragias ${ }^{47}$. Por outro lado, sendo um importante meio de subsistência, permite, depois de reduzido a farinha, o fabrico de pão ${ }^{48}$ :

Exsiccatae porro ad fumum castaneae sanguinem e pectore fluentem sistunt, ex quibus variae gentes annonae penuria panem parant, inter quas Ligures praecipue nominandi veniunt, cum id genus pane frequentissime utantur.

Além disso, secas ao fumo, as castanhas estancam o sangue que flui do peito ${ }^{49}$. Com elas, na falta de trigo, vários povos confeccionam pão $0^{50}$; entre estes devem ser mencionados em particular os Lígures, pois este povo consome pão abundantemente.

A ambivalência do fruto do castanheiro torna ainda mais evidente a proximidade existente entre esta árvore e as restantes espécies de fagáceas a que anteriormente fizemos alusão, apoiados no texto de Amato. De facto, conforme foi referido, as glandíferas pertencentes aos géneros

45 A castanha é composta por amido e água. Quando o amido é aquecido na presença de água, as partículas que formam os grânulos de amido afastam-se e alguma água penetra no interior dos grânulos que incham. Por sua vez, esta água aquecida passa a vapor, aumentando de volume e fazendo rebentar a castanha se a casca desta não tiver sido previamente cortada.

46 Vide o comentário P. A. MatTIOLI, op. cit., p. 147, onde são referidos os efeitos nefastos do consumo de castanhas. A. LAGUNA, op. cit., p. 94, também refere o valor nutritivo da castanha, mas, ao mesmo tempo, aponta alguns efeitos menos agradáveis inerentes ao seu consumo: "Las castañas, segun Galeno, dan al cuerpo mas nutrimento que ningun otro fructo salvaze: empero engendran ventosidades, hinchan y restriñen el vientre, digerense con difficuldad, provocan el apetito venereo, y comiendose en quantidad, hazen dolor de cabeça."

47 Dioscórides refere as propriedades adstringentes do fruto, em especial, da película que se encontra entre a carne e a casca (cf. 1.106.3).

48 À semelhança, aliás, de alguns tipos de bolota.

49 Segundo P. A. MatTIOLI, op. cit., loc. cit., "ristagnano le castagne, et massime le secche, valentemente i flussi stomachali, et del corpo". Já as castanhas verdes são prejudiciais aos pulmões (cf. A. LAGUNA, op. cit., loc. cit.).

50 Sobre a utilização da castanha no fabrico de pão, leiam-se os comentários de P. A. MATTIOLI, op. cit., loc. cit. e A. LAGUNA, op. cit., loc. cit., Este afirma: "de las castañas secas al humo, y mondadas, se haze cierta harina, que suple por la de trigo, en tiempo de carestia". Não é por acaso que as tribos pré-romanas chamavam ao castanheiro 'árvore do pão'. Antes da introdução da batata e do milho na Europa, este fruto, para muitos povos, foi talvez o mais importante farináceo. Alimentava homens e animais, e, em muitos casos, foi o pão dos mais desfavorecidos. Em anos de produção excedentária de castanha, a que sobrava era transformada em castanha pilada (descascada e seca ao fumo), para posterior consumo. 
Quercus (o carvalho, a azinheira e o sobreiro), Fagus (a faia) e Castanea (o castaneiro) eram usadas na terapêutica de problemas de saúde, mas também na alimentação, ocupando um lugar de relevo na economia doméstica. Estas plantas, na verdade, que produzem frutos valiosos para a subsistência humana e alimentação de outros animais, ainda hoje são determinantes na manutenção do equilíbrio dos ecossistemas que integram e de enorme importância económica para os povos que delas beneficiam ${ }^{51}$.

Os comentários de Amato Lusitano sobre as já citadas glandíferas deixam, no entanto, perceber que a sua utilidade não se resumia - como hoje, aliás, não se resume — à alimentaçáo e à cura de males diversos. O exemplo mais evidente será o do sobreiro, cujo contributo económico assenta principalmente na produção da tão versátil cortiça. Desde tempos idos que a sua casca suberosa é usada no fabrico de calçado, na construção de cortiços, na cobertura de estruturas, na confecção de vedantes (como as rolhas) e numa infinidade de outras aplicaçóes.

A natureza lenhosa destas plantas é outra das suas mais-valias. Em virtude de a sua madeira ser, quase sempre, de muito boa qualidade, à semelhança do que acontecia em tempos recuados, continuam a ser utilizadas na construção de edifícios, no revestimento de superfícies, no fabrico de mobiliário e de inúmeros outros objectos que fazem parte do quotidiano.

Deste modo, tudo o que aqui sobre elas foi referido vem confirmar, uma vez mais, a actualidade da notável obra que o médico e humanista João Rodrigues de Castelo Branco nos deixou.

\section{BIBLIOGRAFIA}

Аmato Lusitano, In Dioscoridis Anarzabei De Materia Medica libros quinque Enarrationes Eruditissimae. Veneza, Gualtiero Scoto, 1553.

Bárbaro, Hermolau, Hermolai Barbari patricii Veneti \& Patriarcha Aquileiensis Corollarium libris quinque Absolutum. Veneza, Oficina dos irmãos De Gregori, 1516.

Dioscórides, Plantas y remedios medicinales (De materia medica): Libros I-III, vol. 1., trad. O. García Valdés. Madrid, Editorial Gredos, 1998.

Fernandes, Francisca Maria; Carvalho, Luís Mendonça, Portugal Botânico de A a Z: plantas portuguesas e exóticas. Lisboa, Lidel, 2003.

Ferreira, M. A., "Grã-dos-tintureiros - Kermes vermilio Planchon”, Boletim Técnico do UIPP-BT/06 (2010), pp. $1-2$.

Fiadeiro, José Miguel F. P., O tingimento de materiais têxteis: de arte a ciência (Oração de Sapiência proferida no Dia da Universidade, em 30 de Abril de 1993). Covilhã, Universidade da Beira Interior, 1993.

Galeno, Opera Omnia, ed. C. G. Kühn, vols. 1-20. Lípsia, Oficina de Carl Cnobloch, 1821-1833.

51 Cf. A. Kremer [et alii], op. cit., 2012, p. 584. 
Kremer, Antoine [et alii], "Genomics of Fagaceae", Tree Genetics \& Genomes 8 (2012), pp. 583-610.

Kremer, Antoine [et alii], "Fagaceae Trees", in Chittaranjan Kole (ed.), Genome mapping and molecular breeding in plants, vol. 7, Forest Trees. Heidelberg, Springer, 2007, pp. 161-187.

Laguna, Andrés, Pedacio Dioscorides Anarzabeo. Acerca de la materia medicinal y de los venenos mortiferos. Antuérpia, Casa de Juan Latio, 1555.

Manos, Paul. S.; Zhou, Zhe-Kun; Cannon, Charles H., "Systematics of Fagaceae: phylogenetic tests of reproductive trait evolution", International Journal of Plant Sciences 162 (2001), pp. 1361-1379.

Mattioli, Pietro Andrea, I discorsi di M. Pietro And. Matthioli sanese, medico del sereniss. principe Ferdinando archiduca d'Austria \& c. ne i sei libri di Pedacio Dioscoride Anazarbeo Della materia medicinale. Veneza, Vincenzo Valgrisi, 1563.

Plínio-o-Velho, Naturalis historia libri XXXVII, ed. lit. K. Mayhoff, vols. 1-6. Estugarda, Teubner, reimp. 1967-70.

Teofrasto, Enquiry into Plants: Books 1-5, trad. A. F. Hort. Cambridge, Harvard University Press, reimp. 1916.

Virgílio, Marcelo, Pedacii Dioscoridae Anarzabei De medica materia libri sex. Florença, Herdeiros de Fillippo Giunta, 1518. 


\section{0 mundo mineral nos Comentários a Dioscórides de Amato Lusitano ${ }^{1}$}

ISABEL MALAOUUIAS² \& VIRGÍNIA SOARES PEREIRA³

In Memoriam de Manuel Serrano Pinto

\section{RESUMO:}

$\mathrm{O}$ presente artigo incide sobre o livro V dos Comentários (Enarrationes) de Amato Lusitano ao tratado De materia medica de Dioscórides, um livro que trata essencialmente de metais, pedras e terras. Depois de uma breve introdução de contextualização histórica, o artigo apresenta-se dividido em duas partes: uma primeira, de natureza científica, em torno da identificação de algumas substâncias mineralógicas, e uma segunda de pendor etnocultural, com particular incidência nos usos e costumes relacionados com alguns minerais e pedras.

\section{PALAVRAS-CHAVE:}

Amato Lusitano; Dioscórides; minerais; pedras e gemas.

\section{ABSTRACT:}

This article focuses on Amato Lusitano's book V of Comments (Enarrationes) to Dioscorides' De materia medica, a book that deals essentially with metals, stones and earths. After a brief introduction of historical context, the article is presented in two parts: the first, scientific, around the mineralogical identification of some substances, and a second of ethnocultural bias, with particular focus on the ways and customs related with some minerals and rocks.

\section{KEYWORDS:}

Amatus Lusitanus, Dioscorides; minerals; stones and gems;

1 Este trabalho foi desenvolvido no âmbito do projecto de I\&D "Dioscórides e o Humanismo Português: os Comentários de Amato Lusitano" (http://amatolusitano.web.ua.pt) do Centro de Línguas, Literaturas e Culturas da Universidade de Aveiro, financiado por Fundos FEDER através do Programa Operacional Factores de Competitividade - COMPETE e por Fundos Nacionais através da FCT - Fundação para a Ciência e a Tecnologia, no âmbito do projecto FCOMP-01-0124-FEDER-009102.

2 CIDTFF - Universidade de Aveiro: imalaquias@ua.pt

3 CEH - Universidade do Minho: virginia@ilch.uminho.pt 


\section{AMATO LUSITANO E O SEU TEMPO}

Amato Lusitano (1511-1568) dedicou grande parte da sua vida a comentar o De materia medica de Dioscórides, médico grego do séc. I d.C. que procedeu à descrição, em cinco livros, de substâncias dos reinos vegetal, animal e mineral, das suas características naturais e das suas virtudes terapêuticas. ${ }^{4}$

Tal como acontece na obra de Dioscórides, o livro V dos Comentários (Enarrationes) de Amato começa por prestar atenção a diversas castas de vinhas e de vinhos, para de seguida entrar nos estudos mineralógicos, com a descrição e comentário de uma centena de substâncias inorgânicas. ${ }^{5}$

Pese embora o facto de o tratamento destas matérias decorrer do comentário à obra de Dioscórides, como se disse, Amato revelou um particular interesse pelo assunto, tendo chegado a acalentar o projecto de publicar um livro sobre pedras preciosas, conforme refere no passo em que fala da selenite, ou pedra lunar (5.118):

De quibus et pluribus aliis a nobis visis lapillis, libellum edere et in lucem emittere decrevimus, modo Deus nostris faveat votis.

Sobre estas e várias outras pedras preciosas analisadas por mim, decidi elaborar e dar à luz um tratado, se Deus favorecer o meu intento. ${ }^{6}$

Para o interesse de Amato pelas pedras preciosas terá concorrido a circunstância de ter podido contar com um autêntico tesouro de matérias-primas e com uma fonte de informação

4 Note-se que a parte das Enarrationes de Amato dedicada à matéria lítica ou mineralógica tem sido objecto de escassa atenção. E o motivo será fácil de explicar. A obra de Dioscórides deu a conhecer cerca de setecentas plantas, ao passo que referenciou apenas cerca de cem animais e idêntico número de substâncias do reino mineral. Em resultado desta disparidade, que se reflectiu inevitavelmente nos Comentários do médico albicastrense, este ficou sobretudo conhecido pelo seu grande contributo para a medicina e a terapêutica por meio do recurso a preparados de plantas. Indo no mesmo sentido, as Sete Centúrias, com os seus setecentos relatos de outros tantos casos clínicos e seu tratamento, estão cheias de receitas de fármacos elaborados à base de plantas, muito embora aí surjam frequentemente combinados com preparados ou substâncias de natureza animal ou mineral.

5 A fim de chamar a atenção para a radical mudança de assunto, isto é, para a passagem de vinhos a pedras, a secção relativa às pedras ostenta um título próprio dentro do livro em questão (5.43): De variis lapidibus metallicis et primo de cadmia. Isto é: "Sobre diversas pedras e metais, e em primeiro lugar sobre a cadmia".

6 Tanto quanto se sabe, não chegou a concretizar esta sua intenção. Mas era matéria que valeria a pena explorar. Plínio, tantas vezes citado, dedicara os dois últimos livros da sua História Natural ao estudo das pedras, reservando mesmo o último (o livro 37) ao estudo das pedras preciosas, com o argumento de, em seu entender, ser nas pedrarias que mais se evidencia a majestade da natureza. 
privilegiada, a de um mercador de Ragusa, que lhe permitiu conhecer de visu e observar as pedras de que falava. Ele mesmo o afirma, no Comentário 108 (5.108), dedicado à pedra arábica:

Cum de lapillis sermonem habere statueram, hinc inde omni data opera eos inquirere ac propriis oculis prius videre decrevi, in qua investigatione ecce occurrit mercator quidam Ragusinus, harum rerum curiosissimus, ac indagator maximus, qui ducentos fere varios lapillos, apud se reconditos, et ex variis mundi partibus conquisitos, pro thesauro habet, inter quos Arabicus lapis est (...).

Quando tomei a decisão de dedicar um estudo às pedras preciosas, resolvi fazer todo o esforço no sentido de as procurar por aqui e por ali e vê-las antes de mais com os meus próprios olhos; no decurso dessa procura, eis que me aparece um mercador de Ragusa, muito curioso destas matérias e um grande coleccionador, que tem em sua casa cerca de duzentas pedras muito bem guardadas, como um tesouro, e reunidas de várias partes do mundo, entre as quais a pedra arábica de que falo (...). ${ }^{7}$

A atitude de Amato está em perfeita consonância com o que era habitual no seu tempo, sendo, como se sabe, próprio do espírito do homem do Renascimento procurar observar com os seus próprios olhos os produtos e substâncias em estudo, para desse modo testar as informaçóes colhidas nos livros, antigos e recentes, de que se socorre na sua investigação. O "vi claramente visto” de Camóes aí está para o comprovar. No caso específico do bom médico, vinha já dos tempos clássicos e medievais o preceito que mandava aliar a experiência e a prática à teoria e à razão. Amato Lusitano, médico-filólogo do Renascimento, comungava deste empenho científico e desta postura, embora nem sempre lhe tenha sido possível testar as informaçóes farmacológicas e terapêuticas colhidas em Dioscórides, como acontece sobretudo na parte final do comentário ao livro $\mathrm{V}$, quando procura estudar certas qualidades de terra, mais concretamente as terras da Erétria, de Samos, de Quios, de Selinunte, de Cimolo, a terra pnigite (qualidade de barro escuro), a cinza de terra vermelha dos fornos, a terra de Melos e a terra betuminosa. Exceptuando a terra de Samos (identificada com o talco), nenhuma das terras e substâncias acabadas de referir é objecto de comentário ou identificação. Poder-se-ia pensar que Amato estava cansado ou ansioso por concluir os Comentários, mas o motivo é outro: o médico não dispunha de dados para se pronunciar, como se depreende do seguinte lamento (5.140):

7 Amato refere várias vezes pedras preciosas que viu em casa desse mercador de Ragusa. Vejam-se, por exemplo, as entradas 5.116, 5.118, 5.119, 5.122. Segundo informação gentilmente cedida por Vinicije B. Lupis, Professor de Dubrovnik (Croácia), este mercador de Ragusa seria, muito provavelmente, Jacob di Lovro Sorkočević. 
Olim medici variis iis terra [sic] generibus utebantur; nunc vero hominum negligentia factum est, ut ea omnia ignoremus et illis minime uti possimus.

Outrora, os médicos recorriam a estes diversos tipos de terra; mas hoje, por negligência dos homens, acontece que as desconhecemos a todas e ficamos totalmente privados de poder utilizá-las.

\section{DESCRIÇÃO DE ALGUMAS SUBSTÂNCIAS DO MUNDO MINERAL REFERIDAS POR AMATO}

Como foi dito anteriormente, o Livro $\mathrm{V}$ das Enarrationes contém uma ampla exposição dedicada à videira e aos vinhos, a que se segue o que Amato designa por pedras e metais. ${ }^{8}$

A análise destas diferentes "pedras e metais" remete-nos para a dificuldade em conciliar classificaçôes actuais de definição do que são minerais, usando por exemplo critérios como génese, composição química e estrutura, como a que é apresentada em Dioscórides-Amato. Autores mais eruditos assinalaram autorizadamente as várias dificuldades, de terminologia e variabilidade das classificaçóes, buscando no contexto de autores coevos e outros mais antigos a possibilidade de se irem identificando primeiramente os materiais de que se estaria a falar ao tempo de Dioscórides e também ao tempo de Amato.?

Dioscórides (fl. 50-70 d.C.) menciona autores que lhe serviram de suporte, por exemplo, Teofrasto (372-287 a.C.), que no Tratado das Pedras indicava metais, pedras, sais, nitro e alúmen, os quais também designou de forma genérica por "terras". Plínio (23-75 d.C.), outro autor de referência, depois de tratar das pedras, classificou as gemas de vários modos, ainda que as tenha incluído em designaçóes genéricas como minerais, metais e terras. Por sua vez, Amato Lusitano traz a terreiro algumas autoridades, nomeadamente Galeno e Plínio, seguindo-se-lhes, a grande distância, Teofrasto (Tratado das Pedras), Avicena, Alberto Magno (e o De natura fossilium), Manardo, ${ }^{10}$ e outros mais, escassamente representados.

8 De um total de 142 entradas do livro V (na edição de Veneza, de 1553, das Enarrationes), apenas a partir da entrada 43 (sobre a cadmia, nome antigo da calamina - resíduo que se deposita nas paredes dos altos-fornos e contém entre outros zinco e ferro) nos encontramos perante a parte mineral, encerrando-se este livro com referência à tinta de escrever (5.142).

9 Veja-se José Luis Fresouet Febrer, "El uso de productos del reino mineral en la terapéutica del siglo xVI. El libro de los "Medicamentos simples" de Juan Fragoso (1581) y el "Antidotario" de Juan Calvo (1580)", Asclepio 51.1 (1999), pp. 55-92, p. 57 e segs.

10 Giovanni Manardo (1462-1536), médico e professor no Estudo de Ferrara. 
No seu trabalho sobre "El uso de productos del reino mineral..." ${ }^{11}$, Fresquet Febrer procura contextualizar genericamente as classificações propostas até então, referindo autores medievais que adiantaram outras distinçóes para as "pedras", em que se incluíam frequentemente minerais, metais, terras e pedras preciosas. Por volta de 1640, Alonso Barba (1569-1662) em Arte de los metales referia-se aos quatro géneros de "mistos" a que se reduziam todos os inanimados, que compreendiam os metais, as pedras, as terras e os sucos. Misturando os quatros "mistos" podiam obter-se onze géneros novos, cujas definições estavam imbuídas dos resultados da experiência e da observação.

Náo havendo registo de datas iniciais para a utilização medicinal de minerais, pedras, metais, terras ou gemas, sabe-se que, desde tempos antigos, se lhes atribuíram qualidades terapêuticas, em particular à safira, ao jacinto, esmeralda, berilo, pérola, ouro, ferro, pedra íman, coral, prata. No entanto, em alguns casos, o seu uso era simplesmente talismânico ou mágico, como se exemplificará mais adiante.

Amato reagiu criticamente a muitos destes usos, buscando essencialmente, nos seus comentários a Dioscórides, e também nas Centúrias médicas, as propriedades curativas conhecidas e testadas que o decorrer dos tempos tinha permitido identificar e validar, em verdadeiro espírito de carácter moderno e experimental.

Consultando outras referências de interesse, por exemplo, a tradução e notas de Manuela García Valdés a Dioscórides, no seu Plantas y Remedios Medicinales (De materia medica) Libros $I V-V,{ }^{12}$ verifica-se também a existência neste trabalho de 88 entradas para a parte mineral, que se inicia igualmente com a descrição da 'cadmia'. Estas são antecedidas por 73 entradas que se referem a vinhos e afins.

Por sua vez, comparando as Enarrationes de Amato com o chamado 'manuscrito de Salamanca', verificamos alguma variabilidade, pois este apresenta 102 entradas, das quais as três primeiras correspondem a entradas minerais que ocorrem no Livro I (asfalto, pez asfáltico e nafta). ${ }^{13}$

No seu artigo, intitulado "Healing with minerals and inorganic substances", Efraim Lev introduz-nos numa revisão sobre a prática médico-farmacopeica levantina da Idade Média até ao presente. ${ }^{14} \mathrm{O}$ nosso interesse imediato prendia-se com tentar perceber de que modo um estudioso de vários documentos antigos relativos ao uso de minerais e substâncias inorgânicas

11 Fresouet Febrer, "El uso de productos...", op. cit..

12 Manuela García VAldés (traducción y notas), Dioscórides. Plantas y Remedios Medicinales (De materia medica) Libros IV-V - Pseudo Dioscórides. Madrid, Gredos, 1998. Esta tradutora espanhola segue a edição crítica de Wellmann do tratado de Dioscórides, ao passo que o manuscrito de Salamanca, referido a seguir no texto, representa apenas um dos muitos manuscritos existentes.

13 Ángel Corrochano Sánchez, Descripción de Minerales y Rocas del Dioscórides, Universidad de Salamanca e Dioscorides online [dioscorides.eusal.es] - Minerales y Tierras.

14 Efraim LEV, "Healing with minerals and inorganic substances: a review of Levantine practice from the Middle Ages to the present", International Geology Review 52, Ns. 7-8 (2010), pp. 700-725. 
no tratamento médico fazia uma apresentação dos mesmos, sabendo que estes tiveram categorizaçóes particulares à época e diferentes das actuais. Nesse sentido, procuramos comparar o que tínhamos nas Enarrationes com o que Lev considerava no âmbito dos materiais inorgânicos (metais, minerais, solos), orgânicos (por exemplo, asfalto, petróleo bruto, "glycerine", "sulphanilamide", ${ }^{15}$ ácido tartárico e "vaseline") e misturas, contendo substâncias inorgânicas (por exemplo: tinta) que fizeram parte do inventário das substâncias medicinais de várias culturas desde tempos antigos. Alerta-nos este autor para o facto de, apesar de terem sido considerados importantes, os minerais, metais, terras e outras substâncias inorgânicas terem desempenhado papéis menores na prática curativa dos vários continentes. Relativamente a Dioscórides e ao livro V da sua Materia medica, menciona a existência de 99 substâncias inorgânicas, que compreendem $10 \%$ de todas as substâncias listadas, ${ }^{16}$ onde se incluem metais, minerais e rochas; o "antimónio, asfalto, cálcio, carbon, espécies de solo, cobre, ferro, chumbo, sal $(\mathrm{NaCl})$, sódio, enxofre, zinco e sais metálicos" foram também usados. A utilização que este autor faz de nomenclatura moderna confunde um pouco no que respeita às verdadeiras substâncias em uso em determinado momento que não o actual. Assim, será mais provável e adequado, por exemplo, falar no uso de carvão do que no de carbono, quando se refere a carbon. Ao mencionar o sal, que entende como cloreto de sódio pela fórmula que usa, mas indica também explicitamente o sódio, em inglês, quando este último foi isolado apenas no início do século xix. Provavelmente no original usar-se-ia a palavra 'natro' (carbonato de sódio hidratado) que pode estar a ser traduzido por sódio ('natrium').

Tentando fazer um primeiro agrupamento dos produtos identificados nas Enarrationes, destacamos:

i. 12 tipos de substâncias intituladas de 'terras'

ii. 24 tipos de substâncias intituladas de 'pedras'

iii. cinzas vegetais; cinzas de sarmento/videira; salsugem ${ }^{17}$

iv. metais: cobre, mercúrio, escória de prata, antimónio, chumbo, ferro, arsénico

15 Designação completamente actual de composto para o tratamento de infecções estreptocócicas de que não se tem correspondente antigo.

16 LeV, "Healing with minerals...", op. cit., p. 701.

17 Espuma que no tempo da seca se pega às plantas e pedras, junto às lagoas, pântanos ou à beira-mar e que endurece com o tempo. Lodo, em que há substâncias salíferas. - Lello Universal, 2 vols.. Porto, Lello \& Irmão Editores, 1930. 
v. sais: natro ${ }^{18}$, sal ${ }^{19}$, flor de $\mathrm{sal}^{20}$, cal viva, ${ }^{21}$ caparrosa, ${ }^{22}$ rubricas, ${ }^{23}$ óxidos metálicos vi. minerais / minério: esmeril ${ }^{24}$ asbesto $;{ }^{25}$ pedra magnetite; ${ }^{26}$ jaspe $;^{27}$ pedra selenite e pedra serpentina; galactite, pedra quistosa de azeviche (carvão - madeira fossilizada ou âmbar negro); ${ }^{28}$ pedra de hematite; pedra pirite; gesso, enxofre, calcopirite; cinábrio, azurite;

18 Natro - Natrão, natro ou natrum. Carbonato de sódio hidratado, $\mathrm{Na}_{2} \mathrm{CO}_{3} \cdot 10 \mathrm{H}_{2} \mathrm{O}$. Servia aos Egípcios para conservarem as múmias. In Lello Universal, op. cit.. Salitre - nitrato de potássio; o mesmo que nitro (antiga designação).

19 Sal marinho - cloreto de sódio, NaCl; Sal-gema - cloreto de sódio acompanhado pelos cloretos de potássio e magnésio.

20 Flor de sal - conjunto de cristais de sal que se vão produzindo à superfície da água, à medida que vai havendo evaporação nas salinas. Costuma ser recolhida diariamente, evitando a sua deposição posterior no fundo.

21 Cal é o óxido de cálcio que constitui a base de um grande número de pedras, como o mármore, o cré, o gesso, etc. A cal obtém-se pela calcinação, em fornos especiais, da pedra de cal. Cal viva - cal anidra.

22 Caparrosa - designação vulgar de vários sulfatos: caparrosa-branca (sulfato de zinco); caparrosa-azul (sulfato de cobre); caparrosa-verde (sulfato de ferro), também chamada vitríolo verde-adstringente e tónico - serve para aplicação externa, em solução, contra as úlceras atónicas, hemorragias, oftalmias crónicas, erisipela. Referido também em Georges Louis Le CLeRC De Buffon, Histoire Naturelle Des Mineraux, Vol. 3.

23 Terra vermelha que se empregava outrora para estancar o sangue. Almagre empregado para traçar linhas nas peças de madeira ou para certas indústrias e pinturas grosseiras. In Dicionário Prático ilustrado, Lello \& Irmão editores, 1979.

24 Corindo muito duro que, pulverizado, serve para polir e desgastar o vidro, os metais, o diamante, etc. É também pedra preciosa, formada por alumínio cristalizado.

25 Asbesto ou amianto, designação comercial para um grupo de minerais fibrosos, de que os três principais são o crisólito (amianto branco - silicato de magnésio), a crocidolite (variedade de anfíbola - silicato de sódio, com um pouco de ferro e alumínio) e a amosite (variedade de anfíbolas ferrosas - silicato de ferro, com um pouco de magnésio). Agricola diz-nos que se chama amiantus porque o fogo não destrói o seu brilho ou lustro e que se designa por asbestos também porque dele se fazem pavios para lâmpadas que não são consumidos pelo fogo. Mas existiam outras designações como, por exemplo, linon dado que era possível tecer as fibras como se de linho se tratasse. Georgius AGRICOLA, De Natura Fossilium (Textbook of Mineralogy), translated from the First Latin Edition of 1546, The Geological Society of America, Special Paper 63 (1955), p. 93. Pode ser também chamado de papel-fóssil, cortiçafóssil ou couro-fóssil. Os Antigos fabricavam tecidos com ele nos quais queimavam os seus mortos. In Lello Universal, op. cit..

26 Pedra magnética, magnetite ou íman natural. Óxido de ferro $\mathrm{Fe}_{3} \mathrm{O}_{4}$.

27 O jaspe é um sílex impuro (rocha sedimentar silicatada) que, segundo as matérias que contém, é vermelho, amarelo, verde, etc. Pedra fina, dura e opaca, da natureza da ágata, com veios ou manchas coloridas. A pedra-de-toque dos ourives é um jaspe-negro.

28 Pedra de turfa (De lapide Gagate, 5.105) ou azeviche. É um dos quatro tipos de carvão mineral (turfa, lenhite, hulha e antracite) e usa-se como gema. Substância mineral betuminosa negra, luzidia e frágil. 
crisocola, pedra de alabastro, ocre (argila); auripigmento; ${ }^{29}$ fuligem ou negro-de-fumo (um carvão finamente pulverizado); cacos de barro cozido ${ }^{30}$; areia do mar, pedra de Mênfis ${ }^{31}$ vii. rochas: lápis-lazúli; pedra-pomes

viii. de origem animal: coral negro e coral; esponjas, cinza das conchas do mar

ix. pelas suas propriedades: substâncias adstringentes

x. outras: tinta negra; remédio para a sarna; alvaiade; ${ }^{32}$ litargírio; ${ }^{33}$ aço; cardenilho; ${ }^{34}$ água salgada ${ }^{35}$

Estes agrupamentos merecem reparo, na medida da dificuldade em manter categorias que são, por exemplo, mais utilitárias do que científicas, ou que suscitam a repetição, em virtude de diferentes propriedades e designações que podem atribuir-se às mesmas substâncias. Foi possível encontrar dez grupos que poderão mais finamente ser reduzidos a pelo menos metade. Há diversas substâncias que, em boa verdade, não são pertença do reino mineral. De todo o modo, teremos de ter presente que, à época de Amato, havia ainda muito pouco esclarecimento sobre o que se veio a tornar a(s) nomenclatura(s) mineralógica(s) e geológica(s) posterior(es).

29 Ouro-pigmento ou ouro-pimenta é um sulfureto natural de arsénio, $\mathrm{As}_{2} \mathrm{~S}_{3}$, que se apresenta em lamelas amarelo-ouro ou alaranjado. Encontra-se nos mesmos locais que o rosalgar. Emprega-se em pintura e, em farmácia, na preparação de pastas depilatórias.

30 Historicamente, em geologia e ciência do solo, o termo argila corresponde aos minerais que apresentam tamanho inferior a $2 \mu \mathrm{m}$ em uma rocha. Bocados/ cacos de barro cozido - "óstraka". Ao serem muito cozidos, tornam-se escaróticos, pelo que, aplicados com vinagre, curam pruridos e exantemas, sendo benéficos contra a podagra. In Lello Universal, op. cit..

31 Sobre a pedra de Mênfis (5. 117) Amato refere: "Hoje não dispomos desta pedra e oxalá ela fosse conhecida, para os médicos poderem recorrer a ela." Encontramos a identificação desta pedra em Encyclopédie Méthodique, Arts et Métiers Mécaniques, Tome II, 1783. Trata-se de uma espécie de ónix, com um anel vermelho, conhecido como cornalina vermelha, ou sardónia oriental, que é a mais dura e mais transparente de entre as várias espécies.

32 Alvaiade ou pedra de chumbo $(\mathrm{Pb})$ - encontra-se na natureza sobretudo nas formas de sulfureto (galena), de sulfato (anglesite) e de carbonato (cerusite). Todos os sais de chumbo são venenosos; os vapores de chumbo provocam indisposição grave, denominada cólicas de chumbo ou saturninas. A terapêutica emprega o protóxido de chumbo na preparação do emplastro simples e do extracto de Saturno; o óxido vermelho de chumbo é usado em diversos emplastros; o alvaiade e o iodeto de chumbo utilizam-se em pomadas resolutivas; o subacetato na preparação da água branca, etc. In Lello Universal, op. cit..

33 O litargírio ou fezes de ouro é um óxido de chumbo ( $\mathrm{PbO}$ ).

34 Cardenilho é o nome dado a diversos acetatos de cobre. 0 mesmo que azebre (isto é, verdete). Pode referir-se à tinta feita com essa substância. Obtém-se pela acção do bagaço das uvas acetificado sobre placas de cobre vermelho. In Lello Universal, op. cit..

35 A água do mar caracteriza-se por salinidade acima de 30 partes de mil. In Dicionário Houaiss da Língua Portuguesa. T. I. Lisboa, Círculo de Leitores, 2002. 
Poggendorff ${ }^{6}$ informa-nos, por exemplo, que, se se compararem as obras de Abu Musa Jabir ibn Hayyan, também conhecido como Geber (c.721-c.815), ${ }^{37}$ com a história natural de Plínio ou a matéria médica de Dioscórides, verifica-se que, no intervalo dos seis séculos que separam estes diversos trabalhos, se atingiu um avanço considerável nos conhecimentos químicos. Este progresso ocorreu a dois níveis. Do ponto de vista prático, desenvolveu-se o conhecimento dos factos e, do ponto de vista teórico, verificou-se um esforço por encontrar uma ligação entre os diferentes fenómenos. Relativamente ao primeiro, convém lembrar que os antigos conheciam apenas sete metais em estado de "regule" ${ }^{38}$ : ouro, prata, cobre, estanho, chumbo, ferro e prataviva. Geber conheceu, para além destes, o arsénico metálico.

Buscando as substâncias que verdadeiramente possam ser consideradas do reino mineral, teremos os metais, sais, minerais/ minérios, as rochas e outras. Aqui encontra-se de facto a maior parte dos produtos identificáveis nas Enarrationes de Amato, ainda que possam por vezes ter designaçóes especiais, como iremos apreciar de seguida, seleccionando, para o efeito, a crisocola, o lápis-lázuli, o cinábrio fóssil e artificial, a prata viva, a rubrica de Sinope, algumas terras, o vitríolo, o alúmen, o sal, a hematite, a pedra-de-águia (aetite) e a tinta preta.

O Comentário 64 (De chrysocolla, 5.64) reporta-se à crisocola, uma substância verde de que se serviam os antigos para soldar o ouro. É um silicato natural hidratado de cobre, $\mathrm{CuSiO}_{3}$ que deverá corresponder ao pigmento verde de carbonato de cobre ou malaquite. ${ }^{39}$

No Comentário 66, Amato fala-nos do lápis-lazúli $(\mathrm{Na}, \mathrm{Ca})_{8}\left(\mathrm{AlSiO}_{4}\right)_{6}\left(\mathrm{~S}, \mathrm{SO}_{4}, \mathrm{Cl}\right)_{1-2}$ ou lazulite $\mathrm{Na}_{8}\left[\mathrm{~S} /\left(\mathrm{AlSiO}_{4}\right)_{6}\right]$, silicato de alumínio, sódio e cálcio, pedra azul opaca, riscada de branco e salpicada de amarelo-ouro. Informa que o lápis-lazúli mais apreciado é o que contém "muitas centelhas de ouro, a partir do qual as boticas modernas fabricam pílulas para tratar a bílis negra" (melancolia) ${ }^{40}$ e que também serve aos pintores para preparar o "azul ultramarino". ${ }^{41}$

O Comentário 68 é dedicado ao ocre (ou ocra), variedade de argila colorida pelo óxido de ferro, rica em hematita (ocre vermelho) ou em limonita (ocre amarelo), óxido hidratado de ferro e que serve para o fabrico de tintas. Nas palavras de Amato:

36 Johann Christian Poggendorff, Histoire de la Physique. Paris, Dunod, Libraire-Editeur, 1883. Reimpressão autorizada, Editions Jacques Gabay, 1993, p. 86.

37 Geber é considerado por muitos como um precursor da química moderna. Sintetizou o ácido clorídrico e o ácido nítrico, descobriu o ácido cítrico, o tartárico e o acético e foi o inventor da água-régia, que dissolve o ouro. Produziu vários trabalhos de índole teórica e prática.

38 Substância metálica resultante da fusão de um mineral: "regule d'antimoine, regule d'arsenic".

39 Segundo Estrabão, a crisocola era encontrada na urina de crianças. Vd. Estrabão, Geografia, Livro xvı, Capítulo 2, 43.

40 (...) et illum optimum dicunt, quem multis auri scintillis ornari vident, ex quo hodiernae officinae pilulas pro depellenda atra bile componunt.

41 Ceterum, ex lapide isto cyaneo sive lazulo dicto color paratur caeruleus, quem ultramarinum pictores appellant (...). 
Ochra terra rubra et lapidis modo concreta est, qua pigmentariae officinae fere omnes abundant et ea pictores pro colore utuntur, veluti sarcinatores pro signandis pannorum incisionibus.

O ocre é uma terra vermelha e compacta, como uma pedra, que abunda em quase todas as boticas de pigmentos, e os pintores usam-na para colorir, como fazem os alfaiates para marcar os cortes dos tecidos.

No Comentário 69, Amato refere-se ao cinábrio fóssil e artificial, reportando-se inicialmente ao que Dioscórides refere como "sangue-de-drago" (cinnabar) e que remete para a seiva avermelhada do dragoeiro, ${ }^{42}$ planta arbórea frequente nas ilhas da Madeira (Figura 1) e Canárias, por exemplo, e que nada tem a ver com o que designa por cinábrio fóssil (sulfureto de mercúrio) ou o artificial (cinnabrium fossile \& artificiale), que era obtido por fusão do mercúrio (também designado por prata viva, argentum vivum, hidrargírio ou ainda 'prata líquida dos Romanos') com o enxofre.

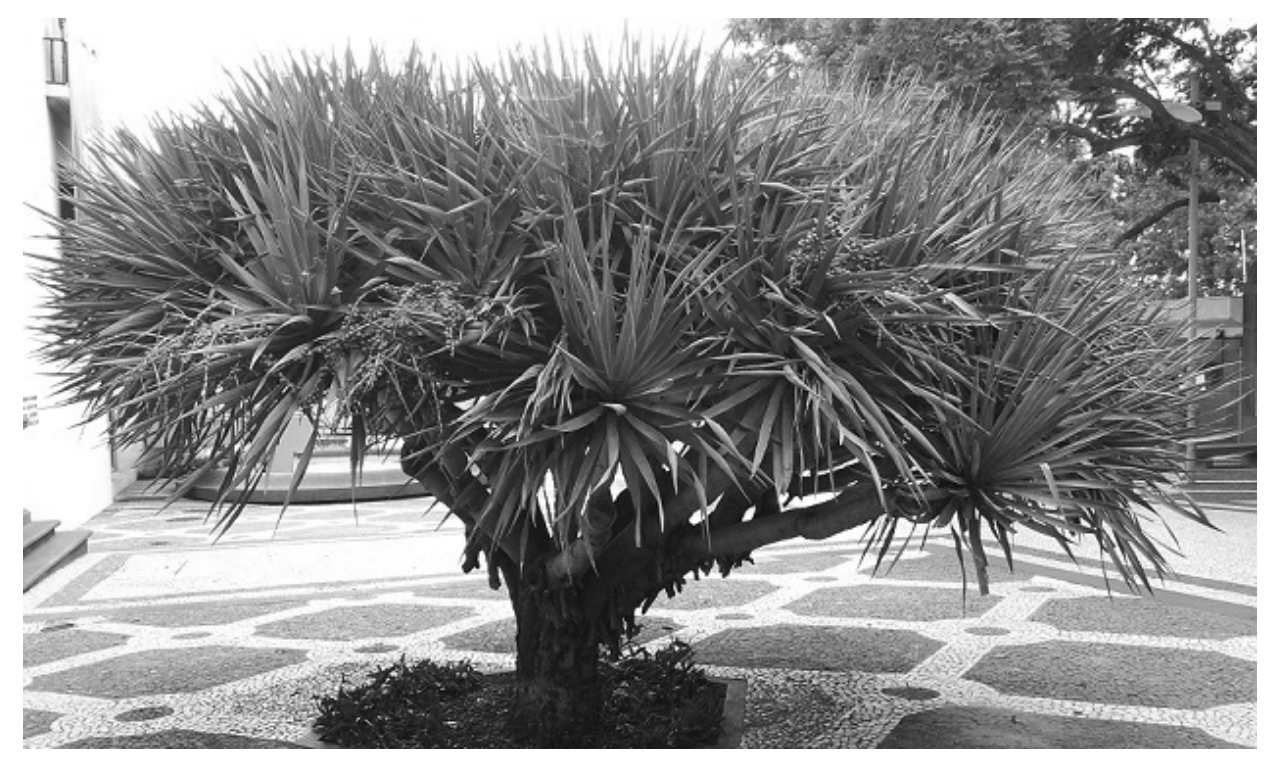

Figura 1 - Dragoeiro - Centro da cidade do Funchal (Madeira). Foto de José Sílvio Fernandes

42 Com propriedades anti-hemorrágicas, antidiarreicas e antiblenorrágicas. In Dicionário Houaiss, op. cit., T. VI, 2003. 
O Comentário 70 é dedicado explicitamente à prata viva ou mercúrio, metal usado sobretudo na produção de unguentos contra o morbus Gallicus (peste gálica), se administrado com moderação, pois pode "rebentar com as entranhas", como dizia Dioscórides, devido à sua elevada massa volúmica. Exemplifica, no entanto, a sua utilidade com o caso ocorrido de uma criança que, tendo bebido uma elevada porção, conseguiu ficar desinfestada dos vermes que continha.

No Comentário 71, Amato debruça-se sobre a chamada "Rubrica de Sinope" que assemelha ao barro de Estremoz, conforme se verá na segunda parte deste trabalho, informando ainda que é uma terra de que se faz uso frequentemente em vez do "bolo arménio". ${ }^{43}$ Rómulo de Carvalho refere que o famoso químico Marcellin Berthelot (1827-1907) identifica a terra de Sinope com o óxido vermelho de chumbo que se designa vulgarmente de mínio ${ }^{44}$, sendo Sinope ${ }^{45}$ o nome de uma colónia grega da antiguidade, situada na costa sul do mar Negro, célebre pelas suas construçôes marítimas e pela indústria do ferro que desenvolveu bastante. ${ }^{46}$ Encontramos também referência como sendo um outro mineral, o cinabrino vermelho, isto é, um sulfureto de mercúrio trigonal, vermelho e brilhante, que na Capadócia é recolhido em certas cavernas, sendo depois filtrado e levado para Sinope onde era vendido, tomando-lhe o nome. Dizia-se que o melhor é espesso e pesado, cor de fígado uniforme e sem pedras, ${ }^{47}$ tal como Amato refere em parte da descrição da mesma rubrica. ${ }^{48}$

No Comentário 74 (De calcantho, 5.74), Amato refere-se à caparrosa, também conhecida por vitríolo. ${ }^{49}$ A possível identificação deste sal — sulfato - conduz-nos a três variedades do mesmo: o vitríolo azul ou caparrosa azul, sulfato de cobre - calcantite, $\mathrm{CuSO}_{4} .5 \mathrm{H}_{2} \mathrm{O}$, também

43 A designação de bolo remete para porção de terra argilosa, outrora empregada como medicamento. O bolo-arménio é reconhecido como uma espécie de argila tónica, in Dicionário Houaiss, op. cit., T. IV, 2003; e também em Medicina Lusitana e socorro delphico a os clamores da natureza humana, por bolo arménico purgante ou de terra sigillata, p. 552.

44 Óxido vermelho de chumbo $\left(\mathrm{Pb}_{3} \mathrm{O}_{4}\right)$, também chamado 'mínio', usado em pinturas e porcelanas, tintas anticorrosivas, etc.; zarcão. Empregue pelos calígrafos medievais, desfeito em água-goma. In Dicionário Houaiss, op. cit., T. V, 2003.

45 Sinople ou sinopla refere-se a vermelho, ocre, preto, verde. In Dicionário Houaiss, op. cit., T. V, 2003.

46 Rómulo de Carvalho, A Ciência Hermética. Lisboa, Relógio D’Água Editores, 1996.

47 In Lello Universal, op. cit..

48 Diz Amato: terra enim est rubrica sinopis densa, gravis, iocinoris colore, non calculosa, sibi concolor, isto é: "Na verdade a rubrica de Sinope é uma terra compacta, pesada, cor de fígado, não pedregosa, de cor uniforme". Veja-se, sobre o assunto, B. F. L. FAGUndes \& S. G. de PAuLA (Orgs.), Glossário: Observações sobre o universo vocabular médico-cirúrgico do Erário Mineral, de Luís Gomes Ferreira. Rio de Janeiro, Editora FIOCRUZ, SCielo Books http://books.scielo.org: "Torrãozinho ou pedaço de terra crassa e pesada, de cor avermelhada, extraída das cavernas da Capadócia, confinantes com a armênia, donde tomou o nome. Há ainda o legítimo bôlo-armênio, medicamento dessecativo, incrassante, repercutiente e adstringente, aromático, brando, sem areia e que, mastigado, se derrete na boca, como manteiga."

49 Por óleo de vitríolo entende-se o ácido sulfúrico, $\mathrm{H}_{2} \mathrm{SO}_{4}$ 
conhecido por pedra-lipes ${ }^{50}$; o vitríolo branco ou sulfato de zinco, $\mathrm{ZnSO}_{4}$; o sulfato ferroso $\left(\mathrm{FeSO}_{4} .7 \mathrm{H}_{2} \mathrm{O}\right)$, também referido como ferro (ii) sulfato, ou vitríolo verde.

No Comentário 75 (De chalcitide, 5.75), Amato indica a calcopirite, também conhecida como pirite de cobre ou sulfureto duplo natural de cobre e de ferro, $\mathrm{S}_{2} \mathrm{FeCu}$.

O Comentário 83 (De alumine, 5.83) é dedicado ao alúmen ou alume, de que existem várias espécies, sendo o mais vulgar o alúmen de potássio ou simplesmente alúmen, sulfato duplo de alumínio e potássio. Outros alúmenes são, por exemplo, o alúmen de cromo, o de soda, o de amoníaco, o de ferro. Encontram-se no estado natural, mas podem preparar-se a partir do alúmen ordinário. Têm propriedades adstringentes, usam-se como mordentes em tinturaria, tornam imputrescíveis várias substâncias animais, usam-se na clarificação de certas águas, na conservação de peles, endurecimento do gesso, entre outras. Em medicina, para além das propriedades adstringentes, usa-se como cáustico, quando está anidro, designando-se por alúmen calcinado. Vicente Coelho Seabra (1763-1804) refere que Wallerio ${ }^{51}$ distinguira muitas espécies de alúmen nativo (por exemplo, "o alumen solido, alumen crystalisado, alumen eflorescente, as terras aluminosas brancas, pardas, negras, e os Schistos aluminosos”) e que, no comércio, também apareciam várias designações entre as quais a do chamado 'alumen de rocha', designação relativa ao alúmen preparado "na cidade de Edessa, antigamente chamada Rocha, em massas grandes." 52

No Comentário 102 são tecidas consideraçóes sobre a pedra pirite (sulfeto de ferro, $\mathrm{FeS}_{2}$ ), para indicar que corresponde ao que os árabes terão traduzido por 'marcassita', referindo-se ao mesmo mineral.

O Comentário 103 reporta-se à hematite, sesquióxido natural de ferro, de cor escura ou vermelha, com propriedades de frialdade e adstrição, que a tornam importante no tratamento dos olhos e no tratamento hemostático.

No Comentário 116 (De sapphiro lapide, 5.116), sobre a safira, Amato refere a existência de dois tipos, uma esbranquiçada e outra azul, sendo esta considerada uma pedra preciosa, usada encastoada em ouro. No que se refere a propriedades medicinais, menciona o uso da safira entre os "medicamentos cordiais" e acrescenta que "uma bebida preparada com esta pedra cura as mordeduras dos escorpióes", de acordo com Galeno..$^{53}$

50 Dicionário Houaiss, op. cit., T. V, 2003.

51 Johan Gotschalk Wallerius (1709-1785) - químico e mineralogista sueco.

52 V. Coelho Seabra, Elementos de Chimica, Vol. 1, 1788, pp. 130-131. Edição fac-similada. Coimbra, Departamento de Química da FCTUC, 1985.

53 Nostri vero temporis medici cum Arabibus inter fragmenta cordialia sapphirum quoque reponunt, nec sane immerito, quia Galenus libro nono de Fac. simpl. med. eius potum scorpionum ictibus mederi tradit. Acrescente-se que a safira é um corindo (óxido de alumínio, $\mathrm{Al}_{2} \mathrm{O}_{3}$ ) e da mesma espécie é o rubi. 
No Comentário 118, Amato fala da selenite (ou pedra da Lua) que vira em Ragusa em casa de um mercador importante, distinguindo-a em termos de características visuais (externas) como diferente do carbúnculo (rubi muito brilhante); sendo "muitíssimo branca, nas trevas emitia de si uma luz", e acrescenta que o seu "espírito se inclina mais para que seja a selenite, branca, diáfana, muito pouco pesada, que nasce na Arábia." ${ }^{54}$

Relativamente à aetite ou pedra-de-águia, também conhecida na tradição popular por "pedra parideira", a verdadeira é extremamente rara no mundo, existindo em Portugal apenas em Arouca, serra da Freita, e no Canadá. Trata-se de medalhóes lenticulares de biotite, com núcleo de quartzo, e de alguns centímetros, que podem ser expelidos a partir da matriz granítica onde estas se situam ${ }^{55}$ (Figura 2). Amato refere, baseado na sua experiência empírica, que não conhece atributos especiais para o seu uso, registando apenas alguma superstição relacionada com situações de parto.

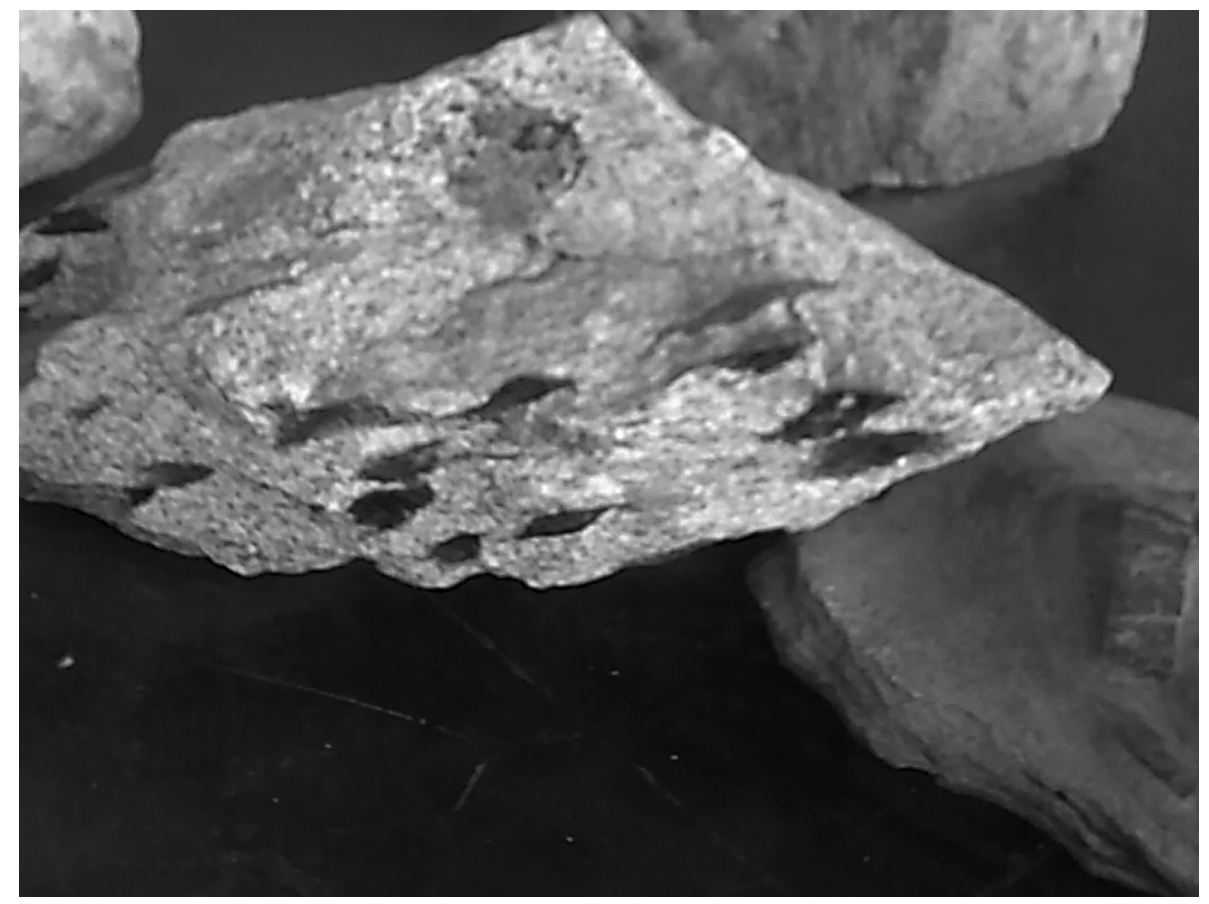

Figura $\mathbf{2}$ - Pedra aetite. Foto de Isabel Malaquias

54 A selenite é um gesso, mais propriamente um sulfato de cálcio hidratado.

55 Biotite em granito $-\mathrm{K}(\mathrm{Mg}, \mathrm{Fe})_{3}(\mathrm{OH}, \mathrm{F})_{2}(\mathrm{Al}, \mathrm{Fe}) \mathrm{Si}_{3} \mathrm{O}_{10}$. 
O Comentário 128 é dedicado à geode, dizendo Amato desconhecer a que pedra se referia Galeno. Em boa verdade, a designação corresponde não a um mineral, mas sim ao conjunto de cristais formados no interior de uma cavidade (Figura 3).

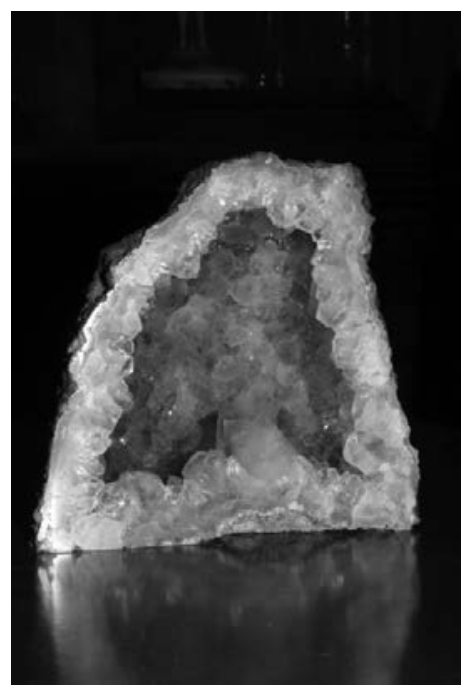

Figura 3 - Geode de quartzo ametista. Foto de Isabel Malaquias

Vários Comentários são dedicados a diferentes tipos de terras com propriedades medicinais, embora nem sempre seja possível identificar com precisão de que tipos são e em que diferem, ou se devem a designação apenas ao local de onde são extraídas. ${ }^{56}$ Sobre a Terra de Samos (5.131), de que nos fala Amato, identificamos a seguinte passagem escrita por Rómulo de Carvalho:

56 Agricola, op. cit., p. 22-35, diz-nos que habitualmente se distingue uma terra de outra com base na utilidade e nos diferentes usos que pode oferecer aos artesãos. Enquanto uma pode ser útil para os agricultores, outra é usada pelos médicos, por exemplo as terras Lémnia, de Samos e Arménia. Algumas são usadas pelos marceneiros, como o ocre vermelho, que por essa razão se chama fabrilis, ou rubrica pelos médicos. Os pintores usam a de Melos, e outras terras. Os lavandeiros utilizam a de Cimolos, pela sua capacidade de absorver gordura, mas também os médicos. Reflecte, contudo, que este tipo de nomenclatura não satisfaz o naturalista, pois não são distinções de espécie ou de género. E prossegue, mencionando outras terras que, essencialmente, se distinguem pelos nomes das localidades (Samos, Erétria, Quios e Selinúsia), mais do que por características intrínsecas. Relativamente ao seu uso em medicina, Agricola relembra que, dado que são naturalmente secas, têm a propriedade de secar e que, em geral são adstringentes e arrefecem e cortam as infecções. Quanto mais adstringente, mais fria é. Uma terra amarga tem gosto característico de calor. Algumas terras de gosto untuoso sentem-se como cola na língua e, não sendo adstringentes nem acres, podem usar-se como pomada e refrescar a pele moderadamente. Com um aumento da untuosidade, torna-se mais quente ou mais fria. 


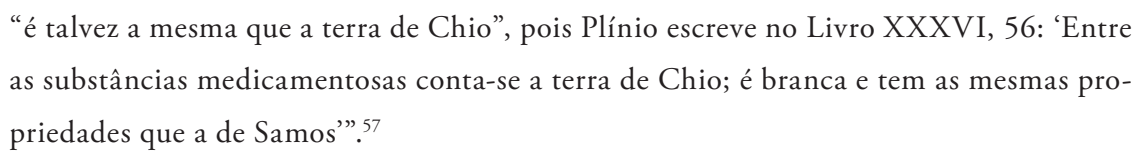

Em outra referência, distingue-se a terra de Samos em duas variedades: uma chamada collyrion, por ser usada habitualmente em remédios para os olhos; e outra designada por aster, por ser marcada com uma estrela no comércio, como acontecia com a terra de Lemnos que era selada com uma cabra, ou por a mesma brilhar devido a conter uma grande quantidade de mica. Ambas foram usadas em medicina. Era uma terra macia, untuosa, porosa, branca, com um gosto de óleo-doce. As descriçôes de diferentes autores sobre determinadas terras e as suas propriedades nem sempre coincidiam, verificando-se, por exemplo, que Dioscórides preferia o collyrion ao aster enquanto Galeno usava o aster para certas doenças e o collyrion para outras, atribuindo-lhe propriedades um pouco diferentes. ${ }^{58}$

A Terra de Selinúsia (5.134), ou de Selinunte deverá o seu nome à antiga cidade e rio da Sicília, ou ainda, à antiga cidade e rio da Cilícia, província da Ásia Menor, situada no norte da Síria. A melhor seria muito lustrosa, branca, friável e quando humedecida dissolvia-se rápida e completamente. Sobre a terra de Cimolos (5.135), assinala-se a existência de uma branca e outra púrpura; possui uma certa gordura natural, sendo bastante fria ao tacto. A terra pnigite (5.136) é parecida com a terra de Erétria, mas de torrôes maciços, cinzenta, fria ao toque, pegando-se à língua. Derivava o seu nome da aldeia de Pnigeus na Líbia egípcia. A Terra de Melos (nome antigo de Milo, ilha das Cíclades), elencada, mas não tratada no Comentário 139, é uma terra semelhante à terra cinzenta da Erétria, áspera quando se esfrega nas mãos,

fazendo um barulho suave como o da pedra-pomes. É parecida com o alúmen, embora mais fraca, pois desidrata ligeiramente a língua.

O Comentário 142 (De atramento librario, 5.142), com o qual se encerra o livro V, é dedicado à tinta de escrever. Em A Ciência Hermética, apresenta-se uma receita para produçáo de tinta de escrever, onde se lê:

\footnotetext{
"73-Outra: enxofre ápiro (...); alúmen lameloso, 1 dracma. Juntai-lhe, pelo meio, ferrugem seca*. Triturai finamente a ferrugem, o enxofre e o alúmen. Misturai-a muito bem, triturai-a com cuidado e utilizai-a como tinta preta de escrever, diluindo-a em vinho isento de água do mar. Escrevei em papiro e pergaminho.
}

57 Carvalho, A Ciência..., op. cit., p. 104.

58 Agricola, op. cit., pp. 22-35. 
Nota*: No caso da receita, é até possível que se refira ao cobre pois, no dizer de Plínio, os tintureiros faziam tinta preta com "uma eflorescência negra que se forma nas caldeiras de cobre" (Liv. XXXV, 25)." 59

\section{Em suma:}

$\mathrm{O}$ livro $\mathrm{V}$ dos Comentários de Amato Lusitano, dedicando apenas uma pequena parte às substâncias minerais, conduz-nos a uma série de metais, terras e pedras que, possuindo uma classificação muito própria da época, permitem contudo que as identifiquemos, na sua maior parte, com metais, minerais, rochas e cristais conhecidos na actualidade, em maior ou menor profundidade pelas suas propriedades físicas e químicas, de que, ao tempo de Amato, havia alguns dados empíricos que corroboravam, ou não, as referidas propriedades medicinais.

\section{AMATO E O MUNDO MINERAL: ALGUNS USOS E COSTUMES}

Excepção feita a comentários que se limitam a referir o título da entrada, sem acrescentar qualquer anotação, Amato Lusitano é geralmente generoso nas informações com que vai preenchendo os seus comentários, que por tal motivo se apresentam muito distintos em extensáo, profundidade de análise e interesse. Em certos casos, é apenas retomado, sem mais desenvolvimento, o que diz Dioscórides. Noutros, o comentário de Amato nada tem a ver com as informaçôes veiculadas pelo médico grego. Noutros casos ainda - e são sobretudo estes que fazem a riqueza e o interesse etnográfico e cultural do texto -, abundam as observaçóes e referências ditadas pela experiência actual ou passada do autor. Assim, Amato vai dando conta de locais onde teve oportunidade de observar alguns espécimes, como quando afirma que viu um coral (5.99) em Ferrara e em Ancona, onde se encontrava quando concluiu os Comentários, ou quando regista, no Comentário 113 (5.113), que teve ensejo de ver um ídolo feito de tuia, vindo do Novo Mundo e enviado a Diego Hurtado de Mendoza, embaixador de Carlos V. ${ }^{60}$

59 Carvalho, A Ciência..., op. cit., p. 115.

60 Diego Hurtado de Mendoza foi pessoa da máxima confiança e embaixador de Carlos V em Inglaterra (1537-1538), em Veneza (1539-1547) e em Roma, em 1547, tendo também sido representante do imperador no Concílio de Trento, em 1545. Segundo Amato, algumas das substâncias que pôde observar em casa do embaixador tinham sido enviadas por um irmão deste, representante do rei de Espanha em terras do Novo Mundo. É provável que Diego Hurtado apreciasse pedras preciosas, se ele é o D. Diego de Mendoza em cuja "rica livraria" se encontrava o Lapidário de D. Afonso X, que, à sua morte, foi adquirido "por Filipe II de Castela e I de Portugal, que os [sc. Livros] depositou na Biblioteca do Escorial" (J. Cardoso GonçALVEs, O Lapidário del Rey D. Alfonso X el Sabio. Lisboa, 1929, p. 20). 
Note-se, contudo, que esta abertura às notas de curiosidade não representa um modo diferente de comentar, pois informaçóes deste tipo são comuns em obras que caem na categoria de 'lapidários', como observou M. Helena Prieto. ${ }^{61}$

Assim sendo, além de assinalar sistematicamente o valor farmacológico e terapêutico das substâncias em estudo - na esteira, aliás, do texto de Dioscórides —, Amato não se cinge aos usos medicinais, alargando o seu interesse ao uso cosmético, ou aos usos na pintura, no teatro, na tinturaria, ou também na olaria e na construção. Aproveitando a oportunidade, esquece por vezes o texto do médico grego e fornece indicações de grande importância para a história dos usos e costumes de muitos dos lugares por onde o levou a sua vida de judeu exilado, como já Ricardo Jorge assinalou, ${ }^{62}$ evocando momentos da sua vida passada e da sua experiência no tratamento médico.

De entre os muitos exemplos que poderiam ser elencados, ${ }^{63}$ prestemos atenção a alguns desses (inesperados) apontamentos relativos a usos e costumes, que contribuem para diversificar e enriquecer os referidos comentários. São breves momentos e apontamentos que assomam quando menos se espera e são expressão das verdadeiras saudades da terra sentidas por Amato. Assim:

\subsection{As bilhas de Estremoz}

O Comentário 71 (5.71), já atrás referido, é dedicado à "rubrica de Sinope" (o chamado ocre vermelho). Entre outras informaçôes, Amato, exilado e com a sua terra no coração, não

61 Segundo M. Helena UReña Prieto ("O significado dos Lapidários Antigos", Revista da Universidade de Coimbra 37 (1992), p. 189), os lapidários são obras "que descrevem pedras preciosas e alguns outros minerais, fornecem ocasionalmente informações de carácter científico e dados que interessam o comércio, a religião e, de uma maneira geral, aquele ramo das ciências históricas a que hoje se chama a história das mentalidades".

62 No subcapítulo "Recordações da Vida Portuguesa" do seu estudo dedicado a Amato Lusitano, pp. 183 e seguintes, Ricardo Jorge chama a atenção para esta componente preciosa da obra do médico português.

63 Assim, por exemplo, a respeito do coral (5.99), que tem utilidade também medicinal, Amato regista o uso que as mulheres the dão, utilizando-o como adereço (em colares e pulseiras). Da pedra íman (5.107) diz que é a bússola dos mareantes. Segundo Amato, os pintores servem-se do lápis-lazúli (5.66) para conseguirem uma tinta de cor azul-marinho de grande qualidade e preço. Recorrem também ao ocre (5.68) para dessa terra vermelha extraírem um pigmento. Ainda segundo Amato, recorrem igualmente ao almagre (5.72), semelhante ao ocre (é ocre queimado), os mimos, actores e pintores. 0 chalcanthos (5.74) é a caparrosa, conhecida como vitríolo, que, de acordo com Amato, serve aos farmacêuticos para o fabrico de um óleo (óleo de vitríolo ou ácido sulfúrico) que é um poderoso cautério, próprio para combater febres pestilentas. A melantéria (5.78), tinta negra, é uma espécie de greda com que se tingia de negro o calçado. Do cinnabar (sangue-de-drago; 5.69) prepara-se uma cera vermelha usada para lacrar cartas. $O$ alúmen (5.83) elaborado a partir de pedras brancas é menos forte e mais brilhante do que o alúmen proveniente de pedras vermelhas, afirma Amato, "sendo usado para tingir seda e ainda lãs de muita qualidade e do mais elevado preço". 
deixa de lembrar os vasa pulcherrima, isto é, os púcaros ou as belíssimas bilhas de Estremoz. Diz o médico albicastrense (5.71):

Rubrica sinopis, quam milton Graeci vocant, ea est terra quam hodie multi vice boli Armenici usurpant, (...); terra enim est rubrica sinopis, densa, gravis, iocinoris colore, non calculosa, sibi concolor, et copiose cum diluitur se diffundit, quam Lusitani nostri in maxima habent copia, praecipue apud Stremozium oppidum, ex qua vasa pulcherrima fiunt, quae quum labiis admonentur, ita haerent, ut difficulter nisi aqua madefiant auelli possint; desiccandi enim ac astringendi vires terra ista habet, ut vice boli Armenici merito usurpari possit. (...)

A 'rubrica de Sinope', a que os Gregos chamam 'milthos', é a terra de que muitos se servem em substituição do bolo arménio. (...) Na verdade, a rubrica de Sinope é uma terra espessa, pesada, cor de fígado, sem pedras, de cor uniforme e, quando se dissolve, espalha-se copiosamente. Os nossos Portugueses têm-na em muito grande quantidade, especialmente nas imediações de cidade de Estremoz, da qual se fazem belíssimas vasilhas que, quando chegadas aos lábios, aderem de tal ordem que dificilmente se conseguem arrancar, a menos que se humedeçam com água. Esta terra tem, de facto, propriedades secativas e adstringentes, pelo que pode ser utilizada em vez de bolo arménio. (..... ${ }^{64}$

Estas palavras revestem-se de algum interesse histórico-etnográfico, dado que atestam a fama da louça de Estremoz já no tempo de Amato, no século xvi, fama essa que passava além-fronteiras, como refere Ricardo Jorge (p. 152, n. 1) em breve nota ao passo. No decurso de pesquisas sobre esta matéria, veio ao meu conhecimento um curioso estudo de Carolina Michaelis de Vasconcelos, datado de 1921, que fornece diversas referências históricas, literárias e etnográficas muito interessantes a respeito dos púcaros e bilhas de Estremoz. ${ }^{65}$ Entre essas informações, Carolina Michaelis assinala a relação de viagem de João Baptista Venturini, secretário do legado pontifício Miguel Bonelli, cardeal Alexandrino, que fora enviado por Pio V, seu tio, a Portugal, com a missão de ultimar os desposórios de D. Sebastião com Margarida de Valois (em 1571). Diz essa relação, a dado passo (p. 13):

\footnotetext{
"Sobre a mesa estava sempre um grande vaso de prata, cheio d'água, do qual se deitava em um jarro, chamado na lingua portugueza pucaro, do feitio de urna antiga, d'altura
}

\footnotetext{
64 Ver nota 47, p. 8.

65 Vd. Carolina MiChaelis De VASCONCELOS, Algumas palavras a respeito de púcaros em Portugal. Coimbra, Imprensa da Universidade, 1921.
} 
d'um palmo e feito de certo barro vermelho, subtilissimo e luzidio, que chamam barro d'Estremoz, pelo qual bebeu seis vezes."

Uma outra menção à afamada louça de Estremoz encontra-a Carolina Michaelis numa das Cartas (de Lisboa) saídas da pena de Camóes, quando o poeta, referindo-se a certas damas da capital, assevera que, entre outros predicados, têm "a boca de um vermelho táo vivo como pucarinho de Estremoz" (p. 20). A par da questão da característica cor do barro em apreço, outros testemunhos quinhentistas, que é possível consultar no referido artigo, dão conta da propriedade que tem o barro de Estremoz de aderir aos lábios, como menciona igualmente Amato Lusitano.

Aos dados recolhidos da erudita Carolina Michaelis, cumpre acrescentar duas outras referências surgidas em textos manuscritos, que nos foram dadas a conhecer pelo colega António Andrade (a quem muito agradecemos):

1) no inventário de bens do banqueiro cristão-novo António da Fonseca, elaborado c.1588, o qual vivia faustosamente em Roma, são descritos "pucaros d'estremoz». ${ }^{66}$

2) no inventário de bens de Duarte Gomes, colega de Amato, que fugiu de Portugal no meio de um processo inquisitorial, em finais de 1542, surgem referências a «hũua panela d'estremoz». ${ }^{67}$

Estas achegas vêm corroborar e sublinhar o apreço tido, nos tempos de Amato, pela louça de Estremoz.

\subsection{Os azulejos de Setúbal}

A entrada relativa ao jaspe (5.119) detém-se em informaçóes sobre a diversidade de cores, a espessura e objectos feitos a partir dessa pedra polida. E a este respeito Amato refere que, tendo de cortar uma pedra de jaspe bastante dura, proveniente das terras do Novo Mundo, o lapicida que trabalhava para o já mencionado embaixador Diego Hurtado se recusava a cortá-la

66 Cf. James Nelson Novoa, "Unicorns and Bezoars in a Portuguese house in Rome. António da Fonseca's Portuguese Inventories", Ágora 14.1 (2012), p. 102.

67 Sobre o estudo do inventário e transcrição do processo, cf. Hugo Miguel CRESPO; "O processo da Inquisição de Lisboa contra Duarte Gomes alias Salomão Usque: móveis, têxteis e livros na reconstituição da casa de um humanista (1542-1544). Em torno da guarda-roupa, livraria e mantearia do rei", Cadernos de Estudos Sefarditas, n. ${ }^{\circ}$ s 10-11 (2011), pp. 587-688, p. 685. Sobre o humanista Duarte Gomes, cf. António Manuel Lopes ANDRADE,"A Senhora e os destinos da Nação Portuguesa: o caminho de Amato Lusitano e de Duarte Gomes", Cadernos de Estudos Sefarditas, n. ${ }^{\circ}$ s 10-11 (2011), pp. 87-130. 
porque, argumentava, com isso acabaria por estragar várias serras. A seguir, aproveitando a ocasião, o médico de Castelo Branco traz à colação um tipo de jaspe existente em Setúbal, a que dá a designação de 'azulejo':

Sed cum de iaspide loquimur, non decet hinc discedere, quin genus eius quoddam describamus, quod apud Salatium oppidum iuxta Lusitaniam praecipue nascitur, interdum coloris cyanei, nonnunquam vero viridis, oculis gratum, quod Lusitani sua voce azuleios appellant. Sunt enim lapilli isti aedificiorum magnum ornamentum.

Mas, já que falamos do jaspe, não convém sair daqui sem descrevermos uma das suas espécies, que nasce especialmente em Setúbal, ${ }^{68}$ uma cidade próxima da Lusitânia, umas vezes de cor azulada, mas por vezes verde, agradável à vista, a que os Portugueses dão, na sua língua, a designação de 'azulejos'. Essas pedras são um grande ornamento de edifícios. ${ }^{69}$

Uma vez mais, a memória da Lusitânia e de uma palavra portuguesa aqui ficaram registadas. Mas o passo é interessante por documentar como as palavras têm a sua história, porquanto a acepção do termo 'azulejo' no século xvi se distingue da actual. Para Amato, o vocábulo designava uma espécie de jaspe usada como adorno de edifícios. Em comentário a este passo, Ricardo Jorge expressa a seguinte opinião, apesar de o fazer pouco convicto das ideias de Amato: "Não me consta que a Serra da Arrábida ou outra possua semelhantes

68 O texto latino diz Salatium, que em rigor corresponde(ria) a Alcácer do Sal, não fosse o facto de o próprio Amato Lusitano ter escrito, equivocadamente embora (em 2.100): Salatium oppidum Setubalium hodie dictum, como observa Ricardo JORGE (op. cit., p. 164).

69 Na dissertação de doutoramento de José Luís Pereira Santos Gonçalves Neto, intitulada "A idade do ouro branco - o contributo da arqueología pós-medieval para o conhecimento de Setúbal, uma cidade portuária portuguesa", refere-se o 'jaspe' como o "mármore de Setúbal" ou a brecha da Arrábida, rocha heterogénea, rosada, que foi profusamente utilizada nas edificações. Algumas igrejas das imediações de Setúbal e da Arrábida são decoradas com este tipo de 'jaspe'.

Provavelmente a designação de "mármore de Setúbal" corresponde simplesmente a uma designação do tipo comercial em que por "mármore" se designa uma qualquer rocha macia, capaz de ser polida. A chamada "brecha da Arrábida" é uma rocha clástica de origem sedimentar, única em Portugal, não sendo na verdade um mármore, que é uma rocha metamórfica originada de calcário exposto a altas temperaturas e pressão. É constituída por fragmentos grandes e angulosos de diversas cores (brancos, amarelos, vermelhos, cinzentos, negros), ligados por um material mais fino, de matriz argilosa vermelha. É susceptível de polimento e de apresentação em ladrilhos. Durante o reinado de D. Manuel I (1469-1521), fizeram-se várias obras notáveis com esta rocha que seria do seu particular agrado A. M. J. Prego, C. KullberG, "D. Manuel I e a "Brecha da Arrábida": report of a remarkable combination in national built patrimony", Revista Electrónica de Ciências da Terra /Geosciences On-line Journal, Volume 15, no 7 (2010), 4p. Em [http://metododirecto.pt/CNG2010/índex.php/vol/article/viewFile/377/306], consultado em 24.06.2014. Dá-se razão a Ricardo Jorge e clarificação ao descrito no texto. 
mármores; deve andar aqui confusão grossa do Amato com os ladrilhos cerâmicos chamados azulejos". ${ }^{70}$

Sabe-se, no entanto, que algumas igrejas da regiáo de Setúbal, como a do antigo Mosteiro ou Convento de Jesus, da mesma cidade, têm altares lajeados deste assim designado 'jaspe'.

\title{
2.3. 0 "aurífero Tejo"
}

Numa longa entrada dedicada ao mercúrio (5.70), já referida anteriormente, são mencionadas, a propósito, as virtudes do ouro. Aproveitando a ocasiáo que se lhe oferecia, Amato recorda o aurífero Tejo, mas recorda muito mais: a sua terra natal. Diz ele:

\begin{abstract}
Non eo infitias tamen, nos Hispanos plurimo abundare auro, praesertim eo inter Tagi fluminis arenas reperto, merito enim aurifer Tagus appellatur fluvius hic, quia inter suas arenas multum et prope infinitum dixerim aurum trahat, ut abunde expertus sum apud Ferreriam oppidum, quod Tagus praeterlabitur, quatuor leucis a Castello Albo, propria mea patria, distans (...).

Não se diga que nós, Hispanos, não temos abundância de ouro, especialmente daquele que se encontra entre as areias do rio Tejo. De facto, este rio é merecidamente chamado 'aurífero', porque entre as suas areias arrasta muito ouro, e, diria eu, em quantidade quase infinita, como tive ocasião de comprovar junto à cidade de Ferreira, que é banhada pelo rio Tejo e que dista quatro léguas de Castelo Branco, que é a minha verdadeira terra natal. ${ }^{71}$
\end{abstract}

Em comentário ao passo, Ricardo Jorge confirma esta característica do Tejo, escrevendo (p. 150, n. 1): "As aluvióes auríferas existem de facto em Portugal, e se não são exploradas tanto como em tempos, é porque a mão-de-obra encareceu. No próprio distrito de Castelo Branco são para citar as aluviōes do Rosmaninhal e Monforte, ribeiras do Tejo."

A fama das areias auríferas do Tejo, um título de glória que os humanistas portugueses quinhentistas se não esqueceram de assinalar, vem de longe, como escreveu Rosado Fernandes na n. 80 ao livro II das Antiguidades da Lusitânia, de André de Resende: "O Tejo

70 Este tipo de ladrilho, quadrado ou poligonal, foi igualmente usado, "por multiplicação, a ornamentar superfícies parietais ou pavimentares: o vocábulo deriva do árabe al-zulaich (pequena pedra polida)", como escreve Santos SIMÕES na Enciclopédia Verbo n. ${ }^{3}$ 3, Lisboa, s. u., col. 249.

71 A Ferreira referida por Amato é, decerto, Herrera de Alcántara, que está situado no lado espanhol, na margem esquerda do Tejo, conforme observou Ricardo JORGE, op. cit., p. 150. 
das areias de ouro é um lugar-comum da literatura antiga que menciona a região." 72 Outros autores antigos falam laudativamente do rio que desagua em Lisboa: Plínio-o-Velho, que na História Natural regista que "as areias deste rio são mais ricas e abundantes de ouro, que as dos mais afamados rios do mundo, como são o Pactolo na Ásia, e o Hermes na Lídia (Livro IV, cap. XXII), e o mesmo confirmam Catulo e Sílvio (sic) Itálico”. ${ }^{73}$

\subsection{0 azeviche e os romeiros de Santiago}

De outra natureza, mas igualmente muito curioso é o comentário produzido acerca do azeviche (De lapide gagates, pedra negra, 5.105), a respeito do qual Amato documenta um costume dos pobres e mendigos que se dirigiam a Santiago, dizendo que trazem presas nos barretes e chapéus umas pequenas imagens do Santo feitas de azeviche. Diga-se que este uso se mantém ainda hoje, como se comprova in loco, e como vem referenciado em estudos académicos dedicados a este lignito (lenhite). É o caso de uma tese de mestrado, apresentada na Universidade de Aveiro em 2008, na qual, a dado passo, a autora (Anabela Costa) afirma (p.3):

\footnotetext{
“em Espanha, esta gema [sc. o azeviche] é muito utilizada deste a idade média para o fabrico de rosários, as tradicionais vieiras e outros objectos religiosos (Fig. 2), e pode ser encontrada em diversas regiốes: Leão, Aragão, Galiza e Astúrias. No século XII as corporaçóes de artesôes de azeviche de Santiago de Compostela eram muito poderosas e, ainda hoje, nessa cidade se fabricam objectos religiosos muito apreciados pelos peregrinos (Suárez-Ruiz et al. 2006, Suárez-Ruiz \& Iglesias 2007)”.74
}

E nessa tese, que consultámos em versão electrónica, são apresentados, na figura 2, exemplos de objectos manufacturados em azeviche, uma espécie de amuletos com valor mítico e religioso, como sejam uma miniatura da estatueta do Santo em azeviche,

72 André de Resende, As Antiguidades da Lusitânia, Introdução, tradução e comentário de R. M. Rosado FernANDES. Lisboa, Fundação Calouste Gulbenkian, 1996, p. 257.

73 Francisco Henrioues, Carlos Batata et alii, "Mineração aurífera, a céu aberto, no Centro e Sul do Distrito de Castelo Branco", in Actas - VI Simpósio sobre mineração e metalurgia históricas no Sudeste Europeu, edição de Carlos BATATA, de 2010, p. 3 (consultado em versão electrónica: http://www.altotejo.org.).

74 Palavras de Anabela COSTA, Estudo petrográfico e geoquímico das ocorrências de azeviche na região da Batalha, Portugal, p. 2., que diz ainda: "O azeviche, embora pouco conhecido em Portugal, é um importante recurso geológico noutros países, nomeadamente em Espanha, particularmente pelo seu polimento e pela preservação ao ar ao longo do tempo (SUÁREz-RUIz et alii, 1994), sendo usado na indústria artesanal para a produção de objectos ornamentais e de joalharia." (consultado em versão electrónica: repositorio-aberto.up.pt). 
uma concha e uma figa. ${ }^{75}$ Sabe-se que o azeviche, também conhecido como âmbar negro, é carvão compacto tido como gema e era, já no tempo dos romanos, usado como joalharia de luto.

\subsection{As viúvas da Galiza e da Alemanha}

E, a propósito da Galiza, refira-se esta outra anotação curiosa. A respeito do auripigmento ou sulfureto natural de $\operatorname{arsénio~}^{76}(5.81)$ e da sandáraca ${ }^{77}$ (5.82), Amato informa que estas substâncias têm efeitos contraditórios, pois são utilizadas no tratamento da asma, nuns casos, mas noutros provocam-na. Documenta então esta sua opinião dizendo que os mineiros da Galiza e da Alemanha morriam cedo, vítimas de problemas respiratórios provocados por tais substâncias. Ficava explicada deste modo uma "curiosidade" que atraiu a sua atenção: a de que as viúvas chegavam a casar com "seis ou oito homens".

Estas são apenas algumas das curiosas anotações com que Amato vai esmaltando os seus comentários ao livro V de Dioscórides, umas referentes a terras e usos portugueses, uma relativa à tradição dos peregrinos a Santiago de Compostela e esta última respeitante a viúvas de mineiros em terras da Galiza e Alemanha. Muitas outras poderiam ser referidas, porquanto - importa sublinhá-lo - Amato Lusitano nos brinda a cada passo, ao longo dos cinco livros dos seus Comentários, com inúmeras observaçôes de interesse para a história dos costumes e das mentalidades do seu tempo.

\section{EM CONCLUSÃO:}

O livro V dos Comentários a Dioscórides de Amato Lusitano é uma valiosa fonte de informações que interessam ora à história da medicina, da botânica, da mineralogia ou da composição de fármacos, ora à história de usos e costumes dos homens do século xvi. Tal como a restante obra do seu autor, este livro é bem a imagem de um humanista médico que consagrou a vida e o saber ao estudo da doença, do seu tratamento e de outras manifestaçóes da vida humana.

75 Veja-se, entre outras, uma imagem da estatueta do santo no artigo citado na nota anterior. Cf. também a nota 27, p. 5.

76 Cf. nota 28, p. 5.

77 Realgar ou sulfureto natural de arsénio, AsS, de cor vermelha. Pode a designação de sandáraca corresponder também à resina aromática de algumas árvores coníferas, por exemplo, do tipo Juniperus communis ou a Thuya aphylla. 


\section{AGRADECIMENTOS}

Ao Professor António Soares de Andrade e aos revisores anónimos, um agradecimento especial pelas sugestóes críticas que em muito beneficiaram este texto. À Beatriz Valle Aguado pela visita detalhada ao mundo da "pedra parideira".

\section{BIBLIOGRAFIA}

Agricola, Georgius, De Natura Fossilium (Textbook of Mineralogy), translated from the First Latin Edition of 1546 by Mark Chance BAndy and Jean A. BAndy for the Mineralogical Society of America, The Geological Society of America, Special Paper 63 (1955), 251p.

Andrade, António Manuel Lopes, "A Senhora e os destinos da Nação Portuguesa: o caminho de Amato Lusitano e de Duarte Gomes", Cadernos de Estudos Sefarditas, n. ${ }^{\circ}$ 10-11 (2011), pp. 87-130.

Barba, Alonso, Arte de los metales. Madrid, En la Imprenta del Reyno, 1640.

Caley, E. \& Richards, J., Theophrastus on Stones: Introduction, Greek Text, English Translation, and Commentary. Columbus, Ohio State University, 1956.

Carvalho, Rómulo de, A Ciência Hermética. Lisboa, Relógio D’Água Editores, 1996.

Corrochano Sánchez, Ángel, Descriptión de Minerales y Rocas del Dioscórides, Universidad de Salamanca e Dioscorides on-line [dioscorides.eusal.es] — Minerales y Tierras.

Costa, Anabela, "Estudo petrográfico e geoquímico das ocorrências de azeviche na região da Batalha, Portugal”. Aveiro, Universidade de Aveiro, 2008 (dissertação de mestrado).

Crespo, Hugo Miguel, “O processo da Inquisição de Lisboa contra Duarte Gomes alias Salomão Usque: móveis, têxteis e livros na reconstituição da casa de um humanista (1542-1544). Em torno da guarda-roupa, livraria e mantearia do rei”, Cadernos de Estudos Sefarditas, n.os 10-11 (2011), pp. 587-688, p. 685.

Encyclopédie Méthodique, Arts et métiers mécaniques, Tome II. Paris et Liège, 1783.

Fagundes, B. F. L., Paula, S. G. de (Orgs.), Glossário: Observaçóes sobre o universo vocabular médico-cirúrgico do Erário Mineral, de Luis Gomes Ferreira. Rio de Janeiro, Editora FIOCRUZ, SCielo Books http:// books.scielo.org

Fresquet Febrer, José Luis, "El uso de produtos del reino mineral en la terapéutica del siglo Xvi. O livro de los medicamentos simples de Juan Fragoso (1581) y el antidotário de Juan Calvo (1580), Asclepio 51.1 (1999), pp. 55-92.

García Valdés, M., Dioscórides. Plantas y remedios medicinales. Madrid, Gredos, 1998.

Gonçalves, J. Cardoso, O “Lapidário del Rey D. Alfonso X el Sabio”, Estudo deste Manuscrito Iluminado do Século XıII (Da Biblioteca de S. Lourenço do Escorial), por (...). Lisboa, MDCDXXIX. 
Henriques, Francisco, Batata, Carlos et alii, "Mineração aurífera, a céu aberto, no Centro e Sul dos Distrito de Castelo Branco", in Actas - VI Simpósio sobre mineração e metalurgia históricas no Sudeste Europeu, edição de Carlos Batata, de 2010, p. 3 (consultado em versão electrónica).

Jorge, Ricardo, Amato Lusitano. Comentos à sua Vida, Obra e Época. Lisboa, s. d.

Laguna, Andrés, Pedacio Dioscórides Anazarbeo, 1555. Madrid, edición facsímil del Instituto de España, 1968.

Le Clerc de Buffon, Georges Louis, Histoire Naturelle Des Mineraux, Vol. 3. Paris, 1785.

Lev, Efraim, "Healing with minerals and inorganic substances: a review of Levantine practice from the Middle Ages to the present”, International Geology Review, Vol. 52, Ns. 7-8 (2010), pp. 700-725.

Michaelis de Vasconcelos, Carolina, Algumas palavras a respeito de púcaros em Portugal. Coimbra, Imprensa da Universidade, 1921.

Nelson Novoa, James, "Unicorns and Bezoars in a Portuguese house in Rome. António da Fonseca's Portuguese Inventories", Ágora. Estudos Clássicos em Debate 14.1 (2012), pp. 91-111.

Neto, José Luís Pereira Santos Gonçalves, "A idade do ouro branco - o contributo da arqueología pós-medieval para o conhecimento de Setúbal, uma cidade portuária portuguesa". Salamanca, Universidade de Salamanca, 2010 (dissertação de doutoramento, acessível em http://hdl.handle.net/10366/83140).

Poggendorff, Johann Christian, Histoire de la Physique. Paris, Dunod, Libraire-Editeur, 1883. Reimpressão autorizada, Editions Jacques Gabay, 1993.

Prego, A. M. J., Kullberg, C., "D. Manuel I e a "Brecha da Arrábida”: report of a remarkable combination in national built patrimony”, Revista Electrónica de Ciências da Terra | Geosciences On-line Journal, Volume 15, no 7 (2010), 4p. Em [http://metododirecto.pt/CNG2010/índex.php/vol/article/viewFile/377/306].

Seabra, Vicente Coelho, Elementos de Chimica, Vol. 1, 1788, pp. 130-131. Edição fac-similada. Coimbra, Departamento de Química da FCTUC, 1985.

Ureña Prieto, Maria Helena, "O significado dos Lapidários Antigos", Revista da Universidade de Coimbra 37 (1992), pp. 189-204. 
(Página deixada prepositadamente em branco.) 


\title{
Alguns comentários de Amato: entre a estranheza e a realidade ${ }^{1}$
}

\author{
JOÃO MANUEL NUNES TORRÃO²
}

\section{RESUMO:}

Este texto aborda alguns comentários de Amato Lusitano nas Enarrationes que poderão apresentar algum grau de estranheza para os leitores atuais, ainda que, em alguns casos, seja possível encontrar aproximações e coincidências com situações da atualidade.

\section{PALAVRAS CHAVE:}

Amato Lusitano; Enarrationes; stercus; cicuta; nerion; fungi; aster Atticus.

\section{ABSTRACT:}

This paper discusses some comments by Amatus Lusitanus in Enarrationes, which may appear somewhat strange to modern readers, although in some cases one may possibly find similarities and coincidences with present day situations.

\section{KEYWORDS:}

Amatus Lusitanus; Enarrationes; stercus; cicuta; nerion; fungi; aster Atticus.

1 Este trabalho foi desenvolvido no âmbito do projeto de IED "Dioscórides e o Humanismo Português: os Comentários de Amato Lusitano" (http://amatolusitano.web.ua.pt) do Centro de Línguas, Literaturas e Culturas da Universidade de Aveiro, financiado por Fundos FEDER através do Programa Operacional Factores de Competitividade - COMPETE e por Fundos Nacionais através da FCT - Fundação para a Ciência e a Tecnologia, no âmbito do projeto FCOMP-01-0124-FEDER-009102.

2 Centro de Línguas, Literaturas e Culturas da Universidade de Aveiro: jtorrao@ua.pt. 
Numa leitura algo despreocupada das Enarrationes ${ }^{3}$ de Amato Lusitano, deparamo-nos com alguns comentários que, nos dias de hoje, nos causam alguma estranheza, ainda que, se refletirmos um pouco, seja possível encontrar na atualidade alguns elementos de realidade que, de algum modo, vêm comprovar o antigo provérbio 'nihil sub sole novum 4 '.

Vamos apresentar alguns comentários que nos chamaram a atenção por motivos bem diversos, nomeadamente, a eventual estranheza da situação; o espanto com que Amato os apresenta; as cautelas com que o autor apresenta a sua opinião; o paralelismo com outros textos renascentistas.

Não se trata, pois, de um conjunto de comentários ligados por um fio condutor de grande pendor lógico, mas antes de situaçóes bem diferenciadas e autónomas que, por um motivo ou outro, nos chamaram a atenção e nos pareceram merecedoras de registo.

\section{DE STERCORE ANIMALIVM - OS EXCREMENTOS DOS ANIMAIS}

No livro segundo, a enarratio $75^{5}$ aborda as utilizaçóes dos excrementos para efeitos medicinais. É um texto com vinte linhas que tem a particularidade de referir por cinco vezes o nome de Galeno que, assim, se torna o referente por excelência deste comentário. Além destas cinco remissóes para Galeno, há uma outra a Avenzoar e ainda a exploração das ideias do próprio Amato.

O nosso autor vai abordar, sucessivamente:

as fezes de cão: que curam a angina e restringem a disenteria — "anginam curat et dysenteriam constringit” — e, além disso, acrescentadas a outros medicamentos, curam as úlceras malignas - "quoque medicamentis maligna ulcera sanantibus adiungitur";

as do homem: que curam os fleimóes da garganta e as anginas — "gutturis phlegmonibus et anginis mederi";

as do lobo: que ajudam nas cólicas graves e sobre as quais Amato, que, nos exemplos anteriores, se socorrera apenas de Galeno, vai, neste caso concreto, aduzir a sua própria experiência, já que

3 Utilizaremos a primeira edição, ainda que tenha havido a colação com as edições posteriores: AMATO LUSITANO, IN DIOSCORIDIS / ANAZARBEI DE MEDICA / MATERIA LIBROS OVINQVE / ENARRATIONES ERVDITISSIMAE / DOCTORIS AMATI LVSITANI MEDICI / AC PHILOSOPHI CELEBERRIMI, / quibus non solum Officinarum Seplasia- / riis, sed bonarum etiam literarum stu- / diosis utilitas adfertur, quum pas- / sim simplicia Graece, Latine, I Italice, Hispanice, Germa- / nice, \& Gallice pro-/ponantur. I Cum Priuilegio Illustriss. Senatus Veneti ad decennium. IVENETIIS / MDLIII.

4 Como se sabe, trata-se de uma expressão bíblica: Eclesiastes, 1.10. Cf. Biblia Sacra iuxta Vulgatam Clementinam. Nova Editio logicis partitionibus aliisque subsidiis ornata a Alberto Colunga, O.P. et Laurentio Turrado. Septima editio. Matriti, La Editorial Católica, MCMLXXXV, p. 606.

5 Enarrationes, pp. 214-215. 
ele próprio procedia à recolha das fezes de lobos para a preparação de medicamentos, dando indicaçóes precisas sobre a maneira como se deveria proceder quando alguém matava um lobo:

\begin{abstract}
Verum ego quum lupus interficitur iubeo illius intestina cum stercore servari ac exsiccata et in pulverem redacta in potu contra colicas affectiones dare, non contemnendo profecto iuvamento
\end{abstract}

Na verdade, eu, quando um lobo é morto, ordeno que os seus intestinos sejam conservados com o estrume e, depois de secos e reduzidos a pó, dados em bebida contra as cólicas graves, coisa que não é, na verdade, uma ajuda desprezível;

as de cabra: que se utilizam nas escrófulas e nos tumores cirróticos, mas que só se devem aplicar em corpos duros ou de camponeses, excluindo, por isso, as crianças e as mulheres, e que servem, ainda, para aliviar as dores de ventre, desde que convenientemente aplicadas:

strumis et scirrhosis tumoribus convenit, praesertim in corporibus duris et rusticorum secus autem puerorum ac mulierum. Extrinsecus quoque pulticulae modo ventri impositum ipsius doloribus subvenit;

e convém às escrófulas e aos tumores cirróticos, sobretudo nos corpos duros e dos camponeses, com exceção, porém, das crianças e das mulheres. Colocado de fora do ventre à moda de papa, também alivia as suas dores;

as de boi, em paralelo com as de pomba: que têm a capacidade de secar e são cáusticas e, por isso, Avenzoar as inclui nos antídotos contra a peste. Esta causticidade era tal que Galeno apresenta a história de uma casa na Ásia que foi queimada com os excrementos de pomba ${ }^{6}$

6 Galeno, De temperamentis, 3: "Siquidem in ea Mysia, quae est Asiae pars, domus hac aliquando ratione conflagrauit. Erat proiectum columbinum stercus, cui iam putri et excalfacto, ac vaporem edenti et tangentibus admodum calido, in propinquo fenestra fuerat, ita ut tam contingeret eius ligna, quae large nuper illita resina fuerant. Media igitur aestate, cum sol plurimus incidisset, accendit tum resinam, tum ligna. Hinc autem et fores quaedam aliae, quae prope fuerant et fenestrae nuper etiam resinae illitae facile ignem conceperant atque ad tectum usque summiserant. Vbi autem excepta semel a tecto est flamma, celeriter in totam domum est grassata.". Citámos a partir de Claudii Galeni Pergameni / DE TEMPERAMENTIS LIBRI III. / DE INAEQVALI INTEMPERIE LIBER I. Thoma Linacro Anglo Interprete. / Cum isagoge in eosdem libros et scholijs marginalibus / longe doctissimis, per lacobum Syluium. / PARISIIS, / Ex officina Christiani wecheli, sub scuto Basiliensi, / in vico lacobaeo: \& sub Pegaso, in vico / Bellouacensi. M. D. XLV. 
At bubulum exsiccatoriae est facultatis veluti columbinum causticae et exedentis potentiae quod Abinzoar inter antidota contra pestem adnumerat et de eo Galenus libro tertio de temperamentis historiam de domo in Asia combusta enarrat;

Mas o de boi, tal como o de pomba, tem a capacidade de secar, e é cáustico e tem o poder de roer pelo que Avenzoar o enumera entre os antídotos contra a peste e, a propósito dele, Galeno, no livro terceiro De temperamentis, conta a história de uma casa queimada na Ásia.

as de cegonha: que Galeno afirma nâo terem efeitos na epilepsia "Ciconiarum vero, comitiali morbo mederi, falsum Galenus invenit";

e, finalmente, as dos lagartos: que, comprovadamente, atacam as névoas dos olhos e as afluências sanguíneas "at lacertarum unice oculorum nebulas eorumque concursus sanguineos delere certi sumus".

Nesta última situação, a afirmação fica a pairar com um tudo-nada de ambiguidade, não nos fornecendo elementos suficientes para podermos afirmar com plena certeza que também aqui entra a experiência de Amato. De facto, apesar de a primeira leitura apontar para essa ideia, já que o autor utiliza a expressão 'certi sumus', pode ficar no ar alguma dúvida, nomeadamente por causa da utilizaçáo da primeira pessoa do plural que, neste caso concreto, pode fazer contraste com a primeira pessoa do singular utilizada quando se referiu aos lobos, atenuando deste modo a afirmação. Assim, é possível que esta primeira pessoa do plural possa ser uma utilização genérica de maneira a não incluir obrigatoriamente o nosso autor através de uma experiência direta.

E se, na verdade, esta utilização dos excrementos nos pode causar alguma impressão, convém não esquecer que, mesmo na atualidade, ainda há quem defenda a sua utilização. De facto, para já não falarmos na urina que, em termos populares era (e ainda continua a ser?) usada como desinfetante, por exemplo para cortes feitos por quem andava a trabalhar no campo, e tem quem defenda a sua utilização para a cura do cancro, tanto no Oriente, como no Ocidente ${ }^{8}$, também os excrementos surgem com utilizaçôes curativas, mesmo em termos da medicina convencional ${ }^{9}$.

7 Veja-se este sítio da internet: http://www.curapelanatureza.com.br/2012/01/conhecendo-urinoterapia.html.

8 Cf. http://www.paulopes.com.br/2010/11/padre-continua-defender-que-pocao-base.html.

9 Cf., por exemplo, http://www.ecycle.com.br/component/content/article/38-no-mundo/1764-tratamento-coreano-utiliza-vinho-medicinal-feito-com-fezes-humanas.html e http://cidadaniatransparencia. blogspot.pt/2013/11/remedio-feito-de-fezes-humanas-pode.html. 


\section{DE CICVTA - A CICUTA}

Amato, na enarratio $82^{10}$ do livro quarto, dedica algumas linhas (onze e meia) à cicuta, onde, como é óbvio, não poderia faltar a referência à morte de Sócrates — "cuius succo olim Socrates, summus philosophus iniuste mortuus fuit".

Além de apontar caraterísticas ligeiramente diferentes de acordo com as regiôes onde nasce esta planta — é menos venenosa a nascida na Hispânia e na Itália —, também afirma que ela é venenosa para o homem, mas já serve de alimento para o gado e para o estorninho — "homini enim cicuta venenum est, pecudi vero et sturno pabulum".

No entanto, esta enarratio tem uma particularidade: de facto, Amato, através da sua experiência pessoal, chegou à conclusão de que a cicuta deveria ser classificada como quente e não como fria, como todos os autores fazem, mas, estranhamente, não se atreve a assumir frontalmente esta sua posição com o argumento de não querer contradizer toda a Antiguidade:

\footnotetext{
Ego vero quandoque cicutae radicem gustans, eam valenter linguam rodere, ac urere deprehendi, qua de causa illam calidam esse, in dubium trahebam, et nisi procul dubio universae antiquitati contradixissem, illam calidam omnino asseverarem.

Eu, na verdade, ao provar a raiz da cicuta, compreendi que ela rói e queima muito a língua e, por isso, tinha dúvidas se ela era quente e, se não estivesse a contradizer, sem sombra de dúvida, toda a Antiguidade, asseguraria que ela era completamente quente.
}

Pode, realmente, parecer estranha esta posição, nomeadamente atendendo a que, em outras circunstâncias, o autor não hesita em apresentar a sua opinião pessoal de forma clara. Julgamos que, neste caso, terá sido todo o peso histórico da caraterização da cicuta, onde se inclui a morte de Sócrates que, como dissemos, ele próprio refere, que aqui acabou por deixar o nosso autor numa posição algo desconfortável.

\section{DE NERIO - O ELOENDRO}

A enarratio 85 do livro quatro ${ }^{11}$ é dedicada ao eloendro e, para além de mais algumas informações de interesse, importa referir duas das temáticas abordadas.

10 Enarrationes, p. 417.

11 Enarrationes, pp. 418-419. 
A primeira aponta para a identificação desta planta com a que dava as famosas flores que o protagonista do romance de Apuleio ${ }^{12}$, quando estava transformado em burro, pensou que eram rosas:
Nascitur ad ripas fluviorum nerion, perpulchras ferens rosas, quas Apuleius in asinum versus, veras rosas putavit, sed ultimo diversas dignovit.
O eloendro nasce junto das margens dos rios, dando rosas muito bonitas, que Apuleio, transformado em burro, considerou que eram rosas verdadeiras, mas, por fim, verificou que eram diferentes.

A segunda está relacionada com a Península Ibérica e com uma tradição muito antiga e que hoje divide claramente opinióes, as touradas.

De facto, de acordo com as palavras de Amato, as crianças utilizavam os ramos deste arbusto para prepararem dardos que atiravam aos touros. $\mathrm{O}$ texto, sendo bastante sucinto, não nos dá mais informação sobre as circunstâncias em que isso acontecia, mas fica bem claro que a envolvência com os touros existia já e que nela estariam também incluídas de algum modo as crianças:

\begin{abstract}
Planta enim fruticosa haec est, lauri folia habens, et illa quidem amarissima, ex cuius virgis, pueri in Hispania aclides, id est tela quaedam, acutis ferris ornata parant, quae in tauros eiaculantur.

De facto, esta é uma planta que tem muitos rebentos, apresentando folhas de louro que são, na verdade, muito amargas; dos seus ramos as crianças na Hispânia preparam garrochas, isto é, uns dardos, enfeitados com ferros afiados que lançam contra os touros.
\end{abstract}

Esta referência aos touros permite-nos trazer à colação um outro pequeno texto quinhentista que também aflora a temática das touradas e que foi publicado pela primeira vez uns anos antes $^{13}$ por D. Jerónimo Osório:

12 Veja-se, por exemplo, a edição da Loeb Classical Library: ApulEIUs, Metamorphoses. Edited and translated. by J. Arthur HANSON. Cambridge (MA), Harvard University Press, 1996. Veja-se também a versão portuguesa: Apuleio, O burro de ouro. Tradução e introdução de Delfim LEÃo. Lisboa, Livros Cotovia, 2007.

13 A editio princeps é de 1549, em Coimbra, embora a obra tenha sofrido algumas alterações para a edição seguinte em 1552, agora em Florença. 
Hac etiam aetate, in Hispania praesertim, cum in ludis publicis undique spicula in tauros intorquentur, illi, qui magnam hominum stragem edunt, egregii tauri atque non uulgari pretio digni reputantur ${ }^{14}$.

No nosso tempo, sobretudo na Hispânia, quando, nos espetáculos públicos se atiram ferros contra os touros, aqueles que causam maior matança de homens são considerados touros notáveis e dignos de um preço não vulgar.

Sublinhe-se que também aqui a referência é muito sucinta, mas, que, apesar disso, consegue remeter para a realização pública destes espetáculos.

\section{DE FVNGIS - OS COGUMELOS}

$\mathrm{Na}$ enarratio seguinte $(86)^{15}$, o médico albicastrense fala dos cogumelos, considerando que se trata de um mau alimento "quos ego cum caeteris, tanquam noxios, ac pessimi et frigidi nutrimenti reiiciendos consulerem". Apesar desta opiniáo, para espanto do autor albicastrense, há um grupo considerável de pessoas que os considera como verdadeiros petiscos e, por essa razão, os contemporâneos de Amato descobriram uma maneira de produzir cogumelos em casa de forma intensiva, quase poderíamos dizer, e em condiçóes muito simples:

Caeterum tantus est hominum hodie luxus gulositasue, ut pro habendis quotidie fungis,
lapides quosdam excogitarint, quos in cellis vinariis, summa cura servant, et eos terra
cooperiunt, super quos, singulis octo vel decem diebus, fungi nascuntur

Ora, atualmente, é tão grande a intemperança e a gulodice dos homens que, para terem cogumelos, inventaram umas pedras que conservam com grande cuidado nas adegas e que recobrem bem com terra, sobre as quais, em cada oito ou dez dias, nascem cogumelos.

\footnotetext{
14 Utilizaremos a edição crítica incluída na nossa tese de doutoramento (João Manuel Nunes ToRRÃo, D. Jerónimo Osório e o tratado De gloria. I. Estudo. II. Edição Crítica. Coimbra, 1991 (tese de doutoramento policopiada) p. 155) em vez de outra mais recente pelas razões aduzidas em João Manuel Nunes TORRÃO, "D. Jerónimo Osório e o De gloria: um best-seller europeu de Quinhentos": em António ANDRADE, João TorRÃo, Jorge Costa e Júlio Costa (Coord.), Humanismo, diáspora e ciência. Estudos, catálogo e exposição. Porto, Universidade de Aveiro, Biblioteca Pública e Municipal do Porto, 2013, pp. 233-250. A edição crítica encontra-se disponível em: http://www2.dlc.ua.pt/classicos/Deglorialibriquinque.htm. Cf. Enarrationes, p. 419.
} 
Como se sabe, este gosto pelos cogumelos já vem da Antiguidade (tornou-se quase proverbial a morte de Cláudio através da ingestão de cogumelos venenosos ${ }^{16}$ ), e continuou até aos dias de hoje. Curiosamente, há técnicas atuais que estão muito próximas, mutatis mutandis, daquela que nos é apresentada por Amato. De facto, há atualmente cursos que ensinam a cultivar cogumelos em casa através da utilização, entre outras coisas, de caixas de cartão, troncos de madeira, fardos de palha (em vez das pedras referidas por Amato, que, eventualmente, também poderão ser utilizadas) e até garrafas plásticas de refrigerantes.

É, aliás, frequente encontrar anúncios a estes cursos de micologia e não são raros os que oferecem, como brinde, um kit de cultivo para a primeira produção. Neste caso, já náo estamos a falar, necessariamente, de 'luxus gulositasue', mas de uma produção caseira para consumo doméstico com uma divulgação cada vez maior.

\section{DE ASTERE ATTICO- LÍRIO-CONVALE ${ }^{17}$ (?)}

A enarratio 121 do livro quarto ${ }^{18}$ apresenta-nos o aster Atticus sublinhando diversos nomes que lhe são atribuídos, bem como a confusão que alguns autores fizeram entre esta planta e outras que com ela têm algumas parecenças, embora sejam diferentes. Mais uma vez se recorre à autoridade de Galeno para apresentar algumas das suas propriedades.

Mais adiante, apoiando-se em outro autor, vai apresentar uma propriedade muito relevante:

et mirabilem habet proprietatem, scilicet ad reddendas steriles mulieres, fecundas illis quolibet mane coclear unum praedictae herbae, in pulverem redactae, cum brodio capi, vel vino generoso, per viginti dies, in potu propinando.

e tem uma caraterística admirável, a saber: a de tornar as mulheres estéreis, fecundas: dando-lhes a beber na bebida, pela manhã, uma colher da dita erva, reduzida a pó, para ser tomada com caldo ou com vinho generoso durante vinte dias.

16 Suetonius, Diuus Claudius. Edited by Donna W. Hurley. Cambridge, Cambridge University Press, 2001, 44.

17 Embora este não seja o termo mais adequado, estamos a utilizar aqui, na ausência de melhor hipótese, a tradução fornecida em: F. R. dos Santos SARAIVA, Novíssimo Dicionário LATINO-PORTUGUÊS. Etimológico, prosódico, histórico, geográfico, mitológico, biográfico, etc.. Rio de Janeiro-Belo Horizonte, Livraria Garnier, ${ }^{10} 1993$. De facto, de acordo com o nosso consultor para os assuntos de botânica, Jorge PaIva, não é conhecido o nome português que se atribui a esta planta.

18 Cf. Enarrationes pp. 433-434. 
Mas, se, até aqui, estava a citar outros autores, não deixa de dar a sua opinião que, aparentemente, estará baseada no conhecimento 'de experiência feito':

Quibus nos addimus, modo mulieres steriles fiant et non concipiant, quia ob lubricitatem humorum, semen genitale non retinent. Est enim herba haec constrictoria, et ea de causa, eius siccae herbae pulvis, iis qui ex alto cadunt, securissimo iuvamento conceditur, modo in decocto eiusdem herbae, vel aqua stillaticia detur, non minus quoque contra enterocelas valet, et muliebres menses constringit, imo ita mulierum genitalia constringit huius herbae decoctum, aut stillaticia aqua, ut corruptas aeque ac virgines reddat, modo super decocto, ad aliquot insedeant dies, non minus quoque pendentes mamillas, rotundas, ac duras, contractasue reddit.

Às quais nós acrescentamos agora as mulheres que se tornam estéreis e não concebem porque não retêm o sémen fecundo por causa da inconstância dos humores. Na verdade, esta erva é adstringente e, por esse motivo, o pó desta erva concede uma ajuda importantíssima àqueles que caem de grande altura, quer seja dada em decocto desta erva ou em água destilada; não tem menos valor também contra as enteroceles e restringe as menstruaçôes das mulheres. E o decocto desta erva ou a água destilada comprime de tal maneira os genitais das mulheres que torna as corruptas iguais às virgens desde que se sentem em cima do decocto por alguns dias: além disso, torna também as maminhas descaídas redondas e duras ou firmes.

Repare-se no final do texto de Amato. Sem fazer qualquer menção moral ou de qualquer outra espécie, apresenta uma propriedade caraterística desta planta já que serviria, por assim dizer, para 'recuperar' a virgindade.

Este texto, embora em contexto diferente, pode ser aproximado de uma reportagem que deu há tempos na televisão ${ }^{19}$ sobre o que aconteceu em França na altura em que as antigas colónias francesas do norte de África se tornaram independentes com o consequente regresso às terras de origem de muitas raparigas que se encontravam a estudar em França. Dizia a reportagem que houve uma procura inusitada de médicos que faziam a recuperação do hímen já que estas raparigas tinham assumido em França determinado tipo de comportamento cujos resultados físicos seriam muito mal recebidos nas sociedades bastante mais fechadas para onde iriam agora viver.

Poderíamos dizer que, se estas raparigas conhecessem este texto de Amato e tivessem acesso a esta planta e, já agora, se a planta tivesse, realmente, as propriedades que o médico albicastrense

19 Agradeço esta informação à Doutora Joana Catarina Mestre da Costa. 
lhe atribui, resolveriam em alguns dias o problema que as afligia e por um preço muito mais reduzido do que aquele que tiveram de pagar pela intervenção cirúrgica a que se tiveram de submeter.

\section{EM JEITO DE REMATE}

Estes exemplos, que se poderiam facilmente multiplicar, mostram-nos que Amato Lusitano se incorporava na cultura da sua época e no ambiente em que exercia a sua atividade, procurando em autores da Antiguidade a confirmação do seu saber que era, em simultâneo, um saber livreiro, no bom sentido do termo, misturado com um 'saber de experiência feito'.

Numa situação particular, ao falar sobre a cicuta, ao contrário do que lhe era habitual, o 'saber de experiência feito' não vai servir para contradizer as teorias da Antiguidade, mas deixa no ar a ambiguidade da questão.

Importa ainda sublinhar as aproximaçôes que podem ser feitas com a atualidade quer através de algumas situações com algum paralelismo, quer de outras onde a visão poderá ser quase antagónica.

\section{BIBLIOGRAFIA}

Amato Lusitano, IN DIOSCORIDIS / ANAZARBEI DE MEDICA / MATERIA LIBROS QVINQVE / ENARRATIONES ERVDITISSIMAE / DOCTORIS AMATI LVSITANI MEDICI / AC PHILOSOPHI CELEBERRIMI, / quibus non solum Officinarum Seplasia- / riis, sed bonarum etiam literarum stu- / diosis utilitas adfertur, quum pas- / sim simplicia Graece, Latine, / Italice, Hispanice, Germa- / nice, \& Gallice pro-/ponantur. / Cum Priuilegio Illustrissi. Senatus Veneti ad decennium. /VENETIIS / MDLIII. Apuleio, O burro de ouro. Tradução e introdução de Delfim LeÃo. Lisboa, Livros Cotovia, 2007.

Apuleius, Metamorphoses. Edited and translated. by J. Arthur Hanson. Cambridge (MA), Harvard University Press, 1996.

Galeno, DE TEMPERAMENTIS LIBRI III. / de inaeqvali intemperie liber I. Thoma Linacro Anglo Interprete. / Cum isagoge in eosdem libros et scholijs marginalibus / longe doctissimis, per Iacobum Syluium. / PARISIIS, / Ex officina Christiani wecheli, sub scuto Basiliensi, / in vico Iacobaeo: \& sub Pegaso, in vico / Bellouacensi. M. D. XLV.

Saraiva, F. R. dos Santos, Novíssimo Dicionário LATINO-PORTUGUÊS. Estimológico, prosódico, histórico, geográfico, mitológico, biográfico, etc.. Rio de Janeiro-Belo Horizonte, Livraria Garnier, ${ }^{10} 1993$.

Suetonius, Diuus Claudius. Edited by Donna W. Hurley. Cambridge, Cambridge University Press, 2001. 
Torrão, João Manuel Nunes, D. Jerónimo Osório e o tratado De gloria. I. Estudo. II. Edição Crítica. Coimbra, 1991 (tese de doutoramento policopiada)

Torrão, João Manuel Nunes, “D. Jerónimo Osório e o De gloria: um best-seller europeu de Quinhentos”, in António Andrade, João Torráo, Jorge Costa e Júlio Costa (Coord.), Humanismo, diáspora e ciência. Estudos, catálogo e exposição. Porto, Universidade de Aveiro, Biblioteca Pública e Municipal do Porto, 2013, pp. 233-250.

\section{SÍTIOS DA WEB}

http://cidadaniatransparencia.blogspot.pt/2013/11/remedio-feito-de-fezes-humanas-pode.html.

http://www.ecycle.com.br/component/content/article/38-no-mundo/1764-tratamento-coreano-utiliza-vinhomedicinal-feito-com-fezes-humanas.html

http://www.paulopes.com.br/2010/11/padre-continua-defender-que-pocao-base.html. 
(Página deixada prepositadamente em branco.) 


\title{
Caracterização e usos terapêuticos de produtos de origem marinha nos Comentários de Amato Lusitano a Dioscórides ${ }^{1}$
}

\author{
JOSÉ SÍLVIO MOREIRA FERNANDES²
}

\section{RESUMO:}

No início do segundo livro dos comentários a Dioscórides, Amato Lusitano trata das características e usos terapêuticos de alguns produtos de origem marinha, derivados do ouriço-do-mar, do cavalo-marinho, de búzios, púrpuras e de outras conchas. Assinala sobretudo as propriedades expurgativas, digestivas, evacuativas, cáusticas, estimulantes do leite materno e do ventre, as aplicações em afeções dos rins, dos olhos e do coração, bem como os usos em cosmética feminina.

\section{PALAVRAS-CHAVE:}

Amato Lusitano; Dioscórides; ouriço-do-mar; cavalo-marinho; púrpura.

\section{ABSTRACT:}

In the beginning of the second book of comments to Dioscorides, Amato Lusitano analyzes the characteristics and the therapeutic uses of some marine origin products as sea urchin, sea horse, purple and other shells. Amato specifies in particular the expurgative, digestive, purgative and caustic properties of these products as well as properties for stimulating breastmilk and the belly, the applications for kidneys, eyes and heart diseases, and for uses in women's cosmetics.

\section{KEYWORDS:}

Amatus Lusitanus; Dioscorides; sea urchin; sea horse; purple.

1 Este trabalho foi desenvolvido no âmbito do projeto de I\&D "Dioscórides e o Humanismo Português: os Comentários de Amato Lusitano" (http://amatolusitano.web.ua.pt) do Centro de Línguas, Literaturas e Culturas da Universidade de Aveiro, financiado por Fundos FEDER através do Programa Operacional Factores de Competitividade - COMPETE e por Fundos Nacionais através da FCT - Fundação para a Ciência e a Tecnologia, no âmbito do projeto FCOMP-01-0124-FEDER-009102.

2 Universidade da Madeira; Centro de Línguas, Literaturas e Culturas da Universidade de Aveiro. silvio@uma.pt. 
No início do Livro II das Enarrationes (1553) Amato Lusitano discorre sobre os temas relacionados com alguns animais de origem marinha que mereceram a atenção de Dioscórides na composição do seu De medica materia. No conjunto desta obra de Dioscórides, é assinalável a desproporção existente entre o tratamento dado a temas e assuntos reservados às plantas, em comparação com a diminuta preferência pelo estudo dos animais.

Interessa-nos no presente estudo acompanhar a sequência expositiva e a metodologia escolhida pelo autor, para examinar aspetos relevantes como a descrição tipológica, os usos e aplicaçôes medicinais, e a não menos valiosa informação atinente ao espetro que vai desde as simples atribuições terminológicas às tão importantes prescriçôes terapêuticas. Aqui e ali, Amato recorre à sua vasta erudiçáo para acrescentar informação específica ou complementar, inscrita na tratadística relativa à matéria em causa, assim como de outra tradição textual ou ainda dos usos e costumes registados na memória coletiva.

Iniciando a análise dos animais marinhos, Amato Lusitano trata do tema do ouriço-do-mar, com a particularidade de remeter, desde início, para o seu equivalente terrestre e para as fontes que consultou: Aristóteles, Plínio, Galeno, Teodoro Gaza de Tessalonica ${ }^{4}$ e Paulo Jóvio. ${ }^{5}$ Usa igualmente informação produzida por estes autores para conferir a exatidão da designação de ouriço-do-mar e de ouriço terrestre, como a de Teodoro Gaza, que, na sua tradução de Aristóteles, talvez influenciado por Plínio, reduz aquelas distintas denominaçóes apenas à designação tipológica de ouriço. Segue-se a caracterização anatómica do ouriço-do-mar. Salienta, a este propósito, alguns factos como a semelhança deste ouriço com o ouriço do castanheiro, a tradição associada ao meio natural onde o ouriço-do-mar se desenvolve (particularmente nos mares Adriático e Tirreno) e, finalmente, a aplicação deste produto como estimulante da urina. A sua indicação terapêutica para afeçōes do trato urinário é decerto uma das que mais se encontra registada na tratadística médica. Amato refere-se, ainda neste contexto, ao facto de

3 In Dioscoridis Anazarbei de medica materia libros quinque enarrationes eruditissimae doctoris Amati Lusitani Medici ac Philosophi Celeberrimi... Venetiis, MDLIII.

4 Teodoro Gaza de Tessalonica (c. 1400-1475) foi um eminente autor do Renascimento, conhecido sobretudo pelas suas traduções para latim de obras de autores como Aristóteles (Problemata, De partibus animalium, de generatione animalium), Teofrastro (Historia plantarum) ou Dionísio de Halicarnasso (De compositione verborum). Também traduziu para grego obras de Cícero, como o De Senectute e o Somnium Scipionis. De sua própria autoria, contam-se a obra De origine Turcarum e uma gramática grega, escrita em grego, que Erasmo traduziu para latim. Sobre o autor, ver Pieter BuLLENs; Allan GotThelf, "Theodore Gaza's Translation of Aristotle's De Animalibus: Content, Influence, and Date", Greek, Roman, and Byzantine Studies 47 (2007), pp. 469-513; e Deno John Geanakoplos, "Theodore Gaza, a Byzantine Scholar of the Palaeologan 'Renaissance' in the Early Italian Renaissance (c. 14001475)", Constantinople and the West, Essays on the Late Byzantine (Palaeologan) and Italian Renaissances and the Byzantine and Roman Churches. Madison WI, 1989, pp. 68-90.

5 Paulo Jóvio (1483-1552), médico, historiador, biógrafo e cronista, embora seja mais conhecido por ter elaborado uma monumental história do seu tempo (Historiarum sui temporis libri XLV), por ter escrito biografias de homens ilustres e crónicas de temática bélica, tornou-se uma fonte importante para a história da ciência com o seu pequeno tratado De romanis piscibus (1524). 
Aristóteles, na sua História dos Animais, ${ }^{6}$ não fazer menção à eficácia do grande ouriço-do-mar contra defluxos urinários, mas apenas ao tipo mais pequeno de ouriço.

O tratamento da matéria relativa ao ouriço-do-mar fica completo com a referência a Galeno, com remissão para o tratado Sobre as Propriedades dos Medicamentos Simples, de onde retira a citação sobre as virtudes do ouriço: "o corpo queimado de ambos os ouriços, o do mar e o da terra, feito inteiramente em cinzas, possui propriedades expurgativas, digestivas e evacuativas". Acresce que a substância é igualmente eficaz em excrescências e chagas.

A alusão inicialmente feita ao ouriço terrestre fez Amato abreviar a exposição que a ele estava reservada. Ainda assim, completa a caracterização deste ouriço com o que o torna semelhante ao ouriço-do-mar, ao teixo ou ao histrix, ${ }^{7}$ concluindo que se trata de um animal de natureza fria, mas repleto de propriedades e, por isso, muito adequado para a alimentação e para a medicina. Nesse sentido, às propriedades, atrás mencionadas, adjunta a que Dioscórides considerou indicada para o tratamento da queda de cabelo.

Merece, neste passo, que se isole o comentário de Amato a Rasis ${ }^{8}$ que também se refere, na obra Sobre os Sessenta Animais, ao ouriço terrestre. O nosso lusitano manifesta-se convicto do carácter apócrifo de muito do que se atribui ao médico persa sobre este assunto. Tal procedimento ilustra bem a atitude crítica de Amato relativamente às fontes, não se escusando, por isso, de as recusar, mesmo que consideradas como autênticas.

Segue-se o tema do cavalo-marinho ou hipocampo, que atualmente concita a atenção da comunidade científica não só por designar a área do cérebro humano que está associada à memória e à imaginação, ${ }^{9}$ mas também pelo facto de se ter conseguido, no Algarve, reproduzir este animal em cativeiro, com prevista aplicação comercial no ramo da aquariofilia. ${ }^{10}$

Retomando a lógica expositiva, Amato Lusitano começa pelos mares de Ancona, para indicar um dos ambientes naturais onde observou o cavalo-marinho e onde verificou que os pescadores designavam este animal com os termos "dragão" ou "cavalinho curvado". Salienta, a propósito da caracterização anatómica do cavalo-marinho, a coloração quase negra, a forma

6 Cf. Maria de Fátima de Sousa e SILva, Aristóteles, História dos animais, vol. I, 2006; vol. II. Lisboa, INCM, 2008.

7 Género de mamíferos roedores.

8 Antropónimo latino do ilustrado médico, filósofo e alquimista persa atribuído a Muhammad ibn Zakarīya al-Rāzi, que viveu entre os sécs. Ix e x d. C.

9 Foi atribuído o nome de hipocampo à referida área do cérebro humano, por causa da sua semelhança com a forma do cavalo-marinho (hippocampus).

10 Os biólogos Jorge Palma e Miguel Correia, investigadores do Centro de Ciências do Mar da Universidade do Algarve, conseguiram obter resultados positivos na reprodução em cativeiro do cavalo-marinho de focinho comprido (hippocampus guttulatus). Sobre este tipo de investigação, cf. Miguel CorREIA; Jorge PALMA; Heather Koldewey; José P. ANDRADE, "Can artificial holdfast units work as a habitat restoration tool for long-snouted seahorse (Hippocampus guttulatus Cuvier)?", Journal of Experimental Marine Biology and Ecology 448, 1 (2013), pp. 258-264. 
equina, alongada e redonda da cabeça, o pescoço largo, e a cauda fina e curvada. No entanto, a parte mais importante da exposição acaba por ficar reservada às questôes etimológicas, certamente motivadas pela animadversão ao humanista Mattioli de Siena, ${ }^{11}$ numa discussão sobre o significado de "hippo" em plantas como hipposelinus" [salsa-de-cavalos] e em hippomarathrus [funcho bravo] ou em animais como o hipocampo e o hipopótamo. Os argumentos que Mattioli apresenta, na sua Apologia contra as críticas de Amato, podem resumir-se à questão fundamental de que o médico lusitano não prova, de forma inequívoca, que o hipocampo dos Gregos corresponde inteiramente ao cavalo-marinho dos Latinos. Para tal aduz um conjunto de fontes, entre as quais sobressai a de Plínio, para mostrar que existem possibilidades de identificação do hipocampo com animais de dimensão semelhante à dos golfinhos e, seguindo doutíssimos tradutores de Dioscórides, também com a lagosta. ${ }^{12}$

De resto, no que de mais significativo se pode retirar quanto à aplicação do cavalo-marinho na prática médica, Amato recorre à tradição popular italiana para especificar que as mulheres de Ancona usavam este "peixinho", reduzido a pó e tomado com vinho, como potente estimulante do leite materno, como Dioscórides reporta e como o próprio Amato tinha comprovado numa experiência.

O comentário seguinte, assaz mais longo e descritivo do que os anteriores, trata da púrpura e dos búzios. A extensão da exposição muito deve à preocupação do médico albicastrense em discriminar características e em enriquecer o tema com recurso a fontes mitológicas (Hércules e Tritão) e históricas (Júlio César e Tibério César), e à tratadística, recorrendo a autores como Aristóteles, Vitrúvio, Dioscórides, Plínio-o-Velho, Galeno e Francisco Massário. ${ }^{13}$

A este propósito, torna-se aqui importante observar os passos que o autor dá no sentido de prover a exposição da maior quantidade possível de informação, como se pode comprovar pela sequência que nos apresenta sobre a púrpura e os búzios: são "conchas" marinhas; a púrpura é mais valiosa do que o búzio; o líquido que lhe é extraído, enquanto viva, adquiriu fama por servir para tingir de vermelho as vestes de imperadores e de reis; o cão de Hércules está associado à descoberta da púrpura; os Latinos atribuem-lhe diferentes denominaçôes; as púrpuras têm a capacidade de se manterem vivas fora de água durante quase dois meses; de acordo com Aristóteles, Plínio e Massário, permanecem escondidas, durante um mês, no início do ciclo

11 Pier Andrea Mattıolı (Siena, 1501- Trento, 1577), médico e botânico italiano, especialmente conhecido pela sua edição latina da obra de Dioscórides (Commentarii in libros sex Pedacii Dioscoridis Anazarbei, de medica materia. Venetiis, apud Vincentium Valgrisium, 1554) e pela atitude censória contra Amato Lusitano, a respeito das suas Enarrationes, de que é exemplo a publicação da Apologia adversus Amathum Lusitanum, cum censura in eiusdem enarrationes. Venetiis, Vincentii Valgrisii \& Balthassar Costantini, 1558. O "hippocampus" é um das vinte defesas de Mattioli às críticas de Amato.

12 Cf. P. A. Mattioli, Apologia adversus..., op. cit., ed. 1559, p. 13.

13 Comentador de Plínio-o-Velho, na obra In nonum Plinii de naturali historia librum... Basileae, Froben, 1537. 
ditado pela constelação do Cão; existe uma semelhança entre a palavra "búzio" e o som que produz; ao som de um búzio Tritão ${ }^{14}$ terá cantado aos habitantes de Lisboa; os búzios, por conselho de Dioscórides e de Galeno, são eficazes para limpar chagas; os Portugueses fazem uso quotidiano dos caros búzios cor de pérola, importados da Índia; existem conchas que produzem pérolas, as margaritas ou pérolas vulgares e a pérola única, isto é, a das conchas que produzem uma única pérola; o uso médico das pérolas é importantíssimo, como a tradição árabe reporta, para o tratamento de afeçóes oculares e cardíacas; as pérolas importadas da Índia são de cor amarelada, por causa da ação do Sol; as que vêm do Peru são muito brancas e de elevado valor; as mais perfeitas são as produzidas no Mar Vermelho, que os Portugueses comercializam e importam; as pérolas usadas adquirem cor amarelada e ficam rugosas; na Irlanda existem pérolas de qualidade não tão excelente, que outrora foram perfeitas e caras, como as que estavam incrustadas na armadura de Júlio César; os pequenos búzios, importados do Egito e denominados "porcelletta", ${ }^{15}$ em Itália, são usados para a cosmética feminina.

A presente enumeração serve fundamentalmente para demonstrar que Amato pretende elucidar os leitores da sua obra com dados náo exclusivamente técnicos, pondo ao seu dispor um manancial de conhecimentos que lhes será muito úteis para compreender a arte da medicina como uma forma integrada de cultura. Nesse sentido, o nosso humanista dedica-se ao trabalho aturado de compulsar fontes e de as explicar e atualizar à luz dos novos saberes. Não surpreende, pois, este método excursivo de apresentação da matéria médica, verdadeiramente desconcertante para algumas das atuais exigências sobre a elaboração técnica de um tratado desta natureza. Não deve, por isso, estranhar-se que o autor exiba aquela que é seguramente uma das suas marcas discursivas mais singulares, a capacidade de fazer derivar o assunto em apreço para matérias circunferentes. Já o havíamos identificado na tradução das enarrationes 39 e 52, deste mesmo segundo livro dos Comentários, respetivamente dedicadas ao vergalho e ao corno do veado. Em ambos os casos, resultou a inclusão dos tão importantes assuntos sobre o bezoar (lapis belzahart) e o unicórnio (unicornis). ${ }^{16}$

14 Deus da mitologia grega, filho de Posídon e Anfitrite.

15 Cf. Dizionario Universale Critico-Enciclopedico della Lingua Italiana Dell'Abbate d'Alberti di Villanuova, Tomo Quinto. Lucca, Presso Domenico Marescandoli, MDCCCIV: "PORCELLETTA, s. f. Porcellana vulgaris. Spezie d'Animale marino, che vive dentro um guscio simile a un pinocchio, di sostanza, e colore simile alla porcellana spezie di conchiglia. Le porcellette, e le blatte bizanzie si dissolvono, tenendole in infusione nel sugo di limoni. Ricett. Fior."; e Gabriel Fallopio, La Chirurgia. Venetia, Steffano Curti, 1675 (trad. ed. lat., 1571) , p. 285: "Ma io hò vn medicamento familiare fatto di succo de Limoni, $\&$ di Lumache, cioè di quele porcellete, che sono come Lumache marine, bianche, \& lucenti le quali si trouano appresso i muschiari, \& quelle Boteghe, oue si vendono cose odorate, $\&$ queste io pongo a molle, o infusione nel succo de Limoni fresco sin tanto, che detto succo consummi tutta quella porcelleta, \& resti come Fango molle, col qual poi vngo il luoco."

16 Cf. José Sílvio Moreira Fernandes; António Manuel Lopes AndRADE, "A Pedra Bezoar e o Unicórnio nos Comentários de Amato Lusitano a Dioscórides: propriedades, valor, tradição e tradução",Cadernos de Cultura Medicina na Beira Interior. Da pré-história ao século xx। 27 (2013), pp. 35-40. 
Voltando à presente análise, segue-se o comentário sobre as propriedades dos mexilhóes, do qual decorre uma conclusão necessariamente breve, sobre o uso medicinal deste molusco. Afirma Amato que, à semelhança das restantes conchas, a cinza obtida por incineração tem efeitos cáusticos. Até chegar a este ponto, o comentário deambulou pela manifestação da discordância quanto à identificação do mexilhão com a telina, ${ }^{17} \mathrm{em}$ Paulo Jóvio, com remissão para Ateneu, ${ }^{18}$ por uma breve revisão de literatura, para validar a opinião sobre a distinção entre mexilhão e telina, confirmada por Dioscórides, de acordo com a tradição hipocrática; por um excurso sobre pérolas; e, finalmente, sobre o ambiente natural onde evoluíram e vivem os mexilhôes.

Depara-se, neste passo, ao tradutor do texto amatiano com a maior dificuldade em determinar os critérios de diferenciação para os moluscos analisados. Podia parecer relativamente seguro optar por termos técnicos na tradução portuguesa, evitando-se a problemática decisão pela escolha de designaçóes comuns, como mexilhão, para mitulus, conquilha, para tellina, e amêijoa, para chama. ${ }^{19}$ A tarefa não se afigura, porém, de fácil solução, uma vez que a tradição tratadística e taxonómica demonstra ter havido variadas aceçôes para designar cada um daqueles moluscos. A juntar aos autores citados ou apenas referidos por Amato Lusitano que escreveram sobre o assunto (Aristóteles, Hipócrates, Dioscórides, Plínio, Ateneu, Teodoro Gaza de Tessalonica e Paulo Jóvio), existe uma prolixa produção de comentários que tanto aditaram mais esclarecimento e apuramento tipológico, quanto incrementaram a dificuldade de resolução do problema colocado pelas diversas interpretaçôes de autores clássicos, medievais e renascentistas. Refira-se, a propósito da complexa classificação das telinas, algumas das obras referidas por Rodrigo César Marques ${ }^{20}$ como as que mais contribuíram para a fascinante história destes bivalves: Belon (1554), Rondeletius (1555), Ulisse Aldrovandi (1606), Charleton (1674), Argenville (1742), Buonnani (1681), Lister (1696), Rumphius (1705), Languius (1722) e Adanson (1757). Dado que a história da classificação científica dos referidos bivalves não permite considerar como inteiramente seguras as denominaçôes adotadas pelos comentaristas,

17 Para uma análise da problemática classificação das tellinidae, cf. Rodrigo César MARQues, Anatomia e filogenia do género Eurytellina (Tellinidae: Tellinoidea). São Paulo, Instituto de Biociências, Universidade de São Paulo, 2012, Diss. Dout., Digital Library of Theses and Dissertations of the USP, pp. 1-12 e passim; e D. Koutsoubas; S. Galinou-Mitsoudi; S. Katsanevakis; P. Leontarakis; A. Metakatos \& A. ZENETOS, "II.5. Bivalve and gastropod molluscs of commercial interest for human consumption in the Hellenic seas", in C. Papakonstantinou, A. Zenetos, V. Vassilopoulou, \& G. Tserpes, eds., State of Hellenic fisheries. Athens, Hellenic Centre for Marine Research, Institute of Marine Biological Resources, 2007, pp. 70-84.

18 Refere-se a Ateneu de Náucrates (c. 150 d. C.) e à sua obra Deipnosophistai. Cf. ed. S. Douglas OLson, Athenaeus, The Learned Banqueters. Cambridge, Mass./London. Harvard University Press, Loeb Classical Library, 2007-2012.

19 Repete-se aqui a dificuldade de identificação sobre o bivalve que é referido. Nas edições de comentaristas ao tratado de Dioscórides, como as de Andrea Mattioli (1554) e Andrés Laguna (1555), as ilustrações apontam para uma distinção entre mituli, tellinae e chamae. Cf. infra, n. 36.

20 Cf. R. C. Maroues, Anatomia..., op. cit., pp. 3-6. 
pelo menos desde a Antiguidade até ao Renascimento, optámos por usar, na presente tradução, respetivamente, as designaçóes mexilhóes, conquilhas e amêijoas, com a prudência de aceitar que cada um destes nomes encerra provavelmente uma maior variedade de bivalves. ${ }^{21}$ Ainda assim, no caso em que a comparação se faz entre os mexilhões e as telinas, parece mais prudente manter esta designação, em vez da denominação comum.

Retomando o comentário às conquilhas, diz Amato que são usadas na alimentação, por serem muito agradáveis ao paladar, embora a areia que muitas vezes trazem prejudique os rins, provocando nefrites. As amêijoas, pelo contrário, apresentam propriedades benéficas como estimulantes do ventre.

Quando delimitámos o presente núcleo de estudo no âmbito dos comentários de Amato a Dioscórides, tivemos a atenção dirigida a linhas de análise que, embora vinculadas a uma ordem sequencial, deveriam, todavia, concentrar uma determinada orientação, de onde pudesse ser retirado o sentido comentarista do autor. Concluímos, destarte, que existe um sentido expositivo, cuja sequência é composta sobretudo pela caracterização anatómica do animal em estudo; pelo ambiente natural onde vive e se desenvolve; pela denominação do género ou da espécie, com as respetivas polémicas, incluindo a discussão etimológica; pela tradição da tratadística; pelo confronto de fontes, com a arrolar de testemunhos, citações, títulos e comentaristas, referências históricas, mitológicas, astronómicas e bibliográficas; pela tradição popular; pela atividade comercial e pelos usos terapêuticos. Tais usos tanto podem dizer respeito à validação do que a tradição havia reportado, sobretudo a partir de autores canónicos na matéria (Aristóteles, Hipócrates, Plínio, Dioscórides e Galeno) ou, por outra parte, ao resultado de experiências realizadas por Amato Lusitano ou até de práticas que no seu tempo considerava admissíveis e verdadeiramente úteis e confortáveis para os doentes.

Por tudo isto e pela convicção que nos move de dar a conhecer o trabalho de uma das personalidades mais prestigiadas da história científica e cultural portuguesa, a tradução desta pequena seleção dos comentários de Amato Lusitano, que ora se apresenta pela primeira vez, com a natural reserva de que se trata de um trabalho sempre inacabado e imperfeito, representa uma tentativa de conciliação entre o conhecimento dos textos e os saberes que enformam a complexa heterogeneidade das culturas humanística e científica.

21 Cf. D. Koutsoubas et alii, "II.5. Bivalve and gastropod molluscs..., op. cit., pp. 70-84. 


\title{
IN DIOSCORIDIS ANAZARBEI LIBRVM SECVNDVM ENARRATIONES DOCTORIS AMATI LVSITANI MEDICI CELEBERRIMI.
}

\author{
De Echino marino

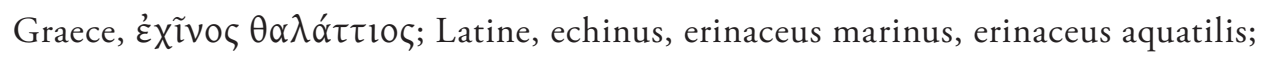

Hispanice, erizo dela mar, ourizo marino; Italice, ericcio marino; Gallice, ericio marino.

\section{Enarratio Primi Capitis}

Echinus tam aquatilis, quam terrestris, notissimum animal est, quod Latini erinaceum marinum et terrestrem appellant, quamquam Theodorus Gaza Thessalonicensis, in suo a se verso Aristotele, echinum marinum non aliter quam echinum interpretatus est, Plinium forte imitatus terrestrem vero echinum erinaceum vertit. Est igitur echinus marinus sive erinaceus marinus, piscis rotundus, aculeis armatus, veluti castanearum echinus, unde et nomen Ėxĩvov enim Graece, Latine hirtum vertunt non minus enim hirtus piscis iste est, quam castanearum calices, aculeis sive spinis armatus, quibus pedum vice ambulat rotaturve. Ceterum piscis iste esui idoneus est et mari Adriatico et Tyrrheno familiaris, quo pro lotio proritando multi vescuntur. Porro echinorum genera sunt plurima, quorum Aristoteles, quarto libro de Historia animalium, unum minutum spinis longis, praeduris, ornatum, non nisi in alto gurgite gigni solitum, maxime contra destillationes urinae laudat. Vnde Paulum Iovium hic decipi certum est, cum libello suo de Piscibus, capite 41, non hoc genus, sed aliud maius, echinometram, quasi echinorum matrem, aut matricem dicas, appellatam ab Aristotele, laudari contendat. Certum enim est, citato loco ab Aristotele non echinometram contra urinae destillationes laudari, sed potius minutum illud genus a nobis delineatum, ut legenti manifestum erit. At de utroque echino, Galenus, libro undecimo de Facultatibus simplicium medicamentorum, ita tradit: erinacei utriusque tum marini tum terrestris corpus ustum cinerem efficit, facultatis tum extergentis, tum digerentis tum detrahentis. Itaque eo quidam et ad excrescentia et ad sordida usi sunt ulcera. 


\title{
COMENTÁRIOS AO LIVRO II DE DIOSCÓRIDES DE ANAZARBO PELO CÉLEBRE DOUTOR AMATO LUSITANO
}

\author{
Sobre o ouriço-do-mar

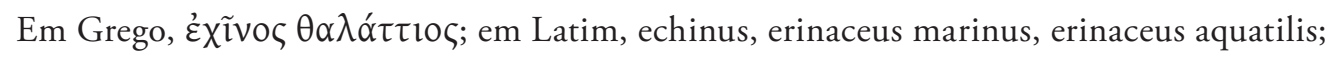 \\ em língua da Hispânia, erizo dela mar, ourizo marino; em língua da Itália, ericcio marino; em
} Francês, ericio marino.

\section{Comentário do primeiro capítulo}

O ouriço, tanto o da água como o da terra, é um animal muito conhecido, a que os latinos chamam ouriço-do-mar e ouriço terrestre, ${ }^{22}$ embora Teodoro Gaza de Tessalonica, na sua traduçáo de Aristóteles, tenha considerado ouriço-do-mar não de outro modo que ouriço, talvez imitando Plínio, que, na verdade, traduz terrestre por ouriço erináceo. Existe, portanto, o ouriço-do-mar ou erináceo marinho, peixe ${ }^{23}$ redondo, armado de espinhos, como um ouriço de castanheiro, pelo

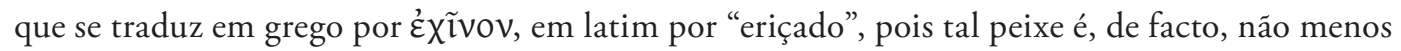
espinhoso do que os invólucros das castanhas e armado de espinhos ou picos, com os quais, em vez dos pés, anda ou roda. Além disso, é um peixe comestível, comum nos mares Adriático e Tirreno, que muitos consomem como estimulante da urina. Existem, na verdade, muitos tipos de ouriços, entre os quais especificamente um, pequeno, que só costuma aparecer no fundo do mar, provido de longos espinhos, muito duros, que Aristóteles, no livro 4 da História dos Animais, recomenda muito contra defluxos urinários. Donde ser certo que nisto se engana Paulo Jóvio, quando, no capítulo 41 do seu opúsculo Sobre os Peixes, sustenta que não é de recomendar este género, mas a outro maior, designado por Aristóteles como o grande ouriço-do-mar, como se se dissesse mãe ou matriz de ouriços. ${ }^{24}$ É, efetivamente, verdade que, no citado passo de Aristóteles, não se nomeia o grande ouriço-do-mar contra defluxos urinários, mas antes o tipo mais pequeno por nós descrito, como ficará bem evidente a quem o ler. E, sobre um e outro destes ouriços, Galeno, no livro 11 do tratado Sobre as Propriedades dos Medicamentos Simples, assim diz: "o corpo queimado de ambos os ouriços, o do mar e o terrestre, feito inteiramente em cinzas, possui propriedades expurgativas, digestivas e evacuativas. E, conforme o que precede, foram usadas em excrescências e em chagas pútridas.

22 Ouriço-cacheiro.

23 Opção pela tradução de "piscis", com o seu sentido usual, para ser fiel ao entendimento epocal acerca da classificação tipológica deste tipo de animal marinho.

24 Para traduzir o jogo de palavras por semelhança fónica entre "echinometram" e "echinorum matrem", poder-se-ia também optar por combinações do género "madre e matriz" ou "mãe e madre", nas quais o segundo termo pareceria concitar sobretudo a aceção de órgão onde se gera e se desenvolve uma cria. 
De Erinaceo terrestri

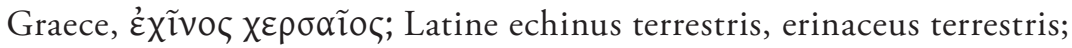

Hispanice, orico quacheiros; Italice, riccio terrestre;

Gallice, ericcio terrestre.

Enarratio capitis secundi

Echinus sive erinaceus terrestris, marino admodum similis est, qui taxo vel potius histrici similatur apparetve. Animal omni ex parte spinis horridum et aculeis armatum. Quod cum uvis aut fructibus aliis adhaeret, eos spinis transfixos, onustum incendit et ad cuniculos et nidi sui anfractus portat. Est enim animal hoc frigidum natura, multis scatens superfluitatibus. Qua de causa eius caro potius in medico usu, quam in continuo victu accipienda est. Habet enim animal hoc, ut obiter hoc notem, testiculos renibus adhaerentes, de quo Razes multa tractatu de Sexaginta animalibus scripta reliquit, quae omnia apocrypha et non Razis esse certissime crediderim. Ad multa tamen valet, quae Dioscorides in praesenti scribit, inter quae alopeciam pilorumve defluvium praecipue nominare est. 
Sobre o ouriço terrestre

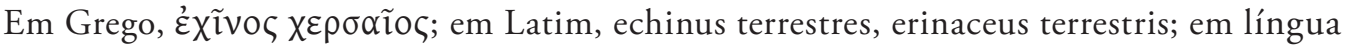
da Hispânia, orico quacheiros; em língua da Itália, riccio terrestre;

em Francês, ericcio terrestre.

Comentário do segundo capítulo

O ouriço ou erinácio terrestre é muito semelhante ao ouriço-do-mar, o qual se assemelha ou aparenta a um teixo ou, de preferência, a um histrix. ${ }^{25}$ É um animal inteiramente eriçado de picos e armado de espinhos. Pelo que, quando se fixa em uvas ou em outros frutos, trespassando-os com os picos, agita-se e, com o corpo carregado de alimentos, transporta-os para as tocas e para o seu ninho sinuoso. Trata-se, na verdade, de um animal frio e superabundante. Por essa razão, a sua carne deve ser mais apreciada para uso médico do que regularmente na alimentação continuada. Com efeito, tem este animal (para referir isto de passagem), os testículos ligados aos rins, e sobre ele Rasis deixou muitas coisas escritas no seu tratado Sobre os Sessenta Animais, que, creio, serem todas apócrifas e, seguramente, não de Rasis. É, todavia, eficaz em muitas situaçóes, que Dioscórides reporta no presente passo, entre as quais se deve sobretudo nomear a alopecia ou queda de cabelo.

25 Género de mamífero roedor. 


\section{De Hippocampo}

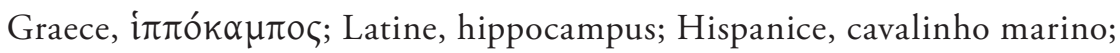

Italice, cavalin marino, cavalin ritorto, dragonetto; Galice, dragoneto

\section{Enarratio tertii capitis}

Nusquam quod equidem notaverim frequentius hippocampus, quam in Anconitano flexuoso hoc mari cernitur, ubi piscatores illum draconem, alii vero equulum circumflexum appellitant, pisciculus scilicet, subniger, equinum habens caput, oblongum et rotundum, collum vero latum multis clavatum ordinibus, nam cauda quadrata, subtilis ac circumflexa in eo cernitur. Verum hunc pisciculum marinum Dioscorides non descripsit, ipsius nomenclatura contentus,

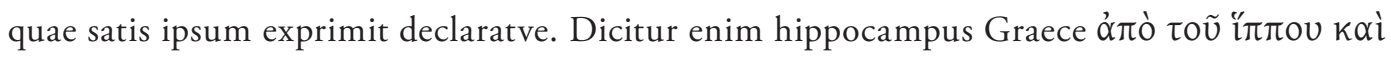
$\kappa \alpha ́ \mu \pi \tau \omega$, id est ab equo et flecto, quasi flexuosus equus. Vnde Mathiolus Senensis haec ignorans, plura non nisi absurda, de hippocampo scripsit. Inquit enim ille particulam hippo magnum significare, ut in hipposelino et hippomarathro sit. Ignorabat enim Mathiolus hippon equum crebrius significare, ut in praesenti evenit et capite 22, sequenti, ubi de hippopotamo, id est fluviatilis equi testiculo agit, ut sexentos alios praeteream locos, in quibus hippos pro equo accipitur. Ceterum, mulieres Anconitanae pisciculo isto in pulverem redacto et vino excepto, pro lacte evocando in potu utuntur, ac ea vero quoque, quae Dioscorides valere tradit, potente esse experimento compertum habeo. 
Sobre o cavalo-marinho

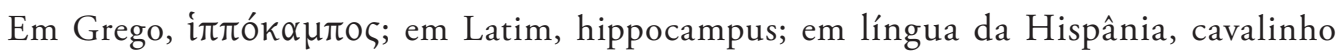
marino; em língua da Itália, cavalin marino, cavalin ritorto, dragonetto; em Francês, dragoneto

\section{Comentário do terceiro capítulo}

Em parte alguma, tenho observado mais frequentemente o cavalo-marinho do que aquele que se vê neste sinuoso mar de Ancona, onde os pescadores o costumam designar como dragão, outros ainda como cavalinho curvado, sem dúvida, um peixinho ${ }^{26}$ quase negro, que possui uma cabeça de cavalo, alongada e redonda, mas com um pescoço largo, guarnecido de muitos filamentos, nele se distinguindo ainda uma cauda esquadrada, fina e curvada. Na verdade, Dioscórides não descreveu este peixinho marinho, porque estava agradado com a designação atribuída, que traduz ou nomeia satisfatoriamente este animal. Diz-se "hipocampo", do grego

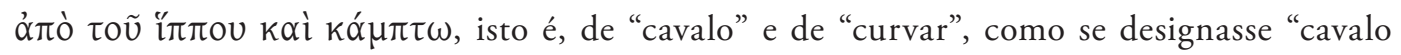
curvado”. É por esta razão que Matttioli de Siena, desconhecedor disto, escreveu muitas coisas que só podem ser absurdas sobre o cavalo-marinho. Afirma, de facto, que o radical hippo tem especial significado, como em hipposelinus" [salsa-de-cavalos] e em hippomarathrus [funcho bravo]. Ignorava, todavia, Mattioli que hippos significa mais frequentemente "cavalo" (como neste passo se verifica e, a seguir, no capítulo 22), ${ }^{27}$ quando ele faz referência aos testículos do hipopótamo, isto é, do "cavalo do rio", ${ }^{28}$ para não mencionar outras seiscentas referências, nas quais se aceita hippos por "cavalo". De resto, as mulheres de Ancona usam tal peixinho, reduzido a pó e misturado com vinho, em bebida, como estimulante do leite materno, e este aspeto, que Dioscórides apresenta como válido, também eu comprovei que é eficaz através da experiência.

26 Opção semelhante à adotada para a tradução de "piscis". Cf. supra n. 23.

27 Amato refere-se à entrada, com a designação de enarratio 22, na qual irá tratar do assunto do hipopótamo.

28 Faz, neste passo, alusão ao comentário de Mattioli à obra de Dioscórides. 
De Purpuris et Bucinis

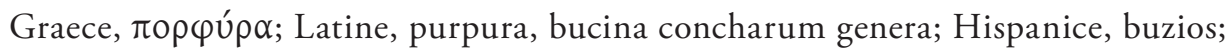
Italice, buccine

\section{Enarratio 4}

Purpura et bucinum e genere concharum in mari repertarum sunt. Nam purpura aculeis clavata, lingua digitali, firma, torosa et valida, ut reliqua conchylia perforare valeat, est. In cuius colli vena liquor ille pretiosissimus, purpureus dictus reperitur, quo purpureae Imperatorum et Regum vestes tingebatur. Hunc vero liquorem casu canem Herculis invenisse dictitant, quem Latini non solum liquorem vel sucum, et florem, verum etiam rorem et sarranum et tyrium, et saniem et pelagium, veluti Vitruvius, ostrum appellant. Extrahitur enim liquor iste a vivis purpuris, nam in mortuis illico evanescit. Qua de causa, piscatores vivas purpuras ad manus habere, maxime soliciti sunt. Vivunt autem purpurae extra mare, quinquagenis diebus saliva sua, si tamen aquam dulcem gustare illis contigerit, illico moriuntur. Latitant vero, ut placet Aristoteli, libro octavo de Historia animalium et libro quinto eiusdem voluminis, circa Canis ortum tricenis diebus. Plura vero apud Plinium legito et illius enarratorem Massarium libro nono, capite trigesimo sexto. Bucina vero, ut praediximus, purpurarum sunt species, minor tamen, quae ideo bucinum dicitur, quia ad similitudinem eius bucini quo sonus editur, est. Habet vero orificium quo sonus illiditur, ut ori sonantis applicetur, aptissimum. Hoc enim bucinum crederem ipse concham illam esse, qua olim Triton apud Olisiponenses canebat, ut eorum legato ad Tiberium Caesarem (referente Plinium) nuntiavit. Ceterum iis bucinis, ut diximus, purpurae sunt maiores, quae rostrum canaliculi modo oblongum, in quo lingua continetur habent, non nisi clavatum, ad turbinem usque, septenis fere in orbem aculeis, qui in bucino non reperiuntur. At commune purpuris et bucinis unum est, quod tot orbes sive volutas habent, quot annos. Bucina tamen non nisi petris adhaerent, circaque scopulos leguntur. Quarum pulvis, ut hodie operatur vel cinis, ut Dioscorides et Galenus suadent, ulcera maxime purgat. Bucinis hodie vice cadorum Lusitani nostri utuntur, praesertim ex India delatis, quae procul dubio, alba, nitida, margaritarum colore conspiciuntur et in maximo pretio habentur. Non est quoque in praesenti silere id quod dicit Dioscorides, scilicet, quod ex bucinis calx sit, cum hodie apud Indios, non alterius calcis quam huius, pro ferruminandis lapidibus et construendis parietibus copia detur. Sed cum de conchis agimos, non alienum erit, inter eas adnumerare eam in qua margaritae sive uniones nascuntur, cum de illis nec Dioscorides nec Galenus ullam fecerunt memoriam. Nascuntur igitur margaritae in concha non multum ab ostreorum conchis differente, ut cottidiana experientia testatur, et Plinius non siluit, libro Naturalis Historiae nono, capite trigesimo quinto, non quattuor aut ad summum quinque in 
Sobre as púrpuras e os búzios

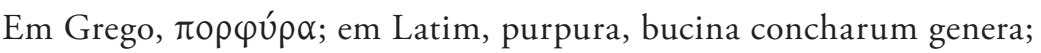
em língua da Hispânia, buzios; em língua da Itália, buccine

\section{Comentário quarto}

A púrpura e o búzio pertencem à espécie das conchas marinhas. A púrpura é guarnecida de pontas, com uma língua da grossura de um dedo, consistente, musculosa e forte, capaz de perfurar as restantes conchas. Na veia que tem no pescoço encontra-se o famoso líquido, de elevadíssimo valor, dito purpúreo, com o qual se tingiam as vestes purpúreas de imperadores e de reis. Na verdade, é comum dizer-se que o cão de Hércules encontrou por acaso este líquido, a que os Latinos chamam não só líquido ou seiva, e flor, mas também orvalho cartaginês e tírio, baba e, segundo Vitrúvio, púrpura do mar. Tal líquido é, na verdade, extraído de púrpuras vivas, pois quando morrem desaparece instantaneamente. Por essa razão, os pescadores sempre se esforçaram por apanhar as púrpuras com vida. Além disso, as púrpuras vivem cinquenta dias fora do mar, apenas com a sua saliva, mas, se lhes acontecer beber água doce, morrem imediatamente. Como refere Aristóteles, no livro 8 da sua História dos Animais e no livro 5 do mesmo volume, escondem-se, na verdade, durante trinta dias, próximo do nascimento da constelação do Cáo. Leia-se, pois, mais informação em Plínio e no seu comentador Massário ${ }^{29}$ (capítulo 30 do livro 9). Os búzios, na realidade, como afirmámos anteriormente, pertencem à espécie das púrpuras, mas são de menor tamanho. Diz-se precisamente "búzio" por se assemelhar à trombeta que emite som. Possui, de facto, um orifício, por onde se projeta o som e que se adapta perfeitamente à boca de quem toca. Com efeito, eu próprio acredito que este tipo de búzio é aquela concha, com a qual outrora Tritão cantava para os habitantes de Olisipo, como contou um seu embaixador, enviado a Tibério César (que Plínio refere). ${ }^{30}$ De resto, maiores do que estes búzios, como dissemos, são as púrpuras, que possuem uma boca meio alongada, apenas com um pequeno canal, onde se encontra a língua, só guarnecida de pontas até à parte cónica, geralmente dispostas em forma de um círculo com sete espinhos, inexistentes no búzio. Há, porém, um aspeto em comum nas púrpuras e nos búzios, o facto de terem tantos círculos ou volutas, quantos os anos. Os búzios, todavia, apenas aderem às pedras e são apanhados em redor de grandes calhaus. A sua cinza ou pó, conforme hoje se usa, de acordo com o que Dioscórides e Galeno aconselham, limpa com grande eficácia as chagas. Os Portugueses

29 Francisci Massarii Veneti in nonum Plinii de naturali historia librum castigationes et annotationes... Basileae, Froben, 1537.

$30 \mathrm{NH}, \mathrm{IX}, \mathrm{V}(4)$. 
concha una, ut ille tradit, inclusae, sed plures, centum numero excedentes, quae procul dubio, ut Arabes testantur, cordis et oculorum affectibus subveniunt. Nec audiendi sunt hodie nonnulli, qui ut aliquid novi afferre videantur, margaritarum contemnunt vires, ignorantes alioqui, margaritarum usum, rei medicae magnum ornamentum ac aegrotantibus non infimum nec contemnendum iuvamentum esse. Ex quibus conditum diamargariton dictum passim in officinis paratum habetur, sed quod margaritae integrae, vel perforatae in usu medico accipiendae sint, id recentiorum est commentum. Nam quae ex India afferuntur margaritae, Solis ingentissimo aestu, flavescunt, secus autem ex Peru provincia, ex qua hodie ad nos albissimae, rotundae admodum in magna quidem copia advehuntur. Quarum si quis exactam desiderat historiam, legat Plinium, loco citato, qui recte mea sententia uniones praestantissimos, in mari Rubro reperiri tradit, id quo nos hodie verum esse deprehendimus, cum Lusitani nostri, apud Ormusium, insulam Persiae, non procul a mari Rubro negotiantes, inde praestantissimos albissimosque portent uniones. Senio tamen confectae margaritae flavescunt et rugosae fiunt. In Hiberniae vero mari, hodie margaritae reperiuntur, non admodum tamen excellentes, olim tamen perfectissimas ac maximi pretii reperiri, Iulii Caesaris thorax indicat. Sunt quoque hodie bucina quaedam parva, quae ex Aegypto advehuntur, Italica voce porcelletta dicta, quibus mulieres pro decoranda facie maxime utuntur. Haec enim in suco limonis cum merguntur, liquefiunt et tanquam unguentum evadunt, quo mulieres ut dixi suas fucant genas et tanto magis, si parum sublimati, illi miscuerint. 
usam atualmente os búzios em vez de vasilhas, sobretudo os trazidos da Índia, que são indubitavelmente notáveis pela cor branca e brilhante das pérolas e têm um preço muito elevado. Náo é também de omitir, neste passo, o que diz Dioscórides, ou seja, a cal tem origem nos búzios, como a que, não diferente desta, hoje se usa com abundância, entre os Indianos, para colar pedras e construir paredes. Mas, em matéria de conchas, não será inoportuno enumerar entre elas a concha de onde nascem as pérolas ou pérolas únicas, ${ }^{31}$ já que nem Dioscórides nem Galeno dela minimamente fizeram qualquer registo. As pérolas nascem, portanto, numa concha, não muito diferente das conchas das ostras, como a experiência quotidiana comprova e Plínio não omitiu, no capítulo 35 do livro 9 da sua História Natural, não sendo, segundo diz, quatro ou cinco, no máximo, inclusas numa única concha, mas em maior número, ultrapassando cem, as quais, como atestam os Árabes, aliviam sem dúvida as afeções dos olhos e do coração. Atualmente não se deve dar ouvidos a alguns, que, parecendo trazer novidades, menosprezam as propriedades das pérolas, desconhecendo, além do mais, que o seu uso é um importante recurso da medicina e até um socorro, não desprezível nem despiciendo, para os doentes. Delas se obtém o composto denominado electuário de pérolas, preparado nas boticas de diversos lugares, mas, à luz da mais recente invenção, as pérolas inteiras ou abertas devem ser aceites nas práticas médicas. Com efeito, as pérolas que são trazidas da Índia apresentam uma cor amarelada, por causa do calor ardente do Sol, diferentes, porém, das do território do Peru, de onde hoje chegam em grande quantidade, alvíssimas e inteiramente redondas. Quem sobre elas quiser procurar a exatidão histórica tem de ler Plínio, no citado passo, onde, perfeitamente de acordo com a minha opinião, conta que as pérolas mais distintas se encontram no mar Vermelho, coisa que, nos nossos dias, compreendemos ser verdade, pelo facto de os Portugueses fazerem comércio perto do mar Vermelho, entre os habitantes da ilha persa de Ormuz, de onde trazem as tão distintas e alvíssimas pérolas únicas. Todavia, com o passar do tempo, as pérolas usadas adquirem uma cor amarelada e ficam com aspeto rugoso. Na verdade, no mar da Irlanda, encontram-se atualmente pérolas, mas não de grande qualidade; outrora, contudo, encontravam-se pérolas perfeitas e de enorme valor, como demonstra a armadura de Júlio César. Também existem atualmente alguns búzios pequenos, que chegam do Egito, que se denominam "porcelletta", ${ }^{32}$ no idioma itálico, e que as mulheres muito usam para embelezar o rosto. Na realidade, quando mergulhados em sumo de limão, liquefazem-se e tornam-se numa espécie de unguento, com o qual as mulheres, como disse, pintam as maçãs do rosto, e acrescentam-lhe mais se a cor deste tiver pouco realce.

31 Margarita é o nome grego para designar pérola. As margaritas são genericamente diferentes das pérolas que os Romanos chamavam uniones, visto que se tratava de uma única pérola produzida apenas por uma concha.

32 Cf. supran. 15. 


\section{De Mitulis}

Graece, $\mu u ́ \alpha \kappa \varepsilon \zeta$; Latine, myaces, mituli, musculi; Hispanice, Lusitanice, mixilhus; Italice, una sorte di lumache marini.

\section{Enarratio 5}

Non elevo iudicium Pauli Iovii viri doctissimi, cum dicat Athenaeum insequendo in eo libello quo de Romanis piscibus egit, mitulum tellinam esse, ut apud ipsum est videre capite quadragesimo primo, Dioscoridis forsan oblitus, qui mitulum a tellina differentem facit, ut ex praesenti capite et sequenti satis clare patente. Nec minus ex Hippocrate hoc satis probari potest, libro secundo de Diaeta, ubi mitulum a tellinis differentem facit, cum dicat: mituli vero et pectines ac tellinae, magis alvo secedunt. Est igitur mitulus conchae margaritiferae species quaedam, testa levi, subtili, nigricante, hirsutave, nam intus lucens, nitensve est, quae, ut tradit Plinius, libro nono capite trigesimo quinto, ubi de margaritis et unionibus agit, in Bosphoro Thracio, rufos ac parvos uniones producebat, at hodie mitulos non solum in mari, sed fluminibus intrantibus mare, non tamen margaritiferos observamus, quos musculos Latiniores appellant, quamquam non me lateat Theodorum Gazam, libro tertio de Historia animalium, mysticetum 
Em Grego, $\mu u ́ \alpha \kappa \varepsilon \zeta$; em Latim, myaces, mituli, musculi; em língua da Hispânia e em Português, mixilhus; em língua da Itália, una sorte di lumache marini.

\section{Comentário cinco}

Retiro a razão a Paulo Jóvio, homem extremamente douto, pelo facto de, seguindo Ateneu, afirmar, no livrinho que fez sair sobre os peixes de Roma, que o mexilhão é uma telina, ${ }^{34}$ como se pode verificar no capítulo 41 da sua obra, talvez esquecido de Dioscórides, que distingue o mexilhão da telina, como neste capítulo e nos seguintes ficará claramente exposto. Isto, ademais, pode ser satisfatoriamente verificado em Hipócrates, no livro 2 do tratado Sobre a Dieta, no qual também distingue o mexilhão da telina, afirmando "os mexilhôes, na realidade, diferem, sobretudo pela cavidade intestinal, das vieiras e das telinas”. O mexilhão é, portanto, uma espécie de concha (das que produzem pérolas), com uma casca leve, fina, escura e eriçada, brilhante ou luzidia no interior, a qual, segundo Plínio, no capítulo 35 do livro 9, onde trata do assunto das pérolas e das pérolas únicas, produzia, no Bósforo Trácio, pérolas avermelhadas e pequenas. Atualmente, observamos mexilhôes não só no mar, mas também nas embocaduras fluviais, mas não os que produzem pérolas, que os mais puristas designam por moluscos, apesar de Teodoro Gaza, no livro 3 do tratado Sobre a História dos Animais, traduzir "mysticetus" 35 ,

33 É de verificar que existe uma discrepância entre as ilustrações insertas nas edições dos comentaristas de Dioscórides, Andrés Laguna e Andrea Mattioli, e a interpretação que é por eles adotada. Cf. Andrés Laguna, Pedacio Dioscorides Anazarbeo, acerca de la materia medicinal y de los venenos mortiferos. Anvers, luan Latio, 1555, p. 126; e P. A. MATTIOLI, Commentarii in Libros..., op. cit., p. 160. Parece que este entendimento acerca dos "mexilhões" descritos e representados nas ilustrações pode também ser extensivo ao bivalve hoje cientificamente conhecido como arca noae. Cf. D. Koutsoubas et alii, "II.5. Bivalve and gastropod molluscs..., op. cit., pp. 74 e 75, figs. 4 e 5.

34 Na comparação específica entre o mexilhão e a telina, é mais conveniente usar na tradução o termo "telina" em vez de "conquilha", uma vez que parece haver aqui uma generalização extensiva a esta espécie, de modo a incluir possivelmente outros bivalves semelhantes ao mexilhão ou às conquilhas. Ver também a referência específica em Paulo Jóvio: De Romanis Piscibus libellus ad Ludovicum Borbonium Cardinalem, amplissimum, ed. Froben, 1531, cap. 41: "Sequuntur parvae illae Conchulae a veteribus latinis Mytili, a Romanis autem hodie Graeco nomine Tellinae nuncupatae...".

35 Termo preferível a "mystocetum", registado na edição de 1553. A tradição que reporta a designação usada por Aristóteles e traduzida por Teodoro Gaza, como neste passo é referido por Amato Lusitano, criou, além de registos diferenciados (mystocetus/mysticetus/mystakoketos), um imaginário que colocou em confronto a associação do nome a cetáceos, precisamente pelo facto de o animal em causa não possuir dentes, e a interpretação de Gaza que aponta para uma hipótese muito diferente, ao optar pela denominação musculus piscis (molusco). Esta questão tem acompanhado a história da tradução do texto aristotélico. Pouco mais de dois séculos depois da edição de Amato, podemos vê-la, por exemplo, na síntese que A. Camus escreveu no seu volume de notas sobre a referida obra de Aristóteles. Cf. A. Camus, Notes sur l'Histoire des Animaux d'Aristote. Paris, Chez la Veuve Desaint, 1783, pp. 540-541. 
in Aristotele, musculum vertisse, imo Hippocrates, citato loco, musculum diversum a mitulis facit. Verum mituli sua sponte in arenosis, extra mare, et fluviis mare intrantibus nascuntur, ut meminit Plinius citato libro, capite 51. Qui capite decimo libri tregesimi secundi, myacas in mitulos degenerare et in algosis non arenosis vivere affert. Ceterum, mituli, ut caetera conchilia, in victus usum veniunt, quorum cinis quoque causticum vim habet.

\section{De Tellinis}

Graece, $\tau \varepsilon \lambda \lambda \tilde{\imath} v \alpha \varepsilon$; Latine, tellinae; Hispanice, brignigoís;

Italice, telline, calcinelli.

\section{Enarratio 6}

Haec conchulae quoque sunt et e conchyliorum genere, quae ubique in mari reperiuntur, et in victus usum cottidianum veniunt, gustui admodum gratae, verum ob arenulas quibus scatent, renibus officiunt et nephritim generant. 
em Aristóteles, por molusco e de até Hipócrates, no citado passo, diferenciar molusco de mexilhão. Na verdade, os mexilhóes nascem espontaneamente, fora do mar, em zonas arenosas e nas embocaduras dos rios, como recordou Plínio no já referido livro, ao capítulo 51. Conta-nos, ainda, no capítulo 10 do livro 32, que as conchas degeneraram em mexilhóes e vivem em locais com algas, não arenosos. Quanto ao resto, os mexilhões, à semelhança das restantes conchas, têm vindo a ser usados na alimentação e a sua cinza também possui propriedades cáusticas.

Sobre as conquilhas ${ }^{36}$

Em Grego $\tau \varepsilon \lambda \lambda \tilde{\imath} v \alpha \varepsilon$; em Latim, tellinae; em língua da Hispânia, brignigoís; em língua da Itália, telline, calcinelli.

\section{Comentário seis}

Ao género das conchas pertencem também estas de pequena dimensão, que se encontram em qualquer lugar no mar, e que têm vindo a ser usadas na alimentação quotidiana. São muito agradáveis ao paladar, mas, devido a virem cheias de grãos de areia, prejudicam os rins e provocam nefrites.

36 Para a problemática relativa à classificação deste bivalve, ver supra n. 17 e 19. Nas já referidas ilustrações das edições de Laguna e de Mattioli, parece claramente tratar-se da espécie de conquilha ou cadelinha existente em Portugal e no Mediterrâneo, a Donax trunculus (Linnaeus, 1758), correspondente à denominada $\tau \varepsilon \lambda \lambda \tilde{i} v \alpha /$ tellina. Cf. D. Koutsoubas et alii, "II.5. Bivalve and gastropod molluscs..., op. cit., p. 77, fig. 9.; Andrés Laguna, Pedacio Dioscorides..., op. cit., p. 126; e P. A. Mattioli, Commentarii in libros..., op. cit., p. 160. 


\section{De Chamis}

Graece, $\chi \tilde{\eta} \mu \alpha 1 ;$ Latine, chamae.

\section{Enarratio 7}

Sunt ut paucis dicam chamae, conchyliorum genus, veluti plura alia, ut digiti, ungues, patellae et alia varia, quae Dioscorides praetermisit et eorum ius esculentum tantum alvum proritant. 
Sobre as amêijoas ${ }^{37}$

Em Grego, $\chi \tilde{\eta} \mu \alpha 1 ;$ em Latim, chamae.

\section{Comentário sete}

Farei apenas uma breve referência às amêijoas que são um género de conchas, como muitas outras que existem sob a forma de dedos, unhas, pratinhos e várias outras (que Dioscórides omitiu), cujo molho suculento muito estimula o ventre.

37 Trata-se, como já referimos, de outro caso de difícil opção terminológica, muito semelhante à que se nos deparou para a classificação dos mituli e das tellinae. O termo chamae, traduzido aqui necessariamente em sentido genérico, pode representar uma ampla variedade de bivalves, com formas semelhantes às das amêijoas. As mencionadas edições de Laguna e de Mattioli exibem também uma variedade deste tipo de bivalves que parece incluir espécies como berbigões ou até pequenas vieiras. Cf. D. Koutsoubas et alii, "Il.5. Bivalve and gastropod molluscs..., op. cit., pp. 76-78, figs. 8-13. 


\section{BIBLIOGRAFIA}

Bullens, Pieter; Gotthelf, Allan, “Theodore Gaza’s Translation of Aristotle’s De Animalibus: Content, Influence, and Date", Greek, Roman, and Byzantine Studies 47 (2007), pp. 469-513.

Camus, A., Notes sur l'Histoire des Animaux d'Aristote. Paris, Chez la Veuve Desaint, 1783.

Correia, Miguel; Palma, Jorge; Koldewey, Heather; Andrade, José P., "Can artificial holdfast units work as a habitat restoration tool for long-snouted seahorse (Hippocampus guttulatus Cuvier)?", Journal of Experimental Marine Biology and Ecology 448, 1 (2013), pp. 258-264.

Dizionario Universale Critico-Enciclopedico della Lingua Italiana Dell'Abbate d'Alberti di Villanuova, Tomo Quinto. Lucca, Presso Domenico Marescandoli, MDCCCIV.

Fernandes, José Sílvio Moreira; Andrade, António Manuel Lopes, "A Pedra Bezoar e o Unicórnio nos Comentários de Amato Lusitano a Dioscórides: propriedades, valor, tradição e traduçáo", Cadernos de Cultura Medicina na Beira Interior. Da pré-história ao século Xxi 27 (2013), pp. 35-40.

Fallopio, Gabriel, La Chirurgia. Venetia, Steffano Curti, 1675 (trad. ed. lat., 1571).

Geanakoplos, Deno John, “Theodore Gaza, a Byzantine Scholar of the Palaeologan 'Renaissance' in the Early Italian Renaissance (c. 1400-1475)", Constantinople and the West, Essays on the Late Byzantine (Palaeologan) and Italian Renaissances and the Byzantine and Roman Churches. Madison WI, 1989, pp. 68-90.

Jóvio, Paulo, De Romanis Piscibus libellus ad Ludovicum Borbonium Cardinalem, amplissimum, ed. Froben, 1531.

Laguna, Andrés, Pedacio Dioscorides Anazarbeo, acerca de la materia medicinal y de los venenos mortiferos. Anvers, Iuan Latio, 1555.

Koutsoubas, D.; Galinou-Mitsoudi, S.; Katsanevakis, S.; Leontarakis, P.; Metaxatos, A. \& ZeNETOS, A., "II.5. Bivalve and gastropod molluscs of commercial interest for human consumption in the Hellenic seas", in C. Papakonstantinou, A. Zenetos, V. Vassilopoulou, \& G. Tserpes, eds. State of Hellenic fisheries. Athens, Hellenic Centre for Marine Research, Institute of Marine Biological Resources, 2007, pp. 70-84.

Marques, Rodrigo César, Anatomia e filogenia do género Eurytellina (Tellinidae: Tellinoidea), Diss. Dout. São Paulo, Instituto de Biociências, Universidade de São Paulo, Digital Library of Theses and Dissertations of the USP, 2012.

Mattioli, Pietro Andrea, Commentarii in libros sex Pedacii Dioscoridis Anazarbei, de medica materia. Venetiis, apud Vincentium Valgrisium, 1554.

Mattioli, Pietro Andrea, Apologia adversus Amathum Lusitanum, cum censura in eiusdem enarrationes. Venetiis, Vincentii Valgrisii \& Balthassar Costantini, 1558.

Massário, Francisco, In nonum Plinii de naturali historia librum castigationes et annotationes... Basileae, Froben, 1537.

Olson, S. Douglas, Athenaeus, The Learned Banqueters. Cambridge, Mass./London, Harvard University Press, Loeb Classical Library, 2007-2012.

Silva, Maria de Fátima de Sousa e, Aristóteles, História dos animais, vol. I, 2006; vol. II. Lisboa, INCM, 2008. 


\section{La mandrágora de Amato Lusitano: edición, traducción y anotación}

MIGUEL ÁNGEL GONZÁLEZ MANJARRÉS ${ }^{1}$

\section{RESUMEN:}

Se presenta una edición latina y traducción castellana anotada del capítulo de la mandrágora que incluyó Amato Lusitano (1511-1568) en sus Enarrationes (Venecia 1553) a Dioscórides. Se trata de plantear un posible modelo de trabajo para la edición y traducción de la obra completa, tal como se presentó en su día dentro del Proyecto de Investigación "Dioscórides e o humanismo português: os Comentários de Amato Lusitano".

PALABRAS CLAVE:

Amato Lusitano; mandrágora; edición; traducción.

\section{ABSTRACT:}

The chapter about mandrake in Amatus Lusitanus's Enarrationes (Venice 1553) is here edited in Latin and translated to Spanish. The text is also annotated. The article is a case-study for editing and translating the Amatus's whole comments on Dioscorides, and it was already presented at a workshop of the research project "Dioscorides and the Portuguese humanism: the Amatus Lusitanus's Comments".

\section{KEYWORDS:}

Amatus Lusitanus; mandrake; edition; translation.

1 Universidad de Valladolid: miguelan@fyl.uva.es. 


\section{INTRODUCCIÓN}

\section{PRELIMINAR}

El texto que aquí se presenta tuvo su origen en una suerte de "case-study" planteado en una de las reuniones de trabajo del Equipo de Investigación que ha llevado a cabo el Proyecto "Dioscórides e o humanismo português: os Comentários de Amato Lusitano". Se trataba entonces de plantear y discutir una posible metodología para afrontar la edición, traducción y anotación de las Enarrationes a Dioscórides del médico portugués Amato Lusitano (1511-1568) y, a partir de un ejemplo concreto, afrontar los problemas principales que pudieran surgir. Se eligió para ello el caso de la mandrágora, una planta célebre desde antiguo que contó con una tradición paralela - aunque a veces también concordante — en el ámbito de la medicina popular y de la medicina docta, y a cuyo estudio nos habíamos acercado ya desde otros puntos de vista, lo que ofrecía un terreno más firme para el propósito perseguido. Fruto de aquel trabajo, por tanto, es esta edición latina y traducción castellana del comentario de Amato, que pasamos a contextualizar brevemente para su mejor comprensión.

\section{LA MANDRÁGORA DE DIOSCÓRIDES}

Desde tiempos muy antiguos se usó la mandrágora como remedio farmacéutico. Debido a la figuración antropomórfica que se adivinó en su rizoma y a sus propios componentes alcalinos, la mandrágora se vio envuelta desde pronto en leyendas, fábulas y ceremonias relacionadas con la magia y la hechicería, que tuvieron una plasmación práctica en la medicina popular y que, poco a poco, fueron aumentando en la Edad Media y el Renacimiento hasta casi constituir hoy día la cualidad misma de la planta ${ }^{2}$.

2 Para la historia de la mandrágora baste citar los siguientes estudios de conjunto: Charles J. S. THOMSON, The Mystic Mandrake. New York, University Books, 1968; Jean-Denis RoLAND, "La mandragore: le mythe d'une racine, la racine d'un mythe", Annales des Sciences Naturells, Botanique 2 (1990-1991), pp. 49-81; Dorit Wittuin, Mandragora. Eine Arzneipflanze in Antike, Mittelalter und Neuzeit. Basel, Dietikon, 1999; Frederik J. Simoons, Plants of Life, Plants of Death. Madison-London, The University of Wisconsin Press, 1999, pp. 101-135; Vera HAMBEL, Die alte Heydnische Abgöttische Fabel von der Alraun: Verwendung und Bedeutung der Alraune in Geschichte und Gegenwart. Diss., Passau, Universität Passau, 2002; Thierry ZARCONE, "Le Mythe de la mandragore: la plante-homme", Diogenes 207 (2004), pp. 140-173; Anne van ArSdall-Helmut W. Klug-Paul Blanz, "The Mandrake Plant and its Legend: A New Perspective", in Peter Bierbaumer-Helmut W. Klug (eds.), Old Names-New Growth: Proceedings of the 2nd ASPNS Conference. Graz, Universität Graz, 2007, pp. 285-346; Marlene VAN DEN BERG-Marianne DIRCKSEN, "Mandrake from Antiquity to Harry Potter", Akroterion 53 (2008), pp. 67-79. 
La tradición popular insistió en su condición humanoide, cuyo origen se explicaría en leyendas muy antiguas: la planta habría brotado del semen que el primer hombre derramó sobre la tierra. En relación con tan curioso nacimiento deberían situarse las dos cualidades que han hecho más célebre a la mandrágora: su valor erótico y su actividad para volver fértiles a mujeres estériles, como se aprecia ya en los textos bíblicos ${ }^{3}$. De hecho, la medicina popular siguió empleando la planta en tales usos y, según frecuentes denuncias de farmacólogos renacentistas, los vendedores ambulantes de boticas y bebedizos la falsificaban con otras semejantes y la vendían a mujeres con problemas para engendrar ${ }^{4}$.

Pero hubo también leyendas relacionadas con su recolección ${ }^{5}$. Teofrasto, por ejemplo, cuenta que debían realizarse tres círculos a su alrededor con una espada y recolectarla mirando a Occidente, al tiempo que, al cortar un segundo trozo, era preciso bailar y decir numerosas retahílas de asunto erótico ${ }^{6}$. La ceremonia, no obstante, se fue complicando con el tiempo: en la Guerra contra los judios de Flavio Josefo se cuenta cómo la planta tenía casi sentimientos, huía de quien se acercaba a ella (solo quedaba paralizada si se le echaba encima orina de mujer o sangre menstrual) y, cuando la arrancaban, el recolector debía atar un perro a su raíz para que tirase de ella, pues quien la sacaba de tierra moría al instante ${ }^{7}$.

En cualquier caso, y de forma paralela a su amplia difusión popular y literaria, el uso racional y "científico" de la mandrágora entró también en la literatura farmacológica y médica (Corpus Hippocraticum, Teofrasto, Dioscórides, Plinio, Galeno, etc.), en que fue objeto de

3 Véase F. J. Simoons, Plants of Life..., op. cit., pp. 107-108; V. HAMBEL, Die alte Heydnische..., op. cit., pp. 27-30; A. van ARSDALL et alii, "The Mandrake Plant...", op. cit., pp. 319-321. Amato Lusitano se refiere a ello en su comentario (línea 20; cf. n. 25). Basándose precisamente en tal creencia popular compuso Maquiavelo en 1518 su célebre comedia de enredo La mandragola: cf. D. WITTLIN, Mandragora..., op. cit., pp. 247-249.

4 También se alude al asunto en el texto de Amato (líneas 26-36), aunque los precedentes son numerosos, como se dirá en el lugar referido (cf. n. 28). Para la falsificación de la mandrágora, véase D. WITTLIN, Mandragora..., op. cit., pp. 259-263.

5 Cf. Maria Patera, "Les rites d'extraction des plantes dans l'Antiquité. Magie, botanique et religion. L'exemple de la mandragore", Revue des Archéologues et Historiens d'Art 27 (1994), pp. 21-34; D. WITTLIN, Mandragora..., op. cit., pp. 238-240; A. van ARSDALL et alii, "The Mandrake Plant...", op. cit., pp. 295-319. Amato, como se verá (líneas 32-33), asocia con la falsificación de la mandrágora sus ritos de extracción.

6 ThPHR., HP, 9.8.8. La cita se repite en PLIN., Nat., 25.147.

7 I., BI, 7.25. La escena se narra aún con más detalle en el Herbarius de Pseudo Apuleyo, un texto farmacológico y botánico de los siglos IV-V: allí, por evitar sacrificar a un perro, se recomienda también el uso de una pértiga (Ps. Apul., Herb., 131). En la Edad Media, por lo demás, se añadió el tópico de los alaridos: la planta gritaría tanto al ser arrancada que el recolector debería ir siempre con los oídos tapados. Andando el tiempo, y sobre todo ya en la Edad Media y el Renacimiento, se añadieron algunas otras fábulas como, por ejemplo, la historia — con el fondo a la vista del esperma primigeniode que la mandrágora nacía del semen y la orina de los ahorcados y otros ajusticiados por tortura, de especial arraigo en zona germana: cf. D. WITTLIN, Mandragora..., op. cit., pp. 240-242; A. van ARSDALL et alii, "The Mandrake Plant...", op. cit., pp. 330-333. 
descripciones morfológicas más o menos ajustadas y en donde se destacaron sus cualidades medicinales más activas. En la Historia de las plantas, por ejemplo, enumera Teofrasto algunos empleos médicos de la mandrágora, que luego se recogerían en Dioscórides: las hojas con miel se aplican para curar heridas; la raíz majada con vinagre vale contra erisipelas, gota e insomnio; y se usa como ingrediente de filtros amorosos ${ }^{8}$. No obstante, Teofrasto describe también la mandrágora en otro lugar como una planta de frutos negros, semejantes a granos de uva y de sabor vinoso. La contradicción de esta especie con la mandrágora tradicional, tiempo después descrita por Dioscórides, llevó ya a algunos farmacólogos renacentistas a ofrecer para ella una identificación diferente y a relacionarla más concretamente con la belladona (Atropa belladona L.), tal como hoy día se admite?

No obstante, el texto científico de la Antigüedad que mejor describe la planta y sus principales usos médicos, ya sin apenas referencias mágicas ni populares, es la obra botánica de

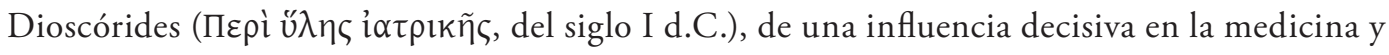
la farmacología desde la Antigüedad al Renacimiento ${ }^{10}$. Dioscórides distingue, de partida, dos especies. A la primera la llama hembra y negra, también conocida por $\theta \rho 1 \delta \alpha$ kí $\alpha$, sin tallo, de hojas parecidas a las de la lechuga, aunque más pequeñas, malolientes, extendidas por tierra, con frutos en forma de manzanas de color amarillento, olorosas, en las que hay unas semillas semejantes a las de la pera, con una raíz doble o triple, grande, negruzca, negra por fuera y blanca por dentro. La otra especie es la blanca y macho, a la que también llaman $\mu \omega ́$ prov (“enloquecedora”), de hojas blancas, grandes, anchas, lisas, semejantes a las de la acelga, con frutos mayores que los de la otra especie, de color azafrán, de olor pesado, que suelen comer los pastores y se quedan adormecidos, con raíz semejante a la anterior y también sin tallo. Los estudiosos suelen identificar ambas especies, respectivamente, con la Mandragora autumnalis L. y la Mandragora officinarum L. (= Mandragora vernalis Bertol.; Atropa mandragora L.), las dos especies hoy reconocidas como propias de la zona mediterránea, que junto a la de zona

8 THPHR., HP, 9.9.1. Una valoración del pasaje puede verse en la edición de Suzanne AmiGUES en THÉOPHRASTE, Recherche sur les plantes. Paris, Les Belles Lettres, 2003, pp. 130-131. No obstante, ya en el Corpus Hippocraticum (Fist., 890; Loc. Hom., 39; Mul., 1.621; Morb., 3.2.474) se citaba también la mandrágora como remedio casi siempre sedante y calmante, aplicado a veces a enfermos mentales.

9 ThPhr., HP, 6.2.9. En la traducción de S. AMIGUES, por ejemplo, se emplea directamente el término "belladone" para esta mandrágora (THÉOPHRASTE, Recherche..., op. cit., pp. 35 y 138).

10 Como estudios básicos sobre Dioscórides baste ver John M. RIDDLE, "Dioscorides", in F. Edward KRANZPaul O. KRISTELLER (eds.), Catalogus translationum et commentariorum. Mediaeval and Renaissance Latin Translations and Commentaries, vol. 4. Washington D.C., Catholic University of American Press, 1980, pp. 1-143; John M. RIDDLE, Dioscorides on Pharmacy and Medicine. Austin, University of Texas Press, 1985; Alain TouwAIDE, "Le Traité de matière médicale de Dioscoride. Pour une nouvelle lecture", Bulletin du Cercle Benelux d'Histoire de la Pharmacie 78 (1990), pp. 32-39; Alain TouWAIDE, "La Thérapeutique médicamenteuse de Dioscoride à Galien: du pharmaco-centrisme au médico-centrisme", in Armelle Debru (ed.), Galen on Pharmacology, Philosophy, History and Medicine. Leiden, Brill, 1997, pp. $255-282$. 
himalaya (M. caulescens Clarke) y tierras turcas (M. turcomanica Mizg) constituirían el grueso de las especies que integran el género Mandragorae ${ }^{11}$.

El resto del capítulo lo dedica Dioscórides a usos médicos: ofrece formas para obtener su zumo y enseña a hacer una cocción con vino que sirve de somnífero, calmante y sobre todo anestésico, pero también de purgante. En forma externa y en varios preparados tiene poder oftálmico y analgésico, vale para expulsar fetos muertos y menstruación retenida, resuelve durezas, lamparones, apostemas y diviesos, y sana la erisipela. A veces puede emplearse como antídoto de mordeduras de serpiente. El fruto purga la matriz y corta la hemorragia menstrual. Algunos de los usos médicos destacados, en efecto, obedecen a la composición propia de la mandrágora: como casi todas las solanáceas, posee cierta riqueza en alcaloides, en especial hiosciamina, atropina, hioscina y escopolamina - que comparte con otras especies como el beleño o la belladona - lo que hace de ella una planta alucinógena, narcótica e hipnótica, si bien hoy día - a diferencia de la belladona misma - no se usa en farmacología científica. Aun así, en homeopatía se le siguen reconociendo algunas cualidades ya vigentes en la Antigüedad: sedante, anti-infecciosa, activa contra la debilidad de la vejiga o laxante ${ }^{12}$.

Al final del capítulo, por lo demás, añade Dioscórides breve información, que parece citar de oídas, sobre una tercera y enigmática especie de mandrágora, a la que también llamarían $\mu \omega ́$ prov. Se trataría de una variedad parecida a la blanca y macho, solo que más tóxica y virulenta en sus efectos paralizantes y anestésicos. A tenor de la imprecisa descripción dioscorídea, la identificación moderna resulta difícil, aunque tiende a considerarse una mera variante de la Mandragora officinarum L., a la que Bertoloni llamó Mandragora vernalis por oposición a la autumnalis.

Tanto las dos especies primeras como la enigmática tercera variedad de mandrágora se incorporaron a la tradición botánica y farmacológica posterior como elementos casi puramente librescos, sin apenas aportaciones nuevas a los datos de Dioscórides, más allá de una rica y amplia representación iconográfica ${ }^{13}$. Para el caso de la tercera especie, además, ni en la Antigüedad misma ni en la Edad Media árabe o latina se hicieron elucubraciones sobre su identificación. Llegado el Renacimiento, fue Ermolao Barbaro (1454-1493) quien propuso una posible relación del morion con la berenjena (Solanum melongena L.), luego rechazada por casi todos los autores, incluido Amato Lusitano, aun cuando los botánicos de zona germana

11 Dsc. 4.75. Para la identificación y descripción científica baste ver D. Wittlin, Mandragora..., op. cit., pp. 10-29; A. van Arsdall et alii, "The Mandrake Plant...", op. cit., pp. 289-292; Christophe Maclaren, Quelle est la part de réalité dans le mythe de la mandragore?, publicado en 2009 y accesible en Inlibroveritas.net (http://www.inlibroveritas.net/lire/oeuvre26291.html), pp. 7-11.

12 Véase D. Wittuln, Mandragora..., op. cit., pp. 48-82, 198-272, 200-252; V. HAMBEL, Die alte Heydnische..., op. cit., pp. 13-17; C. MACLAREN, Quelle est la part..., op. cit., pp. 13-16.

13 Una visión de conjunto sobre ello puede verse en Minta Collins, Medieval Herbals. The Illustrative Tradition. Toronto, University of Toronto Press, 2000, pp. 31-114. 
(en especial Bock [1498-1554], Cordus [1515-1544] y Fuchs [1501-1566]) tendieron a identificarla con la segunda mandrágora de Teofrasto, es decir, con la belladona ${ }^{14}$.

\section{EL COMENTARIO DE AMATO}

Desde finales del siglo XV y a lo largo de todo el XVI el De materia medica de Dioscórides fue objeto de numerosas ediciones griegas y traducciones latinas y vernáculas a menudo acompañadas de comentarios filológicos, botánicos y farmacológicos ${ }^{15}$. Uno de ellos fue el de Amato Lusitano: tras un comentario parcial de juventud titulado Index Dioscoridis (Amberes 1536), publicó en Venecia en 1553 un comentario latino completo (las Enarrationes) a los cinco libros del botánico griego, sin inclusión del texto original. Es aquí, pues, donde se encuentra el breve comentario a la mandrágora objeto de este trabajo, cuya estructura se desarrolla como sigue.

1. Nomenclatura. Como hace en toda la obra y según era frecuente en casi todas las traducciones y comentarios a Dioscórides del Renacimiento, Amato pone antes del texto una serie de nombres con que se designaba la mandrágora en diferentes lenguas, tanto antiguas (griego y latín) como modernas (lenguas hispánicas, italiano, francés y alemán). Algunos de los nombres latinos procedían ya de la tradición genuina de Dioscórides, aunque otros se añadieron en la recensión interpolada, base de las primeras ediciones del Renacimiento ${ }^{16}$.

14 Usamos para las fuentes las abreviaturas resueltas al final de esta introducción: BARBARo, Cor., 79v; Bock, Stirp., 304-305; Cordus, Ann., 509-510; Fuchs, Hist., 529 y 532. La identificación de morion y belladona, no obstante, fue rechazada por autores como MATTIOLI, Disc., 597. Ya casi al final del siglo XVI propuso CesalPINo (Plant., 216) su identidad con el jazmín (Iasminum officinale L.). Sobre ello volvemos en las notas 29 y 30.

15 Para la difusión de Dioscórides en el Renacimiento pueden verse, por ejemplo, Jerry STANNARD, "Dioscorides and Renaissance Materia Medica", in Markus FlorkIN (ed.), Analecta Medico-Historica. I. Materia Medica in the XVIth Century. Oxford, Pergamon, 1966, pp. 1-21; J. M. RIDDLE, "Dioscorides" op. cit.; Alain TouWAIDE, Le Traité de matière médicale de Dioscoride à la Renaissance. Bruxelles, Université Catholique de Louvain, 1984. Para la botánica y la farmacología renacentistas son interesantes Agnes R. ARBER, Herbals. Their Origin and Evolution. A Chapter in the History of Botany, 1470-1670, W.T. STEARN (ed.). Cambridge, Cambridge University Press, 19863; Peter DILG, "Die botanische Kommentarliteratur in Italien um 1500 und ihr Einfluss auf Deutschland", in August Buck-Otto HERDInG (eds.), Der Kommentar in der Renaissance. Boppard, H. Boldt Verlag, 1975, pp. 225-253; Karen Meier ReEDS, Botany in Medieval and Renaissance Universities. New York-London, Garland Publishing, 1991; Paula FInDLEN, Possessing Nature: Museums, Collecting and Scientific Culture in Early Modern Italy. Berkeley-London, University of California Press, 1994; Brian W. OGILVIE, The Science of Describing: Natural History in Renaissance Europe. Chicago, University of Chicago Press, 2006.

16 Un buen ejemplo de dicha recensión, que combina la tradición genuina y la alfabética, puede ser el códice de Salamanca 2659, f. 121r: cf. Alain TouwAIDE, "The Salamanca Dioscorides (Salamanca, University Library, 2659)", Erytheia 24 (2003), pp. 125-158; Antonio LóPEz EIRE-Francisco CoRTÉs GabAUDÁn, Dioscórides, Sobre los remedios medicinales. Manuscrito de Salamanca: estudios y traducción. Salamanca, Universidad de Salamanca, 2006, p. 322. Para la etimología y los nombres de la planta, también en las lenguas modernas, puede verse D. WITTLIN, Mandragora..., op. cit., pp. 30-32 y 33-46; V. HAMBEL, Die alte Heydnische..., op. cit., pp. 19-21. Véase además la n. 19. 
2. Experiencia propia. Amato empieza su comentario reconociendo que nunca había visto la mandrágora en tierras hispanas, aun cuando era planta muy frecuente en Italia y, en especial, en Ferrara, donde había vivido entre 1540 y $1547^{17}$.

3. Descripción botánica. Sin entrar a decir si se refiere a la especie macho o a la hembra, Amato describe la planta que se ve habitualmente en los huertos de Italia. Hace unas primeras alusiones eruditas a Pitágoras y Columela, probablemente de segunda mano.

4. Recomendación medicinal de Dioscórides: vino de mandrágora.

5. Falsificación. Dedica una buena cantidad de texto a denunciar, como era ya tópico entre los farmacólogos del Renacimiento, la falsificación de la mandrágora entre charlatanes y curanderos, que se aprovechaban de sus supuestas virtudes contra la esterilidad femenina para venderla a precios muy elevados. En su denuncia, describe el proceso de falsificación y las creencias sobre su condición antropomórfica y sus especiales ritos de extracción. Termina reclamando la prohibición en Italia de dichas ventas fraudulentas, tal como - afirma - se hacía ya en tierras hispanas, en posible referencia al Tribunal del Protomedicato ${ }^{18}$.

6. Tercera especie. La parte final del texto se reserva para comentar de pasada la posible asociación del morion de Dioscórides con la berenjena. Según habían hecho ya otros comentaristas, rechaza Amato la identificación y aprovecha para aludir a las cualidades alimenticias de las berenjenas, ya por entonces consumidas habitualmente en Italia. Pese a todo, considera

17 En 1533, y a tenor de los problemas que cada vez más acuciaban a los judíos conversos en Portugal y España, Amato emigró a Amberes para trabajar en el negocio de las especias que allí dirigía, entre otros, Henrique Pires, tío carnal suyo. En Amberes, como comerciante y médico, vivió hasta finales de los años treinta. En 1540, siguiendo a su propia familia, se estableció en Ferrara, donde vivió hasta 1547, año en que pasó a Ancona hasta su huida de 1555 y su paso posterior a Dubrovnik y Salónica. En Italia adquirió gran reputación como médico práctico y allí publicó las Enarrationes y sus primeras Centuriae medicinales. Véase, con bibliografía reciente, António M. Lopes ANDRADE, "A Senhora e os destinos da Nação Portuguesa: o caminho de Amato Lusitano e de Duarte Gomes", Cadernos de Estudos Sefarditas 10-11 (2011), pp. 87-130; António M. Lopes ANDRADE, "De Antuérpia a Ferrara: o caminho de Amato Lusitano e da sua família", Medicina na Beira Interior. Da Pré-História ao séc. XXI - Cadernos de Cultura 25 (2011), pp. 5-16.

18 Fundado en 1471 por los Reyes Católicos (en principio solo para la Corona de Castilla, pero pronto extendido a todo el reino y más tarde a las colonias americanas) y vigente hasta el siglo XIX, el Real Tribunal del Protomedicato se encargaba de controlar el ejercicio de la medicina y la farmacia, examinar y dar licencia a médicos y boticarios y controlar el intrusismo profesional. Sobre el asunto pueden verse los artículos recogidos en un dossier especial de la revista Dynamis 16 (1996), pp. 17-259; un estudio detallado es el de Ma Soledad Campos Díez, El Real Tribunal del Protomedicato castellano. Siglos XIV-XIX. Cuenca, Universidad de Castilla La Mancha, 1999; una síntesis de conjunto está también en Juan Riera Palmero, Protomedicato, humanismo y medicina en Castilla. Valladolid, Universidad de Valladolid, 2000. Por lo demás, otros países tuvieron también una institución parecida, como fueron los casos de Portugal o el reino aragonés de Nápoles: véase David GeNTILCORE, "All That Pertains to Medicine: Protomedici and Protomedicati in Early Modern Italy", Medical History 38 (1994), pp. 121-142. A ello, asimismo, debe sumarse el control específico ejercido por las cofradías de médicos, cirujanos y boticarios y, sobre todo, la amenaza omnipresente de la Inquisición, en especial cuando el asunto tocaba a superstición y hechicería. 
la existencia de una especie de berenjenas de frutos amarillentos, para la que admite en cambio una posible identidad con la tercera mandrágora de Dioscórides.

7. Cita galénica. Termina el comentario con una cita de Galeno respecto a las virtudes de la mandrágora.

\section{EDICIÓN LATINA}

Para el texto latino del comentario a la mandrágora de Amato hemos colacionado todas las ediciones existentes y hemos mantenido el siguiente criterio: el texto base es la edición princeps de Venecia de 1553, aunque sus errores y posibles malas lecturas se corrigen con la segunda edición de Estrasburgo de 1554 y la cuarta de Lión de 1558, cuidada por Robert Constantin y única que incluye ilustraciones procedentes de las obras de Leonhart Fuchs y Jacques Daléchamps. La edición de Lión se realizó en cuatro tiradas diferentes, que salieron en imprentas distintas (Roville, Payen, viuda de Arnouillet y Bonhomme) y que son exactamente iguales, por lo que nos hemos servido solo de la primera de ellas para la colación. Se desecha, en fin, la tercera edición de Venecia de 1557 por ser un codex descriptus de la princeps. A los textos manejados les hemos nombrado de la siguiente manera:

\footnotetext{
$\mathrm{V}=$ In Dioscoridis Anazarbei De materia medica libros quinque enarrationes eruditissimae doctoris Amati Lusitani medici ac philosophi celeberrimi..., Venetiis, apud Gualterum Scotum, 1553, pp. 413-414.
}

$\mathrm{A}=$ In Dioscoridis Anazarbei De materia medica libros quinque enarrationes eruditissimae doctoris Amati Lusitani medici ac philosophi celeberrimi..., Argentorati excudebat VVendelinus Rihelius, 1554, pp. 431-432.

$\mathrm{L}=$ In Dioscoridis Anazarbei De materia medica libros quinque enarrationes eruditissimae doctoris Amati Lusitani medici ac philosophi celeberrimi..., Lugduni, apud Gulielmum Rovillium, sub scuto Veneto, 1558, pp. 647-649.

El texto latino respeta la notación original y propia de las ediciones renacentistas, excepto en algunos casos concretos, como la distinción entre $u$ y $v$, que se mantiene igual que en romance. Se resuelven todas las abreviaturas. Las citas literales se ponen entre comillas y las citas de títulos de obras van siempre en cursiva. El texto latino respeta la disposición del original: título, entradilla con sinónimos y comentario. Aunque el texto del comentario va en origen 
todo seguido, se ha preferido disponerlo aquí en párrafos y puntuarlo conforme a las reglas habituales del español moderno.

\section{TRADUCCIÓN Y ANOTACIÓN}

La traducción castellana, primera de este texto, trata de ser fiel en lo posible al original latino, aunque guardando siempre el decoro necesario en la lengua de llegada. Debido a las peculiaridades propias de todo texto técnico, se ha incluido una anotación más o menos amplia que dé cuenta de todos los aspectos relevantes del original: aclaración de términos oscuros, identificación de plantas, aspectos de la vida y la obra del autor, detección de fuentes expresas y otras no citadas, etc.

Respecto a las fuentes, se ha considerado imprescindible rastrear los comentarios a Dioscórides previos al de Amato, así como otros textos botánicos más generales, pues el médico portugués los tuvo muy en cuenta y en algunos casos constituyeron la base de su obra, en especial los textos de Ermolao Barbaro, Marcello Virgilio, Antonio Musa Brasavola y, sobre todo, Pietro Andrea Mattioli. A ellos y otros autores más se remite cada vez que se encuentra una posible deuda o paralelo, sin desdeñar tampoco otras obras posteriores que puedan aportar alguna noticia significativa para entender mejor el comentario de Amato.

\section{ABREVIATURAS}

Por evitar repeticiones prolijas, consideramos conveniente citar de forma abreviada todas las fuentes a que se remite en las notas a la traducción del texto. Se ofrece aquí, por tanto, la equivalencia de tales abreviaturas, con breves comentarios — cuando así se requiera- sobre su fecha de composición.

Avicena, Canon = Avicennae Liber canonis, Venetiis, Iunta, 1527.

Barbaro, Diosc. $=$ Pedacii Dioscoridis Anazarbei de medicinali materia ab eodem Barbaro Latinitate primum donati libri quinque, Venetiis, Barbari, 1516. Edición póstuma de la traducción latina de Ermolao Barbaro (posiblemente de los ańos 1481/82), a cargo de Giovanni Battista Cipelli (Egnatius).

Barbaro, Cor. = Hermolai Barbari ... Corollarium, Venetiis, Barbari, 1516. En la misma edición anterior se incluyen unos comentarios de Barbaro, redactados posiblemente en 1487.

Bock, Stirp. = Heronymi Tragi de stirpium ... usitatis nomenclaturis, propriisque differentiis, neque non temperaturis ac facultatibus commentariorum libri tres, Argentorati, Rihelius, 
1552. Se trata de la versión latina de David Kendel de la obra que Bock había publicado originariamente en alemán: Neu Kreutterbuch, Frankfurt 1539.

Brasavola, Ex. = Antonii Musae Brassavolae Ferrariensis Examen omnium simplicium medicamentorum, quorum in officinis usus est, Lugduni, Frellonii, 1537.

Cesalpino, Plant. = De plantis libri XV Andreae Cesalpini, Florentiae, Marescottus, 1583.

Cordus, Ann. $=$ Valerii Cordi Simesusii Annotationes doctissimae in Dioscoridis de medica materia libros, Argentorati, Rihelius, 1549. Es una edición póstuma de las anotaciones de Cordus (datadas entre 1539 y 1543) efectuada por Walther Ryff. Más adelante las reeditaría Conrad Gesner (Argentorati, Rihelius, 1561).

Fuchs, Hist. = De historia stirpium commentarii insignes ... Leonharto Fuchsio ... autore, Basileae, Isingrinus, 1542.

Galeno, Simpl. = De simplicium medicamentorum temperamentis ac facultatibus, en K. G. Kühn, ed., Claudi Galeni opera omnia, vol. 7, Leipzig, Cnobloch, 1824.

Laguna, Diosc. $=$ Pedazio Dioscorides Anazarbeo, Acerca de la materia medicinal y de los venenos mortiferos, Amberes, Laet, 1555.

Mattioli, Disc. = Il Dioscoride dell'eccelente dottore medico P. Matthioli da Siena con le suoi discorsi..., Venezia, Valgrisi, 1550. Citamos por esta edición de la versión italiana y los comentarios de Mattioli (princeps de Venecia 1544), que correría luego paralela a la edición latina (princeps de Venecia 1554).

Ruelle, Diosc. $=$ Pedacii Dioscoridis Anazarbei de medicinali materia libri quinque ... Ioanni Ruellio Suesionensi interprete, Parisiis, Henricus Stephanus, 1516.

Virgilio, Diosc. $=$ Pedacii Dioscoridae Anazarbei de medica materia libri sex, interprete Marcello Virgilio, Venetiis, Iunta, 1518.

Virgilio, Ann. = Pedacii Dioscoridae Anazarbei de medica materia libri sex, interprete Marcello Virgilio..., cum eiusdem annotationibus, Venetiis, Iunta, 1518. A la traducción anterior añadió Marcello Virgilio unos comentarios. 


\section{Texto Latino}

\section{DE MANDRAGORA}

Graece $\mu \alpha \nu \delta \rho \alpha \gamma o ́ \rho \alpha \zeta$. Latine mandragora, pomum terrestre, pomum caninum, Circe. Hispanice mandracola yerva. Italice la mandragora. Gallice mandragore.

Germanice Alraun.

Enarratio 79

Nunquam quod equidem meminerim in Hispania mandragoram vidi. In Italia vero frequens est herba, praecipue Ferrariae, ubi nullus fere extat hortulus in quo mandragora non reperiatur. In coenobio enim Carthusianorum, apud quod unusquisque monachus suum proprium et particularem hortulum habet, ita felicissime crescit, ut nullus extet

10 qui non hac decoretur herba.

Crescit autem folio lapathi, lato, oblongo, per terram strato, ad cuius radices poma quinque vel sex numero nascuntur, magnitudine parvae pilae, coloris interdum virescunt herbacei; quum vero ad maturitatem perveniunt, lutei saturi efficiuntur. Nascuntur autem, ut obiter hoc attingamus, poma haec pediculis semi dodrantalis altitudinis ita apposite, ut unumquodque pomorum homuncionem quendam absque brachiis repraesentare videatur, qua de causa Pythagoras mandragoram 'anthropomorphon', id est, figura hominis, appellavit, quem secutus Columella mandragoram in suo Horto 'semihominem' dixit. Cui signatae causae alteram addimus vulgarem: quia mandragora radicem in duas fibras, veluti duo crura, divisam habet, unde quoque 'semihomo' appellatur. Haec etiam 'Circe' dicebatur, quia ea ad amatoria et veneficia Circe famosissima incantatrix utebatur. Et de ea in Pentateucho legitur, quam Hebraei ‘dudaim’ sua lingua vocant.

Ex huius vero radice vinum mandragorite parandum Dioscorides et medici suadent, quod plerunque propinant iis quibus secare aut membrum aliquod urere volunt: 25 mirifice enim stupefacit.

Iustum erit hic enarrare tyrannidem ac imposturam nugivendulorum ac impostorum hominum, qui homunculos quosdam, ex radicibus cannarum sculptos, mulieribus

3 yerua VA: om. $L \|$ la VA: om. $L \|$ post mandragora add. Arabice tabora $L \|$ post mandragore add. et mandegloire $L \cdot \mathbf{5} 79 \mathrm{VA}$ : $L X X I X L \cdot \mathbf{1 5}$ homuncionem $A L$ : homuntionem $V \cdot \mathbf{2 5}$ mirifice $A L$ : mirificae $V$. 
sterilibus et non parturientibus loco mandragorae non parvo vendunt pretio. Sculpunt enim hominis effigiem in cannarum, ut dixi, radice ita apposite et solerter ut, ubi opus est appareant capilli, ut in barba, capite et pectine, grana tritici quaedam affingant quae, cum radice simul terra obruta, plures, tenues ac capillis similes radices emittunt, ac inde tota ipsa radix figura homuncionem repraesentat, quam e terra non nisi obturatis auribus eradicari posse vel canis caudae adalligatam alta mente nugantur. Vendunt autem unam vel alteram harum radicem triginta, nonnunquam vero quadraginta aureis ducatis. 35 Pereant igitur balatrones ii falsarii, quos ut Italia universa fert, ita tota Hispania eos fugat et non permittit imperitum vulgus imposturis circumveniri.

Tertia vero species mandragorae 'morion' dicitur, quae procul dubio melongena non est, ut nonnulli opinati sunt. Est enim melongena vel melezana fructus ubique familiaris, quem aliqui 'berengenam' vel 'belongenam', alii vero 'Cupidinis pomum' 40 vel 'insanum pomum' appellant, quod inter cucurbitas et melones seritur, et victui non aspernendum obsonium esset, nisi tristes ac atrabiliarios gigneret humores, ut Avicennam adnotasse legimus. Huius porro altera species in Italia cernitur, pomum gignens luteum, quam ego morion esse dixissem, quia cum mandragora magnam cum figura tum viribus habet similitudinem, de quibus Galenus libro septimo De facultatibus simplicium medicamentorum ita tradit: "Refrigerat tertio excessu mandragora, nonnihil tamen pomis caloris atque humiditatis inest, unde soporem conciliant. Radicis cortex non tantum refrigerat, sed etiam siccat. Quod eo includitur imbecillimum est".

32 homuncionem $A L$ : homuntionem $V \cdot \mathbf{4 6}$ nonnihil $A L$ : uon nihil $V$. 


\section{Traducción y Anotación}

\section{MANDRÁGORA}

Griego: $\mu \alpha v \delta \rho \alpha \gamma o ́ \rho \alpha c$. Latín: mandragora, pomum terrestre, pomum caninum, Circe. Español: mandracola yerva. Italiano: la mandragora. Francés: mandragore.

Alemán: Alraun ${ }^{19}$.

Nunca, que yo recuerde, vi la mandrágora en tierras hispanas ${ }^{20}$. En Italia, sin embargo, es una hierba frecuente, sobre todo en Ferrara, donde casi no hay huertecillo en que no se encuentre la mandrágora. En el cenobio de los cartujos, de hecho, donde cada monje tiene su propio y particular huertecillo, crece de forma tan abundante que ninguno hay sin el adorno de tal hierba ${ }^{21}$.

Crece con hojas como las de la romaza, anchas, largas, echadas por tierra, junto a cuyas raíces nacen cinco o seis manzanas del tamaño de una pelota pequeña, de color herbáceo cuando están en sazón, aunque cuando maduran se vuelven de un tono amarillo oscuro ${ }^{22}$. Nacen tales manzanas, por tocar el asunto de paso, en pedículos de cuatro pulgadas y media

15 de longitud, y en una disposición tal que cada manzana parece representar un hombrecillo sin brazos, de ahí que Pitágoras la llamase antropomorphon, es decir, "con figura humana", a

19 Las expresiones pomum terrestre y pomum caninum remontan a los mala terrestria y mala canina documentados en las tradiciones alfabética e interpolada de Dioscórides, que incorporan una serie de sinónimos de plantas en numerosas lenguas (los llamados notha). Por otro lado, cuando Amato dice Hispanice puede aludir a términos tanto españoles como portugueses: en este caso, "mandrácola" es un hispanismo que se sigue usando en ciertas partes de España, como también la expresión "uva de moro" (el DRAE, no obstante, solo trae "mandrágora" y "mandrágula", nombre citado en LAGUNA, DioSC., 424). Por lo demás, en la edición lionesa de 1558, y posiblemente por obra de Constantin, se añade el sinónimo "mandegloire", usado en francés antiguo, así como el arabismo tabora (erróneamente notado por iabora).

20 Como antes con Hispanice, cuando Amato cita Hispania puede estar refiriéndose a cualquier zona de la Península Ibérica, bien fuese España o Portugal. En cualquier caso, y pese al testimonio de Amato, la mandrágora no es infrecuente de tales zonas (nace silvestre sobre todo en tierras andaluzas).

21 Amato se refiere al monasterio de la Cartuja de Ferrara, fundado en 1452 y desde el siglo XIX cementerio monumental. Hay en MATTIOL noticias similares sobre la abundancia de la planta en Italia, con las que comienza su comentario al capítulo (Disc., 600), para el que parece tomar como base a Brasavola, Ex., 312. Contrasta el dato con la escasez de la planta en tierras alemanas, como se lee en Bock, Stirp., 891, quien reconoce no haberla visto nunca.

22 La comparación de las hojas de mandrágora (sin especificar aquí la especie) con las de la romaza (Rumex obtusifolius L.) se lee ya en Plinio, Nat., 25.147, lo que recoge BARBARO, Cor., 79v. Del tamaño y el color del fruto habla en extenso, entre otros, VIRGILIO, Ann., $247 \mathrm{r}$. 
quien siguió Columela, que en su Huerto designó a la mandrágora 'semihombre'. A la causa aducida podemos añadir otra más conocida: que la mandrágora tiene la raíz bifurcada en dos lóbulos, como si fuesen dos piernas, de ahí que también se la llame 'semihombre'23. Asimismo, se le decía 'Circe', porque la famosísima hechicera Circe usaba de ella para sus filtros amorosos y mágicos ${ }^{24}$. Y de ella se habla en el Pentateuco: los hebreos en su lengua la llaman dudaim ${ }^{25}$.

Dioscórides y los médicos recomiendan que con su raíz se prepare un vino de mandrágora que la mayoría administra a quienes van a sajar o quemar algún miembro, pues anestesia admirablemente ${ }^{26}$.

Justo será narrar aquí la tiranía e impostura de vendedores de baratijas ${ }^{27}$ e impostores que a no escaso precio, y como si fuese mandrágora, venden a mujeres estériles y que no se embarazan unos hombritos esculpidos en raíces de cañas. Como digo, en la raíz de las cañas esculpen la figura de un hombre con tan buena disposición y habilidad que, donde se precisa que nazca vello - en la barba, la cabeza y el pubis - incrustan unos cuantos granos de trigo que, al enterrarse con la raíz, producen a su vez unas raicillas delgadas y semejantes a pelos, y después la raíz entera adquiere la forma de un hombrecillo, que con grandilocuencia fingen no puede arrancarse de tierra sin los oídos tapados, o bien atándola al rabo de un perro. Y venden una o dos raíces de estas por treinta y a veces hasta por cuarenta ducados de oro. Ojalá perezcan esos

23 La referencia al anthropomorphos pitagórico está ya en los antiguos Notha de la tradición interpolada. Aluden a ello algunos comentaristas de Dioscórides y otros botánicos del Renacimiento, no sin censurar que se haya querido establecer una relación literal entre planta y hombre: BARBARO, Cor., 79v; VIRGILIO, Ann., 247r; Bock, Stirp., 891; MATTIOLI, Disc., p. 601. Pero Amato, de forma original, establece una doble causa: primero considera que la relación planta / hombre procedería del fruto, semejante a una figura humana sin brazos, y luego remite a la explicación más vulgar y común: el parecido de la raíz con dos piernas humanas. Cita, asimismo, el semihomo de Columela (ColvM., 10,19-20), en referencia que sigue de cerca a MATTIOLI, Disc., 601 (a su vez dependiente de BrASAVOLA, Ex., 313), quien arremete sin nombrarlo contra VIRGILIO (Ann., 247r) por no haber comprendido la metáfora y haber censurado a los dos clásicos.

24 El término viene ya en la tradición genuina de Dioscórides, solo que en forma adjetiva: Kipkaía. La relación directa con Circe está también en la tradición interpolada, y con más o menos amplitud se recoge en algunas traducciones latinas renacentistas, como la de BARBARo, Diosc., 83v, y sobre todo la de VIRGILIO, DiosC., 246v, fuente directa aquí de Amato: qui Circeam vocarunt nomen illi a Circe fecerunt, quoniam creditur radix eius amatoriis veneficiis utilis esse.

25 Así en el Génesis (Gen. 30.24), donde se alude a la planta por sus bondades para la fertilidad, en este caso de Raquel, que con su ayuda logró concebir a José (también se cita, en otro contexto, en el Cantar de los cantares: Cant. 7.13). Bock, Stirp., 891-893, hace un amplio excursus sobre la mandrágora en fuentes hebreas. Cf. Introducción, n. 2.

26 El vino de mandrágora (hecho de los frutos, la corteza de la raíz o la raíz entera) es una receta que trae Dioscórides en el capítulo propio dedicado a la planta (4.75) y que, al parecer, se empleaba desde tiempos antiguos como bebida útil para anestesiar. No obstante, vuelve a comentarlo con más detalle en 5.71. Amato usa para nombrarlo una transcripción del griego $\mu \alpha v \delta \rho \alpha \gamma o$ pírns, que ya se documenta en las primeras traducciones latinas de la obra: BARBARO, DiosC., 106V; RUELLE, DiosC., 125V; VIRGILIO, Diosc., 308. Un breve comentario a este vino está en BRASAVOLA, Ex., 312-313.

27 El término nugivendulus es un diminutivo del clásico nugivendus, ya atestiguado en PLAUTO (Aul., 525). 
35 tramposos charlatanes a quienes, si en Italia entera se los tolera, en todas las tierras hispanas se les persigue y no se permite que el pueblo sencillo se vea engańado con sus imposturas ${ }^{28}$.

La tercera especie de mandrágora se llama morion, y sin duda no es la berenjena, como algunos han creído ${ }^{29}$. Es, en efecto, la berenjena o "meleçana" un fruto muy común, que algunos llaman 'berengena' o 'belongena', otros 'manzana de Cupido' o 'manzana insana', que se siembra entre

40 las calabazas y los melones y que no sería un alimento despreciable en nuestra dieta si no generase humores tristes y atrabiliarios, como leemos que había dicho Avicena. En todo caso, una segunda variedad de ella puede verse en Italia, con manzanas amarillentas, que es la que yo identificaría con el morion, pues que presenta gran similitud con la mandrágora tanto en su forma como en sus virtudes medicinales ${ }^{30}$, de las que Galeno dice lo siguiente en el libro séptimo de Sobre las

facultades de los medicamentos simples: "Enfría la mandrágora en grado tercero, aunque en sus manzanas tiene algo de calor y humedad, de ahí que provoquen sopor. La corteza de la raíz no solo enfría, sino que también seca. La parte de dentro es mucho más floja” ${ }^{31}$.

\section{REFERENCIAS BIBLIOGRÁFICAS}

Andrade, António M. Lopes, "A Senhora e os destinos da Nação Portuguesa: o caminho de Amato Lusitano e de Duarte Gomes”, Cadernos de Estudos Sefarditas 10-11 (2011), pp. 87-130.

Andrade, António M. Lopes, "De Antuérpia a Ferrara: o caminho de Amato Lusitano e da sua família”, Medicina na Beira Interior. Da Pré-História ao séc. XXI - Cadernos de Cultura 25 (2011), pp. 5-16.

28 La queja está ya en los principales autores que sirven de fuente habitual a Amato: VIRGILIO, Ann., 247r; Brasavola, Ex., 313; Bock, Stirp., 890-89; Cordus, Ann., 510a; Fuchs, Hist., 587; Mattioli, Disc., 600-601. Como se dijo en la Introducción (n. 7), los ritos de extracción aquí aludidos se narraban ya en Flavio Josefo y el Pseudo Apuleyo. Por lo demás, la última frase de Amato parece aludir al Tribunal del Protomedicato (cf. arriba, n. 18).

29 La tercera mandrágora de Dioscórides, hoy considerada una variante de la especie macho, recibió diferentes identificaciones en el Renacimiento, en especial berenjena, belladona y hasta jazmín (cf. arriba, n. 14). La asociación con la berenjena, luego desestimada por casi todos los autores, se debía a Barbaro, Cor., $79 \mathrm{v}$.

30 Como hacen otros comentaristas de Dioscórides (BARBARO, Cor., 79v; MATTIOLI, Disc., 601-602), aprovecha Amato la referencia a las berenjenas para aludir a algunos de sus nombres (casi todos medievales: cf. Mateo Silvático, Pandectae medicinae. Lugduni, T. Paganus, 1541, ff. 130ra-b) y recoger el tópico de su mala calidad alimenticia, para lo que cita a AvICENA (Canon, 2.455, s.v. Melongena), como ya había hecho el propio Mattioli. La planta, ausente de los herbarios antiguos, se describe en numerosas fuentes medievales y renacentistas: véase Marie Christine DaUnAY-Jules JANICK-Henri LATERROT, "Iconography of the Solanaceae from Antiquity to the 17th Century: A Rich Source of Information on Genetic Diversity and Uses", Acta Horticulturae 745 (2007), pp. 59-88. En todo caso, y pese a desestimar la identidad morion I berenjena, Amato habla de una especie de berenjena de fruto amarillo que, en su opinión, bien podría ser la tercera mandrágora de Dioscórides: su opción, en todo caso, no tuvo fortuna.

31 Véase Galeno, Simpl., 7.12.4 (KüHN 12.67). Amato cierra con la cita galénica a imitación de MATTIOLI, Disc., p. 602. 
Arber, Agnes R., Herbals. Their Origin and Evolution. A Chapter in the History of Botany, 1470-1670, W. T. Stearn (ed.). Cambridge, Cambridge University Press, $1986^{3}$.

Arsdall, Anne van; Klug, Helmut W.; Blanz, Paul, “The Mandrake Plant and its Legend: A New Perspective”, in Peter Bierbaumer \& Helmut W. Klug (eds.), Old Names-New Growth: Proceedings of the 2nd ASPNS Conference. Graz, Universität Graz, 2007, pp. 285-346.

Campos Díez, Ma Soledad, El Real Tribunal del Protomedicato castellano. Siglos XIV-XIX. Cuenca, Universidad de Castilla La Mancha, 1999.

Collins, Minta, Medieval Herbals. The Illustrative Tradition. Toronto, University of Toronto Press, 2000.

Daunay, Marie Christine; Janick, Jules; Laterrot, Henri, "Iconography of the Solanaceae from Antiquity to the 17th Century: A Rich Source of Information on Genetic Diversity and Uses", Acta Horticulturae 745 (2007), pp. 59-88.

Dilg, Peter, "Die botanische Kommentarliteratur in Italien um 1500 und ihr Einfluss auf Deutschland", in August Buck \& Otto Herding (eds.), Der Kommentar in der Renaissance. Boppart, H. Boldt Verlag, 1975, pp. 225-253.

Findlen, Paula, Possessing Nature: Museums, Collecting and Scientific Culture in Early Modern Italy. Berkeley -London, University of California Press, 1994.

Gentilcore, David, "All That Pertains to Medicine: Protomedici and Protomedicati in Early Modern Italy", Medical History 38 (1994), pp. 121-142.

Намвеl, Vera, Die alte Heydnische Abgöttische Fabel von der Alraun: Verwendung und Bedeutung der Alraune in Geschichte und Gegenwart. Diss., Passau, Universität Passau, 2002.

López Eire, Antonio; Cortés Gabaudán, Francisco, Dioscórides, Sobre los remedios medicinales. Manuscrito de Salamanca: estudios y traducción. Salamanca, Universidad de Salamanca, 2006.

MaClaren, Christophe, Quelle est la part de réalité dans le mythe de la mandragore?, 2009, accesible en Inlibroveritas.net (http://www.inlibroveritas.net/lire/oeuvre 26291.html).

Mateo Silvático, Pandectae medicinae. Lugduni, T. Paganus, 1541.

Ogilvie, Brian W., The Science of Describing: Natural History in Renaissance Europe. Chicago, University of Chicago Press, 2006.

Patera, Maria, "Les rites d'extraction des plantes dans l'Antiquité. Magie, botanique et religion. L'exemple de la mandragore", Revue des Archéologues et Historiens d'Art 27 (1994), pp. 21-34.

Reeds, Karen Meier, Botany in Medieval and Renaissance Universities. New York-London, Garland Publishing, 1991.

Riddle, John M., “Dioscorides”, in F. Edward Kranz \& Paul O. Kristeller (eds.), Catalogus translationum et commentariorum. Mediaeval and Renaissance Latin Translations and Commentaries, vol. 4. Washington D.C., Catholic University of American Press, 1980, pp. 1-143.

Riddle, John M., Dioscorides on Pharmacy and Medicine. Austin, University of Texas Press, 1985.

Riera Palmero, Juan, Protomedicato, humanismo y medicina en Castilla. Valladolid, Universidad de Valladolid, 2000. 
Roland, Jean-Denis, "La mandragore: le mythe d'une racine, la racine d'un mythe", Annales des Sciences Naturells, Botanique 2 (1990-1991), pp. 49-81.

Simoons, Frederik J., Plants of Life, Plants of Death. Madison-London, The University of Wisconsin Press, 1999.

Stannard, Jerry, "Dioscorides and Renaissance Materia Medica", in Markus Florkin (ed.), Analecta Medico-Historica. I. Materia Medica in the XVIth Century. Oxford, Pergamon, 1966, pp. 1-21.

Théophraste, Recherche sur les plantes, Suzanne Amigues (ed.). Paris, Les Belles Lettres, 2003.

Thomson, Charles J. S., The Mystic Mandrake. New York, University Books, 1968.

Touwaide, Alain, Le Traité de matière médicale de Dioscoride à la Renaissance. Bruxelles, Université Catholique de Louvain, 1984.

Touwaide, Alain, "Le Traité de matière médicale de Dioscoride. Pour une nouvelle lecture", Bulletin du Cercle Benelux d'Histoire de la Pharmacie 78 (1990), pp. 32-39

Touwaide, Alain, "La Thérapeutique médicamenteuse de Dioscoride à Galien: du pharmaco-centrisme au médico-centrisme", in Armelle Debru (ed.), Galen on Pharmacology, Philosophy, History and Medicine. Leiden, Brill, 1997, pp. 255-282.

Touwaide, Alain, “The Salamanca Dioscorides (Salamanca, University Library, 2659)”, Erytheia 24 (2003), pp. $125-158$.

Van Den Berg, Marlene; Dircksen, Marianne, "Mandrake from Antiquity to Harry Potter", Akroterion 53 (2008), pp. 67-79.

Wittun, Dorit, Mandragora. Eine Arzneipflanze in Antike, Mittelalter und Neuzeit. Basel, Dietikon, 1999.

Zarcone, Thierry, “Le Mythe de la mandragore: la plante-homme”, Diogenes 207 (2004), pp. 140-173. 
(Página deixada prepositadamente em branco.) 


\section{O vinho e os vinhos - usos e virtudes de um dom dos deuses nas Enarrationes de Amato Lusitano ${ }^{1}$}

TELMO CORUJO DOS REIS 2

\section{RESUMO:}

O livro quinto das Enarrationes de Amato Lusitano abre com uma série de comentários consagrados à videira e à videira silvestre, ao fruto da videira (a uva e a uva passa) e ao vinho de uva (5.1-4 e 7), aos quais se seguem numerosos comentários consagrados a uma extensa variedade de outros vinhos (5.8, 9 e 19-42). 0 presente texto propõe-se explorar as qualidades terapêuticas do vinho, bem como os usos e virtudes medicinais (e ainda outros aspectos não menos curiosos) de muitos outros vinhos na obra de Amato Lusitano.

\section{PALAVRAS-CHAVE:}

Amato Lusitano; Dioscórides; vinho; medicina.

\section{ABSTRACT:}

The fifth book of the Enarrationes of Amato Lusitano opens with a series of reviews devoted to vine and the wild vine, the fruit of the vine (grape and raisin) and the wine of grapes (5.1-4 and 7 ) to which follow numerous reviews devoted to an extensive variety of other wines (5.8, 9 and 1942). This text aims to explore the therapeutic qualities of the wine of grapes, as well as the uses and medicinal properties (and other no less curious aspects) of many other wines in the work of Amato Lusitano.

\section{KEYWORDS:}

Amato Lusitano; Dioscorides; wine; medicine.

1 Este trabalho foi desenvolvido no âmbito do projecto de I\&D "Dioscórides e o Humanismo Português: os Comentários de Amato Lusitano" (http://amatolusitano.web.ua.pt) do Centro de Línguas, Literaturas e Culturas da Universidade de Aveiro, financiado por Fundos FEDER através do Programa Operacional Factores de Competitividade - COMPETE e por Fundos Nacionais através da FCT - Fundação para a Ciência e a Tecnologia, no âmbito do projecto FCOMP-01-0124-FEDER-009102.

2 Universidade da Madeira; Centro de Estudos Clássicos da Faculdade de Letras da Universidade de Lisboa: treis@uma.pt. 


\section{INTRODUÇÃO}

Conhecido desde a mais remota Antiguidade pelas suas numerosas qualidades e aplicaçóes terapêuticas, a ponto de um médico como Asclepíades, no séc. I. a. C., fazer uso do vinho, criteriosamente ministrado, como remédio contra todas as enfermidades, conforme refere Plínio-o-Velho ${ }^{3}$, o vinho não podia deixar de ocupar lugar de relevo na obra de um tratadista antigo como Dioscórides de Anazarbo. Dele, por conseguinte, e das suas muitas combinaçóes se ocupam as entradas com que se inicia o livro V do seu De materia medica.

Ao ocupar-se, nas Enarrationes, da obra do médico de Anazarbo, Amato Lusitano passa em revista cada uma das suas entradas, proporcionando ao leitor interessado um bom retrato dos seus conhecimentos sobre a matéria em questão, ao mesmo tempo que dá a conhecer usos que hoje nos parecem estranhos, exóticos ou, no mínimo, curiosos.

\section{A ENARRATIO N. ${ }^{\circ}$ 7, DE VINO}

\subsection{Abertura da Enarratio}

Ao vinho propriamente dito consagra Amato Lusitano a enarratio sétima do Livro V. Trata-se de um comentário extenso que ocupa, na edição de Veneza, de 1553, quase duas páginas (471-472). O texto principia com uma apresentação do vinho feita nos seguintes termos:

Vinum ubique suas habet laudes, quod odore, sapore, colore, dignoscitur. Et ut Erasmus Roterodamus, olim viva voce superaddebat, fama: bonum enim et generosum vinum suspensa hedera non habet opus, quod contra cicutam et alia frigida venena, meracum ac potens, praestantissimum antidotum est, ut olim Angelus Politianus ad medicorum mentem exacte exposuit. ${ }^{4}$

Por toda a parte encontra os seus louvores o vinho, que se distingue pelo aroma, pelo paladar e pela cor e ainda, como outrora Erasmo de Roterdáo de viva voz acrescentava, pela fama! Realmente, o vinho bom e generoso não há mister de hera dependurada, porque, puro e forte, é um antídoto muito eficaz contra a cicuta e outros venenos frios, como outrora Ângelo Poliziano expôs, exactamente segundo o pensamento dos médicos.

3 N. H. 23.32 e 26.14.

4 Enarrationes, 1553, p. 471. 


\subsection{Vinhos fortes e fracos, vinhos novos e velhos}

O texto prossegue, mas nele, ao invés do que seria de esperar, Amato não distingue o vinho tinto do vinho branco, nem procede a outras distinçôes que hoje se costumam fazer. Náo obstante, ocupa-se de dois aspectos ainda agora considerados da máxima relevância, por um lado o teor alcoólico do vinho, por outro a sua idade e durabilidade.

Quanto ao teor alcoólico do vinho, Amato não se lhe refere em termos de grau, como se faz na actualidade, mas recorre a um conjunto de adjectivos gregos e aos seus exactos correspondentes latinos: assim, ao vinho de alto teor alcoólico Amato chama oenodes e polýphorum, adjectivos gregos a que correspondem os latinos uinosum e multiferum, acrescentando: «isto é, [o vinho] que tolera [em mistura] muita água» («id est multam ferens aquam»). Já o vinho fraco (debile) é qualificado como oligophorum, vocábulo a que corresponde o adjectivo latino pauciferum, especificando que os vinhos desta qualidade: «não suportam em diluição água nenhuma» («nullam in diluitionem aquam ferentibus»).

Intimamente associada ao teor alcoólico dos vinhos está a sua capacidade para resistir à passagem do tempo, melhorando até, em certos casos, as suas qualidades. Deste mesmo aspecto se ocupa Amato Lusitano, comentando o texto de Dioscórides e reforçando a sua autoridade com o parecer de Galeno. Assim, os vinhos velhos serão aqueles «que ultrapassam os quinze ou os vinte anos de idade» ("quae quindecim vel viginti excedunt aetatis annos»); os vinhos de meia-idade, para Dioscórides, terão entre sete e dez anos e, para Galeno, estarão entre os cinco e os dez anos. E Amato Lusitano conclui com um dado da sua experiência pessoal:

Cuius axioma, non sic superficie tenus ab omnibus intelligatur, velim, cum illud veritatem teneat in vinis potentissimis, et diu perdurantibus, qualia Hispaniarum sunt, quae ad triginta et quadraginta annos, perdurant, et vires suas potentissimas, ac valentissimas servant, veluti duo illa vina, quae nobis magnificus Antonius Musa Brasavola gustanda dedit, e cellario sive cella vinaria, illustrissimi ducis Herculis Estensis, quorum alterum centum quinquaginta annorum erat, alterum vero ducentorum. ${ }^{5}$

Gostaria que a sua afirmação [(de Galeno)] não fosse por todos compreendida assim superficialmente, visto que ela se mantém verdadeira nos vinhos mais fortes e mais duradouros, tais como são os das Espanhas, os quais perduram até aos trinta e aos quarenta anos e conservam as suas forças muito eficazes e muito válidas, como aqueles dois vinhos que nos deu a provar o magnífico António Musa Brasavola, da despensa ou adega do

5 Enarrationes, 1553, p. 471. 
ilustríssimo Duque Hércules de Este, dos quais um tinha cento e cinquenta anos, já o outro tinha duzentos.

A propósito dos vinhos fortes, lembra Amato um preceito de Hipócrates segundo o qual ele deve ser bebido depois da ingestão de melóes e outros frutos frios, e cita:

Quicumque cibi aut flatum, aut aestum, aut morsum, aut repletionem, aut tormen faciunt, a talibus liberat vinum meracum insuper potatum.

Todos aqueles alimentos que produzem flatulência, ou ardor, ou azia, ou enfartamento, ou cólica, de tais efeitos os liberta o vinho puro bebido logo de seguida.

A este conselho opunham-se, naturalmente, os seguidores de Avicena e dos Árabes, que diziam ser preferível beber água após a ingestão de tais frutos. Note-se que aos Árabes era ritualmente interdito o consumo de vinho e outras substâncias psicotrópicas, interdição que, como adiante se verá, era por vezes habilmente contornada.

Novos ou velhos, fortes ou fracos, deve qualquer um precaver-se do seu consumo, conclui, em todo o caso, Amato Lusitano: apenas os vinhos velhos poderáo ser consumidos em segurança, desde que diluídos,

nova vero et recentia, corpus inflant, aegre concoquuntur, ac gravia et tumultuosa faciunt insomnia

já os novos e recentes incham o corpo e são difíceis de digerir e provocam insónias graves e tumultuosas.

E termina o passo com o seguinte conselho:

Nec est quod aliquis mihi obiiciat, Teuthonas, et inferiores omnes Germanos, assuetos potu vini novi, et recentis, mulsi dicti, esse, cum illi non sine noxa, et corporum suorum iactura, vinum illud Rhenense recens ebibant, facillime enim a quovis morbo moriuntur, nec ad senectutem, eorum ullus immunis aut sanus pervenit, quod millies illis obieci, Hispanos nostros, et Italos aliosque exteros mercatores, cum quibus Anthuerpiae magnam contrahunt familiaritatem, a tali usu praecavendo. ${ }^{6}$

6 Enarrationes, 1553, p. 472. 
E não há motivo para que alguém me lance a objecção de que os Teutôes e todos os da Germânia Inferior foram acostumados a beber o vinho novo e recente, chamado mosto, visto que eles bebem aquele vinho do Reno não sem dano e prejuízo dos seus corpos. Realmente, eles morrem com grande facilidade e de qualquer doença, e nenhum chega à velhice imune e são. Por isso, muitíssimas vezes lhes lancei a objecção de que os nossos Hispanos e os Italianos e outros mercadores estrangeiros, com quem eles contraem, em Antuérpia, grande familiaridade, se devem precaver de tal costume.

\subsection{0 vinho de Creta, antepassado do vinho Madeira}

A Enarratio sétima prossegue com uma caracterização do vinho de Creta, a que então se chamava, tal como ainda hoje, malvasia. Amato Lusitano caracteriza-o como potens, et generosum (ou seja, 'potente e generoso'), esclarecendo que era inicialmente designado pelo nome da ilha mediterrânica de onde era originário e celebrando as suas qualidades digestivas, pois stomachum dissolutum reficit, et vires amissas facile recuperat ('repara o estômago indolente e facilmente restabelece as forças perdidas').

Impóe-se, neste ponto, uma consideração relativamente ao celebrado vinho Madeira. É também ele um excelente digestivo e deverá corresponder, pelo menos em parte, ao vinum Cretense de Amato. Efectivamente sabe-se que o Infante D. Henrique, aquando do início da colonização do arquipélago da Madeira, mandou trazer cepas de várias ilhas do Mediterrâneo, a fim de apurar da possibilidade do seu cultivo ${ }^{7}$. Graça Melim, em monografia consagrada ao vinho Madeira, chega mesmo a afirmar que "A vinha, originária de Cândia ou Heraklion, capital da Ilha de Creta, entrou na Madeira por ordem do Infante D. Henrique, em 1445, vinte e seis anos após a sua descoberta" ${ }^{\text {. }}$

Já por meados do século xv, Cadamosto ficou maravilhado com os vinhos da região, deixando registado que na Ilha havia: "vinhos muitíssimo bons, e se se considerar que é habitada há pouco tempo, são em tanta quantidade, que chegam para os da ilha e se exportam muitos deles" 9 .

A extrema generosidade do solo insular, então ainda fertilizado pelas cinzas recentes da sua floresta primordial, contribuiu para que a qualidade deste vinho fosse excepcionalmente boa, possibilitando igualmente a sua produção numa quantidade tal que permitia a sua exportação.

7 Rui CARITA, História da Madeira (1420-1566) - Povoamento e Produção Açucareira. Funchal, Secretaria Regional da Educação, 1989, p. 108.

8 Graça Melım, O Vinho das Ilhas. Funchal, O Liberal - Empresas de Artes Gráficas, 2000, p. 17.

9 Luís de CAdamosto, Viagem de Luís de Cadamosto e Pedro de Sintra (prefácio e notas históricas pelo Prof. Damião Peres). Lisboa, 1948, apud R. CARITA, História da Madeira..., op. cit., p. 108. 
Do seu renome, cedo alcançado, dá testemunho Shakespeare que, na peça Henrique IV, apresenta Falstaff a ser censurado, por Poins, pelo facto de ter vendido a sua alma ao diabo por um copo de vinho Madeira e uma perna de capão frio. A lenda inglesa fixou igualmente que o Duque de Clarence, ao ser condenado à morte após a sua derrota na Guerra das duas Rosas, escolhe morrer afogado num tonel de Malvasia ${ }^{10}$.

\title{
2.4. 0 vinho Albano
}

A Enarratio sétima termina com um apontamento sobre aquele que, no tempo de Amato Lusitano, entre os naturais de Ferrara, era chamado "vinho albano", um vinho branco de cor e frio por natureza, que refrescava até com maior eficácia do que a água, razão pela qual se revelava de extrema utilidade no tratamento dos doentes febris:

\begin{abstract}
At Albanum, non quod equidem putem Antiquorum, sed sic apud Ferrarienses nominatum vinum, colore album, natura frigidum, quod (mea sententia) potentius quam aqua infrigidat; nam aqua suis qualitatibus tantum infrigidat; Albanum vero vinum sua substantia, et praeter hoc, austeritate quadam, quod vinum Galenus intelligit, cum vinum continuo febricitantibus concedat, ut Centuriis curationum nostratum abunde diximus, ad quem locum lectorem relegamus, ut cetera quae de vino desiderantur, ibi legat. ${ }^{11}$
\end{abstract}

O vinho albano, não seguramente porque eu o considere o vinho dos Antigos, mas por ser assim designado entre os naturais de Ferrara, é branco de cor, de natureza frio, pelo que, em minha opiniâo, refrigera mais eficazmente do que a água: na verdade, a água refrigera apenas pelas suas qualidades, mas o vinho albano fá-lo pela sua própria substância e, além disto, por um certo travo acre. Galeno reconhece este vinho pois que de contínuo o administra aos doentes febris, como nós abundantemente dissemos nas Centúrias das nossas curas, para o qual lugar remetemos o leitor, para que aí leia tudo o mais que acerca do vinho se deseja.

10 R. CARITA, História da Madeira..., op. cit., pp. 108-109.

11 Enarrationes, 1553, p. 472. 


\title{
3. AS ENARRATIONES PRECEDENTES
}

Antes de se ocupar do vinho propriamente dito, já Amato Lusitano tratara, nas Enarrationes precedentes, da videira e da videira silvestre (1 e 2); da uva e da uva passa (3 e 4) e ainda da flor da videira e do sumo de agrazes (5 e 6).

\subsection{A videira}

\subsubsection{A combinação das tradições greco-romana e judaico-cristã}

No primeiro destes comentários, consagrado à videira, Amato Lusitano combina duas tradiçóes distintas, a greco-romana e a judaico-cristá, ao abrir o livro quinto com as seguintes palavras:

\begin{abstract}
Vitis planta, Baccho, sive Libero, Noe patri dicto dicata, ubique vulgatissima est, ex qua uvae pendent, et ex illis divinus ille liquor, vinum dictum, paratur

A videira, consagrada a Baco ou a Líber, chamado pai Noé [sic], é uma planta muito comum por toda a parte. Dela pendem os cachos de uvas e deles prepara-se aquele divino líquido chamado vinho.
\end{abstract}

Ora, na tradição pagã, Baco, ou Dioniso, filho de Zeus e de Sémele, é considerado o descobridor da videira e o inventor do vinho. Este deus, em Roma, veio a identificar-se com Liber Pater, uma antiga divindade itálica ${ }^{12}$. Já na tradição judaico-cristã, a descoberta da videira e a consequente invenção do vinho são atribuídas a Noé, como se depreende das seguintes palavras:

Noé foi agricultor e o primeiro a cultivar a vinha. Certa ocasião bebeu vinho, ficou bêbedo e despiu-se completamente dentro da sua tenda. Cam, pai de Canaã, viu o seu pai nu e foi contar o caso aos seus dois irmãos, que estavam fora da tenda. Mas Sem e Jafet pegaram numa peça de roupa, e levantando-a por sobre os ombros, aproximaram-se do pai, caminhando de costas viradas para ele. Assim cobriram o pai, estando sempre de costas para ele, para o não verem nu. ${ }^{13}$

12 Pierre Grimal, Dicionário da Mitologia Grega e Romana. Lisboa, DIFEL - Difusão Editorial, 1992, pp. 121-122.

13 Génesis, 9.20.23. Bíblia Sagrada - A Boa Nova, tradução interconfessional do hebraico, do aramaico e do grego em português corrente. Lisboa, Difusora Bíblica, 1995. 
Ainda que o texto sagrado o não afirme explicitamente, pode deduzir-se que, tendo sido o primeiro a cultivar a vinha, foi também Noé o inventor do vinho. Amato Lusitano opta, portanto, por uma via intermédia que concilia as duas tradiçóes, identificando Noé com Dioniso (ou Líber).

\subsubsection{Caracterização da videira e aplicações terapêuticas}

Sobre a videira propriamente dita, Amato afirma ser um alimento frio: os seus rebentos, frescos, acalmam a azia; a seiva que goteja do tronco de uma videira podada, ainda líquida ou já sob a forma de resina, é um bom diurético, além de tornar as faces mais belas; o sarmento, uma vez seco e posto em brasa, usa-se, como um cautério, para extirpar as verrugas; as cinzas resultantes da sua combustão, combinadas com as do tamarisco, usam-se em unguentos praecipue ad morbum Gallicum (ou seja, 'principalmente para a sífilis').

\subsection{As uvas e as uvas passas}

Quanto às uvas, Amato Lusitano adverte para os perigos da sua ingestão logo após serem colhidas, quando ainda estão saturadas de orvalho, uma vez que perturbam o funcionamento do aparelho digestivo. Quando, porém, essa excessiva humidade desaparece, transformam-se num excelente alimento, acabando por obter a primeira categoria entre os frutos secos, logo seguidas dos figos.

As uvas passas, de que Amato Lusitano se ocupa na Enarratio quarta, são excelentes para as afecções do peito e do fígado, devendo contudo evitar-se a ingestão das suas grainhas, pelo seu efeito excessivamente adstringente. Efectivamente as grainhas pectus constringunt, et obstructiones parant ('constringem o peito e dão origem a obstruçôes.')

Que os doentes devem abster-se a todo o custo de as comer afirmam-no várias autoridades alegadas por Amato, tais como Galeno, Alexandre de Trales, Aécio e ainda Avicena. Excelentes serão, por conseguinte, as passas de uva que já são, por natureza, desprovidas de grainhas, como aquela a que Amato Lusitano chama uva passa de Corinto. Esta ieiuno stomacho sumpta, prius aqua vel vino mersa, trium unciarum pondere, alvum movet, et purgat ('sendo comida com o estômago em jejum, previamente demolhada em água ou em vinho, com o peso de três onças, move e purga o ventre').

As grainhas têm, não obstante, a virtude de fortalecer o estômago, pelo que Amato adverte que a uva passa pode ser comida antes da refeição sem a grainha, se o objectivo terapêutico for purgar o ventre, ou com a grainha, se o objectivo for robustecer o estômago. Sendo tomada após a refeição deverá ser ingerida inteira, pois acumula ambas as funções. 


\title{
3.3. A flor da videira e o sumo de agrazes
}

Nas Enarrationes 5 e 6 referem-se as virtudes da flor da videira e do sumo de agrazes, respectivamente. Da primeira escreve Amato que é

\begin{abstract}
sua natura, constringentem, stomacho conductibilem; qua de causa, inter medicamenta stomachica persaepe miscemus

adstringente pela sua natureza, conveniente ao estômago, motivo pelo qual muitas vezes a misturamos com os medicamentos estomacais.
\end{abstract}

Já sobre o sumo de agrazes, isto é, sobre o sumo obtido a partir de uvas ainda não amadurecidas, escreve Amato que é útil contra as nebulosidades da vista e a lepra e ainda, se não for excessivamente salgado, para os doentes com febre. Se for excessivamente salgado, subverte-se o seu efeito antipirético e acentuam-se as suas qualidades dessecativas, fazendo, assim, aumentar as febres e deixando o corpo mais seco do que o conveniente.

\section{OS OUTROS VINHOS}

\subsection{Alguns vinhos caídos em desuso}

Depois de, na Enarratio sétima, se ocupar demoradamente do vinho propriamente dito, Amato Lusitano apresenta uma extensa série de outros vinhos, que são apenas objecto de um brevíssimo comentário.

Sobre muitos deles a única informação veiculada é que, no tempo de Amato Lusitano, já não se preparavam. De um modo geral, Amato escreve: Hodie non paratur: parari tamen posset facillime (ou seja: 'Não se prepara na actualidade, poderia, contudo, preparar-se muito facilmente'», Enarratio 19) ou Non paratur, sed paucis expensis parari possit (ou seja: 'Não se prepara, mas poderia preparar-se com pouca despesa', Enarratio 22) ou simplesmente Non paratur (ou seja: 'Não se prepara', Enarratio 25). Está nesta situação o vinho de mosto com mel e, muito semelhante a este, o vinho adoçado com mel, o vinho de esquila (cebola-do-mar ou cebola-albarrã), os vinhos preparados com a água do mar, o vinho de marmelos, o vinho de flor de videira silvestre, o vinho de bagas de murta, o vinho de lentisco e de terebinto e o vinho de hissopo (respectivamente Enarrationes 8, 9, $19,20,22,25,28,29,30$ e 38$)$. 


\subsection{Sobre os processos de produção}

Note-se que alguns destes vinhos correspondem, por certo, a preparados obtidos a partir de vinho de uva, devidamente condimentado com outras substâncias, usando-se para suporte destas o álcool resultante do processo de fermentação natural do vinho. Que este uso era habitual entre os antigos Gregos afirma-o Graça Melim, ao referir que eles:

Introduziram também métodos para combater a acidez do vinho e para a preparaçáo de medicamentos feitos à base de uma mistura deste néctar com certas frutas.

E acrescenta que:

Os vinhos, na antiga Grécia, eram também empregues na confecção de molhos, unguentos e cosméticos ${ }^{14}$.

Por outro lado, este modo de preparar os vinhos depreende-se de algumas palavras de Amato Lusitano, por exemplo, num parágrafo como a Enarratio 27, consagrada ao vinho de rosas:

Ex vino, et rosis, balaustiis, et pomis cupressi, ac rosmarino, adiectis aliis constringentibus, ut myrto, galla, summitatibus rubi, lentisco, absinthio, ac aliis similibus, vinum roborans membra debilia et ulceribus affecta, quotidie paratur. ${ }^{15}$

A partir de vinho e de rosas, de flores da romá selvagem e de frutos de cipreste e de alecrim, acrescentados outros adstringentes, como a baga da murta, a noz de gralha e as pontas da amora brava, o lentisco, o absíntio e outros semelhantes, quotidianamente se prepara um vinho que robustece os membros enfraquecidos e afectados por úlceras.

Para idêntica conclusão apontam as palavras do título a que correspondem os números 34, 35 e 36: De vino ex pineis nucibus condito. De vino ex cedro, ac aliis fructibus confecto. De vino picato ('Sobre o vinho temperado com pinhóes; sobre o vinho preparado a partir do cedro e de outros frutos; sobre o vinho aromatizado com pez).

Que o vinho de uva era utilizado como suporte de outras substâncias afirma-o Amato Lusitano, por exemplo, na cura XXXIV das suas Centúrias de Curas Medicinais (quinta centúria), «sobre a aceleração de um parto»:

14 G. Melim, O Vinho das Ilhas..., op. cit., p. 8.

15 Enarrationes, 1553, p. 476. 
R. Cinnamomi optimi, trochiscorum de myrrha, croci optimi ana drachmam mediam: omnia optime, et subtiliter triturentur: et generoso vino excepta, bibenda propinentur. ${ }^{16}$

R. de cinamomo muito bom, de trociscos de mirra, de croco muito bom, ana, meia dracma. Triture-se tudo muito bem e muito fino. Feito um excipiente com vinho generoso, dê-se-lhe a beber.

A propósito deste tópico registe-se o conteúdo da Enarratio 41, a penúltima da série, 'Sobre os vinhos preparados com numerosas e variadas especiarias', que afirma apenas que Multa huiusmodi vina parturientes mulieres praeparant ('As mulheres em trabalho de parto preparam muitos vinhos deste género'). O hábito de ministrar às parturientes um cálice de vinho do Porto (quando não mais!), prevaleceu, em Portugal, pelo menos até ao terceiro quartel do século xx...

A razão do uso do vinho de uva para suporte destas substâncias poder-se-á explicar em função de algumas observações do próprio Amato na já referida Enarratio sétima. Assim, usarse-ia vinho de uva em vez de água, visto esta ser fria por natureza (e o vinho albano, como já vimos, ainda mais frio); os vinhos em geral seriam quentes e, como tal, mostravam-se eficazes no tratamento de afecçôes frias, sendo, como também vimos, antídotos eficazes precisamente contra venenos frios, como, por exemplo, a cicuta. O uso medicinal do vinho, uma substância quente por natureza, seria particularmente conveniente no caso de o paciente ser uma mulher, uma vez que contrabalançava a natureza excessivamente fria e húmida desta, conforme ensinava a doutrina hipocrática dos humores.

Outros vinhos referidos poder-se-iam obter por recurso a outros processos, nomeadamente mergulhando frutos muito doces e secos em água e acrescentando, depois, algum fermento de vinho, por forma a induzir artificialmente a fermentação do açúcar, processo do qual resulta a sua transformação em álcool.

Poderá ser esse o processo de fabrico do vinho de tâmaras, descrito na Enarratio 31 ou do vinho produzido a partir de passas de figo, objecto de comentário em 32-33. Sobre o primeiro deles, escreve Amato que é utilizado como bebida pelos Indianos e que os Turcos (Turcae): ex dactylis, et passis uvis aliisque rebus, potum parant, quod vini vice accipiunt, et eo non raro inebriantur ('preparam uma beberagem a partir de tâmaras e uvas passas e outras substâncias, a qual admitem em lugar do vinho, e com ela não raras vezes se embriagam’). Os Turcos teriam, assim, encontrado uma forma de contornar a interdição do consumo de álcool — entenda-se

16 Amato Lusitano, Centuriae Duae - Quinta et Sexta. Lugduni, apud Gulielmum Rouillium, 1564. Reproduz-se a tradução das Centúrias de Curas Medicinais, vol. III, p. 224, da autoria de Firmino CRESPO, a quem se deve, aliás, a tradução integral da obra do médico albicastrense. 
vinho - a que estavam sujeitos enquanto seguidores da religião islâmica. Note-se que o conteúdo desta Enarratio poderá, pelo menos em parte, resultar da observação directa de Amato Lusitano.

Sobre o segundo destes vinhos, registe-se que ainda hoje é produzido desse modo, a partir não de passas de figo, mas de uva, por exemplo, na Escandinávia, o que acaba por corresponder às palavras do Albicastrense, que afirma que tal vinho era produzido regionibus frigidis (ou seja, 'nas regiōes frias').

\subsection{Alguns outros vinhos}

Alguns outros vinhos referidos por Amato Lusitano são, por exemplo, o vinho de marmelos com mel (Enarratio 21), que pode ser temperado com mel ou com açúcar; o vinho de agrazes com mel Enarratio 23), substituído por um xarope obtido a partir dos mesmos agrazes temperados com açúcar, com larga aplicação contra as febres terçãs; o vinho de peras (Enarratio 24), que ao tempo de Amato se preparava em França, em Espanha, bem como em outros lugares; e que poderá eventualmente corresponder à sidra; o vinho de romã (Enarratio 26), produzido a partir do sumo de romãs ácidas e que era dado de beber aos doentes febris; ou ainda o vinho de absíntio, que Amato afirma ser produzido In universa Germania [...] praecipue Mechliniae prope Lovanium, ubi saepius illud pitissavimus ('por toda a Germânia [...] principalmente em Malines, perto de Lovaina, onde nós muitas vezes dele provámos', Enarratio 37). Note-se, uma vez mais, o teor autobiográfico destas palavras.

\subsection{Alguns vinhos desconhecidos dos Antigos}

Ao aproximar-se do termo da sua abordagem da matéria de Baco, Amato Lusitano não deixa de registar, numa única entrada (Enarratio 39), alguns vinhos que, no tempo em que escrevia, eram preparados com plantas que não eram conhecidas dos Antigos. Assim, o vinho preparado com euphragia era utilizado contra os males da vista; o vinho de sena mostrava-se útil para o tratamento das afecçóes motivadas pelo excesso de bílis negra (os atrabiliarios affectus); o vinho de guaiaco, o "pau da Índia», era usado no tratamento da sífilis; a paineira-vermelhada-índia, uma árvore de grande porte que lembra as sumaúmas, servia para preparar um vinho útil contra os defluxos e, finalmente, a salsaparrilha (em latim, salsa pirrilha) igualmente útil contra as sobreditas afecçóes. 


\section{CONCLUSÃO}

A conclusão da série de comentários consagrados por Amato Lusitano ao vinho e aos vinhos, com a qual concluímos também esta nossa abordagem, surge na Enarratio 42, De variis vinis ex variis herbis confectis ('Sobre vários vinhos, produzidos a partir de várias plantas'). Aí, sem se deter em nenhum vinho em concreto, Amato mostra compreender que, afinal, com a maior facilidade se podem fazer diferentes preparos à base de vinho, utilizando-o como suporte das mais variadas plantas, com os quais seria possível, quase à maneira de Asclepíades, curar o maior número de doenças. Esses vinhos, escreve Amato, rei medicae magnum afferrent ornamentum ('poderiam trazer uma grande glória à ciência médica') e o texto termina com uma nota que associa, de um modo paradoxal, inovação e tradição, uma vez que escreve que: Multa tamen hodie, ut audio parari incipunt ('Actualmente, contudo, muitos começam, segundo ouço dizer, a ser preparados'), acabando por remeter o leitor para a obra de Arnaldo de Vilanova, que é, afinal, uma autoridade medieval.

\section{BIBLIOGRAFIA:}

Amato Lusitano, Centuriae Duae - Quinta et Sexta. Lugduni, apud Gulielmum Rouillium, 1564.

Аmato Lusitano, Centúrias de Curas Medicinais. Volume I [-IV]. Prefácio e tradução Firmino Crespo.

Lisboa, Universidade Nova de Lisboa - Faculdade de Ciências Médicas, s/d [4 vols.].

Amato Lusitano, In Dioscoridis Anazarbei De Medica Materia Libros Quinque Enarrationes Eruditissimae.

Venetiis, apud Gualterum Scotum, 1553.

Bíblia Sagrada - A Boa Nova, tradução interconfessional do hebraico, do aramaico e do grego em português corrente. Lisboa, Difusora Bíblica, 1995.

Cadamosto, Luís de, Viagem de Luís de Cadamosto e Pedro de Sintra (prefácio e notas históricas pelo Prof. Damião Peres). Lisboa, 1948.

Carita, Rui, História da Madeira (1420-1566) - Povoamento e Produção Açucareira. Funchal, Secretaria Regional da Educação, 1989.

Grimal, Pierre, Dicionário da Mitologia Grega e Romana. Lisboa, DIFEL - Difusão Editorial, 1992.

Melim, Graça, O Vinho das Ilhas. Funchal, O Liberal - Empresas de Artes Gráficas, 2000. 
(Página deixada prepositadamente em branco.) 


\section{Amatus Lusitanus e Didaco Pirro: due ebrei portoghesi e cerchia umanistica di Dubrovnik}

VINICIJE B. LUPIS 1

\section{RIASSUNTO:}

Amatus Lusitanus, medico e medico scrittore, e Didacus Pyrrhus Lusitanus (Diogo Pires, Didaco Pirro o Didak Pir), due personalità interessanti del periodo umanistico, nel xVI secolo hanno collegato la Croazia e il Portogallo. Allora Dubrovnik era un centro culturale ed economico estremamente importante di questa zona europea. Nella primavera dell'anno 1556 Amatus arrivò nella città di Dubrovnik, dove rimase per due anni. Curava molti patrizi e plebei di Dubrovnik e aveva pazienti dall'Impero Ottomano. L'opera più importante di Amatus e Curationum Medicinalium Centuriae, cioè le 700 storie più interessanti accadutegli nell'ambito del suo mestiere e seguite da personali interpretazioni (scholia). Per noi, la storia più interessante è la sesta centuria (Ragusina), pubblicata a Lyon nel 1564, contenente 100 casi di pratica di Amatus a Dubrovnik, fornisce un quadro straordinario sulla vita culturale e sanitaria della Dubrovnik rinascimentale. Tra i pazienti di Amatus a Dubrovnik vi era anche Sabo Bobaljević Mišetić Glušac (Dubrovnik, 1529/1530 - Ragusa, 1585), un patrizio e poeta malato di sifilide. Tra le sue opere il Canzoniere italiano, pubblicato postumo a Venezia nel 1589, e la rielaborazione in croato dell'Amor fuggitivo di Tasso. Tramite un lungo soggiorno e le opere letterarie, Didak Pir lasciò un segno incancellabile nella città ragusea. Didak Pir ha ringraziato la sua nuova patria - Dubrovnik - nelle lettere scritte in esametro a Paolo Manuzio, figlio del famoso editore Aldo (Ad Paulum, 1563). Con lo stesso spirito stese la "canzone delle famiglie importanti di Dubrovnik d'oggi" (De illustribus familiis quae hodie Rhacusae exstant, 1582), per la quale fu insignito dal Senato di Dubrovnik.

\section{PAROLE CHIAVE:}

Amatus Lusitanus; Didaco Pirro; Dubrovnik; Toma Budislavić; Medicina

1 Istituto di Scienze Sociali "Ivo Pilar" — Centro regionale in Dubrovnik - Croatia: vinicije.lupis@pilar.hr. 


\begin{abstract}
:
Amatus Lusitanus, physician and medical writer, and Didacus Pyrrhus Lusitanus (Didaco Pirro or Didak Pir) were two interesting personalities of the humanistic period. They have linked Croatia and Portugal in the sixteenth century. Dubrovnik was at the time extremely important cultural and economic center of this part of Europe. In spring of 1556 Amatus arrived in the city of Dubrovnik, where he remained for two years. He looked after many patricians and plebeians of Dubrovnik and had patients from the Ottoman Empire. The most important work of Amatus was Curationum Medicinalium Centuriae, with 700 most interesting stories of his practice with interpretations (scholia). For us the most interesting part of this book is sixth centurion (Ragusina), with 100 instances of the practice of Amatus in Dubrovnik because it gives us an excellent picture of the cultural life and health in Dubrovnik Renaissance. Among other patients of Amatus in Dubrovnik was also the patrician and poet who suffered from syphilis - Sabo Bobaljević Mišetić Glušac (Dubrovnik, 1529/1530 - Dubrovnik, 1585). His Italian Canzoniere was published posthumously in Venice in 1589. He also reworked Tasso's Amor fuggitivo in Croatian. Didak Pir was another important person of Portuguese-Croatian humanistic relations. At his new home - Dubrovnik, Didacus Pyrrhus Lusitanus thanked in his letters (written in hexameter verse) to Paulo Manutius. In the same spirit he wrote the song about most important families of Dubrovnik (De illustribus familiis quae hodie Rhacusae exstant, 1582), for which he was awarded by the Dubrovnik Senate.
\end{abstract}

\title{
KEYWORDS:
}

Amatus Lusitanus; Didacus Pyrrhus Lusitanus; Dubrovnik; Toma Budislavić; Medicine 
La Città-Stato di Dubrovnik (in italiano Ragusa) era estesa circa $1.500 \mathrm{Km}^{2}$ nel periodo della sua massima espansione, con una popolazione oscillante tra 25.000 e 75.000 abitanti fra XVI e XviII secolo, dei quali mediamente non più di 6-7.000 nella capitale. ${ }^{2}$ Forte di una flotta mercantile di circa 200 navi tra grandi e piccole, per un totale di 35.000 carri di tonnellaggio attorno al 1570 - alla pari di quelle di Venezia, Genova, Marsiglia, Napoli e Sicilia, come ha rilevato Braudel $^{3}$ - il commercio marittimo raguseo nel corso del'500 non solo si dispiegava nel Mediterraneo orientale e occidentale, ma altresì nell'Atlantico, essendo attiva per gran parte di questo secolo la linea Dubrovnik — Londra. La seconda città dello Stato è Stagno, la terza è Ragusa Vecchia o Cavtat. Già nei primi decenni del xvi secolo Ragusa - consapevole della propria fragilità, stretta com'è tra terre veneziane e ottomane — attende a migliorare la difesa, sviluppare la flotta, potenziare il porto, stringere più larghe e sicure relazioni internazionali. Dubrovnik, città-stato da 1358, non potrebbe mai contare sulle proprie forze per proteggersi da violenze turche e veneziane. È alle arti della diplomazia che essa deve continuamente ricorrere per garantirsi neutralità indispensabile per mantenere relazioni commerciali con tutte le potenze. Così paga un tributo annuale alla Sublime Porta (dopo averlo a lungo pagato al regno Croato-Ungaro), fa continue professioni di ortodossia cattolica al papa, affittava navi ed equipaggio alla Spagna, cerca di imbonire Venezia, passandole qualche informazione sulle cose dei Turchi, mantiene cordiali relazioni con Ancona e con gli stati di Urbino e Ferrara, dispone di consoli nell'Italia spagnola e intrattiene ottimi rapporti con la Francia. Un miracolo di abilità diplomatica nel convulso mondo mediterraneo del xvi secolo. E se è vero che la comunità di Ragusa viveva perennemente intimorita, è anche vero che, alla fine (1806) nessun esercito nemico abbia mai alzato uno stendardo sulle propie mura. Una struttura politica rigidamente aristocratica, con il maggior consiglio serrato intorno 1320, una stretta commissione di affari pubblici e privati, controllata da antiche famiglie, un'indiscutibile correttezza mercantile unita a grande spirito di intraprendenza, una non comune pazienza di fronte alla pretese di Venezia, della Spagna e di Constantinopoli, sono tra gli elementi caratteristici di questo Stato (chiamato dispettivamente "sette bandiere"), che, in fondo, la gente poco affidabile a Venezia, poco tollerante con l'eccessiva indipendenza di rivali commerciali “in golfo”. Ragusa, Ancona, Venezia: un triangolo di rivalità e complementarità ad un tempo, che ha visto, momenti di rottura profonda, ma ha anche registrato fasi di collaborazione. E basterebbe pensare alla vicenda di molte famiglie di Dubrovnik come quelle di Kabužić, Gučetić, Sorkočević, Zuzorić, Gundulić, Bunić, Pucić, Restić ecc., detentrici contemporaneamente di imprese commerciali a

2 Zdravko ŠUndRICA, "Popis stanovništva Dubrovačke republike iz $1673-74$ godine", Arhivski vjesnik 2 (1959), pp. 419-456; F. W. CARTER, Dubrovnik (Ragusa). A Classic City-State. London-New York, Seminar Press, 1972, pp. 124.

3 Ferdinand Braudel, Civiltà e Imperi del Mediterraneo nell'età di Filippo II. Torino, Einaudi, 1982, vol. I., pp. 477. 
Belgrado, Venezia, Ancona, Londra e Dubrovnik, ognuna diretta da un componente familiare o da un socio. E i traffici continuano con certà regolarità anche in tempo di guerra. Ancona è la porta orientale di Roma e Firenze, ma Dubrovnik è uno dei maggiori accessi all'Impero turco per i generi ponentini. ${ }^{4}$ Scrive Lodovico Beccadelli, arcivescovo di Dubrovnik (1555-1564), al governatore di Ancona: "parmi ad un modo ci siamo tutti in una città medesima, che così reputo Ancona et Ragusa per il frequente commercio ch'hanno insieme, et li spessi passaggi dall'una all'altra". ${ }^{5}$ Nel xvi secolo Dubrovnik è la porta dell'Europa per l'Impero Ottomano, una città commerciale estremamente sensibile a qualsiasi tipo di coinvolgimento in conflitti armati, e ha sviluppato una particolare cura per l'arrivo di stranieri sul proprio territorio.

\section{AMATUS LUSITANUS - AMATO LUSITANO}

Amatus Lusitanus, medico e noto autore di testi medicinali (Castelo Branco, Portogallo, 1511 - Salonicco, 21 gennaio 1568) era marrano, cioè, ebreo fattosi cristiano. Compiuti gli studi di medicina a Salamanca, esercitava la professione medica nelle diverse città portoghesi e spagnole. Dietro l'invito di assumere la carica di medico statale a Dubrovnik, venne nel 1547 ad Ancona dove negoziava le condizioni di servizio con il Senato di Ragusa/Dubrovnik. Le trattative furono lunghe per cui, nel frattempo, esercitava la professione ad Ancona e Roma, dove per un breve tempo fu il medico del papa Giulio III (1550). Poi fuggì a Pesaro a causa della persecuzione degli ebrei. ${ }^{6}$

Nella primavera del 1556 venne a Dubrovnik e vi restò, secondo lo storico Lavoslav Glesinger, due anni. ${ }^{7}$ La tesi di Glesinger sembra essere ben fondata. Con tale datazione è d'accordo anche dalla storica Vesna Miović-Perić. La tesi è corroborata anche mediante la comparazione di fonti archivistiche e con l'età dei suoi pazienti menzionati nel suo libro. ${ }^{8}$

4 Sergio AnSELMI, "Motivazioni economiche della neutralità di Ragusa nel cinquecento" in Antonio Di Vittorio, Sergio Anselmi, Paola Pierucci, Ragusa (Dubrovnik) una repubblica adriatica. Saggi di storia economica e finanziaria. Bologna, Cisalpino, 1994, pp. 25-34.

5 Josip Torbarina, "Fragmenti iz neizdanih pisama Lodovika Beccadellija 1555-1564", Dubrovačka, mjesečna ilustrovana revijal (1929), pp. 9-10.

6 António Manuel Lopes ANDRADE; Hugo Miguel CRESPo, "Os inventários dos bens de Amato Lusitano, Francisco Barbosa e Joseph Molcho, em Ancona, na fuga à Inquisição (1555)", Ágora. Estudos Clássicos em Debate 14.1 (2012), pp. 45-90.

7 Lavoslav GLESINGER, Amatus Lusitanus i njegov lječnički rad u Dubrovniku (1556-1558). Zagreb-Beograd, Biblioteka Jevrejskog narodnog kalendara, 1940; idem, "Amatus Lusitanus i njegov liječnički rad u Dubrovniku (1556-1558)", Omanut 3-4 (1940), pp. 61-62; idem,"Dubrovački lječnik - prvi borac protiv progona vještica", Zaštita zdravlja 3 (1948), pp. 106-107.

8 Vesna Mıović, Židovski geto u Dubrovačkoj Republici (1546-1808). Dubrovnik-Zagreb, HAZU, Zavod za Povijesne Znanosti u Dubrovniku, 2005, p. 24. 
La venuta del Lusitano a Dubrovnik coincide con il ritiro di Carlo V d'Absburgo nel monastero Yuste e l'abdicazione a favore del figlio Filippo II e fratello Ferdinando. Lo storico Bariša Krekić sostiene che Amatus arrivò a Dubrovnik verso la fine del 1557. Dello stesso parere è anche un altro storico, Jorjo Tadić. ${ }^{9}$ Lo storico di Dubrovnik Francesco Maria Appendini sosteneva che Amatus si trattenne a Dubrovnik dal 1551 al 1558. Il governo voleva trattenerlo ancora, ma lui declinò l'invito e partì per Salonicco. ${ }^{10}$ Šime Ljubić conferma la tesi dell'Appendini circa il soggiorno di Amatus Lusitanus a Dubrovnik tra il 1551 e il $1558 .{ }^{11}$ Una notizia del 1557 ci dice che a Dubrovnik si trovasse un medico ebreo interdetto dal governo per l'esercizio ulteriore del suo mestiere. ${ }^{12}$ L'arrivo di Amatus ebbe luogo in un tempo di grande prosperità economica di Dubrovnik, e i marrani qui venuti non ebbero un ruolo sostanziale per la città di Dubrovnik, per cui i loro interessi erano complementari con quelli ragusei. ${ }^{13}$ Amatus curava molti cittadini di Ragusa, sia nobili sia popolani, nonché pazienti venuti dal territori turci, e si presenta perfino come esperto dinanzi al tribunale, ma non riesce a ottenere un posto nell'esercizio statale a causa degli intrighi dei medici ragusei. All'inizio del mese di febbraio del 1558 fu aggredito di notte il chirurgo Gianbattista Vanucci, il quale non riconobbe l'aggressore. Cinque anni prima dell'incidente il patrizio raguseo Giugno Bobaljević (Bobali), fratello di Savino, paziente dell'Amatus Lusitanus, aggredì il medico Giacomo Paccino. Il 23 luglio 1550 il detto Paccino aveva a sua volta aggredito il medico

9 Bariša KREKIĆ, "The role of the Jews in Dubrovnik (thirteenth-sixteenth centuries)", Viator (Medieval and Renaissance Studies) 4 (1973), p. 269; Jorjo TADIĆ, Jevreji u Dubrovniku do polovine XVII. Stoljeća. Sarajevo, Izdala La Benevolencia, 1937, p. 284.

10 Francesco Maria APPEndinı, Notizie istorico-critiche sulle antichità, storia e letteratura de'Ragusei, vol. II. Ragusa, dalle stampe di Antonio Martecchini, 1803, p. 324.

11 Šime LJUBIĆ, Dizionario biografico degli uomini illustri della Dalmazia. Beč, 1856, p. 190: "LUSITANO Amato, portoghese, venne in Ragusa nel 1551 ad esercitarvi l'arte salutare, e nel 1558 si ridusse in Salonichio, ove si fece ebreo e morì. Nella sua opera medica: Centuriae VII. curationum medicinalium dedica la sesta centuria all'analisi de'morbi endemici di Ragusa e suo teritorio".

12 J. TADIč, Jevreji u..., op. cit., p. 249; Državni arhiv u Dubrovniku (DAD), Acta Minoris Consilii, V. (Con. Minus), XLIV, fol. 206.

13 B. KREKIČ, "The role...", op. cit., pp. 270-271; T. MORTIDJIJA, "Židovi u starom Dubrovniku", Hrvatska straža 6 (1934), pp. 221-225; Šalom FreiberGer, "Povijest Židova u Dubrovniku do izgona god. 1515", Omanut 1 (1936), pp. 30-37; David GINSBERG, "Mletački rabin Leo de Modena i dubrovački pjesnik Vinko Komnenović", Omanut 10 (1940), pp. 156-161; Zbornik Židovskog muzeja, vol. 1., contiene "Studije i gradja o Jevrejima u Dubrovniku", Beograd, 1971: Radovan SAMARDžıč, "Dubrovački Jevreji u trgovini xvı i xVII veka", (pp. 21-39), T. Popovıč, "Dubrovnik i Ankona u jevrejskoj trgovini xvı veka", (pp. 41-53); Bogumil HrabaK, "Jevreji u Albaniji od kraja XIII do kraja XVII veka i njihove veze s Dubrovnikom", (pp. 55-97); Ladislav MONSTER, "Proces zbog "ritualnog ubistva" u Dubrovniku 1502 godine i tragična smrt lekara Moše Maralija", (pp. 99-112); Miroslav PANTIČ, "Jevreji u dubrovačkoj književnosti", (pp. 211-238); D. Nevenič-Grabovac, "Iz poezije Didaka Pira", (pp. 253-290); Lavoslav Glesinger, "Dubrovački lječnik Amatus Lusitanus", (pp. 291-312); Mirjana Gušıč, "Neki primjerci tekstila u zbirci sinagoge jevrejske općine u Dubrovniku", (pp. 325-336); Z. Efron, "Jevrejski nadgrobni spomenici u Dubrovniku", (pp. 337-340). 
ebreo Isacco, durante un consiglio medico nel monastero dei frati minori di Dubrovnik. ${ }^{14}$ Fu aperta un'istruttoria, che però non sortì alcun risultato. In occasione dell'incidente con Vanucci l'istruttoria fu condotta in Senato dal 11 fino al 25 febbraio, ma senza giungere a un esito finale. Un mese dopo il chirurgo Vanucci fece istanza di rimborso per un periodo di tre mesi di vacanze non retribuito a causa degli affari aperti in Italia. ${ }^{15}$ Va notato che egli aveva contatti di affari con parecchi patrizi e cittadini pazienti del Lusitano, tra i quali Sjepan Gučetić (Gozze), figlio di Antonio, Bernard Zuzorić (Zuzzeri), Pavao di Luka Sorkočević (Sorgo), Vlaho di Nikola Držić (Darsa). ${ }^{16}$ Durante l'anno 1556 Vanucci ebbe contatti d'affari con Dominik Kladorubović — compagno del Šimun di Miho Zlatarić. ${ }^{17}$ In questo periodo Amatus esercitava la professione medica, ma certi cittadini ragusei si ribellarono contro i medici ebrei. Per questo il 23 marzo 1558 il governo raguseo prese una decisione in tal senso e questa due giorni dopo fu prontamente comunicata al Lusitano. ${ }^{18}$ Egli però continuava l'esercizio professionale senza procacciarsi il permesso dell'arcivescovo. Quando il medico Vanucci lasciò Dubrovnik per le vacanze trimestrali, il 28 aprile 1558 Amatus richiese di essere nominato medico statale per un periodo di sei mesi con lo stesso salario che aveva il chirurgo Gianbattista Vanucci. ${ }^{19}$

14 J. TADIČ, Jevreji u..., op. cit., p. 249; DAD, Lamenti politici, XI, vol. 5, fol. 164.

15 DAD, Acta Consili Rogatorum (Act. Cons. Rog.), III, vol. 54, fol. 121'.

16 DAD, Diversa di Cancelariae ( Div. Canc.), XXV, vol. 142, fol. 51.

17 DAD, Div. Canc., XXV, vol. 142, fol. 102'.

18 DAD, Cons. Min., V, vol. 45, fol. 48: "Captum est de precipiendo Domino Amatto Hebreo, medico, non posit in civitate nostra exercere officium medici si reverendiismum Dominus Archiepiscopus noster sibi non concesserit."

19 DAD, Acta. Cons. Rog., III, vol. 54, fol. 133'. 


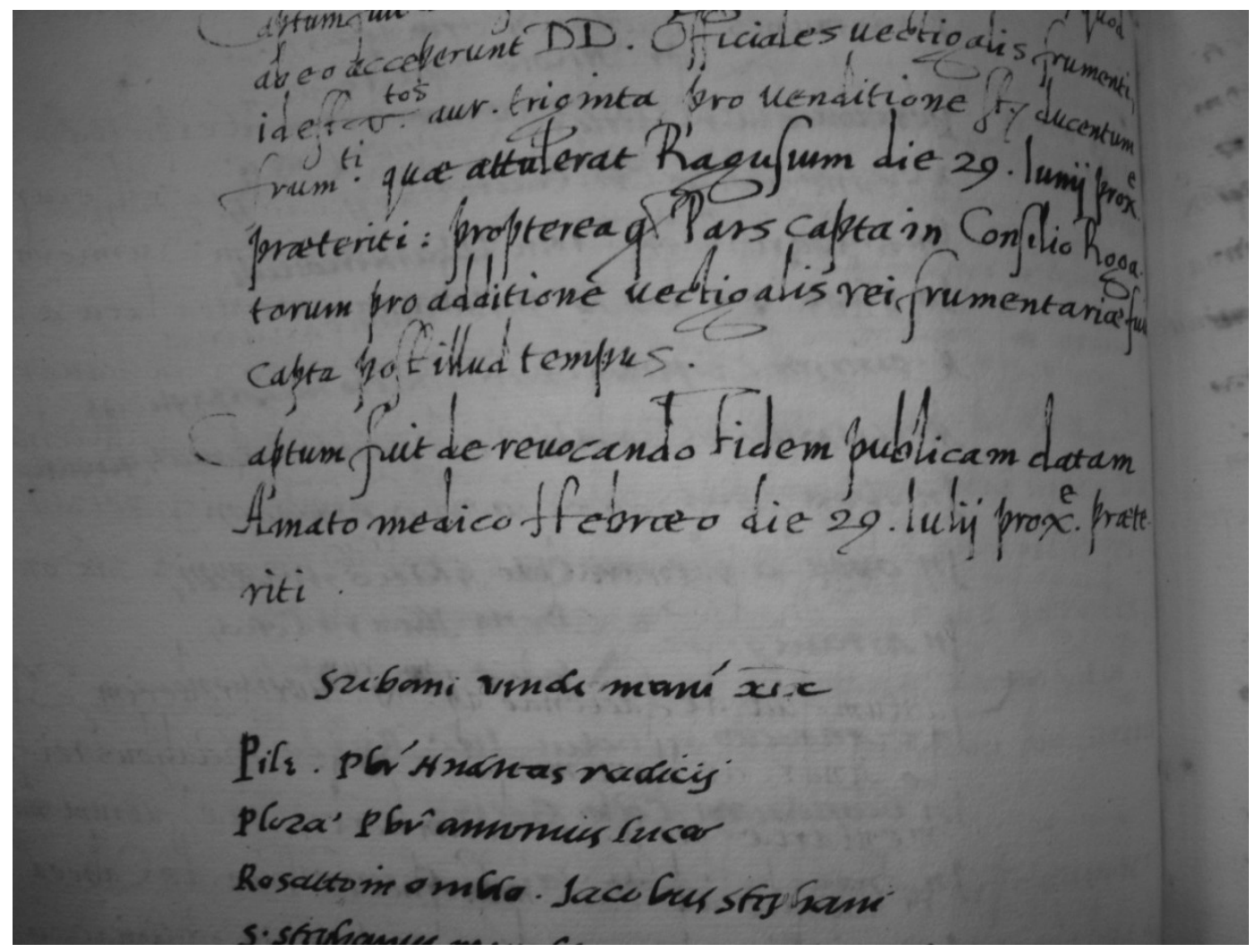

DAD, Acta. Cons. Rog. III., vol. 54, fol. 133', L'autorizzazione del medico Amatus Lusitanus

La mozione del governo ebbe 23 voti in favore e 12 contrari. Il detto risultato mostrava la popolarità di Amatus a Dubrovnik. Due giorni più tardi il Minor Consiglio deliberò favorevolmente in favore di Amato l'ebreo, accordandogli salario dei tre mesi pregressi, in conformità alla decisione presa in seno al Consiglio dei Pregati. ${ }^{20}$ Era evidente il tentativo di cooptare Amato nel servizio statale, e tuttavia questi non ottenne il necessario permesso dell'Arcivescovo. Fu così che il 2 maggio 1558 si avviò il dibattimento al fine di decidere subito ovvero rimandare la decisione, trattando nel frattempo con l'Arcivescovo. Con 20 voti in favore e 15 contrari fu accettata la proposta di dibattere l'accoglimento o meno del Lusitano presso il servizio statale. Fu deciso con 27 voti a favore e 8 contrari di revocargli il servizio e la paga, peraltro già approvata, visto che mancava il permesso dell'Arcivescovo quando fu accolto nel servizio. Cosi Amatus fu dimesso e alcuni cittadini si impegnarono per un intervento presso la Santa Sede

20 DAD, Cons. Min., V, vol. 44, fol. 58'. 
a suo favore, evidenza che fa dedurre la stima generalizzata di cui godeva per il suo mestiere. Un gruppo di cittadini fece appello al governo di adoperarsi presso il Papa, ma il Senato con 20 voti favorevoli e 19 contrari decise di non implicarsi direttamente nel caso. ${ }^{21}$ Questa decisione era un messaggio chiaro che vi erano due gruppi contrastanti e che una corrente politica si opponeva alla sua nomina. Va notato che a quell'epoca l'arcivescovo di Dubrovnik era Lodovico Beccadelli (1555-1560), umanista famoso di Bologna, amico di Michelangelo Buonarotti. La sua partenza da Dubrovnik diede occasione al poeta Savino Bobaljević, paziente di Amatus, di comporre un sonetto in onore dell'arcivescovo. ${ }^{22} \mathrm{E}$ singolare che Amatus Lusitanus non ottenesse il permesso dell'arcivescovo, doveva pur esserci una ragione importante. Dobbiamo tenere conto che il Senato di Dubrovnik, dietro pressione di Ivan Gundulić (Gondola), avesse sollecitato la nomina del Beccadelli prima al papa Giulio III e poi a Marcello II. Amatus era medico della figlia di Ivan Gundulić. ${ }^{23}$ Si tratta di Marija Gundulić, moglie del famoso filosofo Nikola Gučetić (Gozze), amica della potessa Flora-Cvijeta Zuzorić. Marija Gundulić in quell'epoca era una delle donne più erudite di Dubrovnik. Può darsi che una delle ragioni della nomina di Beccadelli fosse l'elezione di papa Paolo IV, grande amico della Repubblica di Dubrovnik e di Bonifacio Stjepović dell'isola di Lopud, custode della Terra Santa, il quale aveva introdotto alcune misure restrittive riguardanti la vita degli ebrei. Può darsi però che una delle ragioni dell'interesse di Amatus per la botanica lo spinse a criticare il rinomato umanista e medico Pietro Andrea Mattioli. Il secondo libro dei commenti al Dioscoride, pubblicado a Venezia, nel 1553, fu dedicato al Senato di Dubrovnik, scritto appunto quando Amatus voleva venire a Dubrovnik. ${ }^{24} \mathrm{Il}$ noto medico raguseo Toma Budislavić (1545-1608) studiava a Bologna e Padova ed era amico del poeta Didaco Pirro del quale parleremo più estesamente nella seconda parte di questo lavoro. A Dubrovnik visse anche Giacomo di Lorenzo Sorkočević (1534-1604) collaboratore del naturalista Ulisse Aldrovandi e del segretario Antonio Gigante, segretario dell'arcivescovo Lodovico Beccadelli. Il patrizio raguseo Giacomo di Lovro Sorkočević senza dubbio conosceva Amato e curava i membri della sua stessa famiglia. Egli scambiava la conoscenza botanica, pesci e molluschi della regione di Dubrovnik, con il professore dell'Università di Bologna. A Dubrovnik era conosciuto il lavoro del medico e botanico Mattioli e il suo

21 DAD, Acta. Cons. Rog., III, vol. 54, fol. 150.

22 Daniele FArLatı, Illyricum sacrum, vol. VI. Venezia, 1800, pp. 230-242; Mijo BrLEk, "Lodovico Beccadelli", Hrvatski biografski leksikon, sv. I. Zagreb, 1983, pp. 562-565; Stjepan Krasıć e Serafino Razzı, Povijest Dubrovačke metropolije i dubrovačkih nadbiskupa (x. - xvı. stoljeća). Dubrovnik, Biskupski ordinarijat, 1999. pp. 141-144.

23 Lavoslav Glesinger,"Dvije studije o Amatusu Lusitanusu”, Židov, vol. I, 20 (1937), p. 83.

24 In Dioscoridis Anazarbei de medica materia libros quinque enarrationes eruditissimae doctoris Amati Lusitani medici ac philosophi celeberrimi, quibus non solum officinarum Seplasiariis, sed bonarum etiam literarum studiosis utilitas adfertur, quum passim simplicia Graece, Latine, Italice, Hispanice, Germanice et Gallice proponantur. Venetiis, [apud Gualterum Scotum], 1553. 
commento all'opera del botanico greco Dioscoride. Pietro Andrea Mattioli nacque il 23 marzo 1501 a Siena e morì 1577 a Trento. Studiò a Padova dove compì gli studi nel 1523 ed esercitò la professione medica a Siena, Roma, Trento e Gorizia, diventando medico personale del Granduca Ferdinando II a Praga e poi di Massimiliano II a Vienna. Nella storia della scienza è noto piuttosto per il suo interesse per la botanica, dato che ha descritto 100 nuove specie nella botanica medica, oppure per l'applicazione medica. Ha esposto le sue conoscenze nel libro I Discorsi di M. Pietro Andrea Mattioli Senese, Medico Cesareo... Di Pedacio Dioscuride Anazarbeo Sulla materia medica (...). La prima edizione del libro di Mattioli fu pubblicata nel 1544 in italiano, dopo di che seguirono molte edizioni in latino, la prima, nel 1554 insieme a varie traduzioni. Amatus Lusitanus criticò fortemente Mattioli nelle sue Enarrationes che furono pubblicate per la prima volta nel 1553. A questa critica il Mattioli replicò con l'Apologia adversus Amathum Lusitanum cum Censura in eiusdem enarrationes, ${ }^{25}$ pubblicata per la prima volta nel 1558 a Venezia come un'opera a se stante, poi nello stesso anno e più volte insieme all'edizione latina dei commenti del Mattioli al Dioscoride. In questa opera Amatus fu accusato di non attenersi ai dogmi della fede cattolica, ma di essere rimasto fedele alla fede giudaica. Mattioli era una persona autorevole ed importante - medico personale del Granduca austriaco, sicchè Amatus procacciò, criticando la sua opera, senza dubbio un nemico pericoloso. La situazione creatasi fu certamente nota al ceto nobile raguseo. Riflettendo sulla prassi di Amatus a Dubrovnik, bisogna prendere in considerazione la situazione politica e la conoscenza medica dell'epoca. Tra i pazienti di Amatus c'erano dei rettori della Repubblica con le loro famiglie. Così nel novembre 1559 il rettore era Pavao di Junije Gradić (Gradi). ${ }^{26}$ I membri del Consiglio Minore per l'anno 1558 erano: Jeronim di Junije Gradić, Martolica di Ivan Kabužić (Caboga), Petar di Luka Lukarević (Luccari), Đuro di Ivan Gučetić (Gozze), Nikola di Leon Đorđić, Junije di Miho Bobaljević, Dragoje di Martolica Crijević ${ }^{27}$, Marin di Damjan Menčetić (Menze), Toma di Jeronim Sorkočević, Lucijan di Jeronim Bunić (Bona) e Stjepan di Marin Džamanjić (Zamanja, Giamagna). ${ }^{28}$ Tra i membri del Minor Consiglio c'erano pure i pazienti di Amatus. Tra i membri del Consiglio dei Pregati durante il mese di aprile c'erano Ivan di Marin Gučetić, Pavao di Marin Gučetić, Marin di Frano Gučetić e Frano di Ivan Kabužić. ${ }^{29}$

Amatus rimase a Dubrovnik ancora per un certo tempo e partì per i dintorni di Dubrovnik, da dove intendeva andare a Venezia. Per essere sicuro chiese al governo raguseo la "fidem publicam" per un periodo di quindici giorni dopo l'arrivo a Dubrovnik, per poter poi trasferirsi

25 J. TADIĆ, Jevreji u..., op. cit., p. 284.

26 DAD, Leges et instructiones, XXI.1., vol. 2, fol. 12.

27 DAD, Div. Canc., XXV, vol. 142, fol.12.

28 DAD, Leges et instructiones, XXI.1., vol. 2, fol. 27.

29 DAD, Leges et instructiones, XXI.1., vol. 2, fol. 70'. 
a Venezia. Il governo accettò la sua richiesta il 29 giugno $1558^{30}$, ma qualcuno si ribellò di nuovo contro Amato sicchè lo stesso governo il 12 agosto ritirò la "fidem publicam". ${ }^{11}$ Si trattava evidentemente di una corrente contraria esistente a Dubrovnik. Nel frattempo, l'8 luglio le autorità ragusee stavano rinnovando accordi con tre medici ed esprimevano l'interesse per un altro medico a due anni ulteriori. Per qualche motivo nascosto Amatus non era desiderabile. Si trattava evidentemente di un'atteggiamento volto a evitare disgrazie delle autorità spagnole, ma anche di dimostrazione della propria neutralità fra i Turchi e le potenze cristiane in quel tempo molto delicato. ${ }^{32}$ Dubrovnik aveva una relazione diplomatica molto amichevole con l'imperatore Carlo V (1519-1558), ma di nascosto dava comandi ai suoi capitani nei porti spagnoli per non prendere parte nella flotta spagnola nelle loro lotte contro gli Ottomani, essendo continuamente accusata da parte dei diplomatici inglesi e francesi alla corte ottomana di essere alleati spagnoli. ${ }^{33}$ Il Lusitano abitava a Dubrovnik in un momento in cui la città era un centro di spie, quando a causa di violenti incursioni turche di anno in anno cadevano, uno dopo l'altro, pezzi del regno di Croazia. Era questa una situazione molto grave nella quale Dubrovnik, isolata ed esposta a permanenti pericoli, cercava di difendersi. Tra le spie spagnole vi era il più noto Marino Giamagna, patrizio raguseo e titolare dell'ordine equestre di S. Giacomo; le lettere di questo delatore sono conservate nell'Archivio General de Simancas riferite a tre periodi, dei quali il medio copriva gli anni 15541562.

I membri della comunità sefardita a Dubrovnik prestavano servizi informativi a diversi Stati. Uno di questi, David Paz (Passi) offriva informazioni agli Ottomani. ${ }^{34}$ La partenza di Amato da Dubrovnik coincise in ogni modo con i preparativi del pascià Piala per occupare la fortezza a Minorca nell'anno 1559. L'atteggiamento di sfiducia nei confronti dei "marrani" e "moriscos" era una conseguenza della sfiducia della Corte spagnola. ${ }^{35}$ Amatus partì verso la fine del 1558

30 DAD, Cons. Min., V, vol. 44, fol. 84: "Fides publica Captum fuit de dando Fidem publicam Amato medico per dies xv; postquam ingressus fuerit Ragusiam; ut hinc possuit traduci Venetias."

31 DAD, Cons. Min., V, vol. 44, fol. 88': "Captum fuit de revocando Fidem publicam datam Amato medico Hebreo die 29. lulij prox.e prateriti."

32 Robin Harris, Povijest Dubrovnika. Zagreb, Golden marketing-Tehnička knjiga, 2006, p. 103.

33 R. HARRIS, Povijest..., op. cit., pp. 100-102.

34 Ari BüLENT, "1. Appendix to the text "An Influental Jew on the Ottoman Court: David Pass": in Mirjana Polıć Bobıć (ed.), Tajna diplomacija u Dubrovniku u xvı. Stoljeću. Zagreb, Sveučilište u Zagrebu, 2011, pp. 194-198.

35 Mirjana Polıć Bobıć, Među križem i polumjesecom, dubrovačke dojave španjolskom dvoru o Turcima u xvı. Stoljeću. Zagreb, Naklada Ljevak, 2000, pp. 1-96; idem, "Activities of the Spanish Secret Service in the Republic of Dubrovnik in the $16^{\text {th }}$ Century and the Role of Spanish Confidant Marin Zamanja", in Mirjana Polıć Bobıć (ed.), Tajna diplomacija u Dubrovniku u xvı. Stoljeću. Zagreb, Sveučilište u Zagrebu, 2011, pp. 181-190; idem, "Španjolska tajna služba u Dubrovačkoj Republici u xvı. stoljeću i uloga španjolskog povjerenika Marina Zamanje u njoj", in Mirjana Polıć Bobıć (ed.), Tajna diplomacija u Dubrovniku u xvı. Stoljeću. Zagreb, Sveučilište u Zagrebu, 2011, pp. 86-93. 
verso Salonicco e lì morì dieci anni più tardi come vittima della peste. Secondo la tradizione sulla sua tomba campeggiava l'epitaffio di quattro distici composti da Didaco Pirro. ${ }^{36}$

\section{L'ATTIVITÀ MEDICA DI AMATUS A DUBROVNIK}

L'opera più importante di Amatus sono le sette centurie, vale a dire le 700 più interessanti storie della sua attività professionale, accompagnate da spiegazioni supplementari — scholia. Per quanto ci riguarda, la più interessante è la sesta centuria (detta Ragusina), pubblicata per la prima volta a Venezia nel 1560, contenente cento casi pratici capitatigli a Ragusa, che ben illustravano le condizioni culturali e sanitarie a Dubrovnik in epoca rinascimentale. A Dubrovnik Amatus fu il primo a introdurre erbe medicinali di origine orientale (radix sinarum), e lottava anche contro la superstizione. ${ }^{37}$ I casi più interessanti e importanti della sua prassi medica Amatus li studiava facendone appunti e protocolli, ottenendo così un grande numero di dati scientifici relativi alle malattie e ai pazienti della sua decennale attività. In tutto ve n'erano sette centurie, alcune delle quali pubblicate più volte. Prima del suo arrivo a Dubrovnik aveva pubblicato a Venezia nel 1557 solo quattro centurie, altre tre le pubblicò più tardi avendo messo in ordine gli appunti corrispondenti. La Quinta Centuria fu scritta ad Ancona e poi rivista e completata durante il soggiorno a Dubrovnik, mentre la Sesta Centuria contiene appunto i cento casi della sua prassi a Dubrovnik. Ambedue furono poi stampate a Lione nel 1564. A Salonicco ha scritto l'epilogo nel 1559 e il proemio nel 1560. Dedicò questa edizione a Joseph Naci. L'opera inizia con un incontro fra tre patrizi ragusei: Giovanni Gradi, Simone Benessa e Pasquale Gozze, i quali guidano Amato presso un patrizio malato, Medo (Orsatto) Gundulić. Segue una breve descrizione di Dubrovnik. Si constata che la città fosse esposta ai forti venti del sud, per quanto durante l'inverno la città fosse colpita dal passaggio di molte malattie; inoltre mancava il frumento, data l'assenza di pianure, mentre il vino è aspro e insalubre. La città è governata da nobili, abili politici che si occupano del commercio, ma anche da semplici cittadini. I popolani sono poveri. Amatus fa una descrizione a parte per ogni caso: in primo luogo narra di chi si tratta e in che modo si è ammalato. Poi descrive la degenza, e la ricetta specifica prescritta, aggiungendovi spesso anche annotazioni (scholia) riferiti a medicine antiche, greche e arabe. Singoli casi sono descritti piuttosto brevemente, a differenza dell'ultimo caso nel quale presenta la cura di un capitano marittimo ferito alla testa da un marinaio. Il caso

36 J. TADIČ, Jevreji u..., op. cit., 1937, p. 297; Diogo PIREs, Cato Minor siue Disticha Moralia ad Ludimagistros Olysipponenses (...). Venetiis, apud Felicem Valgrisium, 1596, p. 163.

37 Vladimir DuGaČKI, "Amatus Lusitanus", Hrvatski biografski leksikon, vol. I. Zagreb, 1983, p. 237; Risto Jeremić e Jorjo TADIĆ, Prilozi za istoriju zdrastvene kulture starog Dubrovnika, vol. 2. Beograd, 1939, pp. 89-124; L. Glesinger, "Amatus...", op. cit., pp. 61-62; idem, "Dubrovački...", op. cit., pp. 106-107. 
è descritto in maniera drammatica alla stessa stregua di quello introduttivo: un certo patrizio della famiglia Gradi prega il Lusitano di ricevere il suo aiuto. Accanto a lui stanno due farmacisti ragusei (Celentano e Vanucci) con i quali Amatus discute e prescrive che cosa bisogna fare. Il libro finisce con Amatus (Amati iusiurandum), che giura su Dio e Mosè ecc. per aver sempre cercato di giovare agli infermi e non a se stesso, di non aver mai guardato chi è ebreo, cristiano o musulmano, di non aver aiutato i farmacisti più di altri, di non aver mai scoperto un segreto affidatogli, né dato veleno a chiunque, né assistito a qualche aborto. Il giuramento è scritto con parole molto serie ed emozionanti. Secondo l'opinione di Amato molte malattie sono causate dal vento del sud, mentre il vino cattivo causava molti casi di calcoli vescicali. D'altra parte sosteneva che a Dubrovnik le ferite alla testa cicatrizzano facilmente. Oltre a Dubrovnik Amatus descrive anche la situazione sanitaria della città di Ston (Stagno), dove andava per curare i casi di grave febbre paludare. Amatus curava pure i patrizi che soffrivano dalle malattie veneree. Le centurie ci presentano Amato come un ottimo medico clinico, molto dotto, teorico e pratico della sua epoca. Conosceva bene la letteratura specifica e si occcupava di anatomia. Era pure un esperto di chirurgia, un buon diagnostico e terapista esperto. ${ }^{38}$ Nella sesta Centuria ${ }^{39}$ Amatus presenta la lode a Dubrovnik (p. 264): "Ragusii civitatis brevis descriptio, per Amatum Lusitanum. Ragusium, urbs parua, sed antiqua, et Venetiarum simia, ad mare Illyricum inter rupes sedet, $\&$ meridiem spectat (...)”. L'opera è molto importante per la conoscenza della storia culturale di Dubrovnik. Oltre ad aspetti geografici vi si trova anche una succinta valutazione del governo: "Il governo è repubblicano, ma vi si ammettono solo i nobili, i quali sono abili politici, uomini abbastanza ricchi e sensati. Oltre ai nobili vi è una moltitudine di cittadini, una parte dei quali si occupano di commercio. Questi sono abbastanza colti e le loro navi sono bellissime. L'altra parte dei cittadini vive in miseria e povertà.” Da queste parole emerge un'immagine meno nota della Dubrovnik rinascimentale. ${ }^{40}$

Tra i pazienti di Amatus vi erano numerose persone di Dubrovnik: Jeronim Binčulić (Hieronimus Bucignolius, p. 265), figlio di Benedikt Gundulić (p. 270), Marko di Jero Basiljević (Marcus filius Hieronimi Basilii, p. 272), Nikola di Vlaho Držić (Nicolaus, filius Blasij Darsae, p. 272), Marin Gradić (Marinus Gradius, patritius raguseus, p. 272 e 285), filius Sacrintoris Ragusini (p. 288), aurifex Racusinus (p. 298), figlio di Nikola Bunić (Filius Nicolai Bonij, patritij ragusaei, p. 289), Dominik Kladorubović, mercante raguseo (p. 291), figlio di Nikola Palmotić (filius Nicolai Palmotae Patritii Ragusaei), figlio di Pietro Katarini (filius

38 J. TADIČ, Jevreji u..., op. cit., pp. 291-295; Milan ReŠETAR, "Amat Luzitanac, dubrovački ljekar xvı. Vijeka", Brankovo kolo 6 (1900), pp. 39-41; Lavoslav Šik, Die jüdische Ärtze in Jugoslavien. Osijek, E. Sekler, 1931, pp. 9-20; B. KREKIČ, "The role...", op. cit., p. 269.

39 Amatı LusıtANI, Curationum medicinalium, Centuriae duae, Quinta et Sexta (...). Lugduni, apud Gulielmum Rouillium, 1564, pp. 262-647.

40 L. Glesinger, "Amatus...", op. cit., pp. 61-62. 
Petri Catarini, p. 293), Jakov di Nikola Bunić (Jacobus, filius alterius Nicolai Bonii Patritii Ragusei, p. 297), moglie di Mudai (vxor Mudai, p. 298), Frano coniatore raguseo (Franciscus nummularius Racusinus, p. 300), la donna turca Imin da Durazzo (Turca Imin, ex Duratio, p. 301), Pavao Gradić (Paulus Gradius, patritius Ragusaeus, p. 303), figlia di Dominik Kladorubović, mercante raguseo (filia Dominici Cladorouichi, mercatoris Racusini, p. 306), Marin Gundulić (Marinus Gondullanus, nobilis iuuenis Ragusanus, p. 308), Stjepan Menčetić (Stephanus Maenssius, patritius Racusinus, p. 314), Sebastijan Bobaljević (Sebastianus Bubalius ex Racusaeis patritiis, p. 320), figlio di Manuele Fragosi (Filius Manuelis Fragosii, p. 325), Sjepan Ranjina (Stephanus Aranius ex patritio Ragusaeorum, p. 331), Didaco Pirro (p. 334$)^{41}$, Pavao Gradić il giovane (Paulus Gradius iuuenis, Patritius Ragusaeus, p. 338), suo nipote Junije Gradić (Junius Gradius, Patritii praedicti nepos, p. 345), moglie del mercante raguseo Đuro Martinić (vxor Georgii a Martinis, ciuis Ragusini (p. 350), moglie di Miho di Scipione Bunić (vxor Michaelis Scipionis Bonii, ex patritia Ragusinorum familia, p. 351), mercante Salonicense Krispin (p. 360), moglie di Božo Prokulić (Vxor Natalis Proculei, patritii Ragusini, p. 368), Giacomo francese ed Enrico francese (Jacobus homo Gallus \& Henrici Francorum Regis, p. 373), Thamir, mercante turco da Pergamon (p. 378), Nikola Gučetić (Nicolaus Gozius, ex nobili Ragusaeorum familia, p. 381), figlio di Zmaj (Draco) Crijević (Filius Draconis Ceruini, patritii Racusini, p. 386), Šimun Beneša (Simeon Benesius, vir doctus, ex nobilibus Ragusaeis, quem e Byzantio, ubi Legatum ad Solimanum regem pro patria egerat, p. 386), Ivan Lukarević (Ioanni Luce, viro probo \& patritio raguseo, p. 396), figlia di Nikola Sorkočević (ex patritia Ragusaeorum familia puella filia Nicolai Sorgij, p. 400), Aloisia, moglie del capitano Dalmata (Aloisia, Dalmatiae Nauarchi uxor, p. 410), Luka Buća (Luca Bucchius, nobilis Ragusaeus, p. 414), Marin Menčetić (Marino Machullio, iuuenis nobilis, p. 416), madre di Frano Sorkočević (mater Francisci Sorgii, p. 418), Andreas Myroparonis Praefectus (p. 429), moglie di Vlaho di Valentin Sorkočević (uxor Blasii Valentini Sorgii, p. 434), Pavao Gradić il maggiore (Paulus Gradius Senior, p. 438), Bernard Bunić (Bernardus Bonius, p. 442), moglie di Abner Alfarin (uxor Abner Alpharini Haebraeorum, p. 443), Bernard, abbate dell'abbazia benedettina di Lacroma (Bernardus Abbas ex Croma insula, p. 444), Abner Alpharinus Haebraeus console (Abner Alpharinus Haebraeus, p. 447, apud Ragusaeos consul), Marin Getaldić (Marinus Guetaldus, ex Ragusaeorum patritia gente, p. 449), Matija Paskalić (Mattheo Paschali nobilis Catharensis, p. 457), figlio di Petar Lukarević (filius nobilis Petri Luchari, p. 461), Marin Gundulić (Marinus Gondulanus, p. 463), Jakov Basiljević (Jacobus Basilius, nobilis Ragusaeus (p. 466), Alojzije (Luigi), mercante raguseo (Aloisius Ragusaeus mercator, p. 470), figlia di Petar Lukarević (filia Petri Luchari, nobilis Ragusaei, p. 475), Stjepan Gučetić (Stephanus

41 "Curatio trigesima, in qua agitur de dolore iocinore. Didacus Pyrrhus, vir Graece et Latine peritissimus, et magni nominis poeta. Cum in suburbio Ragusii ageret". 
Gozius, nobilis \& magnificus Ragusaeus, p. 481), Josip Gučetić (Josephus Gozius, nobilis Ragusaeus, p. 485), madre di Junije Đorđić (p. 487), Marin isolano (Marinus vir insularis, p. 496), Lodovico Spadaio (Ludouicus Spatarius, p. 499), Enea Napolitano musicista (Aeneas Neapolitanus musicus, p. 508) e Marin Sorkočević (Marinus Sorgius, nobilis Ragusaeus, p. 531) e numerosi altri.

Leggendo questi nomi con l'indicazione delle rispettive malattie, Amatus Lusitanus si pone una domanda di tipo etico. Ciononostante, il Lusitano ha fornito un'idea interessante sulla situazione a Dubrovnik del Cinquecento, conosciuta come "epoca aurea di Dubrovnik". Conoscendo i nomi dei pazienti di Lusitano, presso l'Archivio di Stato di Dubrovnik, possiamo trarre numerose conclusioni sull'esito delle cure e sulle sorti dei patrizi e cittadini di Dubrovnik di quell'epoca. Per esempio dal caso di Nikola, figlio di Vlaho Držić, mercante e pittore raguseo (Dubrovnik, 20 luglio 1503 - Dubrovnik 1569), o da quello della famiglia Držić (Darsa) dalla quale provengono parecchi personaggi illustri, artisti ed architetti militari. Vlaho di Marino Držić, mercante e pittore, era fratello maggiore del commediografo Marino, che sin dalla gioventù visse a Venezia, occupandosi di commercio e arte, sposato con una veneziana. Dopo il fallimento dei suoi affari nel 1541 decise di tornare a casa dove tre anni dopo sarebbe entrato al servizio statale quale scrivano per l'arte laniera. Fungeva pure da esperto delle opere d'arte. Come tale fece valutare la qualità artistica di un altare della chiesa di S. Andrea. Nel 1548 firmò un contratto per la realizzazione di una pala d'altare per il nobile Ilija Bunić. Ad ogni modo, Vlaho Držić era un personaggio particolare: teneva rapporti di amicizia con diversi umanisti italiani, fra i quali Antonio Brucinolo e Pietro Aretino. Apparteneva alla cerchia artistica intorno al famoso pittore Tiziano Vecellio coltivando pure rapporti di amicizia con il pittore Giovanni de Ponte, figlio del conosciuto pittore veneziano Giacomo de Ponte. Il famoso matematico, astronomo, commediografo e poeta Nikola Nale-Nalješković (+1587) stenta a trovare le parole adeguate per elogiare il globo adornato da Držić per il cardinale Carapi, e ne risaltava tuttavia la sua spiccata capacità nel ritrattiare i soggetti. Il poeta Michele Monaldi, suo compagno di gioventù a Firenze, compose una poesia in cui loda Držić che con i suoi colori dava vita alla tela, dimostrando di che cosa fosse capace l'arte. Gli si attribuiscono, senza ragione, due pale di altare nella chiesa di s. Domenico a Dubrovnik: la Madonna con i santi Biagio e Francesco e la pala di Sacra Famiglia nella chiesa della Madonna di Šunj sull'isola di Lopud. Alcuni suoi biografi ritengono che era solo un autodidatta di talento, altri invece negarono le qualità artistiche lodate dai suoi contemporanei ineguagliate da nessun'altro pittore di Dubrovnik. Altri sono del parere che egli avrebbe potuto imparare l'arte pittorica durante il suo soggiorno in Italia lavorando presso qualche pittore rinomato. Ad ogni modo, nel 1603 Držić viene menzionato nella Genealogia della fraternità degli Antonini dove esercitava l'arte pittorica e scultorea e realizzava opere lodevoli. Lo storico Serafino Crijević (Cerva) scrive che era un uomo di mano molto abile, un artista universale e collezionista di opere d'arte antiche. 
Si tratta senza dubbio di un personaggio di talento, tipicamente rinascimentale. Egli è spesso menzionato dagli scrittori coevi: Antonio Brucioli fiorentino vissuto a Venezia quale esule politico lo ricordava nei suoi dialoghi platonici; Pietro Aretino invece, in una lettera del 1545 , lo ringraziava per avergli regalato una scatola utile a conservare pettini, elaborata artisticamente, ne lodava le opere ("meravigliose opere ch'escono da voi”, "mirabili lavori”); il poeta Nicola Nale-Nalješković, oltre ad elogiare il globo dorato realizzato per il cardinale Carpi, menzionava anche le doti prospettiche e l'arte di damascare. Il poeta Michele Monaldi, compagno di gioventù a Firenze, in un'epistola a Savino Bobaljević (Bobali) - Mišetić, in una poesia intitolata "In morte del Drusiano" faceva riferimento alla sua morte. Padre di Nicola, paziente di Amato, era Biagio, fratello di Marino Držić (Dubrovnik 1508-Venezia 1567). Durante il soggiorno di Amato a Dubrovnik Marino scrisse diversi drammi e fece una traduzione di Ecuba di Euripide. ${ }^{42}$ La causa della morte prematura di Nicola (1530-1567), che era sordomuto, fu probabilmente la malattia. ${ }^{43}$ Amatus scrive di aver curato anche la moglie di Abner Alfarino, mercante, armatore e console a Dubrovnik. Nel 1559 il console Abner vendette una nave al patrizio raguseo Scipione di Frano Kabužić (Caboga). ${ }^{44}$

42 Franjo Švelec, "Marin Držić", Hrvatski biografski leksikon, vol. III. Zagreb, 1993, pp. 631-636; idem, "Vlaho Držić", Hrvatski biografski leksikon, vol. III. Zagreb, 1993, pp. 636-637.

43 Nenad VekaRIČ, Vlastela grada Dubrovnika, 4. Odabrane biografije (A-D). Zagreb-Dubrovnik, Zavod za povijesne znanosti HAZU u Dubrovniku, 2013, p. 347.

44 J. TADIČ, Jevreji u..., op. cit., p. 226. 


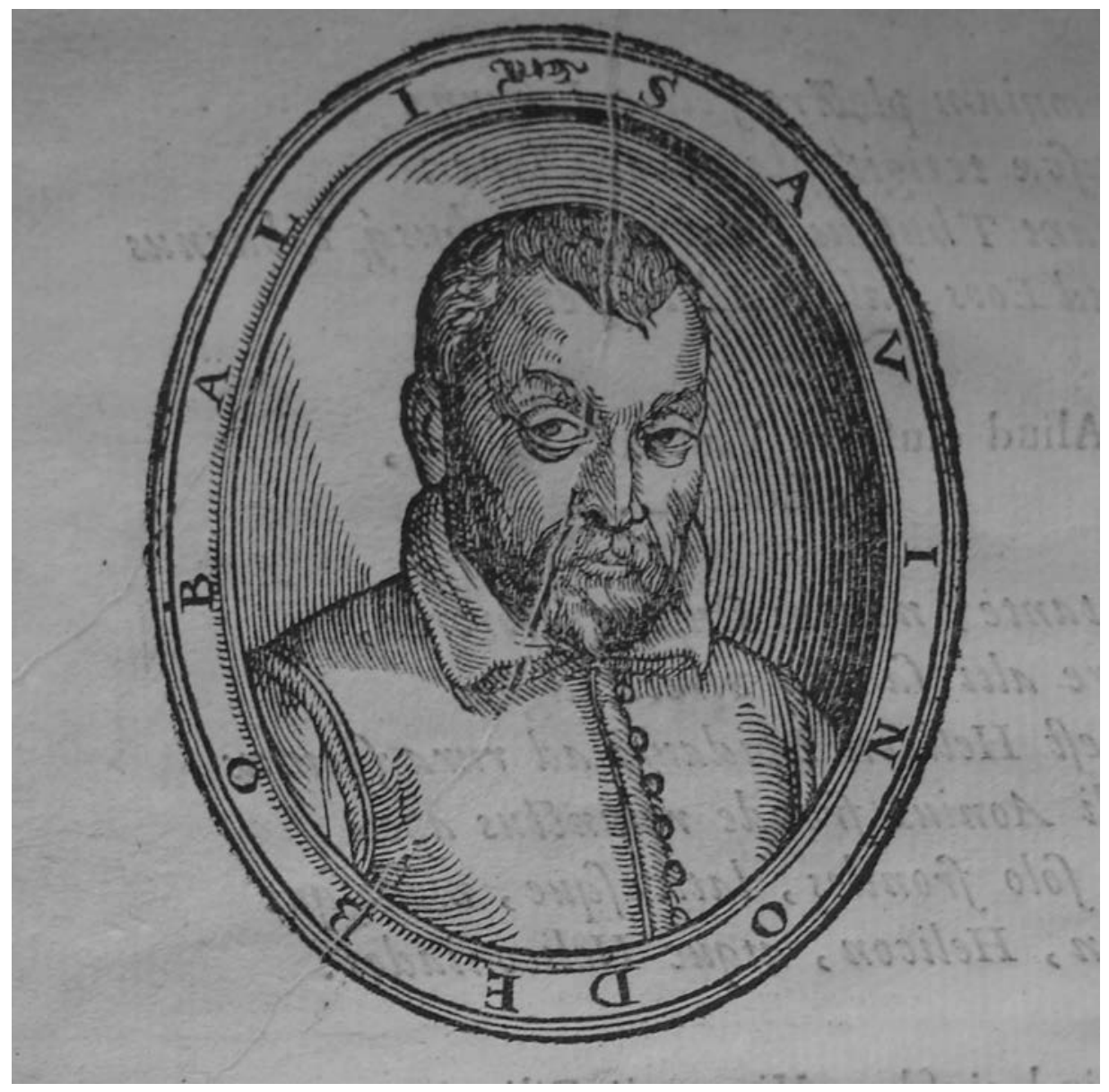

Il ritratto di Savino (Sabo) di Miho Bobaljević (1530-1585) da suo canzoniere Rime amorose, e pastorali, et satire, Venezia, 1629.

Savino (Sabo) di Miho Bobaljević (1530-1585) soprannominato il Sordo, scriveva in italiano e in croato. Il suo canzoniere "Rime amorose, e pastorali, et satire" fu stampato a Venezia (quattro anni dopo la sua morte) dai suoi fratelli Sigismondo e Marino. Nel canzoniere ci sono sonetti dedicati a diversi notabili italiani: Anibale Caro, Laura Battiferri, Domenico Venier, Benedetto Varchi, Lodovico Beccadelli e altri. Altri sonetti sono dedicati ai suoi contemporanei, suoi modelli e amici, poeti: Mavro di Dominik Vetranović (1482-1576), poliglotta Miho di Marin Menčetić - Matufić (ca 1523-1590), filosofo e poeta Matteo di Damiano Benessa (ca 1530-1599), scrittore giuridico Simone di Mateo Beneša (cca 1525-1596), a Marino di Marino Držić (1508-1567) e molti altri. Le sue poesie scritte in croato sono quasi tutte andate perdute. 
È conservato, invece, il "Lamento di Arianna” scritto in stile di Ovidio, versione libera dell'Amor fuggitivo di Tasso, la zingaresca Jeđupka e alcune poesie amorose. Sono pure conservate le sue epistole, le più importanti sono quelle dirette ai poeti Maroje Mažibradić e Mikša Pelegrinović. Egli era probabilmente il fondatore dell'Accademia dei concordi. Il poeta Antonio Sassi-Sassin lo elogia nelle poesie "Drugi san" (Altro sonno) e "U pohvalu pjesnika dubrovačkijeh" (In lode dei poeti ragusei). Un'epitafio in suo onore fu scritto da Dominik di Šimun Zlatarić (ca 1557-1613). Un altro epitafio gli fu dedicato da Miho di Marino Bunić/Bona - Babulinović (ca 1551-1617) e Michele Monaldi (“In morte del Sig. Savino Bobalio il Sordo").45

Era paziente di Amatus anche un figlio di Dragoje Crijević/Cerva, molto probabilmente Martolizza (ca 1537-1608), durante la cura aveva circa venti anni. Suo fratello Orsatto era un notabile diplomatico che difendeva Dubrovnik dalle accuse degli ambasciatori francesi e inglesi di aiutare gli spagnoli in funzione anti turca. Da 1599 fino a 1601 Orsatto fu alla corte del re di Spagna Filippo III la cui interposizione confermava i privilegi commerciali ragusei. ${ }^{46}$

Tra i pazienti di Amato c'era pure una figlia del mercante Dominik Kladorubović, discendente di un nobile bosniaco di Srebrenica. Domenico e sua moglie Deša, della famiglia di mercanti Radalj, ebbero parecchie figlie: Anica, Katarina, Frana (moglie di Šimun di Miho Zlatarić) e figli illegittimi: Jeronim, Secondo, Prudenzia e Nikola — benedettino vissuto sulle isole Tremiti. ${ }^{47}$ La paziente di Amato era probabilmente Anica ovvero Katarina, perchè Frana si era sposata nel 1555. ${ }^{48}$ Questa signora era madre di Dominik Zlatarić, giovane amico di Didaco Pirro il quale nel 1587 sposò Mara, quest'ultima plausibilmente figlia del pittore Pietro di Giovanni: la paziente di Amato, la cui cura è stata descritta, era la zia del pittore. ${ }^{49}$

Della casata Gundulić erano due pazienti di Amato: Marin Gundulić e figlio Benedikt Gundulić. Marino era probabilmente figlio di Ivan, nipote di Lujo (Luigi) di Dragoje Gučetić (Gozze), un ricco mercante di Ancona, noto per la commissione di una pala d'altare di Tiziano Vecellio per i francescani di Ancona. L’anonimo figlio di Benedik Gundulić potrebbe essere il figlio del ricco mercante di Ancona, in precedenza mercante raguseo a Londra. ${ }^{50}$

45 Nenad VeKARIČ, Vlastela grada Dubrovnika, 4..., op. cit., pp. 32-38.

46 Nenad VekARIČ, Vlastela grada Dubrovnika, 4..., op. cit., p. 298.

47 DAD, Testamenta de Notaria, X.1., vol. per l'anno 1568, fol. 7; DAD, Descrizione delle origini e Genealogie dei Cittadini Ragusei che furono in affito della Confraternita di San Antonio nei tre Secoli e più da che comincia la medesima che fù l'anno 1343 e seguita poscia la sua real fondazione come per consentimento del E.mo Maggior Consiglio della Republica di Ragusa che fù l'anno 1348 visino a tutto (...), fol. 277-280'.

48 DAD, Pacta matrimonialia, per la data 26. IV. 1555.

49 DAD, Famiglie Cittadine riconosciute dall'Ex Repubblica di Ragusa e loro descrizione, e parentele, pp. 189-191.

50 Nenad VEKARIČ, Vlastela grada Dubrovnika, 2. Vlasteoski rodovi (A - L). Zagreb-Dubrovnik, Zavod za povijesne znanosti HAZU u Dubrovniku, 2012, pp. 312-313. 
Dalla famiglia patrizia Gradić c'erano parecchi pazienti del nostro. Tra questi Junije di otto anni. Si tratta di Junije di Mato Gradić (1549-1594), donatore del dipinto del maestro di Anversa. Marten de Vos alla chiesa di S. Rocco a Grgurići nel 1586, era un voto contro la peste. Il nome di Giounio si trova scolpito nel giardino del palazzo dei Gradi a Dubrovnik, e il poeta Frano Lukarević (Luccari) Burina (ca 1541-1590), gli dedicò la traduzione della commedia pastorale "Pastor Fido" di Giovanni Battista Guarini (1592). Pavao Gradić è probabilmente figlio di Marin di Junije, curato da Amatus come anziano (ca 1478-1558), dieci volte Rettore della Repubblica di Dubrovnik. Intraprese una corrispondenza letteraria con Marino Santo di Barletta sul significato delle comete. ${ }^{51}$

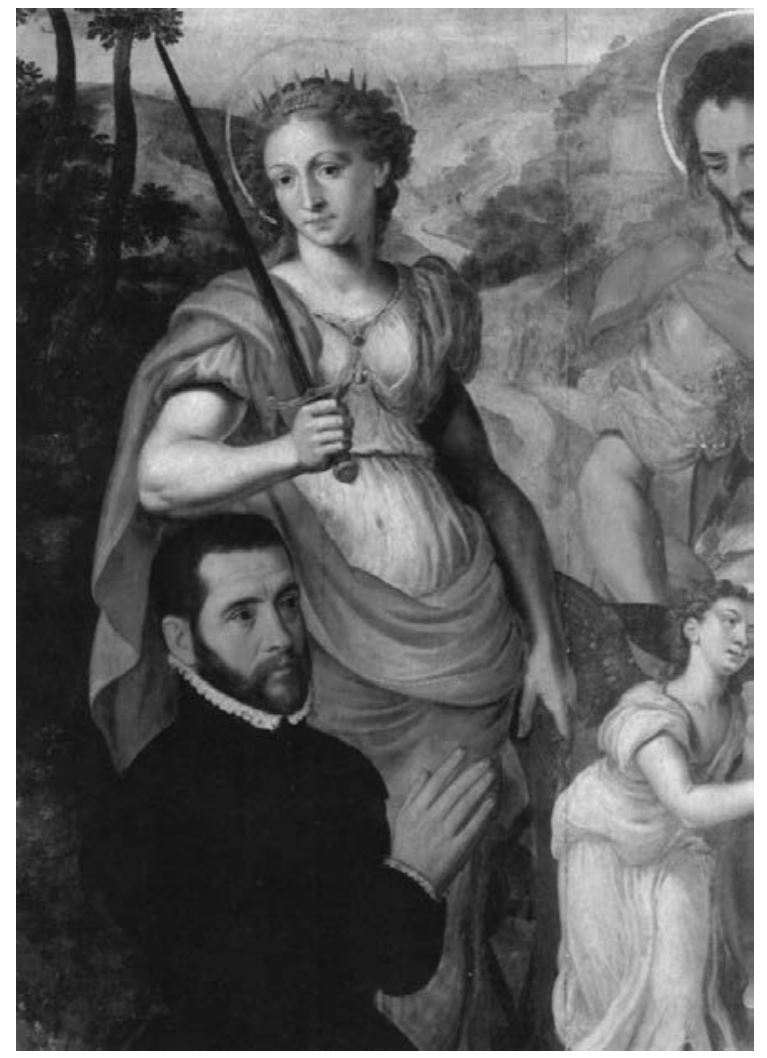

Marten de Vos, fiammingo pittore manirista (c. 1532-1603) dipinse la pala d'altare per la chiesa San Rocco in Grgurići vicino a Dubrovnik e sul quadro è il ritratto di Junije Matov di Gradić

51 Nenad Vekarıč, Vlastela grada Dubrovnika, 2..., op. cit., p. 281. 
Il paziente Marin Getaldić (Ghetaldi) era probabilmente Marin di Mato (ca 1499-1573) al tempo cinquantaquattrenne: da giovane nel 1595, quando fu conte a Trstenica, aveva scoperto e impedito una congiura dei Turchi per occupare la penisola di Pelješac (Sabioncello). ${ }^{52}$

Della famiglia patrizia Sorkočević (Sorgo) aveva come paziente moglie di Vlaho di Valentin (ca 1482-1591), mercante a Londra e quattro volte Rettore della Repubblica. Alle nozze di suo nipote Vlaho fu eseguita Grižula, la commedia del poeta Marino Držić, probabilmente nel $1556 .{ }^{53}$

Tra i più conosciuti pazienti di Amato a Dubrovnik era certamentte Šimun di Mato Beneša (ca 1525-1596) che nel 1554/5 era ambasciatore della Repubblica presso il re di Francia Enrico II e alla corte del Gran Turco a Costantinopoli. Durante quest'ultima missione nel 1563 fu accusato di essersi esibito con due cavalli e tre servitori e perfino di essere ceduto agli incantesimi di una donna turca. Nel 1591 egli scrisse un codice legale: "Praxis curiae ad firmam legum et consuetudinum Reipublicae Ragusinae". Savino di Miho Bobaljević gli dedicò due poesie e Didaco Pirro un poemetto. ${ }^{54}$

Il paziente di Amato era forse anche Nikola Gučetić (Gozze, 1549-1610), patrizio raguseo, membro delle Accademie perugine (degli Insensati e Occulti), autore di diverse opere filosofiche e letterarie: dialoghi platonici Della bellezza e Dell'amore, Discorsi su Meteori di Aristotele, Discorsi su sette Salmi penitenziali di Davide, Governo della famiglia, Dello stato delle repubbliche e Dialogo su immortalità e fortuna umana. L'intera opera di Nikola ebbe successo in diversi campi con le sue problematiche e rappresenta un contributo alla filosofia croata, in particolare alla riflessione estetica. È indubbio il suo contributo nel campo del neoplatonismo e neoaristotelismo rinascimentale. Il suo pensiero originale lo qualifica come precursore di nuove concezioni filosofiche. Anche sua moglie Maria si serviva dell'aiuto di Amato. ${ }^{55}$

Tra i cittadini delle regioni limitrofe curati da Amatus è menzionato il nobile di Cattaro Mato Paskalić (Pasquali), discendente di una nobile famiglia dalla quale proveniva anche il poeta croato Lodovico Pasquale (ca 1500-1551), già studente studiò a Padova, pubblicò in italiano una raccolta di testi intitolata Rime volgari di M. Ludovico Pascale da Cattaro Dalmatino, 1549, contenente 178 sonetti, 13 madrigali, 15 canzoni e numerose lettere. Una breve raccolta di rime in stile petrarchista con ventisei elegie fu pubblicata postuma dal suo amico e poeta italiano Lodovico Dolce (Ludovici Pascalis carmina ad Illustrissimum et Doctissimum

52 N. VEKARIČ, Vlastela grada Dubrovnika, 2..., op. cit., p. 154.

53 N. VeKARIČ, Vlastela grada Dubrovnika, 3. Vlasteoski rodovi (M-Z). Zagreb-Dubrovnik, Zavod za povijesne znanosti HAZU u Dubrovniku, 2012, p. 278.

54 N. VeKARIČ, Vlastela grada Dubrovnika, 4..., op. cit., pp. 96-97.

55 Nikola Vitov GuČetić, Dialogo della Bellezza/Dijalog o ljepoti i Dialogo d'amore/Dijalogo ljubavi. Zagreb, Matica hrvatska, 2008, pp. 1-321. 
Marchionem Austriae Bernardinum Bonifacium per Ludovicum Dulcium nunc primum in lucem edita. Venetiis apud Gabrielem Volitum et fratres de Ferrariis 1551). ${ }^{56}$

Da quanto detto, risulta che i pazienti identificati da Amato erano numerosi, soprattutto appartenenti all'alta borghesia e al patriziato di Dubrovnik e offrono molte informazioni sulle condizioni sanitarie e sociali dell'epoca a Dubrovnik.

\section{DIDACO PIRRO - DIOGO PIRES}

Didaco Pirro (Didacus Pyrrhus Lusitanus, ovvero Iacobus Flavius Eborensis), di nome vero Isaia Koen è un umanista portoghese e poeta scrittore latino. Nato a Evora il 5 aprile 1517 e morto a Dubrovnik il 16 maggio $1599 .{ }^{57}$ Si suppone che insegnasse in maniera privata alla gioventù ragusea, in particolare a coloro che frequentavano il ginnasio. ${ }^{58}$ Tuttavia tale ipotesi non trovano conferma dalle fonti archivistiche. È sicuro invece che le autorità ragusee gli commissionassero le traduzioni dei contratti commerciali dal portoghese ed ebraico in italiano, poi registrati presso l'ufficio notarile della Repubblica. ${ }^{59}$ Spesso era presente in occasioni di stipulazioni dei contratti commerciali. ${ }^{60}$ Visse in una casa privata presa in affitto sul litorale adriatico, poco prima di finire i suoi giorni nel ghetto. ${ }^{61}$ Le autorità ragusee ebbero una grande stima di lui, tanto da dispensarlo dall'obbligo di indossare il capello giallo o rosso. ${ }^{62} \mathrm{Nel}$ suo testamento Didaco Pirro lasciò due

56 Š. LJUBIĆ, Dizionario..., op. cit., pp. 239-240.

57 Bariša KREKIĆ, "The Role of the Jews in Dubrovnik (Thirtheen - Sixteenth Centuries)", in Bariša KREKIĆ, Dubrovnik, Italy and the Balkans in the Late Middle Ages. London, Variorum Reprints, 1980, pp. 257-271; idem, in Bariša KREKIĆ, Dubrovnik: a Mediterranean Urban Society, 1300 - 1600. Aldershot, Variorum, 1997, pp. 840, 842.

58 Toma KERŠA, Della vita e degli scritti di Didaco Pirro altrimenti detto lacopo Flavio Eborense. Commentario di Tommmaso Chersa. Firenze, nella stamperia Magheri, 1826; Antun PASARIć, "Pjesme Didaka Pira", Srđ, Dubrovnik, 1903, pp. 91-92, p. 141, pp. 184-186, pp. 215-218; Đuro KÖRBLER, "Život i rad humanista Didaka Pira Portugalca, napose u Dubrovniku", RAD JAZU, lib. 216 (1917), pp. 82-83; J. TADIć, Jevreji u..., op. cit., pp. 300-301.

59 DAD, Diversa de foris, vol. 3, fol. 131-133; Petar Kolendić, "Nekoliko pesama humaniste Didaka Pira", Zbornik istorije književnosti Odeljenja literature i jezika Srpske akademije nauka i umetnosti, lib. 2. Beograd, 1961, pp. 1-48; Miroslav Pantić, "Jevreji...", op. cit., pp. 211-238; D. Nevecić-Grabovac, "Iz poezije...", op. cit., pp. 253-290; Vesna Mıović, Židovski.., op. cit., p. 27.

60 DAD, Diversa Notariae, XXVI., vol. CXVIII, fol. 112'.

61 Đ. KörBLER, "Život...", op. cit., p. 80; V. Mıovıć, Židovski..., op. cit., p. 28.

62 DAD, Cons. Min., vol. 51, fol. 15v; V. Mıović, Židovski..., op. cit., p. 28. 
ducati ungheresi alla sinagoga di Ragusa. ${ }^{63}$ Il suo testamento conferma la sua natura di scrittore-ponte capace di collegare diversi mondi. ${ }^{64}$

Didaco Pirro studiò in prestigiose scuole in Portogallo e a Salamanca in Spagna. Fece molti viaggi in Inghilterra, Belgio, Italia, Constantinopoli. Intorno al 1558 venne a Dubrovnik dove insegnava lingue classiche stringendo relazioni di amicizia con quasi tutti i nobili di riguardo del suo tempo: Dominik Zlatarić, Toma Budislavić, Miho Monaldi e altri. Nel 1545 fu consacrato alla fama internazionale grazie alla prima raccolta di poesie latine intitolata Carminum liber unus, in cui rivela una propensione verso motivi erotici e soluzioni fantasiose abbastanza pretenziose. Diplomato e letterato, fu onorato da Girolamo Faletti che lo incluse nei tredici brani della sua raccolta di poesie (1546). Giglio Giraldi lo prese nel suo trattato pionieristico sulla letteratura neolatina (1551). Alla sua patria adottiva Didaco espresse gratitudine in un'epistola scritta in esametri e dedicata a Paolo Manuzio, figlio del famoso editore Aldo: Ad Paulum, 1563. Con lo stesso spirito nel 1582 scrisse anche la poesia De illustribus familiis quae hodie Rhacusae exstant, meritoria del premio del Senato ragusino. ${ }^{65}$ Una piccola raccolta intitolata Encomiastes la dedicò all'amico e mecenate Toma Budislavić. Un'altra raccolta di tipo educativo-morale, secondo il titolo ma non sempre secondo il contenuto, è Cato Minor sive dysticha moralia ad Ludimagistros Olyssiponenses, 1592. Dalla raccolta di elegie in tre libri col titolo Elegiarum libri tres, dedicata a Dominik Zlatarić, fu stampata solo una parte. Il De D. Blasio, Rhacusanae Reipublicae Patrone, Carmen rimase un manoscritto. All'inizio del manoscritto si trova l'epistola: "Didaco Pirro, Portoghese saluta Domenico Zlatarich, rettore dell'istituto d'educazione padovano e cavaliere serenissimo". L'epistola introduttoria diretta a Dominik Zlatarić rivela un sincero rapporto tra i due, come anche il sincero attaccamento di Didaco alla sua patria adottiva ove trovò la pace e la possibilità di un'attività indisturbata. Questo scritto appartiene alle sue opere tardive. ${ }^{66}$ Il nostrano Zlatarić (1558-1613), un personaggio importante del circolo letterario raguseo della fine del Cinquecento e l'inizio del Seicento, traduttore dell'opera Aminta di Tasso, allora

63 DAD, Test. Not., 10.1., vol.51, fol. 27'-28'; Moises Orfalı, "Pogled na društveni i duhovni položaj sefardskih Židova u Dubrovniku na temelju zapisa javnih bilježnika (xvI. - xVII. stoljećr)", Dubrovnik 3 (2009), pp. 62-93.

64 Darko Novaković, "Didak Pir", Hrvatski biografski leksikon, vol. 3. Zagreb, 1993, pp. 372-374; Carlos Ascenso ANDRÉ, Um judeu no desterro: Diogo Pires e a memória de Portugal. Coimbra, Centro de Estudos Clássicos e Humanísticos da Universidade de Coimbra - I.N.I.C., 1992; António Manuel Lopes ANDRADE, O Cato Minor de Diogo Pires e a poesia didáctica do século xvı. Lisboa, Imprensa Nacional-Casa da Moeda, 2014. idem, "Os Senhores do Desterro de Portugal: judeus portugueses em Veneza e Ferrara em meados do séc. xVI", Veredas. Revista da Associação Internacional de Lusitanistas 6 (2006), pp. 65-108; idem, "A fábula na obra poética de Diogo Pires", Ảgora. Estudos Clássicos em Debate 9 (2007), pp. 99-118.

65 DAD, Cons. Rog. III., vol. LXVII., fol. 180: "Prima pars est de donando Doctori Didaco ob opusculum nobis dedicatum ducatos au. quindecim. - $p$ XII v cXV".

66 Darko Novaković, Sveti Vlaho dubrovački parac u hrvatskoj književnosti, antologija; redazione: Luko Paljetak, Dunja FališEvc, Miljenko Foretić. Dubrovnik, Matica hrvatska Dubrovnik, 2001, pp. 25-31. 
studente a Padova, acquistò il manoscritto di Tasso pubblicandolo prima dell'autore stesso. ${ }^{67}$ L'amicizia di Didaco con il giovane Zlatarić, nata nello stesso anno di partenza del Lusitano da Dubrovnik, testimonia quanto questo intellettuale irrequieto fosse ben radicato nel nuovo ambiente. La poesia di Didaco è una fonte ricca di dati storico-culturali di Dubrovnik nella seconda metà del Cinquecento. Tra i ragusei che stringevano rapporti di amicizia con Didaco dobbiamo senz’altro segnalare Toma Budislavić (1545-1608), personaggio particolare, medico e vescovo, alunno delle Università di Bologna e Padova, che curava numerose persone notabili, come il sultano Muratto III. ${ }^{68}$ Incaricato dalla Santa Sede, si recò a Cracovia ove dimorò parecchi anni. Il vescovo di Cracovia Piotr Myszkowsky (1577-1591) lo nominò suo medico personale e poi canonico della diocesi. Nel circolo del vescovo Myyszkowski c'era anche Jan Kochanowski, uno dei più grandi poeti del rinascimento polacco. Due anni dopo il suo stanziamento in Polonia, furono conferite la dignità di nobile polacco e il titolo di medico regio a Tommaso Budislavić. Questo raguseo ebbe pure l'onore della dedica di un'opera del teologo polacco Stanislao Sokolowski. Il Budislavić sosteneva l'idea del panslavismo iniziata, a quanto pare, dal poeta di Dubrovnik Ilija Crijević-Cerva (1463-1529), seguito poi dal domenicano croato Vinko Pribojević. Durante il suo soggiorno a Cracovia Budislavić pubblicò una poesia in onore di Dubrovnik e della festività di S. Biagio, scritta da Didaco Pirro De illustribus... con la dedica all'autore. Lo stesso Didaco Pirro aveva pubblicato a Venezia prima della partenza di Budislavić in Polonia, un libretto con versi latini in onore di Dubrovnik. In Polonia a quel tempo la fama di Dubrovnik continuava a consolidarsi, grazie alla sua condizione di piccolo Stato cattolico e libero dal ruolo chiave nelle relazioni diplomatiche con l'Impero Ottomano. A questo scopo il Budislavić fece ristampare in sei varianti il libretto del suo amico Didaco Pirro, aggiungendovi alcune poesie proprie. ${ }^{69}$

In ogni modo, Amatus Lusitanus e Didaco Pirro sono due personaggi interessanti della seconda metà del Cinquecento che hanno lasciato una traccia duratura nella storia culturale di Dubrovnik e nella cerchia umanistica ragusea.

67 Torquato TASSO, Ljuvene rane/Le piaghe d'amore, antologija hrvatskih prepjeva u povodu 400. obljetnice pjesnikove smrti, redazione Mirko Tomasović. Dubrovnik, Matica hrvatska, 1995, pp. 10-11.

68 Jorjo TADIć, Dubrovački portreti, vol. I. Beograd, Srpska književna zadruga, 1948, p. 355; Vinicije B. LuPIS, Dubrovnik i Poljska. Zagreb, Veleposlanstvo Republike Poljske u Zagrebu, 2005, p. 36.

69 Đ. Körbler, "Život...", op. cit., pp. 1-116; Anutn Kolendić, "Šest latinskih knjižica štampanih u Krakovu u čast Dubrovčanina Tome Natalisa Budislavića", Zbornik istorije književnosti Odelenja literature jezika Srpske akademije nauka i umetnosti, Lib. 3. Beograd, 1962, pp. 211-243, V. B. LuPIS, Dubrovnik..., op. cit., pp. 36-39; Š. LJUBIĆ, Dizionario..., op. cit., 1856, p. 255: "PIRRO FLAVIO GIACOMO (Didaco) ebreo, naque Evora nel Portogallo 1517. Espulso dalla patria, scorse l'Inghliterra, la Francia, il Belgo, la Svizzera, l'Italia, la Grecia, l'Egitto e buone parte dell'Asia, indi si ridusse in Ragusa, ove visse fino alla morte. Fu poeta latino tra primi del suo secolo, Una parte de'suoi carmi uscì alla luce nel 1852 presso Tommaso Natali in Cracovia, ristampati nel 1592 in Venezia sub signo leonis, e nel 1596 presso Felice Valriso. Le poesie inedite hanno un tal titolo: Didaci Pirrhi Lusitani elegiarum Libri III. ad D. Slatarichium Patav. Scholae rectorem et equitem splendissimum; accessit Lyricorum libellus eodem auctore." 


\section{BIBLIOGRAFIA}

\section{A. FONTES}

\section{Manoscritti e libri dello Didako Pir a Dubrovnik}

\subsection{Znanstvena knjižnica Dubrovnik:}

N. 217. "Jacobi Flavii Eborensis seu Didaci Pyrrhi Lusitani Carmina" "Elegia I Solimani Laudes" s napomenom pisanom olovkom "Didaci Pyrrhi stampata dell'Appendini”, "De illustribus familiis queae hodie Rhacusae extant, anno 1582. Cal. Ian. Ad amplissimum Senatum Rhacusanum (...)”, "De illustrissima urbe Rhacusa”.

N. 215. "Urbano Lampredio viro ubique gentium clarissimo Antonius Chersa Fratris sui Commentarium de vita et scriptis Flavii Iacobi Eborensis D.D.D. Elegia, Parve liber, prodi; jam prodi lucis in oras".

\subsection{Zavod za povijesne znanosti HAZU - Dubrovniku:}

N. D. a. 5. Commentarius Ludovici Cervarii Tuberonis de origine et incremento urbis Rhacusanae eiusdemque ditionis descriptio auctore Nicolao Joannis de Bona et Stephani Gradi antiquitatum Rhacusanarum brevis diatriba. His accedit de illustribus familiis, quae Rhacusae extant, ad amplissimum senatum elegia Didaci Pyrrhi. Cum notis et supplementis. Rhacusii 1790 typis Andrea Trevisan.

N. D. a 18, pag. 249 listova dall fine xviri. secolo; 3 - 12 i 18 - 21: Jacobi Flavii Eborensis, / seu / Didaci Pyrrhi Lusitani / De Rhacusinae Urbis Laudibus / Carmen / quod habetur in Bibliotheca / Vaticana / inter Numero / 113333.

N. D. a. 29., "Ex Libris Antonii Luce de Sorgo": DIDACI / PYRRHI LVSITANI / ELEGIARVM LIBRI TRES / AD DOMINCVM SLATAEICCIVM PATA - / VINAE SCHOLAE RECTOREM ET EQVITAEM SPLENDIDISSIMVM / ACCESSIT LYRICORVM LIBELLVS EODEM AVCTORE: Elegia I. (“Ite procul...”), Elegia II (“Jam neque...”), Elegia III. (“Ergo ego...”), In Nuptiis Virginis Mandotiae et Petri Albani Elegia IIII., Ad Vincentium Porticum Rhacusanum Antistitem Elegia V., Elegia VI. (“Mamertina Chloe...”), Ad Nicolaum Gozzium Elegia VII., De origine domus Mensiae Elegia VIII., Elegia IX., (“Aegra iacet...”), Elegia X. Ad Simonem Benessium misit cum hor Hendecasyllabo, Hospes et Ianua Elegia CI. - Liber secundus. Ad Benessum. Elegia I., Elegia II. in obitum Mariae Gondulanae foeminae lectiss ad Georgium Gozzium illius uirum, De serrana Alpina. Elegia III. Ad Tassum poetam Tassi f. Elegia IIII., In qymnastica Mercurialis, Elegia V., Elegia VI. De origine Domus Saraccae apud Rhacusanos ad Joannem Saraccam equestris ordinis uirum, De commentarijs Indiae Medici 
Veronensis ad Dominicum Slatariccium iuuenem clariss. Et equestri dignitate insignem., Elegia VII., Elegia VIII., De ultimis Portugalliae Regibus qui aetate meae uixere, De Lusitanorum tumulo in urbe Ferraria. Elegia VIII., Momus ad Luccarum. Elegia X., Elegia XI. (“Quae belli...”) - Liber tertius. Elegia I. sub nomine Galli ueteris poetae edita, In obitum Joannae Etruriae Reginae, Elegia II., Elegia III. (“Non mihi smper...”), Michaeli Mensio Senatori grauiss et Aerarij IIII uiro S.D. - (In Mauri Vetrani Poetae Illyrici obitum. Elegia IIII., Elegia V. ad Proculianum astrologum, Ad Francinnum. Elegia VI. In obitum Nicaeae Paulii u. Manuccium Tuscar. Rer. Scriptorem, Ad Joannem Pinellium Ligurem Ode I., Ad Nicandrum Ode II., Ode III., (“Collige membra...”), Ad Lucium Lusitanum Ode IIII, In obitum Maurij poetae Illyrici scripsit postridie Kal. Feb. Ode V., De Urbe Rhacusa. Ode VI., Ad uirum clarissiumu Chysostomum Calabrum Antistitem Rhacusanum Ode VII. - lirica eiusdem Auctoris. Ad Aldumxoris Elegia VII., In Pulicem Elegia VIII., Renunciat amoribus Elegia IX., Elegia X. de exilio suo scripsit Nouae oppido Dalmatiae Hispanica clade nobilissimo. - Lirica eiusdem Auctoris, Ad Aldum Manuccium Tuscar. Rer. Scriptorem, Ad Joannem Pinellium Ligurem Ode I, Ad Nicandrum Ode II, Ode III (“Collige membra...”), Ad Lucium Lusitanum Ode IIII, In obitum Maurij poetae Ullyrici scripsit postridie Kal. Feb. Ode V. De Urbe Rhacusa. Ode VI., Ad uirum clarissimum Chrysostomum Calabrum Antistitem Rhacusanum Ode VII., Ad Giraldum senem Ode VIII., De nauicula Petri sub Gregorio XIII PM. Ode IX., De Tristano Cunio regis Portugalliae legato ad Leonem X. Pont. Max. Ode X., De Urbe Rhacusa pestilentia laborante, Ode XI. - Tabula omnium elegiarum et lyricorum libricorum libri secundam ordinem alphabeticum. Divus Blasius / Rhacusanus / Didaco Pyrrho Lusitano / Auctore, Didacus Pyrrhus Lusitanus Dominico Slatariccio Patavinae Scholae Rectori, et Equiti splendissimo S. D. - proza, Ad Divium Blasium, D. Blasius. 


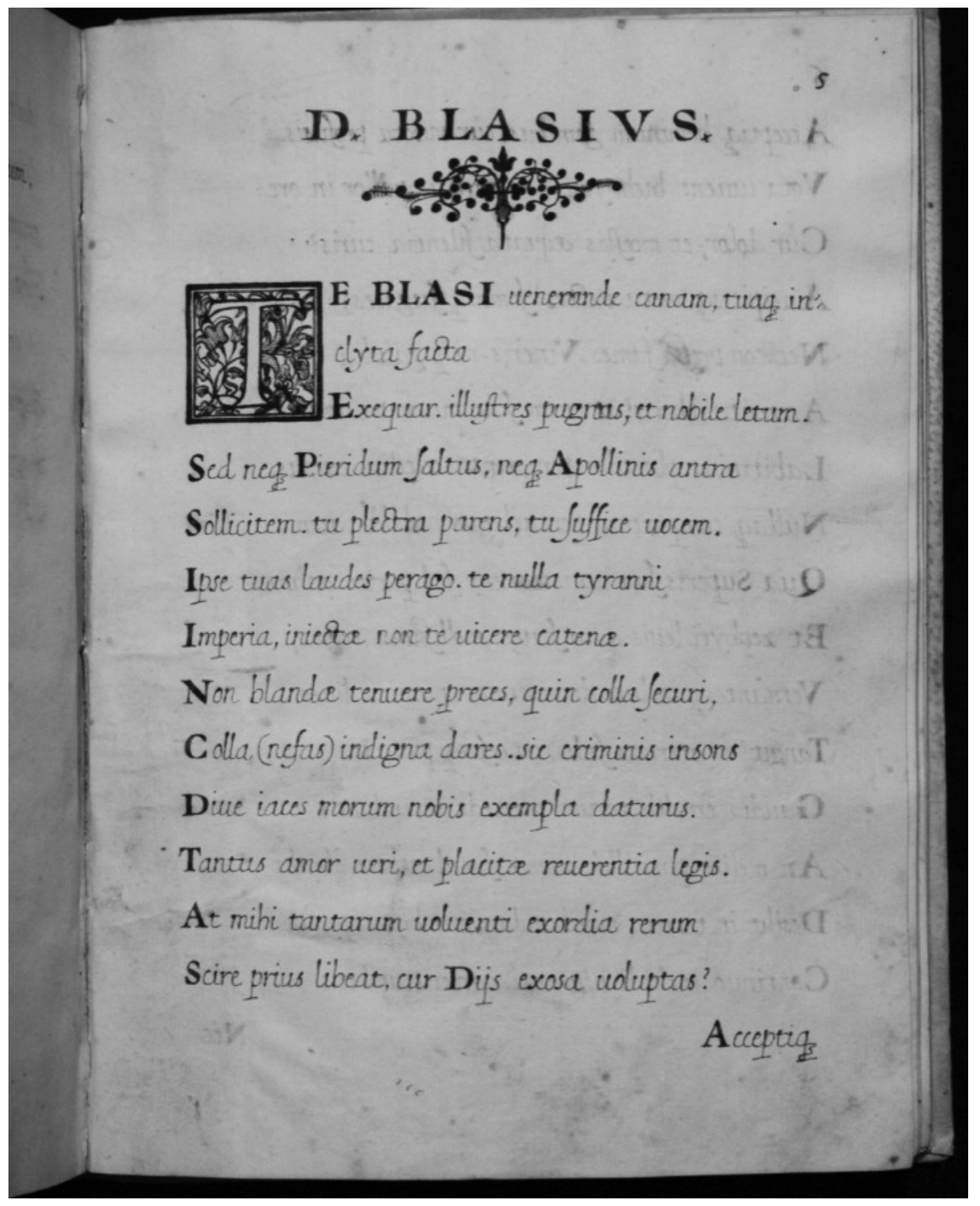

N. D.a. 40. Marko Bruerović, Volgarizzamento di varie poesie latine - Džono Restić, Carmina): Variorum auctorum / Latina Carmina / Italicis versibus reddita / à Marco Bruerio / Cive Gallo. Ili: Volgarizzamento / di varie Poesie Latine / d'Autori diversi / tradotte in verso Volgare / da Marco Bruere / Cittadino Francese.

\subsection{Franjevački samostan Male braće- Dubrovnik}

N.162. Antun Kerša/Chersa (1779. - 1838.), "Urbano Lampredi Anti. Chersa fratris sui Commentarium de vita et scriptis Flavii Jacobi Eborensis... elegia”. 


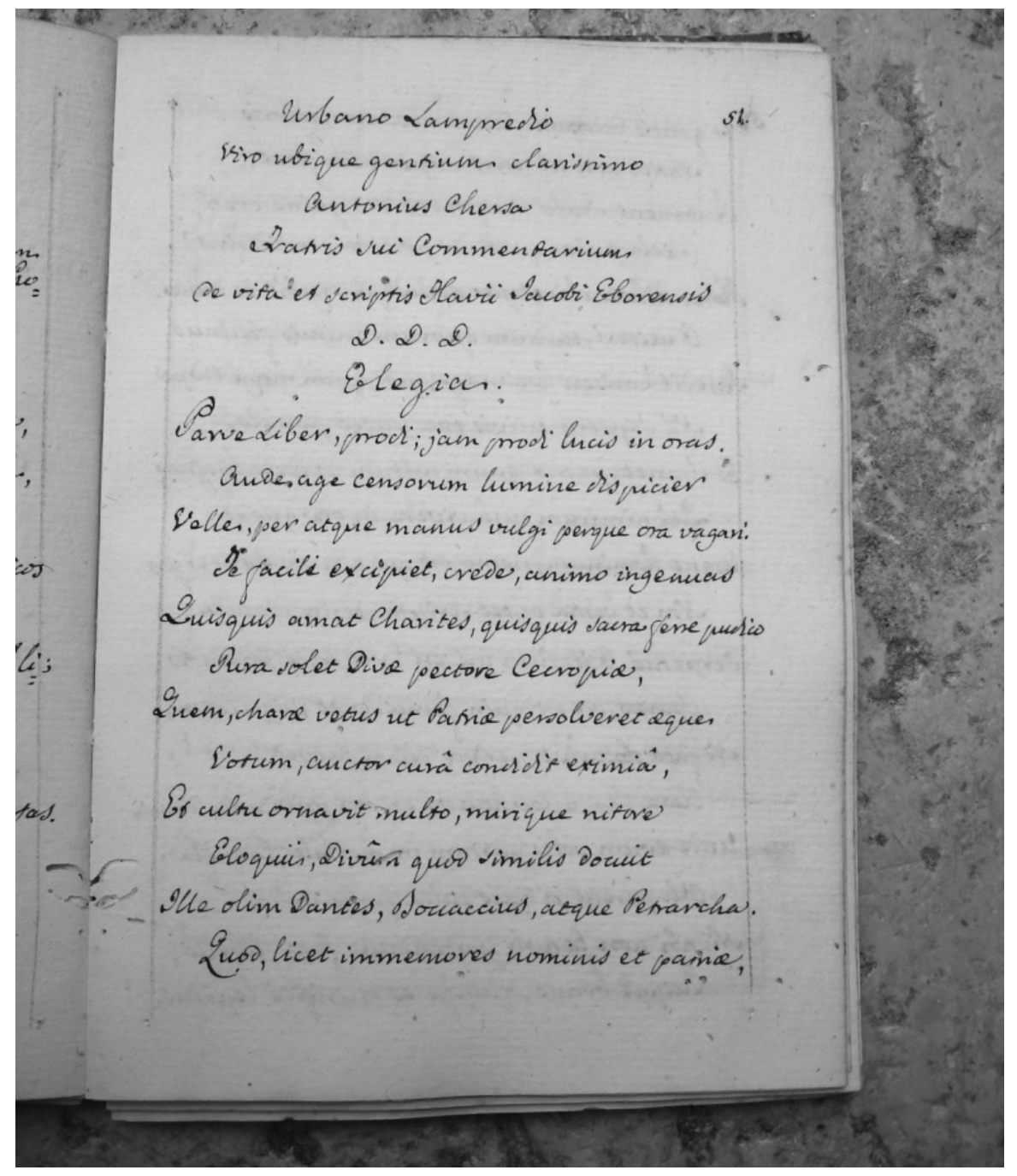

N. 228. "Flavii Jacobi Eborensis ac Didaci Pyrrhi Carmina, MS Aloysii Garmogljesi. Rhacusae Anno Domini 1806”, Scripsi die 19. decembris 1806.”: "Flaviii Jacobi Eborensis Cato Minor, sive Disticha Moralia ad ludimagistros Olysipponenses. Accessere Epigramata, et moralia noñulla eodem auctore, quae sequens pagella indicabit. Opus pium, ac erudiendis pueris apprime necessarium. Venite filii, audite me, timore Domini docebo vos, Osal. 33". Flavius J. Eborensis olysipponensibus ludimagister. S.D. Flavius Jacobus Joanni typographo S.D.

Ad Vicentium Gilianum, In obitum Francisci Medicis Magni Etrurie Ducis, Lactantii monaci Cassinati ad christianum puerum pia exhortio, Acia Monti theologi Hispalensis, Theopili Allobrogis apud Bituricenses ludimagistri, Henrici Angli Jesuitae e Seminario Augustano Gulielmi Budaei adolescentis, Antonii Fulgosii 
Liguris, Dionisyii Hedui D. Germani Abbatis, Valdaurae Medici Valentini in Jacobi Xenia, Martini Gamboae theologi Cantabri carmen.

Praefatio in I. lib. Moralium Distichorum. Ad Antoinum Medicen Capellum Francisci Magni Etruriae D. F. Ad Lectore,

Moralium Distichorum lib. I.

Moralium Distichorum lib. II. Praefatio in II. libr. Ad Ant. Medicen Franc. Magni Etruriae Ducis F. Ad lectorem. Moralium distichorum lib. II.

Moralium Distichorum lib. III. Ad Marinum Bonum patricium ragusinam et senatorem petit sibi commodori Secundi Hagiensis carmina.

Moralium Carminum lib. I. Ad Antonium Medum S.D. Ad eumedum, Fugienda vita et amplectenda virtus, Ad Marcellum de vita brevitate, Qui vere vitalem vitam agit, Vera felicitas in quo consistat, Et erit sicut arbor plantata etc. Ex. I. Ps., Fortunae volubilitas, De Nicolao modestissimo adolescente primam missam celebrante i D. Blasiii aede, Temporis jactura maxima ex Cuspiniano avaro hypocrita, Boni judicis officum, De Regno et publica, Qui vere felix, Unusquisque fortunae suae faber, Epigrammatum libellus ad Ioannem Darsam, De sacello Virg. Rosarii, quod Ragusae constructum est an. 1594., De urbe Rhacusa ab egregio pictore expressa, Ad Matthaeum Benessam Rhacusanum rectorem, Ad eundem, Gratulatur Dominico Slatarichio nobili juveni et Patavinae inscribendum.

Hendecasyllabi: In Gallum poetam maledicum, Ad Thomam, De Portico Rhacusano epo, Vinosii hendecasyllabi ad Matthaeum Benessam V.C., Ad Battidurum, Ad Musorium, Ad Matthaeum Benessam, Ad Simonem Benessam vindemiantem, Ad Aldum Manucium Tuscarum rerum scriptorem.

Lyrica: Ode I. In obitum Mauri poetae Illyrici, ode II. De Urbe Rhacusa, Ode III. De eadem Urbe pestilentia laborante ad Hieronymum Cervinum (...), Ode IV. Ad Michaelem Bonum.

Tumuli: Ad lectorem, Ad P. Maurum Melitensem Abbatem, Dominici Cervii epitaphium, simonis Aurii Michaelis Fili et Catharinae matris Epitaphium (...), Gregori Natalis OP epitaphium, Fr. Bonifatii epitaphium, Mauri Vetranii epitaphium, Marci Rhanniae rag. Archidiaconi epitaphium, Aliud in eundem.

De illustribus familiis: De illustribus familias quae hodie rhacusae extant an. MDVC. Cal. Jan., Due epigrammata Dominico Slatarichio.

Elegiarum lib. III.

Elegiarum lib. I. Elegia I., El II., El. III., Elegia IV., In nauptiis virginis Mandotiae et Petri Albani, Elegia V. Ad Vincentium porticum rag. Antistitem, Elegia VI., Elegia VII. Ad Nicolum Gozzium, Elegia VIII. De origine domus Mensiae, Epigramma, Elegia IX., Elegia X. quam poeta misit ad Simonem Benessam cum hoc hendecasyllabi. Ad eundem epigramma, Elegia XI. Dialogismus inter hospitem et januam.

Lib. II. Eleg. I. Ad Benessum, Elegia II. In obitum Mariae Gundulanae ad Gregorium Gozzium illius virum, Elegia III. de Serrana Alpina, Eleg. IV. Ad Tassum poetam Tassi filium, El. V. In gymnastica mercurialis, Elegia VI. Ad Joannem Saraccam de origine domus Saraccae apud Rhacusanos, El. VII. Ad Dom. Slatarichium de Commentariis Indiae Medici Veronensis.

De ultimis Portugalliae regibus qui aetate mea vixere argumentum 
Eleg. VIII., Eleg. IX. De Lusitanorum tumulo in urbe Ferraria, El. X. momus ad luccarum, El. XI. Epigramma ad Dominicum Rhaniam.

Lib. III. Eleg. I. Sub nomine Galli veteris poetae edita, El. II. In obitum Joannae Etruriae reg., Epigramma de duabus sororibus, Ambrosio Morali Cordubensi S. D., El. III., El. IV. In Mauri Vetrani poetae illyrici obitum, El. V. Ad Proculianum astrologum, El. VI. Ad Francinnum, El. VII. In obitum Nicolae Pauli uxoris, El. VIII. In Vulicem, El. IX. Renunciat amoribus, El. X. De exilio suo. Scripsit Novae oppido Dalmatiae hispanica clade nobilis.

Lyrica: Ode I. Ad Ioannem Pinellium Ligurem, ode II. Ad Nicandrum, Ode III., Ode IV. Ad Lucium Lusitanum, Ode V. Ad Giraldum Senem, Ode VI. De navicula petri sub Gregorio XIII., Ode VII. De Tristano Cunio regis Portugalliae legato ad Leonem X.

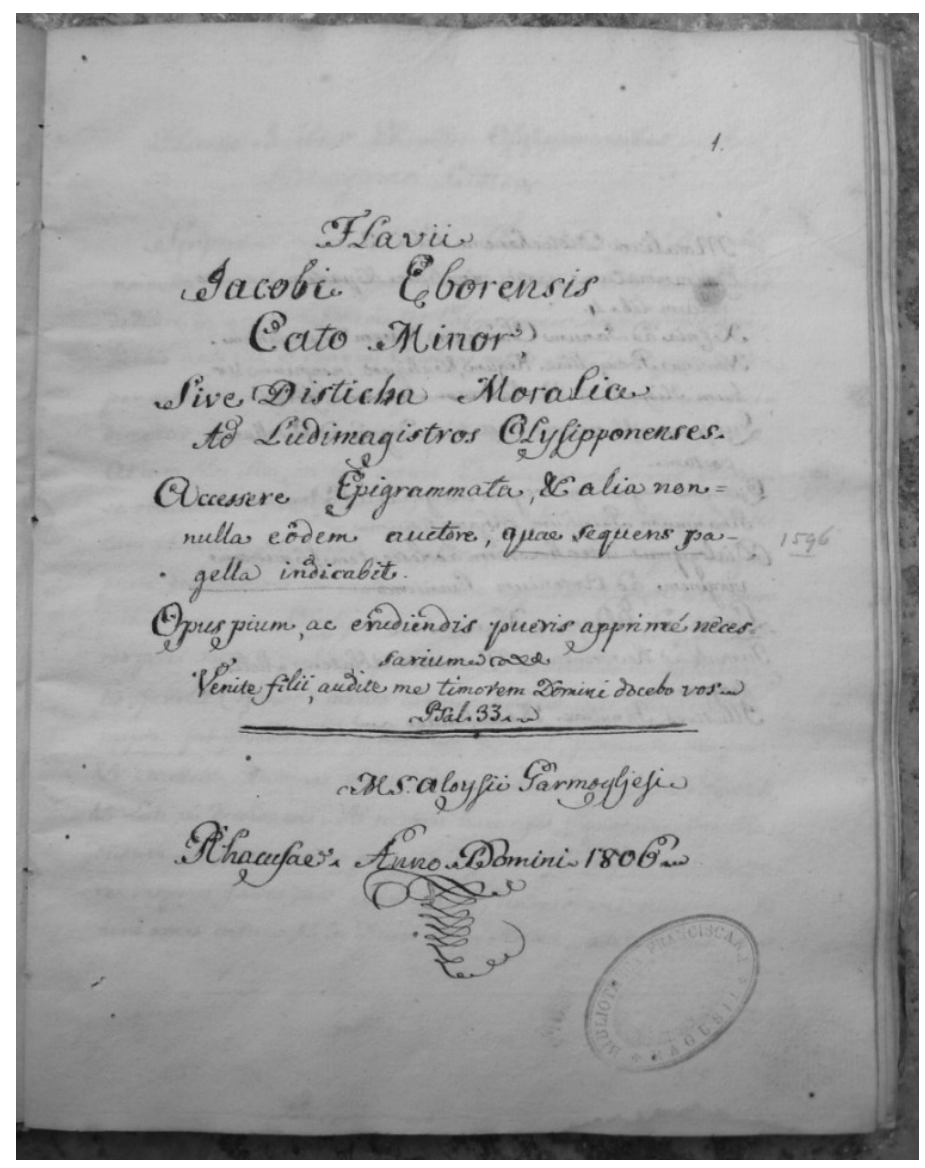

NN. 453., Zibaldone III, Memorie storiche su Ragusa raccolte dal P. Gian Maria Mattei. 


\subsection{Državni arhiv a Dubrovnik}

DAD. XXI. 2. Memoriae - Cronache - Diarii - Manuscripta diversa - Curiosa, N. 42: Jacobi Flavii Eborensis, seu Didaci Pyrrhi De Ragusinae Urbis Laudibus Carmen, Inscriptum habetur in Bibliotheca Vaticana/ inter miscellanea typis vulgatorum/ Volumine quod insignitur numero 11333./ Ferrariae/ Apud Valentem Panizzam Mantuananum/ Ducalem Typographium/ 1563.

DAD. XXI. 2. Memoriae - Cronache - Diarii - Manuscripta diversa - Curiosa, N. 69. De Didache Pirro, Appunti, estratte ex.

DAD. XXI. 2. Memoriae - Cronache - Diarii - Manuscripta diversa - Curiosa, N. 95. T. Chersae de Didaci Pirri Commentario: (...)Hic Accedit de Illustribus Familis, quae Rhacusae Extant ad Amplissimum Senatum Elegia Didaci Pyrrhi. Cum notis Suplementis(...).

R 742 copia dalla biblioteca Raczyńskich da Poznanj, copiata da Władisław Gluck: ENCOMIASTES / CARMINE ELEGIACO / AD RNDUM D. THOMAM NATALEM / Rhacusianum, Art. \& Medic. Doctorem / praestantissimum, necon Ca- / nonicum Cracuien. / dignissimum. / CRACOVIAE / In officina Lazari. Anno Domini / M.D. LXXXIII.

R 265b DELLA / VITA E DEGLI SCRITTI / DI / DIDACO PIRRO / ALTRAMENTI DETTO / IACOPO FLAVIO EBORENSE; / COMENTARIO / DI / TOMMASO CHERSA / FIRENZE / NELLA STAMPERIA MAGHERI / 1826.

R 350 COMMENTARIOLUS / LUDOVICI CERVARII TUBERONIS / De Origine \& incremento Urbis Rhacusanae / EJUSDEMQUE DITIONIS DESCRIPTIO / AUCTORE / NICOLAO JOANNIS DE BONA, / ET / STEPHANI GRADI / ANTIQUITATUM RHACUSANARUM BREVIS / DIATRIBA / His accedit de illustribus Familiiis, quae Rhacusae extant / ad amplissimum Senatum / ELEGIA DIDACI PYRRHI / Cum notis \& Supplementis. / THACUSII MDCCXC. / TYPIS ANDREAE TREVISAN. Indietro e elegia: DE ILLUSTRIBUS FAMILIIS, QUAE RHACUSA/ EXTANT AD AMPLISSIMUM SENATUM DIDACI PYRRHI/ ELEGIA.

\section{B. BIBLIOGRAFIA:}

Amati Lvsitani, Curationum medicinalium, Centuriae duae, Quinta et Sexta (...). Lugduni, apud Gulielmum Rouillium, 1564.

Andrade, António Manuel Lopes, O Cato Minor de Diogo Pires e a poesia didáctica do século Xvi. Lisboa, Imprensa Nacional-Casa da Moeda, 2014.

Andrade, António Manuel Lopes, “Os Senhores do Desterro de Portugal: judeus portugueses em Veneza e Ferrara em meados do séc. xvi”, Veredas. Revista da Associação Internacional de Lusitanistas 6 (2006), pp. 65-108. 
Andrade, António Manuel Lopes, "A fábula na obra poética de Diogo Pires", Ágora. Estudos Clássicos em Debate 9 (2007), pp. 99-118.

Andrade, António Manuel Lopes; Crespo, Hugo Miguel, "Os inventários dos bens de Amato Lusitano, Francisco Barbosa e Joseph Molcho, em Ancona, na fuga à Inqusição (1555)”, Ágora. Estudos Clássicos em Debate 14.1 (2012), pp. 45-90.

André, Carlos Ascenso, Um judeu no desterro: Diogo Pires e a memória de Portugal. Coimbra, Centro de Estudos Clássicos e Humanísticos da Universidade de Coimbra - I.N.I.C., 1992.

Anselmi, Sergio, "Motivazioni economiche della neutralità di Ragusa nel cinquecento" in Antonio Di VIttorio, Sergio Anselmi, Paola Pierucci, Ragusa (Dubrovnik) una repubblica adriatica. Saggi di storia economica e finanziaria. Bologna, Cisalpino, 1994, pp. 25-34.

Appendini, Francesco Maria Notizie istorico-critiche sulle antichità, storia e letteratura de'Ragusei, vol. II. Ragusa, dalle stampe di Antonio Martecchini, 1803.

Braudel, Ferdinand, Civiltà e Imperi del Mediterraneo nell'età di Filippo II. Torino, Einaudi, 1982

Brlek, Mijo, "Lodovico Beccadelli”, Hrvatski biografski leksikon, sv. I. Zagreb, 1983, pp. 562 - 565.

Bülent, Ari, "1. Appendix to the text "An Influental Jew on the Ottoman Court: David Pass": in Mirjana Polić Bobić (ed.), Tajna diplomacija u Dubrovniku u xvi. Stoljeću. Zagreb, Sveučilište u Zagrebu, 2011, pp. 194-198.

Carter, F. W., Dubrovnik (Ragusa). A Classic City-State. London-New York, Seminar Press, 1972.

DugačKi, Vladimir, “Amatus Lusitanus", Hrvatski biografski leksikon, vol. I. Zagreb, 1983, p. 237.

Efron, Z., "Jevrejski nadgrobni spomenici u Dubrovniku”, in Zbornik Židovskog muzeja 1 (1971), pp. 337-340.

Far lati, Daniele, Illyricum sacrum, vol. VI. Venezia, 1800.

Freiberger, Šalom, “Povijest Židova u Dubrovniku do izgona god. 1515.”, Omanut 1 (1936), pp. 30-37.

Ginsberg, David, "Mletački rabin Leo de Modena i dubrovački pjesnik Vinko Komnenović", Omanut, 10 (1940), pp. 156-161.

Glesinger, Lavoslav,“Dvije studije o Amatusu Lusitanusu”, Židov, vol. I, 20 (1937), p. 83.

Glesinger, Lavoslav, Amatus Lusitanus i njegov lječnički rad u Dubrovniku (1556-1558). Zagreb-Beograd, Biblioteka Jevrejskog narodnog kalendara, 1940.

Glesinger, Lavoslav, "Amatus Lusitanus i njegov liječnički rad u Dubrovniku (1556-1558)”, Omanut 3-4 (1940), pp. 61-62.

Glesinger, Lavoslav, "Dubrovački lječnik - prvi borac protiv progona vještica”, Zaštita zdravlja 3 (1948), pp. 106-107.

GLesinger, Lavoslav, “Dubrovački lječnik Amatus Lusitanus”, Zbornik Židovskog muzeja 1 (1971), pp. 291-312. Gučetıć, Nikola Vitov, Dialogo della Bellezza/Dijalog o ljepoti i Dialogo d’amore/Dijalog o ljubavi. Zagreb, Matica hrvatska, 2008.

Gušić, Mirjana, "Neki primjerci tekstila u zbirci sinagoge jevrejske općine u Dubrovniku”, Zbornik Židovskog muzeja 1 (1971), pp. 325-336.

Harris, Robin, Povijest Dubrovnika. Zagreb, Golden marketing-Tehnič ka knjiga, 2006. 
Hrabak, Bogumil, “Jevreji u Albaniji od kraja XIII do kraja Xvir veka i njihove veze s Dubrovnikom”, Zbornik Židovskog muzeja 1 (1971), pp. 55-97.

Jeremić, Risto; Tadić, Jorjo, Prilozi za istoriju zdrastvene kulture starog Dubrovnika, vol. 2. Beograd, 1939.

KeršA, Toma, Della vita e degli scritti di Didaco Pirro altrimenti detto Iacopo Flavio Eborense. Commentario di Tommmaso Chersa. Firenze, nella stamperia Magheri, 1826.

Kolendić, Petar, "Nekoliko pesama humaniste Didaka Pira”, Zbornik istorije književnosti Odeljenja literature i jezika Srpske akademije nauka i umetnosti, lib. 2. Beograd, 1961, pp. 1-48.

Kolendić, Anutn, "Šest latinskih knjižica štampanih u Krakovu u čast Dubrovčanina Tome Natalisa Budislavića”, Zbornik istorije književnosti Odelenja literature jezika Srpske akademije nauka i umetnosti, lib. 3. Beograd, 1962, pp. 211-243.

Körbler, Đuro, “Život i rad humanista Didaka Pira Portugalca, napose u Dubrovniku”, RAD JAZU, lib. 216 (1917), pp. 1-169.

Krasić, Stjepan; Razzi, Serafino, Povijest Dubrovačke metropolije i dubrovačkih nadbiskupa (X. - XVI. stoljeća). Dubrovnik, Biskupski ordinarijat, 1999.

KReKIĆ, Bariša, "The role of the Jews in Dubrovnik (thirteenth-sixteenth centuries)", Viator (Medieval and Renaissance Studies) 4 (1973), pp. 257-272.

Krekić, Bariša, “The role of the Jews in Dubrovnik (thirtheen-sixteenth centuries)”, in Bariša Krekić, Dubrovnik, Italy and the Balkans in the Late Middle Ages. London, Variorum Reprints, 1980, XXI, pp. 257-272.

Krekić, Bariša, Dubrovnik: a Mediterranean Urban Society, 1300-1600. Great Yarmouth, 1997.

Ljubić, Šime, Dizionario biografico degli uomini illustri della Dalmazia. Beč, 1856.

Lupis, Vinicije B., Dubrovnik i Poljska. Zagreb, Veleposlanstvo Republike Poljske u Zagrebu, 2005.

Miović, Vesna, Židovski geto u Dubrovačkoj Republici (1546-1808). Dubrovnik-Zagreb, HAZU, Zavod za Povijesne Znanosti u Dubrovniku, 2005.

Monster, Ladislav, "Proces zbog "ritualnog ubistva" u Dubrovniku 1502 godine i tragična smrt lekara Moše Maralija”, Zbornik Židovskog muzeja 1 (1971), pp. 99-112.

Mortidjija, Tias, “Židovi u starom Dubrovniku”, Hrvatska straža 6 (1934), pp. 221-225.

Nevenić-Grabovac, D., "Iz poezije Didaka Pira”, Zbornik Židovskog muzeja 1 (1971), pp. 253-290.

Nova ković, Darko, “Didak Pir”, Hrvatski biografski leksikon, vol. 3. Zagreb, 1993, pp. 372-374.

Novaković, Darko, Sveti Vlaho dubrovački parac u hrvatskoj književnosti, antologija; redazione: Luko Paljetak, Dunja Fališevc, Miljenko Foretić. Dubrovnik, Matica hrvatska Dubrovnik, 2001.

Pantić, Miroslav “Jevreji u dubrovačkoj književnosti”, Zbornik Židovskog muzeja 1 (1971), pp. 211-238.

Pasarić, Antun, "Pjesme Didaka Pira”, Srd, Dubrovnik, 1903, pp. 91-92, p. 141, pp. 184-186, pp. 215-218.

Pires, Diogo, Cato Minor siue Disticha Moralia ad Ludimagistros Olysipponenses (...). Venetiis, apud Felicem Valgrisium, 1596.

Polıć BoвIć, Mirjana, Među križem i polumjesecom, dubrovačke dojave španjolskom dvoru o Turcima u xvi. Stoljeću. Zagreb, Naklada Ljevak, 2000. 
Polić Bobić, Mirjana, "Activities of the Spanish Secret Service in the Republic of Dubrovnik in the $16^{\text {th }}$ Century and the Role of Spanish Confidant Marin Zamanja”, in Mirjana Polıć Bobić (ed.), Tajna diplomacija u Dubrovniku u xvi. Stoljeću. Zagreb, Sveučilište u Zagrebu, 2011, pp. 181-190.

Polıć Bobıć, Mirjana, “Španjolska tajna služba u Dubrovačkoj Republici u xvi. stoljeću i uloga španjolskog povjerenika Marina Zamanje u njoj”, in Mirjana Polić BobIć (ed.), Tajna diplomacija u Dubrovniku u xvi. Stoljeću. Zagreb, Sveučilište u Zagrebu, 2011, pp. 86-93.

Popović, T., "Dubrovnik i Ankona u jevrejskoj trgovini xvi veka”, Zbornik Židovskog muzeja 1 (1971), pp. 41-53.

ReŠEtar, Milan, “Amat Luzitanac, dubrovački ljekar xvi. Vijeka”, Brankovo kolo 6 (1900), pp. 39-41.

TADIĆ, Jorjo, Jevreji u Dubrovniku do polovine Xvir. Stoljeća. Sarajevo, Izdala La Benevolencia, 1937.

TADIĆ, Jorjo, Dubrovački portreti, vol. I. Beograd, Srpska književna zadruga, 1948.

TAsso, Torquato, Ljuvene rane/Le piaghe d'amore, antologija hrvatskih prepjeva u povodu 400. obljetnice pjesnikove smrti, redazione Mirko Tomasović. Dubrovnik, Matica hrvatska, 1995.

Torbarina, Josip, "Fragmenti iz neizdanih pisama Lodovika Beccadellija 1555-1564”, Dubrovačka, mjesečna ilustrovana revija I (1929), pp. 9-10.

SAmArDŽIČ, Radovan, “Dubrovački Jevreji u trgovini xvi i xviI veka”, Zbornik Židovskog muzeja 1 (1971), pp. 21-39.

Šı, Lavoslav, Die jüdische Ärtze in Jugoslavien. Osijek, E. Sekler, 1931.

ŠUndrica, Zdravko, "Popis stanovništva Dubrovačke republike iz 1673-74 godine”, Arhivski vjesnik 2 (1959), pp. 419-456.

Švelec, Franjo, “Marin Držić”, Hrvatski biografski leksikon, vol. III. Zagreb, 1993, pp. 631-636.

Švelec, Franjo, "Vlaho Držić", Hrvatski biografski leksikon, vol. III. Zagreb, 1993, pp. 636-637.

Vekarič, Nenad, Vlastela grada Dubrovnika, 2. Vlasteoski rodovi (A-L). Zagreb-Dubrovnik, Zavod za povijesne znanosti HAZU u Dubrovniku, 2012.

Vekarič, Nenad, Vlastela grada Dubrovnika, 3. Vlasteoski rodovi (M-Z). Zagreb-Dubrovnik, Zavod za povijesne znanosti HAZU u Dubrovniku, 2012.

VekArIČ, Nenad, Vlastela grada Dubrovnika, 4. Odabrane biografije (A-D). Zagreb-Dubrovnik, Zavod za povijesne znanosti HAZU u Dubrovniku, 2013. 


\section{Estudos contemporâneos sobre Amato Lusitano ${ }^{1}$}

JOÃO RUI PITA² \& ANA LEONOR PEREIRA ${ }^{3}$

\section{RESUMO:}

Este estudo faz uma revisão dos artigos e livros publicados em Portugal sobre Amato Lusitano. Os autores, após analisarem as diferentes publicações, referem com particular destaque as obras resultantes de estudos de investigação mais profundos mas inscrevem igualmente estudos de natureza mais divulgativa sobre Amato Lusitano.

\section{PALAVRAS-CHAVE:}

Amato Lusitano; história da medicina; bibliografia; biografia

\section{ABSTRACT:}

This study is a literature review of articles and books published in Portugal on Amato Lusitano. The authors, after analyzing the different publications, refer specialized articles resulting from thorough research, as well as other studies for the diffusion of scientific knowledge about Amato Lusitano.

\section{KEYWORDS:}

Amato Lusitano; history of medicine; bibliography; biography

1 Este trabalho foi desenvolvido no âmbito do projecto de I\&D "Dioscórides e o Humanismo Português: os Comentários de Amato Lusitano" (http://amatolusitano.web.ua.pt) do Centro de Línguas, Literaturas e Culturas da Universidade de Aveiro, financiado por Fundos FEDER através do Programa Operacional Factores de Competitividade - COMPETE e por Fundos Nacionais através da FCT - Fundação para a Ciência e a Tecnologia, no âmbito do projecto FCOMP-01-0124-FEDER-009102.

2 Professor da Faculdade de Farmácia; Investigador do CEIS20; Cocoordenador Científico do Grupo de História e Sociologia da Ciência e da Tecnologia-Universidade de Coimbra: jrpita@ci.uc.pt.

3 Professora da Faculdade de Letras; Investigadora do CEIS20; Cocoordenadora Científica do Grupo de História e Sociologia da Ciência e da Tecnologia)-Universidade de Coimbra: aleop@ci.uc.pt 
No presente estudo retomamos o trabalho que havia sido publicado em 2003 nos Cadernos de Cultura - Medicina na Beira Interior. Da Pré-História ao Século xxi ${ }^{4}$, estudo esse que havia sido actualizado em 2011 e publicado na mesma revista no ano de $2013^{5}$.

A publicação inicial resultou do projecto de investigação que realizámos há anos e que deu origem a uma linha de pesquisa do grupo de investigação que coordenamos, de História e Sociologia da Ciência e da Tecnologia do Centro de Estudos Interdisciplinares do Séc. xx da Universidade de Coimbra - CEIS20. O projecto intitula-se Repertório Bibliográfico da Historiografia Sanitária Portuguesa. Problemáticas e Fontes Especializadas / SANISTÓRIA (Sécs. XVIII-XX) (desenvolvido com financiamento da Fundação para a Ciência e a Tecnologia - FCT entre 1998 e 2000). A linha de investigação designa-se: "Fontes e bibliografia para a história da ciência em Portugal”. Somos os responsáveis científicos por essa linha cujo objectivo é: publicar e fazer publicar fontes impressas e manuscritas relacionadas, sobretudo, com a história das ciências da saúde e com a história das ciências exactas e naturais possibilitando dar a conhecer esses materiais com vista a investigações futuras. Constitui, também, objectivo desta linha-projecto publicar as investigaçóes sob a forma de repertórios bibliográficos, tanto repertórios gerais como bibliografias temáticas. Dada a natureza do objecto trata-se, então, de uma pesquisa permanente e continuada, sempre em actualização não só relativamente a Amato Lusitano mas também relativamente a outros vultos e temáticas da história das ciências, em particular da história das ciências da saúde e da vida.

O trabalho que agora se publica resulta pois da actualização contínua que temos realizado nesse projecto, neste caso especificamente sobre Amato Lusitano. Estamos conscientes de que é um trabalho inacabável.

Retomando o que foi publicado logo em 2003, sublinhamos que Amato Lusitano é uma das figuras mais relevantes da história da medicina portuguesa e, também, figura incontornável na história universal das ciências da saúde. As comemoraçóes dos 500 anos do nascimento de Amato Lusitano em que muitos investigadores estiveram envolvidos provam, justamente, essa universalidade e as marcas da sua acção clínica e científica. Estas marcas figuram em conceituados manuais de história da medicina e de história da farmácia para ficarmos apenas

4 João Rui PITA; Ana Leonor PEREIRA, "Escritos maiores e menores sobre Amato Lusitano", Medicina na Beira Interior. Da Pré-História ao Século xxı - Cadernos de Cultura 17 (2003), pp. 6-17. O estudo publicado em 2003 foi retomado, sujeito a actualizações e aumentado. Este estudo realiza-se no âmbito da linha de investigação do CEIS20 da Universidade de Coimbra, "Fontes e bibliografia para a história da ciência em Portugal" (FCT/ PEST-OE/HIS/UI0460/2014) e do projecto de investigação "Dioscórides e o Humanismo Português: os Comentários de Amato Lusitano" do Centro de Línguas, Literaturas e Culturas da Universidade de Aveiro, financiado por Fundos FEDER através do Programa Operacional Factores de Competitividade - COMPETE e por Fundos Nacionais através da FCT - Fundação para a Ciência e a Tecnologia, no âmbito do Projecto FCOMP-01-0124-FEDER-009102.

5 João Rui PITA; Ana Leonor PEREIRA, "História da história de Amato Lusitano", Medicina na Beira Interior. Da Pré-História ao Século xx। — Cadernos de Cultura 27 (2013), pp. 63-72. 
em estudos do domínio das ciências da saúde. Mas também poderíamos citar outras obras no campo das humanidades.

A obra de Amato Lusitano tem sido estudada por diversos investigadores dentro e fora do país. Das humanidades, no âmbito da cultura clássica, à história das ciências. As Jornadas de Estudo Medicina na Beira Interior, da Pré-História ao Século xxI, da responsabilidade máxima de António Lourenço Marques e de António Salvado, com a colaboração de Maria Adelaide Salvado, realizadas regularmente em Castelo Branco há duas décadas e meia, são uma prova de que a obra de Amato tem merecido e continua a exigir um estudo regular, envolvendo equipas multidisciplinares integrantes de historiadores da cultura, historiadores da ciência, antropólogos, linguistas, médicos, geógrafos, entre muitas áreas do conhecimento que poderiam ser referidas.

Merece também registo particular o projecto de investigação financiado pela Fundação para a Ciência e a Tecnologia - FCT, na Universidade de Aveiro, que se encontra em fase final. Este projecto de pesquisa tem como investigador responsável o Prof. Doutor António Andrade da referida Universidade de Aveiro. O projecto intitula-se Dioscórides e o Humanismo Português: os Comentários de Amato Lusitano. Trata-se de um programa de investigação pleno de originalidade e que envolve uma enorme quantidade de tradutores e especialistas de diversos domínios científicos, garantia do rigor científico necessário a investimentos dessa natureza e cujo objectivo é traduzir para português algumas das obras mais relevantes de Amato Lusitano. Sublinhese que, nos Cadernos de Cultura de 2010, António Andrade inscreve um artigo intitulado Projecto de Investigação "Dioscórides e o Humanismo Português: os Comentários de Amato Lusitano" onde aborda, justamente, os estudos a realizar e seu interesse ${ }^{6}$. Assinale-se que o projeto de investigação, de acordo com o responsável, "tem como objetivo principal a edição e tradução para português dos dois livros que Amato Lusitano dedicou ao comentário do tratado grego «De materia medica» de Dioscórides, ou seja, o «Index Dioscoridis» (Antuérpia, 1536) e as "In Dioscoridis Anazarbei de medica materia libros quinque...enarrationes» (Veneza, 1553)”. Ainda de acordo com o responsável do projecto, "está prevista, também, a tradução de mais duas obras diretamente correlacionadas com os livros do médico português: a montante, a do próprio tratado grego de Dioscórides sobre a matéria médica; a jusante, a do livro intitulado "Apologia adversus Amathum Lusitanum» (Veneza, 1558) da autoria do humanista Pietro Andrea Mattioli"8. Ainda decorrente deste projecto de pesquisa são de assinalar vários trabalhos intercalares publicados sob a forma de artigos e de livros?

6 António Manuel Lopes ANDRADE, "Projecto de Investigação Dioscórides e o Humanismo Português: os Comentários de Amato Lusitano", Medicina na Beira Interior. Da Pré-História ao séc. XXI - Cadernos de Cultura 23 (2010), pp. 5-9.

7 Cf. Site do projecto em: http://amatolusitano.web.ua.pt (consultado em 07/04/2014).

8 Idem.

9 Ver mais adiante a referência a vários destes estudos na revista Medicina na Beira Interior. Da Pré-História 
Deve também referir-se que a história da medicina portuguesa até meados do século xx não apresenta muitos vultos com projecção internacional, quer na dimensão clínica, quer na vertente científica. Em obras internacionais, raramente se encontra referência a outros nomes portugueses além de Amato Lusitano, de Garcia da Orta, de Ribeiro Sanches, de Bernardino António Gomes e de Egas Moniz, não havendo muitos mais, sendo muito curioso que praticamente todos tiveram profundas relaçóes com a Beira Interior. Amato era natural de Castelo Branco, Garcia da Orta nasceu em Castelo de Vide, Ribeiro Sanches era natural de Penamacor, Egas Moniz realizou praticamente todo o ensino secundário em Castelo Branco, no Colégio de São Fiel.

Pedro Laín Entralgo expóe na sua obra que, nos séculos XVI e XviI, vários médicos na Europa cultivaram uma nova vertente da literatura médica. Justamente uma vertente descritiva, clínica, protagonizada por grandes mestres com o objectivo de "transmitir aos outros o seu saber próprio"10. Laín salienta que entre os séculos XVI e XVII vários desses autores "cultivaram com brilhantismo esse novo género de literatura médica" ${ }^{11}$. Entre eles, o consagrado historiador espanhol cita o nome de Amato Lusitano ${ }^{12}$, sublinhando que todos os autores quinhentistas desse novo estilo de literatura médica tinham como denominador comum uma maior individualização, um tratamento biográfico na descrição das doenças e, para além disso, uma "intenção estética co-cognoscitiva"13. Conforme se lê textualmente, "mais do que a prescrição de um saber fazer" ${ }^{14}$, a observação do doente sensibiliza para um "saber ver"15 e um "saber entender"

ao séc. XXI - Cadernos de Cultura. De qualquer modo refira-se para já os estudos seguintes: o volume temático da revista Ágora. Estudos Clássicos em Debate 14.1 (2012). Número especial da revista decorrente da realização do Colóquio Internacional "Inventários, Livros e Ciência". Disponível em: http://www2. dlc.ua.pt/classicos/agora14.1.htm. A obra de António ANDRADE; João TORRÃo; Jorge COSTA; Júlio COSTA (org.), Humanismo, Diáspora e Ciência (séculos xVI e xVII): estudos, catálogo, exposição. Porto, Câmara Municipal do Porto, Biblioteca Pública Municipal; Universidade de Aveiro, Centro de Línguas e Culturas, 2013. Disponível em: http://arquivodigital.cm-porto.pt/Conteudos/Conteudos_BPMP/OBAD\%20 002710/0BAD\%20002710.htm (volume decorrente do Colóquio Internacional «Humanismo, Diáspora e Ciência» e da Exposição Bibliográfica, realizado na Biblioteca Pública Municipal do Porto, nos dias 7 e 8 de Março de 2013). A obra de António Guimarães PINTo, Apostilas a António Luís: 1. António Luís e João de Barros; 2. António Luís, António Pinheiro e Rodrigo Sánchez. Coordenação editorial e prefácio de Antonio Manuel Lopes Andrade. Lisboa - Aveiro, Cátedra de Estudos Sefarditas "Alberto Benveniste" da Universidade de Lisboa; Centro de Línguas e Culturas da Universidade de Aveiro, 2013 (volume editado numa colecção da Cátedra de Estudos Sefarditas "Alberto Benveniste" da Universidade de Lisboa, uma tradução de latim para português de vários textos de António Luís, um médico português do século xVI, colega de Amato Lusitano em Salamanca, realizada no âmbito do projeto por um membro da equipa).

10 Cf. Pedro Laín Entralgo, Historia de la medicina. Barcelona, Salvat, 1989, p. 312.

11 Cf. Idem, Ibidem, p. 313.

12 Ao lado de Amato Lusitano encontram-se os nomes de Jean Fernel, Giambatista da Monte, Francesco Valleriola, Peter van Foreest, Reiner Sondermann, Schenck von Grafenberg, Félix Platter, etc.

13 Cf. Pedro Laín Entralgo, Historia de la medicina, op. cit., p. 313.

14 Cf. Idem, Ibidem, p. 313.

15 Cf. Idem, Ibidem, p. 313.

16 Cf. Idem, Ibidem, p. 313. 
Muitos outros historiadores da medicina e da farmácia invocam ou referem a figura de Amato Lusitano, a sua vida e a sua obra. Tanto em tratados como em artigos científicos. É o caso, por exemplo, de M. Salomon ${ }^{17}$, Pietro Capparoni ${ }^{18}$, H. Friedenwald ${ }^{19}$, Glessinger ${ }^{20}$, Aldo Mieli $^{21}$, Samoggia ${ }^{22}$, Francisco Guerra ${ }^{23}$, de López Terrada, Salavert Fabiani ${ }^{24}$, Papaspyros ${ }^{25}$, Meunier $^{26}$, Leibowitz ${ }^{27}$, Hrvoje Tartalja ${ }^{28}$, Licurgo dos Santos Filho ${ }^{29}$, Jurica Bacic, Katarina Vilovic, Koraljka Bacic Baronica ${ }^{30}$, etc..

Vários dicionários contemplam a figura e a obra de Amato Lusitano. É o caso, por exemplo, do famoso Dicionário Biográfico de Cientistas, Dictionary of Scientific Biography ${ }^{31}$. Também em

17 Cf. M. Salomon, "Amatus Lusitanus in seine Zeit", Zeitschrift für klinische medizin 41-42 (1901).

18 Cf. Pietro Capparoni, "Amato Lusitano e la sua testimonianza della scoperta delle valvole delle vene fatta da G. B. Canano", in Atti e Memorie dell'Accademia di Storia dell'Arte Sanitaria, appendice alla Rassegna di Clinica, Terapia e Scienze affini, Anno XL, Fascicolo IV, Luglio-Agosto 1941.

19 Cf. H. Friedenwald, "Amatus Lusitanus", Bulletin of the Institute of History of Medicine, Johns Hopkins University 4 (1937).

20 Cf. Ladoslav Glassinger, Amatus Lusitanus. Zagreb-Belgrado, 1940.

21 Cf. Aldo Mielı, "Amatus Lusitanus", Archeion. Roma, 1910.

22 Cf. L. Samoggia, "Aspetti del pensiero scientifico di Amato Lusitano", Pagine di Storia della Medicina 10.3 (1966), p. 14.

23 Cf., por exemplo, Francisco Guerra, Historia de la medicina, vol. 1. Madrid, Ediciones Norma, S.A., 1989, p.294 e ss.; e 305 e ss.

24 Cf. María Luz López Terrada; Vicente L. Salavert Fabiani, "Le médecin de la Renaissance à l'aube des Lumières", in Louis CALLABERT (Dir.), Histoire du médecin. Paris, Flammarion, 1999, p. 143 e ss.

25 Cf. N. S. PAPASPyros, The history of diabetes mellitus, $2^{a}$ ed.. Stuttgart, Georg Thieme Verlag, 1964. 0 autor refere que Amato teve declaradas preocupações com as causas de diabetes: excesso de comida, álcool e sexo (p. 15).

26 Cf. MeUnier, Histoire de la médecine. Depuis ses origines jusqu'à nos jours. Paris, Librairie J.B. Baillière et Fils, 1911. Outra edição: Paris, Librarie E. le François, 1924. O autor faz uma breve súmula da vida de Amato, referindo-se a sua competência profissional, sobretudo em Ancona e refere a publicação das Centúrias (p. 216).

27 Cf., por exemplo, J. O. LeIBowitz, "A probable case of peptic ulcer described by Amatus Lusitanus", Journal of the History of Medicine and Allied Sciences 27 (1953), pp. 212-216; "Amatus Lusitanus and the Obturator in Cleft Palates", Bulletin of the History of Medicine 13 (1958), pp. 492-503.

28 Cf. Hrvoje TARTALja, "Les médicaments qu'Amatus Lusitanus utilisait à l'occasion de son travail à Dubrovnik", in F. J. Puerto SARMIento, Farmacia e industrializacion. Homenaje al doctor Guillermo Folch Jou. Madrid, Sociedad Española de Historia de la Farmacia, 1985, pp. 237-246.

29 Cf. Licurgo dos Santos FILHo, História Geral da Medicina Brasileira, vol. 1. São Paulo, Editora HUCITEC I Editora da Universidade de São Paulo, 1991. Diz o autor: "E João Rodrigues Castelo Branco (1511-1568), o celebrado 'Amato Lusitano', judeu português que estudou em Salamanca, clinicou em Castelo Branco e emigrou para Antuérpia, temeroso do Tribunal da Inquisição, reconheceu a púrpura e escreveu sobre as plantas medicinais das ilhas da Madeira e de São Tomé", p. 283.

30 Cf. Jurica BACIC; Katarina VILOVIC; Koraljka Bacic BARONICA, "The gynaecological-obstetrical pratice of the renaissance physician Amatus Lusitanus (Dubrovnik, 1555-1557)", European Journal of Obstetrics \& Gynecology and Reproductive Biology 104.2 (2002), pp. 180-185.

31 Cf. A. G. Keller, "Lusitanus, amatus (RODRIGUes, JOÃO)", in Charles Gillispie Coulston (Ed.), Dictionary of Scientific Biography, vol. 8. New York, Charles Scribner's Sons, 1973, pp. 554-555. 
dicionários de judaísmo como a Encyclopedia Judaica ${ }^{32}$ o nome de Amato Lusitano é tratado. José Maria López Piñero na sua obra La medicina en la historia reporta-se a Amato Lusitano, valoriza a sua obra e atribui-lhe um lugar de relevo na medicina renascentista no que concerne à anatomia patológica ${ }^{33}$. López Piñero coloca Amato, nalgumas vertentes da sua actividade, a par de Mattiolo, Laguna, Vesálio, Fuchs, Monardes, etc. ${ }^{34}$.

Ugo Baldini, no volume primeiro da obra editada por Leen Spruit intitulada Catholic Church and Modern Science, publica o estudo "Amatus Lusitanus (João Rodriguez de Castelo Branco)" 35.

Por ocasião do quarto centenário do ano da morte de Amato (1568-1968), multiplicaram-se os eventos comemorativos, dentro e fora de Portugal. Vejamos alguns exemplos: na Academia das Ciências de Lisboa, a 25 de Abril de 1968, Maximino Correia e Miller Guerra recordaram Amato Lusitano; o primeiro teceu considerações biográficas e o segundo abordou a sua obra. Na Faculdade de Medicina da Universidade do Porto, Luís de Pina e Maria Olívia Rúber de Meneses, em 30 de Maio de 1968, evocaram nomes portuenses que estudaram a obra de Amato Lusitano. Em Siena, Itália, o xxi Congresso Internacional de História da Medicina, incorporou um simpósio subordinado ao tema "Amato Lusitano". O Simpósio congregou vários especialistas e interessados em Amato de diversos países europeus e de Israel. Em Castelo Branco o Liceu e a escola Comercial e Industrial organizaram sessóes públicas de homenagem a Amato. Destas comemorações resultou a publicação de obras marcantes no panorama historiográfico português e internacional. Saliente-se neste particular que, na obra $I V$ Centenário de João Rodrigues de Castelo Branco - Amato Lusitano, obra prefaciada e compilada por José Lopes Dias em 1968, “coligem-se em tomo independente os estudos de História da Medicina dos investigadores que dentro e fora do País participaram nas comemoraçóes quadricentenárias da morte de João Rodrigues de Castelo Branco — Amato Lusitano"36. Em 2011 tiveram lugar em Portugal as comemoraçóes do quinto centenário de Amato Lusitano. Em Castelo Branco o grupo promotor das Jornadas de Estudo Medicina na Beira Interior - Da Pré-História ao Século XXI organizou um evento comemorativo. Também em Castelo Branco tiveram lugar outras

32 Cf. Joshua O. Leibowitz, "Amatus Lusitanus (João Rodrigues de Castelo Branco", Encyclopedia Judaica, Vol. 2. Jerusalem, Keter Publishing House Ltd., 1971, pp. 795-797. Veja-se, também, por exemplo, "Amato Lusitano (Juan Rodrigo de Castelo Branco)", in Enciclopedia Judaica Castellana. México, Editorial Enciclopedia Judaica Castellana, S. de R. L., 1948, pp. 248-249.

33 Cf. José Maria López PIÑEro, La medicina en la historia. Madrid, La Esfera de los Libros, SL, 2002, pp. 207 e ss..

34 Cf. José Maria López PIÑERo, La medicina en la historia, op. cit., p. 232.

35 Cf. Ugo Baldini, "Amatus Lusitanus (João Rodriguez de Castelo Branco)", in Leen Spruit (ed.), Catholic Church and Modern Science. Documents from the Archives of the Roman Congregations of the Holy Office and the Index. Vol. 1 - 16th Century Documents. Roma, Libreria Editrice Vaticana, 2010. pp. 744-768.

36 Cf. IV Centenário de João Rodrigues de Castelo Branco - Amato Lusitano (Prefácio de José Lopes DIAS). Castelo Branco, Estudos de Castelo Branco, 1968, p. 7. 
manifestaçôes comemorativas ${ }^{37}$. Assinale-se, contudo, desde já as obras de J. David de Morais, Eu, Amato Lusitano. No V Centenário do seu Nascimento ${ }^{38}$ e Amato Lusitano, figura cimeira da Medicina portuguesa. No V Centenário do seu nascimento ${ }^{39}$.

De acordo com a nossa investigação em curso $^{40}$, entre estudiosos clássicos já desaparecidos, destacam-se três autores de escritos maiores sobre Amato Lusitano. São eles Maximiano Lemos, Ricardo Jorge e José Lopes Dias. Quanto às publicações periódicas que frequentemente abordam a obra de Amato destacam-se os Estudos de Castelo Branco e os actuais Cadernos de Cultura. Medicina na Beira Interior, da Pré-História ao Século xxI. Ambas as publicações, pelo conjunto e diversidade de artigos que reúnem constituem um valioso marco para a história de Amato Lusitano e indicam-nos os autores que hoje têm em Amato Lusitano um objecto de estudo. Na Biblioteca Nacional de Portugal, em Lisboa, teve lugar uma exposição e um seminário ${ }^{41}$, tendo sido editado igualmente um livro / catálogo da autoria de João José Alves Dias intitulado Amato Lusitano e a sua obra: séculos Xvi e XVII ${ }^{42}$. O livro tem como objectivo dar a conhecer as obras "que são devidas a Amato Lusitano e que se publicaram durante pouco mais de um século em muitos prelos europeus” ${ }^{\prime 3}$.

\section{A BIOGRAFIA DE AMATO LUSITANO DA AUTORIA DE MAXIMIANO LEMOS}

Em 1907 Maximiano Lemos, professor de História da Medicina da Faculdade de Medicina da Universidade do Porto, publicou a obra Amato Lusitano que tem como sub-título A sua vida e a sua obra ${ }^{44}$. Trata-se de um grosso volume, cerca de 200 páginas, dividido em 12 capítulos e que na época recebeu o reconhecimento escrito por parte de outros investigadores, nomeadamente de Eduardo de Sousa no Diário da Tarde, de Sousa Viterbo em A Medicina Contemporânea e de Ricardo Jorge nos Arquivos da Medicina Portuguesa.

37 Ver mais adiante a propósito da revista Cadernos de Cultura.

38 J. David de Morals, Eu, Amato Lusitano. No V Centenário do seu Nascimento. Lisboa, Edições Colibri, 2011.

39 J. David de Morals, "Amato Lusitano, figura cimeira da Medicina portuguesa. No V Centenário do seu nascimento", Infecção e Sépsis 1 (2012), pp. 5-10.

40 Os resultados da nossa investigação aqui apresentados não pretendem ser um repertório completo da historiografia sobre Amato Lusitano.

41 Realizado em 13 de Setembro de 2011.

42 João José Alves DıAs, Amato Lusitano e a sua obra: séculos xVI e xVII. Lisboa, Biblioteca Nacional de Portugal: Centro Editor Livreiro da Ordem dos Médicos: Centro de Estudos Históricos-Univ. Nova، 2011. Trata-se de uma obra em 183 p.

43 Cf. http://livrariaonline.bnportugal.pt/Issue.aspx?i=2144 (consultado em 07/04/2014)

44 Maximiano Lemos, Amato Lusitano. A sua vida e a sua obra. Porto, Eduardo Tavares Martins, editor, 1907, $212 \mathrm{p}$. 
Maximiano Lemos traçou uma biografia cronológica de Amato no contexto familiar e no quadro da condição dos judeus em Portugal. O leitor acompanha a formação de Amato Lusitano em Salamanca, o exercício clínico de Amato em Portugal, a sua saída do país e o seu percurso pela Europa: Antuérpia, Ferrara, Veneza, Ancona, Roma, Florença, Pesaro, Salónica, etc. A obra apresenta, também, uma inventariação dos trabalhos de Amato Lusitano. Por tudo isto e ainda pela riqueza dos contextos culturais, religiosos, científicos e outros, este é, sem dúvida, um escrito maior sobre Amato Lusitano. Obviamente é um trabalho com a marca do tempo em que foi escrito e por isso mais importante ainda no domínio da história da história da medicina em Portugal que é precisamente o registo em que nos colocamos.

Maximiano Lemos publicou outros trabalhos de menor extensão sobre Amato Lusitano. O seu instinto de historiador dava-lhe a plena consciência de que as pesquisas não acabam com a obra feita. Elas continuam, trazem novidades e perturbam a história já contada e escrita. Maximiano Lemos confessa no artigo Amato Lusitano - Correç̧óes e aditamentos ${ }^{45}$ publicado em 1927 mas definitivamente redigido em 1922: "Muito há que ampliar, corrigir e modificar no que escrevemos há quinze anos acerca dos anos que Amato passou em Antuérpia"6. Entre outros textos de Maximiano Lemos sobre Amato assinalem-se: Amato Lusitano e as valvulas das veias $(1900)^{47}$, Medicos portuguezes no estrangeiro. Século XVI (1900) ${ }^{48}$, Amato Lusitano em Ferrara (1906) ${ }^{49}$ e Amato Lusitano (novas investigaçóes) (1915 e 1927) ${ }^{50}$. Posteriormente, a título póstumo (1955), foi recuperado o último capítulo da sua biografia de Amato para inclusão no volume intitulado Homenagem ao Doutor João Rodrigues de Castelo Branco (Amato Lusitano) publicado em $1955^{51}$. Hoje, cerca de cem anos volvidos, a biografia de Amato publicada em 1907 afirma-se como um documento fundamental para a história em todos os seus ramos, desde a história dos judeus à história da ciência, sendo igualmente um escrito maior para a história da história. Desde logo, a história da história de Amato.

45 Maximiano Lemos, "Amato Lusitano - Correcções e aditamentos", Revista da Universidade de Coimbra 10 (1927), pp. 1-38.

46 Idem, Ibidem, p. 5. No artigo fazem-se aditamentos e correcções a alguns dos capítulos da obra Amato Lusitano. A sua vida e a sua obra. Porto, Eduardo Tavares Martins, editor, 1907. Estão nesta situação aditamentos à presença de Amato em Antuérpia, em Ferrara e em Veneza.

47 Maximiano Lemos, "Amato Lusitano e as valvulas das veias", Gazeta Medica do Porto 4.2 (1900), pp. 37-41.

48 Maximiano Lemos, "Medicos portuguezes no estrangeiro. Século xVI", Gazeta Medica do Porto 3.7-8 (1900), pp. 198-205.

49 Maximiano Lemos, "Amato Lusitano em Ferrara", A Medicina Contemporânea 24.37 (1906), pp. 294-296; 24.38 (1906), pp. 299-301.

50 Maximiano Lemos, "Amato Lusitano (novas investigações)", Revista de Historia 2 (1913), pp. 25-31; "Amato Lusitano: novas investigações", Arquivos de História da Medicina Portuguesa. Nova série 6 (1915), pp. 1-12; 33-43; 89-96; 97-106; 129-145.

51 Maximiano Lemos, "Os trabalhos scientificos de Amato", in Homenagem ao Doutor João Rodrigues de Castelo Branco (Amato Lusitano). Castelo Branco, Câmara Municipal de Castelo Branco, 1955, pp. 37-56. 


\section{O AMATO LUSITANO DE RICARDO JORGE}

Ricardo Jorge é, também, um dos principais biógrafos de Amato Lusitano. Retrata-o muito justamente como "um caminheiro dominado pela paixão da ciência" ${ }^{2}$. Com o seu estilo inigualável, Ricardo Jorge converteu Amato num modelo para muitos cientistas e médicos, nomeadamente para o único Prémio Nobel de Medicina e Fisiologia português que foi Egas Moniz ${ }^{53}$.

Em 1914, Ricardo Jorge publica nos Arquivos de História da Medicina Portuguesa uma biografia de Amato intitulada Comentos à vida, obra e época de Amato Lusitano ${ }^{54}$, que vinha preparando desde 1907. Motivado pela biografia de Amato escrita por Maximiano Lemos, acabou por traçar um novo Amato Lusitano: "O que era a princípio um simples ensaio de apresentação crítica e levemente comentativa, foi-se adensando e dilatando" 55 . Os textos publicados por Ricardo Jorge nos Arquivos de História da Medicina Portuguesa correspondem essencialmente à vida de Amato em Portugal e em Espanha, digamos ao primeiro período da vida de João Rodrigues de Castelo Branco. Em A Medicina Contemporânea Ricardo Jorge publicou em 1908 Commentos á vida, obra e epocha de Amato Lusitano ${ }^{56}$.

Ricardo Jorge escrevia a propósito da publicaçáo de um novo artigo intitulado Comentos à vida, obra e época de Amato Lusitano ${ }^{57}$ : "Maus fados de berço perseguiram o aparecimento deste trabalho, a testemunharem a adversão da publicidade que o meio reserva para certas obras e certos homens como que a condenar-lhes a pena à inércia e ao silêncio. Começado em Maio de 1907, foi tal a azáfama febril com que o acometi que, dentro de dois meses, tinha levado a carreira de Amato até à sua partida de Portugal. Continuado no ano seguinte, ficava o texto integralmente prontificado em meados de 1909"58. A publicação nos Arquivos de História da Medicina Portuguesa surgiu a convite de Maximiano Lemos. Aprontava-se uma edição total dos textos na Imprensa da Universidade de Coimbra, a convite do seu Director, Joaquim de Carvalho, em volume único, em 1933, quando esta instituição foi encerrada. Em 1936 publicou o referido

52 Ricardo JorGe, Amato Lusitano. Comentos à sua vida, obra e época. Lisboa, Edição do Centenário, 1963, p. 29.

53 Cf. Egas Moniz, Ao lado da medicina. Lisboa, Livraria Bertrand, 1940, p. 247.

54 Ricardo JorGe, "Commentos à vida, obra e época de Amato Lusitano", Arquivos de História da Medicina Portuguesa, Nova série 5 (1914), pp. 1-21; 97-119; 173-183; 6, 1915, pp. 161-175; 7, 1916, pp. 23-32; 47-57; 65-84. Ricardo JORGE publicou em 1910 "Mestres d'Amato em Salamanca" em Archivos de Historia da Medicina Portugueza. Nova série 1.1 (1910), pp. 3-12. Veja-se, também, "Celestina (La) em Amato Lusitano", A Medicina Contemporânea 26.52 (1908), pp. 410-411.

55 Ricardo JORGE, "Comentos à vida, obra e época de Amato Lusitano (d'um Livro a publicar)", Arquivos de História da Medicina Portuguesa, Nova série 5 (1914), p. 8.

56 Ricardo JORGE,"Commentos á vida, obra e epocha de Amato Lusitano (d'um livro a publicar)", A Medicina Contemporânea 26.25 (1908), pp. 193-196.; 26.34 (1908), pp. 265-268.

57 Ricardo JORGE, "Comentos à vida, obra e época de Amato Lusitano", Clínica, Higiene e Hidrologia 2.9 (1936), pp. 331-337.

58 Idem, Ibidem. 
artigo Comentos à vida, obra e época de Amato Lusitano ${ }^{59}$, que o próprio autor considera como "a 2 a parte da obra que abrange o ciclo peninsular da vida e acçáo científica do Amato"60. Náo fora a intervenção directa do responsável da revista Dr. Armando Narciso e o artigo sobre a vida de Amato em Lisboa teria ficado apenas em manuscrito ${ }^{61}$. Em 1955, no volume intitulado Homenagem ao Doutor João Rodrigues de Castelo Branco (Amato Lusitano), editado pela Câmara Municipal de Castelo Branco, retoma-se, em capítulo autónomo, parte da escrita de Ricardo Jorge sobre Amato publicada nos Arquivos de História da Medicina Portuguesa $(1914)^{62}$.

A biografia de Amato feita por Ricardo Jorge só postumamente foi editada: Amato Lusitano. Comentos à sua vida, obra e época ${ }^{63}$, numa edição integrada na colecção comemorativa do centenário de Ricardo Jorge e intitulada "Obra Literária e Médico-Literária de Ricardo Jorge". Esta obra compila os artigos dispersos sobre Amato e inclui um capítulo mantido inédito até 1963, intitulado As conquistas e as drogas das Índias. Ricardo Jorge não terá tido tempo para redigir uma biobibliografia de Amato como parece ter sido sua ideia ${ }^{64}$.

As 200 páginas que Ricardo Jorge consagra a Amato ${ }^{65}$ incidem sobre a vida do médico de Castelo Branco até à sua saída para o estrangeiro, para terras de Antuérpia, Ferrara, Veneza, Roma, Salónica, etc. Para além duma nota editorial onde se referem as razóes da publicação, a obra abre com um prefácio intitulado "Carta ao prof. Maximiano de Lemos", documento já publicado nos Arquivos de História da Medicina Portuguesa (vol. 5, 1914, p. 1) e onde Ricardo Jorge, ao dirigir-se a Maximiano Lemos, justifica o seu interesse por Amato e a profunda motivação que recebeu com a leitura da biografia de Amato feita por Maximiano Lemos ${ }^{66}$. $\mathrm{Na}$ obra de Ricardo Jorge, Amato Lusitano também é integrado no contexto científico e cultural da época. Ambos compreenderam que biografar Amato implicava fazer uma viagem pelo

59 Idem, Ibidem.

60 Idem, Ibidem, p. 331.

61 Diz-nos Ricardo JorGE: "Há três anos, prestava-se bizarramente o dr. Joaquim de Carvalho à feitura duma edição total na Imprensa da Universidade que, para cúmulo de má sorte e dano irreparável das nossas letras, foi incontinenti fechada. A instâncias do redactor desta revista [Clínica, Higiene e Hidrologia] o dr. Armando Narciso, será agora arrancada ao esquecimento esta $2^{a}$ parte, depois de 26 anos de sono pesado nas gavetas" (Ricardo Jorge, "Comentos...", op. cit, p. 331).

62 Cf. Ricardo JorGe, "Comentos à vida, obra e época de Amato Lusitano", in Homenagem ao Doutor João Rodrigues de Castelo Branco (Amato Lusitano). Castelo Branco, Câmara Municipal de Castelo Branco, 1955, pp. 57-123.

63 Ricardo Jorge, Amato Lusitano. Comentos à sua vida, obra e época. Lisboa, Edição do Centenário, 1963.

64 Cf. O que nos diz a este propósito José Lopes DiAs em "João Rodrigues de Castelo Branco e a crítica histórica" in Homenagem ao Doutor João Rodrigues de Castelo Branco (Amato Lusitano). Castelo Branco, Câmara Municipal de Castelo Branco, 1955, p. 17.

65 A obra Amato Lusitano. Comentos à sua vida, obra e época. Lisboa, Edição do Centenário, 1963 tem um total de 278 páginas.

66 Referimo-nos a Maximiano Lemos, Amato Lusitano. A sua vida e a sua obra. Porto, Eduardo Tavares Martins, editor, 1907. 
Renascimento português e pela cultura e medicina do século XVI. São extremamente elucidativas as palavras de Américo da Costa Ramalho no artigo intitulado A propósito do Amato Lusitano de Ricardo Jorge ${ }^{67}$ onde, para além de pequenas notas relacionadas com algumas imprecisóes que deveriam ser entendidas "não como crítica, mas como homenagem à memória venerada de Ricardo Jorge” ${ }^{68}$ refere: “... apesar de constituído por elementos díspares e tâo afastados no tempo, o livro apresenta uma certa unidade e, o que é mais, a sua leitura depressa se torna um agradável prazer intelectual. Contribui para isso, não apenas a elegância da prosa de Ricardo Jorge, mas ainda o tom de amena narrativa, sempre reavivada por agudas observaçóes da vida e dos homens. E não lhe falta a nota cáustica de quem escreve para informar, e também para corrigir, no passado e no presente, os vezos dos seus compatriotas" ${ }^{69}$. Em 1963, no periódico Imprensa Médica publica-se um texto póstumo de Ricardo Jorge: um artigo intitulado Amato Lusitano $^{70}$ e que é, afinal, a introdução da obra do higienista publicada em 1963.

\section{JOSÉ LOPES DIAS — OUTRO BIÓGRAFO DE AMATO}

É extensa e valiosa a bibliografia sobre Amato Lusitano produzida por José Lopes Dias, compreendendo vários artigos dispersos em publicaçôes periódicas e algumas monografias. Refiram-se, por exemplo, os textos biográficos sobre Amato publicados no Jornal do Médico $(1943)^{71}$, na Revista Portuguesa de Medicina (1956) ${ }^{72}$, na Imprensa Médica (1961) ${ }^{73}$, em O Médico $(1965 ; 1969)^{74}$, no Colóquio (1969) $)^{75}$, em Estudos de Castelo Branco $(1970 ; 1971)^{76}$.

67 Cf. Américo da Costa Ramalho, "A propósito do 'Amato Lusitano' de Ricardo Jorge", Revista Portuguesa de História 10 (1962), pp. 501-508. Veja-se também em "A propósito do "Amato Lusitano" de Ricardo Jorge", in Estudos sobre a época do Renascimento. Coimbra, 1969, pp. 187-195.

68 Américo da Costa Ramalho, "A propósito...", op. cit., p. 501.

69 Cf. Américo da Costa Ramalho, "A propósito...", op. cit., p. 501.

70 Ricardo Jorge, "Amato Lusitano", Imprensa Médica 28.2 (1963), pp. 58-68.

71 Cf. José Lopes Dias, "Amato Lusitano", Jornal do Médico 3.66 (1943), pp. 417-418.

72 Cf. José Lopes DiAs, "[Amato Lusitano]", Revista Portuguesa de Medicina 5.6 (1956), pp. 178-181.

73 Cf. José Lopes DiAs, "Laços familiares de Amato Lusitano e Filipe Montalto (novas investigações)", Imprensa Médica 25.1 (1961), pp. 22-36; 25.2 (1961), pp. 53-69.

74 Cf. José Lopes Dias, "Doutor João Rodrigues de Castelo Branco (Amato Lusitano)", O Médico, Nova série. 35.721 (1965), p. 947; "IV Centenário de João Rodrigues de Castelo Branco", O Médico, Nova série. 50.916 (1969), pp. 1213-1214.

75 Cf. José Lopes Dias, "Pró-memória do Dr. João Rodrigues de Castelo Branco — Amato Lusitano (1511— 1568)", Colóquio 2 (1969), pp. 58-63.

76 Cf. José Lopes Dias, "João Roiz de Castell Branco — Poeta do "Cancioneiro Geral" de Garcia de Rezende, e João Rodrigues de Castelo Branco, Amato Lusitano - Insigne Médico do Séc. xvı", Estudos de Castelo Branco 34 (1970), pp. 5-18; "Biografia de Amato Lusitano e outros ensaios amatianos", Estudos de Castelo Branco 37 (1971), pp. 3-234. 
Outros estudos versando questóes anatómicas, clínicas e terapêuticas na obra de Amato foram publicados por José Lopes Dias. Por exemplo: o problema das válvulas das veias ${ }^{77}$; questões gerais de terapêutica (Imprensa Médica, 1945) ${ }^{78}$; a sífilis (Arquivos do Instituto de Farmacologia e Terapêutica Experimental, 1944-45)79; casos clínicos (Jornal da Sociedade das Ciências Médicas de Lisboa, 1969; Semana Médica, 1969) ${ }^{80}$.

José Lopes Dias também se dedicou aos estudos sobre Amato Lusitano, dando, assim, um contributo para a história da história de Amato Lusitano. Assinalem-se, por exemplo, os trabalhos: Ensaio do Dr. J. O. Leibowitz sobre Amato Lusitano (Imprensa Médica, 1952) ${ }^{81}$; João Rodrigues de Castelo Branco e a crítica histórica (1955) ${ }^{82}$; a polémica mantida com Abílio Mendes a propósito de Amato, publicada em O Médico e Estudos de Castelo Branco ${ }^{83}$. Refira-se também o seu trabalho sobre o texto do humanista Ambrósio Nicandro publicado em Estudos de Castelo Branco $(1968)^{84}$.

José Lopes Dias legou-nos outros estudos fundamentais: O Renascimento em Amato Lusitano e Garcia d'Orta (Estudos de Castelo Branco, 1964)"85; os Comentários ao "Index Dioscoridis"

77 Cf. José Lopes DiAs, "Nota especial sobre a descoberta das válvulas das veias na cátedra de anatomia de Ferrara, durante o ano de 1547" in Homenagem ao Doutor João Rodrigues de Castelo Branco (Amato Lusitano). Castelo Branco, Câmara Municipal de Castelo Branco, 1955, pp. 125-136.

78 Cf. José Lopes Dias, "Terapêutica de Amato Lusitano", Imprensa Médica 11.4 (1945), pp. 54-56; 11.6 (1945), pp. 84-88; 12.3 (1946), pp. 36-42; 12.4 (1946), pp. 53-58.

79 Cf. José Lopes DIAS, "Terapêutica da sífilis em Amato Lusitano", Arquivos do Instituto de Farmacologia e Terapêutica Experimental 8 (1944-1945), pp. 7-36.

80 Cf. José Lopes DiAs, "Apontamento breve sobre Amato Lusitano (casos clínicos de Portugal e dos portugueses)", Jornal da Sociedade das Ciências Médicas de Lisboa 133.6 (1969), pp. 495-505; José Lopes DIAS, "Apontamentos sobre Amato Lusitano (casos clínicos de Portugal e dos portugueses)", Semana Médica 11:512 suplemento (1969), pp. 1-3.

81 Cf. José Lopes DiAs, "Ensaio do Dr. J. O. Leibowitz sobre Amato Lusitano", Imprensa Médica 16.10 (1952), pp. 495-502.

82 Cf. José Lopes DiAs, "João Rodrigues de Castelo Branco e a crítica histórica" in Homenagem ao Doutor João Rodrigues de Castelo Branco (Amato Lusitano). Castelo Branco, Câmara Municipal de Castelo Branco, 1955, pp. 7-36. Este trabalho foi retomado e alterado nalgumas partes e novamente publicado com o título "Biógrafos, críticos e adversários de Amato Lusitano". Cf. José Lopes DIAS, "Biografia de Amato Lusitano e outros ensaios amatianos", Estudos de Castelo Branco 37 (1971), pp. 3-234.

83 Cf. José Lopes DiAs, "Doutor João Rodrigues de Castelo Branco (Amato Lusitano) [artigo de polémica com Abílio T. Mendes]", O Médico, Nova série, 36.724 (1965), pp. 150-155; "Um desafinado dueto de médicos, sobre Amato Lusitano", Estudos de Castelo Branco 19 (1966), pp. 106-126.

84 Cf. José Lopes DiAs, "Elogio de Amato Lusitano pelo humanista Ambrósio Nicandro", Estudos de Castelo Branco 26 (1968), pp. 164-171.

85 José Lopes DiAs, "O Renascimento em Amato Lusitano e Garcia d'Orta", Estudos de Castelo Branco 11 (1964), pp. 5-34.

86 José Lopes DiAs, Comentários ao "Index Dioscoridis" de Amato Lusitano. Castelo Branco, Gráfica S. José, 1968, 28 p.; "Comentários ao "Index Dioscorides" de Amato Lusitano", Centenário (IV) de João Rodrigues de Castelo Branco - Amato Lusitano. Castelo Branco, Estudos de Castelo Branco, 1968, pp. 87-109; "Comentários ao 'Index Dioscoridis' de Amato Lusitano", Estudos de Castelo Branco 28 (1968), pp. 135-157; "O Index Dioscoridis de Amato Lusitano", Semana Médica 11.521 (1969), 
O clima de Lisboa, de Castelo Branco e da Guarda, segundo os comentários de Amato Lusitano $(1968)^{87}$ e outros textos ${ }^{88}$.

A iconografia amatiana também foi objecto de estudo de José Lopes Dias que publicou sobre esta matéria ${ }^{89}$, para além de vários textos alusivos às comemorações do IV Centenário de Amato $^{90}$. Ficaria incompleta esta abordagem sumária da bibliografia de José Lopes Dias sobre Amato se não referíssemos os textos de prefácio à publicação das Centúrias de Amato, publicados em colaboração com Firmino Crespo ${ }^{91}$.

No conjunto da obra de José Lopes Dias sobressai o grosso volume de textos dispersos, publicado em 1971 como número autónomo da revista Estudos de Castelo Branco, intitulado Biografia de Amato Lusitano e outros ensaios amatianos ${ }^{92}$ e, ainda, Amato Lusitano. Doutor Joáo Rodrigues de Castelo Branco. Ensaio biobibliográfico publicado em $1941^{93}$, trabalho que aborda as relaçôes iniciais de Amato com Portugal, acompanha o percurso de Amato de Portugal para Espanha e depois a saída de Portugal para Antuérpia, Ferrara, Ancona, Roma, Ragusa e Salónica, incide sobre a actividade científica de Amato e ainda se dedica ao tema "Historiadores,

pp. 16-18; 11.522 (1969), pp. 14-20; "Comentários ao "Index Dioscoridis" de Amato Lusitano", O Médico, Nova série 50.905 (1969), pp.156-167.

87 Cf. José Lopes DiAs, "O clima de Lisboa, de Castelo Branco e da Guarda, segundo os comentários de Amato Lusitano", Estudos de Castelo Branco 25 (1968), pp. 138-156.

88 José Lopes DiAs, "Médicos portugueses da renascença vizinhos da Estremadura espanhola", O Médico, Nova série 66.1114 (1973), pp. 110-119; "Médicos portugueses da renascença vizinhos da estremadura espanhola", Notícias Médicas 2.97 (1973), p. 10; 15; 2.98 (1973), p. 10; 15.

89 Cf. José Lopes Dias, "Iconographic memento on Amato Lusitanus (1511-1568)" in Centenário (IV) de João Rodrigues de Castelo Branco - Amato Lusitano, Castelo Branco, Estudos de Castelo Branco, 1968, pp. 69-86; "Iconographic memento on Amatus Lusitanus (1511-1568)", Estudos de Castelo Branco 28 (1968), pp. 117-130 com tradução portuguesa para "Memória iconográfica sobre Amato Lusitano", Estudos de Castelo Branco 28 (1968), pp. 131-134.

90 Cf, por exemplo, José Lopes DiAs, "Prefácio", in Centenário (IV) de João Rodrigues de Castelo Branco - Amato Lusitano. Castelo Branco, Estudos de Castelo Branco, 1968, pp. 7-12; José Lopes DiAs, "IV Centenário de João Rodrigues de Castelo Branco", O Médico, Nova série 50.916 (1969), pp. 1213-1214.

91 Cf., por exemplo, José Lopes DiAs; Firmino CRESPo (Introdução e notas), "Primeira Centúria de Curas Médicas de João Rodrigues de Castelo Branco (Amatus Lusitanus)", Arquivo de Patologia 16 (1944), pp. I-LIX. José Lopes DiAS; Firmino CRESPo, (Introdução e notas), "Segunda Centúria de Curas Médicas de João Rodrigues de Castelo Branco (Amatus Lusitanus)", Arquivo de Patologia 20 (1948). José Lopes DIAS; Firmino CRESPO, "Terceira Centúria de Amato Lusitano. Fragmentos da Introdução" Clínica Contemporânea 7.3 (1953), pp. 186-193. José Lopes DiAs; Firmino CRESPO (Introdução e notas), "Primeira Centúria de Curas Médicas de João Rodrigues de Castelo Branco (Amatus Lusitanus)", Arquivo de Patologia 16 (1944), pp. I-LIX. José Lopes DiAS; Firmino CRESPo (introdução e notas), "Segunda Centúria de Curas Médicas de João Rodrigues de Castelo Branco (Amatus Lusitanus)", Arquivo de Patologia 20 (1948).

92 Cf. José Lopes DiAs, "Biografia de Amato Lusitano e outros ensaios amatianos", Estudos de Castelo Branco 37 (1971), pp. 3-234.

93 Cf. José Lopes DiAs, Amato Lusitano. Doutor João Rodrigues de Castelo Branco. Ensaio biobibliográfico. Lisboa, 1942. Este texto foi apresentado ao Congresso sobre a Actividade Científica Portuguesa (1940), constando no volume XIII do livro das comunicações. 
críticos, amigos e tradutores. Testamento profissional de Amato", um documento também importante na perspectiva da história da história.

\section{OUTROS ESTUDOS E OUTROS ESTUDIOSOS}

É longa a lista de autores e de estudiosos que publicaram em Portugal sobre Amato.

Independentemente da profundidade, rigor e extensão, alguns fizeram um retrato biográfico de Amato como é o caso de: Maximino Correia ${ }^{94}$, Diogo Barbosa Machado ${ }^{95}$, Rodrigues de Gusmão ${ }^{96}$, Sousa Viterbo ${ }^{97}$, Abílio Mendes $^{98}$, Barbosa Sueiro ${ }^{99}$, Ferreira de Mira ${ }^{100}$, Xavier Morato $^{101}$, A. Tavares de Sousa ${ }^{102}$, Eduardo Ricou ${ }^{103}$, José Manuel Pereira da Silva ${ }^{104}$, Garcia e

94 Cf. Maximino Correia, "[Amato Lusitano]". Revista Portuguesa de Medicina 5.6 (1956), pp. 181-184; Comemorações do IV Centenário da morte de Amato Lusitano. Estudos de Castelo Branco 27 (1968), pp. 5-21; "Alguns passos da vida de Amato Lusitano". Memórias da Academia das Ciências de Lisboa. Classe de Ciências 12 (1968), pp. 117-134; "Comemoração do IV Centenário da morte de Amato Lusitano na Academia das Ciências de Lisboa", in Centenário (IV) de João Rodrigues de Castelo Branco - Amato Lusitano. Castelo Branco, Estudos de Castelo Branco, 1968, pp. 13-28.

95 Cf. Diogo Barbosa MACHAdo, "Amato Lusitano" in Bibliotheca Lusitana, Tomo 1. Coimbra, Atlântida Editora, 1965, pp. 128-130 (Fac-simile da edição de Lisboa, Na Officina de Antonio Isidoro da Fonseca, 1741).

96 F. A. Rodrigues de Gusmão, "João Rodrigues de Castelo Branco", Coimbra Médica 5.10 (1885), pp. 170-171.

97 Cf. Sousa Viterbo, "Amato Lusitano", A Medicina Contemporânea 25.13 (1907), pp. 98-100; "Bibliografia. Amato Lusitano. A sua vida e a sua obra por Maximiano Lemos. 1 vol. de 212 pag. Porto 1907", A Medicina Contemporânea 25.11 (1907), pp. 82-84.

98 Cf. Abílio T. Mendes, "Doutor ]oão Rodrigues de Castelo Branco (Amato Lusitano) [artigo de polémica com José Lopes Dias]. Ao Dr. José Lopes Dias", O Médico. Nova série 36.723 (1965), pp. 100-101; "Doutor João Rodrigues de Castelo Branco (Amato Lusitano) - Nota biográfica", O Médico. Nova série 34.714 (1965), pp. 430-431.

99 Cf. Barbosa M. B. Sueıro, "A propósito de Amato Lusitano", Imprensa Médica 9.13-14 (1943), pp. $210 ; 221$.

100 Cf. Ferreira de MIRA, "Amato Lusitano", Médico Policlínico 3.44 (1980), pp. 41-44.

101 Cf. Xavier Morato, "[Amato Lusitano]", Revista Portuguesa de Medicina 5.6 (1956), pp. 1172-174.

102 Cf. A. Tavares de SousA, "[Amato Lusitano]", Revista Portuguesa de Medicina 5.6 (1956), pp. 174-178; "No quarto centenário da morte de Amato Lusitano" in Centenário (IV) de João Rodrigues de Castelo Branco - Amato Lusitano. Castelo Branco, Estudos de Castelo Branco, 1968, pp. 177-189; "No quarto centenário da morte de Amato Lusitano", Coimbra Médica 16.4, $3^{a}$ série (1969), pp. 303-314; "No quarto centenário da morte de Amato Lusitano", Estudos de Castelo Branco 29 (1969), pp. 8-20. Veja-se, também, "La valeur de l'oeuvre scientifique de Amatus Lusitanus, quatre siècles après sa mort", Clio Medica, Acta Academiae Internationalis Historiae Medicinae 7 (1972), pp. 69-72.

103 Cf. Eduardo Rıcou, "A longa jornada de Amato Lusitano", Jornal do Médico 125.2293 (1988), p. 732.

104 Cf. José Manuel Pereira da SILva, "Acerca de Amato Lusitano", Estudos de Castelo Branco 17 (1965), pp. 130-134; "Acerca de Amato Lusitano", Itinerário 1 (1965). 
Silva ${ }^{105}$, Pires de Lima ${ }^{106}$. Augusto d'Esaguy foca o Juramento de Amato Lusitano ${ }^{107}$. Alfredo Rasteiro, a propósito da medicina dos descobrimentos e da medicina judaica portuguesa aborda Amato Lusitano ${ }^{108}$, temática em que incide frequentemente noutras publicações.

Em obras gerais de autores portugueses sublinhem-se, por exemplo, Maximiano Lemos que, ao referir-se aos estudos da anatomia no Renascimento, sublinha que para esse período "ocorre logo o nome de um português, notável por muitos outros títulos, João Rodrigues de Castelo Branco, mais conhecido pelo nome de Amato Lusitano" ${ }^{109}$. J. A. Pires de Lima que refere que "a sua obra é notabilíssima e ocupa-se de vários ramos das ciências médicas" ${ }^{110}$, sublinhando que Amato se mostrou, também, como um "grande naturalista, nos seus comentários às obras de Dioscórides"111. M. Ferreira de Mira considerou que "os passos de Amato pelo mundo, e foram muitos, marcou-os ele próprio na sua obra científica: os Comentários aos dois primeiros livros de Dioscórides e as Centúrias de curas médicas" ${ }^{112}$. A. Tavares de Sousa que considera Amato como "o mais ilustre médico português do século Xvi" ${ }^{113}$.

Rocha Brito dedicou-se ao Juramento de Amato ${ }^{114}$, publicando e ocasionando reflexóes sobre a matéria ${ }^{115}$. Também teve semelhantes preocupaçôes Miller Guerra ${ }^{116}$.

105 Cf. L. Garcia e SILVA, "Amato Lusitano: um médico europeu no tempo dos descobrimentos", Acta Médica Portuguesa $2^{\text {a }}$ série 3:5 (1990), pp. 297-300.

106 Cf. F. C. Pires de LımA, "Amato Lusitano", in Verbo. Enciclopédia Luso-Brasileira de Cultura. Lisboa, Editorial Verbo, s.d., pp. 1621-1622.

107 Cf. Augusto d'Esaguy, Oração e Juramento Médico de Moisés Maimonide e Amato Lusitano. Lisboa, edição do autor, 1955.

108 Cf. Alfredo RASteiro, Medicina e descobrimentos. Coimbra, Livraria Almedina, 1992; Alfredo RASteIRo, Medicina judaica lusitana, século xvı. Coimbra, Quarteto, 2000, p. 71 e ss.

109 Cf. Maximiano Lemos, História da medicina em Portugal. Doutrinas e instituições. Lisboa, Publicações Dom Quixote/Ordem dos Médicos, 1991, p. 189.

110 Cf. J. A. Pires de LIMA, Epitome de história da medicina portuguesa. Porto, Portucalense Editora, SARL, 1943, p. 41.

111 Idem, Ibidem.

112 M. Ferreira de MIRA, História da medicina portuguesa. Lisboa, Edição da Empresa Nacional de Publicidade, 1948, p. 110.

113 Cf. A. Tavares de SousA, Curso de história da medicina. Das origens aos fins do século xvı. $2^{a}$ edição. Lisboa, FCG, 1996, p. 304. Na primeira edição da obra vide página 300.

114 Sobre o Juramento de Amato vejam-se, por exemplo, os artigos: "Juramento (0) de Amato Lusitano", Médico Hospitalar 12 (1998), pp. 31-32 e "Juramento de Amato Lusitano (um dos notáveis documentos médicos da renascença)", Clínica Contemporânea 3.28 (1949), pp. 1622-1623.

115 A. Rocha BRITO, "Poeira dos arquivos - juramento de Amato Lusitano", Coimbra Médica 4.1, 2a série, (1937), pp. 33-38.

116 Cf. Miller Guerra, "Amati Jusjurandum" in Centenário (IV) de João Rodrigues de Castelo Branco — Amato Lusitano. Castelo Branco, Estudos de Castelo Branco, 1968, pp. 173-175. "Amati Jusjurandum", Estudos de Castelo Branco 29 (1969), pp. 5-7. 
Silva Carvalho ocupou-se da relação de Amato com a urologia ${ }^{117}$. José Paiva Boléo preocupou-se com a invenção do obturador palatino ${ }^{118}$. Caria Mendes incidiu a sua atenção sobre Amato anatomista ${ }^{119}$, tal como Quintino Rogado. Por seu turno Luís de Pina tem, entre outros, um interessante estudo sobre as ideias de Amato em questôes psiquiátricas ${ }^{120}$ e de colaboração com Olívia Rúber de Meneses um estudo sobre as relaçóes da escola médica do Porto com os estudos biográficos de Amato ${ }^{121}$. Miller Guerra interessou-se pela obra científica de Amato Lusitano $^{122}$. Costa Sacadura estudou um caso clínico de Amato ${ }^{123}$.

Pelo seu valor historiográfico é de sublinhar com particular destaque a obra de A. J. Andrade Gouveia, Garcia d'Orta e Amato Lusitano na ciência do seu tempo, monografia com perto de 100 páginas e, do mesmo autor, Posiçóes de Garcia d'Orta e de Amato Lusitano na ciência do seu tempo ${ }^{124}$.

117 Cf. Augusto da Silva Carvalho, "João Rodrigues na história da urologia" in Homenagem ao Doutor João Rodrigues de Castelo Branco (Amato Lusitano). Castelo Branco, Câmara Municipal de Castelo Branco, 1955, pp. 137-141.

118 Cf. José de Paiva BolÉo, "Amatus Lusitanus, the inventor the palatine obturator", Estudos de Castelo Branco" 28 (1968), pp. 205-213; tradução em "Amatus Lusitanus inventor do obturador palatino", Estudos de Castelo Branco 28 (1968), p. 213. Veja-se também em "Amatus Lusitanus, the inventor the palatine obturator", in Centenário (IV) de João Rodrigues de Castelo Branco — Amato Lusitano. Castelo Branco, Estudos de Castelo Branco, 1968, pp. 159-172.

119 Cf. J. Caria Mendes, "Amatus Lusitanus anatomista", Estudos de Castelo Branco 28 (1968), pp. 179-204. "Amatus Lusitanus anatomista", in Centenário (IV) de João Rodrigues de Castelo Branco - Amato Lusitano. Castelo Branco, Estudos de Castelo Branco, 1968, pp. 133-158; "Amatus Lusitanus anatomista", Arquivo de Anatomia e Antropologia 35 (1971), pp. 269-291; "Amatus Lusitanus", Notícias Médicas 18:1812 (1989), pp. 11-12. Veja-se o trabalho de colaboração J. P. Miller GUERRA; J. Caria MENDES; L. Quintino RoGADo, "As válvulas das veias ázigos. As experiências de Amatus Lusitanus e a posição actual do problema", Jornal da Sociedade das Ciências Médicas de Lisboa 135:1 (1970), pp. 35-59. Ver também "As válvulas das veias ázigos. As experiências de Amatus Lusitanus e a posição actual do problema", Arquivo de Anatomia e Antropologia 35 (1971), pp. 147-167.

120 Cf. Luís de PINA, "Amato Lusitano na história da psiquiatria portuguesa", in Homenagem ao Doutor João Rodrigues de Castelo Branco (Amato Lusitano). Castelo Branco, Câmara Municipal de Castelo Branco, 1955, pp. 143-175. Veja-se também de Luís de Pina, "Amato Lusitano — lusitano e europeu", Imprensa Médica 20.6 (1956), pp. 342-350. Veja-se uma biografia muito sintética de "Amato em [Amato Lusitano]", Revista Portuguesa de Medicina 5.6 (1956), pp. 168-172.

121 Cf. Luís de Pina; Maria Olívia Rúber de Meneses, "A Escola Médica do Porto nos estudos biográficos e críticos de Amato Lusitano", Estudos de Castelo Branco 28 (1968), pp. 96-116. Veja-se também em: "A Escola Médica do Porto nos estudos biográficos e críticos de Amato Lusitano (no $4^{\circ}$ centenário da sua morte)" in Centenário (IV) de João Rodrigues de Castelo Branco - Amato Lusitano. Castelo Branco, Estudos de Castelo Branco, 1968, pp. 47-67.

122 Cf. Miller Guerra, "A obra científica de Amato Lusitano", Estudos de Castelo Branco 26 (1968), pp. 22-32; "A obra científica de Amato Lusitano", Memórias da Academia das Ciências de Lisboa. Classe de Ciências 12 (1968), pp. 135-146. Ver também "A obra científica de Amato Lusitano", in Centenário (IV) de João Rodrigues de Castelo Branco — Amato Lusitano. Castelo Branco, Estudos de Castelo Branco, 1968, pp. 29-39.

123 Cf. Costa SACADURA, "Certo caso, admirável mas verdadeiro, de uma mulher grávida, de que nos fala Amatus Lusitanus em 1564, repetido em nossos dias", A Medicina Contemporânea 73.7 (1955), pp. 347-350.

124 Cf. A. J. Andrade GouvelA, Garcia d'Orta e Amato Lusitano na ciência do seu tempo. Lisboa, Instituto de Cultura e Língua Portuguesa, 1985, 93 p.; do mesmo autor, "Posições de Garcia d'Orta e de Amato Lusitano na ciência do seu tempo" in História e Desenvolvimento da Ciência em Portugal, vol. 1. Lisboa, 
Mais recentemente assinalem-se também os estudos de Isilda Rodrigues sobre os problemas sexuais nas Centúrias de Amato Lusitano ${ }^{125}$.

\section{A TRADUÇÃO DAS CENTÚRIASE OUTROS ESTUDOS}

Firmino Crespo foi um tradutor das Centúrias de Amato. Legou-nos, também, alguns trabalhos de investigação sobre João Rodrigues ${ }^{126}$ e colaborou noutros trabalhos de co-autoria com José Lopes Dias ${ }^{127}$. Relativamente à tradução das Centúrias, assinale-se a edição, traduzida e prefaciada por Firmino Crespo, editada pela Faculdade de Ciências Médicas da Universidade Nova de Lisboa, obra em quatro volumes. No prefácio do primeiro volume, Firmino Crespo faz um breve historial das traduções para português das Centúrias de Amato, desde a proposta de José Lopes Dias, passando pela publicação das três primeiras centúrias, em 1946, 1949 e 1956, na revista do Instituto de Oncologia e no Arquivo de Patologia e, graças ao empenho de Francisco Gentil e de Mark Athias; passados mais de vinte anos, em 1979, Carlos dos Santos Reis intenta publicar as restantes Centúrias nos Anais do Instituto de Higiene e Medicina Tropical. Finalmente, a concretização, nos anos oitenta, em virtude do empenho de Luís Nuno Ferraz de Oliveira e da Faculdade de Ciências Médicas em patrocinar a edição completa das Centúrias ${ }^{128}$. Assinale-se, muito recentemente, a reedição das Centúrias traduzidas por Firmino Crespo numa edição da Ordem dos Médicos ${ }^{129}$. Trata-se de uma edição que retoma a versão de Firmino Crespo,

Publicações do II Centenário da Academia das Ciências de Lisboa, 1986, pp. 303-333. Veja-se "Severo de Melo, Garcia de Orta e Amato Lusitano na ciência do seu tempo", Vértice 46.470-472 (1986), p. 189.

125 Cf. Isilda Rodrigues, Amato Lusitano e as problemáticas sexuais - Algumas contribuições para uma nova perspetiva de análise das Centúrias de Curas Medicinais. Tese de Doutoramento - Universidade de Trás -os-Montes e Alto Douro. Vila Real, 2005. Veja-se, também, "Amato Lusitano e as questões sexuais - Algumas contribuições para uma nova perspectiva de análise das Centúrias de Curas Medicinais", Revista Portuguesa de Ciência das Religiões 11 (2007), pp. 317-333.

126 Cf. Firmino CRESPO, "Amato Lusitano revelado através da sua obra", in Centenário (IV) de João Rodrigues de Castelo Branco - Amato Lusitano. Castelo Branco, Estudos de Castelo Branco, 1968, pp. 193-204; "Amato Lusitano revelado através da sua obra", Estudos de Castelo Branco 29 (1969), pp. 23-24; "Bristol e Londres nas Centúrias de Amato Lusitano", Ocidente 76.369 (1969), pp. 4-5; "Amatus Lusitano, professor universitário de Ferrara", Ocidente. Revista Portuguesa de Cultura, Nova Série 80.393 (1971), pp. 36-38; "Alguns aspectos da vida e obra de Amato Lusitano", Medicina na Beira Interior. Da Pré-História ao Século xx - Cadernos de Cultura 8 (1994), pp. 3-4.

127 Cf. Firmino CRESPO; José Lopes DiAs (tradução), "Cura de Amato Lusitano de uma queda por coice de cavalo", Imprensa Médica 19.1 (1955), pp. 61-62; Firmino CRESPO; José Lopes DiAs, "Escorço biográfico [de Amato Lusitano]" in Homenagem ao Doutor João Rodrigues de Castelo Branco (Amato Lusitano). Castelo Branco, Câmara Municipal de Castelo Branco, 1955, pp. 215-250.

128 Cf. Amato Lusitano (João Rodrigues de Castelo Branco), Centúrias de curas medicinais. Lisboa, Universidade Nova de Lisboa - Faculdade de Ciências Médicas, s.d. [1980], 4 vols.

129 Cf. Amato Lusitano (João Rodrigues de Castelo Branco), Centúrias de curas medicinais. Lisboa, Centro Editor Livreiro da Ordem dos Médicos, 2010. 2 vols. Prefácio e tradução de Firmino Crespo com introdução de Pedro Nunes. 
com umas palavras de abertura de Pedro Nunes. Teria sido interessante que esta edição tivesse um estudo introdutório relevante, a propósito dos quinhentos anos do nascimento de Amato.

Muito úteis neste horizonte são, também, as publicaçôes de Américo da Costa Ramalho ${ }^{130}$. Assinalem-se e sublinhem-se, também, os estudos actuais de António Manuel Lopes Andrade sobre Amato Lusitano (vários aspectos biográficos) e ainda alguns estudos sobre algumas questôes contextuais e familiares de Amato. É o caso de Ciência, Negócio e Religião: Amato Lusitano em Antuérpia ${ }^{131}$; Os Senhores do Desterro de Portugal: Judeus portugueses em Veneza e Ferrara, em meados do século Xvi ${ }^{132}$; As tribulaçóes de Mestre João Rodrigues de Castelo Branco (Amato Lusitano) à chegada a Antuérpia, em 1534, em representação do mercador Henrique Pires, seu tio materno ${ }^{133}$; A mundividência de Diogo Pires à luz da colectânea poética dos Xenia ${ }^{134}$; A Senhora e os destinos da Nação Portuguesa: o caminho de Amato Lusitano e de Duarte Gomes ${ }^{135}$; Dioscórides renovado pela mão dos humanistas: os comentários de Amato Lusitano ${ }^{136}$.

Neste âmbito assinale-se ainda de António Andrade a entrada no Dizionario storico dell'Inquisizione sobre o tio de Amato, pai de Diogo Pires ${ }^{137}$. Sublinhe-se, também, a obra da responsabilidade de António Andrade, João Torrão, Jorge Costa; Júlio Costa (org.), Humanismo,

130 Cf. Américo da Costa Ramalho, "Prefácio" in Mário Santoro, Amato Lusitano ed Ancona. Coimbra, Centro de Estudos Clássicos e Humanísticos da Faculdade de Letras da Universidade de Coimbra / Instituto Nacional de Investigação Científica, 1991, 177 p. Vejam-se os artigos "A propósito do 'Amato Lusitano' de Ricardo Jorge", Revista Portuguesa de História 10 (1962), pp. 501-508. Veja-se também "A propósito do "Amato Lusitano" de Ricardo Jorge", in Estudos sobre a época do Renascimento, Coimbra, 1969, pp. 187-195.

131 António Manuel Lopes AndRADE, "Ciência, Negócio e Religião: Amato Lusitano em Antuérpia", in Inês de Ornellas e CASTRO; Vanda ANASTÁCIO (coord.). Revisitar os Saberes - Referências Clássicas na Cultura Portuguesa do Renascimento à Época Moderna. Lisboa, Centro de Estudos Clássicos - Faculdade de Letras da Universidade de Lisboa, 2010, pp. 9-49.

132 António Manuel Lopes ANDRADE, "Os Senhores do Desterro de Portugal: Judeus portugueses em Veneza e Ferrara, em meados do século xvı", Veredas - Revista da Associação Internacional de Lusitanistas 6 (2006), pp. 65-108.

133 António Manuel Lopes ANDRADE, "As tribulações de Mestre João Rodrigues de Castelo Branco (Amato Lusitano) à chegada a Antuérpia, em 1534, em representação do mercador Henrique Pires, seu tio materno", Medicina na Beira Interior. Da Pré-História ao séc. XxI - Cadernos de Cultura 23 (2009), pp. 7-14

134 António Manuel Lopes ANDRADE, "A mundividência de Diogo Pires à luz da colectânea poética dos Kenia", in Francisco de Oliveıra; Cláudia TeıxeIra; Paula Barata Dias (Coords.), Espaços e Paisagens: Antiguidade Clássica e Heranças Contemporâneas. Vol. 2. Línguas e Literaturas. Idade Média. Renascimento. Recepção. Coimbra, Associação Portuguesa de Estudos Clássicos - Centro de Estudos Clássicos e Humanísticos da Universidade de Coimbra, 2009, p. 345-351. Trata-se de uma colectânea poética que resultou da parceria entre Diogo Pires e Amato, amigos e primos direitos, inspirada em parte nos comentários a Dioscórides.

135 António Manuel Lopes ANDRADE, "A Senhora e os destinos da Nação Portuguesa: o caminho de Amato Lusitano e de Duarte Gomes", Cadernos de Estudos Sefarditas 10.11 (2011), pp. 87-130.

136 António Manuel Lopes ANDRADE, "Dioscórides renovado pela mão dos humanistas: os comentários de Amato Lusitano", in Carmen SoAres (Coord.), Espaços do Pensamento Científico da Antiguidade. Volume I. Coimbra, Imprensa da Universidade de Coimbra, 2013, pp. 71-90.

137 António Manuel Lopes ANDRADE, s. v. PIRES, Henrique: Dizionario storico dell'Inquisizione, diretto da Adriano Prosperi con la collaborazione di Vincenzo Lavenia e John Tedeschi. Pisa, Edizioni della Normale, 2010. 
Diáspora e Ciência (séculos XVI e XVII): estudos, catálogo, exposiçāô ${ }^{138}$. Trata-se de um volume que provém do Colóquio Internacional «Humanismo, Diáspora e Ciência» e da Exposição Bibliográfica, realizados na Biblioteca Pública Municipal do Porto, entre 7 e 8 de Março de 2013. Neste volume assinalem-se os estudos António Manuel Lopes Andrade, Amato Lusitano, Diogo Pires e Pedro Santerna: os caminhos entrecruzados de um médico, de um poeta e de um jurisconsulto portugueses ${ }^{139}$; Virgínia Soares Pereira, Plantas de uso terapêutico e alimentar em Amato Lusitano e Diogo Pires ${ }^{140 "}$ ". Nesta linha de estudos salientem-se ainda os trabalhos seguintes: António Manuel Lopes Andrade; Hugo Miguel Crespo, Os inventários dos bens de Amato Lusitano, Francisco Barbosa e Joseph Molcho, em Ancona, na fuga à Inquisição (1555) ${ }^{141}$; João Manuel Nunes Torrão, Marcelo Virgílio e Amato Lusitano: a utilização do saber alheio para a lenta construção de um saber próprio (breves indicaçôes) ${ }^{142}$; António Guimarães Pinto, Ciência e Preconceito: $O$ ataque de Pietro Andrea Mattioli a Amato Lusitano ${ }^{143}$; Ana Alexandra Macedo Lima, La melancolía en las Primeira y Segunda Centúrias de Curas Medicinais de Amato Lusita$n o^{144}$. Na obra-catálogo, Arte Médica e Imagem do Corpo. De Hipócrates ao final do século XviII são várias as referências aos trabalhos de Amato Lusitano ${ }^{145}$.

138 António ANDRADE; João ToRRÃo; Jorge Costa; Júlio Costa (org.), Humanismo, Diáspora e Ciência (séculos xVI exVII): estudos, catálogo, exposição. Porto, Câmara Municipal do Porto, Biblioteca Pública Municipal; Universidade de Aveiro, Centro de Línguas e Culturas, 2013.

139 António Manuel Lopes Andrade, "Amato Lusitano, Diogo Pires e Pedro Santerna: os caminhos entrecruzados de um médico, de um poeta e de um jurisconsulto portugueses", in António ANDRADE; João TORRÃo; Jorge COSTA; Júlio Costa (org.), Humanismo, Diáspora e Ciência (séculos XVI e XVII): estudos, catálogo, exposição. Porto, Câmara Municipal do Porto, Biblioteca Pública Municipal; Universidade de Aveiro, Centro de Línguas e Culturas, 2013, pp. 117-138.

140 Virgínia Soares Pereira, "Plantas de uso terapêutico e alimentar em Amato Lusitano e Diogo Pires", in António ANDRADE; João ToRRÃo; Jorge CostA; Júlio Costa (org.). Humanismo, Diáspora e Ciência (séculos XVI exVII): estudos, catálogo, exposição. Porto, Câmara Municipal do Porto, Biblioteca Pública Municipal; Universidade de Aveiro, Centro de Línguas e Culturas, 2013, pp. 313-326.

141 António Manuel Lopes ANDRADE; Hugo Miguel CRESPo, "Os inventários dos bens de Amato Lusitano, Francisco Barbosa e Joseph Molcho, em Ancona, na fuga à Inquisição (1555)", Ágora. Estudos Clássicos em Debate 14.1 (2012), pp. 45-90.

142 João Manuel Nunes TorRÃo, "Marcelo Virgílio e Amato Lusitano: a utilização do saber alheio para a lenta construção de um saber próprio (breves indicações)", in Maria Cristina PIMENTEL; Paulo Farmhouse AlBerto (eds.), Vir bonus peritissimus aeque. Estudos de homenagem a Arnaldo do Espírito Santo. Lisboa, Centro de Estudos Clássicos, 2013, pp. 601-610.

143 António Guimarães PINTO, "Ciência e Preconceito: O ataque de Pietro Andrea Mattioli a Amato Lusitano", Humanitas 65 (2013), pp. 157-182.

144 Ana Alexandra Macedo LiMA, "La melancolía en las Primeira y Segunda Centúrias de Curas Medicinais de Amato Lusitano", in Manuel Lázaro Pulido, José Luis Fuertes Herreros, Ángel Poncela González (coord..), La filosofía de las pasiones y la Escuela de Salamanca: Edad Media y Moderna, 2013, pp. 87-97. Da mesma autora também "La melancolía en la Primeira y Segunda Centúrias de Curas Medicinais de Amato Lusitano", Cauriensia: revista anual de Ciencias Eclesiásticas 7 (2012), pp. 89-99.

145 Cf. Adelino Cardoso, António Braz de Oliveira; Manuel Silvério Maroues (coord.), Arte Médica e Imagem do Corpo. De Hipócrates ao final do século XVIII. Lisboa, Biblioteca Nacional de Portugal, 2010. 


\section{OUTROS TEXTOS}

Diversos artigos de reduzidas dimensóes ou de tipo nota abordam a figura de Amato. Compilámos textos desta natureza em publicaçóes como O Bacilo $(1963)^{146}$ e a Revista da Associação Portuguesa de Clinicas Privadas de Hemodiálise (1994) ${ }^{147}$. Manuel Freitas e Costa na obra Personalidades e grandes vultos da medicina portuguesa através dos séculos tem uma entrada com Amato Lusitano $^{148}$. Manuel Machado Macedo na obra panorâmica sobre a medicina em Portugal no século xx intitulada História da Medicina Portuguesa no século xx refere Amato o que acentua a sua condição de vulto incontornável da medicina do nosso país ${ }^{149}$. Assinale-se, também, uma publicação de natureza educativa da autoria de Maria Adelaide Neto Salvado e Maria de Lurdes Pires Cardoso intitulada $O$ horto de Amato Lusitano. Uma ponte para cultura, educaçáo e cidadania ${ }^{150}$.

\section{VOLUMES MONOGRÁFICOS E PUBLICAÇÕES PERIÓDICAS}

Um volume intitulado Homenagem ao Doutor João Rodrigues de Castelo Branco (Amato Lusitano), editado em Castelo Branco em 1955 e prefaciado por José Lopes Dias constitui também um valioso estudo colectivo sobre Amato. Nas 250 páginas da obra encontramos trabalhos de vários autores, alguns já referidos, sendo outros estrangeiros. É igualmente de registar o grosso volume de cerca de 200 páginas, comemorativo do IV Centenário de Joáo Rodrigues de Castelo Branco — Amato Lusitano, prefaciado por José Lopes Dias e editado em $1968^{151}$.

A revista Estudos de Castelo Branco cuja publicação se iniciou em 1961 constitui um espólio de enorme valor para o estudo da vida e obra de Amato Lusitano, dada a qualidade dos artigos que encerra sobre o médico albicastrense, muitos dos quais já referidos.

Incontornável é a publicação Medicina na Beira Interior. Da Pré-História ao Século xxI - Cadernos de Cultura ${ }^{152}$ pois apresenta para o estudo da vida e obra de Amato Lusitano, contributos

146 Cf. "João Rodrigues Castelo Branco — Amato Lusitano (1511-1568)", O Bacilo. za série 2 (1963), pp. 3; 15-16.

147 Cf. "História (Da)... João Rodrigues de Castelo Branco", Revista da Associação Portuguesa de Clínicas Privadas de Hemodiálise 1 (1994), p. 21.

148 Manuel Freitas e Costa na obra Personalidades e grandes vultos da medicina portuguesa através dos séculos. Lisboa, Lidel, 2010, pp. 143-144.

149 Cf. Manuel Machado MACEDo, História da Medicina Portuguesa no século xx. Lisboa, CTTCorreios, 1999, p. 17.

150 Cf. Maria Adelaide Neto SAlvado; Maria de Lurdes Pires CARdoso, O horto de Amato Lusitano. Uma ponte para cultura, educação e cidadania. Castelo Branco, 2004.

151 Cf. Centenário (IV) de João Rodrigues de Castelo Branco - Amato Lusitano (Prefácio de José Lopes Dias). Castelo Branco, Estudos de Castelo Branco, 1968, 204 p.

152 Além da consulta obrigatória da revista veja-se, também, Maria Adelaide Neto SALVADo; António Lourenço Maroues (orgs.), Amato Lusitano nos Cadernos de Cultura "Medicina na Beira Interior - Da Pré-História ao Século xxı, Castelo Branco, Semedo Sociedade Tipográfica, Lda, 2004. 
muito diversificados de vários autores como António Andrade (já referido) e em colaboração com José Sílvio Moreira Fernandes ${ }^{153}$, Romero Bandeira ${ }^{154}$, Maria de Lourdes Barata ${ }^{155}$, Firmino Crespo ${ }^{156}$, Fanny Xavier da Cunha ${ }^{157}$, A. M. Lopes Dias ${ }^{158}$, António Lourenço Marques ${ }^{159}$,

153 Cf. José Sílvio Moreira Fernandes; António Manuel Lopes AndRADE, "A pedra bezoar e o unicórnio nos comentários de Amato Lusitano a Dioscórides: propriedades, valor, tradição e tradução", Medicina na Beira Interior. Da Pré-História ao Século xxI — Cadernos de Cultura 24 (2010), pp. 35-40.

154 Cf. Romero BANDEIRA, "Amato, médico sem fronteiras", Medicina na Beira Interior. Da Pré-História ao Século Xx - Cadernos de Cultura 10 (1996), pp. 45-46. Romero BANDEIRA; José Viana PINHEIRo; Mário LOPES, "Evolução e conceitos revendo o Juramento de Amato. O segredo na iatroética", Medicina na Beira Interior. Da Pré-História ao Século xx — Cadernos de Cultura 6 (1993), pp. 22-23.

155 Maria de Lurdes Gouveia da Costa Barata, "Um poder do fogo - de Amato Lusitano aos poetas", Medicina na Beira Interior. Da Pré-História ao Século xxI - Cadernos de Cultura 14 (2000), pp. 58-63.

156 Cf. Firmino CRESPo, "Alguns aspectos da vida e obra de Amato Lusitano", Medicina na Beira Interior. Da Pré-História ao Século xx - Cadernos de Cultura 8 (1994), pp. 3-4.

157 Cf. Fanny Andrée Font Xavier da CunHA, "A arte de curar em Amato Lusitano (1511-1568) e o quotidiano terapêutico português no século XVIII. Panaceias nossas de cada dia, "ontem e hoje" ". Medicina na Beira Interior. Da Pré-História ao Século xx — Cadernos de Cultura 9 (1995), pp. 11-19; "A alimentação na obra de Amato Lusitano (1511-1568)", Medicina na Beira Interior. Da Pré-História ao Séculoxx — Cadernos de Cultura 11 (1997), pp. 9-14; "A água, medicina universal, e Amato Lusitano (1511-1568)", Medicina na Beira Interior. Da Pré-História ao Século xx — Cadernos de Cultura 13 (1999), pp. 10-16; "O "fogo" na obra de Amato Lusitano", Medicina na Beira Interior. Da Pré-História ao Século xxI - Cadernos de Cultura 14 (2000) pp. 30-33; "A cultura clássica nas obras de dois grandes autores-médicos naturais da Beira Interior: Amato Lusitano e Ribeiro Sanches", Medicina na Beira Interior. Da Pré-História ao SéculoxxI —Cadernos de Cultura 15 (2001), pp. 30-37; "Amato Lusitano (1511-1568) e o homem esse desconhecido", Medicina na Beira Interior. Da Pré-História ao Século xxI - Cadernos de Cultura 20 (2006), pp. 42-45; "As terapêuticas preferenciais de Amato Lusitano (1511-1568) e seu ressurgimento", Medicina na Beira Interior. Da Pré-História ao Século xxI - Cadernos de Cultura 21 (2007), pp. 32-35; "A cirurgia na obra de Amato Lusitano", Medicina na Beira Interior. Da Pré-História ao Século xxI — Cadernos de Cultura 23 (2009), pp. 20-22.

158 Cf. A. M. Lopes DiAs, "Algumas plantas aromáticas usadas por Amato Lusitano", Medicina na Beira Interior. Da Pré-História ao Século xx - Cadernos de Cultura 5 (1992), pp. 16-18; "Plantas usadas por Amato Lusitano. Sua localização em solos aráveis do Distrito de Castelo Branco, algumas em perigo de extinção", Medicina na Beira Interior. Da Pré-História ao Século xx — Cadernos de Cultura 6 (1993), pp. 24-28; "Estudo da Primeira Centúria de Amato Lusitano - 0 uso das plantas, imagens de aromáticas da região da Serra da Estrela e abordagem da sua composição florística", Medicina na Beira Interior. Da Pré-História ao Século

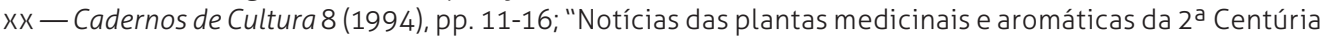
de Amato Lusitano. Achegas para o estudo da ecologia de vegetação da Beira Interior", Medicina na Beira Interior. Da Pré-História ao Século xx - Cadernos de Cultura 9 (1995), pp. 25-30; "A influência mediterrânica na vida científica do século xvı. A botânica da bacia mediterrânica em Amato Lusitano", Medicina na Beira Interior. Da Pré-História ao Século xx — Cadernos de Cultura. 11 (1997), pp. 32-36

159 Cf. António Lourenço MARQues, "Para a história da morte do século xVI. A certificação da morte em Amato Lusitano e as novas artes de morrer em Frei Heitor Pinto" Medicina na Beira Interior. Da Pré-História ao Séculoxx - Cadernos de Cultura 2 (1990), pp. 26-30; "A medicina e o médico perante o doente incurável e moribundo no século XVI — testemunhos de Amato Lusitano", Medicina na Beira Interior. Da Pré-História ao Século xx - Cadernos de Cultura 4 (1991), pp. 13-15; "A realidade da dor nas curas de Amato Lusitano", Medicina na Beira Interior. Da Pré-História ao Século xx - Cadernos de Cultura 5 (1992), pp. 19-22; "A velhice no tempo de Amato Lusitano", Medicina na Beira Interior. Da Pré-História ao Séculoxx — Cadernos de Cultura,"À procura da idade do cancro nas Centúrias de Amato Lusitano", Medicina na Beira Interior. Da Pré-História ao Século xx - Cadernos de Cultura 9 (1995), pp. 21-24; "Amarguras do nascimento e o génio de Amato Lusitano", Medicina na Beira Interior. Da Pré-História ao Século xx — Cadernos de Cultura 10 (1996), pp. 21-24; "O vinho na época de Amato lusitano: consolo, sustento e alívio", Medicina na 
Albano Mendes de Matos ${ }^{160}$, Manuel Lourenço Nunes ${ }^{161}$, José Morgado Pereira ${ }^{162}$, Alfredo Rasteiro ${ }^{163}$,

Beira Interior. Da Pré-História ao Século xx - Cadernos de Cultura 11 (1997), pp. 23-26; "A água e a vida quotidiana à luz das IV e V centúrias de curas medicinais de Amato Lusitano", Medicina na Beira Interior. Da Pré-História ao Século xx — Cadernos de Cultura 13 (1999), pp. 19-21; "Os quatro elementos e a vida quotidiana dos doentes na obra de Amato Lusitano", Medicina na Beira Interior. Da Pré-História ao Século XXI - Cadernos de Cultura 14 (2000), pp. 34-37; "Amato Lusitano e o uso da palavra médica na tradição hipocrática", Medicina na Beira Interior. Da Pré-História ao Século xxI — Cadernos de Cultura 15 (2001), pp. 25-29; "Os temas Universais em Amato Lusitano", Medicina na Beira Interior. Da Pré-História ao Século XXI - Cadernos de Cultura 16 (2002), pp. 25-28; "Saberes efémeros duradouros — o caso da sangria com passagem por Amato Lusitano", Medicina na Beira Interior. Da Pré-História ao SéculoxxI —Cadernos de Cultura 18 (2004), pp. 38-43; "Sentir dor no tempo de Amato Lusitano", Medicina na Beira Interior. Da Pré-História ao Século xx। — Cadernos de Cultura 20 (2006), pp. 37-41.

160 Cf. Albano Mendes de Matos, "A mulher e as suas doenças em Amato Lusitano", Medicina na Beira Interior. Da Pré-História ao Século xx - Cadernos de Cultura 10 (1996), 9-11; "Os produtos de origem animal na terapêutica de Amato Lusitano", Medicina na Beira Interior. Da Pré-História ao Século xx — Cadernos de Cultura 12 (1998), pp. 13-19.

161 Cf. Manuel Lourenço Nunes, "A saúde oral em Amato Lusitano", Medicina na Beira Interior. Da Pré-História ao Século xx - Cadernos de Cultura 12 (1998), pp. 25-26.

162 Cf. José Morgado Pereira, "A melancolia nas centúrias de Amato Lusitano", Medicina na Beira Interior. Da Pré-História ao Século xx - Cadernos de Cultura 7 (1993), pp. 3-5; "A doença e a condição feminina em Amato", Medicina na Beira Interior. Da Pré-História ao Século xx - Cadernos de Cultura 12 (1998), pp. 21-23; "Os comportamentos alimentares nas centúrias de curas medicinais", Medicina na Beira Interior. Da Pré-História ao Século xx - Cadernos de Cultura 12 (1998), pp. 4-7; "A ironia em Amato Lusitano", Medicina na Beira Interior. Da Pré-História ao Século xx — Cadernos de Cultura 13 (1999), pp. 30-33; "A epilepsia nas Centúrias de Curas Medicinais", Medicina na Beira Interior. Da Pré-História ao Século xx। - Cadernos de Cultura 15 (2001), pp. 22-24; "Amato Lusitano e as fronteiras da prática médica", Medicina na Beira Interior. Da Pré-História ao Século xxI - Cadernos de Cultura 16 (2002), pp. 29-32; "Considerações sobre o Morbo Gallico nas Centúrias de Amato Lusitano". Medicina na Beira Interior. Da Pré-História ao Século xxI — Cadernos de Cultura 17 (2003), pp. 31-35.

163 Cf. Alfredo RASTEIRO, "João Rodrigues de Castelo Branco e a solidariedade médica na luta contra a doença e a morte", Medicina na Beira Interior. Da Pré-História ao Séculoxx — Cadernos de Cultura 1 (1989), pp. 16-18; "Memória de Amato", Medicina na Beira Interior. Da Pré-História ao Séculoxx — Cadernos de Cultura. 5 (1992), pp. 3-7; "Amato, Vesálio, Paré e os traumatismos da cabeça em 1559", Medicina na Beira Interior. Da Pré-História ao Séculoxx —Cadernos de Cultura 6 (1993), pp. 20-21; "Amato, Montalto e a arte dos olhos nos séculos XVI e XVII", Medicina na Beira Interior. Da Pré-História ao Século xx — Cadernos de Cultura 8 (1994), pp. 5-9; "Amato e os nasci", Medicina na Beira Interior. Da Pré-História ao Século xx - Cadernos de Cultura 9 (1995), pp. 3-10; "A mulher, o sofrimento e a compaixão na obra de Amato Lusitano", Medicina na Beira Interior. Da Pré-História ao Século xx — Cadernos de Cultura 10 (1996), pp. 13-20; "A receita do "manjar de fígados" do Doutor Amato Lusitano (1511-1658)", Medicina na Beira Interior. Da Pré-História ao Séculoxx — Cadernos de Cultura 11 (1997), pp. 3-7; "Salamanca e os Lusitanos", Medicina na Beira Interior. Da Pré-História ao Século xx — Cadernos de Cultura 11 (1997) pp. 66-69; "Índias de Castela e Índias de Portugal na obra de Amato Lusitano", Medicina na Beira Interior. Da Pré-História ao Século xx - Cadernos de Cultura 12 (1998), pp. 8-11; "A água em "De Medica Materia", Dioscórides, segundo Amato Lusitano e Andres Laguna", Medicina na Beira Interior. Da Pré-História ao Século xx — Cadernos de Cultura 13 (1999), pp. 5-9; "Quatro elementos, reacção Hipocrática, Amato Lusitano e "O Múmia", Medicina na Beira Interior. Da Pré-História ao Século xx। — Cadernos de Cultura 14 (2000), pp. 13-18; "Cultura clássica, barbarismos e arcaísmos em Amato Lusitano (1511-1568)", Medicina na Beira Interior. Da Pré-História ao Século xxI —Cadernos de Cultura 15 (2001), pp. 10-14; "Amato Lusitano — Fronteiras políticas, religiosas e linguísticas", Medicina na Beira Interior. Da Pré-História ao Século xx। —Cadernos de Cultura 16 (2002), pp. 11-18; "Religião, medicação e informação / desinformação na época de Amato Lusitano", Medicina na Beira Interior. Da Pré-História ao Século xx। — Cadernos de Cultura 17 (2003), pp. 18-22; "Amato Lusitano e a medicina das navegações no século xvı", Medicina na Beira Interior. Da Pré-História ao Século xx। - Cadernos de Cultura. 18 (2004), pp. 24-28; "Amato Lusitano (1511-1568). Tensões e diferenças na Europa do século xvı", Medicina na Beira Interior. Da Pré-História ao Século xxı - Cadernos de Cultura 19 (2005), pp. 6-16; "Escorbuto, pepinos, inquisição e opúncias na época de Amato Lusitano (1511-1568)", Medicina na Beira Interior. Da Pré-História ao Século xxI — Cadernos de Cultura 20 (2006), pp. 23-36; "Amato Lusitano (1511-1568). Religião e imagem", Medicina na Beira In- 
Maria Adelaide Neto Salvado ${ }^{164}$, Daniel Cartucho, Gabriela Valadas ${ }^{165}$, João Maria Nabais ${ }^{166}$,
Maria de Lurdes Cardoso $^{167}$, Maria de Fátima Paixão, Fátima Regina Jorge, Ana Isabel Flórido ${ }^{168}$,

terior. Da Pré-História ao Século xx। - Cadernos de Cultura 21 (2007), pp. 28-31; "Calcanhar de Amato", Medicina na Beira Interior. Da Pré-História ao Século xx। — Cadernos de Cultura 22 (2008), pp. 17-25; "Amigos de Amato, cidadãos do mundo", Medicina na Beira Interior. Da Pré-História ao Século xx। - Cadernos de Cultura 23 (2009), pp. 15-19; "O Juramento do Doutor Amato e o compromisso dos essénios", Medicina na Beira Interior. Da Pré-História ao Século XXI - Cadernos de Cultura 24 (2010); "Doutor Amado (1511-1568), sete apontamentos", Medicina na Beira Interior. Da Pré-História ao Século xxI — Cadernos de Cultura 27 (2013), pp. 13-22.

164 Cf. Maria Adelaide Neto SAlvado, "O espaço geográfico nas centúrias de Amato", Medicina na Beira Interior. Da Pré-História ao Séculoxx — Cadernos de Cultura 5 (1992), pp. 9-15; "Catástrofes naturais na visão de Amato Lusitano", Medicina na Beira Interior. Da Pré-História ao Séculoxx - Cadernos de Cultura 6 (1993), pp. 15-19; "A mulher do século xVI no olhar de Amato Lusitano", Medicina na Beira Interior. Da Pré-História ao Século xx - Cadernos de Cultura 10 (1996), pp. 3-8; "Os frutos e as leguminosas nas Centúrias de Curas Medicinais de Amato Lusitano", Medicina na Beira Interior. Da Pré-História ao Séculoxx - Cadernos de Cultura 11 (1997), pp. 15-21; "As águas santas — das velhas crenças à voz de Amato Lusitano", Medicina na Beira Interior. Da Pré-História ao Século xx — Cadernos de Cultura 13 (1999) pp. 23-29; "Os quatro elementos, os astros, as doenças e o homem - a visão de Amato Lusitano", Medicina na Beira Interior. Da Pré-História ao Século xx। - Cadernos de Cultura 14 (2000), pp. 21-28; "A História Natural de Plínio, o Velho, no olhar de Amato Lusitano", Medicina na Beira Interior. Da Pré-História ao Século xx — Cadernos de Cultura 15 (2001), pp. 15-21; "Amato Lusitano - Médico sem Fronteiras em Ragusa do Séc. Xvı", Medicina na Beira Interior. Da Pré-História ao Século xxı — Cadernos de Cultura 16 (2002), pp. 19-24; "De Amato Lusitano a Mircea eliade - os elos de religação", Medicina na Beira Interior. Da Pré-História ao Século xxı — Cadernos de Cultura 17 (2003), pp. 23-30; "O "mau olhado" em dois tratados de medicos portugueses contemporaneous de Amato Lusitano", Medicina na Beira Interior. Da Pré-História ao Século xx। - Cadernos de Cultura 19 (2005), pp. 25-35; "De um caso de raiva contado por Amato Lusitano, em Salónica do século XVI, aos casos de raiva na região de Castelo Branco em finais do século XIX", Medicina na Beira Interior. Da Pré-História ao Século XXI — Cadernos de Cultura 20 (2006), pp. 47-54; "Dos casos de varíola tratados por Amato Lusitano na 3 a centúria às epidemias de varíola na Beira Interior em finais do século XIX", Medicina na Beira Interior. Da Pré-História ao Século XXI — Cadernos de Cultura 22 (2008), pp. 49-55; "Amato - 'amável de nome e de facto' ". Medicina na Beira Interior. Da Pré-História ao Século xx। Cadernos de Cultura 23 (2009), pp. 36-38.

165 Cf. Daniel CARTUCho; Gabriela VALAdAS, "Abcessos de drenagem pura e branca - a propósito de uma cura em Amato Lusitano", Medicina na Beira Interior. Da Pré-História ao Século xxI - Cadernos de Cultura 16 (2002), pp. 33-36.

166 Cf. João Maria NABAIS, "A importância de Amato Lusitano na medicina do século xvı", Medicina na Beira Interior. Da Pré-História ao Século xxI — Cadernos de Cultura 16 (2002), pp. 37-40; "Garcia de Orta, um contemporâneo de Amato (médico naturalista do século xvı: cerca 1500-1568)", Medicina na Beira Interior. Da Pré-História ao Século xxI - Cadernos de Cultura 18 (2004), pp. 44-48; "Contributos de Amato Lusitano para a história das religiões e da ciência", Medicina na Beira Interior. Da Pré-História ao Século xx। - Cadernos de Cultura 21 (2007), pp. 48-54; "A criança no tempo de Amato Lusitano, uma análise historiográfica das centúrias de curas medicinais", Medicina na Beira Interior. Da Pré-História ao Século xxI - Cadernos de Cultura 23 (2009), pp. 53-62; "O humanismo na medicina: a importância de Amato Lusitano na visão ecumenical de Ricardo Jorge", Medicina na Beira Interior. Da Pré-História ao Século xxI - Cadernos de Cultura 24 (2010), pp. 21-27.

167 Cf. Maria de Lurdes CARDoso, "História da ciência e ensino das ciências - a história da ciência a partir da vida e obra de Amato Lusitano", Medicina na Beira Interior. Da Pré-História ao Século xxI Cadernos de Cultura 16 (2002), pp. 79-80; "O cruzamento de olhares: humanismo em Amato Lusitano e Luís Vives", Medicina na Beira Interior. Da Pré-História ao Século xx। — Cadernos de Cultura 23 (2009), pp. 39-43; "Saúde e ambiente - perspectives amatianas e darwinianas", Medicina na Beira Interior. Da Pré-História ao Século xxı — Cadernos de Cultura 24 (2010), pp. 28-35.

168 Maria de Fátima PaIXÃo; Fátima Regina JoRGE; Ana Isabel FlóRIDo, "Pesos e medidas na obra de Amato Lusitano: dos saberes e das certezas da época", Medicina na Beira Interior. Da Pré-História ao Século xxI - Cadernos de Cultura 19 (2005), pp. 17-24. 
Manuel Costa Alves ${ }^{169}$, Maria José Leal ${ }^{170}$, Aires Gameiro ${ }^{171}$, Armando Moreno ${ }^{172}$, J. A. David de Morais ${ }^{173}$; Isilda Teixeira Rodrigues ${ }^{174}$, Pedro Salvado ${ }^{175}$, António Romeiro Carvalho $^{176}$, António Maria Martins Melo ${ }^{177}$, Maria do Sameiro Barroso ${ }^{178}$, Ana Margarida Borges $^{179}$, Emília Oliveira ${ }^{180}$. De todos estes sublinhamos os nomes de Alfredo Rasteiro e António Lourenço Marques, mas também de José Morgado Pereira, Maria Adelaide Neto Salvado e Fanny Xavier da Cunha ${ }^{181}$ pelos estudos que realizaram e continuam a realizar sobre

169 Manuel Costa Alves, "Amato Lusitano e a doença de D. Sebastião", Medicina na Beira Interior. Da Pré-História ao Século xxI - Cadernos de Cultura 19 (2005), pp. 36-39.

170 Maria José LeAL, "As incursões de Amatus Lusitanus pela cirurgia pediátrica", Medicina na Beira Interior. Da Pré-História ao Século xxI — Cadernos de Cultura 22 (2008), pp. 29-34; "Nempe color — o preceito galenico nas centúrias de Amato Lusitano", Medicina na Beira Interior. Da Pré-História ao Século xx। Cadernos de Cultura 24 (2010), pp. 16-20; "O caminho de Hades - o verbo, a palavra, a voz de Amato", Medicina na Beira Interior. Da Pré-História ao Século xxI — Cadernos de Cultura 27 (2013), pp. 23-26.

171 Aires GameIro, "Amato Lusitano (1511-1568) e S. João de Deus (1495-1550): contemporâneos, aventureiros e cuidadores de doentes com princípios éticos", Medicina na Beira Interior. Da Pré-História ao Século xxI - Cadernos de Cultura 22 (2008), pp. 35-43.

172 Armando Moreno, "Ética em Amato Lusitano", Medicina na Beira Interior. Da Pré-História ao Século xxı - Cadernos de Cultura 23 (2009), pp. 55-86; "Os mitos em Amato Lusitano", Medicina na Beira Interior. Da Pré-História ao Século xxI - Cadernos de Cultura 23 (2009) pp. 23-29.

173 J. A. David de Morals, "O tratamento vernáculo do cobro (herpes zoster) nas Centúrias de Amato Lusitano e no Sul de Portugal: abordagem médico-antropológica", Medicina na Beira Interior. Da Pré-História ao Século xxI - Cadernos de Cultura 21 (2007), pp. 43-47; "Ainda a questão do desaparecimento do túmulo de Amato Lusitano", Medicina na Beira Interior. Da Pré-História ao Século xxı - Cadernos de Cultura 27 (2013), pp. 7-12; "O mercador de Salónica, o seu gato e os seus criados: contribuição para o estudo das zoonoses nas "Centurias" de Amato Lusitano", Medicina na Beira Interior. Da Pré-História ao Século xxI - Cadernos de Cultura 24 (2010), pp. 31-34.

174 Isilda Teixeira Rodrigues, "Paralelismos e divergencias entre as Centúrias e o traité des Monstres et des Prodiges", Medicina na Beira Interior. Da Pré-História ao Século xx। — Cadernos de Cultura 23 (2009) pp. 30-35; "O contributo de Amato Lusitano para a história da sexologia", Medicina na Beira Interior. Da Pré-História ao Século xxI - Cadernos de Cultura 23 (2009), pp. 44-52.

175 Pedro Salvado, "Amato Lusitano e outras presences médicas no espaço urbano albicastrense visibilidades e invisibilidades", Medicina na Beira Interior. Da Pré-História ao Século xxı - Cadernos de Cultura 23 (2009), pp. 69-82.

176 António Maria Romeiro Carvalho, "O número e a superstição em Amato Lusitano", Medicina na Beira Interior. Da Pré-História ao Século xxI - Cadernos de Cultura 24 (2010), pp. 36-39.

177 António Maria Martins Melo, "Amato Lusitano, leitor da Odisseia", Medicina na Beira Interior. Da Pré-História ao Século xxI - Cadernos de Cultura 27 (2013), pp. 27-30.

178 Maria do Sameiro BARRoso, "Amato Lusitano - os bezoares e a tradição das pedras curativas", Medicina na Beira Interior. Da Pré-História ao Século xxI — Cadernos de Cultura 24 (2010), pp. 41-46.

179 Ana Margarida BoRGES, "Anotações metalinguísticas nas obras de Amato e de Laguna: a metáfora terminológica", Medicina na Beira Interior. Da Pré-História ao Século XXI — Cadernos de Cultura 24 (2010), pp. 47-50.

180 Emília Oliveıra, "Da romã à nêspera: propriedades e fins terapêuticos de alguns frutos comuns em Portugal nas Enarrationes de Amato Lusitano", Medicina na Beira Interior. Da Pré-História ao Século XXI - Cadernos de Cultura 24 (2010), pp. 51-56.

181 Falecida em 2011. Ver Sociedade de Geografia de Lisboa. Relatório da Gerência e Parecer da Comissão Revisora de Contas. Referido a 31 de Dezembro de 2011. In: http://www.socgeografialisboa.pt/wp/ wp-content/uploads/2009/01/Relatorio-2011.pdf (consultado em 23/04/2014). 
Amato, sendo, igualmente dinamizadores importantes das Jornadas e dos Cadernos de Cultura. Nos últimos anos sublinhem-se os estudos de António Andrade integrados no projecto de investigação referido. Em 2011, ano de comemoração dos 500 anos de Amato Lusitano, os Cadernos de Cultura publicaram sobre Amato os seguintes estudos: António Andrade, De Antuérpia a Ferrara: o caminho de Amato Lusitano ${ }^{182}$; Alfredo Rasteiro, João Rodrigues Lusitano, Doutor Amado (1511-1568) e Armando Tavares de Sousa, estudioso de Amado ${ }^{183}$; João Maria Nabais, Amato e os médicos da diáspora: a face oculta das atribulaçóes dos judeus portugueses ${ }^{184}$; Emílio Rivas Calvo; Carlos d'Abreu, Amato Lusitano: na Universitatis Studii Salamantini ${ }^{185}$; Maria José Leal, Amato, Inédia e Chi Kung: quebrando o circuito da fome ${ }^{186}$; António Lourenço Marques, Amato Lusitano: o médico vai até ao fim ${ }^{187}$; Aires Gameiro, Amato Lusitano (1511-1568): identidade e cultura judaico-cristã europeia do século Xvi ${ }^{188}$. E em 2012 foram publicados textos que serviram de base a comunicaçóes apresentadas aquando da sessão comemorativa do quinto centenário de Amato Lusitano: João Marinho dos Santos, A história de "Amato Lusitano" na história de Portugal ${ }^{189}$; Luís Nuno Ferraz de Oliveira, O meu Amato Lusitano ${ }^{190}$; António Manuel Lopes Andrade, Amato Lusitano em Ancona: a tragédia da família Pires ${ }^{191}$; João Manuel Nunes Torrão, Amato Lusitano: entre o Index Dioscoridis (1536) e as Enarrationes (1553) ${ }^{192}$; Carlos de Miguel Mora, Do Index às Enarrationes. Um esboço de estudo comparativo através de quatro

182 António Manuel Lopes ANDRADE, "De Antuérpia a Ferrara: o caminho de Amato Lusitano e da sua família", Medicina na Beira Interior. Da Pré-História ao séc. XxI - Cadernos de Cultura 25 (2011), pp. 5-16.

183 Alfredo RASTEIRO, "João Rodrigues Lusitano, Doutor Amado (1511-1568)". Medicina na Beira Interior. Da Pré-História ao séc. XXI - Cadernos de Cultura 25 (2011), pp. 17-20; "Armando Tavares de Sousa, estudioso de Amado. In Memoriam". Medicina na Beira Interior. Da Pré-História ao séc. xxI - Cadernos de Cultura 25 (2011), pp. 47-48.

184 João Maria Nabals, "Amato e os médicos da diáspora: a face oculta das atribulações dos judeus portugueses". Medicina na Beira Interior. Da Pré-História ao séc. XXI - Cadernos de Cultura 25 (2011), pp. 21-30.

185 Emílio Rivascalvo; Carlos d'Abreu, "Amato Lusitano: na Universitatis Studii Salamantini". Medicina na Beira Interior. Da Pré-História ao séc. XXI - Cadernos de Cultura 25 (2011), pp. 31-36.

186 Maria José LeaL, "Amato, Inédia e Chi Kung: quebrando o circuito da fome". Medicina na Beira Interior. Da Pré-História ao séc. XXI - Cadernos de Cultura 25 (2011), pp. 37-40.

187 António Lourenço Maroues, "Amato Lusitano: o médico vai até ao fim". Medicina na Beira Interior. Da Pré-História ao séc. XXI - Cadernos de Cultura 25 (2011), pp. 41-44.

188 Aires GAmeIRo, "Amato Lusitano (1511-1568): identidade e cultura judaico-cristã europeia do século xvı". Medicina na Beira Interior. Da Pré-História ao séc. xxı - Cadernos de Cultura 25 (2011), pp. 45-46.

189 João Marinho dos Santos, A história de "Amato Lusitano" na história de Portugal, Medicina na Beira Interior. Da Pré-História ao séc. XXI - Cadernos de Cultura 26 (2012), pp. 8-13.

190 Luís Nuno Ferraz de OliveIRA, "O meu Amato Lusitano", Medicina na Beira Interior. Da Pré-História ao séc. XXI - Cadernos de Cultura 26 (2012), pp. 14-19.

191 António Manuel Lopes AndRADE, "Amato Lusitano em Ancona: a tragédia da família Pires", Medicina na Beira Interior. Da Pré-História ao séc. xxI - Cadernos de Cultura 26 (2012), pp. 20-27.

192 João Manuel Nunes TorRÃo, "Amato Lusitano: entre o Index Dioscoridis (1536) e as Enarrationes (1553)", Medicina na Beira Interior. Da Pré-História ao séc. XxI - Cadernos de Cultura 26 (2012), pp. 28-30. 
entradas ${ }^{193}$; Alfredo Rasteiro, João Rodrigues Lusitano - Doutor Amado - serviu as Musas: amou a Poesia, cultivou a Ciência ${ }^{194}$; J. A. David de Morais, As Parasitoses nas "Centúrias" de Amato Lusitano ${ }^{195}$; António Lourenço Marques, O ser humano na clínica de Amato Lusitano - rumo ao conceito de dignidade ${ }^{196}$; Maria Adelaide Neto Salvado, Amato num mito e um mito em Amato ${ }^{197}$; Joaquim Candeias da Silva, João Rodrigues... Amado, Lusitano, de Castelo Branco (1511-1568): Contributo para uma aclaração dos seus elos familiares ${ }^{198}$; Maria José Leal, No Cenotáfio de Amato ${ }^{199}$; Virgínia Soares Pereira, Amato Lusitano: a propósito de uma breve nota resendiana ${ }^{200}$; António Maria Martins Melo, Janela de aromas: excertos do Index de Amato Lusitano ${ }^{201}$; Maria do Sameiro Barroso, As filhas de Pirra em Amato Lusitano, um caso de embriotomia (VI Centúria, Cura LI) 202; Gabriela Valadas e Daniel Cartucho, Tumor da mama em Amato Lusitano - da semiologia à terapêutica ${ }^{203}$; Isilda Teixeira Rodrigues, Alguns factores que contribuiram para o desenvolvimento da Medicina de Amato Lusitano ${ }^{204}$; Albano Mendes de Matos, A atitude Cientifica em Amato Lusitano ${ }^{205}$; Lurdes Cardoso, Amato Lusitano e alguns dos seus contemporâneos ${ }^{206}$;

193 Carlos de Micuel Mora, "Do Index às Enarrationes. Um esboço de estudo comparativo através de quatro entradas", Medicina na Beira Interior. Da Pré-História ao séc. XxI - Cadernos de Cultura 26 (2012), pp. 31-36.

194 Alfredo RASTEIRO, "João Rodrigues Lusitano - Doutor Amado - serviu as Musas: amou a Poesia, cultivou a Ciência", Medicina na Beira Interior. Da Pré-História ao séc. XXI - Cadernos de Cultura 26 (2012), pp. 37-44.

195 J. A. David de Morals, "As Parasitoses nas "Centúrias" de Amato Lusitano", Medicina na Beira Interior. Da Pré-História ao séc. XXI - Cadernos de Cultura 26 (2012), pp. 45-54.

196 António Lourenço MARoues, "O ser humano na clínica de Amato Lusitano - rumo ao conceito de dignidade", Medicina na Beira Interior. Da Pré-História ao séc. xxI - Cadernos de Cultura 26 (2012), pp. 55-60.

197 Maria Adelaide Neto Salvado, "Amato num mito e um mito em Amato", Medicina na Beira Interior. Da Pré-História ao séc. XXI - Cadernos de Cultura 26 (2012), pp. 61-66.

198 Joaquim Candeias da SILVA, "João Rodrigues... Amado, Lusitano, de Castelo Branco (1511-1568): Contributo para uma aclaração dos seus elos familiares", Medicina na Beira Interior. Da Pré-História ao séc. xxI - Cadernos de Cultura 26 (2012), pp. 67-73.

199 Maria José LeAL, "No Cenotáfio de Amato", Medicina na Beira Interior. Da Pré-História ao séc. xxI Cadernos de Cultura 26 (2012), pp. 74-77.

200 Virgínia Soares Pereira, "Amato Lusitano: a propósito de uma breve nota resendiana", Medicina na Beira Interior. Da Pré-História ao séc. XXI - Cadernos de Cultura 26 (2012), pp. 78-80.

201 António Maria Martins Melo, "Janela de aromas: excertos do Index de Amato Lusitano", Medicina na Beira Interior. Da Pré-História ao séc. xx। - Cadernos de Cultura 26 (2012), pp. 81-87.

202 Maria do Sameiro BARroso, "As filhas de Pirra em Amato Lusitano, um caso de embriotomia (VI Centúria, Cura LI)", Medicina na Beira Interior. Da Pré-História ao séc. XXI - Cadernos de Cultura 26 (2012), pp. 88-93.

203 Gabriela VAladAs; Daniel CARTUCho, "Tumor da mama em Amato Lusitano - da semiologia à terapêutica", Medicina na Beira Interior. Da Pré-História ao séc. XxI - Cadernos de Cultura 26 (2012), pp. 94-97.

204 Isilda Teixeira RodRIGUes, "Alguns factores que contribuíram para o desenvolvimento da Medicina de Amato Lusitano", Medicina na Beira Interior. Da Pré-História ao séc. xxI - Cadernos de Cultura 26 (2012), pp. 98-100.

205 Albano Mendes de Matos, "A atitude Científica em Amato Lusitano", Medicina na Beira Interior. Da Pré-História ao séc. XXI - Cadernos de Cultura 26 (2012), pp. 101-104.

206 Lurdes CARDoso, "Amato Lusitano e alguns dos seus contemporâneos", Medicina na Beira Interior. 
Aires Gameiro, Amato Lusitano, homo europeus: Expoente Cimeiro da Cultura Europeia JudaicoCristã no século Xvi ${ }^{207}$; João Maria Nabais, O Judaísmo Humanista em Amato Lusitano ${ }^{208}$; Maria Antonieta Garcia, Cinco médicos Beirões e a conversão forçada ${ }^{209}$. Na mesma revista de 2012 assinale-se nas últimas páginas a informação diversificada das actividades realizadas aquando das comemoraçôes do V Centenário do Nascimento de Amato Lusitano ${ }^{210}$.

\section{AUTORES ESTRANGEIROS ESTUDIOSOS DE AMATO QUUE PUBLICARAM EM PORTUGAL}

Vários autores estrangeiros publicaram sobre Amato Lusitano, designadamente em Portugal. Com frequência aborda-se a presença de Amato em Itália ou no extremo da Europa. É o caso de Jacob Seide ${ }^{211}$, J. Nehama $(1955)^{212}$, Hirsh Rudy (1955) ${ }^{213}$, Harry Friedenwald

Da Pré-História ao séc. xxI - Cadernos de Cultura 26 (2012), pp. 105-108.

207 Aires GameIro, "Amato Lusitano, homo europeus: Expoente Cimeiro da Cultura Europeia Judaico-Cristã no século XVI", Medicina na Beira Interior. Da Pré-História ao séc. XXI - Cadernos de Cultura 26 (2012), pp. 109-112.

208 João Maria Nabals, "O Judaísmo Humanista em Amato Lusitano", Medicina na Beira Interior. Da Pré-História ao séc. XxI - Cadernos de Cultura 26 (2012), pp. 113-117.

209 Maria Antonieta GARCiA, "Cinco médicos Beirões e a conversão forçada", Medicina na Beira Interior. Da Pré-História ao séc. XXI - Cadernos de Cultura 26 (2012), pp. 118-128.

210 Sublinhe-se, entre vários, além dos discursos oficiais introduzidos na revista, do Presidente da República e do Presidente da Câmara de Castelo Branco, as actividades desenvolvidas em 2011, homenagem aos estudiosos de Amato e algumas edições realizadas como: Amato Lusitano Judeu Errante, de Armando Moreno (Peça vicentina em 3 actos - Comemorações dos 500 anos do nascimento de Amato Lusitano, Prémio Marcelino Mesquita); Amato Lusitano e as Rosas, textos de Maria Adelaide Neto Salvado, Edição da Câmara Municipal de Castelo Branco; O Corpo do Coração - Horizontes de Amato Lusitano - catálogo da Exposição - Pedro Salvado, Edição da Câmara Municipal Castelo Branco; Amato Lusitano Cidadão de Castelo Branco, de José Lopes Dias - Reedição da Câmara Municipal Castelo Branco; Amato Lusitano nos Caminhos do Mundo - O Saber sem Fronteiras - Caderno Especial do Jornal do Fundão de 10/11/2011; Catálogo da inauguração da estátua Diáspora, Edição da Câmara Municipal Castelo Branco; Amado Amato - antologia de poesia dedicada a Amato Lusitano, organizada por Maria de Lurdes Barata e Pedro Salvado, Edição da Câmara Municipal Castelo Branco; Jardim Amato Lusitano, de Maria Adelaide Salvado e Maria de Lurdes Cardoso, Edição da Câmara Municipal Castelo Branco; Ode a Amato Lusitano, da autoria de António Salvado, Edição da Câmara Municipal Castelo Branco.

211 Cf. Jacob SEIDE, "The two diabetics of Amatus Lusitanus", Imprensa Médica 19.11 (1955), pp. 670-674.

212 Cf. J. NehAmA, "Amato Lusitano à Salonique", in Homenagem ao Doutor João Rodrigues de Castelo Branco (Amato Lusitano). Castelo Branco, Câmara Municipal de Castelo Branco, 1955, pp. 213-214.

213 Cf. Hirsch Rudy, "Amatus Lusitanus (Biographischer Rahmen)", in Homenagem ao Doutor João Rodrigues de Castelo Branco (Amato Lusitano). Castelo Branco, Câmara Municipal de Castelo Branco, 1955. pp. 193-211. 
$(1955)^{214}$, Lavoslav Glesinger (Estudos de Castelo Branco, 1968) ${ }^{215}$, Joshua O. Leibowitz (Estudos de Castelo Branco, 1961, 1968) ${ }^{216}$, Ivolino de Vasconcelos ${ }^{217}$, Marija Ana Dürrigl, Stella Fatovic Ferencic (Acta Médica Portuguesa, 2002) ${ }^{218}$, Alfredo Pérez Alencart (Medicina na Beira Interior. Da Pré-História ao Século XxI - Cadernos de Cultura $)^{219}$

214 Harry FriedenwALD, "Medical works of Amatus Lusitanus". Homenagem ao Doutor João Rodrigues de Castelo Branco (Amato Lusitano). Castelo Branco, Câmara Municipal de Castelo Branco, 1955. pp. 177-191.

215 Cf. Lavoslav Glesinger, "Amatus Lusitanus à Raguse" in Centenário (IV) de João Rodrigues de Castelo Branco - Amato Lusitano, Castelo Branco, Estudos de Castelo Branco, 1968, pp. 111-131; Amato Lusitano em Ragusa. Estudos de Castelo Branco 28 (1968), pp. 170-178.

216 Cf. Joshua O. LeIBowitz, "Amatus Lusitanus on sudden death due to 'Obstruction in the heart'" (1560), Estudos de Castelo Branco, 4 (1961) pp. 11-26; "Simpósio de Amato Lusitano em Sena. Amatus Lusitanus à Salonique" in Centenário (IV) de João Rodrigues de Castelo Branco - Amato Lusitano. Castelo Branco, Estudos de Castelo Branco, 1968, pp. 41-46; "Amatus Lusitanus (1511-1568) à Salonique", Estudos de Castelo Branco 28 (1968) pp. 90-93; "Amato Lusitano (1511-1568) em Salónica", Estudos de Castelo Branco 28 (1968) pp. 93-95.

217 Cf. Ivolino de Vasconcelos, "Discurso de encerramento de 'Simpósio de Amato Lusitano', em Siena, do Prof. (...)" in Centenário (IV) de João Rodrigues de Castelo Branco - Amato Lusitano. Castelo Branco, Estudos de Castelo Branco, 1968, pp. 191-192; Discurso de encerramento do "Simpósio de Amato Lusitano" em Siena. Estudos de Castelo Branco 29 (1969), pp. 21-22.

218 Cf. Marija-Ana Dürrigl; Stella Fatovic-Ferentic, "The medical practice of Amatus Lusitanus in Dubrovnik (1556-1558) a short reminder on the $445^{\text {th }}$ anniversary of his arrival", Acta Médica Portuguesa 15.1(2002), pp. 37-40.

219 Alfredo Pérez Alencart, "Descubrimiento de Amato Lusitano", Medicina na Beira Interior. Da Pré-História ao Século xxI - Cadernos de Cultura 19 (2005) pp. 40-41. 


\section{CONCLUSÃO}

Pelo que fica exposto, Amato Lusitano, figura maior da história da medicina portuguesa é, igualmente, uma referência na história da medicina internacional. Apesar de muitos estudos publicados sobre a sua vida e a sua obra, de dimensôes, âmbitos e profundidades diferentes, sendo uma boa parte muito recente, Amato Lusitano continua a aguardar um trabalho historiográfico de grande fôlego, segundo os mais recentes e autorizados métodos da história cultural da ciência e da medicina e que seja marcante para a historiografia médica, sobretudo um trabalho de natureza biográfica. Os trabalhos sobre Amato sublinham igualmente a possibilidade de trabalhos multifacetados que sobre Amato se podem realizar e que o tornam numa fonte de investigação de enorme fecundidade. O quinto centenário de Amato proporcionou diversas iniciativas e produçóes científicas. As diferentes actividades levadas a bom porto em Castelo Branco, na Biblioteca Nacional de Portugal, bem como o projecto de investigação Dioscórides e o Humanismo Português: os Comentários de Amato Lusitano do qual decorre a presente publicação testemunham o excelente trabalho realizado nos últimos anos sobre Amato Lusitano. 
(Página deixada prepositadamente em branco.) 
A partir dos alvores do século XVI, a matéria médica torna-se indiscutivelmente um tema de primeira grandeza entre os membros da República das Letras, objecto de estudo e de controvérsia entre os mais notáveis humanistas europeus, em particular entre os cultores da arte médica. Entre os autores em destaque neste volume encontram-se, à cabeça, os nomes de Amato Lusitano, Garcia de Orta e Nicolás Monardes, famosos pelos contributos valiosos que deram para o conhecimento do mundo natural. 0 volume encontra-se dividido em duas partes: a primeira, subordinada ao título "Humanismo e Ciência", alberga os estudos que versam sobre todos os autores estudados, à excepção de Amato Lusitano; a segunda está reservada a um conjunto de trabalhos dedicados exclusivamente ao médico albicastrense, cuja autoria se fica a dever, em boa parte, aos membros da equipa do projecto de I\&D "Dioscórides e o Humanismo Português: os Comentários de Amato Lusitano", tomando, por isso, 0 seu próprio título. Nesta segunda parte, oferece-se, desde já, aos leitores uma amostra significativa do trabalho desenvolvido no âmbito do projecto e que culminará, assim se espera, na edição e tradução integral para língua portuguesa das quatro obras previstas de Dioscórides, Amato Lusitano e Pietro Andrea Mattioli. 
